\title{
Manifestações da arquitetura residencial paulistana entre as Grandes Guerras.
}

Manifestations of residential architecture in São Paulo between the Great Wars.

Clara Correia d'Alambert

Tese apresentada à Faculdade de Arquitetura e Urbanismo da Universidade de São Paulo para obtenção de título de Doutor.

Orientador : Prof. Dr. Carlos Alberto Cerqueira Lemos

São Paulo, 2003. 


\section{Manifestações da arquitetura residencial paulistana entre as Grandes Guerras.}

Clara Correia d'Alambert

Tese apresentada à Faculdade de Arquitetura e Urbanismo da Universidade de São Paulo para obtenção de título de Doutor.

Orientador : Prof. Dr. Carlos Alberto Cerqueira Lemos

São Paulo, 2003. 


\section{Agradecimentos}

A todos que contribuíram para a realização deste trabalho e, em particular, a:

Cleide de Andrade e funcionários de DAF-42

(Arquivo Geral da Prefeitura do Município de São Paulo - Piqueri)

Fernão Dias de Lima

Francisca Correia d' Alambert

Francisca Correia Godoy d' Alambert

Glória Bayeux

Ignácio Henrique de Azevedo Guilhon

Jorge Lody

Nilza Nunes da Silva

Vitor José Baptista Campos

Um agradecimento especial ao nosso orientador Prof. Dr. Carlos Alberto Cerqueira Lemos pela inspiração deste trabalho e pelo acompanhamento e dedicação ao longo de todo o processo de elaboração da tese. 


\section{Resumo}

Esta tese representa uma contribuição ao estudo da arquitetura residencial paulistana produzida no período entre as Grandes Guerras. Com base em uma amostra de projetos sorteados de residências, constantes nos processos de aprovação de construção sob a guarda do Arquivo Geral da Prefeitura do Município de São Paulo (Piqueri), analisa as inovações técnicoconstrutivas, os programas de necessidades e o repertório formal e estilístico empregados nas residências paulistanas das décadas de 20 e 30, enfocando particularmente as de classe média.

Examina o quadro econômico, social, cultural e urbano existente na cidade de São Paulo no entre-guerras. Caracteriza os modelos estilísticos em voga nos anos 20 e 30 - o Neocolonial, em suas duas versões, e o Art Déco refletindo acerca das mudanças de gosto, de comportamento e das influências estilísticas da arquitetura erudita sobre aquela popularizada na classe média. Revela o surgimento de uma nova linguagem estilística, o "Maneirismo Paulistano", e identifica um "Estilo Indefinido", também significativo na composição do panorama urbano da cidade de São Paulo desse período.

Palavras-chave: SÃO PAULO / ARQUITETURA RESIDENCIAL / ARQUITETURA POPULAR / ANOS 20 E 30. 


\section{Abstract}

This thesis represents a contribution to the study of São Paulo's residential architecture in the period between the Wars. Based on samples of residential projects, appeared in the construction approval processes at General Archive of São Paulo's Municipal Government (Piqueri), it analyses the technical and constructive innovations, the necessity programs and the formal and stylistic repertoire used in São Paulo's homes in decades of 1920 and 1930, focusing specially the middle class.

This work examines the economic, social, cultural and urban situation at São Paulo by that time. It characterizes the stylistic models in the twenties and thirties - the Neocolonial, in its two versions, and Art Déco - reflecting the changes in stylistic preferences, behaviours and erudite's influences over the popular architecture. It reveals the appearance of a new stylistic language, the "Maneirismo Paulistano", and identifies an "Undefinied Style", also significant in the composition of São Paulo's urban context in that period.

Key words: SÃO PAULO / RESIDENTIAL ARCHITECTURE / POPULAR ARCHITECTURE / TWENTIES AND THIRTIES. 


\section{SUMÁRIO}

\section{Apresentação, 2}

Introdução, 5

\section{São Paulo nas primeiras décadas do século XX}

I.1. Panorama Geral, 20

I.2. Aspectos Urbanísticos, 25

I.3. Aspectos Arquitetônicos, 31

\section{Os modelos estilísticos em voga nos anos 20 e 30}

II.1. O Neocolonial e a procura da modernidade e da identidade cultural

II.1.1. Surgimento do Movimento Neocolonial, 44

II.1.2. O Neocolonial em São Paulo, 51

II.1.3. Neocolonial - polêmicas e opiniões da época, 55

II.1.4. Neocolonial - algumas reflexões, 59

II.2. A nova moda do Art Déco

II.2.1. Surgimento do Art Déco, 65

II.2.2. A feição Déco na arquitetura, 72

II.2.3. A arquitetura Déco em São Paulo, 76

\section{Residências paulistanas entre as Grandes Guerras}

(análise baseada em pesquisa realizada no Arquivo Geral da PMSP)

III.1. As inovações técnico-construtivas, 86

III.2. Os programas de necessidades, 97

III.3. O repertório formal e estilístico, 112

III.4. As recriações e os sincretismos arquitetônicos : o surgimento de uma linguagem estilística paulistana

III.4.1. A questão da cópia, da imitação, das recriações, dos sincretismos, 143

III.4.2. O "Maneirismo Paulistano", 146

III.4.3. Um "Estilo Indefinido", 156

Considerações Finais, 170

Referências Bibliográficas, 174

\section{Apêndices}

- Principais estilos ou correntes estilísticas presentes na arquitetura residencial paulistana a partir do final do século XIX, 186

. Relação dos projetos residenciais sorteados classificados por ano / autor do projeto, 204 


\section{Lista de figuras :}

. FIGURA 1 : Vista do bairro do Brás nos anos 20. p. 9.

fonte : DONATO, Hernani. A Revolução de 32, p. 12 e 13.

. FIGURA 2 : Vista do bairro de Campos Elíseos a partir da Estação da Luz (1925), p. 10. fonte : A Cidade da Light 1899/1930, p. 80.

. FIGURA 3 : "Diagramma das construcções em S. Paulo de 1901 a 1928" (elaborado pelo engenheiro Arthur Saboya / 1929), p.22

fonte : lllustração Brasileira. no 109, set. 1929 / acervo : Biblioteca Nacional (RJ)

. FIGURA 4 : Bonde elétrico no centro de São Paulo. p.25

foto: Hildegard Rosenthal / fonte: Memória Paulistana

. FIGURA 5 : Residência Cândido de Moraes. (Ramos de Azevedo / São Paulo, 1892), p.33. acervo : Biblioteca FAUUSP

. FIGURA 6 : Palacete Viscondessa de Parnaíba. (Ramos de Azevedo / São Paulo, final do século XIX), p.33.

acervo : Biblioteca FAUUSP

. FIGURA 7 : Casa à rua Martinico Prado. p.34.

foto da autora / acervo particular

. FIGURA 8 : "Typos da casas communs em São Paulo". p.35.

fonte: FREIRE, Victor da Silva. "A Cidade Salubre." In: Revista Polytechnica. no 48, out. / nov. 1914, p.325.

. FIGURA 9 : Casa modernista da rua Santa Cruz. (Gregori Warchavchik / São Paulo, 1927/28), p.41.

fonte: Arte em Revista, № 4, p.5.

. FIGURA 10 : Casa da rua Bahia. (Gregori Warchavchik / São Paulo, 1930), p.41.

fonte: XAVIER, Alberto \& alii. Arquitetura Moderna Paulistana, p.3.

. FIGURA 11 : Residência à avenida Angélica. (Ricardo Severo / São Paulo, 1910), p.44.

foto : Gustavo Neves da Rocha / acervo : Biblioteca FAUUSP

. FIGURA 12 : Capa do "Estylo colonial brasileiro". (Felisberto Ranzini / 1927), p.46.

fonte : RANZINI, Felisberto. Estylo Colonial Brasileiro. Composições Architectonicas de Motivos Originaes.

. FIGURA 13 : "Exemplo de applicações de varios motivos numa Fachada em estylo Tradicional", p.46.

fonte : RANZINI, Felisberto. Estylo Colonial Brasileiro. Composições Architectonicas de Motivos Originaes. (prancha 40)

. FIGURA 14 : Exemplos de coroamentos de envasaduras. p.46.

fonte : RANZINI, Felisberto. Estylo Colonial Brasileiro. Composições Architectonicas de Motivos Originaes. (pranchas 1 e 4)

. FIGURA 15 : Exemplos de óculos. p.46.

fonte : RANZINI, Felisberto. Esstylo Colonial Brasileiro. Composições Architectonicas de Motivos Originaes. (prancha 38)

. FIGURA 16 : Exemplos de mísulas. p.46.

fonte : RANZINI, Felisberto. Estylo Colonial Brasileiro. Composições Architectonicas de Motivos Originaes. (prancha 22)

. FIGURA 17 : Instituto de Educação. (Ângelo Brunhs , José Cortez / Rio de Janeiro,1928/30), p.50. fonte : Guia da Arquitetura Eclética no Rio de Janeiro.

. FIGURA 18 : Museu Histórico Nacional. (A. Memória, F. Cuchet / Rio de Janeiro, 1920/22), p. 50.

fonte : Guia da Arquitetura Eclética no Rio de Janeiro.

. FIGURA 19 : Pouso da Maioridade. (Victor Dubugras / Caminho do Mar, São Paulo, 1922), p.51. acervo : Arquivo CONDEPHAAT (SP) 
. FIGURAS 20 e 21: Ladeira da Memória em 1922 e 2003. (Victor Dubugras / São Paulo, 1922), p.51. fonte : REIS FILHO, Nestor Goulart. Racionalismo e Protomodernismo na obra de Victor Dubugras, p. 203. foto da autora (2003) / acervo particular

. FIGURA 22 : Vista fundos da residência de Numa de Oliveira à avenida Paulista. (Ricardo Severo / São Paulo, 1916/18), p.52. acervo : Biblioteca FAUUSP

. FIGURA 23 : Residência à rua Veiga Filho. (Adhemar de Moraes / São Paulo, 1923), p. 52. foto da autora / acervo particular

. FIGURA 24 : Casa Lusa de Ricardo Severo na rua Taguá. (Ricardo Severo / São Paulo, 1924), p.53. acervo : Biblioteca FAUUSP

. FIGURA 25 : Residência à rua São Carlos do Pinhal. (Guilherme Winter / São Paulo, 1928), p.53.

foto da autora / acervo particular

. FIGURA 26 : Cartaz da Exposition Internationale des Arts Décoratifs et Industriels Modernes. (Robert Bonfils / Paris, 1925), p. 65.

fonte : Guia da Arquitetura Art Déco no Rio de Janeiro.

. FIGURA 27: Pavilhão da Rússia. (Melnikov / Paris, 1925), p. 66.

fonte : HOLLINGSWORTH, Mary. Architecture of the 20 th Century, p. 49.

. FIGURA 28 : Pavilhão L'Esprit Nouveau. (Le Corbusier / Paris, 1925), p. 66.

fonte: HOLLINGSWORTH, Mary. Architecture of the 20 th Century, p. 63.

. FIGURA 29 : Detalhe da porta do elevador do edifício Chrysler Building. (Nova lorque, 1928/30), p. 68.

foto da autora / acervo particular

. FIGURA 30 : Arquitetura tipo “barco”. ("Hook of Holland” - J.J. Oud / Holanda, 1924), p. 74.

fonte : HOLLINGSWORTH, Mary. Architecture of the 20 th Century, p. 53.

. FIGURA 31: Chrysler Building. (Nova lorque, 1928/30), p. 75.

fonte : HOLLINGSWORTH, Mary. Architecture of the 20 th Century, p. 71.

. FIGURA 32 : Empire State Building. (Nova lorque, 1930), p. 75.

fonte : HOLLINGSWORTH, Mary. Architecture of the 20 th Century, p. 66.

. FIGURAS 33, 34 e 35 : Residência Caio da Silva Prado à avenida Higienópolis. (Elisiário Bahiana / São Paulo, final da década de 1920), p. 77.

fonte : HOMEM, Maria Cecília Naclério. Higienópolis - grandeza e decadência de um bairro paulistano, p. 101 e 222.

. FIGURA 36 : Casa à rua Tomé de Souza. (detalhe de cunhal / São Paulo), p. 78.

foto da autora / acervo particular

. FIGURA 37 : Casa à rua Piauí. (detalhe de porta / São Paulo), p. 78.

foto da autora / acervo particular

. FIGURA 38 : Edifício Saldanha Marinho. (Elisiário Bahiana / São Paulo, 1929/33), p. 79.

foto da autora / acervo particular

. FIGURAS 39, 40 e 41 : Edifício do antigo Banco de São Paulo. (Álvaro Botelho / São Paulo, 1935/38), p. 80.

fotos da autora / acervo particular

. FIGURAS 42 e 43 : Residência Armando Álvares Penteado. (Dácio Aguiar de Moraes / São Paulo, 1931), p. 81.

fotos : Guilherme Amadeu / fonte : CAMPOS, Vitor J. B. O Art Déco e a construção do imaginário moderno - um estudo de linguagem arquitetônica, p. 63.

. FIGURAS 44, 45, 46 e 47 : Residência à rua Ceará, 184. antiga residência Heloísa Fonseca Rodrigues (Jayme C. Fonseca Rodrigues / São Paulo, 1935), p.82.

fonte: Acrópole. ํㅜ 16, ago. 1939, p.p. 25 a 30.

foto da autora (2003) / acervo particular 
. FIGURAS 48, 49 e 50 : Residência à rua Ceará, 202. antiga residência Jayme C. Fonseca Rodrigues (Jayme C. Fonseca Rodrigues / São Paulo, 1935), p. 82.

fotos da autora / acervo particular

. FIGURA 51 : Pozzolana - ingrediente básico para a preparação do concreto romano. p. 86. fonte: ARTIFEX - Ingeniería en España, p.38.

. FIGURA 52 : OPUS CAEMENTICIUM - abóbada de concreto romano. (Almuñecar / Espanha), p.86. fonte: ARTIFEX - Ingeniería en España, p.39.

. FIGURA 53 : Estação Ferroviária de Mairinque. (Victor Dubugras / Mairinque, 1905 / 1908), p. 89. fonte : REIS FILHO, Nestor Goulart. Racionalismo e Protomodernismo na obra de Victor Dubugras, p. 84.

. FIGURA 54 : Exemplo do emprego de lajes de concreto armado em residências paulistanas : no piso do banheiro superior, na laje de cobertura da garagem e no terraço. (projeto sorteado de duas casas geminadas localizadas na alameda Itu - projeto 62 / processo no 74.345/24), p.93.

foto da autora / fonte : Arquivo Geral da Prefeitura do Município de São Paulo

. FIGURA 55 : Exemplo do emprego de vigas de concreto armado em residências paulistanas. (projeto sorteado de residência localizada na rua Pinto Ferraz - projeto 315 / processo no 34.553/34), p.94. foto da autora / fonte : Arquivo Geral da Prefeitura do Município de São Paulo

. FIGURA 56 : Projeto estrutural da residência Armando Álvares Penteado / prancha relativa ao detalhamento das vigas, pilares e lajes do teto do pavimento superior, do atelier e da caixa d'água. (projeto 231 / processo no $42.716 / 31$ ), p.95.

foto da autora / fonte : Arquivo Geral da Prefeitura do Município de São Paulo

FIGURA 57 : Residências à rua Eça de Queirós. p. 100.

foto da autora / acervo particular

. FIGURA 58 : Casas geminadas à rua Martim Francisco. p.100.

foto da autora / acervo particular

. FIGURAS 59, 60 e 61 : Casa mista localizada na esquina das ruas do Arouche e Bento Freitas. (projetos 391 a 396 / processo no 269 / 23), p.101.

fotos da autora (2003) / fonte : Arquivo Geral da Prefeitura do Município de São Paulo

. FIGURA 62 : Casa operária na rua Bartira. (projeto 212 / processo oㅜ 5.379/29), p.102.

foto da autora / fonte : Arquivo Geral da Prefeitura do Município de São Paulo

. FIGURA 63 : Casa operária na rua Cardeal Arcoverde. (projeto 302 / processo no 55.979/34), p. 102.

foto da autora / fonte : Arquivo Geral da Prefeitura do Município de São Paulo

FIGURAS 64 e 65 : Fachada e plantas (térreo e porão) de casa na rua Caramuru projetada por Rino Levi. (projeto 223 / processo no 14.857/30), p.103.

fotos da autora / fonte : Arquivo Geral da Prefeitura do Município de São Paulo

. FIGURA 66 : Plantas (térreo e superior) e fachada de casa na rua Lisboa. (projeto 104 / processo no 12.791/26), p.103.

foto da autora / fonte : Arquivo Geral da Prefeitura do Município de São Paulo

. FIGURAS 67 e 68 : Fachada e plantas (térreo e superior) de casa na rua Alves Guimarães. (projeto 137 / processo no $23.575 / 28)$, p.104.

fotos da autora / fonte : Arquivo Geral da Prefeitura do Município de São Paulo

. FIGURAS 69 e 70 : Fachada e plantas (térreo e superior) de duas casas geminadas na rua Afonso de Freitas projetadas pelo escritório Moya \& Malfatti. (projeto 289 / processo no 76.281/34), p.104.

fotos da autora / fonte : Arquivo Geral da Prefeitura do Município de São Paulo

. FIGURAS 71 e 72 : Fachada e planta de casa localizada na rua Cunha Gago. (projeto 156 / processo no 54.901/28), p.105.

fotos da autora / fonte : Arquivo Geral da Prefeitura do Município de São Paulo

. FIGURAS 73, 74 e 75 : Fachada e plantas (térreo e superior) de residência na rua Tupi projetada por Otávio Lotufo. (projeto 320 / processo no 50.029/35), p.106.

fotos da autora / fonte : Arquivo Geral da Prefeitura do Município de São Paulo 
. FIGURAS 76 e 77: Fachada e plantas (térreo e superior) de residência na rua da Consolação projetada por Álvaro da Costa Vidigal. (projeto 11 / processo nํ32.139/23), p.107.

fotos da autora / fonte : Arquivo Geral da Prefeitura do Município de São Paulo

. FIGURAS 78, 79 e 80 : Fachada e plantas (térreo e superior) de residência na rua José Maria Lisboa projetada por Alfredo Becker. (projeto 255 / processo no 18.049/32), p.107.

fotos da autora / fonte : Arquivo Geral da Prefeitura do Município de São Paulo

. FIGURA 81: Plantas (térreo e superior) de residência localizada na rua Pinto Ferraz. (projeto 315 / processo no $34.553 / 34)$, p. 108.

foto da autora / fonte : Arquivo Geral da Prefeitura do Município de São Paulo

. FIGURA 82 : Plantas (térreo e superior) de casa na avenida Brigadeiro Luiz Antonio. (projeto 283 / processo no 63.548/34), p. 109.

foto da autora / fonte : Arquivo Geral da Prefeitura do Município de São Paulo

. FIGURA 83 : Plantas (porão e térreo) da residência Armando Álvares Penteado na rua Ceará esquina da rua Alagoas. (projeto 231 / processo $n^{\circ} 42.716 / 31$ ), p. 110.

foto da autora / fonte : Arquivo Geral da Prefeitura do Município de São Paulo

. FIGURA 84 : Plantas (térreo e superior) de residência na rua Cubatão. (projeto 154 / processo no 25.740/28), p.111.

foto da autora / fonte : Arquivo Geral da Prefeitura do Município de São Paulo

. FIGURA 85 : Plantas (térreo e garagem / térreo e superior) de casa na rua da Consolação. (projeto 70 / processo no 23.406/25), p.111.

foto da autora / fonte : Arquivo Geral da Prefeitura do Município de São Paulo

. FIGURA 86 : Plantas (térreo e pavimentos superiores) de casa na rua Oscar Freire. (projeto 314 / processo no $55.646 / 34)$, p.112.

foto da autora / fonte : Arquivo Geral da Prefeitura do Município de São Paulo

. FIGURA 87 : Residência de Rui Nogueira. (Ricardo Severo / São Paulo, década de 1920), p. 114.

fonte : Homenagem a Ricardo Severo. Centenário de seu nascimento $1869-1969$, p.48.

. FIGURA 88 : Residência Névio Barbosa na rua Condessa de São Joaquim esquina da rua Bororó. (Victor Dubugras / São Paulo, 1914), p.115.

fonte: REIS FILHO, Nestor Goulart. Racionalismo e Protomodernismo na obra de Victor Dubugras, p. 184.

. FIGURAS 89 e 90 : Residência Eugênio Gomes do Val na rua Albuquerque Lins - foto e desenho da fachada de fundo. (Victor Dubugras / São Paulo, 1918), p.116.

fonte: REIS FILHO, Nestor Goulart. Racionalismo e Protomodernismo na obra de Victor Dubugras, p. 192 e 79.

. FIGURA 91: Residências Luiz Franco do Amaral (1º plano) e Miguel Presgrave (fundo). (Victor Dubugras / Santos, 1915), p. 116.

fonte: REIS FILHO, Nestor Goulart. Racionalismo e Protomodernismo na obra de Victor Dubugras, p. 187.

FIGURA 92 : Residência Miguel Presgrave. (Victor Dubugras / Santos, 1915), p.116.

fonte: REIS FILHO, Nestor Goulart. Racionalismo e Protomodernismo na obra de Victor Dubugras, p. 74.

. FIGURA 93 : Residências Coronel Bento de Carvalho (1ำ plano) e Saturnino de Brito (fundo). (Victor Dubugras / Santos, 1917), p.116.

fonte: REIS FILHO, Nestor Goulart. Racionalismo e Protomodernismo na obra de Victor Dubugras, p. 185.

FIGURA 94 : Residência Adalberto Alves. (Victor Dubugras / Santos, 1917), p.116.

fonte: REIS FILHO, Nestor Goulart. Racionalismo e Protomodernismo na obra de Victor Dubugras, p. 77.

. FIGURA 95 : Ladeira da Memória / detalhe do painel de azulejo do Monumento do Piques. (Victor Dubugras / São Paulo, 1919/22), p.117.

foto da autora / acervo particular

. FIGURA 96 : Ladeira da Memória / detalhe do muro de arrimo. (Victor Dubugras / São Paulo, 1919/22), p.117.

foto da autora / acervo particular 
- FIGURA 97 : Fachada de residência na rua José Maria Lisboa projetada por Bratke \& Botti. (projeto 360 / processo no 105.178/36), p. 118.

foto da autora / fonte : Arquivo Geral da Prefeitura do Município de São Paulo

. FIGURA 98 : Casa da rua Itápolis. (Gregori Warchavchik / São Paulo, 1927), p.118.

fonte: XAVIER, Alberto \& alii. Arquitetura Moderna Paulistana, p.2.

. FIGURA 99 : Instituto Biológico. (Mário Whately \& Cia / São Paulo, 1928/45), p. 119.

acervo : Arquivo CONDEPHAAT (SP)

. FIGURA 100 : Edifício Saldanha Marinho. (Elisiário Bahiana / São Paulo, 1929/33), p. 119.

foto da autora / acervo particular

. FIGURA 101: Edifício João Brícola - antigo Mappin Store. (Elisiário Bahiana / São Paulo, 1936/40), p.119.

foto da autora / acervo particular

. FIGURA 102 : Residência Armando Álvares Penteado na rua Ceará esquina da rua Alagoas. (Dácio Aguiar de Moraes / São Paulo, 1931), p.120.

foto : Guilherme Amadeu / fonte : CAMPOS, Vitor J. B. O Art Déco e a construção do imaginário moderno - um estudo de linguagem arquitetônica, p. 63.

. FIGURA 103 : Residência na rua Ceará, 184. (Jayme C. Fonseca Rodrigues / São Paulo, 1935), p.120. foto da autora / acervo particular

. FIGURA 104 : Residência na rua Ceará, 202. (Jayme C. Fonseca Rodrigues / São Paulo, 1935), p. 120.

foto da autora / acervo particular

. FIGURA 105 : Casa na alameda Itu. (projeto 89 / processo no 2.916/26), p. 125.

foto da autora / fonte : Arquivo Geral da Prefeitura do Município de São Paulo

. FIGURA 106 : Casa à rua Antonio Carlos. (projeto 64 / processo no 21.877/25), p.126.

foto da autora / fonte : Arquivo Geral da Prefeitura do Município de São Paulo

. FIGURA 107: Casa à rua Clélia. (projeto 67 / processo no 21.179/25), p. 126.

foto da autora / fonte : Arquivo Geral da Prefeitura do Município de São Paulo

. FIGURA 108 : Casa à rua da Consolação. (projeto 70 / processo no 23.406/25), p. 126.

foto da autora / fonte : Arquivo Geral da Prefeitura do Município de São Paulo

. FIGURA 109 : Casa à rua da Consolação esquina da alameda Itu. (projeto 6 / processo no 252/23), p. 126.

foto da autora / fonte : Arquivo Geral da Prefeitura do Município de São Paulo

. FIGURA 110 : Casa à rua Conselheiro Brotero. (projeto 121 / processo oํ 48.206/27), p. 127.

foto da autora / fonte : Arquivo Geral da Prefeitura do Município de São Paulo

. FIGURA 111: Casa à rua Domingos Rodrigues. (projeto 208 / processo no 48.556/29), p. 127.

foto da autora / fonte : Arquivo Geral da Prefeitura do Município de São Paulo

. FIGURA 112 : Casa à rua Cônego Eugênio Leite. (projeto 152 / processo no 22.384/28), p. 129.

foto da autora / fonte : Arquivo Geral da Prefeitura do Município de São Paulo

. FIGURA 113 : Casa à rua Araújo. (projeto 215 / processo no 2.602/29), p. 129.

foto da autora / fonte : Arquivo Geral da Prefeitura do Município de São Paulo

. FIGURA 114 : Casas geminadas à rua da Consolação. (projeto 71 /processo no 25.377/25), p. 129.

foto da autora / fonte : Arquivo Geral da Prefeitura do Município de São Paulo

. FIGURA 115 : Casas geminadas à rua Afonso Sardinha. (projeto 86 / processo no 26.000/25), p. 130. foto da autora / fonte : Arquivo Geral da Prefeitura do Município de São Paulo

. FIGURA 116 : Casa à rua Homem de Mello esquina da rua Caetés. (projeto 114 / processo no 4.322/27), p. 130.

foto da autora / fonte : Arquivo Geral da Prefeitura do Município de São Paulo 
FIGURA 117 : Casa à rua Oscar Freire. (projeto 168 / processo oํ 22.042/28), p. 130. foto da autora / fonte : Arquivo Geral da Prefeitura do Município de São Paulo

. FIGURA 118 : Casa à rua Cônego Eugênio Leite. (projeto 151 / processo ํㅜ 50.175/28), p. 131. foto da autora / fonte : Arquivo Geral da Prefeitura do Município de São Paulo

. FIGURA 119 : Casa à rua Sena Madureira. (projeto 179 / processo no 23.836/28), p. 131. foto da autora / fonte : Arquivo Geral da Prefeitura do Município de São Paulo

. FIGURA 120 : Casa à rua Bela Cintra. (projeto 98 / processo oํ 10.896/26), p.131. foto da autora / fonte : Arquivo Geral da Prefeitura do Município de São Paulo

.FIGURA 121 : Casa à alameda Casa Branca. (projeto 90 / processo no 45.780/26), p. 131. foto da autora / fonte : Arquivo Geral da Prefeitura do Município de São Paulo

. FIGURA 122 : Casa à rua da Consolação. (projeto 118 / processo no 40.583/27), p. 133. foto da autora / fonte : Arquivo Geral da Prefeitura do Município de São Paulo

. FIGURA 123 : Casa à rua Fernando de Albuquerque esquina da rua Augusta. (projeto 402 / processo $\left.n^{\circ} 26.715 / 27\right)$, p. 133 .

foto da autora / fonte : Arquivo Geral da Prefeitura do Município de São Paulo

. FIGURA 124 : Casa à alameda Itu. (projeto 279 / processo oㅡ 23.066/34), p. 133.

foto da autora / fonte : Arquivo Geral da Prefeitura do Município de São Paulo

. FIGURA 125 : Casa à rua Sena Madureira. (projeto 316 / processo no 65.345/34), p. 133. foto da autora / fonte : Arquivo Geral da Prefeitura do Município de São Paulo

FIGURA 126 : Casa à rua Martinico Prado. (projeto 240 / processo no 48.428/31), p. 134. foto da autora / fonte : Arquivo Geral da Prefeitura do Município de São Paulo

. FIGURA 127 : Casas geminadas à rua Oscar Freire. (projeto 314 / processo no 55.646/34), p.134. foto da autora / fonte : Arquivo Geral da Prefeitura do Município de São Paulo

. FIGURAS 128 e 129 : Fachadas da residência Armando Álvares Penteado projetada por Dácio Aguiar de Moraes. (projeto 231 /processo ํㅜ 42.716/31), p. 135.

fotos da autora / fonte : Arquivo Geral da Prefeitura do Município de São Paulo

FIGURA 130 : Casa à rua Albuquerque Lins. (projeto 16 / processo № 37.081/23), p. 136. foto da autora / fonte : Arquivo Geral da Prefeitura do Município de São Paulo

. FIGURAS 131 e 132 : Perspectiva e fachada frontal da residência da rua Dr. Franco da Rocha projetada pelo escritório Moya \& Malfatti. (projeto 266 / processo no 17.317/33), p.136. fotos da autora / fonte : Arquivo Geral da Prefeitura do Município de São Paulo

FIGURAS 133 e 134 : Fachada da residência da rua Dr. Franco da Rocha em 2003. p. 136. fotos da autora / acervo particular

. FIGURA 135 : Residência à rua Sabará. (projeto 4 / processo o 9.760/23), p. 137. foto da autora / fonte : Arquivo Geral da Prefeitura do Município de São Paulo

FIGURA 136 : Residência à rua Conselheiro Brotero. (projeto 23 / processo no 15.172/23), p.138. foto da autora / fonte : Arquivo Geral da Prefeitura do Município de São Paulo

. FIGURA 137 : Residência à alameda Santos. (projeto 59 / processo no 56.040/24), p. 138 foto da autora / fonte : Arquivo Geral da Prefeitura do Município de São Paulo

.FIGURAS 138, 139 e 140 : A antiga residência David Ribeiro localizada na alameda Joaquim Eugênio de Lima ilustra os principais estilemas empregados por Victor Dubugras nas suas casas. (Victor Dubugras / São Paulo, 1920), p.148.

fotos da autora / acervo particular

.FIGURAS 141 e 142 : Notar a semelhança volumétrica e de composição arquitetônica entre o desenho de fachada elaborado por Victor Dubugras $(\mathrm{s} / \mathrm{d})$ e a residência à rua Estados Unidos esquina da avenida Brigadeiro Luiz Antonio /.../. p. 149.

fonte: REIS FILHO, Nestor Goulart. Racionalismo e Protomodernismo na obra de Victor Dubugras, p. 198. acervo particular 
. FIGURA 143 : Cunhais e embasamento de pedras na fachada de alvenaria aparente de casa à rua Tupi, artifício de composição arquitetônica muito utilizado nas residências de Victor Dubugras. p.149.

foto da autora / acervo particular

.FIGURAS 144 e 145 : Exemplo de pedras soltas na fachada de tijolos aparentes de casa à rua Desembargador do Vale. Na residência de paredes revestidas da rua Sampaio Viana, nota-se uma interpretação livre da aplicação de pedras na fachada disseminada por Dubugras nas suas obras. p.149.

fotos da autora / acervo particular

.FIGURA 146 : Detalhe de série de janelas seqüenciais da antiga residência David Ribeiro localizada na alameda Joaquim Eugênio de Lima. (Victor Dubugras / São Paulo, 1920), p.150.

foto da autora / acervo particular

FIGURA 147 : Fachada lateral de residência à rua Bela Cintra apresentando série de três janelas seqüenciais marcando a caixa da escada como nas casas de Dubugras . (projeto 144 / processo no 28.938/28), p. 150.

foto da autora / fonte : Arquivo Geral da Prefeitura do Município de São Paulo

.FIGURAS 148, 149 e 150 : Os elementos vazados em forma de meias-luas superpostas dos guardacorpos dos balcões dos terraços superiores comparecem tanto na residência Carlos Whately, projetada por Victor Dubugras (São Paulo, s/d), quanto nas casas da avenida Brasil (projeto 55 / processo no 54.356/24) e da alameda Barros, representantes do "Maneirismo Paulistano". p. 150.

fontes : REIS FILHO, Nestor Goulart.Racionalismo e Protomodernismo na obra de Victor Dubugras, p. 201 / Arquivo Geral da Prefeitura do Município de São Paulo / acervo particular

. FIGURA 151 : Detalhe de beiral decorado com falsos "cachorros" de casa à rua Traipu. p.151. acervo particular

. FIGURA 152 : Detalhe de requadros de massa branca nas envasaduras e nos cunhais de casa à rua Traipu. p.151.

acervo particular

. FIGURA 153 : Residência à rua Piauí apresentando os principais estilemas do "Maneirismo Paulistano". p.152.

foto da autora / acervo particular

. FIGURA 154 : Casas geminadas à rua Frei Caneca. p.153.

foto da autora / acervo particular

. FIGURA 155 : Residência à rua Gabriel dos Santos. p. 153.

foto da autora / acervo particular

. FIGURA 156 : Casas geminadas à rua Jorge Moreira. p.153.

foto da autora / acervo particular

FIGURA 157 : Casa à rua Tomé de Souza. p.154.

foto da autora / acervo particular

. FIGURA 158 : Casa à rua Itararé esquina da rua Herculano de Freitas. p.154.

foto da autora / acervo particular

. FIGURA 159 : Casas geminadas à rua José Antonio Coelho. p.154.

foto da autora / acervo particular

. FIGURAS 160 e 161 : Exemplos de decoração parietal e de ornamentos de massa. Notar o guardacorpo do balcão com figuras de anjos da residência da rua dos Ingleses e o painel em alto relevo embaixo da jardineira da casa da rua Bandeirantes. p.154.

fotos da autora / acervo particular

. FIGURA 162 : Casa à rua Colômbia. p. 155.

acervo particular 
. FIGURAS 163 e 164: Dois conjuntos de casas geminadas à rua Dona Antonia de Queiroz. (projeto 3 / processo no $10.665 / 23)$, p.155.

fotos da autora / fonte : Arquivo Geral da Prefeitura do Município de São Paulo

. FIGURA 165 : “Casa da Árvore” na rua dos Ingleses. p.157.

foto da autora / acervo particular

. FIGURA 166 : Detalhe do muro frontal da "Casa da Árvore”. p.157.

foto da autora / acervo particular

. FIGURA 167 : Desenhos de um depósito de água, ponte rústica e quiosque para jardim utilizando elementos estruturais em forma de troncos e galhos de árvore, constantes no "Relatorio descriptivo sobre o pedido de previlegio de construcções de beton e ferro (melhoramento do Systema Monier)." (eng. Carlos Poma / Rio de Janeiro, 1891), p.157.

acervo : Arquivo Nacional (RJ)

. FIGURA 168 : Casa à rua Canuto do Val esquina da rua Fortunato. p.158.

foto da autora / acervo particular

. FIGURA 169 : Casa à rua Gabriel dos Santos. p.158.

foto da autora / acervo particular

. FIGURA 170 : Casa à rua Goiás. p.158.

foto da autora / acervo particular

. FIGURA 171 : Residência à rua Goiás. p.158.

foto da autora / acervo particular

. FIGURA 172 : Vila Savoy à rua Vitorino Carmilo. p.158.

foto da autora / acervo particular

. FIGURA 173 : Casa à rua dos Franceses. p. 159.

foto da autora / acervo particular

. FIGURA 174 : Casa à rua Herculano de Freitas. p. 159.

foto da autora / acervo particular

. FIGURA 175 : Casa à avenida Independência (inscrição da data 1924 no medalhão), p. 159.

foto da autora / acervo particular

. FIGURA 176 : Casa à rua Canuto do Val. p. 159.

foto da autora / acervo particular

. FIGURA 177 : Residência à rua dos Franceses. p. 159.

foto da autora / acervo particular

. FIGURA 178 : Casa à avenida Pompéia. p.160.

foto da autora / acervo particular

. FIGURA 179: Casa à avenida Pompéia. p.160.

foto da autora / acervo particular

. FIGURA 180: Casa à rua Itambé. p.160.

foto da autora / acervo particular

. FIGURA 181 : Casa à rua Sampaio Viana. p.160.

foto da autora / acervo particular

. FIGURA 182 : Casa à rua Sampaio Viana. p.160.

foto da autora / acervo particular

. FIGURA 183 : Residência à rua Brasílio Machado. p.161.

foto da autora / acervo particular

. FIGURA 184 : Residência à rua Ceará. p.161.

foto da autora / acervo particular 
. FIGURA 185 : Residência à rua Gabriel dos Santos. p.162. foto da autora / acervo particular

. FIGURA 186 : Residência à rua Carlos Sampaio. p.162.

foto da autora / acervo particular

. FIGURA 187 : Casa à rua Venâncio Aires. p.162.

foto da autora / acervo particular

. FIGURA 188 : Residência à rua Aureliano Coutinho. p.162.

foto da autora / acervo particular

. FIGURA 189 : Casas geminadas à avenida Pompéia. p.162.

foto da autora / acervo particular

. FIGURAS 190 e 191 : Residência à rua Avaré em 1931 e em 2003. (Camargo \& Mesquita Engs. Civis e Architectos / São Paulo, 1931), p. 163.

fonte : Revista Polytechnica. no 101, março/abril 1931.

foto da autora (2003) / acervo particular

. FIGURAS 192 e 193 : Residência à rua Treze de Maio. p. 163.

fotos da autora / acervo particular

. FIGURA 194 : Casa à rua Tomé de Souza. p. 163.

foto da autora / acervo particular

. FIGURAS 195 e 196 : Antiga residência de Theodoro Braga na rua Traipu em 1937 e em 2003. p. 164.

fonte: Illustração Brasileira. ํㅜ 26, jun. 1937 / acervo: Biblioteca Nacional (RJ)

foto da autora (2003) / acervo particular

. FIGURA 197 : Detalhe do balcão e do guarda-corpo de ferro trabalhado em motivos marajoaras (1937), p. 164.

fonte: Illustração Brasileira. n 26, jun. 1937 / acervo: Biblioteca Nacional (RJ)

. FIGURA 198 : Vista interna da sala de jantar para o estúdio / piso e gradil em motivos marajoaras (1937), p. 164.

fonte: Illustração Brasileira. n 26, jun. 1937 / acervo: Biblioteca Nacional (RJ)

. FIGURA 199 : Os dois balcões da fachada e a vista sobre o bairro do Pacaembu (1937), p. 164. fonte: Illustração Brasileira. n 26, jun. 1937 / acervo: Biblioteca Nacional (RJ)

. FIGURA 200 : Residência à rua dos Franceses. p.165.

foto da autora / acervo particular

. FIGURA 201 : Casa à avenida Pompéia. p.165.

foto da autora / acervo particular

. FIGURA 202 : Casa à rua Desembargador do Vale. p.165.

foto da autora / acervo particular

. FIGURA 203 : Casa à rua Cotoxó. p.165.

foto da autora / acervo particular

. FIGURA 204 : Residência à praça Farias Brito. p.166.

foto da autora / acervo particular

. FIGURA 205 : Residência à praça Farias Brito esquina da rua Avaré. p.166.

foto da autora / acervo particular

. FIGURA 206 : Casa à rua Cotoxó. p.166.

foto da autora / acervo particular

. FIGURA 207 : Residência à avenida Pacaembu. p.167.

foto da autora / acervo particular 
. FIGURA 208 : Casa à rua João Annes. p.167.

foto da autora / acervo particular

. FIGURA 209 : Residência à rua Goiás. p.167.

foto da autora / acervo particular

. FIGURA 210 : Residência à alameda Barros. p.167.

foto da autora / acervo particular

. FIGURA 211 : Residência Cardoso de Almeida. (Ramos de Azevedo, São Paulo), p. 187. fonte : CARVALHO, Maria Cristina Wolff. Ramos de Azevedo, p. 303.

. FIGURA 212 : Residência Ramos de Azevedo à rua Pirapitingui. (Ramos de Azevedo / São Paulo, 1891), p.187.

acervo : Biblioteca FAUUSP

. FIGURA 213 : Residência do final do século XIX no Largo do Arouche. p.187. fonte: Paulicéias Perdidas, p.75.

. FIGURA 214 : Vila Nenê / Residência Mário Rodrigues. (Victor Dubugras / São Paulo, 1910), p. 188. fonte: REIS FILHO, Nestor Goulart. Racionalismo e Proto-Modernismo na obra de Victor Dubugras, p. 152.

. FIGURA 215 : Residência Horácio Sabino. (Victor Dubugras / São Paulo, 1903), p. 188.

fonte: REIS FILHO, Nestor Goulart. Racionalismo e Proto-Modernismo na obra de Victor Dubugras, p. 51.

. FIGURA 216 : Vila Penteado. (Carlos Ekman / São Paulo, 1903), p. 188.

fonte: Comissão do Patrimônio Cultural. Bens imóveis tombados ou em processo de tombamento da USP, p. 139.

. FIGURA 217 : Residência Numa de Oliveira à avenida Paulista. (Ricardo Severo / São Paulo, 1918), p. 189.

fonte : Homenagem a Ricardo Severo. Centenário de seu nascimento 1869 - 1969, p. 39.

. FIGURA 218 : Residência na avenida Angélica c/ rua Pará. (projeto atribuído a Ricardo Severo / São Paulo, década de 1910), p. 189.

acervo : Biblioteca FAUUSP

. FIGURA 219 : Casa do Guarujá de Ricardo Severo. (fachada frontal), p. 189.

fonte : Homenagem a Ricardo Severo. Centenário de seu nascimento $1869-1969$, p. 80.

. FIGURA 220 : Residência Saturnino de Brito. (Victor Dubugras / Santos, 1916), p. 190. fonte: REIS FILHO, Nestor Goulart. Racionalismo e Protomodernismo na obra de Victor Dubugras, p. 76.

. FIGURA 221 : Residência Heitor Ferreira de Carvalho (Victor Dubugras / Santos, 1920), p. 190. fonte: REIS FILHO, Nestor Goulart. Racionalismo e Protomodernismo na obra de Victor Dubugras, p.78.

FIGURA 222 : Detalhe de parede revestida com pedras ditas "canjiquinha" da antiga residência David Ribeiro à alameda Joaquim Eugênio de Lima. (Victor Dubugras / São Paulo,1920), p. 190. foto da autora / acervo particular

. FIGURA 223 : Residência David Ribeiro à rua Joaquim Eugênio de Lima. (Victor Dubugras / São Paulo, 1920), p. 191.

fonte: REIS FILHO, Nestor Goulart.Racionalismo e Protomodernismo na obra de Victor Dubugras, p. 197.

. FIGURA 224 : Detalhe dos elementos vazados em forma de meias-luas superpostas do muro de casa à rua dos Franceses. p. 191.

foto da autora / acervo particular

. FIGURA 225 : Exemplos de muros com elementos vazados . (Niterói / Rio de Janeiro, c. 1846), p. 191.

fonte: EWBANK, Thomas. Vida no Brasil ou Diário de uma visita à terra do cacaueiro e da palmeira, p. 220.

FIGURA 226 : Residência à rua Brasílio Machado. p. 192.

foto da autora / acervo particular

. FIGURA 227 : Casas à avenida Pompéia. p. 192.

foto da autora / acervo particular 
. FIGURA 228 : Detalhe de painel quadrilobado de azulejos de casa à rua Tomé de Souza. p. 192. foto da autora / acervo particular

. FIGURA 229 : Detalhe das colunas do alpendre de residência à rua Gabriel dos Santos. p. 192. foto da autora / acervo particular

. FIGURA 230 : Residência à rua Peru. p. 193.

foto da autora / acervo particular

. FIGURA 231: Residência à rua Turiassu esquina da rua Capitão Messias. p. 193.

foto da autora / acervo particular

. FIGURA 232 : Residência à avenida Higienópolis esquina da avenida Angélica. p. 193.

foto da autora / acervo particular

. FIGURA 233 : Residência à rua Tomé de Souza. p. 193.

foto da autora / acervo particular

. FIGURA 234 : Casa de vila à alameda Franca. p. 194.

acervo particular

. FIGURA 235 : Casa à rua Traipu. p. 194.

acervo particular

. FIGURA 236 : Detalhe de ornamentos de massa aplicados na fachada de casa à rua Martim Francisco. p. 195.

foto da autora / acervo particular

. FIGURA 237 : Casa à rua Brasílio Machado. p. 195.

acervo particular

. FIGURA 238 : Detalhe do oitão com "triângulos" laterais e guarda-corpo do balcão superior com elementos vazados em forma de meias-luas superpostas de casa à rua Colômbia. p. 195.

acervo particular

. FIGURA 239 : Residência à avenida Pacaembu. p. 196.

foto da autora / acervo particular

. FIGURA 240 : Residência à rua Tomé de Souza. p. 196.

foto da autora / acervo particular

. FIGURA 241: Casa à rua Aureliano Coutinho. p. 196.

foto da autora / acervo particular

. FIGURA 242 : Casa à rua Estados Unidos. p.197.

foto da autora / acervo particular

. FIGURA 243 : Detalhe da empena frontal de casa à rua Tomé de Souza. p.197.

foto da autora / acervo particular

. FIGURA 244 : Casa à rua Minas Gerais. p.197.

foto da autora / acervo particular

FIGURA 245 : Residência à avenida Higienópolis. p.198.

foto da autora / acervo particular

. FIGURA 246 : Residência à rua Bahia. p.198.

foto da autora / acervo particular

. FIGURA 247 : Residência à rua dos Ingleses. p.198.

foto da autora / acervo particular

. FIGURA 248 : Residência à rua Treze de Maio. p.198.

foto da autora / acervo particular

. FIGURA 249 : Residência à rua Treze de Maio. p.198.

foto da autora / acervo particular 
. FIGURA 250 : Residência à rua Estados Unidos. p.199.

foto da autora / acervo particular

. FIGURA 251: Residência à avenida Pacaembu. p.199.

foto da autora / acervo particular

. FIGURA 252 : Sobrados geminados à rua Humberto I. p.199.

foto da autora / acervo particular

. FIGURA 253 : Detalhe de enxaimel de residência à rua Bahia. p.199.

foto da autora / acervo particular

. FIGURA 254 : Casa à rua Rosa e Silva. p. 200.

foto da autora / acervo particular

. FIGURAS 255, 256 e 257 : Vila Art Déco à rua Piauí. Detalhes de porta e de janela. p. 200.

fotos da autora / acervo particular

. FIGURAS 258 e 259 : Antiga residência Sylvio de Almeida à avenida Pacaembu esquina da rua Tupi em 1940 e em 2003. (Moya \& Malfatti, Prêmio Prefeitura - 2ํ Salão Paulista de Belas Artes de 1935 / São Paulo), p. 200.

fonte: Acrópole. ํㅡ 31, nov. 1940, p. 241.

foto da autora (2003) / acervo particular

. FIGURA 260 : Residência Gregori Warchavchik à rua Santa Cruz. (G. Warchavchik / São Paulo, 1927), p. 201

fonte: Arquitetura Italiana em São Paulo, p.131.

. FIGURA 261: Residência à rua Dr. Franco da Rocha. (Moya \& Malfatti - projeto 266 / processo no 17.317/33), p. 201

foto da autora / acervo particular

. FIGURA 262 : Casa Modernista da rua Bahia. (Gregori Warchavchik / São Paulo, 1930), p. 201.

foto da autora / acervo particular

. FIGURAS 263 e 264 : Residência à rua Gabriel dos Santos. p. 202.

fotos da autora / acervo particular

. FIGURA 265 : Residência à rua Treze de Maio. p. 202.

foto da autora / acervo particular

. FIGURA 266 : Residência à rua Bahia. p. 202.

foto da autora / acervo particular

. FIGURA 267 : Residência à rua Goiás. p. 202.

foto da autora / acervo particular

. FIGURA 268 : Residência à avenida Pompéia esquina da rua Cel. Melo de Oliveira. p. 203.

foto da autora / acervo particular

. FIGURA 269 : Casa no bairro da Consolação. p. 203.

acervo particular

. FIGURA 270 : Casas à rua Goiás esquina da rua Bahia. p. 203.

foto da autora / acervo particular 


\section{Lista de plantas:}

- Planta Geral da Cidade de S. Paulo (1905). Comissão Geográfica e Geológica. Planta elaborada por Alexandre Mariano Cococi e Luiz Fructuoso e Costa. esc.: 1.20.000. acervo : Biblioteca Municipal Mário de Andrade. p. 8

- Planta da Cidade de São Paulo (1916). Directoria de Obras e Viação da Prefeitura Municipal. esc.: 1:20.000. acervo : Biblioteca Municipal Mário de Andrade. p. 8

. Planta da Cidade de São Paulo (1928). Repartição de Águas e Esgotos de São Paulo. esc.: 1: 20.000. acervo : Biblioteca Municipal Mário de Andrade. p. 27

\section{Lista de gráficos etc.:}

- Mapa com os perímetros dos dez bairros sorteados das zonas Oeste e Sudoeste/Sul. p. 12 base : Planta da Cidade de São Paulo (1928) / Repartição de Águas e Esgotos de São Paulo. esc.: 1: 20.000

- Gráfico mostrando o número de processos de construcões residenciais levantados por ano nas ruas sorteadas da pesquisa. p. 14

- Curva mostrando a variação do número de processos de construções residenciais levantados por ano nas ruas sorteadas do Grupo I/zona Oeste. p. 15

- Curva mostrando a variação do número de processos de construções residenciais levantados por ano nas ruas sorteadas do Grupo II /zona Sudoeste-Sul. p. 15

. Levantamento dos Estilos - Grupo I /zona Oeste e Grupo II /zona Sudoeste-Sul (período 19231936). p. 122

. Levantamento dos Estilos - Grupo I /zona Oeste. p. 123

. Levantamento dos Estilos -Grupo II /zona Sudoeste-Sul. p. 123

Evolução do Neocolonial Simplificado por ano. p.124

. Evolução do Estilo Indefinido por ano. p.128

. Evolucão do Neocolonial Luso-brasileiro por ano. p. 132

Evolucão do Art Déco por ano. p. 134

. Evolução do Eclético Classicizante por ano. p. 137

. Incidência dos Estilos por ano (período 1923-1936). p. 139

Incidência dos Estilos por Tipologia Programática - Grupos I e II (período 1923-1936). p. 140

Incidência dos Estilos por Tipologia Programática - Grupo I (1923-1935). p. 141

. Incidência dos Estilos por Tipologia Programática - Grupo II (1924-1936). p. 141

Cronologia dos Principais Estilos ou Correntes Estilísticas. p. 186 


\section{Lista de processos de aprovação de construção citados no texto*:}

* O número do projeto corresponde ao número de cadastramento do processo de aprovação de construção no banco de dados Edificações Residenciais. O número de cada processo é composto pelo número do processo propriamente dito seguido de uma barra e do ano em que o projeto de construção foi encaminhado para aprovação na Prefeitura do Município de São Paulo (PMSP).

1. . projeto 4 (processo $n^{\circ} \mathbf{9 . 7 6 0 / 2 3 )}$

2. . projeto 6 (processo $\mathrm{n}^{\circ} \mathbf{2 5 2 / 2 3}$ )

3. . projeto 11 (processo $\mathrm{n}^{0} \mathbf{3 2 . 1 3 9 / 2 3 )}$

4. . projeto 16 (processo $n^{0} \mathbf{3 7 . 0 8 1 / 2 3 )}$

5. . projeto 17 (processo $n^{\circ} \mathbf{2 3 . 8 0 8 / 2 3 )}$

6. . projeto 23 (processo $n^{0} \mathbf{1 5 . 1 7 2 / 2 3}$ )

7. . projeto 59 (processo $\mathrm{n}^{\circ} \mathbf{5 6 . 0 4 0 / 2 4}$ )

8. . projeto 62 (processo $n^{\circ} \mathbf{7 4 . 3 4 5 / 2 4 )}$

9. . projeto 64 (processo $\mathrm{n}^{\circ} \mathbf{2 1 . 8 7 7 / 2 5}$ )

10. . projeto 67 (processo no 21.179/25)

11. . projeto 70 (processo $\mathrm{n}^{\circ} \mathbf{2 3 . 4 0 6 / 2 5}$ )

12. . projeto 71 (processo $\mathrm{n}^{\circ} \mathbf{2 5 . 3 7 7 / 2 5 \text { ) }}$

13. . projeto 86 (processo $n^{0} \mathbf{2 6 . 0 0 0 / 2 5 )}$

14. . projeto 89 (processo $\mathrm{n}^{\circ} \mathbf{2 . 9 1 6 / 2 6}$ )

15. . projeto 90 (processo $\mathrm{n}^{\circ} \mathbf{4 5 . 7 8 0 / 2 6}$ )

16. . projeto 98 (processo $\mathrm{n}^{-} \mathbf{1 0 . 8 9 6 / 2 6}$ )

17. . projeto 104 (processo $n^{\circ} \mathbf{1 2 . 7 9 1 / 2 6 )}$

18. . projeto 114 (processo $\mathrm{n}^{\circ} \mathbf{4 . 3 2 2 / 2 7}$ )

19. . projeto 121 (processo $n^{0} \mathbf{4 8 . 2 0 6 / 2 7}$ )

20. . projeto 137 (processo $n^{0} \mathbf{2 3 . 5 7 5 / 2 8}$ )

21. . projeto 144 (processo $\mathrm{n}^{0} \mathbf{2 8 . 9 3 8 / 2 8}$ )

22. . projeto 151 (processo $n^{\circ} \mathbf{5 0 . 3 7 5 / 2 8}$ )

23. . projeto 152 (processo no $\mathbf{2 2 . 3 8 4 / 2 8}$ )

24. . projeto 154 (processo $\mathrm{n}^{\circ} \mathbf{2 5 . 7 4 0 / 2 8}$ )

25. . projeto 156 (processo no $\mathbf{5 4 . 9 0 1 / 2 8 )}$

26. . projeto 168 (processo $\mathrm{n}^{\circ} \mathbf{2 2 . 0 4 2 / 2 8}$ )

27. . projeto 179 (processo $\mathrm{n}^{\circ} \mathbf{2 3 . 8 3 6 / 2 8}$ )

28. . projeto 208 (processo $n^{0} \mathbf{4 8 . 5 5 6 / 2 9}$ )

29. . projeto 212 (processo $n^{\circ} \mathbf{5 . 3 7 9 / 2 9}$ )

30. . projeto 215 (processo $\mathrm{n}^{\circ} \mathbf{2 . 6 0 2 / 2 9}$ )

31. . projeto 223 (processo $n^{0} \mathbf{1 4 . 8 5 7 / 3 0}$ )

32. . projeto 231 (processo $\mathrm{n} 0 \mathbf{4 2 . 7 1 6 / 3 1}$ )

33. . projeto 240 (processo $\mathrm{n}-\mathbf{4 8 . 4 2 8 / 3 1}$ )

34. . projeto 255 (processo $\mathrm{n}^{0} \mathbf{1 8 . 0 4 9 / 3 2}$ )

35. . projeto 266 (processo $\mathrm{n}$ - 17.317/33)

36. . projetos 268 e 269 (processo $n^{\circ} \mathbf{5 . 0 6 1 / 3 3}$ )

37. . projeto 283 (processo no $\mathbf{6 3 . 5 4 8 / 3 4 )}$ 
38. . projeto 289 (processo $\mathrm{n}^{0} \mathbf{7 6 . 2 8 1 / 3 4 )}$

39. . projeto 302 (processo $\mathrm{n}^{\circ} \mathbf{5 5 . 9 7 9 / 3 4}$ )

40. . projeto 310 (processo $\mathrm{n}$ - 14.942/34)

41. . projeto 314 (processo $\mathrm{n}-55.646 / 34$ )

42. . projeto 315 (processo $\mathrm{n} \times \mathbf{3 4 . 5 5 3 / 3 4}$ )

43. . projeto 320 (processo $n^{0} \mathbf{5 0 . 0 2 9 / 3 5}$ )

44. . projeto 339 (processo $\mathrm{n} 0 \mathbf{4 5 . 4 7 2 / 3 5}$ )

45. . projeto 340 (processo $\mathrm{n}^{\circ} \mathbf{6 4 . 7 1 9 / 3 5}$ )

46. . projeto 360 (processo $\mathrm{n}^{\circ} \mathbf{1 0 5 . 1 7 8 / 3 6 )}$

47. . projetos 375,376 e 377 (processo no 94.125/36)

48. . projetos 391 a 396 (processo no 269/23)

49. . projeto 402 (processo $\mathrm{n}^{\circ} \mathbf{2 6 . 7 1 5 / 2 7}$ )

\section{Abreviaturas utilizadas nesta tese}

\section{Estilos / Correntes Estilísticas:}
. AD - Art Déco
. EC - Eclético Classicizante
. EH - Eclético Historicista
. EI - Estilo Indefinido
. MO - Moderno
. NH - Neocolonial Hispano-americano
. NL - Neocolonial Luso-brasileiro
. NO - Normando / Estilos Norte-europeus
. NS - Neocolonial Simplificado

\section{Tipologias Programáticas Residenciais:}

. CM - casa mista

. CMA - casa classe média alta

. CMB - casa classe média baixa

. CMM - casa classe média média

. CO - casa operária

. PA - palacete 


\section{Apresentação}
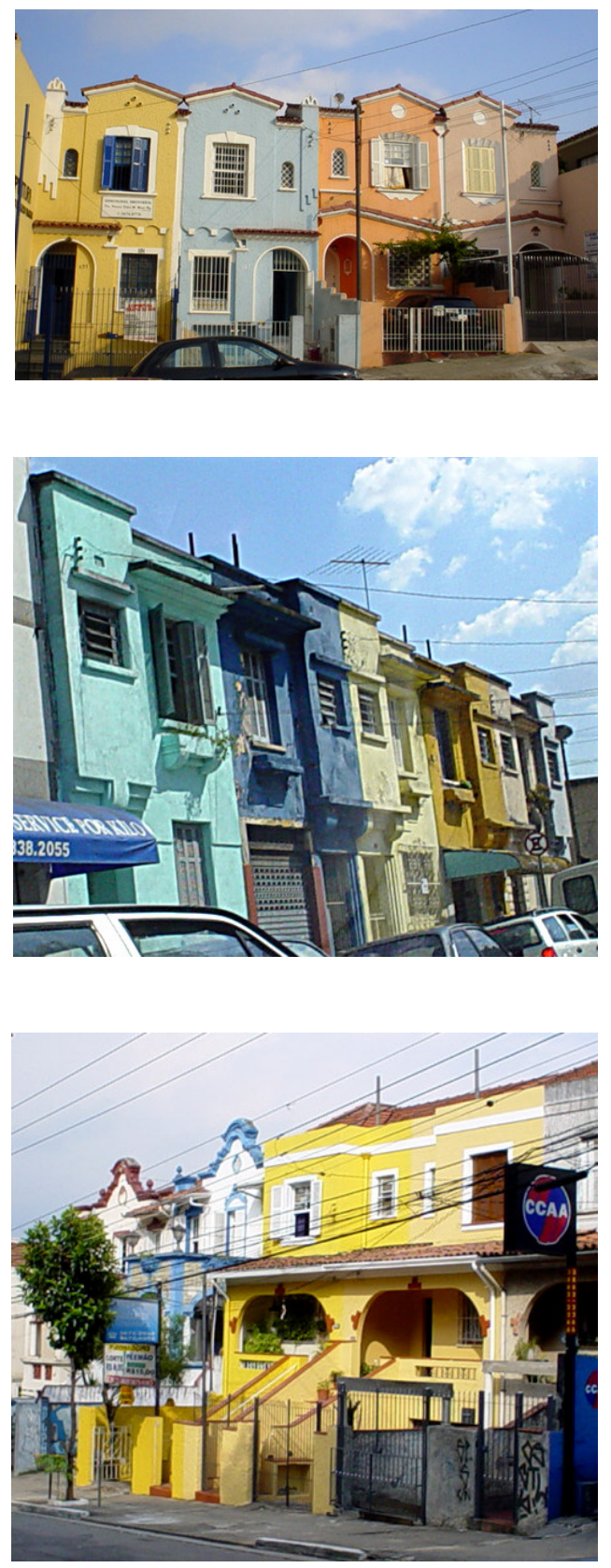
A presente Tese de Doutorado - “Manifestações da arquitetura residencial paulistana entre as Grandes Guerras" - tem como intento dar continuidade ao processo de desenvolvimento de pesquisa acadêmica relativa à história da arquitetura paulistana iniciado por nós com a Dissertação de Mestrado “O Tijolo nas Construções Paulistanas do século XIX" (FAU/USP - 1994).

Devido à nossa formação em Arquitetura e Urbanismo e à atuação profissional na área de preservação do patrimônio cultural da cidade de São Paulo, ${ }^{1}$ temos nos dedicado ao estudo da formação e configuração da paisagem urbana, na qual as edificações apresentam-se como elementos componentes fundamentais de análise. Como decorrência disto surgiu 0 interesse de investigar com maior profundidade a arquitetura residencial popular produzida na cidade de São Paulo durante as décadas de 20 e 30 do século XX, transformando este tema no objeto de pesquisa desta tese. Assim, o foco do trabalho é a caracterização do partido residencial paulistano de classe média através da identificação das suas alterações programáticas e construtivas e da explicitação das questões relativas às mudanças de gosto e à apropriação de novas soluções arquitetônicas e linguagens estilísticas surgidas neste período. ${ }^{2}$

Podemos destacar como justificativa para a elaboração desta tese a oportunidade que tivemos de desenvolver um estudo sistemático e abrangente sobre a produção arquitetônica residencial paulistana de um período pouco estudado pela historiografia da Arquitetura. Pela nossa experiência e contínua observação do espaço urbano, pudemos constatar, ao longo dos anos, que a ocorrência de edifícios de grande valor arquitetônico é excepcional no tecido urbano de São Paulo, cuja paisagem é composta fundamentalmente por casas e edifícios, pertencentes às classes média e baixa da população. Estas construções residenciais populares são bens culturais componentes do patrimônio ambiental urbano paulistano e refletem o estágio tecnológico e cultural alcançado por um grupo ou camada social, revelando também os costumes, as técnicas e os gostos predominantes na época em que foram construídas. Por serem consideradas como destituídas de interesse arquitetônico, essas moradias têm sido freqüentemente esquecidas ou desprezadas pelos

\footnotetext{
${ }^{1}$ Desde 1989 atuamos no Departamento do Patrimônio Histórico (DPH) da Secretaria Municipal de Cultura de São Paulo, onde desenvolvemos, entre outras atividades, inventários de imóveis de interesse de preservação em diversos bairros paulistanos, os chamados IGEPACs - Inventário Geral do Patrimônio Ambiental, Cultural e Urbano da cidade de São Paulo.

2 “.../ Procurando ir além de seus aspectos formais mais elementares, procurando identificar as condições de ocorrência das mudanças sofridas e os agentes das mesmas, com seus alvos sociais, é possível abrir novas perspectivas de interpretação, referindo as mudanças ao contexto social mais amplo, caracterizando os seus mecanismos de emergência e captar, desse modo, os significados assumidos pelos elementos plásticos, para os agentes em questão." In: REIS FILHO, Nestor Goulart. Quadro da Arquitetura no Brasil, p. 187.
} 
estudiosos e críticos da nossa arquitetura. Desse modo, consideramos que o interesse maior deste texto se deve basicamente à abordagem mais aprofundada do tema, insuficientemente explorado pela historiografia corrente da arquitetura paulistana e ao emprego pouco usual de um método de amostragem numa pesquisa de História da Arquitetura.

Finalmente, acreditamos que a reflexão crítica aqui empreendida sobre a produção arquitetônica residencial realizada em São Paulo no período entre as duas Guerras Mundiais nos permitiu precisar com maior clareza o valor intrínseco dessas edificações dentro da história da arquitetura paulistana, ao mesmo tempo em que colaborou efetivamente para uma leitura abrangente do espaço urbano da capital paulista, através do conhecimento mais minucioso dessas edificações, seus construtores e seus habitantes. 


\section{Introdução}
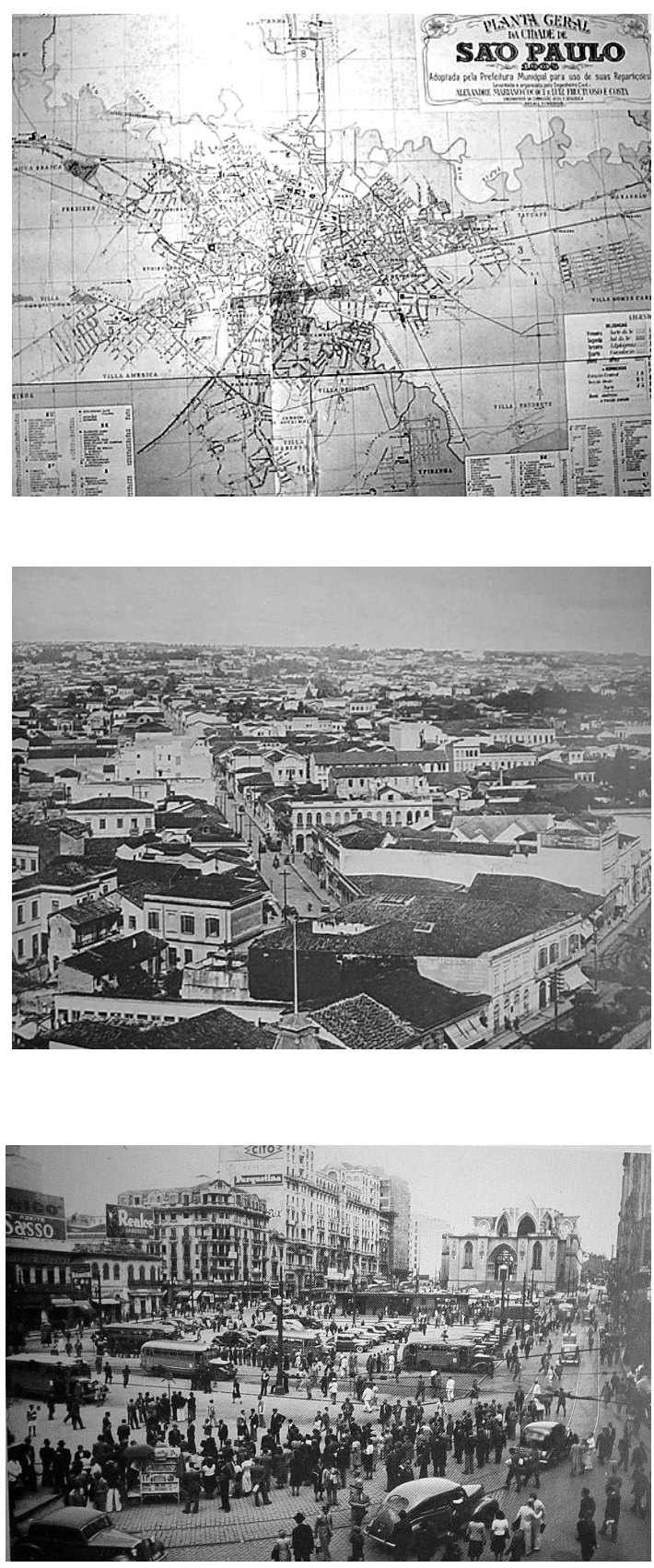
A presente tese se configura numa redação alusiva à produção arquitetônica residencial na cidade de São Paulo no período situado entre as duas Guerras Mundiais, ${ }^{3}$ quando, pela primeira vez, podemos reconhecer que os estratos médios da sociedade paulistana se expressaram "artisticamente" tomando atitudes inéditas dentro do quadro da arquitetura residencial local.

A partir de uma intenção plástica coletiva, motivada muitas vezes por problemas de firmação social e regida por variados processos de criação, a classe média manifestou naquele momento um gosto particularizado através da escolha seletiva de estilemas ${ }^{4}$ e de recriações de estilos arquitetônicos ${ }^{5}$. Apesar de se caracterizar em muitos casos como uma arquitetura realizada anonimamente, essa produção residencial paulistana manipula, reinterpreta e combina soluções estilísticas previamente lançadas por profissionais habilitados, ao mesmo tempo, em que se beneficia de liberdades de expressão nunca admissíveis na arquitetura dita erudita, já que não possui compromisso com qualquer estilo arquitetônico pré-estabelecido, como veremos adiante.

Acreditamos que complementarmente ao estudo desenvolvido neste trabalho, seria muito enriquecedora uma abordagem semiótica do tema, a partir da análise das edificações residenciais do período como signos, o que certamente nos permitiria vislumbrar com novo foco os fenômenos arquitetônicos apresentados. Porém, devido à nossa formação de arquiteto, não nos sentimos capacitados a empreender tal análise no momento, deixando registrada aqui a interessante possibilidade de continuação desse estudo por pesquisadores mais afeitos àquele assunto.

Pelo exposto acima, podemos definir as seguintes indagações consideradas como hipóteses de trabalho nesta Tese de Doutorado:

1. Quais foram os fatores sócio-econômicos que determinaram, na entrada do século XX, a expansão urbana da cidade de São Paulo nas direções oeste, sudoeste e sul e a formação nestas zonas de inúmeros bairros de classe média.

\footnotetext{
${ }^{3}$ Ficou estabelecido, de comum acordo com o professor orientador, um intervalo de estudo para esta tese de catorze anos, de 1923 a 1936. Assim, o ano de 1923 foi escolhido para iniciar a pesquisa porque consideramos que transcorreu um período de mais ou menos quatro anos, após o final da Primeira Grande Guerra, para que o nível de construção em São Paulo fosse completamente normalizado. Esse intervalo de tempo foi definido a priori levando-se em consideração que dentro desse período se manifestaram na sua plenitude os fenômenos arquitetônicos que se desejava estudar, ou seja, a arquitetura residencial paulistana de classe média.

${ }^{4}$ Nesta tese consideraremos estilema como "o termo com que por vezes se designa um traço ou constante estilística." (verbete : Dicionário Eletrônico Houaiss da língua portuguesa 1.0 , 2001). Desta forma, um estilema seria um elemento de repertório estilístico cuja repetição caracteriza um modo peculiar de manifestação artística.

${ }^{5}$ Para efeito deste trabalho definiremos estilo arquitetônico como sendo a singularidade expressiva que confere uma identidade de linguagem a um conjunto de obras arquitetônicas a partir de uma dada combinação de estilemas.
} 
2. Como se caracterizou a ocupação desses "novos" bairros; qual o repertório formal e estilístico empregado nas residências de classe média; quais os programas de necessidades adotados e como as funções da habitação (estar, repouso, serviço) eram exercidas no espaço físico das moradias; quais foram as inovações técnico-construtivas utilizadas nas edificações das décadas de 20 e 30.

3. Quais as possíveis vinculações estéticas entre essa produção arquitetônica popular ${ }^{6}$ e os estilos eruditos vindos do século XIX e os recentes, como o Neocolonial, em suas várias expressões, e o Art Déco.

Assim, para nortear o nosso estudo estabelecemos como pontos de referência :

I. A estruturação social existente na capital paulista no início do século $X X$, cujas camadas médias eram formadas em grande quantidade por imigrantes ou descendentes de estrangeiros;

II. A miscigenação e as mudanças de hábitos surgidas a partir da presença maciça de europeus em São Paulo;

III. A nascente industrialização e a sua rápida expansão, resultante da inversão de capitais provenientes da cultura do café;

IV. O impacto da crise de 1929 na importação de materiais de construção e conseqüentemente sobre o nível construtivo da cidade de São Paulo;

V. Os reflexos das revoluções de 1924, 1930 e 1932 na produção de moradias da capital paulista;

VI. A influência do Código Sanitário (1918) e do Código de Obras (1929) na arquitetura produzida nesse período;

VII. O crescimento horizontal da cidade em todas as direções vinculado à expansão das linhas de bonde elétrico;

VIII. O aparecimento de novos bairros de classe média a partir de loteamentos em áreas até então consideradas rurais;

IX. As "novidades" estilísticas do Neocolonial, Missões, Art Déco etc. difundidas pelos meios de comunicação como o cinema e inúmeras publicações técnicas e de variedades correntes na época.

\footnotetext{
${ }^{6}$ Entenda-se aqui como residências populares as habitações dos diferentes estratos da classe média - classe média baixa, classe média média e classe média alta - diferenciadas das casas operárias (classe baixa) e dos palacetes (classe alta). Segundo Roland Mousnier (As Hierarquias Sociais - de 1450 aos nossos dias) a sociedade de classes aparece com a economia de mercado, cujo valor social máximo está na produção de bens materiais. Os indivíduos se distinguem nos diversos graus da hierarquia social pelo seu papel desempenhado nos modos de produção. A uma dada classe social corresponde um papel análogo no modo de produção, fonte de renda semelhante, estilo de vida e interesses comuns.
} 
Com o objetivo de verificação das hipóteses de trabalho acima formuladas e considerando a natureza desta tese como sendo um estudo de caráter históricoarquitetônico, além da pesquisa bibliográfica específica, realizamos um extenso levantamento nos processos de aprovação de construções residenciais da cidade de São Paulo entre os anos 20 e 30, atualmente sob a guarda do Arquivo Geral da Prefeitura do Município de São Paulo (Piqueri). Consideramos essa pesquisa arquitetônica essencial para o estudo proposto na presente Tese de Doutorado, uma vez que somente o exame aprofundado da documentação e dos projetos integrantes desses processos de construção nos permitiu caracterizar com precisão as manifestações arquitetônicas residenciais paulistanas do período.

Diante da impossibilidade prática de estudar todo o universo de exemplares produzidos na capital paulista entre as Grandes Guerras, tornou-se necessário estabelecer uma amostragem representativa dessas edificações residenciais. Com este objetivo foi executada uma amostragem em três estágios, a partir da seleção através de sorteio das seguintes unidades : bairros, ruas e processos de aprovação de construções residenciais. Assim, inicialmente foi realizada a seleção dos bairros; depois foi feita a escolha das ruas dos bairros sorteados e, por último, procedeu-se à seleção dos processos de construção de residências das ruas previamente escolhidas. O procedimento adotado para os sorteios foi o seguinte :

\section{A-) Unidades do primeiro estágio / Bairros}

O primeiro passo foi identificar quais as áreas da cidade onde predominava o uso residencial de classe média, tendo como base a análise da evolução urbana da cidade de São Paulo ${ }^{7}$ e o estudo do modo de ocupação dos bairros paulistanos existentes no início do século XX.

A cartografia analisada revela que na primeira década a cidade de São Paulo estruturava-se em três porções distintas. A partir da área central observamos que além Tamanduateí situavam-se os bairros da zona leste e além Tietê a ocupação urbana da zona norte. O maior bloco, composto pelo centro histórico e pelos bairros das zonas oeste, sudoeste e sul, encontrava-se limitado pelos rios Tamanduateí, Tietê e Pinheiros. ${ }^{8}$

\footnotetext{
${ }^{7}$ Para esta análise foram utilizados os seguintes elementos cartográficos : Planta da Cidade de São Paulo. (1905); Planta Geral da Cidade de São Paulo (1914) ; Planta da cidade de São Paulo (1916) ; Planta da Cidade de São Paulo para o Indicador Prático (1922) ; Planta da Cidade de São Paulo mostrando todos os Arrabaldes e terrenos arruados (1924) ; Planta da cidade de São Paulo (1928) ; Mappa Topographico do Municipio de São Paulo (1930) .

${ }^{8}$ Ao analisar a situação urbana de São Paulo na primeira década do século $X X$. Pasquale Petrone considerou a divisão da cidade em dois blocos principais, tomando como referência a ocupação geográfica dos imigrantes. Desta forma, para o autor existiam duas cidades : a dos "italianos" (zona leste) e o resto da cidade. Petrone nos diz que ".../ a documentação fotográfica
} 


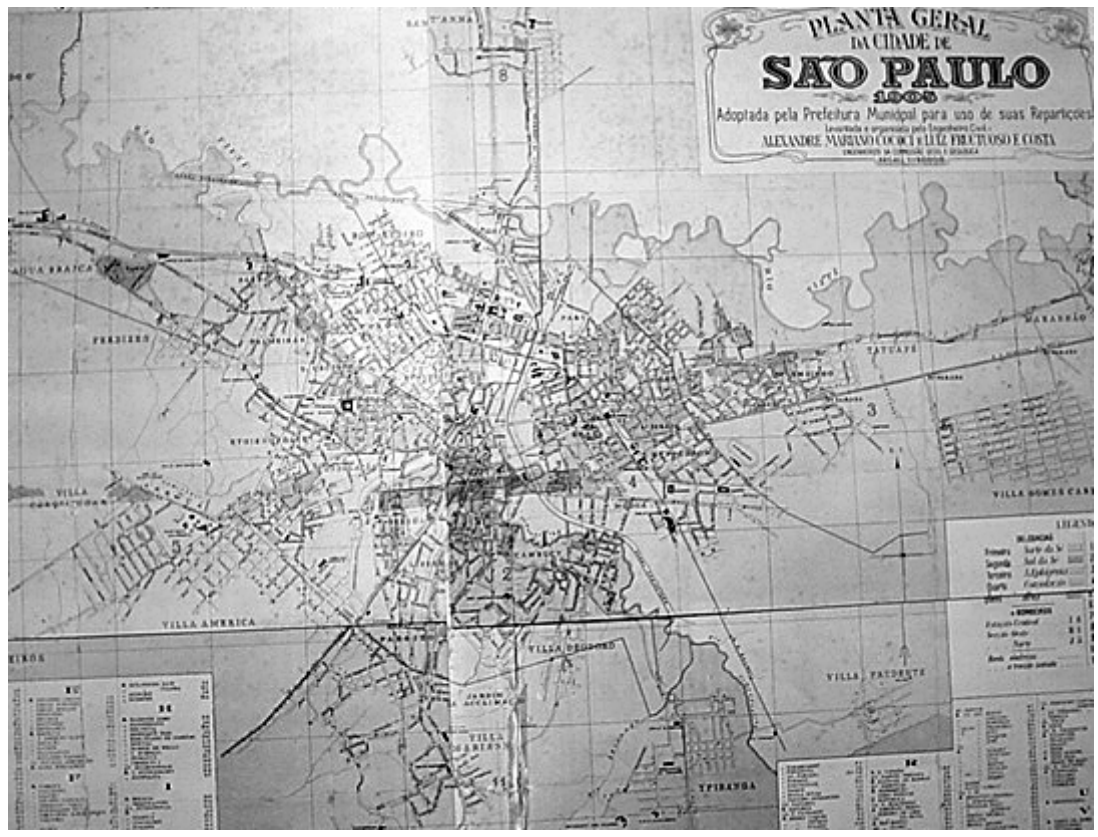

PLANTA GERAL DA CIDADE DE SÃO PAULO (1905)

Comissão Geográfica e Geológica

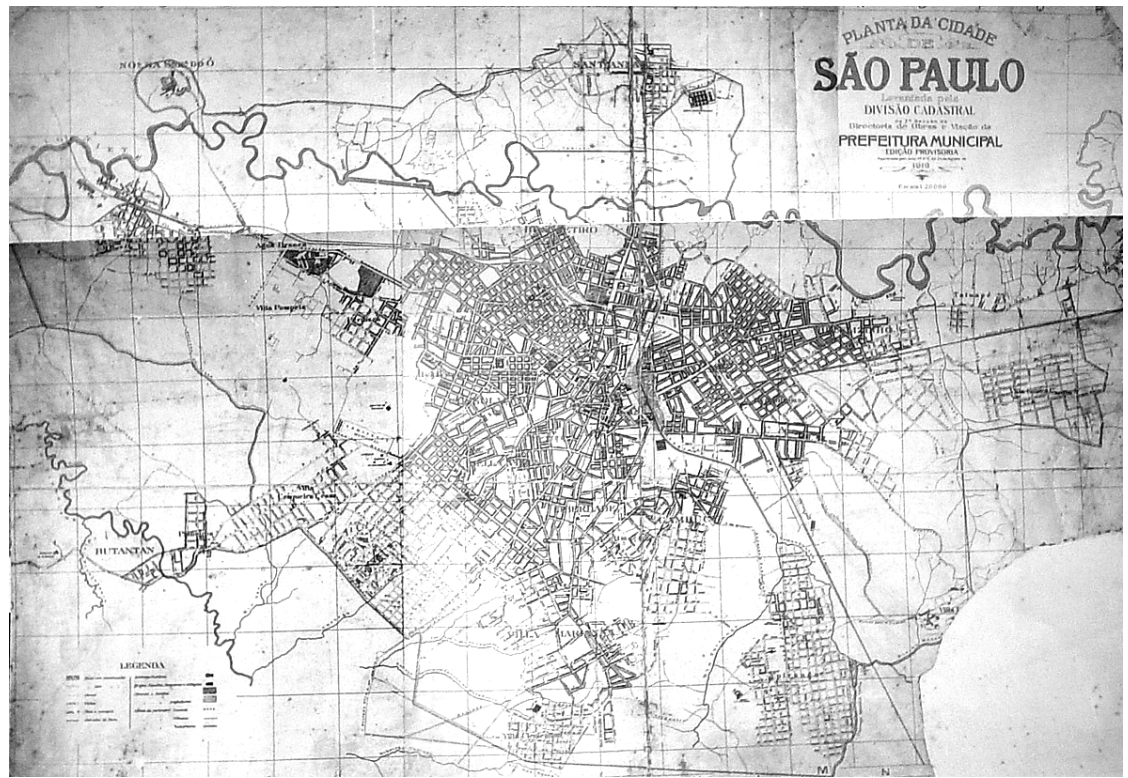

PLANTA DA CIDADE DE SÃO PAULO (1916)

Directoria de Obras e Viação da Prefeitura Municipal

da época /.../ fornece-nos elementos suficientes para que possamos fixar a área urbana, na primeira década do século atual. Dois importantes blocos constituíam a cidade e o divisor entre ambas era representado pela várzea do Tamanduateí. Tal separação apresentava-se com maior nitidez entre o Cambuci e a Moóca e na chamada Várzea do Carmo (atual Parque D. Pedro II). As duas áreas interpenetravam-se, porém no Parí e na Luz, embora através de número reduzido de ruas. Êsses dois blocos formavam, então, duas cidades distintas, como se fôssem duas cidades gêmeas /.../ De um lado, apareciam o velho centro e os bairros das Zonas Oeste, Sudoeste e Sul; de outro lado, o Brás e seus prolongamentos no rumo do Leste." PETRONE, Pasquale. "A Cidade de São Paulo no século XX" In: Revista de História. no 21 e 22, 1955, p. 136. 


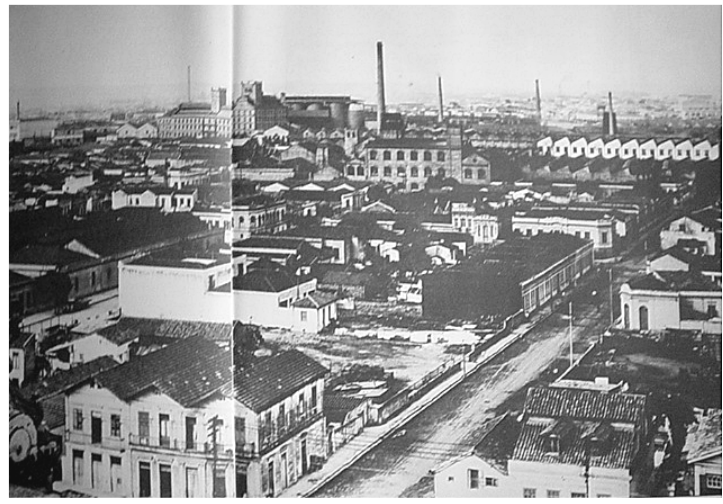

FIGURA 1: Vista do bairro do Brás nos anos 20.

$\mathrm{Na}$ porção leste da cidade, situavamse bairros como o Brás, a Moóca, o Belenzinho e a Penha. Fatores econômicos determinavam o crescimento da cidade nesta direção, como a localização da rede ferroviária, que aproveitava o relevo plano e baixo das várzeas do Tamanduateí e Tietê, e - parque industrial paulistano, que acompanhava os eixos ferroviários em busca de terrenos convenientes para a sua instalação.

A paisagem urbana nesses bairros apresentava uma feição heterogênea marcada por fábricas de médio porte e por habitações ocupadas pelo proletariado estabelecido próximo às indústrias. Estas moradias de classe baixa, padronizadas estilísticamente e de programa de necessidades limitado, representam obras de pouco interesse ao nosso tema.

$\mathrm{Na}$ direção norte, a Freguesia do Ó e Santana encontravam-se fora das intenções expansionistas da época. A ligação física da zona norte com o restante da cidade era precária, restrita à Ponte Grande. O bairro de Santana, surgido a partir de um núcleo colonial do século XVII que se desenvolveu além Tietê por influência do antigo caminho de Atibaia, que passava por Bragança Paulista seguindo em direção a Minas Gerais (Lavras e Pouso Alegre), apresentava até o final da década de 20 uma ocupação urbana ainda incipiente.

$\mathrm{Na}$ terceira e maior porção da cidade localizava-se o centro histórico, onde estava concentrada a maior parte do comércio varejista, das oficinas, das lojas, dos escritórios, dos estabelecimentos de crédito e das repartições públicas, e os bairros das zonas oeste, sudoeste e sul da cidade, que se caracterizavam por serem áreas predominantemente residenciais de classe média e alta.

Na segunda década do século XX a cartografia paulistana mostra que prossegue a rápida expansão horizontal de São Paulo. Os bairros de classe média implantavam-se na periferia da área central, seguindo preferencialmente as direções oeste, sudoeste e sul; enquanto a elite paulistana instalava-se em Campos Elíseos, Higienópolis e nas vertentes leste e oeste do espigão da Avenida Paulista. 


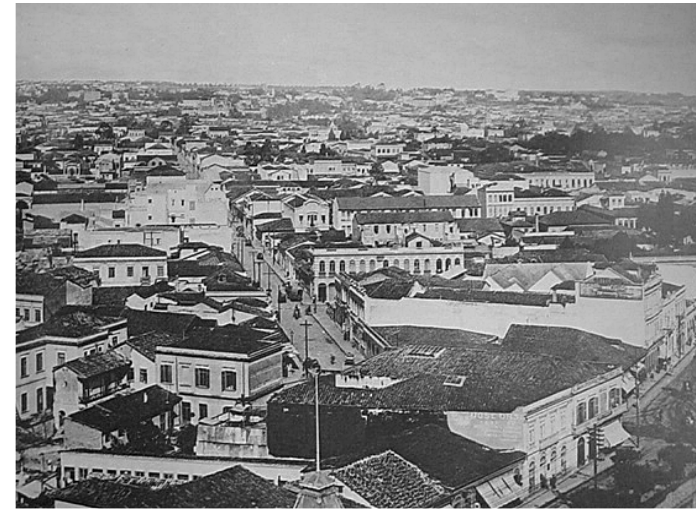

Nesse período surgiram também os primeiros bairros-jardins na porção oestesudoeste-sul da cidade, ocupados primordialmente pela classe alta. O Jardim América foi o pioneiro em 1915 e posteriormente foram loteados e urbanizados o Jardim Europa, o Pacaembu e o Alto da Lapa $^{9}$.

FIGURA 2 : Vista do bairro de Campos Elíseos a partir da Estação da Luz. (1925)

Em face da constatação de localização preferencial de bairros de classe média média e média alta nas zonas oeste, sudoeste e sul da cidade, interesse do nosso trabalho, e tomando como base o Mappa Topographico do Municipio de São Paulo, elaborado por S.A.R.A. Brasil S.A. em 1930, foram listados os vinte bairros existentes nessas regiões. Esta relação de bairros paulistanos teve como objetivo efetuar um primeiro recorte operacional no universo a ser estudado na tese. A seguir, estes vinte bairros foram agrupados e numerados ${ }^{10}$ em dois blocos de dez, em função da sua localização na cidade.

O Grupo I reuniu os bairros da zona Oeste :
1. Consolação ;
2. Vila Buarque ;
3. Higienópolis ;
4. Pacaembu ;
5. Palmeiras / Santa Cecília ;
6. Barra Funda ;
7. Perdizes ;
8. Água Branca ;
9. Lapa ;
10. Vila Pompéia.

\footnotetext{
9 "Coube à Companhia City, de capitais ingleses, iniciar a construção dos bairros-jardins em São Paulo, a partir de 1915. Antes da primeira Grande Guerra, comprou essa empresa extensas áreas de terrenos nas zonas urbanas, investindo desde logo importantes somas em obras de terraplanagem, arruamentos e pavimentação. Já em 1916, achava-se completamente arruado o Jardim América; e outros se Ihe seguiram : Jardim Europa, Pacaembu, Alto da Lapa, Bairro Siciliano e Alto de Sant'Anna." PETRONE, Pasquale. "A Cidade de São Paulo no século XX" In: Revista de História. no 21 e 22, 1955, p. 142.

${ }^{10}$ A numeração dos bairros foi feita em função da necessidade de ordenação dos elementos do universo a ser pesquisado, tendo em vista a realização de um sorteio. Assim, numeramos os bairros listados de acordo com o seguinte critério geográfico : tomamos como ponto inicial o centro histórico e, a partir deste ponto, todos os bairros existentes na zona Oeste foram numerados em ordem crescente e seqüencial até o limite oeste da cidade na época. Os bairros da zona Sudoeste/Sul foram numerados da mesma forma, ou seja, do centro em direção ao sul até a periferia de São Paulo.
} 


\title{
O Grupo II agrupou os bairros da zona Sudoeste/Sul :
}

\author{
11. Cerqueira César ; \\ 12. Vertente Leste da avenida Paulista (lado da rua São Carlos do Pinhal) ; \\ 13. Vertente Oeste da avenida Paulista (lado dos Jardins) ; \\ 14. Vila América (inclui Jardim América); \\ 15. Pinheiros ; \\ 16. Paraíso ; \\ 17. Vila Mariana / Vila Clementino ; \\ 18. Aclimação ; \\ 19. Saúde ; \\ 20. Vila da Saúde.
}

A fim de obtermos a amostra de bairros paulistanos com edificações predominantemente residenciais de classe média, foi realizado um sorteio utilizando a Amostra sistemática com início casual. ${ }^{11} \mathrm{~A}$ opção pela aplicação desse sorteio deveu-se à necessidade de obtermos uma amostra homogênea, ou seja, a mais fiel possível à realidade a ser pesquisada. A Amostra sistemática com início casual é baseada numa escolha aleatória inicial, seguida de uma seleção sistemática dos elementos a partir de uma dada razão de sorteio. ${ }^{12}$ Este procedimento evita o sorteio ao acaso, que poderia provocar distorções na amostra, como a concentração de elementos com determinada característica e a falta de outros significativos para a pesquisa, mascarando os resultados e induzindo a erros na análise.

A definição dos parâmetros estatísticos ${ }^{13}$ utilizados no cálculo da amostra de bairros se deu em função da certeza que possuíamos de encontrar elementos representativos para a pesquisa (edificações residenciais de classe média) em cada um dos vinte bairros listados para o sorteio. O programa de informática empregado para o cálculo da amostra foi o

\footnotetext{
${ }^{11}$ A realização desse sorteio contou com a orientação e a supervisão técnica do estatístico Fernão Dias de Lima, da Faculdade de Saúde Pública / USP.

${ }^{12} \mathrm{~A}$ razão ou intervalo de sorteio é igual à razão entre o número total de elementos a serem pesquisados sobre a amostra. $\mathrm{A}$ razão de sorteio dá o "passo" da Amostra sistemática com início casual, ou seja, define um número que dará a seqüência da seleção dos elementos a partir do primeiro elemento sorteado aleatoriamente. Assim, se a razão de sorteio for igual a dois e o primeiro elemento sorteado é o número um, o próximo elemento a ser escolhido será o número três, seguido pelo cinco, e assim por diante.

13 Para o cálculo da amostra de bairros a serem sorteados foram utilizados os seguintes parâmetros : risco de $5 \%$; expectativa de prevalência de $95 \%$; precisão desejada de $10 \%$; size de 20 . Estes valores foram previamente estabelecidos em função das condições apresentadas e dos resultados desejados para a pesquisa a ser realizada.

$\mathrm{O}$ fator risco corresponde à porcentagem de erro admissível na seleção. A expectativa de prevalência representa o grau de certeza, ou seja, o quanto a amostra vai atender aos critérios desejados. Assim, quanto menor o valor da expectativa de prevalência, maior será o tamanho da amostra, e vice-versa.

A precisão desejada (p.d.) equivale à porcentagem de possibilidade de erro que pode ocorrer no sorteio e depende do quanto se conhece do universo a ser pesquisado; assim, quanto maior o valor da precisão desejada, menor será a amostra e menos rigorosa será a seleção, ou seja, haverá maior possibilidade de erro. O size corresponde ao tamanho do universo a ser pesquisado, que no nosso caso é igual a vinte bairros.
} 
EPIINFO, desenvolvido pelo CDC (Atlanta / EUA), que estabeleceu o sorteio de cinco bairros do Grupo I e de outros cinco do Grupo II, totalizando uma amostra de dez. O sorteio dos dois primeiros bairros de cada um dos grupos foi aleatório, seguido de uma escolha alternada dos outros componentes da amostra numa razão de sorteio igual a dois. ${ }^{14}$ Do Grupo I foram sorteados os bairros da Consolação, Higienópolis, Palmeiras / Santa Cecília, Perdizes e Lapa ; e do Grupo II foram selecionados Cerqueira César, Vertente Oeste da avenida Paulista, Pinheiros, Vila Mariana / Vila Clementino e Saúde.

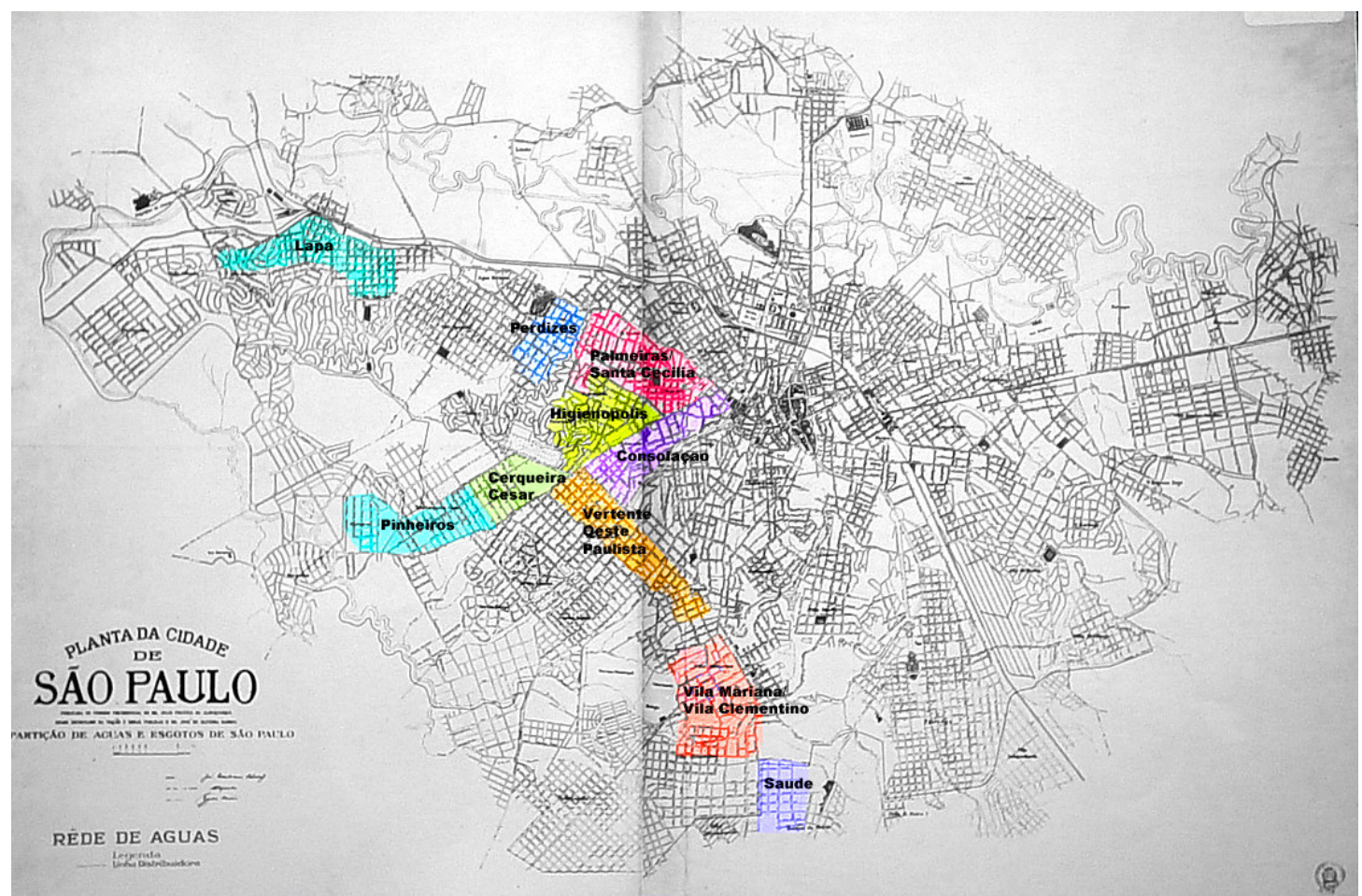

Mapa com os perímetros dos dez bairros sorteados das zonas Oeste e Sudoeste/Sul.

base : Planta da Cidade de São Paulo (1928) / Repartição de Águas e Esgotos de São Paulo. esc.: 1: 20.000

\section{B-) Unidades do segundo estágio / Ruas}

O passo seguinte foi a delimitação do perímetro de cada um dos bairros sorteados a partir da identificação dos arruamentos e loteamentos originais na cartografia paulistana das primeiras décadas do século XX. Com base no Mappa Topographico do Municipio de São

\footnotetext{
${ }^{14}$ Os outros bairros componentes da amostra foram escolhidos em ordem seqüencial de acordo com o sorteio inicial dos dois primeiros elementos. Assim, se no sorteio inicial deu o número um, foram selecionados todos os elementos ímpares e, se deu o número dois, foram escolhidos todos os elementos pares do conjunto.
} 
Paulo (1930) listamos e numeramos todas as ruas existentes dentro dos limites de cada bairro. A numeração das ruas foi realizada em ordem crescente e obedeceu a um critério geográfico : as ruas paralelas de cada bairro foram numeradas do norte para o sul e as ruas transversais foram numeradas do leste para o oeste. No Grupo I (zona Oeste) relacionamos 212 ruas ${ }^{15}$ e no Grupo II (zona Sudoeste/Sul) listamos 179 ruas, ${ }^{16}$ perfazendo um total de 391.

Com o auxílio do programa EPIINFO ${ }^{17}$ calculamos a amostra de ruas proporcional para cada bairro pesquisado. Assim, ficou estabelecido que do total de 391 ruas seriam sorteadas 130 por sorteio sistemático com intervalo igual a três. A amostra foi estratificada pelas duas zonas, sendo sorteadas 68 ruas dos bairros da zona oeste e 62 dos bairros da zona Sudoeste/Sul.

Após o sorteio elaboramos listagens das ruas selecionadas para cada um dos dez bairros. Estas listagens serviram de base para a pesquisa realizada nos processos de aprovação de construções residenciais do Arquivo Geral da Prefeitura do Município de São Paulo (Piqueri).

\section{C-) Unidades do terceiro estágio / Processos de Aprovação de Construções}

\section{Residenciais}

Antes de dar início à etapa de levantamento e seleção dos processos de aprovação de construções residenciais e considerando a necessidade de uma nova adequação operacional, resolvemos efetuar um recorte temporal para a redução do número de elementos a serem pesquisados. Deste modo, para obtermos uma amostra confiável da produção residencial paulistana dos anos 20 e 30 , que revelasse todas as manifestações estilísticas e programáticas ocorridas entre as Grandes Guerras, definimos o intervalo de 1923 a 1936 como período base da pesquisa. ${ }^{18}$

\footnotetext{
${ }^{15}$ Foram listadas 36 ruas no bairro da Consolação, 43 em Higienópolis, 50 em Palmeiras / Santa Cecília, 33 em Perdizes e 50 na Lapa.

${ }^{16}$ Foram listadas 13 ruas no bairro de Cerqueira César, 40 na Vertente Oeste da avenida Paulista, 32 em Pinheiros, 46 em Vila Mariana / Vila Clementino e 48 na Saúde.

${ }^{17}$ Os parâmetros utilizados para a amostra de ruas foram os mesmos empregados no cálculo da amostra de bairros - risco de $5 \%$, expectativa de prevalência de $95 \%$ e precisão desejada de $10 \%$.

${ }^{18}$ Como já dissemos o intervalo da pesquisa (1923-1936) foi estabelecido de comum acordo com o orientador. Na ocasião também se decidiu que os processos de construção dos bairros do Grupo I (zona oeste) seriam levantados nos anos ímpares (1923, 1925 etc.), enquanto que os do Grupo II (zonas sudoeste e sul) seriam pesquisados nos anos pares (1924,1926 etc.). Este procedimento foi considerado admissível dentro da proposta da tese, uma vez que o intervalo alternado de um ano entre os levantamentos não implicou em alterações significativas na definição do quadro arquitetônico de cada zona.
} 
A pesquisa no Arquivo Geral da Prefeitura do Município de São Paulo (Piqueri) teve início com o levantamento das fichas ${ }^{19}$ de todos os processos de aprovação de construções residenciais aprovados nas ruas sorteadas entre 1923 e 1936. Neste levantamento foram listados 2.295 processos, dos quais 937 correspondiam à construção de residências localizadas em ruas do Grupo I (zona Oeste) e 1358 referiam-se a casas situadas nas ruas do Grupo II (zona Sudoeste/Sul). O cálculo da amostra ${ }^{20}$ determinou o sorteio de 573 processos de construção, estratificado em 273 processos para as ruas do Grupo I e 300 para as do Grupo II. Como nos sorteios anteriores, adotamos a Amostra sistemática com início casual com intervalo igual a quatro para selecionar os processos por ano e por bairro, na ordem seqüencial das ruas numeradas em ordem alfabética. Finalmente, calculamos a fração de amostragem (f), que corresponde à porcentagem do universo que vai ser pesquisada, alcançando a fração de 0,0416 , ou seja, uma amostra equivalente a pouco mais de $4 \%$ do total. ${ }^{21}$

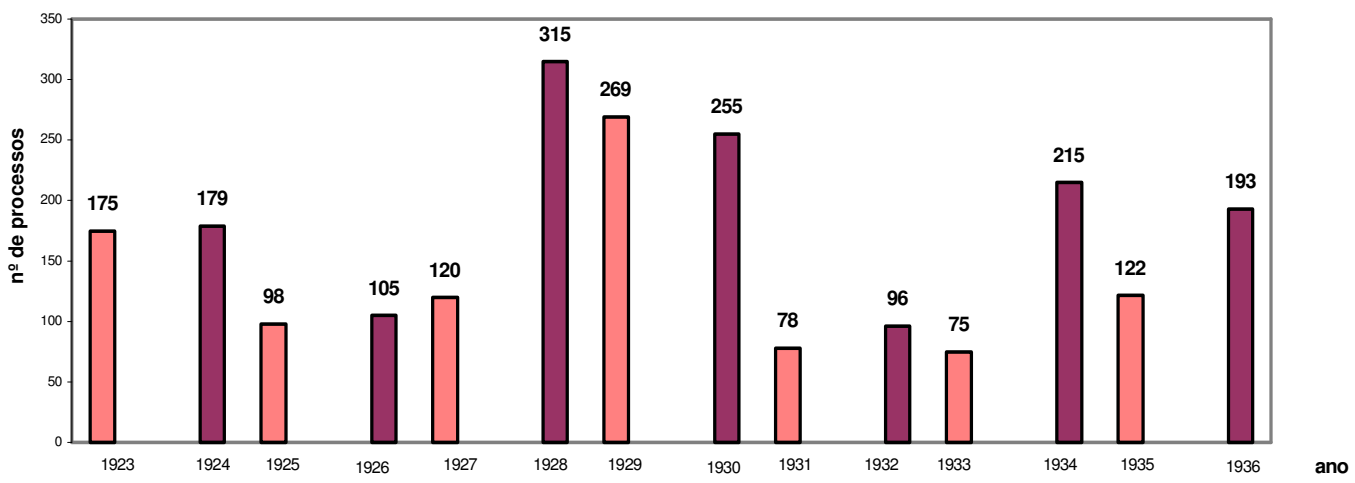

\section{GRÁFICO MOSTRANDO O NÚMERO DE PROCESSOS DE CONSTRUÇÕES RESIDENCIAIS LEVANTADOS POR ANO NAS RUAS SORTEADAS DA PESQUISA}

\section{Grupo I /zona Oeste}

Grupo II /zona Sudoeste/Sul

\footnotetext{
${ }^{19}$ O fichário de processos de construção do Arquivo Geral da Prefeitura do Município de São Paulo está organizado por ano e por endereço dos imóveis (nome de rua em ordem alfabética). As fichas contém os seguintes dados : número do processo (antigo), assunto, nome do interessado, endereço do imóvel, data de autuação do processo.

${ }^{20}$ Adotamos como parâmetros estatísticos para a amostra dos processos uma precisão desejada de $5 \%$ e uma expectativa de prevalência de $50 \%$. Este valor de expectativa de prevalência é comumente utilizado na análise da pior situação de incerteza, ou seja, nos casos em que não se conhece o universo a ser pesquisado e não se tem certeza se os elementos encontrados irão atender aos objetivos da pesquisa.

${ }^{21}$ A fração de amostragem (f) é definida pelo produto das probabilidades de sorteio estabelecidas em cada um dos três estágios, que no nosso caso é igual a $(1 / 2) \times(1 / 3) \times(1 / 4)=0,0416$; este valor é considerado próximo do ideal que é de 0,05 , o que nos permite garantir confiabilidade à amostra alcançada. A avaliação do processo de obtenção da amostra e o cálculo da fração de amostragem foram realizados pela professora Dra. Nilza Nunes da Silva, Livre Docente da Faculdade de Saúde Pública / USP, especialista em amostragem.
} 


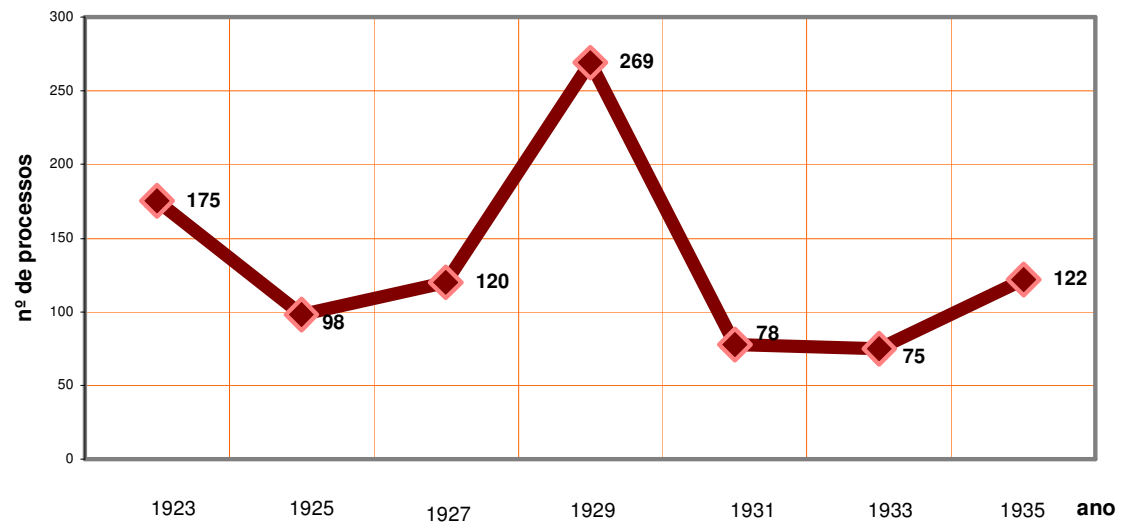

\section{CURVA MOSTRANDO A VARIAÇÃO DO NÚMERO DE PROCESSOS DE CONSTRUÇÕES RESIDENCIAIS LEVANTADOS POR ANO NAS RUAS SORTEADAS DO GRUPO I / ZONA OESTE}

total de processos levantados : 937

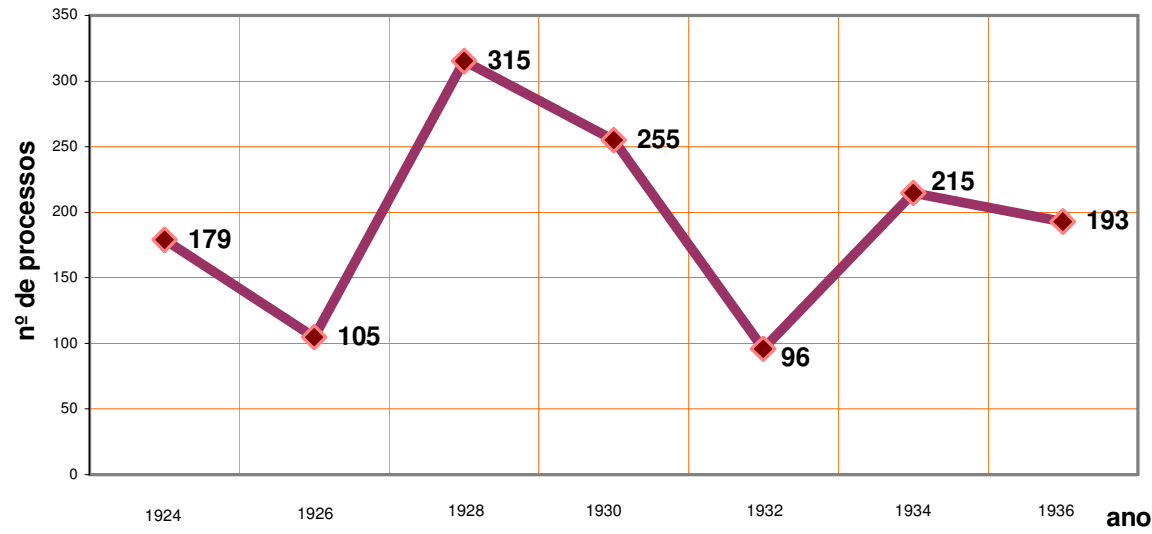

\section{CURVA MOSTRANDO A VARIAÇÃO DO NÚMERO DE PROCESSOS DE CONSTRUÇÕES RESIDENCIAIS LEVANTADOS POR ANO NAS RUAS SORTEADAS DO GRUPO II / ZONA SUDOESTE/SUL}

total de processos levantados : 1358

Notar a semelhança entre as duas curvas que indicam a variação do nível construtivo nas zonas Oeste e Sudoeste/Sul da cidade de São Paulo durante o período estudado. As duas curvas foram elaboradas a partir do levantamento do número total de processos de projetos residenciais apresentados para aprovação da Municipalidade nas ruas sorteadas dos bairros selecionados nas duas zonas pesquisadas. Entre 1923 e 1926 percebe-se nas duas curvas o decréscimo do número de novas construções como decorrência provável da turbulência política que culminou na Revolução de 1924. Em meados da década de 20, as curvas se tornam ascendentes denotando o crescimento do nível de construção de moradias na capital paulista. A partir de 1929 nota-se um acentuado declínio das curvas, talvez conseqüência direta do adverso contexto econômico (crise causada pelo crack da Bolsa de Nova lorque) e político (Revoluções de 30 e 32) vigente na época. Após a Revolução Constitucionalista, há uma retomada do nível construtivo na cidade de São Paulo, que pode ser percebida no progressivo aumento do número de novas casas em ambas as zonas. 
Após o último sorteio, elaboramos listagens organizadas por ano dos processos de construção a serem inventariados. A seguir, estas listagens foram encaminhadas ao Arquivo Geral para a localização dos 573 processos sorteados, visando o posterior fichamento e documentação fotográfica dos projetos arquitetônicos neles incluídos. Em função da não localização de inúmeros processos e do descarte de outros tantos, referentes a assuntos que não se adequavam aos propósitos específicos da pesquisa (que visava somente projetos de construção de residências unifamiliares), foram fichados e documentados 407 projetos, ${ }^{22}$ correspondendo este número ao universo de elementos da pesquisa arquitetônica.

O inventário das edificações residenciais do período foi realizado com base nesses processos de construção e a partir da análise das partes gráficas dos projetos (plantas, cortes e fachadas etc.) e da documentação anexada, como requerimento, memorial descritivo, memória de cálculo etc. Para cada imóvel foi elaborada uma ficha individual, na qual constavam dados gerais sobre o processo ( $n^{\circ}$ do processo, data de autuação na Prefeitura, endereço, proprietário, autor do projeto e construtor, documentação integrante do processo e peças gráficas) e sobre a edificação (número de construções existentes no terreno, recuos, número de pavimentos, programa de necessidades, tipologia programática, acabamentos externos e estilo arquitetônico). As informações constantes nas fichas foram complementadas com uma documentação fotográfica das plantas e fachadas das edificações.

No momento seguinte, reconhecemos a necessidade operacional da elaboração de um banco de dados tendo em vista uma eficiente sistematização das fichas, que permitisse uma agilização na recuperação, cruzamento e superposição das informações, possibilitando também a realização de tabelas, listagens e gráficos com os dados cadastrados. Assim, tomando como base o modelo de ficha utilizado na pesquisa arquitetônica, foi desenvolvido o banco de dados Edificações Residenciais, empregando o programa Access da Microsoft. ${ }^{23}$ Nesse banco de dados foram inseridas todas as informações coletadas nos processos e constantes nas fichas de inventário, ${ }^{24}$ que serviram de base para as nossas análises na presente tese.

\footnotetext{
${ }^{22}$ Este número de processos fichados incluiu todas as tipologias arquitetônicas residenciais previamente estabelecidas. Foram consideradas na pesquisa desde casas operárias até palacetes, sem exclusão, porque o que se pretendia montar era um quadro que refletisse a situação arquitetônica residencial em São Paulo, tanto em termos quantitativos, quanto em termos qualitativos.

${ }^{23}$ O projeto e a montagem do banco de dados foram realizados pelos arquitetos Jorge Lody e Glória Bayeux da Seção Técnica de Divulgação e Publicações (STDP) do Departamento do Patrimônio Histórico (DPH).

${ }^{24}$ A inserção dos dados das fichas de inventário no banco de dados foi realizada por Francisca Correia Godoy d' Alambert.
} 
Paralelamente à pesquisa arquitetônica, via sorteio, efetuamos um levantamento fotográfico livre e complementar de exemplares residenciais remanescentes das décadas de 20 e 30, em diversos bairros das zonas oeste, sudoeste e sul da cidade de São Paulo, para documentar os diferentes estilemas que caracterizaram estilisticamente as residências paulistanas de classe média desse período, definindo um código estético particularizado.

$\mathrm{Na}$ análise crítica dos dados sistematizados das fichas de inventário das edificações residenciais foi empregado o método comparativo indutivo. Este método permitiu a identificação e a classificação dos elementos programáticos, construtivos, formais e estilísticos dos projetos arquitetônicos sorteados a partir da comparação com as obras paradigmáticas do período e com os exemplares remanescentes fotografados. Esta análise comparativa indutiva nos permitiu obter a objetividade necessária para realizarmos a crítica da produção arquitetônica residencial paulistana dos anos 20 e 30, ao mesmo tempo, em que nos possibilitou priorizar uma análise morfológica, imprescindível para o nosso estudo. Graças a este método foi possível comparar os diversos estilemas encontrados "/../ para flagrar, entre eles, aproximações e diferenças a fim de captar as peculariedades que os diversificam e especificam." ${ }^{25}$ A comprovação das hipóteses e a formulação das conclusões foram feitas a partir dos parâmetros definidos no início desta introdução.

O conteúdo teórico da presente Tese de Doutorado foi estruturado e desenvolvido em três capítulos : São Paulo nas primeiras décadas do século XX; Os modelos estilísticos em voga nos anos 20 e 30 ; Residências paulistanas entre as Grandes Guerras.

No capítulo São Paulo nas primeiras décadas do século $X X$ esboçamos um quadro geral da situação da capital paulista e de seus habitantes a partir do final do oitocentismo até os anos 30 , salientando os aspectos mais relevantes de caráter econômico, social, urbanístico e arquitetônico, de modo a detectar e melhor compreender as causas que influenciaram e, em alguns casos, até determinaram a singular manifestação arquitetônica residencial das camadas médias da população paulistana nos anos entre a Primeira e a Segunda Grandes Guerras. Esta seção foi subdividida em três partes: Panorama Geral, Aspectos Urbanísticos e Aspectos Arquitetônicos.

O capítulo Os modelos estilísticos em voga nos anos 20 e 30 teve como objetivo descrever e caracterizar estilisticamente as correntes arquitetônicas mais significativas deste período que, no nosso entender, influenciaram mais diretamente o gosto da classe média

\footnotetext{
${ }^{25}$ In: FERRARA, Lucrécia D’ Aléssio. A Estratégia dos Signos, p.XIII.
} 
paulistana. Dessa forma, foram apresentados O Neocolonial e a procura da modernidade e da identidade cultural e A nova moda do Art Déco.

Na última seção da tese, Residências paulistanas entre as Grandes Guerras, identificamos e caracterizamos as edificações residenciais construídas neste período, com base na análise dos projetos selecionados na mencionada pesquisa, realizada no Arquivo Geral da Prefeitura do Município de São Paulo (Piqueri), e apoiados pela nossa documentação fotográfica de exemplares arquitetônicos remanescentes. Assim, para facilitar a abordagem deste tema, que constitui o fundamento da presente tese, este capítulo foi subdividido em quatro sub-capítulos : As inovações técnico-construtivas ; Os programas de necessidades ; O repertório formal e estilístico ; As recriações e os sincretismos arquitetônicos : o surgimento de uma linguagem estilística paulistana.

Nos três primeiros sub-capítulos investigamos mais atentamente questões próprias às residências produzidas pelos estratos médios da sociedade paulistana, como a introdução do uso do concreto armado e suas implicações na melhoria da qualidade construtiva, as várias soluções programáticas surgidas naquela época, as diferentes formas de expressão arquitetural e o repertório estilístico empregado, entre outras. Na última parte do capítulo apresentamos a discussão sobre o aparecimento de uma linguagem arquitetônica particularizada em São Paulo, resultante de recriações e soluções sincréticas baseadas em estilemas dos modelos arquitetônicos eruditos mais difundidos nos anos 20 e 30.

Nas Considerações Finais do trabalho expomos de modo sintético as constatações e deduções a que chegamos a partir do estudo pormenorizado das construções residenciais paulistanas empreendido ao longo da tese. Complementando o texto, as Referências Bibliográficas e uma seção de Apêndices, com uma Síntese dos principais estilos ou correntes estilísticas presentes na arquitetura residencial paulistana a partir do final do século XIX e uma Relação dos projetos residenciais sorteados classificados por ano e autor do projeto, ambas elaboradas para um melhor entendimento do trabalho na sua integralidade. 


\section{São Paulo nas primeiras décadas do século XX}
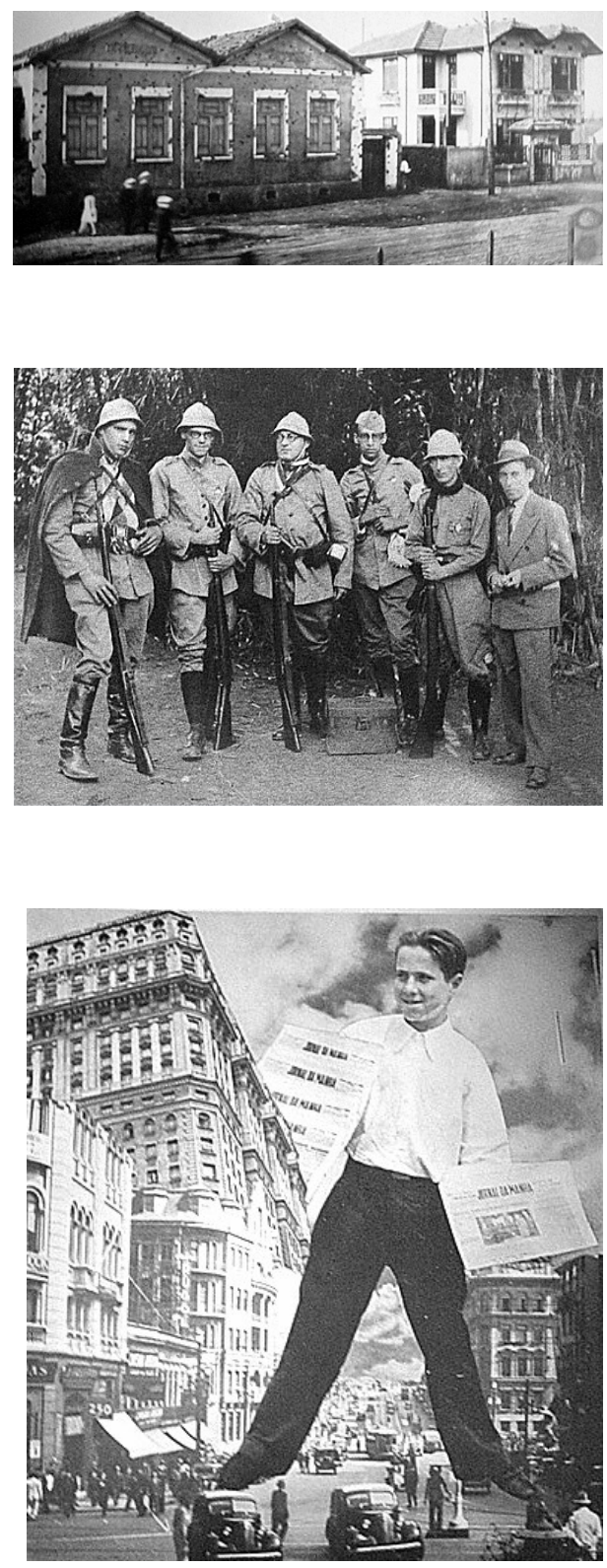


\section{I.1. Panorama Geral}

A cidade de São Paulo rompeu o século $X X$ no mesmo ritmo alucinante de crescimento econômico, demográfico e urbano que a marcou no último quartel do oitocentismo. A cada dia os números cresciam assustadoramente.

Era o dinheiro das safras do café em ascensão gerando grandes somas de dinheiro que circulavam pelo comércio paulistano e eram reempregadas em novas atividades econômicas, como a indústria nascente, atividades comerciais, de serviços e a construção de moradias de aluguel para os contingentes populacionais continuamente incorporados à cidade. ${ }^{1}$

Eram as novas levas de imigrantes estrangeiros, principalmente italianos, chegando incessantemente e trazendo consigo novos costumes e gostos, e transformando rapidamente a capital paulista numa cidade cosmopolita, de vários sotaques, de diversas feições.

Era a cidade se expandindo em todas as direções através do surgimento de novos bairros e da abertura de novas ruas a partir do loteamento ininterrupto do cinturão de chácaras que envolviam o centro histórico.

Eram construções ecléticas de todos os tipos - comerciais, residenciais, institucionais etc. - sendo levantadas em alvenaria de tijolos num frenesi incontrolável por todos os cantos da cidade.

Assim, o quadro econômico, social e urbano de São Paulo nos primeiros anos do novo século assombrava sobremaneira todos os que aqui passavam ${ }^{2} \mathrm{e}$, principalmente, os seus habitantes, que assistiam perplexos às rápidas e acentuadas mudanças que estavam ocorrendo na cidade. ${ }^{3}$

\footnotetext{
“.../ Desde que a nova sistemática da economia cafeeira entrou em ação, São Paulo passou a crescer numa escala espetacular e, de núcleo periférico com população flutuante, passou a pólo econômico mais dinâmico do país e a centro político onde eram decididos os destinos da República." In: SEVCENKO, Nicolau. Orfeu Extático na Metrópole - São Paulo Sociedade e Cultura nos frementes anos 20, p. 108 e 109.

${ }^{2}$ Ver : BRUNO, Ernani da Silva. Memória da cidade de São Paulo: depoimentos dos moradores e visitantes, 1553-1958.

3 "De tal modo o estranhamento se impunha e era difuso, que envolvia a própria identidade da cidade. Afinal, São Paulo não era uma cidade nem de negros, nem de brancos e nem de mestiços; nem de estrangeiros e nem de brasileiros; nem americana, nem européia, nem nativa; nem era industrial, apesar do volume crescente das fábricas, nem entreposto agrícola, apesar da importância crucial do café; não era tropical, nem subtropical; não era ainda moderna, mas já não tinha mais passado. Essa cidade que brotou súbita e inexplicavelmente, como um colossal cogumelo depois da chuva, era um enigma para seus próprios habitantes, perplexos, tentando entendê-lo como podiam, enquanto lutavam para não serem devorados." In: SEVCENKO, Nicolau. Orfeu Extático na Metrópole - São Paulo Sociedade e Cultura nos frementes anos 20, p. 31.
} 
Até os anos 10 essa situação pouco se alterou, progredindo num movimento contínuo de expansão urbana, de aumento do nível de construção, de grandes modificações da sociedade paulistana etc.

Com o início da Primeira Guerra Mundial (1914/18) a economia paulistana se retraiu devido à diminuição da exportação do café. A importação de produtos europeus foi interrompida, provocando o desabastecimento, que era suprido parcialmente pelos Estados Unidos. ${ }^{4}$ Como conseqüência, o nível de construção em São Paulo caiu drasticamente, impactado pelo aumento abusivo dos preços dos materiais de construção e de acabamentos, quase todos importados, com exceção dos materiais cerâmicos, tijolos e telhas, que já eram produzidos em grande escala na cidade.

Essa redução significativa do nível de construção paulistano pode ser claramente constatada através do "Diagramma das Construcções em S. Paulo de 1901 a 1928" elaborado pelo engenheiro Arthur Saboya em 1929, que retrata a variação do número de novas edificações aprovadas pela municipalidade paulistana ao longo de quase três décadas. ${ }^{5}$ A curva delineada neste diagrama tem como base dados constantes dos Relatórios Anuais da Diretoria de Obras Municipais relativos ao movimento construtivo de São Paulo entre 1901 e 1928. O engenheiro Arthur Saboya, então Diretor da Segunda Secção Técnica da Prefeitura Municipal, em entrevista ao jornal "Correio Paulistano", aponta além da Primeira Grande Guerra, a Lei Municipal no 1.874 (1915), ${ }^{6}$ a Gripe Espanhola

\footnotetext{
4 "A retração do comércio internacional que acompanha a $1^{\text {a }}$ Guerra Mundial induz os Estados Unidos a ocupar importante papel no fornecimento de manufaturas. A sua entrada na guerra e a suspensão das importações de café por parte da Inglaterra contribuem para o crescimento do setor industrial. O desestímulo a novos investimentos no setor cafeeiro disponibilizou capitais para outros setores. A suspensão forçada das importações mobiliza a produção interna de bens industrializados. Além desses fatores, a existência de uma demanda interna e o aproveitamento da capacidade ociosa da indústria já disponível contribuem para o avanço do setor industrial." In : SOMEKH, Nadia. A Cidade Vertical e o Urbanismo Modernizador, p. 68.

5 "\%../ Os materiais básicos, especialmente os de construção, quando importados, tornavam-se proibitivos. E toda uma série de fatores veio a interferir no ritmo das construções paulistanas, em particular, estabelecendo uma grave crise no mercado de edificações. Praticamente,e de repente, São Paulo parou. Quase nada de obras civis e essa situação anômala é muito bem retratada pelo gráfico organizado pelo engenheiro da Prefeitura, Arthur Saboya, em 1929.

Aquele renomado engenheiro, em seu "diagrama das construções em S. Paulo, de 1901 a 1928", mostra-nos que o grande surto construtivo da cidade iniciou-se timidamente em 1906, ano em que foram licenciadas 1.091 construções, quando já existiam no perímetro urbano 26.780 edificações. A partir daí, o número de novas construções foi aumentando geometricamente. Em 1911, aos 36.128 edifícios existentes, somaram-se 4.148 novas construções. Em 1913, o ápice da curva mostra 5.791 novas licenças, sendo 5.268 casas térreas e 523 assobradadas, possuindo a cidade 43.940 construções habitadas. A partir desse ano, o número de novas licenças cai vertiginosamente, atingindo o ponto mais baixo em 1918 com o número significativo de 610 casas, sendo quase 500 térreas. Ao longo dessa linha, quase vertical, escreveu o referido engenheiro : "influência da Guerra Europea e da Grippe." In: LEMOS, Carlos A. C. Alvenaria Burguesa, p.157 e 158.

6 "A lei n. 1.874, de caracter permanente, não pode furtar-se a produzir effeitos tambem permanentes. Para os que não conhecem a legislação Municipal de S. Paulo é necessario dizer que a citada lei n. 1.874 eximio de pagamento de emolumentos, de alvará de licença e de toda e qualquer subordinação ao Padrão das construcções, as casas de habitação construidas na Zona Rural, no interior dos lotes, guardadas certas distancias do alinhamento das ruas ou estradas e das divisas lateraes e do fundo. À sombra dessa lei e por ella incentivada formaram-se as intrincadas rêdes de arruamentos que cobrem a maior parte da Zona Rural com isenção de emolumentos para as construcções e gravame futuro para o Thesouro Municipal." "Aspectos da Cidade Maravilhosa." In: Correio Paulistano. 03/04/1927, p.4.
} 
(1918) e a Revolução de 1924 como causas coadjuvantes que contribuíram para a diminuição das construções no perímetro oficial da cidade neste período.

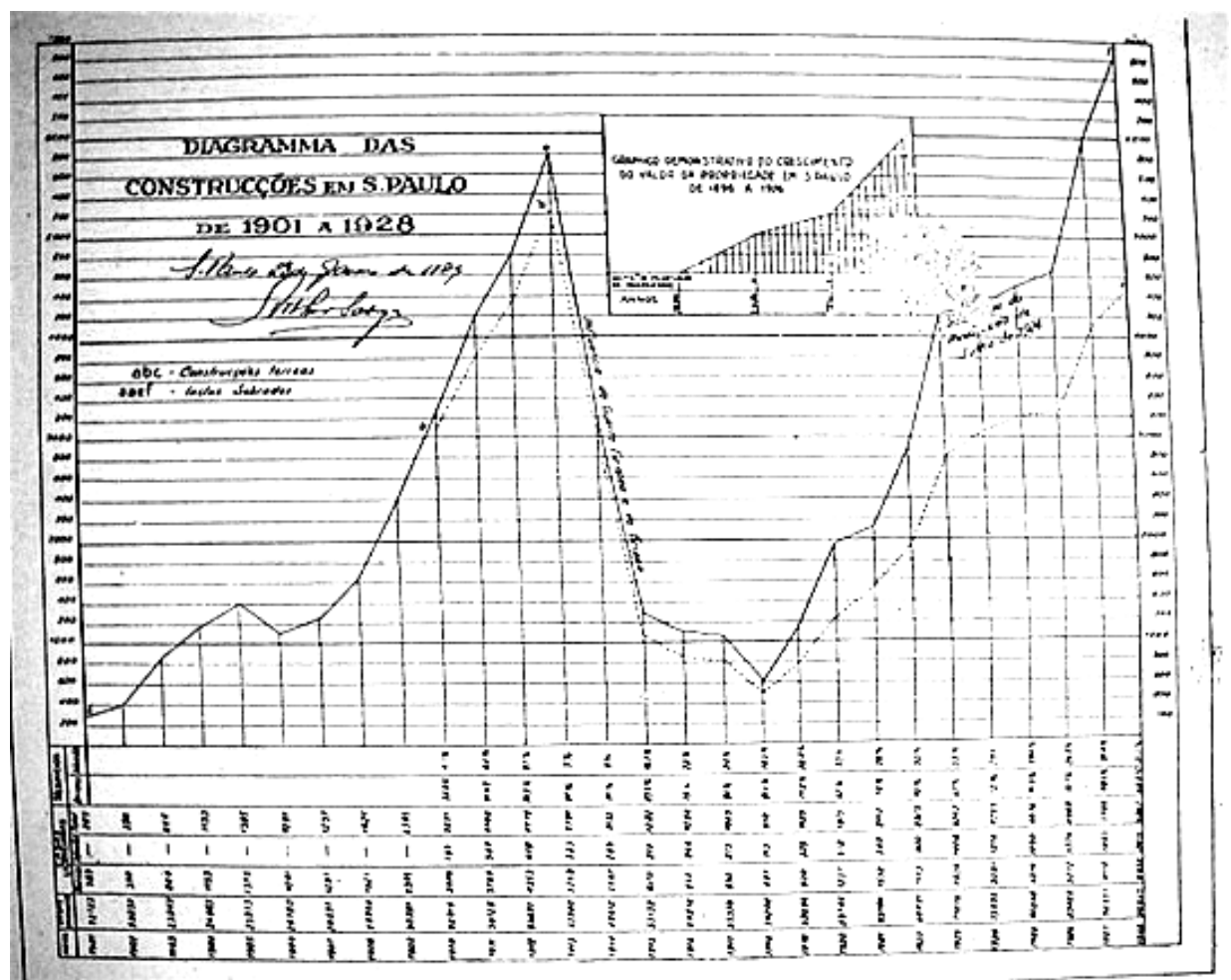

FIGURA 3: "DIAGRAMMA DAS CONSTRUCÇÕES EM S. PAULO DE 1901 A 1928”

(elaborado pelo engenheiro Arthur Saboya /1929)

Com o armistício de 1918 o ritmo do crescimento econômico começou vagarosamente a se recuperar e, aos poucos, São Paulo foi retomando o seu nível de urbanização acelerada e iniciando o processo de metropolização, que a caracterizaria anos depois.

$\mathrm{Na}$ década de 20 as exportações de café retomaram o ritmo anterior à guerra, o que perdurou até a crise cafeeira motivada pelo crack da Bolsa de Nova lorque em 24 de outubro de $1929,{ }^{7}$ que abalou novamente as bases da economia paulista e, em particular, a paulistana.

\footnotetext{
7 "A crise econômica de 1929, apesar dos efeitos negativos iniciais, acaba sendo benéfica para a indústria nacional. A produção fabril interna é estimulada, à medida que a evasão de reservas de ouro e a queda das exportações cafeeiras dificultam a obtenção de reservas cambiais para as importações. Essa dificuldade induz a abertura de filiais de empresas manufatureiras estrangeiras e a diminuição das exportações de café direcionam parte do capital para as indústrias." In: SOMEKH, Nadia. A Cidade Vertical e o Urbanismo Modernizador, p. 70.
} 
Durante os anos 30 ocorreu o grande "boom" do setor industrial paulistano. No final desta década a capital paulista se transformou no maior centro industrial da América Latina devido ao expressivo desenvolvimento da indústria local. Esta significativa expansão industrial pode ser atribuída a uma série de fatores dentre os quais podemos destacar o estabelecimento de uma rede de transportes centralizada em São Paulo, a expansão da rede de energia elétrica, a grande oferta de mão-de-obra, um mercado consumidor em crescimento e o afluxo de capitais estrangeiros aliados a nacionais para a constituição de indústrias de grande porte.

Paralelamente à industrialização, foi se desenvolvendo a função comercial e de serviços de São Paulo, ao mesmo tempo em que se acentuou a sua preeminência políticoadministrativa e cultural no cenário nacional.

Acontecimentos político-militares, como as revoluções de 1924, de 1930 e a Revolução Constitucionalista de $1932^{8}$ contribuíram também para perturbar a economia e a vida da população paulistana e, conseqüentemente, o desenvolvimento urbano e o nível de construção em São Paulo.

Durante as três primeiras décadas do século passado a sociedade paulistana se transformou rapidamente com a incorporação do elemento estrangeiro, que ingressava maciçamente na cidade desde o final do século XIX.

Segundo dados censitários do Instituto Brasileiro de Estatística (Departamento de Censos), a população paulistana que era de cerca de 239.820 habitantes em 1900, passou para 579.033 habitantes em $1920,{ }^{9}$ sofrendo um acréscimo de $141,0 \%$ em vinte anos, o que corresponde a uma taxa média de crescimento populacional de 4,5\% ao ano.

"O crescimento populacional relativo da cidade de São Paulo é maior entre os anos 20/30 do que entre os anos 30/40. Em 1920, São Paulo tinha 579.033 habitantes, passando a 901.645 em 1930 e a 1.326.261 em 1940. De 1920 a 1930, a população cresce 56\% e de 1930 a 1940 o

\footnotetext{
8 "Em 1930, com a vitória do movimento político-militar liderado por Getúlio Vargas, a hegemonia mantida pelos cafeicultores paulistas no cenário nacional chegou ao fim. Profundas alterações agitariam todos os segmentos da vida econômica, social, política e administrativa brasileira /.../ Os primeiros anos da década foram particularmente perturbadores em São Paulo. Entre outubro de 1930 e setembro de 1934 /.../ a cidade contou com nada menos do que dez chefes diferentes do Executivo municipal /.../ Ao mesmo tempo, as classes dominantes paulistas relutavam em aceitar os jovens oficiais fiéis ao Governo Provisório de Getúlio Vargas designados como interventores do estado, o que também provocava uma profunda instabilidade nas máquinas administrativas municipais e estadual. O auge da reação paulista ocorreu em 1932, com o movimento armado "constitucionalista" contra o governo federal. Valendo-se da sua superioridade econômica, a burguesia paulista empreendeu um verdadeiro esforço de guerra contra as tropas de Getúlio Vargas, na tentativa de recuperar a hegemonia política perdida. 1.... A derrota paulista aumentou ainda mais a desorganização do poder público na capital do estado. Por outro lado, as ações centralizadoras do executivo nacional iriam atuar com grande profundidade também nas esferas municipais, impondo mecanismos autoritários de controle e planejamento." BARROS, Liliane S. Lehmann \& MOIZO, Rosana P. Azanha. "Formação Administrativa da cidade de São Paulo 1554 - 1954" In : Revista do Arquivo Municipal. no 199, 1991, p. 57.

${ }^{9}$ Ver : FICHER, Sylvia. Ensino e Profissão, p. 31.
} 
crescimento é de 47\%. Em 1933, a população superava a cifra de um milhão de habitantes." (SOMEKH, 1997, p. 126 e 127)

Esses valores significativos demonstram claramente o vertiginoso aumento da massa da população nas primeiras décadas do século $X X$, motivado principalmente pelo constante fluxo imigratório de italianos e, em menor número, de ibéricos, alemães, sírio-libaneses e japoneses.

"Nos anos imediatamente posteriores à Primeira Grande Guerra, novos contingentes chegaram, insatisfeitos com as conseqüências do após-guerra: húngaros e povos do Báltico. Tudo isso sem falar nos elementos germânicos e anglo-saxões." (PETRONE, 1955, p.144)

Desde os finais do século XIX, os locais sentiram-se ameaçados pela introdução no seu cotidiano de novos gostos, hábitos, conhecimentos e valores culturais trazidos pelos estrangeiros e ficaram receosos com a possibilidade de perda da sua identidade cultural. Houve de início uma grande resistência à incorporação deste contingente populacional à sociedade paulistana. ${ }^{10}$ Esta desconfiança, apesar de natural, foi se dissipando ao longo do tempo, com a convivência social e pela percepção das melhorias advindas através dos novos "saber fazer", pela produção material dos estrangeiros, pelas influências recíprocas etc.

Nos anos 30 os estrangeiros e seus descendentes já eram aceitos com mais espontaneidade, sendo paulatinamente absorvidos na estrutura social existente através de um amplo processo de miscigenação, que criou novos valores culturais, nos quais se amalgamavam elementos das duas culturas, a nativa e a externa, sem a predominância de nenhuma.

É certo também que este incremento de população imigrante ajudou a formar e a definir os estratos médios da "nova" sociedade paulistana, ao exercer atividades ligadas ao comércio, serviços e indústria e a aumentar a demanda habitacional na capital paulista.

\footnotetext{
10 "Esse isolamento de serra acima condicionou muito os paulistas, que custaram bastante a perder o seu caipirismo. Hoje nos é muito difícil imaginar, em toda a sua amplitude, os conflitos entre comportamentos de gente da terra e aqueles dos imigrantes trazidos pelo nascente ciclo industrial. São Paulo da passagem do século, com mais de $40 \%$ de sua população composta de italianos, certamente foi uma cidade cheia de problemas psicosociais. Não foi sem resistência que os hábitos sa popularizaram uniformemente. E isso levou muito tempo." LEMOS, Carlos A. C. "O Morar no Modernismo Paulistano." In: O Caderno de São Paulo, 1979, p. 11 e 12.
} 


\section{I.2. Aspectos Urbanísticos}

Como já dissemos anteriormente, a área urbana de São Paulo na primeira década do século XX apresentava-se fracionada em três blocos principais.Pela análise da cartografia ${ }^{11}$

".../ pode-se perceber, com relativa facilidade, quais eram, por essa época, os rumos prováveis da expansão da cidade: na direção Oeste e de Noroeste, através da Avenida Água Branca e da rua Itapicurú (no trecho hoje denominado rua Turiaçú), até o bairro da Água Branca (de onde partia a estrada para a veneranda Freguesia do Ó) e à nascente Lapa; no rumo do Norte, através da rua dos Voluntários da Pátria, que ia ter ao pequenino núcleo de Sant' Anna, à margem direita do Tietê; em direção do Leste, através da então Avenida da Intendência (atual Celso Garcia), em busca do isolado e pequeno núcleo da Penha; no rumo de Sudoeste, através de um simples caminho carroçável de que resultou a atual Avenida Rebouças, a qual alcançava a "Vila dos Pinheiros". Já arruados, embora pouco habitados e ainda isolados da cidade, apareciam o Ipiranga e Vila Prudente." (PETRONE, 1955, p.138)

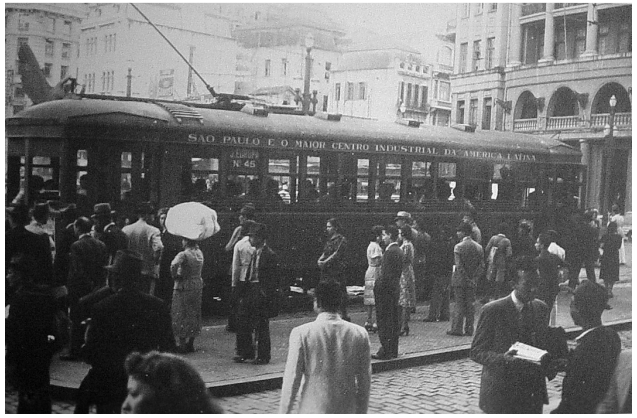

FIGURA 4 : Bonde elétrico no centro de São Paulo.

Além da diversidade econômica e funcional assumida pela capital paulista e do abrupto aumento de população, outro fator colaborou para a expansão horizontal de São Paulo no início do século XX : a implantação de várias linhas de bondes elétricos pela companhia Light \& Power, ligando o centro a núcleos distantes da cidade e cortando áreas ainda não loteadas e desocupadas.

".../ a concessionária Light and Power não hesitou em estender suas linhas aos principais, dentre os bairros isolados mais afastados, atravessando grandes extensões ainda não urbanizadas e que por algum tempo ainda não poderiam garantir um transporte lindeiro. Assim, os elétricos atingiam, em 1914 : Santana, Penha de França, Ipiranga, Vila Prudente, Bosque da Saúde, Pinheiros e Lapa." (LANGENBUCH,1971, p. 84)

A Planta da Cidade de S. Paulo elaborada em 1922 pela Comissão Geográfica e Geológica de São Paulo mostra a tendência de expansão da cidade para leste, e mais

${ }^{11}$ Ver : Planta da Cidade de São Paulo (1905) ; Planta Geral da Cidade de São Paulo (1914) ; Planta da Cidade de São Paulo para o Indicador Prático (1922) ; Planta da Cidade de São Paulo mostrando todos os Arrabaldes e terrenos arruados (1924) Planta da Cidade de São Paulo e Municípios circunvizinhos (1926-1927) ; Mappa Topographico do Municipio de São Paulo (1930) . 
acentuadamente, para as regiões oeste, sudoeste e sul, com o surgimento de vários loteamentos e esboços de arruamentos nestas direções. Assim: entre Perdizes e Lapa nascem as Vilas Pompéia e Romana; entre Lapa e Vila Leopoldina surgem os loteamentos do Alto da Lapa e Bela Aliança; na área entre Pinheiros e Consolação e nos bairros do Pacaembu, Jardim América, Jardim Europa, Jardim Paulista e Alto da Moóca aparecem delineadas ruas novas. Cabe ressaltar aqui que a maioria das ruas abertas naquela época apresentava uma pequena densidade construtiva, característica esta que marcou o processo de urbanização da cidade de São Paulo nas primeiras décadas do século XX. ${ }^{12}$

Na década de 20 já começa a ser verificado um processo de verticalização nas construções paulistanas, principalmente na área central. Ramiro de Almeida em seu artigo sobre "A Expansão Vertical e Latitudinal da cidade de S. Paulo" nos informa que

“.../ o crescimento vertical de São Paulo, na expansão geral, em número de casas, póde ser apreciado pelos dados seguintes : em 1910, a cidade possuia 32.914 edificações, com a porcentagem de 4,1, em casas assobradadas; essa porcentagem vem crescendo sempre, com maiores ou menores oscillações, até attingir, no anno de 1928, e num total de 99.247 edificações, a 35,2 \%." (ALMEIDA, 1929)

Por volta de 1925 a área urbana da capital paulista continuava a crescer para todas as direções, ampliando os seus limites suburbanos e mantendo a descontinuidade de ocupação. ${ }^{13}$ No segundo quartel do século XX a cidade de São Paulo estruturava-se em :

“a-) um bloco compactamente edificado, limitado ao Norte pelas vias férreas, a Leste pelo Vale do Anhangabaú, a Oeste pelo Vale do Pacaembu e ao Sul pelo espigão da Avenida Paulista;

b-) uma área compactamente edificada, a leste do Tamanduateí, compreendendo o Brás, a Moóca e o Belenzinho, a qual é cortada em três pontos por estradas de ferro;

c-) uma área pequena, porém populosa, situada na várzea, ao norte das linhas férreas, compreendendo o Bom Retiro, a Luz e a Baixa Casa Verde;

d-) uma área a oeste do Vale do Pacaembu, compreendendo Perdizes, Vila Pompéia, Água Branca, Lapa e o início do Alto da Lapa;

e-) uma zona de bairros novos, situados nas vizinhanças do Tietê (margem esquerda) e da colina da Penha;

\footnotetext{
${ }^{12}$ Ver : LANGENBUCH, Juergen. Estruturação da Grande São Paulo. Estudo de Geografia Urbana ; AZEVEDO, Aroldo (org.) $\underline{A}$ Cidade de São Paulo. Estudos de Geografia Urbana ; São Paulo (cidade). Estudo da Evolução Urbana da cidade de São Paulo - Análise da Expansão da Cidade de São Paulo a partir de uma Coleção de Plantas Históricas.

13 "A área total da cidade era submetida a uma tal prática especulativa, sem qualquer regulamentação, que, além de tolher a ação administrativa da autoridade pública, /.../ tornava desconexos entre si os vários bairros e setores do município, ao mesmo tempo que centralizava o comércio e os serviços, criando dificuldades extremas de transportes e saturação dos fluxos, já por si agravados pela topografia acentuada, pelos rios, alagados e trilhos ferroviários." In: SEVCENKO, Nicolau. Orfeu Extático na Metrópole - São Paulo Sociedade e Cultura nos frementes anos 20, p. 109.
} 
f-) o Ipiranga, então bairro subúrbio, instalado parte na várzea e parte nas vertentes do Tamanduateí;

g-) uma zona irregular, nucleada pelo centro da cidade, entre o Vale do Anhangabaú e a Aclimação;

h-) a zona localizada a sudeste do espigão da Avenida Paulista, compreendendo Vila Cerqueira Cesar, Pinheiros, Vila América e Jardim América;

i-) uma zona situada ao sul da Avenida Paulista, constituída principalmente pela Vila Mariana;

j-) uma pequena área ao norte do Tietê, com o antigo núcleo de Sant'Anna."(PETRONE, 1955, p. 141)

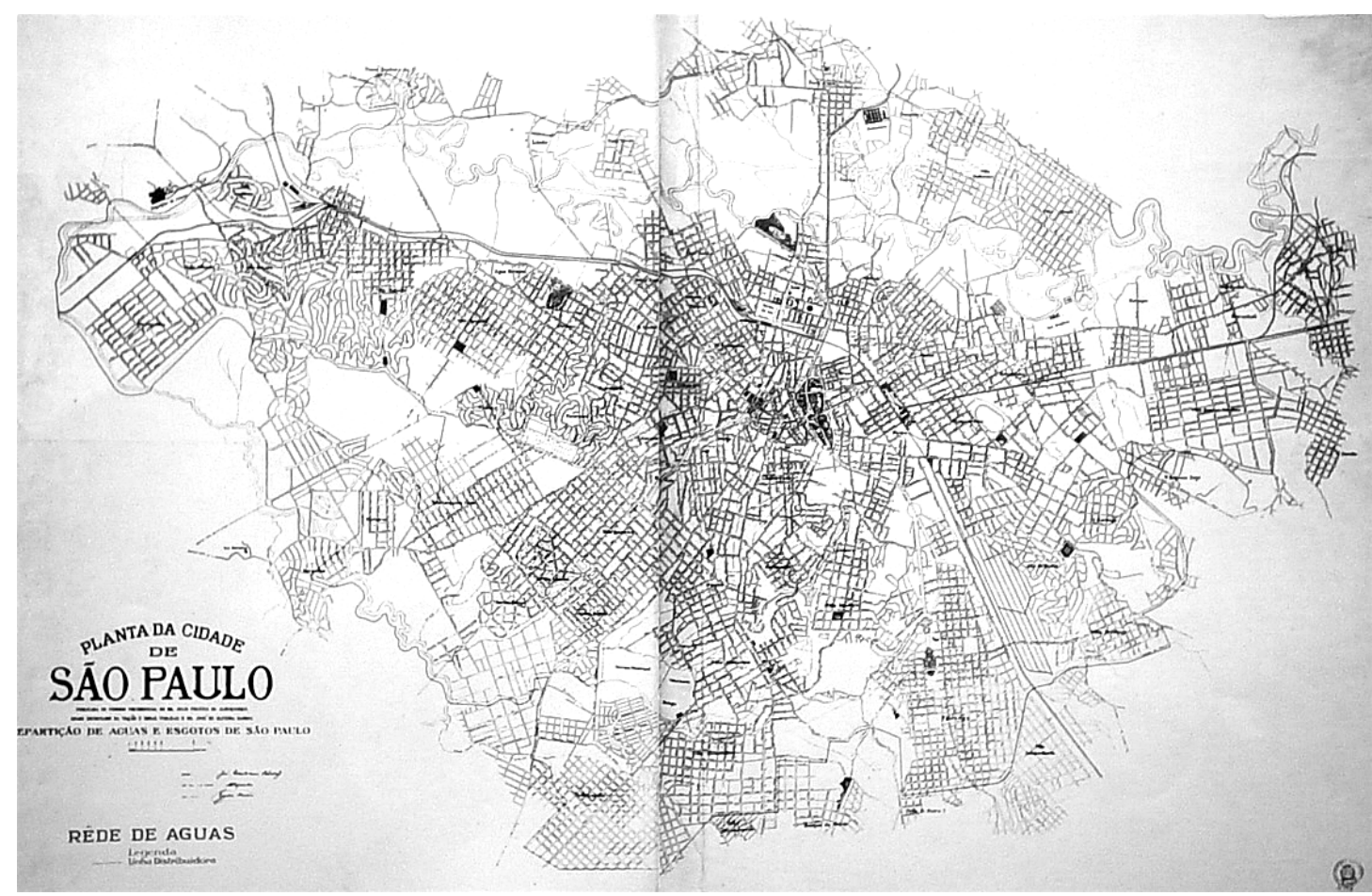

PLANTA DA CIDADE DE SÃO PAULO (1928)

Repartição de Águas e Esgotos de São Paulo

A partir dos anos 30, as linhas de ônibus surgem como um novo fator propiciador de expansão urbana. ${ }^{14} \mathrm{O}$ transporte coletivo, avançando para áreas distantes e ainda desocupadas, promoveu o preenchimento dos "vazios" urbanos deixados pelo rápido crescimento da cidade nas primeiras décadas do século $X X$, ao mesmo tempo em que incorporou bairros e antigos arrabaldes e alterou os subúrbios da cidade.

\footnotetext{
14 "O transporte é uma variável que se compõe com muitos outros fatores na configuração da cidade. O desenvolvimento da infra-estrutura e dos transportes tem a característica de favorecer o crescimento das cidades e não simplesmente criá-lo." MONCLUS, Francisco J. "Infraestructuras de transporte y crescimiento urbano en EEUU : literatura recente y nuevas perspectivas." In : Revista Historia Urbana 1, 1992, p. 41.
} 
A ampliação dos limites urbanos, a intensa ocupação do território (ainda que descontínua), a assunção de diversas funções urbanas e a estruturação de uma sociedade mais complexa, incorporando estratos médios à sociedade local tradicional, definiram uma nova espacialização para a cidade de São Paulo no início dos $30 .{ }^{15}$

Com relação à distribuição das áreas residenciais na geografia da cidade, era nítida a distinção das zonas ocupadas pelos diferentes estratos sociais, estabelecidos em setores diferenciados da capital paulista. Percebe-se também que nas novas áreas de expansão da cidade se delineavam compartimentações ou preferências locacionais. Este fato revelava uma clara relação entre a ocupação urbana e a estrutura social paulistana existente naquele momento. Esta relação era determinada principalmente por fatores de ordem econômica, como a capacidade financeira de cada classe social em adquirir lotes para construção de suas moradias. ${ }^{16}$

Assim, os terrenos situados nos bairros considerados nobres da cidade, localizados no alto dos espigões, nas direções oeste e sudoeste até as vertentes do espigão da Avenida Paulista, eram maiores e mais valorizados, sendo ocupados preferencialmente pelos palacetes e bangalôs da elite paulistana. Os bairros a leste e sudeste definiram-se de imediato como áreas proletárias, acompanhando o eixo ferroviário e as indústrias. Estes bairros caracterizavam-se pela oferta de lotes mínimos e de custo reduzido, localizados numa área insalubre ao longo da várzea inundável do rio Tamanduateí, o que incentivava a ocupação residencial pelas camadas de baixa renda. A zona norte, além de Santana, ainda era passagem para o caminho do Juqueri, Atibaia e Bragança e apresentava uma ocupação pouco significativa. Sem o poder econômico da elite, mas sempre desejosa em possuir o seu "status" e as suas condições de conforto, a classe média paulistana, interesse do nosso estudo, procurou se instalar próxima aos bairros elegantes da classe alta, em lotes tradicionais de preços moderados situados nas ruas recém abertas nas direções oeste, sudoeste e sul.

"Em termos dos bairros e loteamentos, a maioria dos empreendimentos da época seguia os traçados em xadrez, sem dúvida o sistema de parcelamento do solo que permite um ótimo aproveitamento da área. Somando-se às determinações de ordem histórica quanto à qualidade de uma localização no conjunto da cidade, o elemento essencial que distinguia os loteamentos para

\footnotetext{
15 "A Lei n. 3.427, de 1929, primeiro código de obras que /.../ definia quatro zonas na cidade de São Paulo (central, urbana, suburbana e rural) /.../ " In: SOMEKH, Nadia. A Cidade Vertical e o Urbanismo Modernizador, p. 77.

16 "O espaço é um produto social e seu valor é produzido pelas atividades da sociedade. O preço da terra urbana é uma criação social. /.../ A lei do valor no espaço é estruturada, manipulada pela classe capitalista e suas relações sociais. /.../ Existem, portanto, diferentes demandas por solo urbano, pelas condições específicas de valorização e pela lógica de cada fração do capital. Isto provoca a constituição de uma multiplicidade de mercados fundiários, hierarquicamente estabelecidos, que por sua vez definem uma hierarquia de uso do solo urbano." Idem, p. 113.
} 
casas operárias daqueles para as moradias das camadas mais ricas e dava o ton social do empreendimento era o dimensionamento previsto para a testada dos lotes, o qual determinava o tipo de edificações passíveis de serem erigidas: geminadas ou isoladas.” (FICHER, 1989, p. 32)

Contrapondo-se a esta predeterminação urbanística de traçados hipodâmicos, a Companhia City (City of São Paulo Improvements and Freehold Land Company Limited) ${ }^{17}$ surpreendeu o setor imobiliário paulistano na década de 10 ao implantar o primeiro bairrojardim de São Paulo, o Jardim América (1915). Este empreendimento de características inovadoras, quando comparado aos padrões até então conhecidos e praticados na capital paulista, baseava-se em princípios urbanísticos pioneiros, oriundos de experiências inglesas desenvolvidas desde o final do oitocentismo através de um modelo de ocupação conhecido como garden city. ${ }^{18} \mathrm{O}$ traçado orgânico das ruas, os lotes de grandes dimensões, a exigência de padrões de ocupação dos lotes com amplos recuos frontais, laterais e de fundos, a construção restrita de edificações residenciais, eram alguns dos fatores diferenciais que caracterizavam o novo bairro paulistano de classe alta, que possuía regras próprias, independentes das estipuladas pelo poder público.

Outros empreendimentos imobiliários surgiram nos anos posteriores em vários pontos da cidade por iniciativa da mesma companhia, como o Alto da Lapa (1917), o Butantã (1918), o Alto de Pinheiros e o Pacaembu (ambos em 1925). Não obstante as indiscutíveis e notáveis qualidades higiênicas, ambientais e paisagísticas proporcionadas pelo modelo introduzido pela Cia. City, a aquisição de terrenos nos novos bairros era proibitiva às camadas média e baixa da população paulistana pelo alto custo dos terrenos e

\footnotetext{
17 "Finalmente, cabe destacar /.../ uma significativa transação envolvendo capitais estrangeiros e proprietários fundiários locais, que redundou na organização da City of São Paulo Improvements and Freehold Land Company Limited. Os acertos iniciais deram-se em 1911, Edouard Fontaine de Lavelaye e Antoine Joseph Bouvard /.../ procuraram o então Diretor de Obras Públicas de São Paulo, Victor da Silva Freire, em busca de informações sobre proprietários fundiários na capital com interesse em negociar grandes extensões de terras para futuros empreendimentos imobiliários. /.../Paralelamente, este último (Lavelaye) entabulava negociações com banqueiros londrinos, com os quais levantou recursos para constituir na Inglaterra, em 25 de setembro de 1911, a City of São Paulo Improvements and Freehold Land Company Limited, que mantinha escritórios em Paris e São Paulo.

Os terrenos negociados com a Cia. City perfaziam um total de $12.380 .098 \mathrm{~m}^{2}$, espalhados por diversos quadrantes da cidade, a saber : $6.750 \mathrm{~m}^{2}$ nas ruas Traipu e Palmeiras; $800.000 \mathrm{~m}^{2} \mathrm{em}$ Higienópolis; $354.000 \mathrm{~m}^{2} \mathrm{em}$ Vila Romana; $2.141 .700 \mathrm{~m}^{2} \mathrm{na}$ Lapa; $785.100 \mathrm{~m}^{2}$ na antiga Estrada das Boiadas, em Pinheiros, parte deles pertencentes ao Coronel Martinho Ferreira da Rosa; $2.347 .400 \mathrm{~m}^{2}$ em Pinheiros, pertencentes a Alzira de Salles; $919.600 \mathrm{~m}^{2}$ em Vila América e Caaguassu, pertencente aos coronéis Joaquim e Martinho Ferreira da Rosa; $180.000 \mathrm{~m}^{2}$, em Vila América, pertencentes a João Batista de Oliveira, mais $150.000 \mathrm{~m}^{2}$ na mesma localidade, pertencentes à Cia. Edificadora da Vila América; $133.000 \mathrm{~m}^{2}$ na Avenida Brigadeiro Luís Antonio, pertencentes aos herdeiros da Carlos Bresser; $34.000 \mathrm{~m}^{2}$ no bairro do Bexiga, às ruas Paim, Augusta e Martinho Prado; $800.000 \mathrm{~m}^{2}$ no Alto da Moóca, além de outros não especificados, mas que espalhavam-se por Água Branca, Butantã, Ipiranga e Vila Mariana. /.../ Cabe destacar, ainda, que a venda dos terrenos adquiridos em 1911 só foi concluída em 1950." In: BRITO, Mônica S. A Participação da Iniciativa Privada na Produção do Espaço Urbano: São Paulo, 1890-1911, p. 119, 120 e 121.

18 “.../ Apesar de não garantir o melhor aproveitamento da área do empreendimento, este sistema tinha outras qualidades: do ponto de vista propagandístico, oferecia aquelas condições higiênicas e sanitárias consideradas desejáveis pelos padrões da época, e do ponto de vista do status social, criava uma localização de imediato prestígio. Assim, a mera situação de um lote no bairro jardim garantia a elevação no preço médio do seu metro quadrado, sofisticando-se a demanda imobiliária e hierarquizando-se os novos espaços urbanos que estavam sendo colocados no mercado, aumentavam os lucros no negócio da construção." In: FICHER, Sylvia. Ensino e Profissão, p. 33.
} 
pela reduzida ocupação do lote, devida aos recuos determinados na escritura de compra e venda do imóvel.

Submetida a determinações de ordem econômica, motivada pelo desejo de ascensão à classe alta e limitada pelo atendimento da legislação estadual e municipal, a classe média paulistana teve que continuar a se instalar em lotes tradicionais, procurando adequar as suas novas expectativas programáticas, construtivas e estilísticas aos terrenos de pouca testada e profundidade reduzida, ${ }^{19}$ disponíveis nos bairros recém criados nas zonas oeste, sudoeste e sul da cidade.

Com respeito à legislação edilícia em vigor na época, podemos dizer que o Código Sanitário de $1918^{20}$ influenciou de modo decisivo a implantação e a volumetria das residências deste período. Este código foi pioneiro ao introduzir e incorporar noções de higiene das habitações em São Paulo. Reconhecendo os benefícios propiciados pela ação bactericida do sol, descobertos nos finais do século XIX, este código recomendava cuidados especiais quanto à implantação das edificações no terreno e à orientação das janelas. Assim, deveria ser evitada a incidência direta dos ventos úmidos que açoitavam a capital paulista em determinadas épocas do ano e as construções precisariam manter afastamentos dos limites dos lotes de modo que os cômodos de permanência recebessem uma insolação mínima diária.

As recomendações prescritas no Código Sanitário foram tão significativas que muitas delas foram endossadas anos depois pelo Código de Obras de São Paulo (1929). ${ }^{21} \mathrm{O}$ Código de Obras, promulgado como Código Arthur Saboya em 1934, sistematizou e codificou toda a legislação municipal anterior composta de normas e determinações relativas às edificações na cidade de São Paulo e inovou ao estabelecer parâmetros científicos para

\footnotetext{
${ }^{19}$ Por volta do final da década de 20 o lote médio em São Paulo apresentava profundidade menor que a dos lotes coloniais, devido à grande valorização sofrida pelos terrenos na cidade; “/... e essa tendencia, que póde ter outras causas secundarias, é provocada pela grande valorização dos terrenos da qual decorre a necessidade de reducção das dimensões do lôte em profundidade. É o que vimos quando estudámos a constituição do lôte médio, hoje, com a profundidade reduzida a 36,0 m em média." Informação prestada pelo engenheiro Arthur Saboya em entrevista ao Correio Paulistano ("Aspectos da Cidade Maravilhosa", de 03/04/1927, p.4).

20 O primeiro Código Sanitário de São Paulo é de 1894; o segundo Código Sanitário do Estado é de 1911 e foi regulamentado na capital pela Lei Municipal de 1915. O Código Sanitário de 1918 serviu de base para o Código de Obras municipal (Lei $n^{\circ}$ 3.427 de 1929), que se consubstanciou num autêntico código de edificações. Anteriormente ao Código de Obras, vigoravam em São Paulo outras leis municipais que procuravam estipular parâmetros para as construções paulistanas, como as Leis $n^{\circ}$ 2.332 (1920) e no 2.818 (1925). Em 1934 o Ato no 663 regulamentou o Código de Obras, que passou então a ser denominado Código Arthur Saboya.

${ }^{21}$ "No entanto, a primeira tentativa de normatizar a construção de edificações, na cidade de São Paulo deu-se em 1929, com o Código de Obras conhecido como "Código Arthur Saboya", que vai durar até 1970, influenciando também, o código atualmente em vigor (lei 8.266 de 20 de junho de 1975) /.../ " In: SOUZA, Maria Adélia Aparecida de. A Identidade da Metrópole, p. 221.
} 
a insolação diurna e noturna das habitações. ${ }^{22}$ A partir daí, tornou-se uma exigência legal a aplicação do "Diagrama de Insolação" nos projetos de construção na cidade de São Paulo. ${ }^{23}$

O Código Arthur Saboya estabeleceu um padrão para as edificações residenciais paulistanas ao definir, por exemplo, especificações relativas aos recuos mínimos (frontais, laterais e de fundo) que deveriam ser atendidas pelas construções particulares. Esta preocupação de garantir condições mínimas de afastamento entre as habitações em busca de salubridade sugere uma incorporação parcial pelo Poder Público dos critérios de implantação trazidos pelos loteamentos da Cia. City, sucessos imobiliários na época e paradigmas do "bem morar" em São Paulo.

Desta forma, podemos dizer que esses códigos determinaram condições novas de implantação, higiene e conforto para as edificações residenciais no entre-guerras, em especial para as da classe média paulistana, que sofreram influência direta destas legislações nas plantas e volumes de suas casas.

\section{I.3. Aspectos Arquitetônicos}

Para avaliarmos com precisão o quadro arquitetônico residencial existente na cidade de São Paulo nas décadas de 20 e 30 do século XX, onde estava consubstanciado o gosto da classe média, que nos interessa particularmente, torna-se necessário retroceder no tempo.

A arquitetura residencial dos três primeiros séculos em São Paulo caracterizava-se pela uniformidade formal e construtiva das edificações. As variações eram basicamente quantitativas, uma vez que a técnica construtiva empregada era sempre a taipa de pilão. As casas ricas, de maior porte e número de cômodos, apresentavam ocasionalmente discretas ornamentações nas envasaduras e nos "cachorros" dos beirais, em distinção às habitações mais humildes, que eram menores e destituídas de qualquer decoração.

\footnotetext{
22 "Diz-nos o arquiteto Henrique Mindlin que o Código de Obras de São Paulo foi o primeiro do mundo a estabelecer bases científicas asseguradoras de insolação correta às dependências de uso diurno e noturno das habitações, graças aos estudos do arquiteto Alexandre Albuquerque, em 1916 /.../" In: LEMOS, Carlos A. C. Alvenaria Burguesa, p. 84.

23 “.../ diagrama de insolação, gráfico impresso em papel transparente que permitia viabilizar a garantia de quantas horas se quisesse de osculação solar nos pátios ou nas paredes. Tal diagrama, criado pelo referido arquiteto Alexandre Albuquerque, baseava-se na inclinação dos raios solares (mais ou menos $45^{\circ}$ ) às 12 horas do dia mais curto do ano, em junho, em São Paulo que, como se sabe, é cortado pelo Trópico de Capricórnio. Assim, todos os cômodos de uma residência deveriam possuir janelas deitadas para pátios ou corredores externos que fossem capazes de conter uma paralela à linha norte-sul com comprimento tal que fosse igual à altura média das paredes que olhassem para o sul multiplicada por 1,07. Este número representa justamente o comprimento da sombra que faz uma estaca de 1,00m fincada no solo ao meio-dia no solstício de inverno, em 21 de junho. Desse modo, estava garantida a "osculação solar", como se dizia, aos ambientes de construção cuja salubridade era a meta de todos. " Idem, ibidem.
} 
Este partido vernacular resultante das condições locais e, sobretudo, do isolamento de São Paulo serra acima, permaneceu até o terceiro quartel do século XIX, quando então a cidade começou a sofrer a influência direta da riqueza trazida pela cafeicultura e da imigração estrangeira.

As condições econômicas e sociais manifestadas nesta época na capital paulista permitiram o aparecimento de uma nova arquitetura trazida pelos imigrantes, capaz de atender aos recentes programas de necessidades surgidos com a ferrovia e os decorrentes da especialização das funções urbanas - comerciais, administrativas, de serviços etc. Com a introdução e difusão de um novo "saber fazer", baseado na alvenaria de tijolos, e de um novo gosto, o Ecletismo, o ambiente arquitetônico e urbano paulistano se modificou completamente num curto período de tempo e quase não se alterou até a Primeira Guerra Mundial.

Em conseqüência dessas novas condições a arquitetura residencial também se transformou. Assim, naquele momento, as diferenças qualitativas $e$ as variações programáticas entre as moradias foram possibilitadas pelo dinheiro do café e pela nova estrutura social que começava a se configurar.

"Na São Paulo do século passado, a novidade arquitetônica, /.../ surgiu tanto na classe alta, através de renomados arquitetos, como na classe operária auto-suficiente imigrante, restando à burguesia quatrocentona o papel de simples espectadora destinada a absorver lições de ambos os extremos sociais." (LEMOS, 1985, p. 11)

A classe alta dos fazendeiros ricos, grandes negociantes e industriais adotou o palacete como forma de viver com luxo e conforto. Este programa arquitetônico caracterizava-se por uma discreta monumentalidade ditada pela implantação da edificação no centro do lote, cercada por caprichosos jardins. Com relação à volumetria, estas construções apresentavam via de regra mais de um pavimento e possuíam planta recortada para aproveitar todas as possibilidades do terreno. A composição estudada de volumes salientes e reentrantes definia telhados movimentados e provocava distinções entre as diferentes fachadas dessas edificações.

Os palacetes, projetados por profissionais habilitados, estavam equipados com os aperfeiçoamentos técnicos mais modernos da época, que podiam possibilitar o máximo conforto ambiental para os seus moradores, como iluminação domiciliar a gás, banheiros junto aos dormitórios no piso superior etc. 
As revistas especializadas e as publicações técnicas importadas veiculavam a moda estilística vigente na Europa, ${ }^{24}$ ao mesmo tempo em que serviam de referência para a escolha dos estilos a serem copiados pelos palacetes paulistanos. ${ }^{25}$ Os estilos adotados eram então variados e determinados muitas vezes pelo gosto pessoal do proprietário.

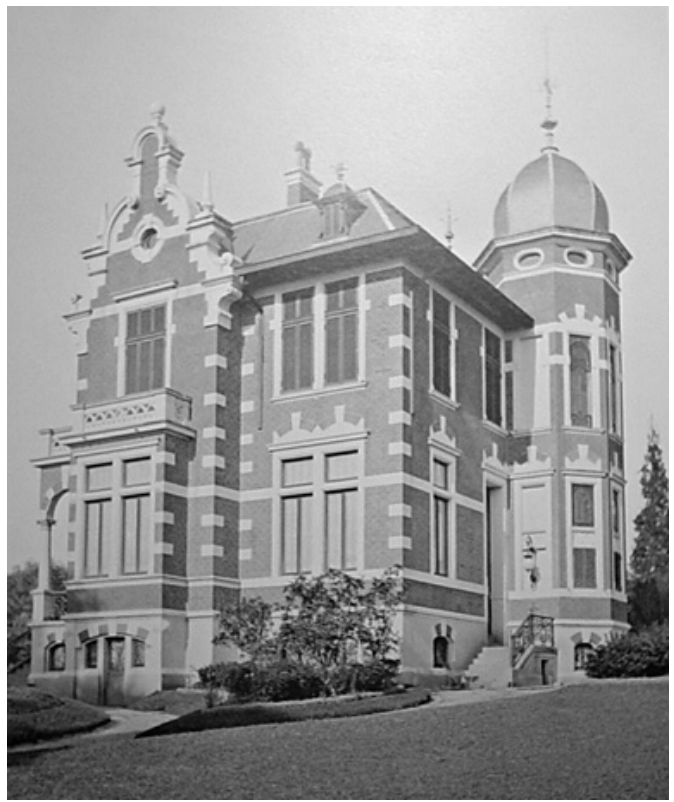

FIGURA 5 : Residência Cândido de Moraes (Ramos de Azevedo / São Paulo, 1892)

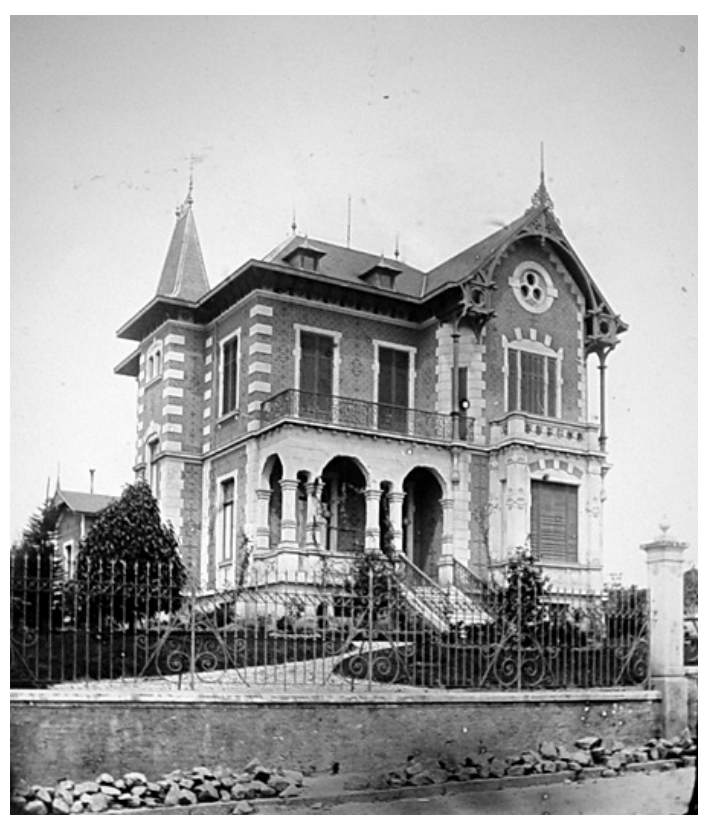

FIGURA 6 : Palacete Viscondessa de Parnaíba (Ramos de Azevedo / São Paulo. final do século XIX)

\footnotetext{
${ }^{24}$ Em particular, na França, sob influência direta dos nove volumes de autoria do arquiteto César Daly, repletos de desenhos de elegantes residências.

25 "Ramos de Azevedo projetou assim centenas de casas de gente importante, criando até uma linguagem própria baseada nas paredes de tijolos à vista sempre arrematadas nos cunhais e nos aros das envasaduras por bossagens fingindo pedras angulares em massa de cal e areia, pois não havia aqui à disposição rochas brandas de fácil manejo." In: LEMOS, Carlos A. C. Alvenaria Burguesa, p.132.
} 
No outro extremo da hierarquia social, as camadas mais humildes da população paulistana habitavam o que se convencionou chamar de casa operária. ${ }^{26}$ Estas moradias, de alvenaria de tijolos, eram térreas e pequenas, com uma área construída em torno de $30 \mathrm{~m}^{2}$. O programa era resolvido de uma maneira simples: uma seqüência de um até três cômodos encarreirados sem corredor interno, mais o WC no quintal. Não havia um uso exclusivo para cada peça (por exemplo, o que era sala durante o dia podia se transformar em quarto à noite), o que demonstrava uma clara sobreposição de funções da habitação.

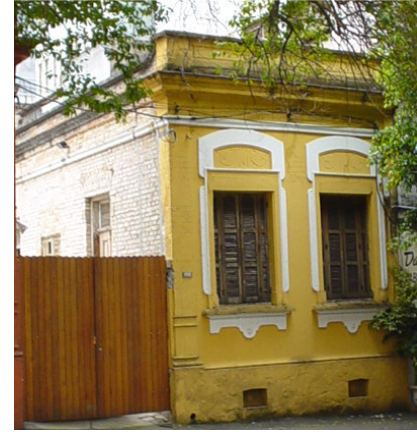

FIGURA 7 : Casa à rua Martinico

A feição dessas casas de classe baixa era eclética e quase padronizada, composta invariavelmente pelo porão alto, platibanda escondendo a cobertura de telhas planas tipo Marselha, o portão e o corredor externo lateral e uma discreta decoração parietal de inspiração neo-renascentista, neoclássica, art nouveau etc.

Prado.

Nas primeiras décadas do século $X X 0$ ramo de construção de moradias - em especial, as de aluguel - era muito lucrativo em São Paulo, ${ }^{27}$ o que induzia inúmeros empresários a investir grandes somas de capitais no mercado imobiliário paulistano. ${ }^{28}$ Como locatária contumaz a classe média era o público alvo dessa produção capitalista que lhe impunha sem opção modos de morar e modelos estilísticos.

No período anterior à Primeira Guerra Mundial as casas de aluguel, quase sempre geminadas e no alinhamento, apresentavam partido arquitetônico muito semelhante ao das casas operárias, distinguindo-se destas somente pelo maior número de cômodos. Este partido repetia à exaustão os mesmos arcabouços de alvenaria de tijolos envolvidos por

\footnotetext{
26 "\%... A expressão "casa operária", por exemplo, incorporou-se ao linguajar comum e designa oficialmente a morada modesta de poucas dependências, mas perfeitamente enquadrada nos critérios de composição arquitetônica que os novos materiais permitiam dentro das lições construtivas dos imigrantes." Idem, p.55.

27 Isto se deve à enorme carência de habitações causada pelo rápido e descontrolado crescimento populacional da capital paulista entre o final do século XIX e as primeiras décadas do século XX.

${ }^{28}$ "No começo do século $X X$, com o aumento do ritmo de edificações, surgem as primeiras firmas especializadas no setor de construção civil. I.../ Nas décadas iniciais do século XX, formam-se as sociedades de capitalização e os bancos de crédito hipotecário, que financiam a construção da casa própria /.../" In: SOMEKH, Nadia. A Cidade Vertical e o Urbanismo Modernizador, p. 100 e 102.
} 
uma roupagem eclética classicizante, sobretudo neo-renascentista de inspiração italiana, com poucas variações. ${ }^{29}$

O engenheiro arquiteto Victor da Silva Freire, no seu artigo "A Cidade Salubre", apresentou vários exemplos de habitações populares comumente encontrados na capital paulista no período anterior a 1914. Pela ilustração "Typos de casa communs em São Paulo", constante no citado artigo, podemos perceber que o programa dessas casas mantinha-se próximo ao tradicional, com a mesma setorização funcional, ou seja, as salas na frente, os quartos no meio e a varanda e cozinha nos fundos com o WC como anexo. A ligação da rua para o quintal era feita externamente através de uma passagem lateral e internamente através de um corredor ou, como nas casas mais simples, passando-se pelos cômodos enfileirados. ${ }^{30}$

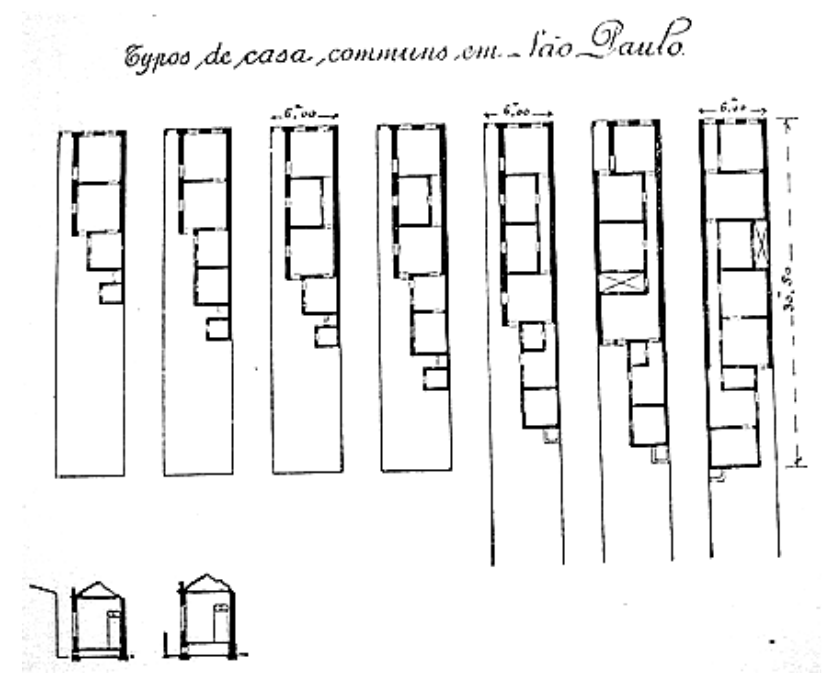

FIGURA 8 : "TYPOS DE CASA COMMUNS EM SÃO PAULO.” (eng. arq. Victor da Silva Freire/ São Paulo, primeiras décadas do século XX)

29 "Em São Paulo, o ecletismo classicizante teve portanto um caráter bem peculiar, um toque italiano, perceptível principalmente depois de 1900, em oposição ao predomínio francês que ocorria então no Rio de Janeiro. E também foi mais diversificado, a Renascença e a pós-Renascença forneceram os modelos preferidos, mas não os únicos : desde o Quattrocento até o século XIX, de Roma a Veneza, de Florença a Milão, todos os estilos e suas variantes regionais foram em maior ou menor grau empregados." In: BRUAND, Yves. Arquitetura Contemporânea no Brasil, p. 41. Ver também : DEBENEDETTI, Emma \& SALMONI, Anita. Arquitetura Italiana em São Paulo ; PASSAGLIA, Luiz Alberto do Prado. $\underline{\mathrm{O}}$ Italianizante : a arquitetura no período de 1880 a 1914 na cidade de São Paulo.

${ }^{30}$ Preocupado com questões de salubridade das habitações, Freire ao comentar as casas de São Paulo nos diz que "com a suppressão das alcovas apparecem-nos nas edificações, d'ahi em deante, os espaços descobertos destinados a dar luz e ar directos aos compartimentos de moradia : as areas internas e os corredores lateraes. "Saguões" e "corredores", como os denominaremos mais brevemente de ora em deante, desempenham papel importante na meia duzia de typos a que se reduzem tres sobre quatro das casas de S. Paulo. É bom tambem não esquecer que, nos vinte e cinco por cento restantes, metade obedece á mesma disposição, que enfileira os commodos mais interessantes para o hygienista, os de permanencia habitual e nocturna, segundo uma normal ao eixo da rua; distingue-se essa metade na massa da construcção costumeira por, apenas, um pouco mais de amplidão nos vasios deixados." In: FREIRE, Victor da Silva. "A Cidade Salubre." In: Revista Polytechnica. ํㅡ 48, 1914, p. 324. 
Do ponto de vista construtivo, essas casas populares eram realizadas quase que integralmente com materiais importados, excluindo-se tão somente os tijolos e as telhas, que já eram produzidos pelas olarias locais. Como já foi dito anteriormente, a eclosão da Guerra de 1914 provocou a cessação imediata das importações da Europa, o que, por sua vez, ocasionou a escassez e a elevação do custo dos materiais de construção, paralisando temporariamente o ramo de edificações paulistano. Foi um tempo de espera, de improvisações e de paulatino esquecimento da estética dos "capomastri" italianos.

Contemporaneamente ao início da Primeira Guerra Mundial começaram a surgir em São Paulo reações nacionalistas à idéia subjacente do desaparecimento da cultura paulista, tolhida pela presença avassaladora do elemento estrangeiro no cotidiano da cidade. No dia 20 de julho de 1914, o engenheiro português Ricardo Severo proferiu na Sociedade de Cultura Artística a conferência "A Arte Tradicional no Brasil". ${ }^{31}$ Nesta palestra, Severo apresentou com sucesso à elite paulistana ali presente suas teorias sobre a importância da preservação dos valores da "raça" portuguesa ${ }^{32}$ e a sua influência na cultura brasileira, então em formação. Ricardo Severo propugnava a criação de um estilo brasileiro "destinado a revalorizar as tradições históricas locais, adaptando-as mais ou menos às necessidades do presente." ${ }^{33}$ Este desejo de volta às tradições culturais e construtivas ${ }^{34}$ trazia no seu bojo uma reação latente ao predomínio estrangeiro na arquitetura, configurado nas misturas exageradas de estilos históricos assumidas pelo ecletismo paulistano.

Nos anos que se seguiram ao fim da Primeira Grande Guerra o Neocolonial, como ficou conhecido posteriormente, se afirmou ${ }^{35}$ e se vulgarizou em duas correntes : uma de cunho erudito, derivada da atuação direta de Severo e praticada por profissionais habilitados

\footnotetext{
${ }^{31}$ Ricardo Severo chegou a São Paulo pela segunda vez em 1907, onde se estabeleceu permanentemente e se tornou sócio de Ramos de Azevedo na Companhia Iniciadora Predial em 1908. O texto integral da sua palestra, pronunciada na Sociedade de Cultura Artística em 1914, foi publicado no volume intitulado Conferências 1914-1915.

${ }^{32}$ Até o início do século XX a palavra "raça" designava o que hoje entendemos como "cultura" no sentido antropológico. Desta forma, quando Ricardo Severo defendia a "raça" portuguesa estava na verdade se referindo à proteção de valores, instituições e criações resultantes do grau de desenvolvimento cultural do povo português.

${ }^{33}$ In: BRUAND, Yves. Arquitetura Contemporânea no Brasil, p. 25 . Ver também: LEMOS, Carlos A . C. Ramos de Azevedo e seu escritório ; SEGAWA, Hugo . Arquiteturas no Brasil 1900 - 1990.

34 ".../ Surge a idéia de recuperação de nossa tradição arquitetônica - estava nascendo o neocolonial, que dizem ter sido inspirado pelo engenheiro Ricardo Severo, e nessa hora começavam a chegar os reflexos da 1a Grande Guerra, melhor dizendo a nova estética nacionalista surgiu no momento em que caía vertiginosamente o ritmo das construções paulistanas devido às conseqüências daquele conflito. Paradoxalmente, essa nova idéia vingou ; germinou a semente plantada na entressafra para dominar a produção burguesa de residências dos anos 20." In: LEMOS, Carlos A. C. Alvenaria Burguesa, p. 154.

${ }^{35}$ O Neocolonial não foi aceito passivamente no cenário arquitetônico de São Paulo da segunda década do século XX. Um dos principais opositores do movimento tradicionalista na arquitetura foi o engenheiro arquiteto Christiano Stockler das Neves, que polemizou com o escritor e jornalista Monteiro Lobato em uma série de artigos publicados na imprensa local da época. Ver : LOBATO, Monteiro. Idéias de Jeca Tatú ; NEVES, Christiano Stockler das. "Architectura Colonial." In: Jornal do Commercio. 03/02/1917, p.4 e 5 .
} 
para a classe alta; e outra popular, decorrente da primeira e realizada de modo despoliciado, em geral, por construtores anônimos para as camadas médias da população paulistana.

Representando a corrente erudita do Neocolonial luso-brasileiro em São Paulo podemos apontar, dentre outros, como expoentes do movimento, além do próprio Ricardo Severo, ${ }^{36}$ o arquiteto francês Victor Dubugras, radicado em São Paulo em $1891 .{ }^{37}$ A arquitetura residencial produzida por Victor Dubugras nos anos 20 e 30 tornou-se quase um paradigma para a vertente de caráter popular do Neocolonial, que será estudada mais atentamente, na seqüência do trabalho, quando tratarmos da arquitetura de classe média em São Paulo.

No início da década de 20 o movimento Neocolonial, lançado por Severo, se inseriu num rol de manifestações culturais de cunho patriótico, influenciadas pela proximidade das comemorações do Centenário da Independência brasileira, que iriam acontecer em 1922, e adquiriu expressão nacional. No Rio de Janeiro, então capital federal, estava prevista a realização da Exposição Internacional do Centenário da Independência, na qual o Neocolonial teve oportunidade de se firmar como estilo oficial adotado nas construções públicas. $^{38}$

No mesmo ano das comemorações da Independência, ocorreu em São Paulo a Semana de Arte Moderna. ${ }^{39}$ Esta manifestação artística de impacto na época e de significativa importância para as transformações que se processaram posteriormente no quadro cultural nacional apresentava uma dualidade: ${ }^{40}$ ao mesmo tempo em que seus

36 Ricardo Severo "não se limitou a conduzir com vigor sua campanha em favor do "estilo colonial brasileiro", deu o exemplo construindo, para si próprio e para alguns clientes atraídos por suas idéias e pela elegância de sua arquitetura, belas residências." In: BRUAND, Yves. Arquitetura Contemporânea no Brasil, p. 52. Ver também: LEMOS, Carlos A. C . Alvenaria Burguesa.

37 "Desde 1915 Dubugras vinha adotando o novo estilo; portanto parece que sua conversão foi devida à campanha em favor do neocolonial feita por Ricardo Severo em 1914. I... Sua "arquitetura tradicional brasileira" (termo que adotou para designar essa última tendência) não rompeu totalmente com as fases anteriores da sua obra, como ainda hoje pode ser constatado /.../: a escadaria da Ladeira da Memória /... / e o conjunto de monumentos comemorativos da Independência, construídos em 1922 ao longo da antiga estrada para Santos." In: BRUAND, Yves. Arquitetura Contemporânea no Brasil, p. 53.

38 " /.../ O estilo neocolonial encontrou de imediato uma magnífica oportunidade de afirmar-se : a Exposição Internacional do Centenário da Independência, inaugurada em 1922. Alguns dos pavilhões brasileiros eram inteiramente acadêmicos, mas a sua maioria /.../ prendia-se ao novo estilo, considerado "símbolo da emancipação artística do país, cem anos após a sua emancipação política. /.../ O sucesso do neocolonial na exposição internacional de 1922 teve uma profunda repercussão ; o estilo não apreciado apenas em termos locais, mas também elogiado pelos estrangeiros, encantados com o exotismo que ele exalava ; por sua vez, esses elogios reforçaram o entusiasmo brasileiro pelo movimento, que a partir de então passou a contar com o apoio oficial declarado.” In: BRUAND, Yves. Arquitetura Contemporânea no Brasil, p. 55 e 56.

${ }^{39}$ A Semana de Arte Moderna aconteceu entre 11 e 18 de fevereiro de 1922 no Teatro Municipal de São Paulo, idealizada e realizada por artistas, intelectuais e membros da elite paulistana. A Semana mostrou ao público uma exposição de artes plásticas e três festivais com a apresentação de conferências e recitais de música e de poesia. Os seus organizadores pretendiam chocar a burguesia paulistana com propostas literárias e artísticas de vanguarda. Ver: AMARAL, Aracy. Artes Plásticas na Semana de 22

${ }^{40}$ Ver: CAMARGOS, Márcia. Semana de 22 entre vaias e aplausos, p. 159 e 160 
idealizadores buscavam a afirmação de uma identidade cultural local a partir da valorização de expressões nacionalistas ou regionalistas, ${ }^{41}$ procuravam também expressar uma modernidade e um cosmopolitismo em sintonia com o que estava acontecendo na Europa e nos Estados Unidos. Naquela Semana, a arquitetura exposta nada tinha a ver com a "modernidade" européia então em voga (baseada no cubismo, no racionalismo e no funcionalismo), ao contrário das demais manifestações artísticas nela apresentadas, como a pintura, a música e a poesia, que se inspiravam diretamente nos modelos europeus.

"Acreditamos que os organizadores da "Semana de Arte Moderna" de 1922 tenham, até o último momento, esquecido da arquitetura como sendo, também, uma expressão artística. Tem-se a impressão que ainda não circulava entre aquelas pessoas da elite cafezista a idéia da modernidade advinda da nova estética ligada aos novos materiais de construção. /.../ Para representar a arquitetura moderna na exposição da artes plásticas foram escolhidos o espanhol de Granada Antônio Garcia Moya, de 31 anos, e o arquiteto polonês George Wilhelm Emil Przyrembel, de 37 anos." (LEMOS, 2002, p. 1)

Moya apresentou no saguão do Teatro Municipal de São Paulo desenhos de residências, de uma fonte e de um mausoléu em um estilo indefinido, semelhante às construções da região da Mesopotâmia ou pré-colombianas do México. Já Przyrembel mostrou o projeto de uma residência de veraneio na Praia Grande com referências pouco explícitas ao Neocolonial. ${ }^{42}$ Pela amostragem do que foi exposto durante a Semana de 22 podemos dizer que o "moderno" em arquitetura para a intelectualidade paulistana do início dos anos 20 era tudo o que fosse diferente das soluções ecléticas dos imigrantes, não importando se o arquiteto se abstraísse para o exótico ou para o fantasioso. E, nas palavras de Yves Bruand se

"/.../ não exerceu a Semana de Arte Moderna qualquer influência direta sobre a arquitetura. /... Ela criou um clima novo, revelou um espírito de luta contra o marasmo intelectual, contra a aceitação incondicional dos valores estabelecidos." (BRUAND, 1981, p.63)

\footnotetext{
41 "O sentimento nativista, como todos sabemos, veio a impregnar toda a produção pós-Semana, na literatura, na música e nas artes plásticas, através dos movimentos Pau Brasil, Verde Amarelo etc., consubstanciados pela antropofagia oswaldiana. Assim, foi a arquitetura a primeira manifestação patrioteira de nossa arte moderna, vinda bem antes da dedicação da intelectualidade às nossas raízes. /.../ Esse tradicionalismo assumido pelos modernistas veio como uma firmação indicativa de independência cultural na produção artística, tanto na literatura como nas artes plásticas. É claro que não se tratava de mero saudosismo. Buscava-se na tradição a identidade brasileira expressa agora através da nova linguagem da nova estética. Essa firmação nacionalista deve ter sido provocada por mais de um motivo \%.... A nosso ver, a espantosa presença dos imigrantes estrangeiros na cidade, /... justificou o início da preocupação nativista. E, depois, a exacerbação do nacionalismo decorrente das comemorações do centenário da Independência, coincidentes, inclusive, com os dias da Semana de Arte Moderna." In: LEMOS, Carlos A. C. A Arquitetura dos Modernistas de 1922, p. 3 e 4

${ }^{42}$ Sobre o assunto ver: AMARAL, Aracy. Artes Plásticas na Semana de 22.
} 
Como opção estilística paralela ao Neocolonial luso-brasileiro apareceu no final da década de 1920 a moda do Neocolonial hispano-americano ou Missões, ${ }^{43}$ inspirado na arquitetura colonial produzida nas missões espanholas do México e da Califórnia. ${ }^{44}$ Este novo estilo teve fácil aceitação e logo se propagou por influência direta dos meios de comunicação de massa como as revistas femininas e de variedades e o cinema. ${ }^{45} \mathrm{~A}$ rápida e intensa difusão do gosto da arquitetura missioneira, tanto em residências da classe alta em bairros como o Jardim América, quanto em soluções sincréticas nas casas populares dos bairros de classe média, pode ser em parte explicada pelo fato do Neocolonial hispanoamericano ser um estilo mais elegante e requintado nos seus detalhes ornamentais em comparação ao Neocolonial luso-brasileiro. ${ }^{46}$

Concomitantemente às versões do Neocolonial luso-brasileiro e do hispanoamericano surge no cenário arquitetônico paulistano outra corrente estilística de grande aceitação popular, o Art Déco. A estética déco difundiu-se mundialmente a partir da Exposition Internationale des Arts Décoratifs et Industriels Modernes realizada em Paris entre abril e outubro de $1925 .{ }^{47} \mathrm{Na}$ arquitetura européia aparece como uma reação ao Art Nouveau e ao Ecletismo Historicista ao propor uma "modernização dos estilos" através da simplificação formal e da redução e geometrização ornamental das fachadas apoiada no uso da nova técnica construtiva do concreto armado. Em função dos seus estilemas que induziam a uma idéia de modernidade ${ }^{48}$ o Art Déco ganhou rapidamente adeptos em todas

\footnotetext{
${ }^{43}$ Eduardo Kneese de Mello, Oswaldo Bratke e Alfredo Ernesto Becker, no início de suas carreiras, foram os arquitetos mais fecundos no emprego do estilo Missões em São Paulo.

44 "Já em 1901 a evocação da herança espanhola comparece na arquitetura americana. Nos EUA as regiões urbanizadas no início do século XX se caracterizam pela "salada" estilística. O mexicano, o "misiones", são estilos que a burguesia endinheirada edifica na Califórnia e na Flórida principalmente, à imagem do que aconteceria em nossos "jardins" (urbanizados pela Cia. City) nas décadas de 30 e 40. Como analogia, vale dizer que Hollywood nos "crazy twenties" é inteiramente neocolonial, ou seja, neo-americana em geral (neocolonial mexicano, neocolonial "misiones", neocolonial "pueblos indígenas", neo-astecas, etc.). Cinematografiza-se o passado, para sofisticar o presente." In: COSTA, José Horácio de Almeida Nascimento. Sobre o Neocolonial, p. 22.

45 "A linguagem neocolonial hispano-americana aparecia nos projetos publicados em revistas brasileiras de arquitetura subdividido em estilo missões, espanhol, mexicano, californiano, cujas especificidades pouco evidentes não parecem relevantes sob um exame atual." In: WOLFF, Silvia Ferreira Santos. Jardim América - o primeiro bairro-jardim de São Paulo e sua arquitetura, p. 175

${ }^{46}$ Nas palavras de Paulo Santos "o neocolonial era grave e viril ; o mission style gracioso e delicado ; a conjugação dos dois /.../ constituiu uma das notas características da sensibilidade artística da segunda metade da década. Na luta pela sobrevivência seriam as formas hispânicas - talvez por mais leves e menos anacrônicas - as que mais resistiram /.../ " SANTOS, Paulo. "400 Anos Memoráveis." In: Jornal do Brasil. 09/12/1965, p. 295.

47 "O Art Déco foi um conjunto de manifestações artísticas, estilisticamente coeso, originado na Europa e que se expande para as Américas do Norte e do Sul, inclusive o Brasil, a partir dos anos 20. Seu lançamento formal ao público ocorre na Exposition Internationale des Arts Décoratifs et Industriels Modernes, acontecida em Paris, em 1925, muito embora haja registro de manifestações isoladas antes dessa data." In: CZAJKOWSKI, Jorge (org.). Guia da Arquitetura Art Déco no Rio de Janeiro, p.9.

${ }^{48}$ Modernismo de aparência conseguido através de ".../ artifícios de desenho : linhas retas, platibanda ocultando o telhado de telhas tipo Marselha, revestimento com mica, alguns ornamentos retilíneos e o fingimento de uma poderosa estrutura de concreto." In: REIS FILHO, Nestor Goulart. Quadro da Arquitetura no Brasil, p. 68.
} 
as classes sociais em São Paulo e se propagou durante a década de 30 em construções residenciais de todos os tipos : desde requintados palacetes nos bairros nobres da capital paulista $^{49}$ até simples casas operárias.

Neste texto não podemos deixar de mencionar também uma manifestação isolada e particularizada ocorrida entre o final dos anos 20 e início dos 30, mas de grande significância para a historiografia arquitetônica brasileira, representada pela arquitetura modernista introduzida na capital paulista pelo arquiteto russo Gregori Warchavchik. ${ }^{50} \mathrm{Em}$ 1925 Warchavchik escreveu um artigo pioneiro intitulado "Futurismo" publicado em São Paulo no jornal $\underline{\text { Picolo }},{ }^{51}$ no qual defendia uma nova estética arquitetônica que deveria ser baseada em conceitos de racionalidade e funcionalidade mais adequados aos tempos modernos. ${ }^{52}$ Este manifesto trazia idéias inovadoras a respeito de um novo conceito de modernidade na arquitetura em consonância com a produção européia contemporânea da época. Assim, propugnava uma arquitetura vinculada diretamente aos novos modos de construção, ferro, vidro e, sobretudo, o concreto armado. ${ }^{53}$

\footnotetext{
${ }^{49}$ Ver : HOMEM, Maria Cecília Naclério. Higienópolis - grandeza e decadência de um bairro paulistano ; MACEDO, Silvio Soares. Higienópolis e Arredores. Processo de Mutação de Paisagem Urbana.

${ }^{50}$ O arquiteto Gregori Warchavchik emigrou para São Paulo em 1923, contratado pela Companhia Construtora de Santos. Ver : SEGAWA, Hugo. "Modernidade Pragmática. Uma Arquitetura dos anos 1920/40 fora dos manuais." In: Revista Projeto. 1995, p.74.

${ }^{51}$ Em 14 de junho de 1925 Warchavchik publica no jornal italiano II Picolo (São Paulo) um manifesto em prol da estética modernista intitulado "Futurismo" ; este mesmo manifesto foi traduzido e republicado no Correio da Manhã (Rio de Janeiro) em 1ํ de novembro de 1925 com o título "Acerca da Arquitetura Moderna".

52 "Para que a nossa arquitetura tenha seu cunho original, como o têm as nossas máquinas, o arquiteto moderno deve não somente deixar de copiar os velhos estilos, como também deixar de pensar o estilo /.../ A nossa arquitetura deve ser apenas racional, deve basear-se apenas na lógica e esta lógica devemos opô-la aos que estão procurando por força imitar na construção algum estilo. Construir uma casa a mais cômoda e barata possível, eis o que deve preocupar o arquiteto construtor da nossa época de pequeno capitalismo, onde a questão de economia predomina sobre todas as mais. A beleza da fachada tem que resultar da racionalidade do plano da disposição interior, como a forma da máquina é determinada pelo mecanismo que é a sua alma. O arquiteto moderno deve amar sua época /.../. Tomando por base o material de construção de que dispomos, estudando-o e conhecendo-o como os velhos mestres conheciam sua pedra, não receando exibi-lo no seu melhor aspecto do ponto de vista de estética, fazendo refletir em suas obras as idéias do nosso tempo, a nossa lógica, o arquiteto moderno saberá comunicar à arquitetura um cunho original, cunho nosso, o qual será talvez tão diferente do clássico como este o é do gótico. Abaixo as decorações absurdas e viva a construção lógica, eis a divisa que deve ser adotada pelo arquiteto moderno." WARCHAVCHIK, Gregori. "Acerca da Arquitetura Moderna" In: Arte em Revista. no 4, ago.1980, p. 6.

${ }^{53}$ Quase simultaneamente ao manifesto de Warchavchik, o arquiteto Rino Levi publicou em 15 de outubro de 1925 no jornal $\underline{\mathrm{O}}$ Estado de São Paulo a carta intitulada "A Arquitetura e a Esthetica das Cidades". Como diz Yves Bruand "/../ com efeito, encontravam-se temas comuns em Warchavchik e Rino Levi : a arquitetura ditada pela praticidade e pela economia, a redução dos elementos decorativos ao mínimo e que deveriam corresponder a uma função, a necessidade da união do artista e do técnico na pessoa do arquiteto. Mas o espírito dos dois textos era muito diverso. Rino Levi, formado pela mesma escola que Warchavchik, mas ainda estudante em Roma, interessava-se sobretudo por urbanismo e aceitava sem hesitação o neoclassicismo simplificado de seu professor, Marcelo Piacentini /.../ Warchavchik era bem mais radical : rejeitava a idéia de estilo contemporâneo /.../ e propunha uma explicação racionalista para a história da arquitetura." In: BRUAND, Yves. Arquitetura Contemporânea no Brasil, p. 64 e 65.
} 
Como forma de divulgação explícita de suas idéias Gregori Warchavchik constrói em 1927 a que é considerada a primeira casa modernista de São Paulo, sua própria residência na rua Santa Cruz, no bairro de Vila Mariana. A edificação apresenta externamente uma volumetria e uma linguagem formal e estilística inspirada na estética cubista, apesar de possuir um arcabouço construtivo tradicional de alvenaria de tijolos e cobertura de telhas canal. A sua feição "moderna" advém da platibanda reta, sem beiral, e da ausência de ornamentos parietais externos, que a distinguia de todas as edificações residenciais contemporâneas. No final dos anos 20 e durante a década de 30 Warchavchik projetou e construiu várias residências em São Paulo aplicando os estilemas da sua casa modernista, o que definiu uma marca pessoal na produção de uma arquitetura residencial de exceção, ${ }^{54}$ um modo próprio do arquiteto, que levou Mário de Andrade a chamá-lo de "casas no estilo das de Warchavchik". 55

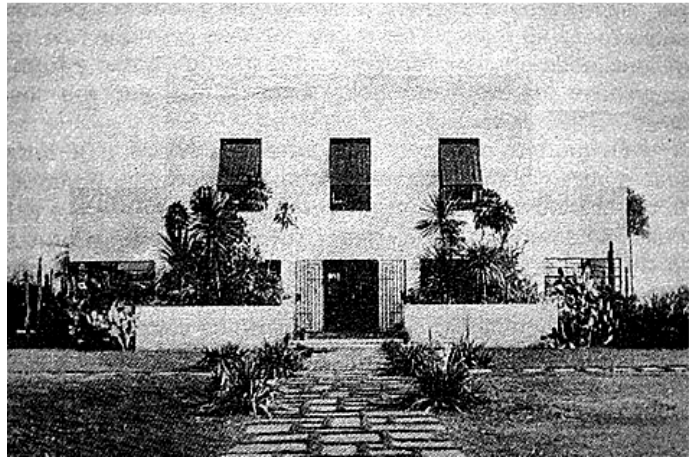

FIGURA 9 : Casa Modernista da rua Santa Cruz. (Gregori Warchavchik / São Paulo, 1927/28)

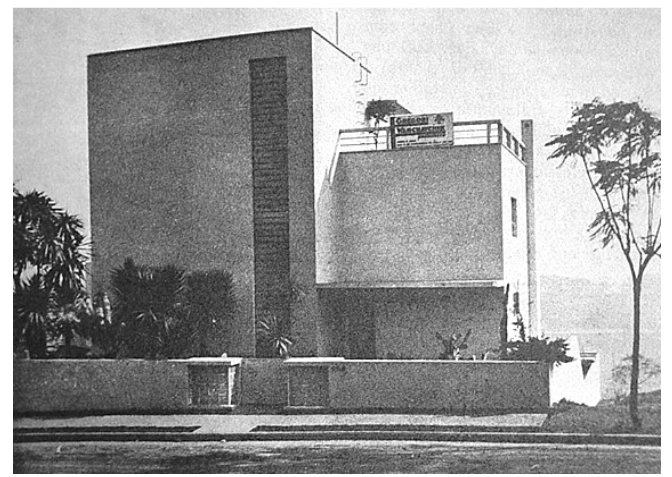

FIGURA 10 : Casa da rua Bahia. (Gregori Warchavchik / São Paulo, 1930)

\footnotetext{
54 “.../ a casa de Max Graf na Rua Melo Alves (1928-1929), Warchavchik empregou decididamente o concreto armado. A partir de então, o estilo Warchavchik já estava definido, em suas linhas básicas. Sua evolução nos anos seguintes deveu-se aos rápidos progressos da técnica, que propiciaram maiores audácias ao arquiteto. /.../ Podia-se de fato, falar de um estilo Warchavchik /.... Inspirado nas teorias de Le Corbusier, fundia intimamente o funcionalismo e o cubismo arquitetônico, em moda na década de 20. /... Entretanto, o objeto dessas audaciosas inovações não era em princípio de ordem estética ; visava principalmente mostrar todas as possibilidades que o concreto armado possibilitava, liberando o arquiteto e permitindo-Ihe concentrar-se na solução dos problemas funcionais. Não se procurava a forma a priori , nem a forma pela forma - ela era o resultado lógico de um programa coerente : habitação clara, com os ambientes amplamente voltados para o exterior, prolongados na medida do possível por terraços e balcões. /.../ O que ele não conseguiu foi impor essa arquitetura de modo definitivo." In: BRUAND, Yves. Arquitetura Contemporânea no Brasil, p. 68 e 70.
}

${ }^{55}$ Ver : ANDRADE, Mário de. "Exposição duma Casa Modernista (Considerações)". In: Arte em Revista. no 4, 1980, p. 8. 
Quanto às principais alterações técnico-construtivas ocorridas nas habitações paulistanas a partir do final dos anos 20 podemos destacar o efeito causado pela utilização gradual de estruturas de concreto armado neste tipo de construção. A introdução do concreto armado representou naquele momento um importante aperfeiçoamento técnico nas residências, em comparação à alvenaria estrutural de tijolos, até então empregada.

As primeiras aplicações do novo modo construtivo em São Paulo ocorreram em prédios localizados no centro da cidade, o que nos leva a considerar que o uso do concreto armado possibilitou o início do processo de verticalização experimentado na capital paulista a partir dos anos 20. 


(2)



II. Os modelos estilísticos em voga nos anos 20 e 30
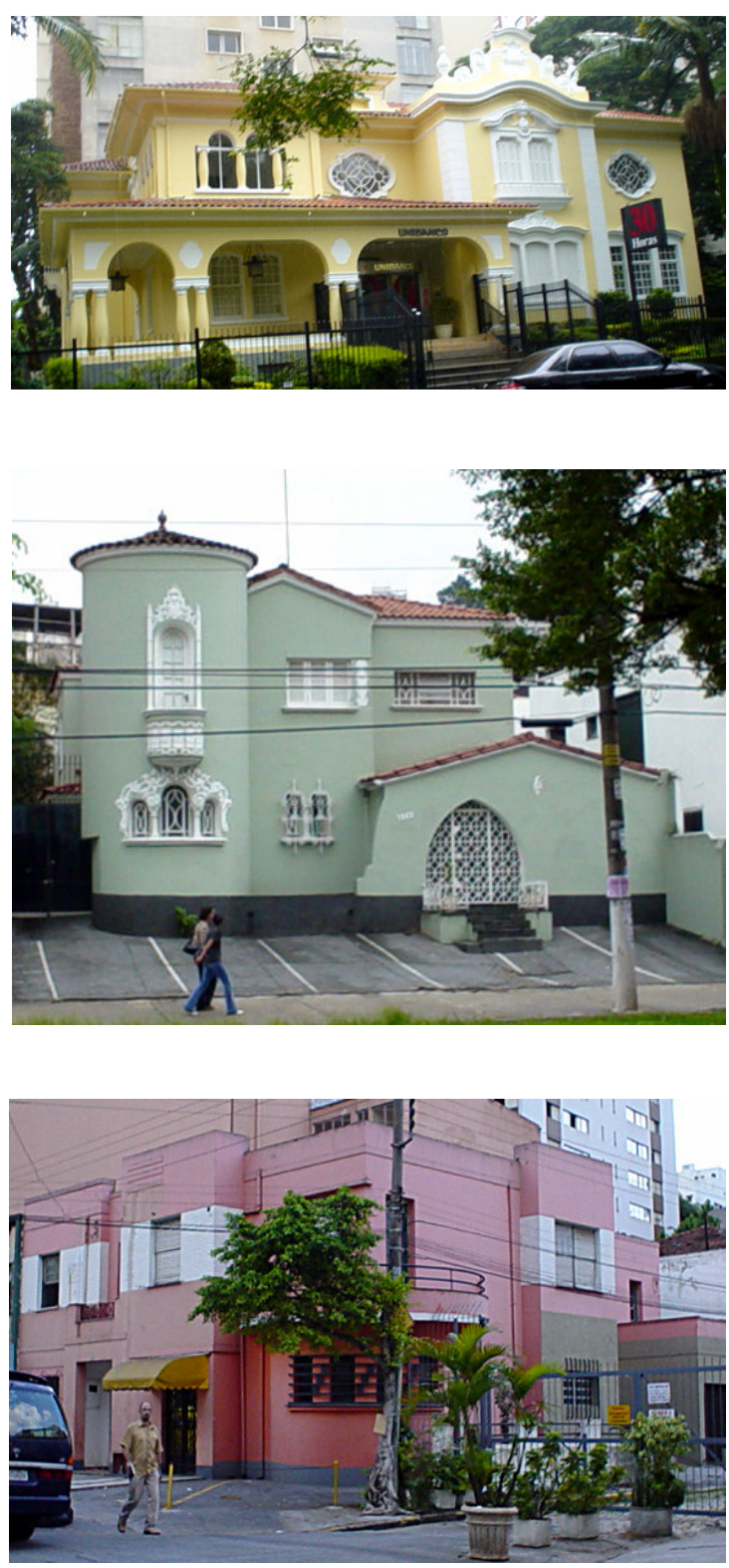


\section{II.1. O Neocolonial e a procura da modernidade e da identidade cultural}

\section{II.1.1. SURGIMENTO DO MOVIMENTO NEOCOLONIAL}

A idéia do movimento Neocolonial ou Tradicional, como era chamado na época pelos seus seguidores, foi lançada em São Paulo durante a apresentação da conferência "A Arte Tradicional no Brasil" por Ricardo Severo da Fonseca Costa na Sociedade de Cultura Artística em 1914, como já foi dito. Naquela ocasião o engenheiro português preconizou "/.../ a valorização da arte tradicional como manifestação de nacionalidade e como elemento de constituição de uma arte brasileira." ${ }^{1}$ Para Ricardo Severo a arquitetura tradicional era a única expressão artística apropriada ao espírito da nação brasileira e não significava uma simples reprodução de construções antigas de taipa ou de pau a pique, sem higiene e sem aparência estética. Severo propunha uma revalorização das tradições construtivas brasileiras, adaptando-as às condições e necessidades contemporâneas.

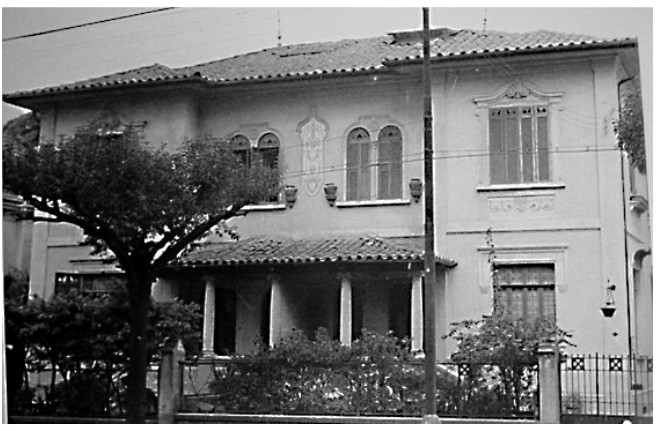

FIGURA 11 : Residência à avenida Angélica. (Ricardo Severo / São Paulo, 1910)
A divulgação das idéias tradicionalistas de Severo coincidiram historicamente com o início da Primeira Grande Guerra (1914-1918), o que fez com que o movimento Neocolonial não se difundisse de imediato. $^{2}$ Não existem até 0 momento referências precisas sobre qual foi a primeira obra de cunho neocolonial realizada em São Paulo. Suspeitamos que uma das edificações pioneiras tenha sido uma residência na avenida Angélica (hoje demolida), projetada e construída por Ricardo Severo no ano de 1910, portanto, dois anos depois da sua fixação na capital paulista. ${ }^{3}$

\footnotetext{
${ }^{1}$ In: SEGAWA, Hugo. Arquiteturas no Brasil 1900-1990, p.35.

2 "A publicação de sua conferência de 1914 e de outra palestra, proferida na Escola Politécnica de São Paulo em 1917, constituem as primeiras tentativas de sistematização do conhecimento sobre a arquitetura tradicional brasileira. Todavia, a manifestação pioneira de Severo não encontrou rebatimento imediato em forma de obras realizadas, porquanto a deflagração da Primeira Guerra (1914-1918) repercutiu negativamente no ritmo da construção civil no país. Victor Dubugras, nesse sentido, já em 1915 projetava as primeiras casas de inspiração tradicional na cidade de Santos [Motta 1957]." Idem, ibidem.

${ }^{3}$ Esta residência é considerada por vários autores como a casa neocolonial mais antiga conhecida em São Paulo. Ver : LEMOS, Carlos A. C. Ramos de Azevedo e seu escritório, p. 85 ; WOLFF, Silvia Ferreira Santos. Jardim América. O primeiro bairro-jardim de São Paulo e sua arquitetura, p. 171 ; FAUSTO, Bóris. Negócios e Ócios.
} 
Somente após a cessação do conflito mundial, com o restabelecimento das condições econômico-políticas, mundiais e nacionais, e com a preocupação iminente das comemorações do centenário da Independência em 1922, que exarcebaram sobremaneira o sentimento nacional de patriotismo, é que o Neocolonial pôde empolgar vivamente a elite paulistana com a sua retórica nacionalista, e num momento seguinte, contagiar e influenciar decisivamente o gosto popular. ${ }^{4}$

Com o objetivo de identificar e documentar o repertório estilístico da arquitetura antiga brasileira, cujos elementos pudessem servir de referência para a elaboração de projetos de cunho tradicionalista, Ricardo Severo financiou pioneiramente no final da década de 1910 as viagens de pesquisa de Felisberto Ranzini e José Wasth Rodrigues para o interior do país. ${ }^{5}$

A partir do material coletado nestas viagens, o arquiteto Felisberto Ranzini editou em 1927 o livro Estylo Colonial Brasileiro - Composiç̃es Architectonicas de Motivos Originaes. ${ }^{6}$ Nesta obra o professor de Desenho de Composição Geral da Escola Politécnica de São Paulo apresentava pranchas com desenhos primorosos de variantes de detalhes da arquitetura colonial brasileira, misturando sem escrúpulo elementos da arquitetura civil e religiosa. No texto introdutório o editor Amadeu de Barros Saraiva justificava a publicação esclarecendo que a

".../ ausência de documentação, bôa e farta, das formas de detalhe e conjuncto, sobre a nossa Architectura Tradicional, tem sido um entrave forte para sua expansão" e que "os presentes desenhos /.../ foram inspirados em trabalhos existentes nas varias regiões do Paiz." (RANZINI, 1927, p. 6)

\footnotetext{
${ }^{4}$ Assim, ".../ as novas idéias preconizadas por Ricardo Severo - pejadas do mais alto nacionalismo - repercutiram em tôda a sociedade paulistana, alastrando-se depois pelo país. O entusiasmo contagiante do ilustre arquiteto tocou fundo a maioria dos nossos artistas plásticos e principalmente os jovens arquitetos de sua época. Tomou vulto o movimento do nacionalismo renovador da nossa arquitetura. Muitas construções particulares, desde a mais modesta casinha até os suntuosos palácios, foram vasados no estilo colonial ou Arquitetura Tradicional Brasileira, não só em São Paulo, como no Rio de Janeiro e nos demais estados da federação brasileira. Revistas, jornais, enfim toda a imprensa do país, e mesmo estrangeira, referia-se ao nôvo estilo arquitetônico com a maior simpatia e aprovação." Excertos da conferência proferida por José Maria da Silva Neves em 06/11/1969. In: Homenagem a Ricardo Severo - Centenário de seu nascimento 1869 - 1969, p. 71.

${ }^{5}$ Ver : PINHEIRO, Maria Lúcia Bressan. “Ricardo Severo e o Estilo Tradicional Brasileiro.” In: Revista d’Art. ํo 3, 1998.

6 "Esta obra - na qual se não pouparam esforços para apresental-a atrahentemente que é a primeira no gênero /.../ se destina quer aos architectos de nossa Terra e a todos os artistas auxiliares do constructor, quer aos amantes da Arte Colonial." In: RANZINI, Felisberto. Estylo Colonial Brasileiro. Composições Architectonicas de Motivos Originaes, p. 6.
} 


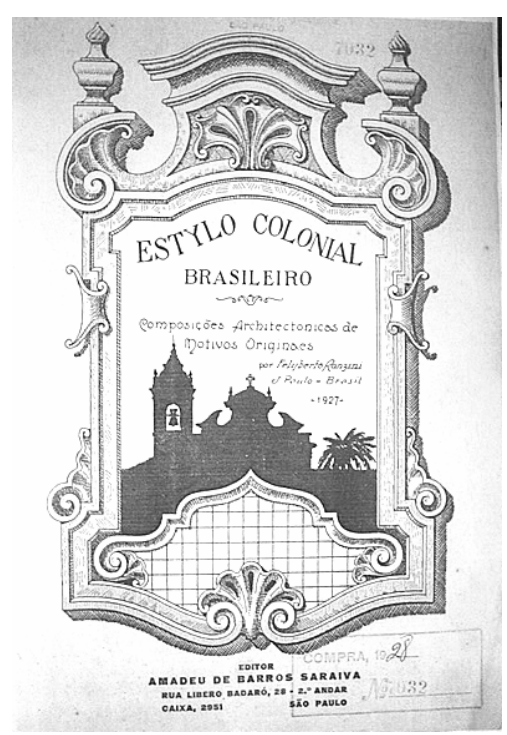

FIGURA 12 : Capa do "Estylo colonial brasileiro". (Felisberto Ranzini / 1927)
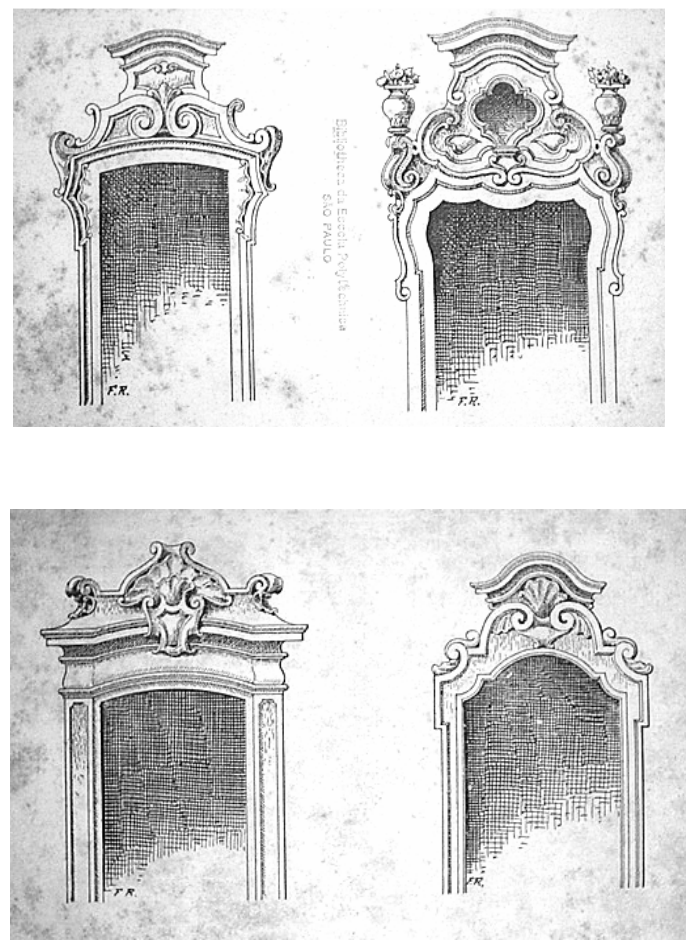

FIGURA 14: Exemplos de coroamentos de envasaduras. (Felisberto Ranzini / 1927)

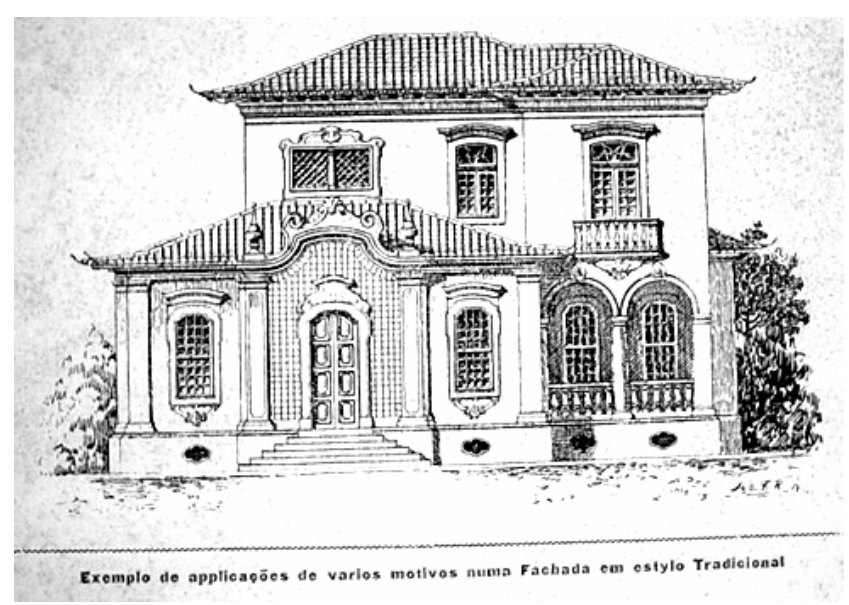

FIGURA 13 : "Exemplo de applicações de vários motivos numa Fachada em estylo Tradicional" (Felisberto Ranzini / 1927)

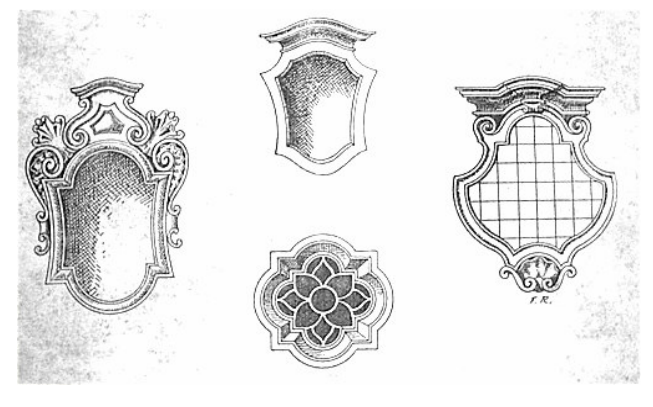

FIGURA 15 : Exemplos de óculos. (Felisberto Ranzini, 1927)

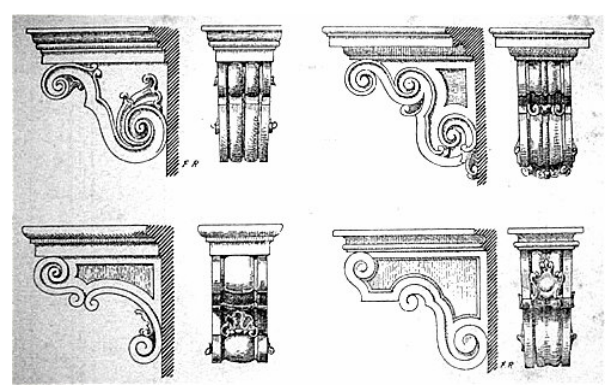

FIGURA 16 : Exemplos de mísulas. (Felisberto Ranzini / 1927) 
Apesar de ter realizado as suas primeiras viagens de pesquisa a Iguape e Minas Gerais, em 1918, José Wasth Rodrigues só conseguiu publicar o seu Documentário Arquitetônico no ano de 1945. No prefácio do seu livro explicou que ".../ circunstâncias /.../ alheias à nossa vontade, impediram que tal publicação se realizasse" e, lamentou mais adiante que

“.../ fosse feita há alguns anos atrás a sua divulgação, teria a presente coleção, com certeza, servido para corrigir num melhor sentido o neo colonial, fornecendo sugestões e detalhes autênticos, /.../pois, uma obra nacional, para ser inteiramente útil a essa finalidade, deveria ter aparecido há mais de vinte anos, no momento do surto sentimental pela casa brasileira antiga. " (RODRIGUES, 1975, p.1)

A importância do trabalho do artista Wasth Rodrigues baseado em fotografias antigas (como as de Militão de Azevedo em São Paulo) ${ }^{7}$ e nos apontamentos elaborados durante as suas viagens às cidades do interior de Minas Gerais, Rio de Janeiro, Bahia e São Paulo, se deve principalmente à minúcia com que os desenhos foram realizados, refletindo uma preocupação constante do seu autor de documentar fielmente os modelos que observava.

Estes dois levantamentos foram úteis devido ao seu caráter eminentemente prático de manuais organizados didaticamente de forma a orientar os arquitetos e construtores da época na melhor fatura e elaboração de seus projetos neocoloniais. Ao mesmo tempo, esses trabalhos pioneiros de sistematização devem ser valorizados porque permitiram um conhecimento mais aprofundado da nossa arquitetura colonial e o estabelecimento de uma série de estilemas que definiram o receituário do Neocolonial luso-brasileiro. ${ }^{8}$

A postura desse movimento caracterizava-se pela livre combinação de elementos das arquiteturas residencial e religiosa barroca portuguesa, da bandeirista paulista, do rococó mineiro e do colonial nordestino. O espírito eclético estava configurado na mistura sem escrúpulo de frontões curvos, volutas, contra-volutas, balcões, portadas de pedra, treliças, beirais, coberturas de várias águas com telhas de barro tipo "paulistinha", gradis e "cachorros" de madeira trabalhada, uso decorativo de painéis de azulejos portugueses, aplicação de elementos de cantaria nos embasamentos e cunhais das fachadas etc.

\footnotetext{
${ }^{7}$ José Wasth Rodrigues nos explica que "a documentação fotográfica da cidade de São Paulo nos meados do século passado é muito limitada. O primeiro fotógrafo a se ocupar do assunto parece ter sido Militão, que nos deixou uma valiosa coleção de ótimas fotografias iniciadas em 1862, coleção que nos dá uma idéia perfeita da cidade naqueles tempos, informando-nos sobre preciosos detalhes arquitetônicos. /.../ Da paciente análise das fotografias de Militão conseguimos selecionar e reproduzir algumas casas típicas e detalhes dignos de destaque /.../ "In: RODRIGUES, José Wasth. Documentário Arquitetônico Relativo à antiga construção civil no Brasil, p.7.

${ }^{8}$ As pesquisas de José Wasth Rodrigues e Felisberto Ranzini, em São Paulo, e de Lúcio Costa e outros, no Rio de Janeiro, contribuíram muito para o estudo sistemático da arquitetura colonial brasileira; e, pode-se mesmo dizer, que estas pesquisas pioneiras deram ensejo ao surgimento das primeiras preocupações preservacionistas relativas à arquitetura antiga do país, que culminaram com a criação do IPHAN (Instituto do Patrimônio Histórico e Artístico Nacional) em 1937 (decreto oㅜ 35/37).
} 
No final dos anos 20, por influência direta do cinema americano e pela intensa veiculação de revistas femininas e de variedades, que mostravam a última moda arquitetônica e decorativa das mansões dos "astros hollywoodianos", é introduzida aqui uma expressão variante do Neocolonial, que agradou de imediato e logo se tornou um modismo na arquitetura residencial da época. Esta variante, também conhecida como "Mission Style", tinha inspiração hispano-americana, com fortes referências à arquitetura produzida nas missões espanholas estabelecidas na Califórnia e no México na época colonial. Diferentemente do que ocorreu nos Estados Unidos, em que o estilo Missões adquiriu um caráter artificial de mera moda arquitetônica, ${ }^{9}$ nos países latino-americanos o desejo de busca das raízes das identidades culturais regionais e de afirmação nacional atingiu todo o continente, não se configurando num evento isolado. Contemporaneamente esses países se voltaram para o estudo das suas formações de origem pré-colombiana e colonial espanhola. Esta linguagem neocolonial hispano-americana se disseminou rapidamente por todos os países da América Latina, inclusive pelo Brasil, e teve uma duração efêmera, cujo ápice ocorreu por volta de meados dos anos $30 .^{10}$

Não podemos deixar de mencionar aqui a importância histórica destacada que o movimento Neocolonial assumiu na cidade do Rio de Janeiro. O fato de ser capital federal e possuir um ambiente social e cultural mais conservador e homogêneo (e, portanto, mais amistoso às idéias patrióticas), somado ao sentimento exacerbado de afirmação nacionalista propagado no final dos anos 10, que culminou na Exposição Internacional do Centenário da Independência em 1922, ${ }^{11}$ contribuíram para que o Neocolonial luso-brasileiro tivesse um caráter mais emblemático no Rio de Janeiro do que em São Paulo.

O médico e historiador de arte pernambucano José Mariano Filho foi o principal articulador e divulgador do movimento no Rio de Janeiro ${ }^{12}$ e a sua influência teórica,

\footnotetext{
${ }^{9}$ O Neocolonial hispano-americano ou Missões foi amplamente empregado nas construções residenciais da Costa Oeste dos Estados Unidos (principalmente na Califórnia) e na Flórida durante os anos 20 e 30.

${ }^{10}$ Sobre o assunto ver : AMARAL, Aracy (coord.) Arquitectura Neocolonial : América Latina, Caribe, Estados Unidos.

11 "O Neo-Colonial, que já vinha se firmando por todo o Brasil na década de 1910-1920, teve para pregação de seus propósitos o mais espetacular palco que se poderia desejar : o recinto da Exposição Internacional do Centenário, realizada no Rio de Janeiro, em setembro de 1922, em que grande número dos principais pavilhões, inclusive um dos mais importantes, o das Grandes Indústrias -, foram vazados no novo pseudo-estilo, que se alastraria por residências, escolas, embaixadas, pavilhões de exposições, inclusive no exterior, etc.e daria lugar a uma sistemática pregação de seus adeptos pelos jornais e revistas /.../ " SANTOS, Paulo F. "Constantes de Sensibilidade na Arquitetura do Brasil." In: Arquitetura Revista FAU / UFRJ . v.6, 1998, p. 66.

12 “.../ Mas foi José Mariano Filho a alma do Movimento e seu virtual chefe a partir de 1919-1920 e quem o levou a adquirir aqui amplitude maior do que em S. Paulo. Embora não fosse arquiteto nem praticasse artes plásticas (médico de profissão), tinha a têmpera de um condottieri , a que a riqueza posta a serviço do que chamava "a minha causa", "a causa da nacionalidade", conferia ares de Mecenas da arquitetura, facilitando dominasse rapidamente o panorama - seja através da palavra falada e escrita, seja pela direta atuação junto aos arquitetos, primeiro no Instituto Brasileiro de Arquitetos fundado em janeiro de 1921, depois na Sociedade Central de Arquitetos fundada no mesmo ano meses depois por elementos dissidentes daquele Instituto, a seguir no Instituto Central de Arquitetos que resultou da fusão em 1924 das duas associações /.../ ambos
} 
econômica e política, ${ }^{13}$ além do forte envolvimento pessoal, marcado pelo seu espírito combativo e quase obsessivo, colaboraram decisivamente para a ampla difusão do movimento tradicionalista, tanto em termos quantitativos, quanto em termos qualitativos.

José Mariano Filho

".../ assegurou maior repercussão à linha tradicionalista com maiores conseqüências que a ação de Severo em São Paulo. Responsável pela denominação "neocolonial" ao movimento /.../ seu ativismo, a partir de 1919 como ideólogo e incentivador junto aos arquitetos e artistas, abriu espaço para que uma série de obras públicas fossem executadas com inspiração na arquitetura tradicional brasileira." (SEGAWA, 1998, p. 36)

A proposta teórica de José Mariano Filho de apropriação do repertório arquitetônico colonial visando uma reinterpretação criativa e contemporânea, não ocorreu na prática. ${ }^{14}$ Os seguidores de Mariano incorreram no mesmo equívoco que permeou as obras de Ricardo Severo e de outros arquitetos em São Paulo, ou seja, eles realizaram simplesmente recriações arquitetônicas desvinculadas das modinaturas originais. Os profissionais de então não conseguiram criar uma nova arquitetura a partir da tradicional; limitaram-se a misturar ornamentações retiradas da arquitetura religiosa, incorporando às fachadas das suas casas frontões, volutas, pináculos etc., sem contudo, tentarem compreender as importantes lições do passado referentes sobretudo às questões de conforto ambiental, como o emprego usual de alpendres sombreadores das paredes mestras. Porém, não podemos deixar de reconhecer que algumas obras neocoloniais analisadas sob a óptica atual podem ser consideradas excepcionais pela sua complexidade volumétrica, inédita na época colonial e resultante de plantas minuciosamente elaboradas, só possíveis de ser executadas graças ao emprego da nova técnica construtiva do concreto armado.

os Institutos o tendo tido como diretor, e ainda pela sua estreita convivência com os artistas em geral na Sociedade Brasileira de Belas Artes, de que foi muitos anos presidente.” In: SANTOS, Paulo F. Quatro Séculos de Arquitetura, p. 98.

${ }^{13}$ Mariano Filho escreveu inúmeros textos e artigos e se envolveu em vários embates na imprensa defendendo as sua idéias a favor da estética tradicionalista ; escreveu "Os Dez Mandamentos do Estylo Neo-Colonial aos Jovens Architectos". Subsidiou as viagens de pesquisa dos arquitetos Lúcio Costa (Diamantina), Nestor de Figueiredo (Ouro Preto) e Nereu Sampaio (São João del Rey e Congonhas), para levantamento in loco em Minas Gerais do repertório estilístico colonial. José Mariano com a sua influência política conseguiu também que o Neocolonial fosse exigido como estilo oficial nos projetos apresentados em vários concursos públicos dos anos 20. "A conquista de posição do neocolonial fez-se através de uma avalanche de concursos públicos de projetos, que José Mariano patrocinou ele próprio, no Instituto de Arquitetos /.../ "SANTOS, Paulo F. "400 Anos Memoráveis." In: Jornal do Brasil. 09/12/1965, p. 295.

14 "José Mariano valorizava fundamentalmente o aspecto plástico, mas, de acordo com seu ponto de vista, o estilo neocolonial não devia limitar-se apenas a retomar as formas do século XVII ou XVIII : devia ser expressão de novas formas, fiéis ao mesmo tempo ao espírito do passado e ao do presente. Essa idéia de procura criativa, não estando vinculada à forma mas ao conteúdo, podia dar uma contribuição fecunda, mas não se aplicava ao setor específico que interessava a José Mariano. Este não percebeu a contradição básica criada ao limitar suas preocupações ao aspecto formal : o vocabulário arquitetônico e decorativo da época colonial correspondia à utilização de determinados materiais, a determinados usos e a um determinado tipo de sociedade; desejar manter parte desses elementos, limitando-se a fazer algumas variações sobre os mesmos temas, quando seu significado profundo e sua verdadeira razão de ser tinha desaparecido, era o mesmo que cair no anacronismo que ele queria evitar." In: BRUAND, Yves. Arquitetura Contemporânea no Brasil, p. 55. 
O apogeu do Neocolonial no Rio de Janeiro foi na década de 20 e os arquitetos Edgar Vianna, Heitor de Mello, Archimedes Memória, Francisque Cuchet, Nereu Sampaio, Ângelo Bruhns, Nestor de Figueiredo e Cipriano de Lemos foram alguns dos seus principais expoentes. Na capital federal o estilo disseminou-se não só na produção de residências de variadas tipologias programáticas, como também se destacou na construção de inúmeras obras públicas. ${ }^{15} \mathrm{Em}$ nome da "atualização estilística" foram realizadas metamorfoses desfiguradoras em edifícios tradicionais da cidade. Como exemplos podemos citar as transformações da Casa do Trem, um autêntico prédio do século XVIII, ${ }^{16}$ e a da antiga residência neoclássica, que hoje abriga o Museu do Açude no Alto da Boa Vista, que foram reformadas segundo a moda Neocolonial.

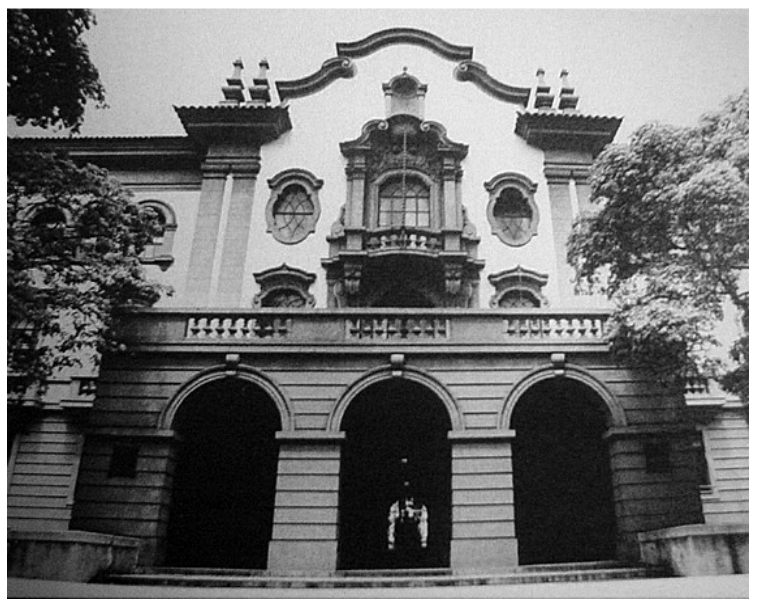

FIGURA 17 : Instituto de Educação. (Ângelo Brunhs , José Cortez / Rio de Janeiro,1928/30)

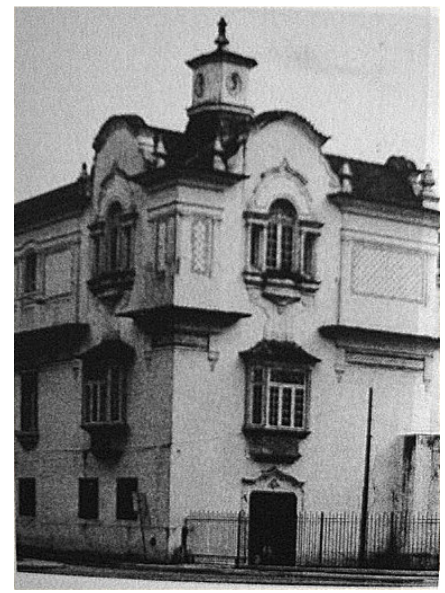

FIGURA 18: Museu Histórico Nacional. (A. Memória, F. Cuchet / Rio de Janeiro, 1920/22)

\footnotetext{
${ }^{15}$ Como exemplares de obras públicas neocoloniais do período podemos mencionar as escolas municipais Henrique Dodsworth em Ipanema, a Uruguai em Triagem, a Soares Pereira (projeto de José Amaral Nieddermeyer / 1926-1927) e o Instituto de Educação (projeto de Ângelo Brunhs e José Cortez / 1928-1930) ; estes dois últimos localizados no bairro da Tijuca.

16 "Para as comemorações do Centenário da Independência do Brasil em 1922 no Rio de Janeiro foram construídos inúmeros prédios neocoloniais, hoje demolidos, e reformado "à maneira neocolonial" o antigo Arsenal de Guerra, autêntico remanescente do século XVIII, com o objetivo de torná-lo compatível com as outras edificações da exposição. Permanece de pé a antiga fábrica colonial de pólvora e fortificação, conhecida como Casa do Trem que foi transformada pelos arquitetos Memória e Cuchet, no Palácio das Indústrias da exposição, num trabalho descrito como de "aformosear" o edifício "em seu estilo original". In: CZAJKOWSKI, Jorge (org.). Guia da Arquitetura Eclética do Rio de Janeiro, p. 16. Atualmente a Casa do Trem faz parte do complexo do Museu Histórico Nacional localizado no centro do Rio de Janeiro.
} 


\section{II.1.2. O NEOCOLONIAL EM SÃO PAULO}

A moda do estilo Neocolonial teve grande aceitação pelos arquitetos e construtores paulistanos e como já dissemos anteriormente ".../ logo manifestou-se dentro de duas vertentes. A primeira, era a ortodoxa, ou melhor, a erudita, que ia buscar nas fontes primárias a inspiração e os modelos exemplares /.../." 17 Como obras públicas mais emblemáticas da vertente erudita em São Paulo podemos destacar a reformulação da Ladeira da Memória (1919-1922), os Monumentos do Caminho do Mar (1922) ${ }^{18}$, estes últimos de autoria do arquiteto Victor Dubugras, e o edifício da Faculdade de Direito do Largo de São Francisco (1935-1939), projeto de Ricardo Severo.

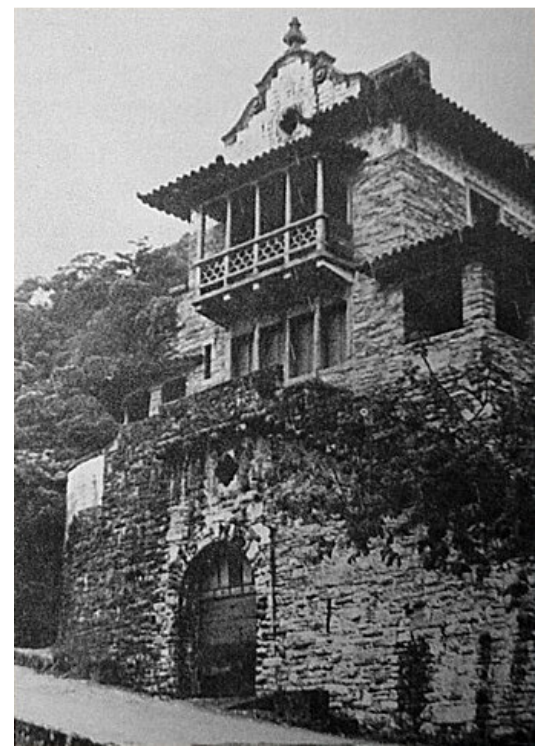

FIGURA 19 : Pouso da Maioridade. (Victor Dubugras / Caminho do Mar, São Paulo, 1922)

FIGURAS 20 E 21: Ladeira da Memória em 1922 e 2003. (Victor Dubugras / São Paulo,1922)
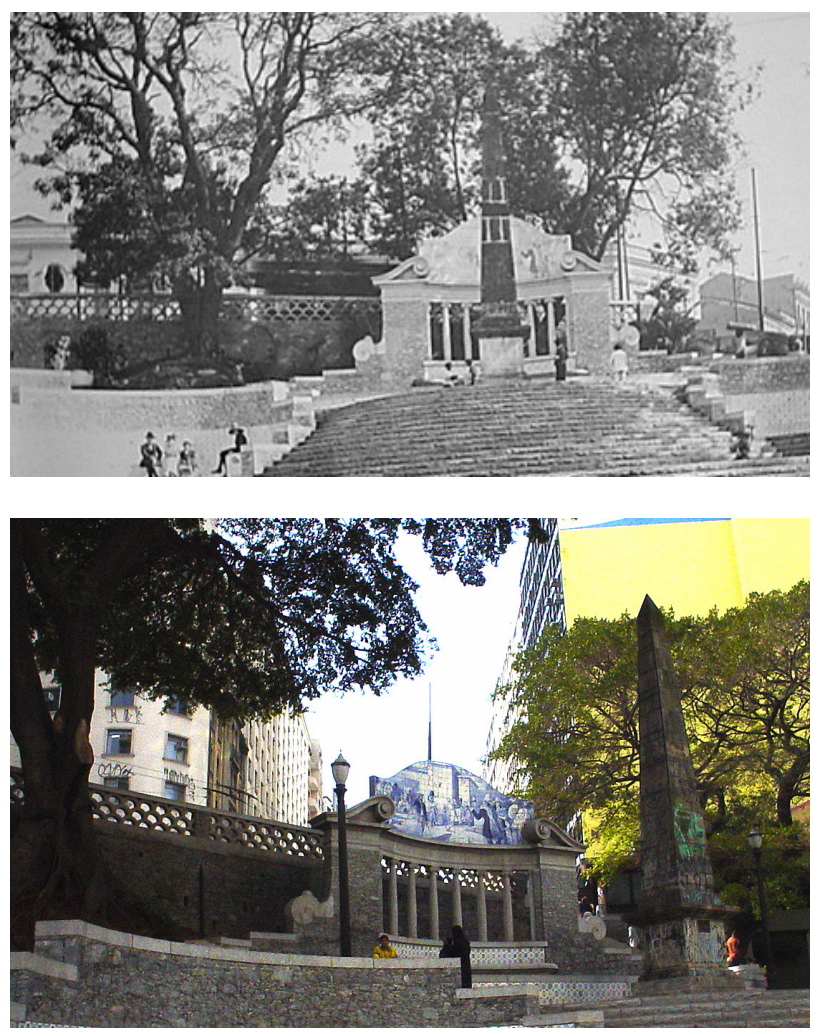

\footnotetext{
${ }^{17}$ LEMOS, Carlos A.C. "Ecletismo em São Paulo." In: FABRIS, Annateresa (org.) Ecletismo na Arquitetura Brasileira, p. 95.

18 "Também visando às comemorações do Centenário da Independência, o já governador Washington Luís providencia, com o mesmo arquiteto, os chamados monumentos do Caminho do Mar /... \%. Ao longo desse caminho foram construídos o Pouso Paranapiacaba, o Padrão do Lorena, /.. / o Rancho da Maioridade e o Cruzeiro Quinhentista /... /" In: LEMOS, Carlos A. C. Alvenaria Burguesa, p. 166.
} 
Como exemplares residenciais significativos temos a residência de Ricardo Severo na rua Taguá, também conhecida como Casa Lusa (1924), a residência de Numa de Oliveira (1916/1918) na avenida Paulista com alameda Campinas (ambas projetadas por Ricardo Severo e já demolidas) e muitas das casas projetadas por Victor Dubugras, Guilherme Winter, Alexandre Albuquerque, Álvaro Botelho, Alexandre Marcondes Machado, Dácio Aguiar de Moraes, entre outras. ${ }^{19}$ Estas edificações residenciais foram construídas para a elite paulistana e caracterizavam-se por serem, em geral, palacetes implantados no centro do terreno em meio a jardins. Apresentavam invariavelmente portadas rebuscadas de pedra, semelhantes a das igrejas barrocas, molduras de massa em cores contrastantes nas envasaduras, vidraças estruturadas em quadrados e losangos, uso de vitrais decorativos e painéis de azulejos etc., denotando esmerado apuro na escolha dos materiais de construção e na execução dos detalhes ornamentais e construtivos. ${ }^{20}$

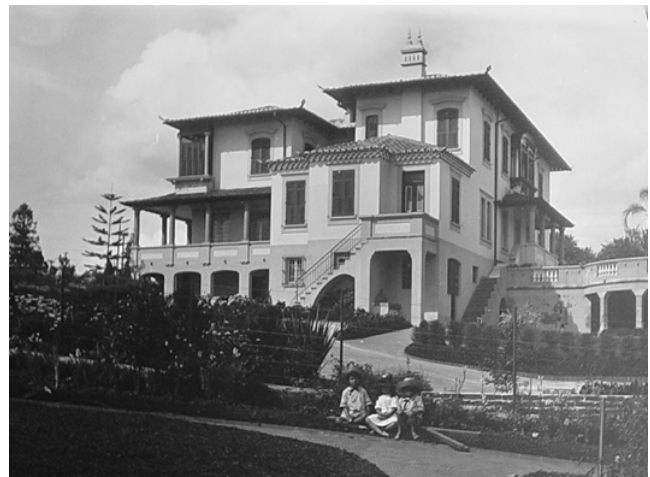

FIGURA 22 : Vista dos fundos da residência de Numa de Oliveira à avenida Paulista. (Ricardo Severo / São Paulo. 1916/18)

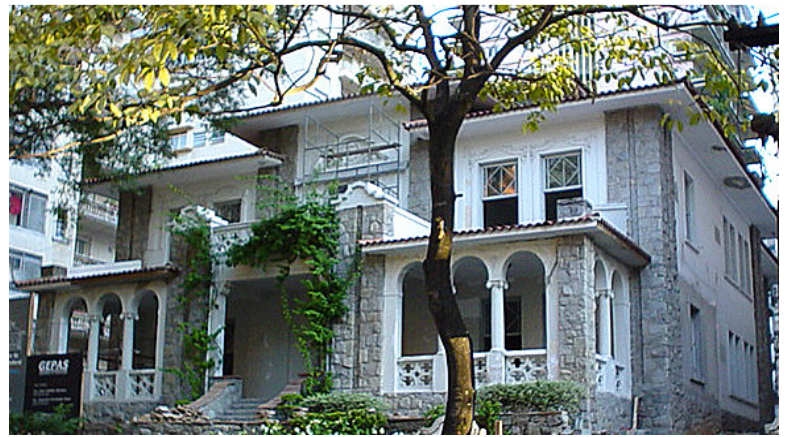

FIGURA 23 : Residência à rua Veiga Filho. (Adhemar de Moraes / São Paulo, 1923)

\footnotetext{
${ }^{19}$ Infelizmente muitas das edificações residenciais mais expressivas da vertente erudita do Neocolonial em São Paulo já se perderam devido principalmente à falta de medidas de proteção por parte dos órgãos oficiais de preservação.

${ }^{20}$ Yves Bruand nos diz que "/.. / o caráter dessas residências provinha do emprego sistemático de elementos tomados de empréstimo à arquitetura civil portuguesa dos séculos XVII e XVIII : varandas sustentadas por simples colunas toscanas, telhados planos com largos beirais, feitos de telhas - canal e tendo, nos vértices, uma telha em forma de pluma virada para cima (lembrando a moda do exotismo chinês no Século das Luzes), rótulas e muxarabis de longínqua origem muçulmana, azulejos fabricados diretamente no Porto recobrindo as paredes das varandas." In: BRUAND, Yves. Arquitetura Contemporânea no Brasil, p. 52.
} 


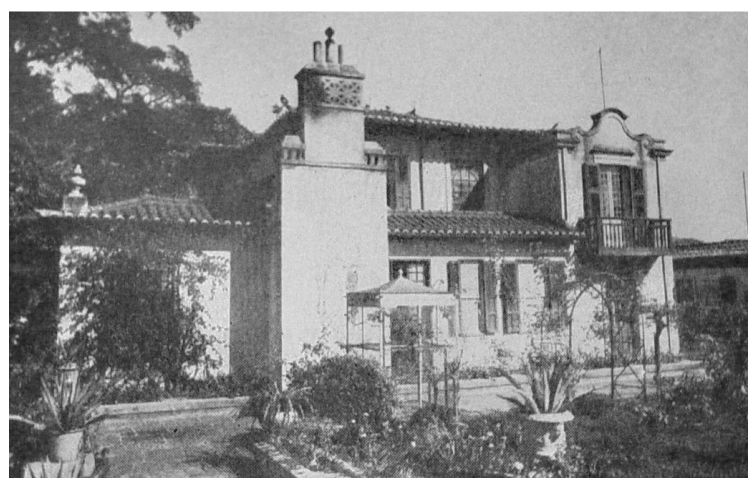

FIGURA 24 : Casa Lusa de Ricardo Severo na rua Taquá. (Ricardo Severo / São Paulo. 1924)

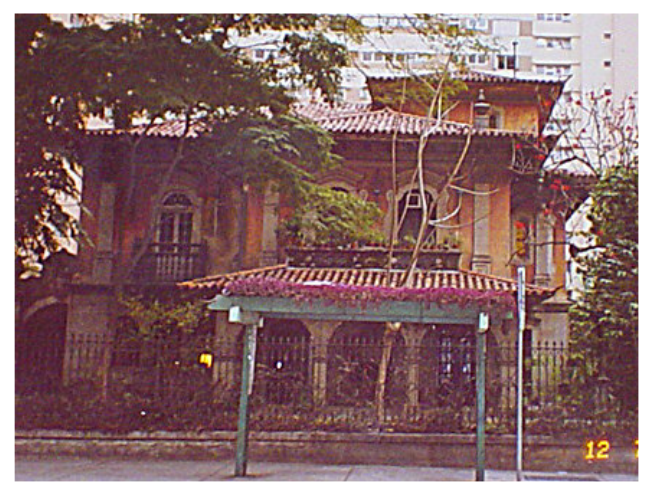

FIGURA 25 : Residência à rua São Carlos do Pinhal. (Guilherme Winter / São Paulo, 1928)

A segunda vertente do Neocolonial representava uma versão mais popular e simplificada do estilo. A maioria dos exemplares remanescentes do Neocolonial corresponde a esta versão, que se incorporou à paisagem urbana de muitos bairros paulistanos através da atuação de construtores anônimos que o adotaram como linguagem arquitetônica. As formalizações neocoloniais espalharam-se pelas edificações residenciais de classe média durante as décadas de 20,30, 40 e até de 50, diluindo ao longo do tempo o abecedário neocolonial original. ${ }^{21} \mathrm{Na}$ prática esta vertente popular se apropriou de vários estilemas do Neocolonial luso-brasileiro reinterpretando-os livremente. O que resultou disto foi uma composição arquitetônica mais estilizada, descompromissada com uma teoria ou vocabulário arquitetônico erudito.

O movimento Neocolonial adquiriu especificidade própria em São Paulo em função do contexto sócio-cultural existente na capital paulista no início dos anos 20. A sociedade local, como já dissemos, caracterizava-se pela sua heterogeneidade derivada da intensa imigração ocorrida desde o final do oitocentismo. Desta conformação social resultou uma marcante influência do elemento estrangeiro (em particular, do italiano), que fez com que o Ecletismo Classicizante e o Historicista predominassem nas construções residenciais até a Primeira Guerra Mundial. No pós-guerra surgiu na sociedade paulistana o forte desejo de renovação e de esquecimento de tudo que lembrasse o passado imediato, inclusive a

\footnotetext{
${ }^{21}$ Nas palavras de Carlos A. C. Lemos ".../ o mais interessante de tudo é que a variante eclética historicista lançada por Severo ao sugerir o "estilo colonial" agradou a todos os gostos e se popularizou, inclusive, no âmbito da arquitetura sem arquitetos, pois adotava soluções inesperadas cuja filiação à gramática erudita era, às vezes, difícil de identificar. Eram soluções emanadas da incorporação espontânea por parte do povo." LEMOS, Carlos A. C. "El estilo que nunca existió "In: AMARAL, Aracy (coord.) Arquitectura Neocolonial : América Latina, Caribe, Estados Unidos, p. 160.
} 
arquitetura de cunho "italianizante". ${ }^{22}$ Isto propiciou deveras o aparecimento e o florescimento do movimento Neocolonial em São Paulo. A esta reação, consciente ou não, dos arquitetos e construtores paulistanos podemos creditar parte do sucesso alcançado pelas propostas de Ricardo Severo nos anos 20. Porém devemos reconhecer que o Neocolonial de inspiração luso-brasileira só foi aceito sem restrições nas classes mais altas, orgulhosas das suas origens "quatrocentonas" e as únicas capazes de financiar uma arquitetura refinada e de alto custo, dependente da contratação de arquitetos renomados (arquitetura de autor) e do emprego de materiais de construção requintados. Outro aspecto a ser considerado na caracterização do Neocolonial em São Paulo é que o forte apelo progressista e o desejo de modernidade reinantes naquele momento na sociedade local fizeram com que este movimento tradicionalista tivesse aqui uma penetração e uma aceitação limitadas, quando comparado com o Rio de Janeiro. ${ }^{23}$

A arquitetura neocolonial atingiu seu apogeu na capital paulista entre os anos 20 e 30 e deve a sua importância à participação que teve na constituição do panorama arquitetônico de vários bairros paulistanos que surgiram e se desenvolveram no início do século XX. Neste período o Neocolonial imprimiu a sua feição em construções de todo o tipo $^{24}$ localizadas, principalmente, nas imediações da Avenida Paulista, nos bairros próximos ao centro (Higienópolis, Santa Cecília etc.) e nos novos bairros de classe média que se desenvolviam em regiões mais distantes da área central da cidade (Perdizes, Pompéia, Pinheiros, Vila Mariana etc.).

O Neocolonial hispano-americano ou Missões logrou grande sucesso em São Paulo, concorrendo diretamente com a versão luso-brasileira na preferência das classes altas e médias, estando presente em residências de todos tamanhos da capital paulista. ${ }^{25}$

\footnotetext{
22 "\%... em São Paulo a onda nacionalista na arquitetura nasceu da necessidade da classe média de reafirmar-se frente aos imigrantes que haviam ascendido socialmente /.../ " LEMOS, Carlos A. C. "El estilo que nunca existió "In: AMARAL, Aracy (coord.) Arquitectura Neocolonial : América Latina, Caribe, Estados Unidos, p. 157.

23 "Embora o movimento neocolonial tenha começado em São Paulo em 1914 /.../ não foi nesse Estado que alcançou grande expansão e importância em termos históricos. /.../ Por conseguinte, a priori uma volta ao passado não apresenta grandes atrativos, ainda mais quando se considera que a grande maioria da população era composta de imigrantes, sem qualquer vínculo com o país. A cidade, pelo contrário, orgulhava-se de seu crescimento extraordinário, que provocava a destruição sistemática de tudo que era um pouco mais antigo. Tal mentalidade não podia ser favorável a um movimento tradicionalista. $A$ situação no Rio de Janeiro era bem diversa. /.../ A volta às fontes da arquitetura "nacional" oferecia um meio de afirmar em público a personalidade brasileira e a maturidade do país." In: BRUAND, Yves. Arquitetura Contemporânea no Brasil, p. 54.

24 "Embora em toda a década 1920-1930 prosseguisse o Ecletismo e, na Arquitetura Monumental, o LUÍS XVI e os estilos classicizantes em geral, o Movimento que mais marcou a década foi o Neo-Colonial." SANTOS, Paulo F. "Constantes de Sensibilidade na Arquitetura do Brasil." In: Arquitetura Revista FAU / UFRJ . v.6,1988, p. 66.

${ }^{25}$ Segundo Silvia Wolff “/... / pode-se dizer que esta linguagem correspondeu a uma moda, muito intensa e fugaz e que enquanto durou suplantou ou diluiu a eles se mesclando os atributos formais do estilo neocolonial brasileiro./.../ Dos cento e dois projetos realizados para o Jardim América entre 1935 e 1940 /.../ quase a metade /.../ tem presentes motivos forjados pelo estilo neocolonial hispano-americano." In: WOLFF, Silvia Ferreira Santos. Jardim América. O primeiro bairro-jardim de São Paulo e sua arquitetura, p. 176.
} 
"Na construção residencial o californiano ou missões teve a enorme importância de modernizar efetivamente a casa de moradia, propondo plantas mais funcionais, fachadas de poucos elementos decorativos, volumes mais baixos e esparramados, geralmente circundando um pátio." (CZAJKOWSKI, s/d, p. 33.)

Nesta época foi também muito comum a adoção de soluções sincréticas na composição das fachadas das residências, que usavam e, às vezes, abusavam da mistura indiscriminada de elementos formais e estilísticos do Neocolonial luso-brasileiro e do hispano-americano. Este último, no entanto, agradava mais pela sua ligeireza e delicadeza de formas e pelo emprego de materiais como o ferro trabalhado, caprichosamente retorcido em arabescos, que lembravam a decoração ibérica de origem árabe.

\section{II.1.3. NEOCOLONIAL - POLÊMICAS E OPINIÕES DA ÉPOCA}

A proposta do estilo Neocolonial na arquitetura gerou inúmeras discussões na época. A primeira polêmica se deu em 1917 entre Monteiro Lobato e o arquiteto Christiano Stockler das Neves, que debateram através da imprensa. ${ }^{26} \mathrm{O}$ primeiro era fervoroso defensor das coisas brasileiras, um ferrenho nacionalista, que defendia o Neocolonial como verdadeira expressão da nossa gente e da nossa cultura. Já Christiano das Neves considerava os modelos da arquitetura religiosa jesuítica utilizados pelo Neocolonial destituídos de beleza, ${ }^{27}$ e defendia o Ecletismo Historicista como o estilo mais adequado e nobre para as edificações em geral. Apesar de se colocar frontalmente contra o Neocolonial de inspiração lusobrasileira, afirmando que "Architectura não se inventa e estylo não se impõe" ${ }^{28}$ Christiano aceitava a versão hispano-americana do movimento, talvez devido à sua formação acadêmica nos Estados Unidos. ${ }^{29}$ Referindo-se aos comentários exarados por Monteiro Lobato em seus artigos argumentou que

\footnotetext{
${ }^{26}$ A controvérsia foi iniciada por Monteiro Lobato no "O Estado de São Paulo" e foi seguida pela resposta de Christiano Stockler das Neves no "Jornal do Commercio".

27 "Conclue-se portanto que a evolução da Arte entre nós começou pela peor phase do estylo Barroco, que é, como seu nome indica, caracterisado pela extravagância de suas formas, composições exageradas, molduras pesadas, tympanos e coroamentos de formas as mais bizarras, ornamentos ridiculos, principalmente no período do declinio do estylo, que tambem chamam de "estylo jesuita", e que desprezou quase completamente as bellezas do classicismo. /.../ Acharão por acaso os leitores, bellezas de linhas e motivos architectonicos nas Igrejas de Santo Antonio, de Santos, na velha Sé de S. Paulo, nas Igrejas antigas do Rio de Janeiro e de outras cidades do norte do Brasil ? Pois foi nesses "monumentos architectonicos" que os enthusiastas do "Estylo" foram inspirar-se para o desenvolver." NEVES, Christiano Stockler das. "Architectura Colonial." In: Jornal do Commercio. 03/02/1917, p. 4.

${ }^{28}$ Idem, ibidem.

29 "Será coroado de êxito semelhante e audacioso emprehendimento ? Na minha fraca opinião creio que o "Estylo" terá existência ephemera, pois que os seus adeptos não conseguirão desenvolver as formulas mortaes da peor phase, do Barroco ou as "atamancadas" dos mestres de obras. /... Attribuo esse movimento, formado por um pequeno número de adeptos, a uma simples imitação do que os americanos fizeram em relação á architectura colonial da Califórnia. É preciso, porém, considerar que as construcções modernas da Califórnia são originarias da Hespanha, muitíssimo mais fecunda em Architectura. Os
} 
"Architectura não se compara com poesia /.../ O poeta póde ter o seu estylo próprio, /.../ como diz o ilustre articulista, mas com o architecto não se dá o mesmo ; não há architecto com seu estylo original e nem é possível ao mesmo fazer das formas do bruto antigo (da peor phase do Barroco) um novo-bello." (NEVES, 1917, p. 4)

Assim, Christiano das Neves achava ainda imatura a proposição de um estilo nacional, fruto da identidade brasileira, que ele afirmava ainda estar em formação; para ele o mais justo era escolher dentre os estilos históricos o que melhor condissesse com os programas a serem atendidos, elegendo pessoalmente o estilo Luís XVI. ${ }^{30}$ Monteiro Lobato, por sua vez, rebateu a postura do arquiteto afirmando que considerava

".../ absurdo negarmo-nos direito á fisionomia. Se ainda não a temos, te-la-emos. /.../ Esse movimento fecundo que Ricardo Severo iniciou com tanta discreção e ao qual já se filia uma plêiade de artistas altamente compreensivos, é o primeiro sinal de uma coisa muito mais significativa do que o sr. Stokler supõe. É o tactear dos primeiros passos para a criação do estilo brasileiro." (LOBATO, 1967, p. 39 e 40)

A discussão conceitual entre os defensores do Neocolonial e os adeptos do Ecletismo Historicista sobre o estilo mais adequado a ser empregado na arquitetura paulistana dos anos 20 continuou exaltada. Em abril de 1926 o jornal O Estado de São Paulo publicou uma série de artigos com o título "Architectura Colonial", sob a coordenação do sociólogo Fernando de Azevedo, nos quais Ricardo Severo, José Wasth Rodrigues, José Mariano Filho, Alexandre Albuquerque, Adolfo Pinto, entre outros, expressavam suas opiniões sobre o assunto. O principal objetivo da publicação destes depoimentos era trazer a público a discussão da validade da arquitetura tradicional e propor critérios para a sua normalização. ${ }^{31}$ Os entrevistados argumentavam que apesar de utilizarem um repertório estilístico baseado na arquitetura antiga a sua proposta estética estava imbuída da idéia de

architectos americanos têm muita razão em desenvolver essa architectura, que, realmente, possue motivos belíssimos ; há architectos que se dedicam quase que exclusivamente a esse estylo, a que chamam "Spanish Renaissance" /.../. Esse é o estylo que devíamos cultivar por ser realmente agradavel e adaptavel ao nosso clima e á nossa natureza. Nos "films" americanos os leitores terão occasião de observar as construcções nesse estylo." NEVES, Christiano Stockler das. "Architectura Colonial." In: Jornal do Commercio. 03/02/1917, p. 4

30 "Todo o architecto tem que recorrer ás formas dos estylos anteriores. Não constitue isso plagio e sim um grande esforço que só o talento e a perseverança poderão conseguir para modernizal-os, melhoral-os e adaptal-os aos differentes climas. E o que os francezes têm feito em relação ao estylo Luiz XVI, /.../ Os inglezes /.../ adoptam também outros estylos em suas construcções, como o Luiz XVI modernizado /.../ O Estylo Luiz XVI modernizado, também já tomou grande incremento na grande Republica /.../"Idem, ibidem.

31 "O jornal O Estado de São Paulo, por exemplo, chegou a publicar uma série de nove grandes artigos sobre o assunto a partir de abril de 1926, onde vários especialistas entrevistados tiveram a oportunidade de externar opiniões, não necessariamente conflitantes, mas tendentes a normalizar a produção da "architectura colonial". Combateu-se a expressão "estilo colonial" porque na verdade aqui nunca foi gerado "estilo" algum. /.../ Um estilo, portanto, deveria ser escolhido como geratriz da nossa moda tradicionalista. /.../ a coisa não deveria cingir-se somente a uma despreocupada providência de se embelezar um volume de alvenaria com a mera distribuição de simples ornatos. O partido arquitetônico deveria propiciar os agenciamentos caracterizadores da arquitetura antiga enquanto necessariamente deveria a obra ostentar flagrantemente a sua "modernidade". In: LEMOS, Carlos A. C. Alvenaria Burguesa, p. 168. 
progresso, ou seja, representava uma evolução natural daquela arquitetura que caracterizou os tempos coloniais e que fora temporariamente substituída pelo ecletismo forasteiro.

Outra polêmica contemporânea a ser destacada ocorreu entre os arquitetos Dácio Aguiar de Moraes e Gregori Warchavchik através do jornal Correio Paulistano nos anos de 1928 e 1929. Dácio de Moraes, defensor e praticante do Neocolonial, começou a discussão escrevendo uma série de artigos nos quais alertava para os equívocos resultantes de uma arquitetura internacional, enquanto Warchavchik, em resposta, fazia a apologia da "Architectura Nova" que vinha realizando em São Paulo. ${ }^{32}$

Mário de Andrade, numa série de quatro artigos publicados no Diário Nacional (São Paulo) em 1928, também intitulados "Arquitetura Colonial", ${ }^{33}$ abordou a questão do Neocolonial como tentativa de criação de um estilo arquitetônico brasileiro e desenvolveu reflexões teóricas a respeito da sua validade como expressão verdadeira da identidade cultural brasileira em comparação às propostas modernistas. Inicialmente Mário colocou a discussão contemporânea sobre a possibilidade de um nacionalismo ou regionalismo na América Latina em contraposição ao internacionalismo vigente na Europa e Estados Unidos nos anos 20. No segundo artigo apresentou a questão da imaturidade da arquitetura modernista, afirmando que a sua situação era

“.../ duma tendência ainda. Não se pode falar que esteja firmada, unanimizada e muito menos tradicionalizada. /.../ Os arquitetos modernistas inda fazem mais obra de escola, obra pra mostrar as idéias deles, que obra de invenção e de expressão fatalizadamente moderna /.../ E o que é mais importante pro nosso caso : tudo isso inda não se generalizou. Não existem senão casas pequenas em estilo moderno." (ANDRADE, 1980, p. 13)

Mário de Andrade expõe no terceiro texto a sua crença de que a arquitetura modernista ".../ não permanecerá nem no anonimato nem no internacionalismo em que está agora. Se se normalizar ela virá, fatalmente, a se distinguir em frações étnicas e a se depreciar em função do indivíduo." ${ }^{34} \mathrm{E}$, no último artigo da série, quando discorreu sobre "o fenômeno da nossa atualidade", considerado como o contexto econômico, político, social e cultural brasileiro, admitiu que

".../ os arquitetos que estão trabalhando por normalizar no país um estilo nacional "neocolonial", ou o que diabo se chame, estão funcionando em relação à atualidade nacional. $A$

\footnotetext{
${ }^{32}$ Ver: BRUAND, Yves. Arquitetura Contemporânea no Brasil. p. 68; WARCHAVCHIK, Gregori. "São Paulo e a Architectura Nova" In: Illustração Brasileira. 1929.

${ }^{33}$ Ver a íntegra dos quatro artigos publicados inicialmente em 1928 no Diário Nacional (São Paulo): ANDRADE, Mário de. "Arquitetura Colonial." (1928) In: Arte em Revista. № 4, 1980, p.12-14.

${ }^{34}$ ANDRADE, Mário de. "Arquitetura Colonial." (1928) In: Arte em Revista. nº 4, 1980, p. 14.
} 
função deles é pois, perfeitamente justificável e mesmo justa. O que resta saber é se estão funcionando bem." (ANDRADE, 1980, p.14)

Por estas reflexões podemos deduzir que Mário de Andrade aceitava de início a possibilidade de um estilo nacional, ${ }^{35}$ porém não descartava as tendências modernistas, manifestando uma defesa subliminar e um desejo mal admitido para o sucesso da arquitetura modernista, ${ }^{36}$ demonstrando naquele momento uma postura ainda indefinida.

No artigo "Exposição duma Casa Modernista (Considerações)" de 1930, publicado também no Diário Nacional (São Paulo), Mário de Andrade já assumia uma clara posição em favor da arquitetura modernista de Gregori Warchavchik, situando o Neocolonial ao lado das expressões ecléticas vigentes desde o início do século XX em São Paulo. Neste texto Mário colocou a questão do "falso" e do "legítimo" na arquitetura ao afirmar que

"... / o neo-colonial, o bangalô, o neo-florentino são "falsos". /.../ Lhes falta aquela orgulhosa força de legitimidade que justifica e valoriza até os defeitos. /.../ Não é o conceito de falsificação deturpadora de princípios arquiteturais que me preocupa. Agora, é a noção do faux, do que é feito para enganar, da prática extemporânea. /.../ Uma casa de Warchavchik berra junto das outras, berra orgulhosamente porque é legítima. I.../ Ora a Arquitetura também possui um destino, que não consiste nela ser bonita, mas agasalhar suficientemente não um corpo mas um ser humano, com corpo e também alma. /.../ Pois nós também, se almas atuais, temos que agasalhar nossas almas nas casas atuais a que chamam de "modernistas". Tudo mais é desagasalho, é desrespeito de si mesmo e só serve pra enganar. É o falso." (ANDRADE, 1980, p. 8)

A opinião do modernista Mário de Andrade expressa neste artigo, escrito apenas dois anos após a publicação da série sobre a "Arquitetura Colonial", mostra claramente a mudança de pensamento e de atitude do ilustre escritor com relação aos estilos em voga na década de 20. Mário assumiu naquele momento uma posição declarada em favor da arquitetura modernista, renegando qualquer valor aos ideais nacionalistas do Neocolonial, considerado como uma expressão falsa de uma realidade brasileira e, portanto, vazio de conteúdo antropológico e cultural. Este juízo, no entanto, deve ser relativizado, uma vez que Mário de Andrade expressou suas idéias num momento histórico de afirmação e exaltação do Movimento Moderno.

\footnotetext{
35 "Os arquitetos brasileiros andam trabalhando num estilo de casa a que chamam de Colonial ou de Neocolonial. Por mais que certas idéias e tendências modernas se tenham incrustado na minha cabeça, não acho um mal isso não. Mas não posso achar que seja um bem apesar de todo o meu entusiasmo pelo que é brasileiro."ANDRADE, Mário de. "Arquitetura Colonial." (1928) In: Arte em Revista. no 4, 1980, p. 12.

36 "\%/ Por mim acho que a arquitetura modernista acabará se impondo definitivamente porém eu sou torcedor e sou um só. Minha contribuição pessoal, minha torcida não basta pra resolver um fenômeno destes. Por aí se justifica em parte a procura dum neocolonial pro Brasil." Idem, p.13.
} 


\section{II.1.4. NEOCOLONIAL - ALGUMAS REFLEXÕES}

A escolha do estilo arquitetônico mais adequado a cada programa residencial era uma das principais preocupações dos arquitetos desde o final do século XIX. O arquiteto assumia nesta época, portanto, o papel de mero "fachadista" ou "decorador de exteriores", projetando muitas vezes em função do gosto dos clientes. Assim, os defensores do Neocolonial luso-brasileiro acreditavam que os elementos estilísticos oriundos do repertório arquitetônico do Brasil colonial e do Barroco português ${ }^{37}$ comporiam a "roupagem" mais apropriada para expressar uma nova atitude perante o Ecletismo, e conseqüentemente, para gerar uma arquitetura de caráter moderno e realmente autóctone. ${ }^{38}$

A tentativa de reabilitação da linguagem estilística da arquitetura colonial brasileira, proposta pelo Neocolonial, representou a nossa primeira expressão artística dirigida explicitamente a uma procura de identidade cultural. $^{39}$ Esta busca de uma identidade brasileira a partir de valores resgatados do passado colonial revelava sem dúvida um intenso sentimento romântico presente em alguns setores da intelectualidade da época. Acreditava-se, então, que o estudo profundo das questões de raça, economia, vida social e artística brasileiras poderia ajudar na recuperação e compreensão de importantes valores perdidos no passado, que seriam fundamentais para o entendimento da realidade brasileira que se apresentava naquele momento. Estes valores raciais, econômicos, sociais e culturais configurariam, enfim, o elo que permitiria compreender o contexto existente, ao mesmo tempo, em que possibilitaria uma conscientização das potencialidades futuras da cultura brasileira. ${ }^{40}$

$\mathrm{Na}$ época, ser nacionalista era também sinônimo de "modernista". Para Ricardo Severo não havia nenhuma incompatibilidade no fato de se propor um movimento

\footnotetext{
${ }^{37}$ Severo usou vários estilemas da arquitetura do norte e do centro de Portugal em seus projetos brasileiros.

38 "Paradoxalmente, o neocolonial reage contra o passado recente olhando para trás. É um "revival" que se pretende novidade." KESSEL, Carlos. "Estilo, discurso, poder : Arquitetura Neocolonial no Brasil." In: História Social - Revista da Pósgraduação em História IFCH/UNICAMP. 1999, p. 68.

${ }^{39}$ Esta procura de brasilidade expressa pelo Neocolonial seria também a tônica do discurso das manifestações iniciais dos proponentes do Movimento Moderno, surgido contemporaneamente na década de 20. Desta forma, consideramos de certo modo equivocada a colocação de alguns autores que caracterizam cronologicamente o Neocolonial como uma fase de transição entre o Ecletismo Historicista e a Arquitetura Moderna brasileira (que se consolidaria no final da década de 30). Este sentimento nacionalista estava fortemente impregnado em todas as manifestações culturais dos anos 20 , só que foi interpretado diferentemente pelos diversos grupos da intelectualidade atuantes naquele momento. A respeito ver : BRUAND, Yves. Arquitetura Contemporânea no Brasil; SANTOS, Paulo F. Quatro Séculos de Arquitetura; SEGAWA, Hugo. Arquiteturas no Brasil $1900-1990$.

${ }^{40}$ Ou como quer Bruand, ".../ esse movimento foi na realidade a primeira manifestação de uma tomada de consciência, por parte dos brasileiros, das possibilidades do seu país e da sua originalidade." In: BRUAND, Yves. Arquitetura Contemporânea no Brasil, p. 52.
} 
"tradicional revolucionário" ${ }^{41}$ inspirado na estética do passado colonial, tratada de modo contemporâneo. Em nome desta postura dicotômica, que pretendia ser ao mesmo tempo "tradicionalista" e "modernizadora", é que se permitiu em 1932 a demolição do antigo convento franciscano localizado no Largo de São Francisco, no centro de São Paulo, para dar lugar ao prédio da Faculdade de Direito, projetado por Ricardo Severo (1935-1939). A nova edificação, de feição neocolonial e porte monumental, não respeitou a escala das vizinhas Igrejas da Ordem Primeira e Terceira de São Francisco, ${ }^{42}$ autênticas construções coloniais dos séculos XVII e XVIII, respectivamente. O desejo de "modernidade" era tão exacerbado nos anos 20 e 30 em São Paulo que até mesmo as edificações residenciais ecléticas sofreram grandes reformas no afã de adaptá-las ao gosto tradicional. ${ }^{43}$

Outra faceta interessante do movimento Neocolonial, quando analisado às luzes contemporâneas, é a sua clara proposta de repúdio ao domínio da cultura européia que predominava nos meios intelectuais e artísticos nacionais desde o final do século XIX. ${ }^{44} \mathrm{Em}$ São Paulo esta reação dos paulistanos tornava-se ainda mais visível considerando-se o elevado número de imigrantes e seus descendentes que naquele momento compunham a sociedade local.

Não obstante a discordância com relação à "vestimenta" que deveria ser usada nas edificações em geral, tanto os adeptos do Neocolonial, ${ }^{45}$ quanto os praticantes do Ecletismo

\footnotetext{
${ }^{41}$ SEVERO, Ricardo. "Architectura Colonial III : Entrevista com o Dr. Ricardo Severo." In: O Estado de São Paulo, de 15 / 04 / 1926.

${ }^{42}$ Ao lado da Faculdade de Direito do Largo São Francisco localizam-se as Igrejas de São Francisco de Assis da Venerável Ordem dos Frades Menores e a das Chagas do Seráfico Pai São Francisco da Venerável Ordem Terceira de São Francisco da Penitência.

${ }^{43}$ O depoimento de Paím em artigo na revista Illustração Brasileira em 1929 é revelador ; ele nos conta que "... / é inutilmente que se esforçam as nossas patrícias, por adoptar ás linhas modernas as suas typicas casas de há 40 anos. Trabalho inútil. Por mais que essas bem intencionadas pessoas tirem a platibanda, adaptem um commodo as funções de hall, liguem, por um arco, a sala de jantar á de visitas, ajustem um bow-window a qualquer recanto, e Ihes accrescentem outros tantos pormenores da construcção atual, os arranjos serão sempre um remendo. Jamais se conseguirá modernizar aquillo que se tornou antigo /.../ O interesse pelas antiguidades tem-se tornado enorme ultimamente em S. Paulo com o advento do bungallow e da casa colonial, uma manifesta intenção nacionalista /.../ Em muitas construcções já se recorre aos tijolos polychromicos para os assoalhos. As fontes e repuxas que povoavam o ambiente com a monotonia de seu canto, os acquarios, os vitraes e azulejos de bons autores, as grades de ferro forjado, os lavabos, elementos de arte superior, de aristocrático aspecto, são facilmente encontrados nas modernas vivendas em todos os recantos da terra paulista. E por toda a parte, impregnando tudo, e vivendo em todos, uma profunda intenção nacionalista como represália ao tempo que se perdeu em copias e imitações. Não estará portanto longe o dia, em que, á maneira do que já se vae conseguindo, em animadoras proporções, se chegue á perfeição de contemplar em todos os cantos da terra da Garoa, uma tão exacta comprehensão da arte da moradia, rigorosamente ajustada ás necessidades do meio e ás nossas tradições, desde o jardim até os alimentos, desde as decorações até aos habitos de modestia que herdamos, que fale alto da nossa raça, nos mínimos detalhes da vida domestica, onde renascerão os clássicos costumes das visitas e dos doces serões de trabalho em família /.../ " PAím. "Sobre a Arte dos Interiores." In: Illustração Brasileira. ํㅜ 109, 1929.

${ }^{44}$ Ver: CAMARGOS, Márcia. Villa Kyrial - Crônicas da Belle Époque Paulistana ; HOMEM, Maria Cecília Naclério. Higienópolis - grandeza e decadência de um bairro paulistano.

${ }^{45}$ O Neocolonial ".../ de reação de vanguarda ao que era visto como excesso de estrangeirismo eclético na arquitetura que se fazia no Brasil do início do século, transmuta-se em resistência ao modernismo calcada ideologicamente no tradicionalismo conservador." KESSEL, Carlos. "Estilo, discurso, poder : Arquitetura Neocolonial no Brasil." In: História Social - Revista da Pós-graduação em História IFCH/UNICAMP.1999, p. 69.
} 
Historicista, colocavam-se lado a lado, quando se tratava de repudiar a obra modernista de Warchavchik, apelidada pejorativamente de "estilo caixa d'água". ${ }^{46}$ A sua arquitetura de caráter funcionalista e racionalista era considerada sem atrativo estético por ambas as correntes. "Os "modernos", por seu turno, alegavam que a leitura "neocolonial" do passado era superficial, estando restritas as suas construções a meros pastiches arquitetônicos". ${ }^{47}$ Por outro lado, Ricardo Severo não aceitava a imagem de anacrônico que Ihe imputavam os defensores da Arquitetura Moderna, e dizia que procurara ".../ lançar a orientação tradicionalista na arquitetura brasileira /.../ Tradicionalismo não quer dizer anacronismo, passadismo, ou mesmo necronihilismo. Quer dizer simplesmente o ressurgimento da tradição." 48

Outra consideração que pode ser feita é o descompasso surgido entre o discurso teórico e as construções neocoloniais realizadas nos anos 20 e 30, nas quais muitos arquitetos e construtores misturaram elementos do repertório colonial, civil e religioso, sem qualquer critério. $^{49}$ Esta postura claramente pragmática e eclética permitia que os profissionais transitassem livremente pelas diferentes versões do Neocolonial, misturando algumas vezes estilemas das correntes luso-brasileiras com as hispano-americanas, o que resultava freqüentemente em soluções de gosto duvidoso. ${ }^{50}$ Foram poucos os arquitetos que com uma centelha de criatividade impuseram um caráter próprio às suas construções neocoloniais em São Paulo, como foi o caso ímpar de Victor Dubugras, ${ }^{51}$ que tão bem 46 "Essa negação completa do (quase) totalmente novo permite situar o neocolonialismo numa posição simétrica ao sistema
Beaux-arts: ambos se sustentam e se legitimam no passado, com discursos tautológicos - demonstram teses repetindo-as com
palavras diferentes. O perfil distinto na retórica neocolonial é o tempero nacionalista; o repertório sistematizado das formas do
colonial brasileiro ou do barroco ibérico enquanto indiciador de manifestação nacional, no lugar das regras clássicas, seria o
rompimento à norma. Efetivamente, esses aportes não propõem uma ruptura estrutural - apenas a substituição de formas.
Mudam-se as formas, não os princípios. O neocolonial, na prática concreta, afigurou-se como uma variação do ecletismo no
que busca eleger um "estilo" mais adequado para o fim que se tinha em vista, num contexto ainda de desconcertantes dilemas
sobre a nova arquitetura do século 20 \%...." In: SEGAWA, Hugo. Arquiteturas no Brasil 1900-1990, p.38.

${ }^{47}$ In: CAVALCANTI, Lauro. As Preocupações do Belo, p. 76.

${ }^{48}$ Discurso do Embaixador Morais Leme proferido em 05/11/1969, citando palavras de Ricardo Severo. In : Homenagem a Ricardo Severo - Centenário de seu nascimento 1869 - 1969. 1969, p. 15.

49 “.../ não se fez uma diferenciação entre a arquitetura laica e a religiosa, nem se levou em conta as várias diferenças regionais existentes. A preocupação predominante com a forma decorativa levou a tomar de empréstimo e a misturar sem discernimento o repertório utilizado nas construções mais ricamente ornamentadas /.../ Dessa confusão entre os gêneros e desse arbítrio resultava uma inevitável artificialidade." In: BRUAND, Yves. Arquitetura Contemporânea no Brasil, p. 58.

50 "Avesso à simplicidade da arquitetura civil da colônia, o neocolonial valia-se geralmente de uma colagem indiscriminada de elementos da arquitetura religiosa barroca, interpretados, no entanto, através do olho eclético : medidas, proporções e composições típicas da arquitetura acadêmica do fim-de-século, muito diferentes da escala colonial. Confundiu-se também, desde logo, com o historicismo pan-americano que atravessava as Américas a partir dos Estados Unidos. O Colonial espanhol, mais rebuscado, respondia melhor ao gosto da época que a nossa arquitetura tradicional. Os pavilhões neocoloniais da Exposição de 22, por exemplo, foram muito mais espanhóis que portugueses ou brasileiros." CZAJKOWSKI, Jorge. "A Arquitetura Racionalista e a Tradição Brasileira." In: Gávea - Revista de História da Arte e Arquitetura, p. 33.

51 "Dubugras foi tambem um precursor na nossa architectura colonial. /.../ Nas suas composições inspiradas no colonial não se limitava a fazer archeologia. Aquellas formas simples e pezadas, tomavam atravez do seu espírito, uma proporção clássica perfeita, um recorte modernisado e elegante sem perder o característico do estylo inspirador. O colonial de Dubugras era característico. As construcções que executou, ora applicando a enxilharia de pedra, ora com o tijolo apparente até hoje são das 
traduziu o espírito tradicionalista através de uma expressão arquitetural particularizada, que serviu de paradigma para as recriações populares da arquitetura residencial paulistana, como veremos adiante. A obra neocolonial produzida por Dubugras caracterizava-se por suas constantes preocupações de pesquisa de novas formas e materiais e pela procura de racionalização da construção e de um modo próprio de expressão, em distinção à praticada por Ricardo Severo e seus seguidores, que se mantinham presos a um rígido receituário estilístico e formal. ${ }^{52}$

Concluindo, podemos dizer que o Neocolonial, estilo arquitetônico que foi durante muito tempo depreciado e ignorado pela historiografia da arquitetura brasileira, começa a ser estudado e avaliado com maior atenção pelos pesquisadores contemporâneos. ${ }^{53}$ Discute-se atualmente qual teria sido a influência que o Movimento Neocolonial exerceu na arquitetura produzida nos anos 20 e 30, ao mesmo tempo em que se coloca a questão sobre a sua representatividade no panorama arquitetônico da época. No final, resta saber se o Neocolonial foi simplesmente mais um modismo eclético de curta duração, um episódio nacionalista sem maiores conseqüências; ou se se configurou num movimento de reflexão, discutindo pioneiramente questões de identidade cultural e nacionalismo vinculadas diretamente a uma idéia latente de modernidade; ou ainda, se se consubstanciou num momento de transição necessária entre o Ecletismo vigente em São Paulo desde o final do oitocentismo e a Arquitetura Moderna, como querem alguns autores. ${ }^{54}$ Consideramos, enfim, que apesar do Movimento Neocolonial não ter conseguido criar na prática arquitetural um estilo de cunho nacionalista, que traduzisse a essência do povo e da cultura brasileiros, não se pode desprezar a sua importância na busca pioneira de uma identidade cultural e de valores representativos da brasilidade.

"Não se nega, entretanto, ao episódio neocolonial na arquitetura brasileira um papel significativo no debate das idéias sobre novos conceitos arquitetônicos. O discurso de seus defensores não é isento de uma vontade modernizadora no sentido de atualizar a arquitetura face às transformações da sociedade e da cultura material do início do século 20. Independente do

mais interessantes desta capital." NEVES, José Maria da Silva. "Victor Dubugras“ In: Boletim do Instituto de Engenharia. nำ 90, 1933, p. 320.

52 "A distinção alcançada com naturalidade, sem esforço aparente, por Ricardo Severo, não podia ser encontrada em Victor Dubugras. /.../ Era bem diferente portanto o espírito que o animava : não se preocupava em empregar os mesmos materiais da época colonial, nem em reproduzir sistematicamente um repertório decorativo fiel, limitando-se a um certo parentesco formal, sem jamais se ater ao respeito de princípios absolutos. Com efeito, seu espírito ao mesmo tempo eclético e inovador levava-o a pesquisar todas as fontes, para delas extrair o que considerava o melhor." In: BRUAND, Yves. Arquitetura Contemporânea no Brasil, p. 53.

${ }^{53}$ Este fato pode ser atestado pelas referências cada vez mais freqüentes ao estilo em obras como Arquitectura Neocolonial : América Latina, Caribe e Estados Unidos (org. Aracy Amaral) ; Alvenaria Burguesa (Carlos A. C. Lemos) ; Ecletismo na Arquitetura Brasileira (org. Annateresa Fabris); Arquiteturas no Brasil 1900-1990 (Hugo Segawa), entre outras.

\footnotetext{
${ }^{54}$ Ver nota de rodapé 39.
} 
referencial de "modernidade" que adotavam, o principal aporte da postura neocolonial foi a introdução do contraponto regionalista - a busca de uma arquitetura identificadora da nacionalidade - como fator de renovação. $O$ substrato conceitual dos líderes do movimento era de natureza reacionária, porém interpretações mais brandas /.../ formaram a base de uma atitude de assimilação de posições aparentemente antagônicas, como o próprio Ricardo Severo formulou, mas não materializou: o "tradicionalismo revolucionário". A busca de uma arte moderna no contexto brasileiro foi alimentada por um intenso debate da questão da nacionalidade e da autonomia nacional /.... " (SEGAWA, 1998, p.38)

O Neocolonial assumiu na capital paulista um caráter simbólico muito forte no sentido de afirmação orgulhosa de um passado pela classe dominante, ou seja, de comprovação da existência de uma cultura paulista anterior à invasão estrangeira, daí a sua maior aceitação na elite. A vertente popular do Neocolonial teve penetração mais restrita, condicionada às condições sociais, econômicas e culturais das camadas médias e baixas da população local. Do ponto de vista estilístico, a expressão anônima do Neocolonial manifestou-se mais livre, criativa e simplificada, devido ao surgimento de soluções inusitadas derivadas da inventividade dos construtores para superar as limitações decorrentes do alto custo dos materiais de construção e da mão-de-obra especializada.

Analisando-se hoje o Neocolonial em São Paulo podemos dizer que o movimento foi coerente dentro do contexto da época, na medida em que se propunha novidade transfigurada em modernidade, num instante de renascimento e de intenso desejo de progresso e mudança em sintonia com o quadro internacional pós-Primeira Guerra. Naquele momento se buscava renegar a arquitetura dos imigrantes e promover uma imagem de progresso, apesar da inspiração nos elementos do repertório colonial. Sob este aspecto é compreensível o motivo pelo qual o discurso de uma arquitetura tradicionalista conseguiu impressionar e ser assimilado por todas as camadas da população paulistana; podemos mesmo dizer que nos anos 20 e 30 existia um terreno fértil que facilitou a germinação dessas idéias em São Paulo. A nossa visão e análise atual sobre esse fato arquitetônico do passado, por mais imparcial que se pretenda, será sempre insuficiente para apreender e avaliar completamente o sentimento, as vontades e a necessidade de expressão subliminares da sociedade paulistana naquele momento histórico. 
Ao longo do tempo, o ímpeto inicial de novidade do movimento Neocolonial foi esmorecendo em função da concorrência de outras modas estilísticas que foram surgindo, como o Art Déco e a Arquitetura Moderna. O pós-Segunda Guerra determinou novas condições sócio-econômico-políticas mundiais com implicações em todos os países ocidentais, o que repercutiu também na arquitetura brasileira. Agora a evolução da técnica construtiva do concreto armado, a industrialização da produção e o surgimento de novos materiais de construção, novos gostos e expectativas programáticas, indicavam outros caminhos alternativos para a arquitetura. 


\section{II.2. A nova moda do Art Déco}

\section{II.2.1. SURGIMENTO DO ART DÉCO}

No final da década de 20 chegou na capital paulista, importada da Europa, uma novidade arquitetônica que logo se tornou concorrente do Neocolonial na preferência de todas as classes sociais. Era o Art Déco, que apareceu por aqui com uma proposta de modernidade artística associada ao progresso tecnológico e industrial, que seduziu os paulistanos naqueles anos posteriores à Primeira Grande Guerra. ${ }^{55}$

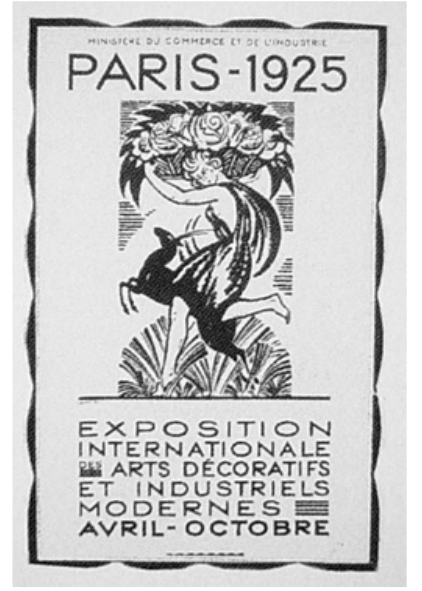

FIGURA 26 : Cartaz da Exposition Internationale des Arts Décoratifs et Industriels Modernes (Robert Bonfils / Paris, 1925)

Conhecido na época genericamente como "Arte Moderna", o fenômeno Déco derivava de um modismo das artes utilitárias e decorativas européias, surgido na Exposition Internationale des Arts Décoratifs et Industriels Modernes (Paris/1925). Os pavilhões representando os vários países participantes da exposição distribuíram-se pela Esplanade des Invalides, no centro de Paris, e, na sua maioria, procuravam apresentar ao público visitante uma nova linguagem visual, um novo universo decorativo, que objetivava em suma criar uma ambientação cenográfica apropriada para o modo de vida progressista e agitado de então. A amostragem do novo design exibida na Exposition Internationale des Arts Décoratifs et Industriels Modernes sintetizava todas as especulações artísticas que haviam se manifestado desde o início do século $X X^{56}$ em novas propostas estilísticas para as artes aplicadas, que anos depois se convencionou agrupar e chamar de Art Déco.

\footnotetext{
${ }^{55}$ Hugo Segawa nos fala em diversas modernidades (pragmática, programática etc.) surgidas no Brasil a partir dos anos 20. A arquitetura Art Déco, na sua opinião, seria apenas mais uma expressão de modernidade entre tantas outras que ocorreram naquele período. Este autor nos diz que ".../ no entanto, a modernidade de inspiração européia preconizada pelo arquiteto russo (Warchavchik) era apenas uma vertente entre tantas outras que se formularam no imediato pós-primeira guerra. Modernidades que caracterizavam as incertezas de uma sociedade instável, recém-saída de uma conflagração /.../ O Brasil não deixou de sentir a voga modernizadora européia dos anos de 1910 a 1930. I.../ São arquiteturas que também foram chamadas de "modernas", "cúbicas", "futuristas", "comunistas", "judias", "estilo 1925", "estilo caixa d'água" e assim por diante. Hoje podem ser identificadas ainda como Déco e também como fascista." In: SEGAWA, Hugo. Arquiteturas no Brasil 1900$\underline{1990}$, p. 54

${ }^{56}$ Como o Cubismo, que configurava uma nova ótica do objeto a partir da sua fragmentação e posterior reconstrução no plano da tela ; o Expressionismo, que procurava retratar a realidade de modo exagerado ou deformado de acordo com os sentimentos e a percepção do artista ; o Futurismo e o Vorticismo (versão inglesa do Futurismo), que defendiam que o artista deveria representar o dinamismo e a mudança permanente das coisas, ou seja, expressar o "vórtice" da vida moderna ; e, após a Primeira Guerra Mundial, o Dadaísmo e o Fovismo, que procuravam a plasticidade das obras na simplificação das formas e valorização das cores e do brilho.
} 


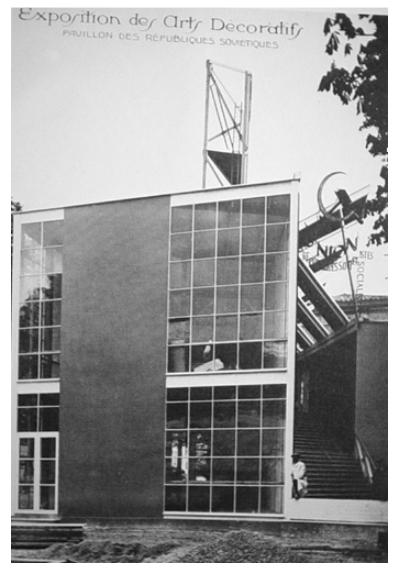

FIGURA 27 : Pavilhão da Rússia. (Melnikov / Paris, 1925)
Com exceção dos pavilhões apresentados por Le Corbusier e Melnikov (responsável pelo pavilhão construtivista da Rússia), que se destacavam pelas suas propostas arquitetônicas e decorativas diferenciadas, os demais pavilhões da Exposição de 1925 adotavam uma linguagem livre inspirada numa interpretação do Neoclassicismo, que variou de soluções mais simples até outras excessivamente rebuscadas.

Numa atitude de repúdio ao caráter essencialmente decorativo da Exposition Internationale des Arts Décoratifs et Industriels Modernes (1925), Le Corbusier expôs no seu pavilhão denominado “L'Esprit Nouveau”, um protótipo-síntese da sua "máquina de morar".

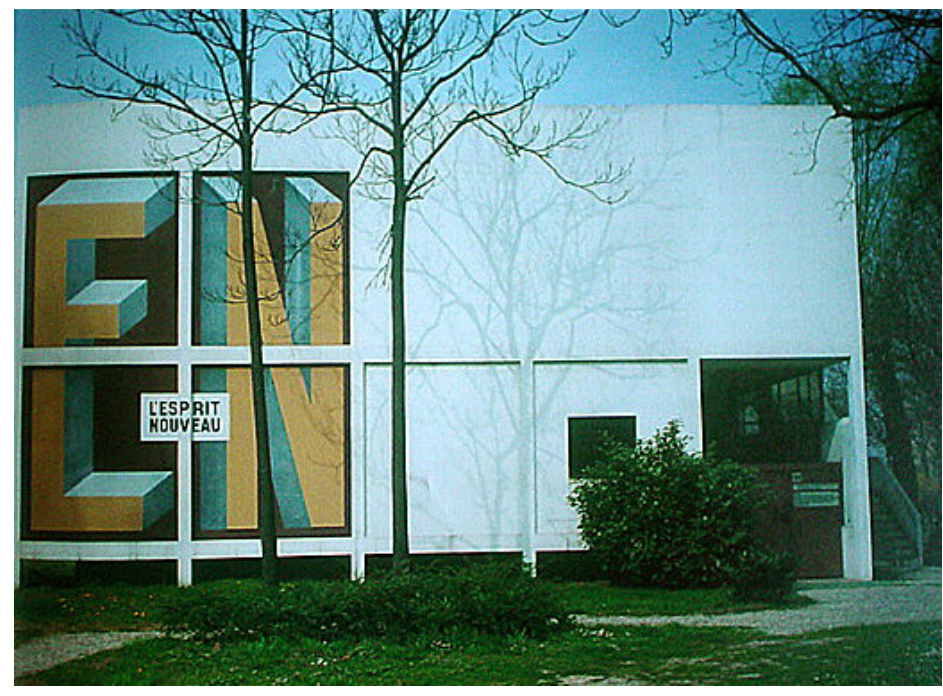

FIGURA 28 : Pavilhão L'Esprit Nouveau. (Le Corbusier / Paris, 1925)

"Ele era branco no exterior e no interior - como toda a sua arquitetura - o pavilhão que Le Corbusier projetou em forma de habitação-tipo : uma harmonia de volumes puros, em contraste com os espaços claramente delimitados por eles. Vazios e cheios, sombra e luz. /.../ No que toca às soluções práticas, economia de espaços úteis, funcionalismo com procura essencial /.../ no arranjo do mobiliário. /.../ Um rigor absoluto."(VERONESI, 1968, p. 320) 
Com o seu pavilhão e os artigos publicados logo em seguida na revista Esprit $\underline{\text { Nouveau (e transformados mais tarde no livro Vers une Architecture) }},{ }^{57}$ o arquiteto francosuíço firmou publicamente sua oposição à nova estética divulgada na exposição de artes decorativas e industriais, chamando de "bagatelas" os objetos ali expostos.

O uso da denominação Art Déco, para identificar e qualificar a ampla e variada produção material de natureza artística e industrial dos anos 20 e 30, é recente. O termo, resultante da abreviação de "Art Décoratif", apareceu durante a exposição "Les Années 25 Art Déco / Bauhaus / De Stijl / Esprit Nouveau", uma mostra retrospectiva dos anos 20, realizada em Paris em 1966 no Musée des Arts Décoratifs.

Com uma proposta de design caracterizada como "moderna", porque era uma novidade em relação ao rebuscado e artesanal "Art Nouveau", e cosmopolita, porque propunha uma expressão universal, padronizada e democrática para as artes aplicadas, a linguagem Déco demonstrou de imediato o seu claro comprometimento com os meios produtivos industriais desenvolvidos nas primeiras décadas do século XX na Europa, expandindo-se rapidamente e com muito sucesso pelo mundo ocidental até o início da Segunda Grande Guerra.

"O Art Déco objetivava sobretudo criar o cenário da vida moderna, o que fez com que ele freqüentemente se referisse metaforicamente à indústria e à tecnologia, mantendo uma relação formal abstrata. A relação concreta e efetiva, ou seja, a relação com os sistemas industriais de produção, se deu apenas em alguns setores da produção de objetos. Em setores do desenho industrial - o desenho de moda /.../, o desenho de móveis, objetos de vidro, prata, esmalte, cerâmica, tecidos, jóias, encadernações, vitrais e ferro forjado - houve uma real aliança entre arte e a indústria, onde o design era especialmente produzido para a produção em massa."(SAWAYA, 1982, p.44)

A sua "modernidade" estava implícita na sintonia que procurava assumir com os tempos agitados que se vivia então, associando-se fundamentalmente aos objetos ligados à vida cotidiana como peças decorativas, mobiliário, utensílios e aparelhos domésticos etc., e estendendo-se até à arquitetura, ao paisagismo, às artes gráficas, à caricatura, à moda e ao vestuário.

\footnotetext{
${ }^{57}$ Nos seus textos polêmicos Le Corbusier defendia para a habitação uma estética funcional semelhante à das máquinas.
} 


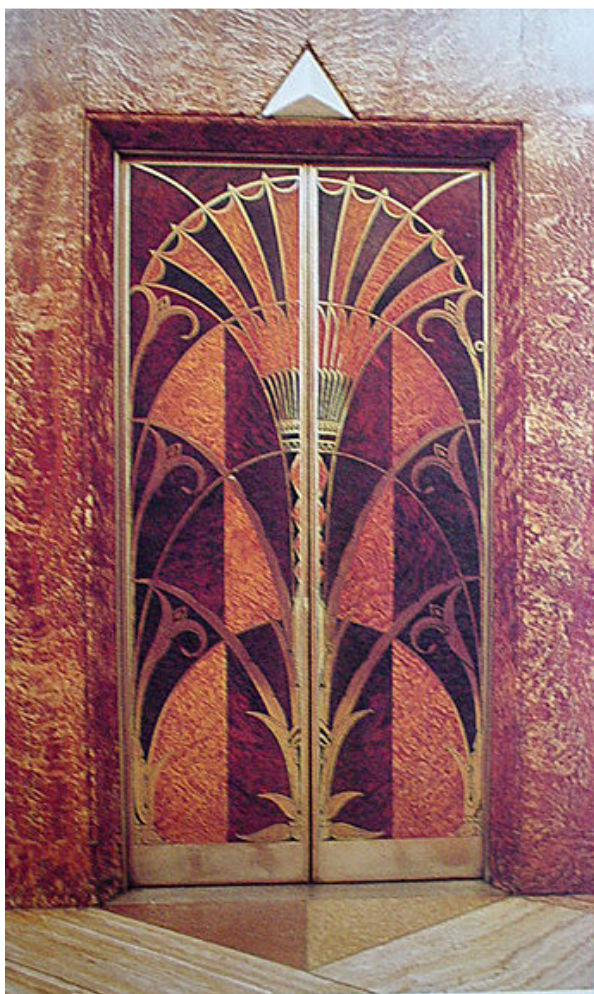

FIGURA 29 : Detalhe da porta do elevador do edifício Chrysler Building. (Nova lorque, 1928/30)

A linha - reta, curva, contínua, quebrada, escalonada, horizontal, vertical, espessa, delgada - era a base da expressividade do Art Déco. ${ }^{58}$ A linearidade do design possibilitava o emprego de elementos produzidos industrialmente, o que redundava, via de regra, num desejado barateamento dos custos de produção dos objetos, fator que incentivava a sua popularização. Em função das marcantes influências que recebeu dos diversos movimentos artísticos surgidos no início do século XX, o Art Déco incorporava também no seu repertório ornamental motivos geométricos (ziguezague, "grega" etc.); formas aerodinâmicas inspiradas no dinamismo e na velocidade das máquinas ; além de simplificações e estilizações de elementos figurativos da natureza (raio-desol, arco-íris, fauna, flora etc.).

O Art Déco surgiu numa Europa perplexa e desorientada, ainda em fase de reestruturação após o forte impacto causado pela Primeira Guerra Mundial, que ocasionou profundas mudanças no quadro político e econômico internacional. Esta linguagem estética apareceu, portanto, num momento de recuperação mundial, em que tudo que se desejava era esquecer o horror dos tempos da guerra, buscando desvairadamente em expressões artísticas extravagantes e diferentes o "novo", ${ }^{9}$ que se confundia invariavelmente com o "moderno". ${ }^{60}$ Assim, naquela época foram nomeadas indistintamente como "modernas"

\footnotetext{
58 "Um dos princípios formais prevalentes no Déco é aquele do predomínio da linha, a qual, traçada com um movimento contínuo, desenha, realiza ; a linha não é fluida e ondulada, serpenteante, mas, seca, dobrada no ângulo, até mesmo no típico andamento do zig-zag, ou do motivo "à grega" do labirinto, /.../ na maior parte das vezes é limpa porque espaçada : trata-se de fórmula que abandonou totalmente o "horror vacui" do Art Nouveau /.../" In: BOSSAGLIA, Rossana. Guide all'Architettura Moderna : L' Art Déco, p. 7.

59 "A sociedade do pós-guerra estava embriagada de ilusões e passava de uma moda para outra com rapidez. Vivia dominada por um espírito frívolo, inconseqüente e superficial que se refletiu nas suas manifestações artísticas mais populares." In: SAWAYA, Silvana T. Arquitetura Déco na cidade de São Paulo, p. 26.

60 "A França sublimou uma noção de moderno de difícil caracterização. A grande celebração à modernidade, a Exposition Internationale des Arts Décoratifs et Industriels Modernes, em 1925, bem espelhou a busca de qualquer modernidade, a necessidade de exprimir idéias novas, de tentar ser moderno mesmo sem que se pudesse esclarecer o que isso significava ou como se chegava à condição de moderno. A busca de um comportamento novo refletia a instabilidade de uma sociedade mais
} 
".../ várias manifestações ocorridas nas décadas de 20 a 40 e que em alguns casos eram conflitantes entre si /.../ Desde a coreografia do ballet russo de Diaghilev, a fascinação construtivista do cubismo de fins do século, a exaltação arcaizante dos anos 30 até o "Esprit Nouveau" de Le Corbusier."(BLAY, 1979, p.7)

O Art Déco aparece e se dissemina no final dos anos 20 em diferentes contextos urbanos na Europa e nas Américas, afetados diretamente pela expansão dos meios de comunicação, como a imprensa e o cinema, que começavam a estabelecer um rápido e eficiente processo de integração de massa entre os povos dos vários continentes. Fatos diversos eram amplamente divulgados pela imprensa mundial tais como : as descobertas arqueológicas da tumba do faraó Tutankhamon no Egito (1922) e das culturas exóticas dos povos nativos das Américas (maias, astecas, incas), da Ásia e da África; a expedição de exploração do Coronel Fawcett, e depois a de resgate de Peter Fleming, ambas desaparecidas na selva amazônica (1925); e a primeira travessia aérea sem escalas do Oceano Atlântico realizada pelo aviador norte-americano Charles Lindenbergh em 1927. O cinema, por sua vez, exercia uma influência cada vez mais determinante na vida das pessoas, principalmente depois do advento dos filmes sonoros em 1927. As "estrelas" e os "astros" de Hollywood ditavam o vestuário, os costumes, o modo de morar e de se portar, que eram seguidos sem questionamentos por milhões de espectadores no mundo inteiro ávidos por novidades.

Eram tempos de intensa agitação social e cultural, marcados pela luta de emancipação das mulheres, pela influência das idéias comunistas e socialistas e pelas manifestações artísticas de vanguarda representadas na música por Stravinsky e Satie, na dança por Diaghilev e Nijinsky, na arte por Picasso, Braque, Matisse, Miró, e na arquitetura pelo racionalismo de Ludwig Mies van der Rohe, pelo funcionalismo de Walter Gropius (Bauhaus - 1919/1933) e pela "máquina de morar" de Le Corbusier.

Eram tempos de frivolidades e de excentricidades. Esse período, conhecido também como "les folles 20", caracterizou-se pela celebração da diversão irrestrita, ${ }^{61}$ pela divulgação internacional do jazz e do blues, do "foxtrote" e do "charleston", pelas viagens intercontinentais de luxuosos transatlânticos, como o francês "Normandie" e o britânico

preocupada com prazeres efêmeros que com realizações duráveis /.../ Essa ambigüidade também alimentou os sonhos de uma afluente sociedade norte-americana, que tomou emprestado e multiplicou os artifícios decorativos do lado próspero da cultura européia - artifícios que, décadas depois, convencionou-se chamar Art Déco." In: SEGAWA, Hugo. Arquiteturas no Brasil $1900-1990$, p. 54

61 “.../ apenas haviam cessado as hostilidades (da Primeira Guerra Mundial) /.../ uma loucura desenfreada de prazeres se abateu sobre a Europa, arrastando homens e mulheres numa mesma onda de folia e de doido entusiasmo /.../" In: $\underline{\mathrm{O} \text { Estado }}$ de São Paulo, de 19/04/1920, p.4. Apud: SEVCENKO, Nicolau. Orfeu Extático na Metrópole. São Paulo sociedade e cultura nos frementes anos 20, p.36. 
"Queen Mary", 62 pelas audácias esportivas, como as corridas de carros etc. Concomitantemente, Paris ditava a moda da Alta Costura e lançava o "prêt-à-porter". "La Garçonne" (1923), o personagem título do romance de Victor Margueritte, logo se tornou o arquétipo da mulher liberada dos anos 20 ; e, baseado na jovem heroína emancipada de Margueritte, o estilista Paul Poiret criou um novo visual e vestuário para as mulheres, de feitio assumidamente masculino e esportivo.

Contemporaneamente, os avanços da ciência e da tecnologia traziam novos confortos ao modo de vida urbano das camadas médias da população mundial nos anos 20 e 30, comodidades até então exclusivas da elite.

"A vida alcança nos grandes centros um ritmo intenso. Devido à iluminação elétrica das ruas, as cidades puderam oferecer mais atrações à noite e os grandes centros - Paris, Londres e Nova lorque - vivem vinte e quatro horas por dia." (SAWAYA, 1982, p.33)

Graças ao barateamento dos produtos, resultante da expansão industrial, começavam a se tornar acessíveis e, conseqüentemente, a se popularizar, desde aparelhos eletrodomésticos até automóveis.

"No plano econômico ocorre a ampliação do mercado baseado sobretudo na produção industrial de bens de consumo. A questão arte e indústria é recolocada num sentido mais amplo. Tratava-se de se apropriar das possibilidades oferecidas pela máquina, ao invés de combatê-la. Um novo tempo. Uma nova estética possibilitada pelo advento da industrialização. Era então necessário compreendê-la e adaptá-la às novas exigências. As artes decorativas assumem um papel fundamental. É a arte do cotidiano; de um bule de café à decoração de interiores." (BLAY, 1979, p.13)

Tudo isto colaborou para que se criasse um ambiente cultural propício ao desenvolvimento de idéias progressistas voltadas ora para o futuro vislumbrado pela ficção científica de filmes como "Metrópolis", de Fritz Lang (1925), e "Flash Gordon"(1934), ora para o exotismo dos mundos recém-descobertos da América, da África e da Ásia.

Neste contexto é compreensível porque no pós-Primeira Guerra a idéia propagada pelo Art Déco de "modernização" do repertório estilístico teve pronta aceitação, sem grandes polêmicas, pelos artistas e consumidores em geral. O Art Déco não intentava na sua essência nem se consubstanciar numa ruptura artística, sob um prisma filosófico, e nem representar uma nova estética que derivasse diretamente da concepção mecânica da

\footnotetext{
62 ".../ Esses enormes e elegantes navios produziram um encanto por suas formas o que influenciou o desenho de edifícios como a gigantesca estrutura em forma de navio do Radio City Music Hall de Nova lorque e o desenho de objetos decorativos." In: SAWAYA, Silvana T. Arquitetura Déco na cidade de São Paulo, p. 33.
} 
produção industrial. ${ }^{63}$ Sua proposta plástica voltada deliberadamente para 0 design configurava-se menos pretensiosa, no sentido em que se limitava a introduzir nova linguagem ornamental dentro de um vocabulário eclético já aplicado à exaustão. Tratava-se tão somente de descobrir, reinterpretar e criar sem escrúpulos novos elementos formais e decorativos a partir da livre apropriação das linhas aerodinâmicas das máquinas, ou da estilização dos motivos originais de civilizações exóticas ou greco-romanas, ou ainda da simplificação e geometrização das formas advindas da estética cubista.

"Assim fica mais claro compreender como conviviam "harmoniosamente" os motivos arcaizantes helênicos, os zig-zags astecas e os elementos geometrizantes da cultura egípcia, que serviram juntamente com as linhas aerodinâmicas fornecidas pela máquina a compor o formulário do Art Déco." (BLAY, 1979, p.14)

Quanto à discussão se o Art Déco se configurou ou não num estilo, existem muitas controvérsias a este respeito. Enquanto alguns autores como Luiz Paulo Conde e Mauro Almada consideram que "se não foi um movimento, o Art Déco certamente foi um estilo, com estilemas claramente identificáveis" ${ }^{64}$ outros discordam desta premissa afirmando que o Art Déco como estilo nunca existiu ${ }^{65}$ porque ".../ não foi um movimento. Não teve fundador, nem manifesto e nem filosofia. Simplesmente aconteceu porque designers e decoradores em Paris durante o período depois da primeira guerra foram estimulados por demandas de uma sociedade em reestruturação." 66 Já Vitor Campos, em seu estudo sobre o Art Déco, observa

"que o termo estilo /.../ não parece ser capaz de contemplar, de maneira satisfatória, a diversidade de formas de expressão reunidas sob o manto do Art Déco, potencializada pelas variantes surgidas ao longo do mundo /.../" porque "a unidade de linguagem é fator determinante para a caracterização de um estilo, implicando a delimitação de um repertório formal básico e a definição de parâmetros compositivos, claramente identificáveis, que, no caso da arquitetura Déco, é matéria de difícil consenso." (CAMPOS, 2003, p.39 e 97)

À parte a polêmica estabelecida entre os estudiosos de História da Arte e da Arquitetura a respeito da existência ou não do estilo Art Déco, que não se configura tema específico para ser tratado nesta tese, é clara a identificação de uma constância de

\footnotetext{
${ }^{63}$ "No caso do Art Déco, a questão da máquina entra mais como um formulário à disposição de quem se interessasse em buscar ali os seus motivos ornamentais, do que realmente o entendimento da sua essência e do significado maior que ela teria sobre a evolução da sociedade moderna. /.../ Essa formulação viria com a Bauhaus e o De Stijl que se converteram nos denunciadores desse falso "estilo moderno". In: BLAY, Beatriz . Roteiro Art Déco em São Paulo, p.14.

${ }^{64}$ In : Guia da Arquitetura Art Déco no Rio de Janeiro, p.10.

${ }^{65}$ Ver: KLEIN, Dan et alii. In the Deco Style, p. 7; SEGAWA, Hugo.Arquiteturas no Brasil 1900 - 1990, p.59; BLAY, Beatriz. Roteiro Art Déco em São Paulo, p. 7.

${ }^{66}$ In: KLEIN, Dan et alii. In the Deco Style, p. 7.
} 
estilemas entre várias manifestações artísticas e arquitetônicas mundiais ocorridas nas décadas de 20 e 30 dando ensejo àquela denominação.

"Se admitirmos que gosto e estilo são frutos do consenso social e referendo da sua época , igualmente teremos que admitir /.../ que as manifestações Art Déco /.../ são o reflexo fiel da época que refletem, da sua frivolidade, refinamento e nervosismo. São pois, ao menos, o testemunho fidedigno de uma época da qual somos - desde o técnico até o moral - em grande medida depositários." (MAENZ, 1974, p. 17)

A estética Déco não passava, portanto, de mais uma opção ornamental, só que agora carregada de uma considerável carga simbólica que remetia às idéias de modernidade, progresso e popularização, intensamente almejadas por todos naqueles tempos posteriores a Primeira Grande Guerra.

\section{II.2.2. A FEIÇÃO DÉCO NA ARQUITETURA}

A manifestação Déco na arquitetura expressou-se através da introdução de um repertório decorativo inédito, qualificado na época de "moderno," porque diferente das desgastadas linguagens eclética historicista e Art Nouveau difundidas até os anos 20. O Art Déco, com sua predominância de linhas puras e ornamentos geométricos e estilizados, induzia a uma aparência de limpeza plástica das edificações, invariavelmente associada a uma imagem de modernidade.

A arquitetura filiada ao Art Déco não tinha como proposta promover alterações substanciais no partido arquitetônico das edificações porém intentava criar uma nova estética vinculada ao uso do concreto armado. Esta pretensa relação racionalista de influência "perretiana", 67 pode ser deduzida no texto do relatório final da Exposition Internationale des Arts Décoratifs et Industriels Modernes quando se define arquitetura "moderna" como aquela que, ".../ tirando vantagem das conquistas da indústria, utiliza, para realizar os novos programas, os materiais e os procedimentos da construção do seu tempo." ${ }^{68}$ Por esta afirmação, é claramente perceptível a estreita relação estabelecida desde o início entre a arquitetura déco e o concreto armado, quase sempre presente na estrutura das edificações.

\footnotetext{
$67 \mathrm{O}$ arquiteto franco-belga Auguste Perret foi o pioneiro na busca de uma nova linguagem arquitetônica através do uso do concreto armado. O seu edifício da rua Franklin (1902-3), em Paris, é considerado a primeira obra a empregar o concreto armado de forma aparente com objetivo ornamental. Ver: ALAMBERT, Clara Correia d'. Um Novo Modo de Construção no Limiar do século XX. Concreto Armado: Experiências Técnicas / Especulações Estéticas.

${ }^{68}$ In: Exposition Internationale des Arts Décoratifs et Industriels Modernes - Paris, 1925 : Rapport Général. v.2, 1928, p. 10.
} 
O Art Déco distinguia-se nos contextos urbanos em que se inseria por ser uma arquitetura marcada pela severidade da volumetria resultante de linhas retas, pela simetria planejada dos corpos e elementos de composição das fachadas, pelo equilíbrio entre os cheios e os vazios, pelo emprego ocasional de materiais como o vidro e metais para obter reflexo e brilho, e, via de regra, pela discrição da ornamentação estilizada ou geométrica aplicada em pontos estratégicos das elevações, de modo a criar efeitos de relevo e contrastes de luz e sombra. Assim, sobre uma estrutura de inspiração cubista, que podia ser um único arcabouço ou um volume fragmentado em vários blocos de composição e dimensões variadas, a ornamentação déco aplicava-se em locais pré-determinados das fachadas procurando destacá-los.

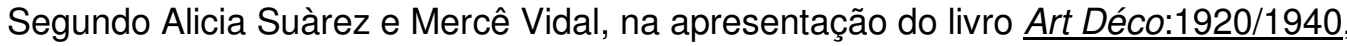

".../ as fachadas (Déco) apresentam as seguintes características predominantes : paredes externas realçadas por uma profusão de formas angulares ; distribuição regular dos vazios e simetria muito acentuada, que em vários casos aparece marcada por dois corpos laterais salientes ; janelas geminadas que destacam a horizontalidade ; mansardas geometrizadas do tipo francês coroando os edifícios ; faixas paralelas horizontais escalonadas que se repetem em toda a fachada ou aparecem nos espaços entre as janelas e as portas ; utilização de elementos de estilos históricos (colunas, capitéis, volutas) de forma plana e esquemática ; uso de espessos balaústres de cimento cilíndricos ou prismáticos ; introdução de baixos-relevos em placas que se encontram geralmente sobre a porta (os mais significativos são os que têm como tema a velocidade : barcos, trens, aviões). Mas, talvez, seja nas grades das sacadas e das portas onde as características do estilo podem ser captadas de forma mais imediata : as formas geométricas simples, paralelas, ondas, zig-zags, espirais, fontes de água, temas florais simplificados ou silhuetas de cactus e palmeiras, aparecem constantemente /.../" (MAENZ, 1974)

Por seu caráter pretensamente "moderno" o Art Déco foi a linguagem estilística preferida pela maioria dos arquitetos e construtores no mundo inteiro para caracterizar as inúmeras tipologias programáticas que se afirmavam nos anos 20 e 30, como os cinemas, teatros, prédios industriais, de escritórios e de apartamentos. Neste período, a nova corrente arquitetônica também se disseminou em variados programas residenciais, imprimindo democraticamente a sua nova feição tanto nos palacetes da elite quanto nas habitações populares. $^{69}$

\footnotetext{
69 "A generalização do Art Déco levaria à construção de cinemas /.../ escritórios, /.../ hospitais, indústrias e outras edificações, mas provavelmente o mais importante foi a adoção de seus códigos decorativos (frisos, capitéis, batentes, colunas) pelos arquitetos, empreiteiros e mestres-de-obra, que os empregaram massivamente em casas da pequena burguesia e em edifícios de apartamentos." In:TORAYA, Juan de las Cuevas. Contribuição dos materiais de construção cubanos no desenvolvimento e generalização do Art Déco em Cuba, acesso 2003.
} 
A arquitetura déco se estabeleceu em duas fases seqüenciais com particularidades formais e ornamentais distintas. O divisor entre ambas foi o crack da Bolsa de Nova lorque em 1929, acontecimento desencadeador de uma profunda crise econômica, política e social nos Estados Unidos, a qual se propagou pelos países europeus e abalou o espírito frívolo dominante até então.

".../ A crise americana de 1929 apagou o luxo artificial de um muito prolongado "pós-guerra" : o estilo da burguesia internacional, que havia triunfado /.../ até a Expo 25, cedeu lugar à crise da economia burguesa. /.../ Era sobretudo a condenação de um sistema. E na ruína do sistema foram arrastados os símbolos do seu precedente poder : dentre eles o fausto decorativo foi particularmente atingido." (VERONESI, 1968, p. 311)

Assim, a primeira etapa déco, conhecida também como "zigue-zague", abrangeu a totalidade da produção arquitetônica dos anos 20, a qual privilegiou obsessivamente as ornamentações geométricas baseadas em estilizações de motivos de origem grega, asteca, oriental, egípcia etc., e valorizou sobremaneira as soluções volumétricas marcadas pela sobreposição de planos escalonados em profundidade e altura. Já na segunda fase desenvolvida a partir dos anos 30 foi dada maior ênfase aos temas que induziam a uma noção de movimento e dinamismo, surgindo daí as formas aerodinâmicas, mais arredondadas e suavizadas, ligadas inequivocamente ao desenho das máquinas e à velocidade. ${ }^{70}$ A chamada "arquitetura barco", inspirada nos transatlânticos, e o arranha-céu, que se configurava num bloco vertical se projetando em direção ao céu, são exemplos característicos da linguagem predominante do período, que se manifestou plena e vigorosa nos Estados Unidos. ${ }^{71}$

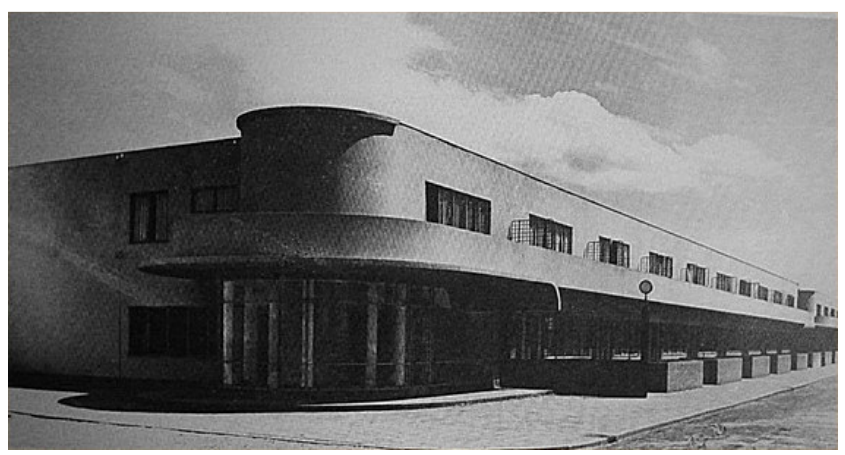

FIGURA 30 : Arquitetura tipo "barco" ("Hook of Holland" J.J. Oud / Holanda, 1924)

\footnotetext{
${ }^{70}$ Paul Maenz chama a primeira fase da arquitetura Art Déco (anterior a 1929) de "zig-zag moderno" e a segunda (anos 30) de "aerodinâmica moderna". In: MAENZ, Paul. Art Déco : 1920-1940. Formas entre dos guerras, p.199.

71 "Contrariamente ao que ocorreu no cenário arquitetônico moderno europeu, o Art Déco encontrou nos Estados Unidos um ambiente favorável para seu pleno desenvolvimento, vindo a contribuir de maneira decisiva para a criação da imagem da metrópole moderna americana." In: CAMPOS, Vitor J. B. O Art Déco e a construção do imaginário moderno - um estudo de linguagem arquitetônica, p. 11.
} 


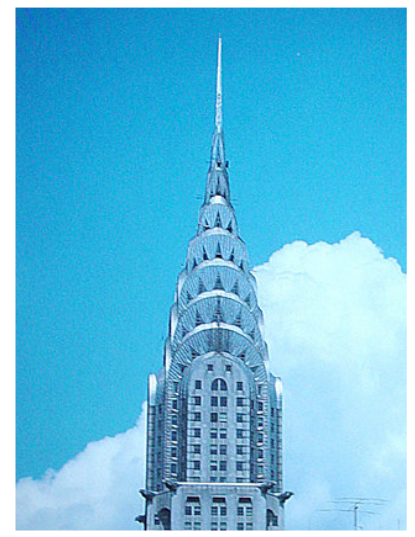

FIGURA 31 : Chrysler Building (Nova lorque, 1928/30)

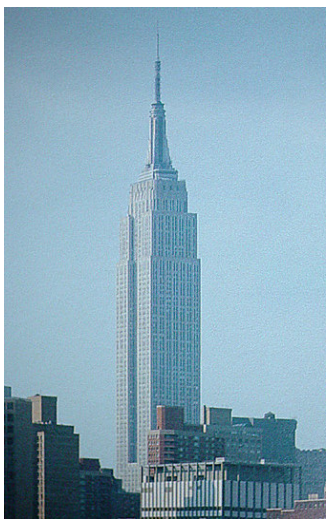

FIGURA 32 : Empire State

Building. (Nova lorque, 1931)
A imagem do Art Déco esteve intimamente ligada a verticalização nos grandes centros urbanos mundiais. $\mathrm{Na}$ década de 30 a paisagem de diversas cidades dos Estados Unidos foi transformada pela construção de elevados edifícios décos, os arranha-céus ou os famosos "skyscrapers", como é o caso típico de Nova lorque. Chrysler Building (1928-30) ${ }^{72}$, o General Electric Building (1930-31), antigo R.C.A. Victor, o Empire State Building (1931), e o complexo do Rockfeller Center (1933), entre outros arranha-céus, imprimiram a sua feição déco na identidade novaiorquina. ${ }^{73}$ Contemporaneamente, no Rio de Janeiro, foi construído o edifício "A Noite" (1928-30), antiga sede do jornal do mesmo nome, considerado o primeiro arranha-céu déco brasileiro. Com 22 andares e construído totalmente em concreto armado, o prédio projetado por Elisiário Bahiana e Joseph Gire, apresenta ordenação geométrica nas fachadas, discreta ornamentação de inspiração déco na porção central do bloco e frisos horizontais nos coroamentos e cimalhas do edifício. $^{74}$

Difundida no Brasil a partir do final dos anos 20, a arquitetura Déco teve seu ápice durante a década de 30, perdendo fôlego com a eclosão da Segunda Guerra Mundial. Neste período o Art Déco rivalizou intensamente com o Neocolonial como opção estilística para atender diversos programas como residências, escolas, edifícios públicos etc. Ambas as correntes se propugnavam modernas, porém com uma fundamental diferença : enquanto o Neocolonial buscava inspiração no repertório da arquitetura tradicional brasileira, o Art Déco baseava-se em modelos estrangeiros. Por outro lado, a valorização pelo Art Déco das artes

\footnotetext{
${ }^{72}$ Paul Maenz considera o arranha-céu novaiorquino Chrysler Building (projeto de Willian von Allen) como ".../ uma mostra impressionante da transição da primeira fase do Art Déco /.../ para a segunda." In: MAENZ, Paul. Art Déco : 1920-1940. Formas entre dos guerras, p.199.

${ }^{73} \mathrm{Na}$ mesma época, as novas áreas urbanas de algumas cidades americanas, como Miami, foram quase que integralmente edificadas segundo a nova moda estilística do Art Déco. Hoje são atração turística os hotéis e as construções déco que se sucedem por quilômetros na famosa Collins Avenue de Miami Beach.

74 "Joseph Gire e Elisiário Bahiana, ao projetarem o edifício A Noite, davam vazão ao preceito perretiano de uma arquitetura integrada à estrutura." SEGAWA, Hugo. "Modernidade Pragmática. Uma Arquitetura dos anos 1920/40 fora dos manuais." In: Revista Projeto. № 191, 1995, p. 78.
} 
nativas de países fora da tradição européia permitiu que na sua expressão brasileira fossem incorporados temas baseados na flora e fauna nacionais, além de motivos indígenas geométricos, como os das cerâmicas marajoaras do Pará. ${ }^{75}$ Este fato possibilitou que esta corrente entrasse em convergência com os ideais do nacionalismo modernista vigente nos anos 30 , assumindo aqui um caráter regionalista.

Partindo da proposta original do Art Déco de criação de um design integrado para todas as artes aplicadas, ${ }^{76}$ inúmeros arquitetos brasileiros procuraram desenvolver um trabalho planejado visando harmonizar com a mesma linguagem estilística os exteriores e os interiores das edificações, projetando também os seus espaços internos - mobiliário e decoração. Como obra paradigmática mais eloqüente desta integração artística pode ser citado o edifício do antigo Banco de São Paulo (projeto do arquiteto Álvaro Botelho /1935), no qual a riqueza do repertório ornamental do Art Déco comparece em todo o seu esplendor, desde a correta composição das fachadas até os seus requintados espaços internos.

\section{II.2.3. A ARQUITETURA DÉCO EM SÃO PAULO}

Os arquitetos paulistanos não assimilaram de imediato a linguagem estilística do Art Déco. No ambiente cultural conservador que ainda predominava em São Paulo nos anos 20 é bastante compreensível que a nova corrente tenha sofrido uma resistência inicial. Apesar de estarem atualizados com as modernidades e novidades técnicas e construtivas surgidas no cenário arquitetônico mundial, os construtores paulistanos continuavam projetando edificações ecléticas ou neocoloniais.

Não se sabe até o momento qual foi o arquiteto pioneiro a lançar a moda do Art Déco e nem qual teria sido a primeira edificação déco realizada na cidade de São Paulo. No entanto, pode-se afirmar que o Instituto Biológico (projeto de Mário Wathely /1928) e o edifício Saldanha Marinho (projeto de Elisiário Bahiana /1929) estão entre as primeiras obras realizadas segundo o novo gosto na capital paulista. Outra referência é fornecida por Maria Cecília Naclério Homem, no seu livro sobre o bairro de Higienópolis, quando descreve

\footnotetext{
75 "Em termos de linguagem arquitetônica, o Art Déco caracteriza-se como um sistema sígnico aberto, tendo permitido a incorporação de elementos regionais a um repertório básico internacional." In: CAMPOS, Vitor José Baptista. O Art Déco e a construção do imaginário moderno - um estudo de linguagem arquitetônica, p. 34.

${ }^{76}$ Para os artistas da época a arquitetura era considerada a primeira das artes aplicadas pelo seu caráter essencialmente funcional.
} 
a residência Caio da Silva Prado, construída no final dos anos 20, que na sua opinião teria sido uma das obras precursoras do déco em São Paulo. ${ }^{77}$

"Ainda nos finais da década de 1920, antes de terminar o período "áureo" do Bairro, a Avenida Higienópolis seria em São Paulo uma das lançadoras do estilo "art déco", trazido por uma nova geração. O casal Caio Prado mandou demolir a "Vila Antonieta" e fez edificar em seu lugar uma residência ao gosto dos modernistas, a cargo da Cia. Comercial e Construtora, e conforme projeto do arquiteto da firma, Elisiário Bahiana /.../." (HOMEM, 1980, p.98)
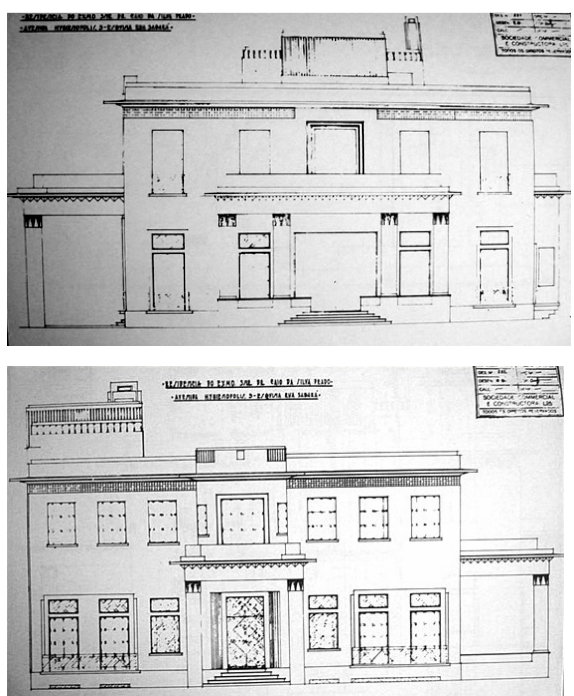

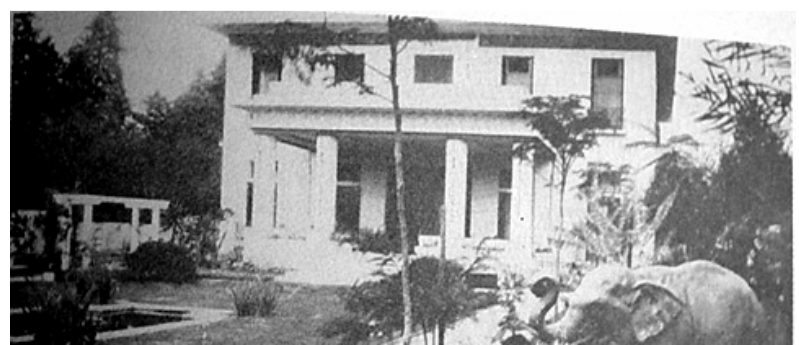

FIGURAS 33, 34 e 35 : Residência Caio da Silva Prado à avenida Higienópolis. (Elisiário Bahiana / São Paulo, final da década de 1920)

\section{Desenho da fachada da avenida Higienópolis. Desenho da fachada da rua Sabará.} Fachada da avenida Higienópolis.

Nos anos 30 o Art Déco se estabeleceu e se difundiu em São Paulo. Como uma nova opção estilística, travestida de moderna, a arquitetura déco logo se tornou um modismo de caráter popular, espalhando-se rápida e amplamente em construções de variadas tipologias programáticas por toda a cidade - edifícios comerciais, industriais, cinemas, teatros, escolas, residências, prédios de apartamentos etc. ${ }^{78}$

\footnotetext{
77 Pela análise de fotografias antigas da edificação (hoje demolida), acreditamos que se tratava na realidade de exemplar arquitetônico de inspiração cubista, e, portanto, mais próximo da linguagem modernista, divulgada pelo arquiteto Gregori Warchavchik, do que da déco.

78 "Diferentemente de outros momentos da História da Arquitetura na América Latina, onde o "novo" sempre chegava com uma defasagem de alguns anos, o Art Déco disseminou-se com muita rapidez contando com a vantagem de não ter ficado restrito aos círculos internos das elites econômica e cultural. Pelo contrário, foi absorvido por amplos setores da sociedade, contemplando praticamente todas as categorias de edificações - do grande edifício comercial à casa operária." In: CAMPOS, Vitor José Baptista. O Art Déco e a construção do imaginário moderno - um estudo de linguagem arquitetônica, p. 13.
} 
Nesta época a estética déco foi adotada sem restrições por todas as camadas sociais em função da novidade da sua proposta de uma volumetria pura com discreta ornamentação parietal, invariavelmente geométrica ou estilizada. O seu sucesso entre as classes média e baixa pode ser explicado também pelo baixo custo da construção, resultante da simplificação formal e decorativa e do uso de um grande número de materiais padronizados produzidos industrialmente, como esquadrias, caixilhos, ferragens, ornamentos de gesso e cimento etc. Assim, enquanto Warchavchik construía para a elite paulistana as suas casas "modernistas", de nítida inspiração cubista (apelidadas pejorativamente na época de "futuristas" ou estilo "caixa d'água"), o Art Déco era empregado sem constrangimento na década de 30 como linguagem arquitetônica identificadora de muitos conjuntos de sobradinhos geminados chamados "tipo Ford" ou "casas V 8", porque construídos em série. ${ }^{79}$

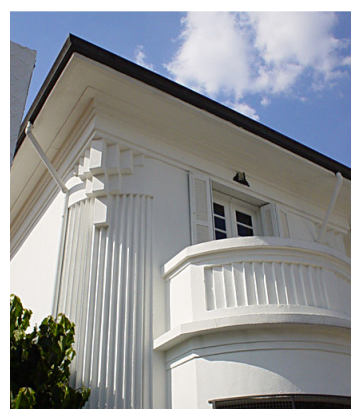

FIGURA 36 : Casa à rua Tomé de Souza. (detalhe de cunhal / São Paulo)

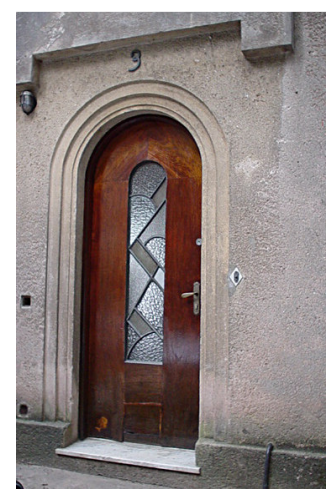

FIGURA 37 : Casa à rua Piauí. (detalhe de porta / São Paulo)
Os arquitetos e construtores que praticaram o Art Déco na cidade de São Paulo adotaram diversos estilemas, que na análise da produção arquitetônica do período podem ser reconhecidos claramente. Estes traços estilísticos constantes em muitas obras deram uma identidade própria à manifestação déco na capital paulista. Os estilemas mais caracterizadores desta arquitetura podem ser sintetizados : na ordenação cubista das formas geométricas que compõem o edifício (prismas, cilindros, esferas etc.) ; na utilização de faixas e outros elementos de composição para dar impressão de horizontalidade ou verticalidade ; nos terraços com gradis tubulares de terminações curvas ; no emprego de janelas circulares nas circulações verticais, hall de escada, banheiros etc.; no escalonamento e jogo volumétrico de elementos decorativos das fachadas; nos caixilhos de ferro trabalhados com motivos geométricos ou estilizados ; no emprego de vitrais combinando vidros de diferentes cores e texturas de modo a compor motivos variados (desde figurativos até geométricos e estilizados) ; no uso de revestimento à base de mica.

\footnotetext{
79 "O Art Déco conquistava adeptos populares, adotado em linhas mais simplificadas em vilas operárias, como em singelas moradias conhecidas como "porta-e-janela", em todos os quadrantes do Brasil." SEGAWA, Hugo. "Modernidade Pragmática. Uma Arquitetura dos anos 1920/40 fora dos manuais." In: Revista Projeto. № 191, 1995, p.82.
} 
A expansão do Art Déco em São Paulo foi favorecida pela introdução e difusão do uso estrutural do concreto armado nas edificações nas primeiras décadas do século $X X$. Este novo modo de construção representava um avanço técnico que colocava os construtores paulistanos em sincronia com o que se fazia na Europa e Estados Unidos. $\mathrm{Na}$ mentalidade predominante dos anos 30 o concreto armado representava o progresso tecnológico, que naquele momento deveria estar atrelado necessariamente a uma nova estética - o Art Déco. O modo de execução das estruturas de concreto armado remetia a uma idéia de arquitetura de formas puras e simples. As idéias racionalistas de busca de uma verdade construtiva, então em voga, favoreciam a apropriação desta "modernidade" arquitetônica.

A linguagem Art Déco e o concreto armado estão também intimamente associados à verticalização e aos novos programas surgidos nos anos 30 em São Paulo. Importantes edifícios comerciais e de serviços localizados no centro, além de inúmeros prédios de apartamentos situados nos bairros em processo de adensamento próximos à área central, foram construídos segundo a nova estética.

Dentre os arquitetos que difundiram com maior expressão a linguagem Art Déco em São Paulo, destacam-se Elisiário Antonio da Cunha Bahiana, Álvaro Carlos de Arruda Botelho, Dácio Aguiar de Moraes, Jayme C. Fonseca Rodrigues e Mário Wathely.

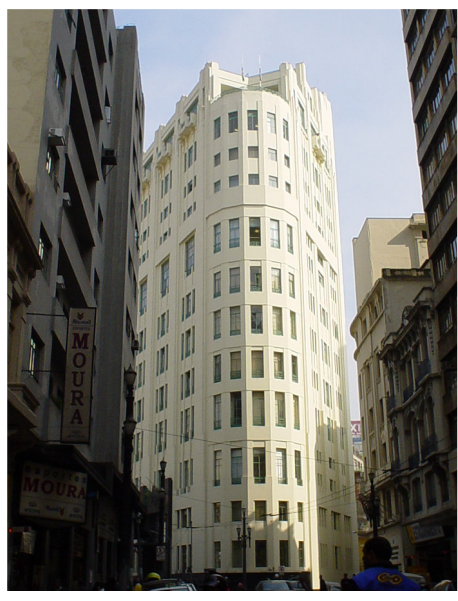

FIGURA 38 : Edifício Saldanha Marinho. (Elisiário Bahiana / São Paulo, 1929/33)
Elisiário Bahiana, contratado pela Sociedade Comercial e Construtora Ltda., foi o arquiteto que melhor traduziu a estética déco na cidade de São Paulo. Bahiana pode ser considerado o principal divulgador desta linguagem arquitetônica, por ter projetado inúmeras obras emblemáticas que se incorporaram definitivamente na paisagem paulistana, como o Viaduto do Chá (1935-38), o edifício Saldanha Marinho (1929-33), o edifício João Brícola (sede do antigo Mappin Stores / 1936-40), entre outras, no estilo que o próprio arquiteto denominava "moderno, gênero Perret". 80

\footnotetext{
${ }^{80}$ Segundo relato de Hugo Segawa a partir de entrevista realizada com Elisiário Bahiana em 1979. Ver : SEGAWA, Hugo. "Modernidade Pragmática. Uma Arquitetura dos anos 1920/40 fora dos manuais." In: Revista Projeto. oㅡ 191, 1995, p.75
} 
"Como tantos outros arquitetos de sua geração, Bahiana pode ser tomado como um profissional arquetípico de uma etapa da arquitetura brasileira : formado nos valores Beaux-arts, "infringiu" os ensinamentos adotando uma linguagem distinta da boa norma acadêmica, em busca de uma arquitetura moderna, sem estardalhaço ou panfletismo. Modernidade nem à Le Corbusier, nem à Bauhaus, nem aos funcionalistas / racionalistas europeus. Talvez um pouco disso tudo : mas, modernidade, como o próprio Bahiana reverenciava, à Auguste Perret." (SEGAWA, 1998, p. 59)

Da obra déco do arquiteto Álvaro Botelho sobressai o edifício do antigo Banco de São Paulo (1935-1938), localizado na rua 15 de Novembro, com frente também para a rua São Bento, no centro de São Paulo. Todo construído com estruturas de concreto armado, este prédio impõe-se no contexto urbano em que se insere pela sua implantação diferenciada, pelo seu porte monumental e, principalmente, pela requintada composição e ornamentação parietal de todas as suas fachadas. Outros elementos de destaque do edifício são as suas áreas internas, planejadas em perfeita harmonia com a sua linguagem exterior. O uso de materiais nobres e o cuidado e a minúcia no tratamento dos detalhes construtivos e decorativos, externos e internos, são claramente revelados nos esmerados vitrais, nos pisos de mosaicos e mármores, nas ferragens trabalhadas, no mobiliário do saguão principal (que se mantém até hoje original) etc., que o convertem sem dúvida numa obra ímpar dessa estética na cidade de São Paulo.
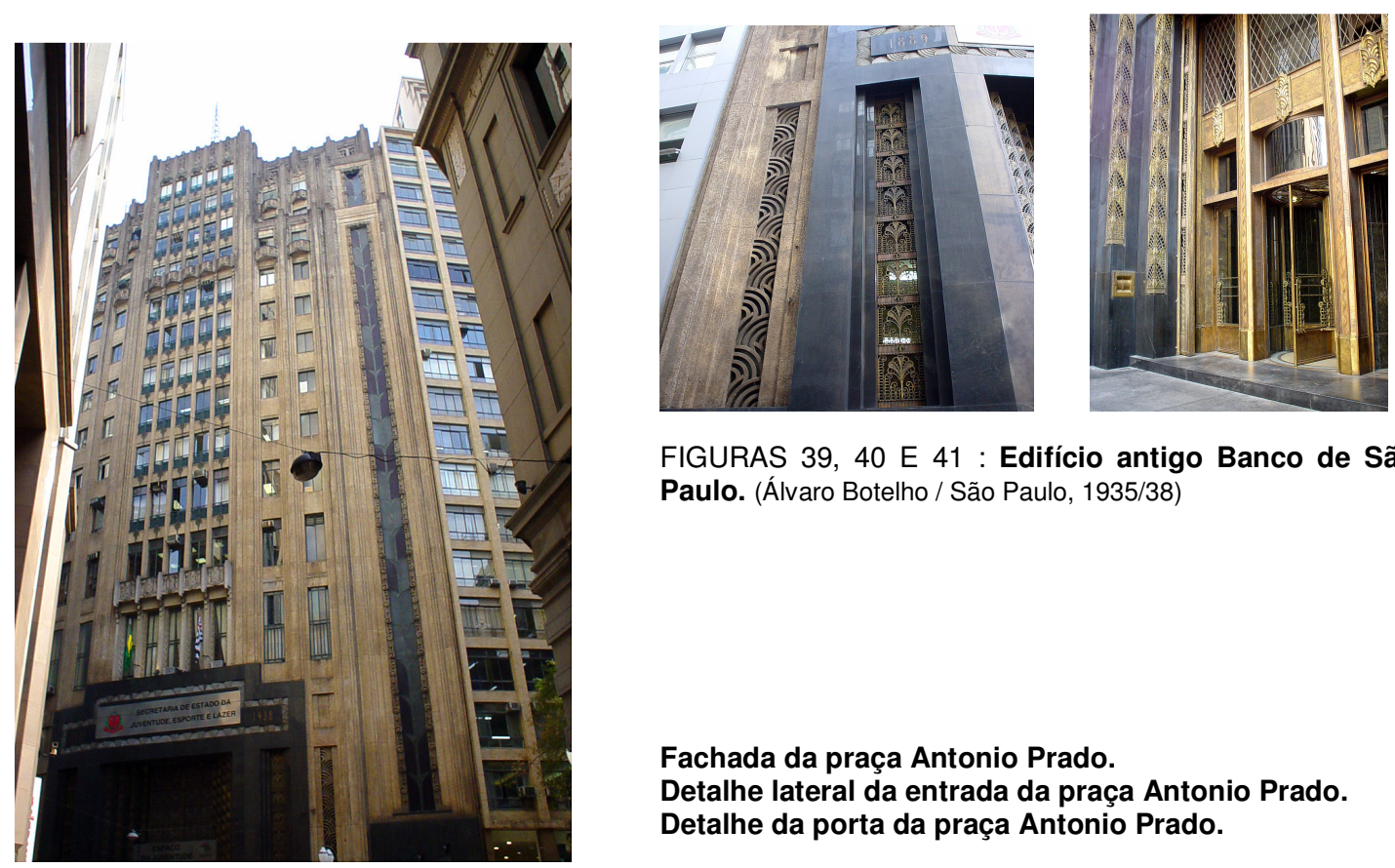

FIGURAS 39, 40 E 41 : Edifício antigo Banco de São Paulo. (Álvaro Botelho / São Paulo, 1935/38)

Fachada da praça Antonio Prado. Detalhe lateral da entrada da praça Antonio Prado. Detalhe da porta da praça Antonio Prado. 


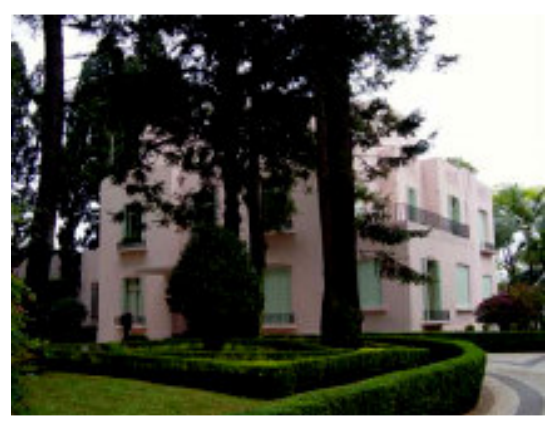

A residência de Armando Álvares Penteado (1931-32), projeto do engenheiro-arquiteto Dácio Aguiar de Moraes na rua Ceará esquina da rua Alagoas, em Higienópolis, representa o exemplar mais importante de palacete Art Déco ainda existente na capital paulista. Com uma implantação privilegiada, localizada no alto de uma pequena colina com vista para o vale do Pacaembu, e situada em meio a um jardim de inspiração francesa, esta residência déco de grandes dimensões, toda executada em concreto armado, destaca-se pela sua configuração volumétrica composta de corpos cúbicos escalonados em profundidade e altura, pela discrição da ornamentação geométrica empregada nas fachadas e pelo emprego de materiais nobres e fatura esmerada dos exteriores e interiores da construção. Por suas qualidades plásticas inovadoras, remetendo a uma modernidade comportada, acreditamos que esta

FIGURAS 42 e 43 : Residência Armando Álvares Penteado. (Dácio Aguiar de Moraes /São Paulo, 1931) residência da elite paulistana tenha se constituído na época da sua construção em uma das edificações residenciais paradigmáticas da estética déco, servindo de referência arquitetônica para muitas casas de classe média contemporâneas, como veremos adiante.

A contribuição déco mais significativa do engenheiro-arquiteto Jayme C. Fonseca Rodrigues pode ser sintetizada nas duas residências que projetou e construiu em 1935, para sua irmã, Heloísa Fonseca Rodrigues, e para si próprio, na rua Ceará, 184 e 202, no bairro de Higienópolis. ${ }^{81}$ As duas casas foram integralmente realizadas com estruturas de concreto armado, inclusive a laje de cobertura. A conformação geral das residências remete à "arquitetura barco", pelos seus corpos arredondados salientes, janelas seqüenciais horizontalizadas, beirais e frisos lisos ao longo da fachada marcando a volumetria das edificações. O requinte ornamental déco está concentrado na serralheria das portas e janelas, com destaque para a porta da casa de número 202. Estas residências também podem ser referidas como obras modelares desta variante do Art Déco, tendo sido os seus

\footnotetext{
${ }^{81} \mathrm{O}$ arquiteto Jayme C. Fonseca Rodrigues projetou também os edifícios dos antigos IAPAS, no viaduto Santa Ifigênia, e IAPTEC, na avenida Nove de Julho.
} 
estilemas principais muito copiados e recriados em inúmeros conjuntos residenciais populares construídos na década de 30.
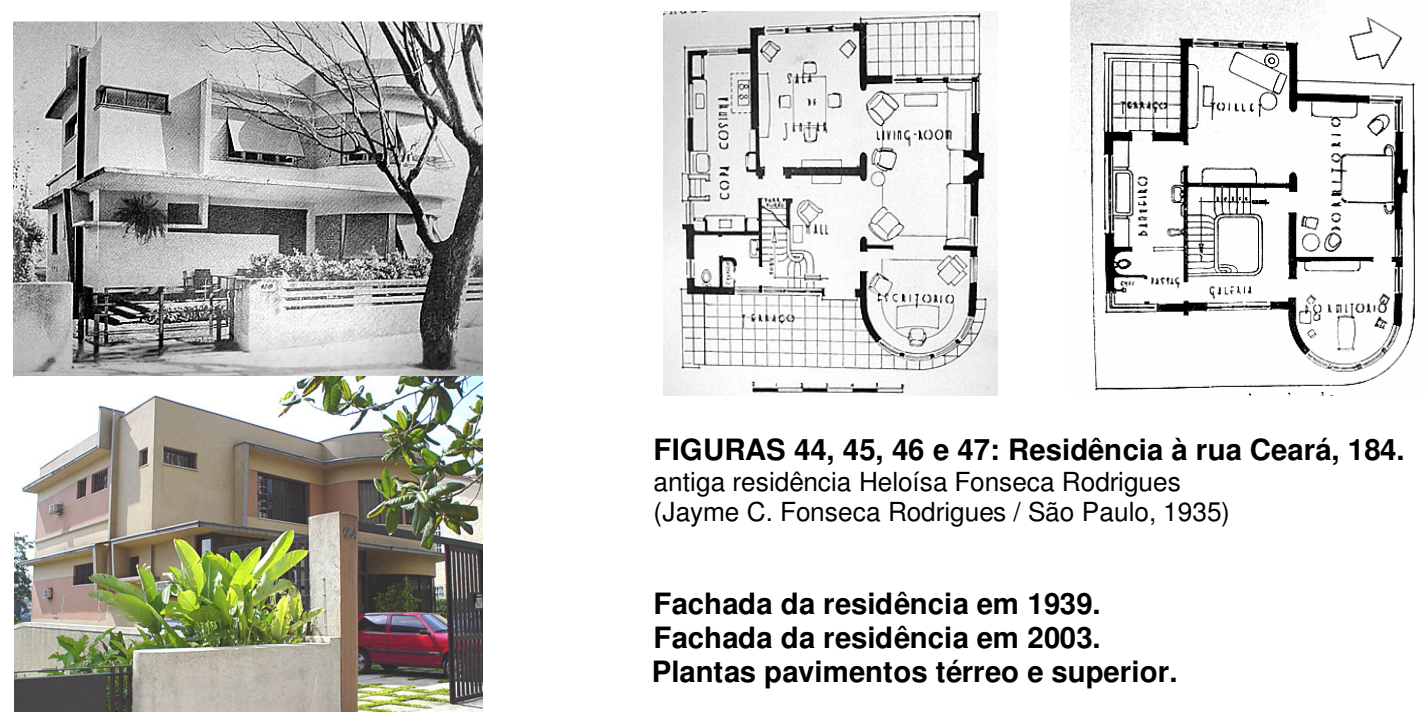

FIGURAS 44, 45, 46 e 47: Residência à rua Ceará, 184. antiga residência Heloísa Fonseca Rodrigues (Jayme C. Fonseca Rodrigues / São Paulo, 1935)

Fachada da residência em 1939.

Fachada da residência em 2003.

Plantas pavimentos térreo e superior.
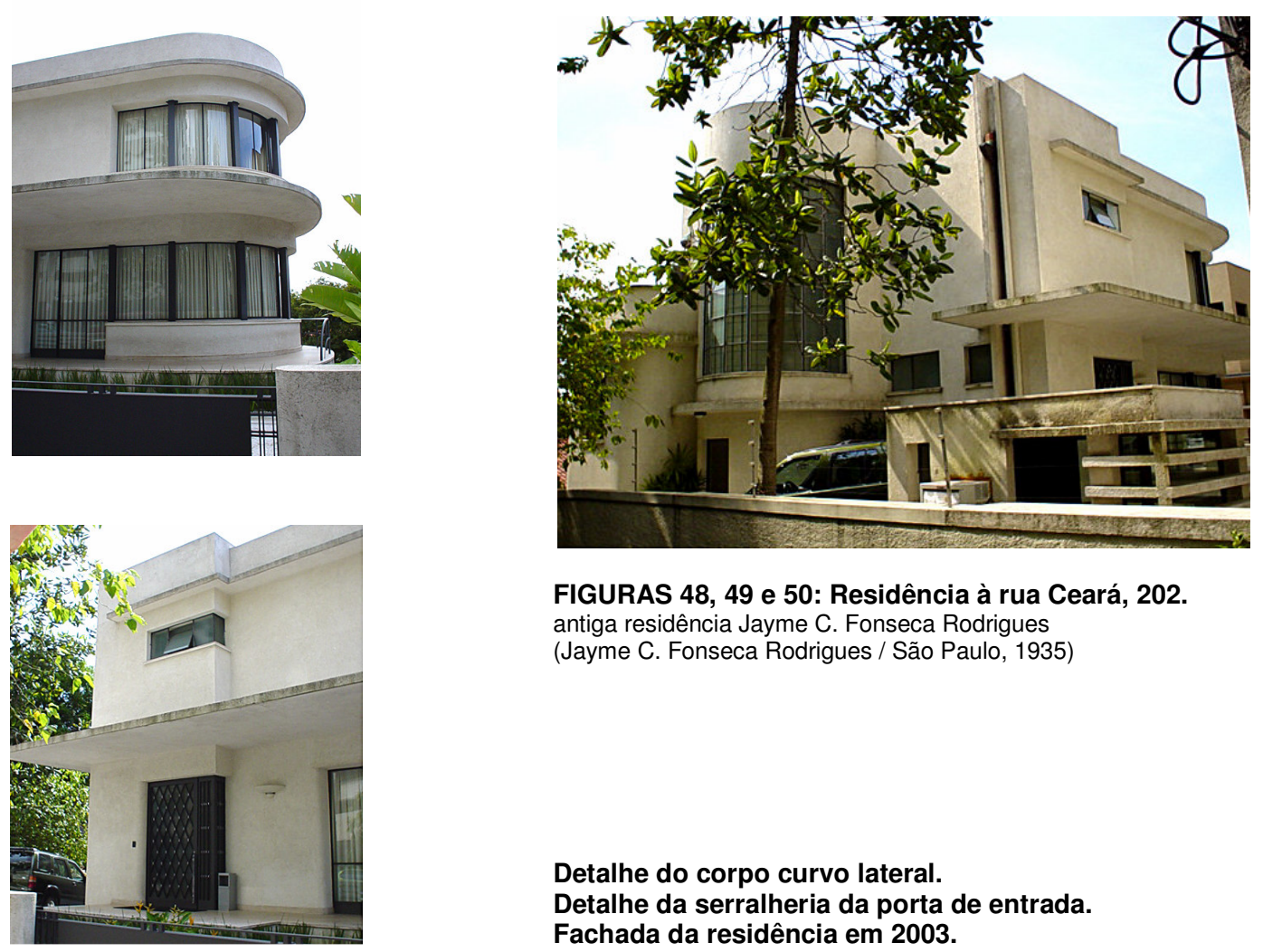

FIGURAS 48, 49 e 50: Residência à rua Ceará, 202. antiga residência Jayme C. Fonseca Rodrigues (Jayme C. Fonseca Rodrigues / São Paulo, 1935)

Detalhe do corpo curvo lateral.

Detalhe da serralheria da porta de entrada. Fachada da residência em 2003. 
O engenheiro-arquiteto Mário Wathely, através da Mário Wathely \& Cia Engenheiros, Architectos Civis e Industriaes, foi o responsável pelo projeto e construção do imponente conjunto arquitetônico Art Déco do Instituto Biológico (1928-1945), localizado na avenida Conselheiro Rodrigues Alves, Vila Mariana. Esta obra que já foi citada como uma das pioneiras na implantação do novo gosto na capital paulista, merece também ser apontada como uma das obras emblemáticas da estética déco em São Paulo. O edifício principal do Instituto Biológico apresenta os estilemas mais representativos da fase "ziguezague" do Art Déco : composição de volumes sobrepostos e escalonados em profundidade e altura, corpos apresentando uma geometria rígida e ortogonal, ornamentos de cimento de temas naturais estilizados em pontos pré-determinados das fachadas, além de frisos e faixas horizontais e verticais com desenhos geométricos.

Concluindo, podemos dizer que o Art Déco se manifestou nos anos 20 e 30 na capital paulista propondo uma modernidade de aparência, sintetizada numa volumetria comportada e numa diminuição da carga ornamental das fachadas. O que se buscava efetivamente era uma simplificação plástica, sem negar totalmente o ornamento e sem promover uma verdadeira ruptura com a tradição eclética das primeiras décadas do século $\mathrm{XX}$.

"Com efeito, o Art Déco permite realizar uma transição gradual - sem mudanças bruscas dos princípios de composição "Belas Artes" às propostas mais racionalistas da arquitetura renovadora, eliminando seus vínculos com as ordens clássicas e a linguagem historicista, mas mantendo a organização simétrica de volumes e a utilização de elementos decorativos aplicados, permitindo dessa maneira uma aceitação de base social muito mais ampla." (MARGENAT, 1994, p.46)

O modernismo propugnado pelo Art Déco era, portanto, encarado como uma evolução lógica e coerente dos estilos históricos, em contraposição à arquitetura funcionalista difundida por Warchavchik, totalmente desprovida de ornamentos e que representava um rompimento drástico dos conceitos arquitetônicos vigentes até então. $O$ Art Déco foi então a opção encontrada na época para "modernizar" o estilo

".../ sem no entanto romper com ele. Incorporando alguns elementos consagrados como "modernos" e aplicando-os a esquemas tradicionais. A modernização era tida como uma necessidade, mas sempre dentro de determinados padrões pré-estabelecidos. Procurava-se dissimular os efeitos que a introdução do concreto armado trazia, através de uma "polidez" geometrizante. Não há a negação do ornamento, o que há é a sua modernização. “(BLAY, 1979, p.23) 
Assim, a ampla difusão do Art Déco na capital paulista durante os anos 30 pode ser explicada pelo desejo prevalente na sociedade local de mudança de gosto sem romper com a tradição arquitetônica, pela idéia de modernidade e progresso técnico que a nova linguagem propagava, e, no caso das edificações residenciais populares, também por motivos econômicos, derivados do barateamento da construção. 


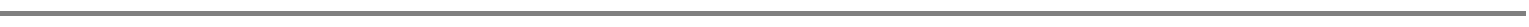


III. Residências paulistanas entre as Grandes Guerras
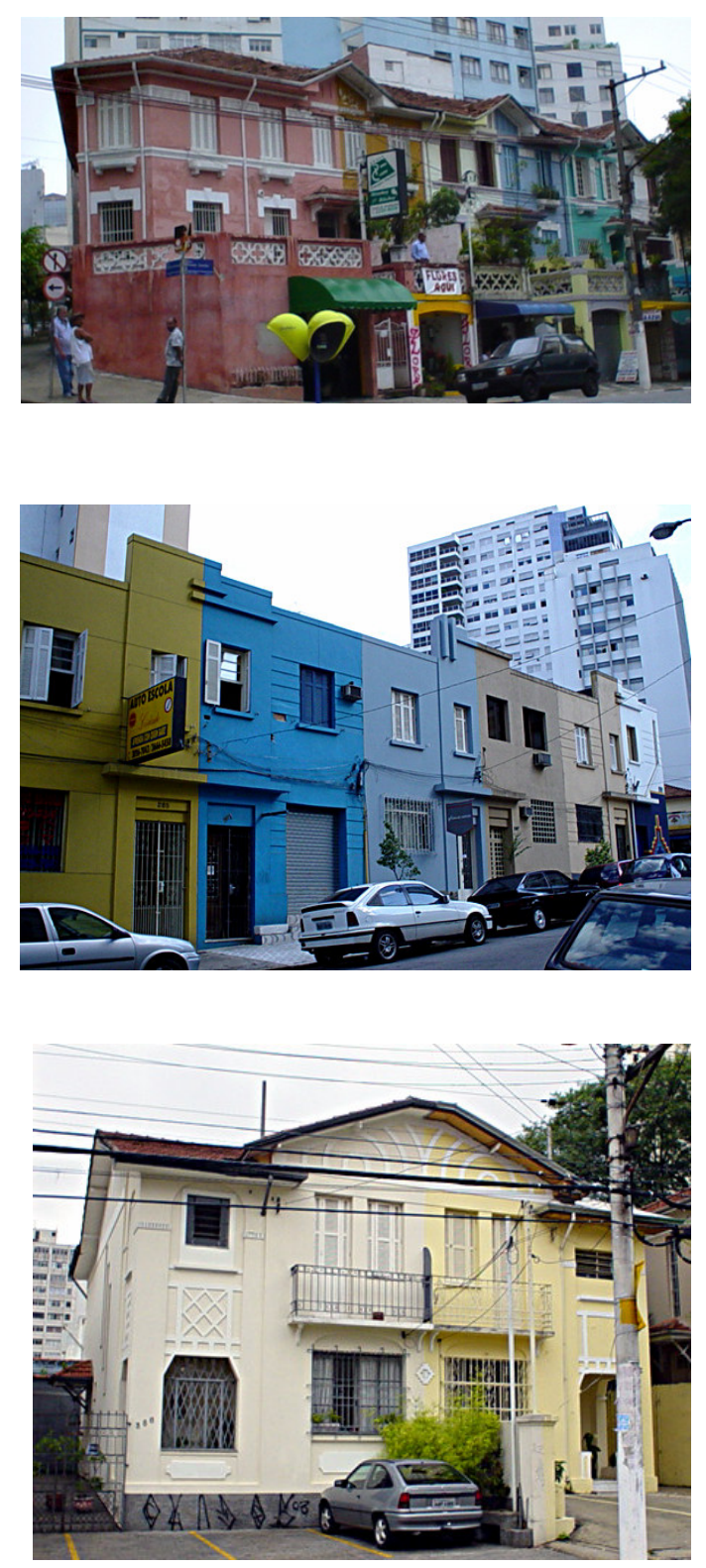


\section{III.1. As inovações técnico-construtivas}

No limiar do século XX começou a ser divulgado no Brasil um novo conhecimento técnico-construtivo, um novo "saber fazer" - o concreto armado. Enquanto na Europa e nos Estados Unidos o concreto armado já era aplicado vulgarmente em obras civis e construções desde o final do oitocentismo, o seu uso no Brasil nestes primeiros anos ainda era bastante restrito.

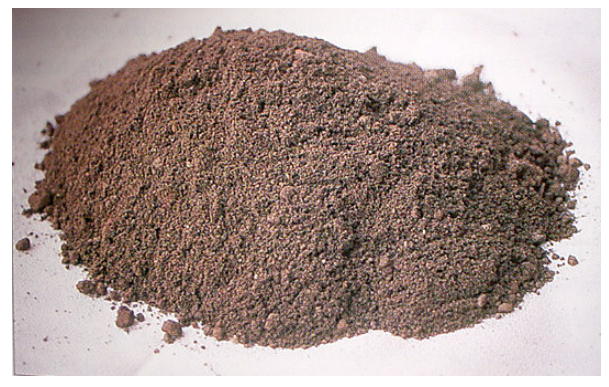

FIGURA 51 : Pozzolana - ingrediente básico para a preparação do concreto romano.

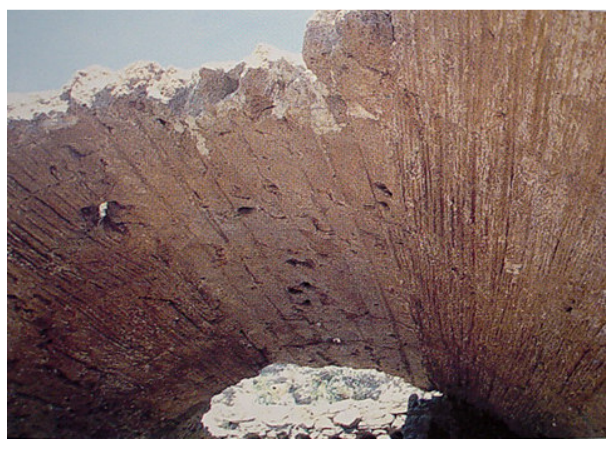

FIGURA 52 : OPUS CAEMENTICIUM abóbada de concreto romano. (Almuñecar / Espanha)
A utilização do concreto em construções é muito antiga. Por volta de 3.000 a.C. os egípcios já empregavam um material muito semelhante ao que hoje se conhece como concreto; mas foram os romanos, em torno de 300 a.C., que desenvolveram uma espécie de pedra sintética. O concreto romano era feito a partir da mistura de cinzas vulcânicas ("pozzolana") com cal, areia, cascalho e água, que endurecia quando secava. A técnica construtiva que empregava esse material era conhecida como opus caementicium ${ }^{1}$ e possibilitou um grande desenvolvimento à arquitetura e engenharia romanas, permitindo a construção de estruturas como arcos, abóbadas, paredes etc.

\footnotetext{
1 "OPUS CAEMENTICIUM : Também denominado structura caementicia e opus structile, é o concreto romano formado por uma mistura de areia e cal com fragmentos de pozzolana (pulvis puteolanus), seixos e, às vezes, também de telhas, ânforas e tijolos quebrados. É uma das contribuições mais transcendentes da engenharia e arquitetura romanas, por suas qualidades construtivas de solidez, adaptabilidade, assim como, por ser de fácil aplicação e resultado econômico." Verbete OPUS CAEMENTICIUM. "Glossário de termos de engenharia civil, técnica, indústria e ofícios em latim." In: ARTIFEX - Ingeniería Romana en España, p. 427.
} 
Desde a época dos romanos até o século XIX o concreto praticamente não sofreu aperfeiçoamentos técnicos, constituindo-se durante todo esse tempo como um material de uso estrutural limitado, que suportava somente esforços de compressão. A idéia de introduzir na massa do concreto um elemento capaz de absorver os esforços mecânicos de tração e flexão só foi concretizada na segunda metade do século XIX, quando franceses como Lambot, Coignet e Monier associaram empiricamente o concreto com o ferro e o aço, na forma de barras ou de malha. ${ }^{2}$

O concreto armado pode ser considerado um conhecimento técnico recente quando comparado com outros modos construtivos tradicionais como a taipa, alvenarias de pedra, de adobe ou de tijolos e estruturas de madeira ou metálicas. A idéia de aliar esses dois materiais de construção, tão distintos entre si, na elaboração de um terceiro com novas potencialidades construtivas, não era inédita. Apesar de já ser vislumbrada a possibilidade de obter-se um novo material de construção a partir da união do concreto com o ferro (ou o aço) desde o início do século XIX, foram necessárias várias décadas até que se conseguisse os primeiros resultados positivos nas experiências construtivas com o concreto armado e que, posteriormente, fosse desenvolvida uma nova tecnologia ${ }^{3}$ baseada nesse material.

A difusão do concreto armado esteve condicionada desde o início ao desenvolvimento da indústria siderúrgica, responsável pelo fornecimento de ferro e aço em vários perfis e bitolas, e ao descobrimento de um aglutinante de alta resistência e de pega rápida como o Cimento Portland, essencial para a execução do concreto.

No início do século $X X$ a produção de ferro no Brasil era incipiente e bastante limitada; a maior parte do ferro produzido no país era proveniente de pequenas fundições e se destinava à fabricação de sobressalentes para as ferrovias, equipamentos agrícolas e militares. A produção industrial de barras de aço no Brasil só teve início em 1921, com a instalação no país da Companhia Siderúrgica Belgo-Mineira.

As primeiras experiências brasileiras na fabricação de aglomerantes hidráulicos ocorreram no final do século XIX. A iniciativa pioneira partiu de Antônio Proost Rodovalho, que no ano de 1888 iniciou a instalação de uma fábrica de cimento na Fazenda Santo

\footnotetext{
${ }^{2}$ Sobre o assunto ver: ALAMBERT, Clara Correia d'. Início do Concreto Armado em São Paulo - o Palacete do Engenheiro Francisco Notaroberto (2001); da mesma autora, Um Novo Modo de Construção no Limiar do século XX. Concreto Armado: Experiências Técnicas / Especulações Estéticas (2002).

3 "Por tecnologia, se entenda : o estudo ou tratado das aplicações de métodos, teorias, experiências e conclusões das ciências ao conhecimento dos materiais e processos utilizados pela técnica. " In: VARGAS, Milton (org.) História da Técnica e da Tecnologia no Brasil, p.213.
} 
Antônio, de sua propriedade, nas proximidades de São Paulo. A usina foi inaugurada em 1897, teve seu funcionamento interrompido em 1904, retomou atividades em 1907 e fechou definitivamente em 1918. A primeira indústria brasileira de cimento realmente importante foi implantada somente em 1924 com capital estrangeiro. Nesse ano teve início a instalação da fábrica de Perus em São Paulo pela Cia. Brasileira de Cimento Portland, cuja primeira produção foi entregue ao mercado consumidor nacional em $1926 .{ }^{4}$

O concreto armado não era completamente desconhecido no Brasil no início do século XX. De início chamado de cimento armado, ou ciment armé, ou béton armado, ou ferro-béton, ou sidero-cimento, ou armored-concrete, ou fire-proofing, ou ainda, reinforced concrete, o concreto armado era definido na época como “... uma construção de argamassa, concreto ou beton de cimento, com uma ossatura ou esqueleto metállico de ferro ou aço. ${ }^{, 5}$

Inúmeras publicações estrangeiras, como catálogos e manuais de construção, traziam informações aos construtores brasileiros sobre os diferentes sistemas de concreto armado empregados na Europa e Estados Unidos. Em 1904, o professor Antonio de Paula Freitas publicou um artigo pioneiro sobre o assunto na Revista dos Cursos da Escola Polytechnica do Rio de Janeiro, intitulado "Construcções de Cimento Armado". Em São Paulo o estudo da técnica construtiva do concreto armado foi introduzido na Escola Politécnica, em 1905, pelo emérito professor Antonio Francisco de Paula Souza, responsável pelas cadeiras de Resistência dos Materiais e Estabilidade das Construções. ${ }^{6}$

As primeiras obras calculadas de concreto armado que se tem notícia no Brasil datam do início do século XX e eram ligadas à construção de estradas de ferro, como pontes, viadutos e muros de arrimo. Até essa época ainda não havia calculistas de concreto armado trabalhando no país e todo o cálculo de estruturas era realizado no exterior. Somente a partir da década de 10, com a vinda de vários calculistas estrangeiros, o cálculo de obras de engenharia passou a ser feito no Brasil. $^{7}$

\footnotetext{
4 "A necessidade crescente de cimento, que era importado, para suprir a indústria da construção, estimula a implantação de indústrias produtoras desse componente. A indústria do cimento surge no período, em 1926, instalando-se com uma fábrica em São Paulo. Até então, todas as necessidades do consumo nacional do produto eram atendidas por importações /.../As tentativas de fabricação do cimento no Brasil foram infrutíferas ou intermitentes até 1924, data da implantação efetiva da indústria de cimento Portland no país, quando Companhia Brasileira de Cimento Portland fundou a sua fábrica em Perus (SP). Com uma aparelhagem avançada, começou a produzir em maio de 1926 e depois de sete meses chegou à produção de 13.392 toneladas.” In: SOMEKH, Nadia. A Cidade Vertical e o Urbanismo Modernizador, p. 73.

${ }^{5}$ FREITAS, Antonio de Paula. "Construcções de Cimento Armado." In: Revista dos Cursos da Escola Polytechnica do Rio de Janeiro. 1904, p. 153.

6 In: TELLES, Pedro Carlos da Silva. História da Engenharia no Brasil , p. 29.

${ }^{7}$ Em 1911 chegou ao país o alemão Lambert Riedlinger, que fundou no ano seguinte no Rio de Janeiro a Companhia Constructora de Cimento Armado - L. Riedlinger, que pode ser considerada a primeira empresa brasileira especializada na elaboração de projetos e construção de obras de concreto armado. Esta empresa seria mais tarde incorporada pela Wayss \& Freytag, dando origem à Companhia Construtora Nacional. O calculista alemão Wilhelm Fillinger chegou ao Brasil em 1912, e
} 
No início, como não havia cálculos nem ensaios científicos que definissem as dimensões das peças, os coeficientes de segurança, os esforços a serem suportados etc., o uso do concreto armado era bastante restrito na construção civil, sendo utilizado unicamente em lajes e pisos. A "experiência" do construtor é que ditava a quantidade e a posição da ferragem empregada e a composição do concreto a ser utilizado. Tudo era executado de maneira empírica e, em alguns casos, até experimental. Assim, o emprego nas construções de técnicas mistas, inventadas, fruto de interpretações pessoais da associação do concreto ou da argamassa de cimento com o ferro ocorreu livremente nos primeiros tempos.

Um exemplo significativo desta

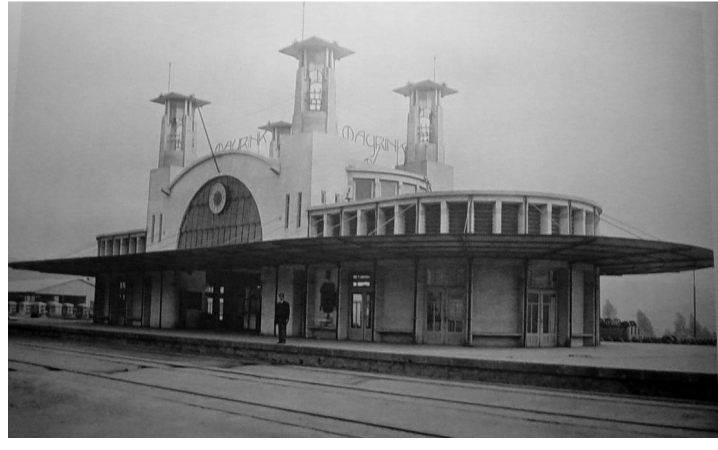

FIGURA 53 : Estação ferroviária de Mairinque. (Victor Dubugras / Mairinque, 1905 / 1908) experimentação inicial é a Estação Ferroviária de Mairinque (1908), da E.F. Sorocabana, projetada pelo arquiteto francês Victor Dubugras, radicado no Brasil desde 1891. A obra tem sido freqüentemente citada como um dos primeiros exemplos do emprego de concreto armado em uma construção no estado de São Paulo. A estação configura-se em um bloco monolítico feito de concreto reforçado por uma estrutura de trilhos e metal déployé. ${ }^{8}$

A par da atuação dos arquitetos pioneiros no uso do concreto armado na Europa, como Auguste Perret e Tony Garnier, o arquiteto Victor Dubugras realizou muitas obras em São Paulo utilizando estruturas mistas, nas quais mesclou criativamente o novo modo construtivo com técnicas tradicionais de construção. Assim, Dubugras empregou freqüentemente o concreto armado em suas obras residenciais e desempenhou um papel fundamental no desenvolvimento de uma mentalidade racionalista na arquitetura paulista. ${ }^{9}$

trabalhou inicialmente na Brazilian Ferro-Concrete Co. Ltd., depois na Companhia Construtora de Santos, e prestou serviço também para os Escritórios Técnicos de Ramos de Azevedo e de Samuel das Neves. Em 1924 Fillinger estabeleceu seu próprio escritório de projeto e construções de concreto armado. Ver: TELLES, Pedro Carlos da Silva. História da Engenharia no Brasil, p.41.

${ }^{8}$ O pioneirismo arquitetônico e estrutural da obra foi saudado na época em artigo da Revista Polytechnica, assinado por P. J. (provavelmente o engenheiro Hyppolito Pujol Jr.), como "o exemplar de mais judiciosa aplicação do cimento armado". In: Revista Polytechnica. ํㅡㄹㅡ. 22, 1908, p. 189.

\footnotetext{
${ }^{9} \mathrm{Na}$ mentalidade racionalista vigente nos anos 20 e 30 na cidade de São Paulo a arquitetura deveria ser a expressão plástica dos modos construtivos do seu tempo. Este era o pensamento predominante entre os engenheiros e arquitetos atuantes no período, que consideravam como ".../ architectura actual, aquella verdadeiramente "moderna" que evidencia claramente a technica e as condições sociaes da época que estamos vivendo." ALBUQUERQUE, Alexandre. "Architectura Moderna." In: Revista Polytechnica. №102, nov./dez. 1931, p. 398.
} 
"Victor Dubugras foi o grande precursor do Modernismo no Brasil e do uso do concreto armado com objetivos de modernização e racionalização do projeto arquitetônico. Sua obra, com um forte caráter de racionalismo construtivo, desenvolveu-se paralelamente à dos principais mestres europeus, nos fins do século XIX e nas primeiras décadas do século XX." (REIS FILHO, 1997, p. 27)

O primeiro edifício a utilizar estruturas de concreto armado na cidade de São Paulo foi o palacete projetado e construído por Francisco Notaroberto em 1909, na esquina das ruas Direita e São Bento. ${ }^{10}$ Os edifícios Casa Médici (1912), localizado na esquina das ruas Líbero Badaró com Dr. Falcão Filho, e o Guinle (1913), situado na rua Direita, podem ser citados como pioneiros na aplicação racional do concreto armado em construções de São Paulo. ${ }^{11}$ Durante os anos 20 e 30 o concreto armado firmou-se definitivamente na capital paulista como a técnica construtiva ideal para satisfazer os novos programas associados à verticalização, como os edifícios de escritórios e os de apartamentos.

Até a década de 20 o emprego de estruturas de concreto armado em residências paulistanas era pouco habitual, limitado em geral a terraços e a lajes de piso de banheiros localizados no pavimento superior. O alto custo do cimento e das barras de ferro/aço (que até meados dos anos 20 eram importados) dificultava a vulgarização do uso residencial do concreto armado.

"A crise de 1929 talvez tenha provocado outro talvegue na curva de construções paulistanas e a partir dessa depressão podemos dizer que se iniciou verdadeiramente o império do concreto armado, até então empregado com muita timidez entre nós. Só nos anos 30 é que o concreto armado foi empregado sistematicamente nas residências de classe média /.../" (LEMOS, 1985, p. 190)

$\mathrm{Na}$ década de 30 o concreto armado passou a ser utilizado mais comumente na arquitetura residencial paulistana para resolver problemas estruturais e construtivos (maiores vãos, execução de banheiros nos andares superiores, uso de lajes planas impermeabilizadas) e para obter maior liberdade de projetação (distribuição de cômodos no pavimento superior independente da planta inferior). Gregori Warchavchik representou neste momento um importante papel na difusão e valorização das qualidades construtivas do novo modo construtivo em residências, através da utilização de estruturas de concreto armado em suas casas modernistas. ${ }^{12}$

${ }^{10}$ Maiores informações sobre esse edifício poderão ser encontradas no trabalho programado da mesma autora. Ver: ALAMBERT, Clara Correia d'. Início do Concreto Armado em São Paulo - o Palacete do Engenheiro Francisco Notaroberto.

${ }^{11}$ A estrutura de concreto armado do edifício da Casa Médici, projeto do Escritório Técnico Samuel das Neves, é considerada a primeira estrutura calculada para permitir a construção de vários andares ; e, o Edifício Guinle, projetado por Hyppolito Pujol Jr, teve a colaboração do Gabinete de Resistência dos Materiais da Escola Politécnica de São Paulo no estudo experimental da sua estrutura e nos ensaios dos materiais a serem empregados na sua construção.

${ }^{12}$ A casa modernista da rua Itápolis, projetada por G. Warchavchik em 1930, ".../ foi realizada com a ainda incipiente tecnologia de concreto, o que faz com que a fita de vidro que deveria percorrer sem interrupções as duas arestas da fachada, 
Apesar dos profissionais paulistanos já possuírem nas primeiras décadas do século XX informação suficiente para empregar com desenvoltura o concreto armado, foram poucos os profissionais que conseguiram se libertar das estéticas conservadoras do Ecletismo Historicista e do Neocolonial. ${ }^{13}$ Somente na década de 30 , com a difusão do Art Déco, é que o uso de estruturas de concreto armado vai se vulgarizar na execução de lajes de terraços, marquises e frisos salientes em balanço.

Com base na pesquisa realizada nos projetos constantes nos processos de aprovação de construções residenciais do Arquivo Geral da Prefeitura Municipal de São Paulo (Piqueri), pudemos constatar na amostra estudada que o emprego do concreto armado já ocorria discretamente nas residências paulistanas dos anos 20 , aumentando sensivelmente nos anos 30

$\mathrm{Na}$ análise e avaliação quantitativa das edificações residenciais do período consideramos unicamente os projetos em que havia menção explícita da presença de peças estruturais de concreto armado nos memoriais descritivos ou nas peças gráficas (plantas e cortes). Assim, chegamos ao número de 40 projetos em um total de 407 , o que representa cerca de $10 \%$ da amostra. ${ }^{14}$ Suspeitamos porém, que, na realidade, o número de construções residenciais em que foram empregadas estruturas de concreto armado tenha sido superior ao detectado na amostra de projetos sorteados. Acreditamos na possibilidade de que muitos construtores tenham deixado de especificar detalhadamente nos projetos a técnica construtiva a ser empregada nas construções devido ao uso freqüente de formulários padrão de memorial descritivo, ou ainda, pelo fato do profissional responsável não considerar pertinente ou conveniente a menção do uso de estruturas de concreto armado no memorial acompanhante do projeto arquitetônico, que seria objeto de análise e aprovação pela Prefeitura Municipal de São Paulo.

No conjunto dos 40 projetos analisados observamos que todos, sem exceção, eram assinados por engenheiros, arquitetos ou escritórios de engenharia, o que nos leva a crer que o emprego do concreto armado em edificações residenciais paulistanas neste período ainda estava restrito ao círculo de profissionais habilitados.

possua em seu vértice uma incômoda coluna de sustentação."In: CAVALCANTI, Lauro. Quando o Brasil era Moderno. Guia de Arquitetura 1928-1960, p. 116

13 “.../ não se deve ver no triunfo do ecletismo até por volta de 1930, o reflexo automático de um atraso técnico e o indício de um desconhecimento das possibilidades materiais dos novos meios de construção; os arquitetos sabiam servir-se destes perfeitamente, e fizeram-no com freqüência, mas sem abandonar o antigo vocabulário arquitetônico, reduzido a um papel puramente formal. /... Essa atitude era fruto de uma escolha voluntária, explicada por um apego conservador a princípios superados /...." In: BRUAND, Yves. Arquitetura Contemporânea no Brasil, p. 59

${ }^{14}$ Dos 40 projetos da amostra, em que foi evidenciado o uso de estruturas de concreto armado, foram contabilizados 12 na década de 1920 e 28 na década de 1930, o que corresponde às porcentagens de $30 \%$ e $70 \%$ respectivamente do total. 
Através da análise dos projetos selecionados verificamos a incidência exclusiva de estruturas mistas, resultantes da livre associação do concreto armado com outras técnicas construtivas; na amostra levantada observamos um único caso de estruturas autônomas de concreto armado - a residência Armando Álvares Penteado (projeto 231). As cintas de amarração, as lajes e as vigas de concreto armado estavam sempre vinculadas à alvenaria de tijolos auto-portante ou a estruturas metálicas. As vigas duplo $\mathrm{T}$ ou trilhos eram comumente usados para vencer vãos entre paredes de alvenaria, sustentando as lajes de concreto armado da cobertura e as existentes entre os pavimentos térreo e superior. Eventualmente, o concreto armado era também usado na confecção de elementos de composição de fachada, como frisos salientes em balanço, muito comuns na arquitetura Art Déco dos anos 30.

As cintas de amarração de concreto armado ${ }^{15}$ serviam para solidarizar as paredes de alvenaria de tijolos, evitando deste modo trincas e rachaduras a $45^{\circ}$. Estas cintas trabalhavam à tração e eram utilizadas para absorver os esforços decorrentes de recalques diferenciais e/ou os empuxos da estrutura do telhado. Como exemplos do uso destas cintas de amarração podemos citar os projetos 62 (processo $n^{0}$ 74.345/24), 151 (processo $\mathrm{n}^{\circ}$ 50.375/28), 266 (processo ํo 17.317/33) e 283 (processo no 63.548/34).

No memorial descritivo do projeto 62 , relativo à construção de duas residências geminadas na alameda Itu, o arquiteto e proprietário Affonso Chiocarelli descreveu que "os dormitórios serão assoalhados cujas pontas dos barrotes serão revestidos de pixe assentes sobre cinta de cimento armado construída entre o pav. terreo e o pav. superior." No memorial do projeto 151 constava a existência de uma ".../ cinta de concreto armado embaixo dos vigamentos do $1^{\circ}$ andar" da edificação. No memorial descritivo do projeto 266 , referente à construção de uma residência em Perdizes, os arquitetos Moya \& Malfatti declararam que "serão feitas duas faixas em concreto armado sobre os muros do perímetro do prédio e armadas com dois ferros de $3 / 8$ " sendo uma debaixo do vigamento do sobrado e outra debaixo da armação do telhado." E, no projeto 283 , de autoria de Lindenberg, Alves \& Assumpção engenheiros, aparece a referência que "como remate superior das paredes do sobrado, junto ao vigamento do telhado, será corrida uma cinta de amarração e distribuição de cargas, em concreto armado."

\footnotetext{
${ }^{15}$ Cinta é o nome dado à "faixa usada para cingir ou envolver certas construções de alvenaria com a função de evitar possíveis desagregamentos. /.../ Modernamente dá-se o nome de cinta de amarração à sucessão de vigas que se situa nas paredes perimetrais das construções de alvenaria visando tornar mais solidárias entre si as paredes concorrentes." In: CORONA, Eduardo \& LEMOS, Carlos A. C. Dicionário da Arquitetura Brasileira, p. 131.
} 
As lajes de concreto armado ${ }^{16}$ eram utilizadas para absorver os esforços horizontais, distribuindo as cargas nas paredes de alvenaria de tijolos, que por sua vez suportavam os esforços verticais; e no caso das lajes invertidas, eram usadas também para solucionar problemas hidráulicos dos banheiros, como instalação no piso de canalização para escoamento de esgotos. Como pudemos observar nos projetos selecionados, as lajes de concreto eram freqüentemente empregadas em pisos de garagem e WC, localizados no pavimento térreo, em pisos e tetos de cozinhas, ${ }^{17}$ em pisos de banheiros situados no andar superior das residências, em lajes de cobertura, em terraços e marquises. O projeto 62 pode ser citado como exemplo destes usos de lajes de concreto armado.

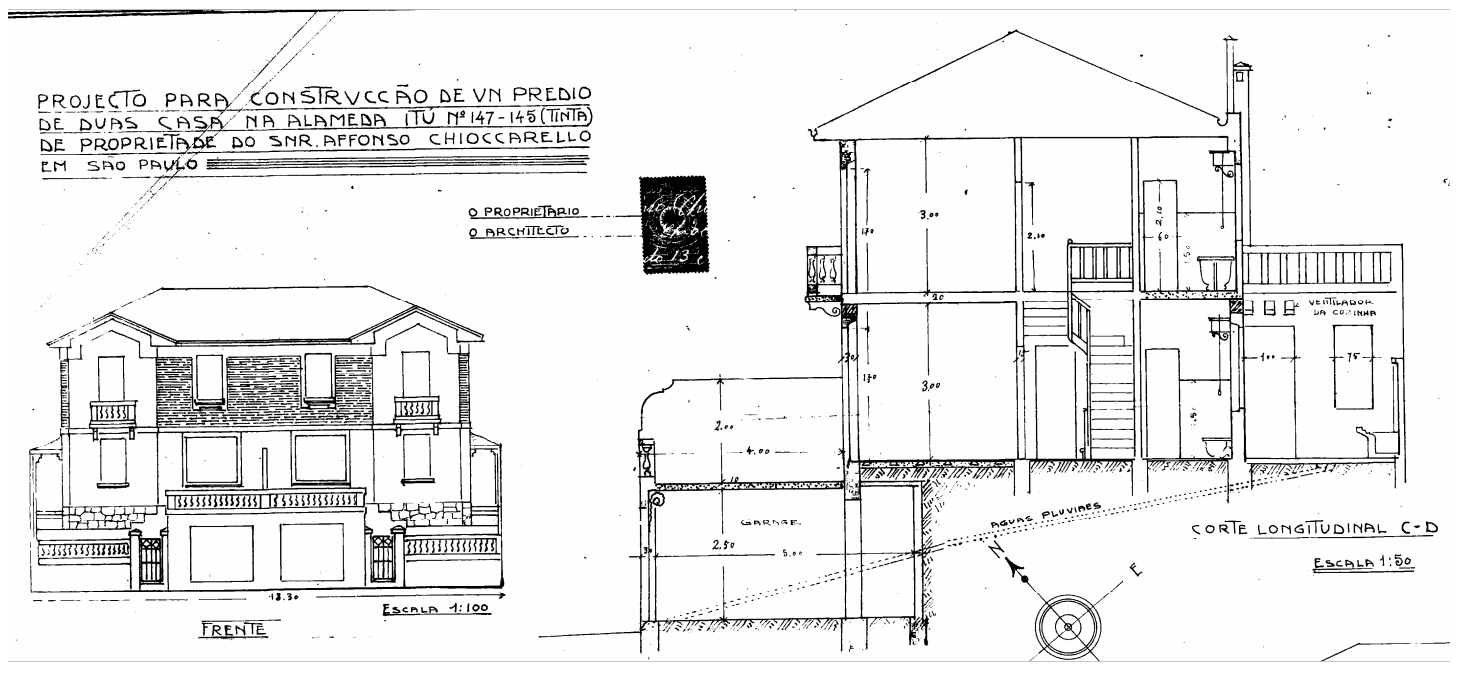

FIGURA 54 : Exemplo do emprego de lajes de concreto armado em residências paulistanas : no piso do banheiro superior, na laje de cobertura da garagem e no terraço. (projeto sorteado de duas casas geminadas localizadas na alameda Itu - projeto 62 / processo no 74.345/24)

\footnotetext{
16 "Laje /.../ hoje em dia o termo é empregado /.../ para designar as superfícies contínuas horizontais de concreto armado, que constituem versões modernas de SOBRADOS ou tetos." CORONA, Eduardo \& LEMOS, Carlos A. C. Dicionário da Arquitetura Brasileira, p. 294.

${ }^{17}$ No memorial dos projetos 375,376 e 377 (processo no 94.125/36) os construtores Rodrigues, Sá \& Cia. Ltda. declaram que nas três casas ".../ os forros das cosinhas que tiverem quarto em cima /.../" seriam executados em concreto armado. No memorial do projeto 340 (processo no 64.719/35) constava o ".../ forro da cosinha, em laje de concreto (arts. 260 e 411). " A citação dos artigos do Código de Obras Arthur Saboya, em vigência na cidade de São Paulo desde 1934, denota a exigência municipal do uso de lajes de concreto armado nas cozinhas que tivessem cômodos de dormir em cima, por medidas explícitas de segurança contra incêndios.
} 
As vigas de concreto armado eram pouco utilizadas, estando freqüentemente associadas a vigas duplo $\mathrm{T}$ ou trilhos, configurando estruturas mistas. No projeto 154 (processo no 25.740/28) foram usadas "vigas de concreto armado com vergalhões como requer." No projeto 283 (processo $\mathrm{n}^{\circ}$ 63.548/34) foram utilizadas vigas de concreto armado e de aço. No memorial aparece descrito que "todos os vãos de grande amplitude receberão como coroamento uma viga de concreto armado" e que "as paredes suspensas do andar superior serão construídas sobre vigas de aço, de perfil sufficiente." Nos desenhos dos cortes do projeto 315 (processo $\mathrm{n}^{0}$ 34.553/34) aparece a indicação de vigas de concreto armado sustentando a laje do piso do banheiro superior.
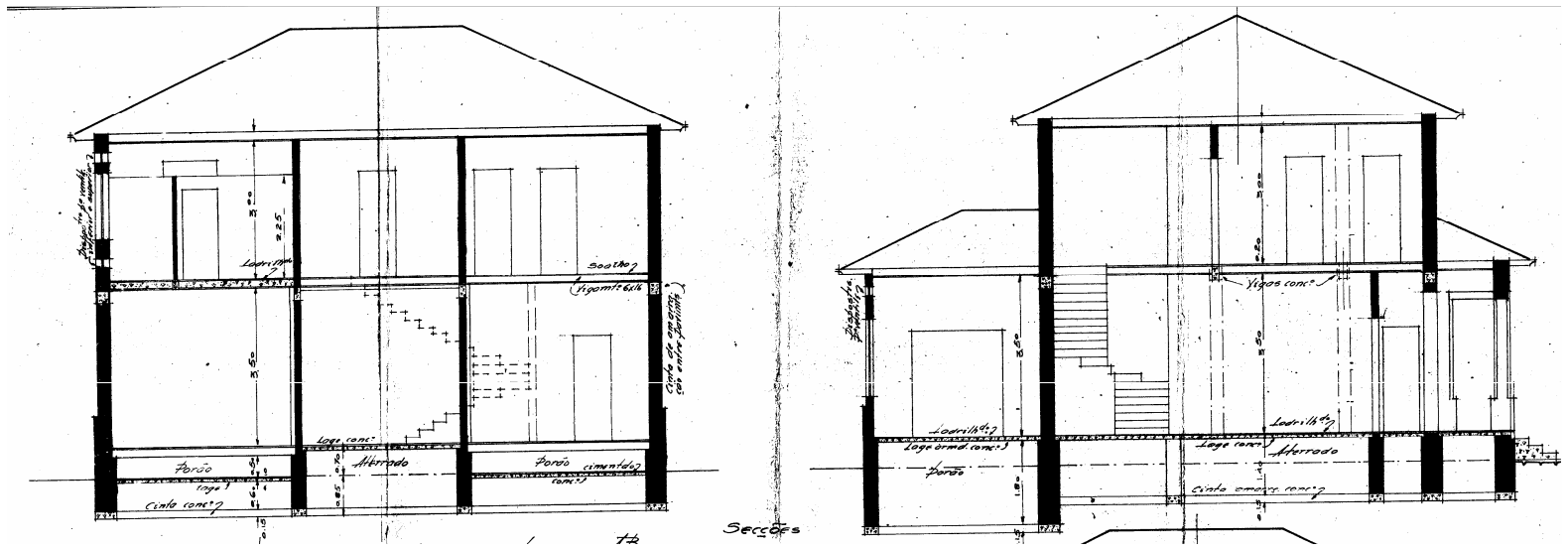

FIGURA 55 : Exemplo do emprego de vigas de concreto armado em residências paulistanas. (projeto sorteado de residência localizada na rua Pinto Ferraz - projeto 315 / processo no $34.553 / 34$ )

O traço do concreto, a quantidade e a bitola dos ferros utilizados na execução das peças estruturais variavam geralmente segundo a experiência e a intuição do construtor, muitas vezes sem cálculos aparentes, o que revelava que neste período o emprego do concreto armado ainda era regido por uma alta dose de empirismo e de experimentação. No memorial do projeto 144 (processo no 28.938/28) constava que "as vigas e lages de concreto armado serão de concreto de cimento, pedregulho e areia, na proporção respectiva de 300 kilos, $760 \mathrm{dm}^{3}, 340 \mathrm{dm}^{3}$ por $\mathrm{m}^{3}$ armadas com barras e estribos de aço. As dimensões e armaduras serão de accordo com os coefficientes de segurança admittidos pela lei municipal. As vigas de aço duplo $T$ serão mergulhadas em concreto." No projeto 339 (processo n $45.472 / 35$ ) aparece especificado que "as lages serão de argamassa de concreto na dosagem de 1:3:3, levando trançamento de ferros de $1 / 2 p$. na distancia de $20 x$ 0,15 c." Já no memorial do projeto 283 (processo no 63.548/34), aparece menção que "/../ as vigas e lages serão construídas de accôrdo com calculos, usando-se concreto na 
dosagem de 1:2:4; as cintas terão a secção de 12 por 12 centimetros, e serão armadas com 3 ferros de $1 / 4 . "$

Uma exceção é o caso já citado da residência Armando Álvares Penteado, projetada pelo engenheiro-arquiteto Dácio Aguiar de Moraes e localizada na rua Ceará esquina da rua Alagoas (Higienópolis). A residência corresponde ao projeto 231, no qual consta além das plantas de detalhamento estrutural toda a memória de cálculo empreendida para o dimensionamento das vigas, pilares e lajes de concreto armado da construção. No memorial descritivo da edificação cabe destacar a descrição detalhada do tratamento de impermeabilização que seria adotado na laje de cobertura; o arquiteto Dácio de Moraes declarou no item Cobertura que "a lage de cobertura levará, além da camada impermeabilisante (Johns Manville, 3 camadas), uma fiada de tijolos furados como isolamento, evitando assim a dilactação da mesma." Pela documentação constante no processo deste palacete podemos comprovar de maneira clara os avanços alcançados na época pela técnica construtiva do concreto armado aplicado especificamente numa edificação particular.

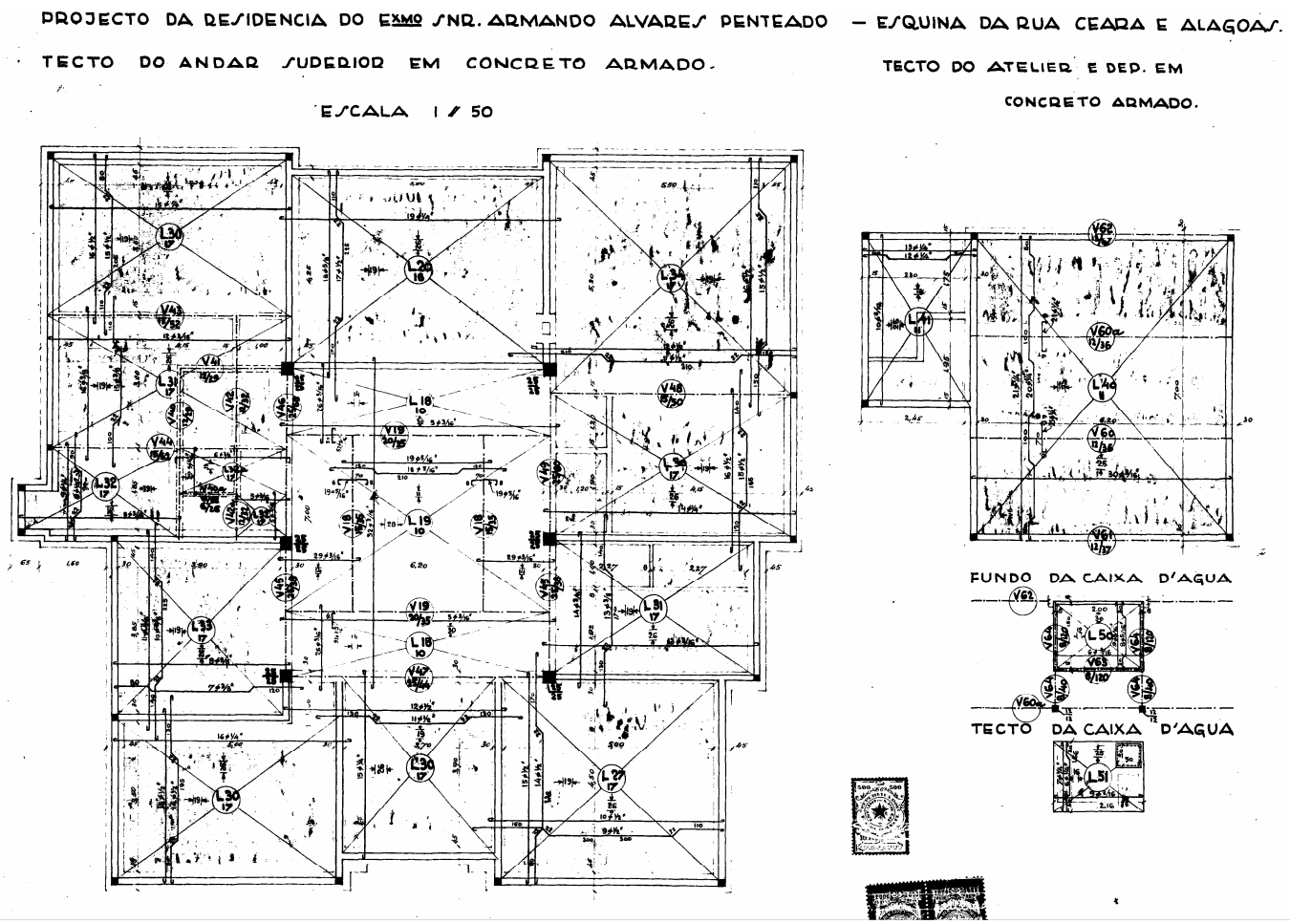

FIGURA 56 : Projeto estrutural da residência Armando Álvares Penteado / prancha relativa ao detalhamento das vigas, pilares e lajes do teto do pavimento superior, do atelier e da caixa d'água. (projeto 231 / processo ํㅜ 42.716/31) 
Dentre a amostra analisada da década de 30 constatamos um número expressivo de projetos referentes a residências de classe média de feição Art Déco, o que comprova existir uma estreita relação entre o novo modo construtivo e a linguagem déco. Esta nova estética, difundida na capital paulista a partir dos anos 30, foi também a responsável por outra inovação construtiva nas residências deste período, a aplicação do revestimento de massa raspada à base de cimento, areia e mica ${ }^{18}$ para dar brilho, textura e cor às fachadas. Exemplo disto aparece descrito no memorial do projeto 266 (processo № 17.317/33), o qual especifica que "o rebocco externo será patinado levando mica de tom claro para o réz do chão e sobrado e mais escuro para o porão." No memorial do projeto 310 (processo no 14.942/34) constava que o revestimento da fachada seria executado "com cimento, cal e areia, com adjunção de mika e pedregulho miúdo." Nos projetos 268 e 269 (processo oㅜ 5.061/33) o engenheiro responsável pela obra especificou para as paredes externas da edificação "revestimento de cimento penteado misturando pó de mica na argamassa."

Estimulada pela moda do Art Déco a indústria começou a produzir a partir da década de 30 vários tipos de janelas de ferro de correr, de bascular, de pivotar etc. Com um design mais moderno estes caixilhos foram usados comumente nas salas, cozinhas e banheiros das residências populares construídas nesta época. Para os quartos surgiu a novidade das janelas de madeira com venezianas tipo "Ideal", que possibilitavam o controle da luminosidade interna dos cômodos de dormir.

Concluindo, consideramos que o concreto armado representou a mais importante inovação técnico-construtiva nas edificações residenciais paulistanas no período entre as Grandes Guerras, possibilitando maior liberdade de projetação e meios para a resolução de problemas técnicos enfrentados pelos construtores atuantes naquela época. Porém, o seu uso cada vez mais disseminado na construção residencial não implicou necessariamente na procura de uma estética arquitetônica derivada do novo modo construtivo. O Neocolonial e o Art Déco, com seus discursos pretensamente modernos, se apropriaram do concreto armado com freqüência, porém dissimulando as estruturas (consideradas pouco atraentes na época) atrás de revestimentos ou de ornamentações aplicadas nas fachadas. Assim, o aparecimento de uma nova estética baseada no concreto armado só iria surgir e se desenvolver plenamente num momento posterior com o advento da Arquitetura Moderna.

\footnotetext{
${ }^{18}$ Ocasionalmente, a mica podia ser substituída por mármore triturado ou feldspato; quando se desejava dar efeito de cor às fachadas adicionava-se corante à massa raspada.
} 


\section{III.2. Os programas de necessidades}

Do início do século $X X$ até seus anos 30 ocorreram poucas modificações significativas nos programas das residências paulistanas. ${ }^{19}$ Como já dissemos anteriormente, a partir do terceiro quartel do oitocentismo a riqueza proporcionada pelo café e a ferrovia possibilitaram uma melhoria construtiva e qualitativa nas casas da cidade de São Paulo, principalmente nas de classe alta, com a difusão da alvenaria de tijolos, com o uso de materiais de construção importados e o emprego de mão-de-obra especializada de origem européia. Nesta época surgiu o desejo generalizado de esquecer o passado colonial, considerado caipira, construindo novas edificações diferenciadas segundo um novo gosto, trazido pelos arquitetos, engenheiros e mestres-de-obras estrangeiros, o Ecletismo de inspiração neo-renascentista. Como decorrência destas importantes alterações no partido arquitetônico residencial o programa também sofreu transformações e se particularizou em várias tipologias programáticas de acordo com a classe social e o poder aquisitivo dos seus moradores. Assim, aparecem neste período

".../ casas de todos os tamanhos, desde as de três cômodos ditas operárias, até as enormes, com dependências descomunais. /.../ casas operárias , casas da baixa classe média, casas da classe média propriamente dita, casas da classe média alta, palacetes e soluções mistas, em que o estabelecimento comercial era provido de residência anexa /.../" (LEMOS, 1999, p.32)

O "morar à francesa", introduzido nas residências da elite pelo arquiteto Francisco de Paula Ramos de Azevedo em fins do século XIX, representou uma profunda mudança no modo como se vivia até então na capital paulista. ${ }^{20}$ Este programa inédito na época foi implantado inicialmente nos palacetes da alta burguesia paulistana e previa um novo zoneamento funcional das habitações, com áreas distintas de estar, repouso e serviço, interligadas pelo vestíbulo (ou saguão central de distribuição) e por circulações secundárias. Podia-se transitar de uma zona da casa para outra sem passar necessariamente pela terceira. Esta separação funcional da habitação possibilitada pelo vestíbulo, que passou a chamar-se hall a partir da década de 20 , se difundiu, influenciando decisivamente nos agenciamentos das moradias de classe média nos anos entre as Grandes Guerras. Isto provocou o desaparecimento progressivo do esquema tradicional adotado nas residências populares desde os tempos de colônia, caracterizado pela sala de jantar ou "varanda", que

\footnotetext{
19 "O programa da casa moderna está completamente definido no século XIX. /.../ Publicações específicas e periódicos de arquitetura, /.../ guiavam arquitetos e clientes em todas as partes, sugerindo comportamentos, padrões sociais e estéticos relativos à habitação."In: CARVALHO, Maria Cristina Wolff. Ramos de Azevedo, p. 257.

20 "A idéia da Habitação Burguesa - a noção de habitar que Ramos de Azevedo trouxe de sua formação européia liga-se aos hábitos, necessidades, idéias, aspirações e costumes burgueses. /... Em seus projetos Ramos de Azevedo utiliza o zoneamento, a compartimentação, as peças e a denominação que são encontrados nas residências projetadas por seus pares na segunda metade do século XIX." Idem, p. 260.
} 
representava o centro de interesse da moradia e era passagem obrigatória em direção à cozinha e aos dormitórios (ou alcovas).

A vulgarização do "morar à francesa" durante as primeiras décadas do século XX em São Paulo fez com que os programas residenciais de classe média dos anos 20 e 30 procurassem se adaptar às novas expectativas programáticas. A maior diversidade funcional dos cômodos e circulações e o estabelecimento de um zoneamento interno distinguiam as residências populares, que naquele momento passavam a adquirir um valor simbólico, revelador da posição social e econômica do seu proprietário. ${ }^{21}$ Desta forma, sempre que possível, eram previstas entradas independentes sociais e de serviço (com acesso por passagem lateral); surgiam pequenos vestíbulos de distribuição no térreo e no superior interligados por escada interna; a sala de visita ou estar era independente da sala de jantar e situada com destaque na frente da casa; as áreas de repouso (dormitórios e banheiro completo) eram localizadas no andar superior; e a copa, a cozinha, o quarto da criada e o WC eram posicionados no fundo da habitação de modo a criar uma zona de serviço.

$\mathrm{Na}$ década de 20, pela forte influência da cultura norte-americana, que penetrava maciçamente através dos meios de comunicação (publicações diversas, imprensa e cinema) os nomes dos cômodos das casas populares passaram a assumir denominações inglesas. Assim, os paulistanos começaram paulatinamente a chamar o vestíbulo de hall, a sala de estar transformou-se no living-room e as instalações sanitárias se tornaram simplesmente WC (water closet). ".../ Só o velho termo varanda, denominando a grande sala de jantar é que resistiu galhardamente até a $2^{\underline{a}}$ Guerra." 22

Com a chegada da água encanada domiciliar as instalações sanitárias e de banho puderam ser incorporadas no corpo da edificação, proporcionando maior conforto e sensíveis melhorias nas condições higiênicas das habitações. Nas casas de classe média estas áreas e a cozinha apareciam sistematicamente próximas umas das outras, devido principalmente ao alto custo das tubulações hidráulicas, que eram importadas, o que caracterizava quase uma dependência programática deste período. Cabe ressaltar aqui que o modelo de instalação sanitária doméstica que se vulgarizou na cidade de São Paulo (e, em todas as cidades brasileiras) foi o norte-americano, que ao contrário do europeu, não

\footnotetext{
21 "A arquitetura doméstica possui um significado simbólico. Ela se apresenta como representante da condição social de seus moradores e materializando um código de valores a serem exibidos e divulgados. Ela caracteriza uma forma de poder, seja ele político, seja econômico, seja da tradição." Idem, p. 266 e 267.

${ }^{22}$ In: LEMOS, Carlos A. C. A República ensina a morar (melhor), p. 87.
} 
separa a latrina das outras peças sanitárias, reunindo num mesmo cômodo bacia, bidê, lavatório ou pia e a banheira ou semicúpio. ${ }^{23}$

A introdução da copa nas casas de classe média paulistanas foi outra novidade surgida nos anos 20. Originada nos programas diversificados dos palacetes, que adotavam como norma a especialização funcional decorrente do "morar à francesa", ${ }^{24}$ a copa apareceu neste período nas residências populares como um espaço de convivência doméstica; era o local no qual a família se reunia de maneira informal para fazer as refeições do dia, substituindo de certa forma as funções de estar da antiga varanda. ${ }^{25}$ Situada sempre junto à cozinha, a copa configurava-se nestas casas, via de regra, como um cômodo de transição entre a zona social (sala de jantar ou de estar) e a de serviço (cozinha, dependências de serviço, quarto da criada e o quintal).

Nos anos 20 e 30 as garagens começaram a ser vulgarizadas nas casas de classe média de São Paulo. Estas edificações destinadas à guarda e proteção dos automóveis ficavam localizadas geralmente no fundo dos lotes. O acesso até as garagens era feito através de uma estreita passagem lateral; nas casas geminadas duas a duas, tipologia residencial muito comum naquele período, este corredor situava-se ora à esquerda, ora à direita, conforme a posição da habitação. Em geral as garagens possuíam dimensões suficientes apenas para o abrigo do carro da família; porém, em alguns casos de casas de classe média alta e de palacetes ocorriam edículas de dois pavimentos, com garagem, oficinas e instalações de lavagem de roupa no térreo e apartamentos para o motorista (ou "chauffeur", como se dizia antigamente) e/ou criadagem no pavimento superior.

A edícula apareceu nos programas residenciais no início do século XX como opção para abrigar numa mesma edificação a garagem, o depósito, o quarto de empregada, o W.C., as instalações do tanque e, ocasionalmente, o quarto de engomar. ${ }^{26}$ Comumente

\footnotetext{
${ }^{23}$ "Casas com água encanada, a maioria, já com instalações sanitárias internas, sempre contíguas às cozinhas por causa da economia da tubulação importada, mesmo nas casas de sobrado /.../ Instalações que, em virtude da moderna moda americana, acomodavam num mesmo espaço a latrina e os equipamentos destinados à higiene das pessoas /.../" In: LEMOS, Carlos A. C. A República Ensina a Morar (Melhor), p. 67.

24 "Evidentemente a copa tem origem erudita e foi copiada dos projetos maiores surgidos a partir da presença de arquitetos inovadores a serviço da elite. Era uma dependência que nossa arquitetura colonial, ou do Império, não conhecera direito. Portanto, a copa da casa vulgar foi inspirada na do palacete importante, constituindo exemplo de influência de cima para baixo, do particular para o geral, do rico para o pobre." In: LEMOS, Carlos A. C. Cozinhas, etc. p.153 e 154.

25 “/... Enfim, nesse período de tempo que estipulamos /.../que vai desde 1918 a 1945 /.../ a copa firmou-se definitivamente como o centro de interesse da morada de classe média, no lugar da varanda, transformada em sala de jantar, de pouco uso /.../ A copa tornou-se o local de estar preferido da família de classe média." Idem, ibidem.

26 "Com o tempo, as cavalariças das casas ricas foram dando, aos poucos, lugar às garagens. E estas, por sua vez, em telhados puxados, sugeriram a proximidade dos apartamentos de empregadas e depósitos formando um todo separado da construção principal. Foi a época em que entrou para o linguajar cotidiano o termo edícula. /.../ A edícula - quarto de empregada, instalação sanitária, lavanderia, depósitos e garagem - parece constituir outra solução arquitetônica eminentemente nacional. Por mais que se procure, em quantos livros existam sobre a arquitetura residencial em outras terras, não são encontrados exemplos de casas possuindo, à parte, construções para abrigo de empregados." Idem, p.146 e 149.
} 
localizada no fundo do quintal, a edícula sempre se configurou numa construção auxiliar, independente da casa principal.

Outro acontecimento digno de nota na arquitetura residencial paulistana de classe média no período entre as Guerras foi a substituição gradativa das casas de porão alto, situadas no alinhamento, por sobrados isolados no terreno com discretos recuos de todos os lados. ${ }^{27} \mathrm{O}$ surgimento dos sobradinhos para aluguel formando conjuntos com mais de três unidades (tipo "Ford"), ou geminados dois a dois de frente para a rua, ou formando vilas (com entrada comum para todas as unidades), é também posterior a Primeira Grande Guerra. $^{28}$

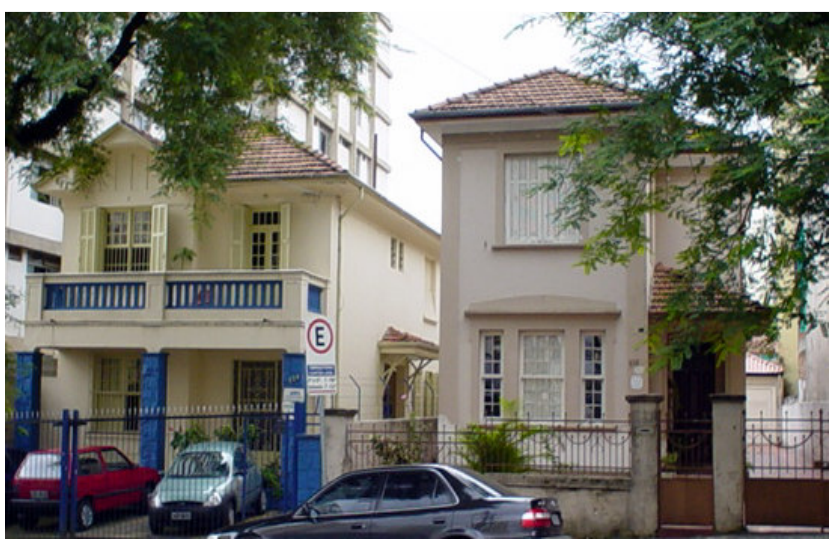

FIGURA 57 : Residências à rua Eça de Queirós.

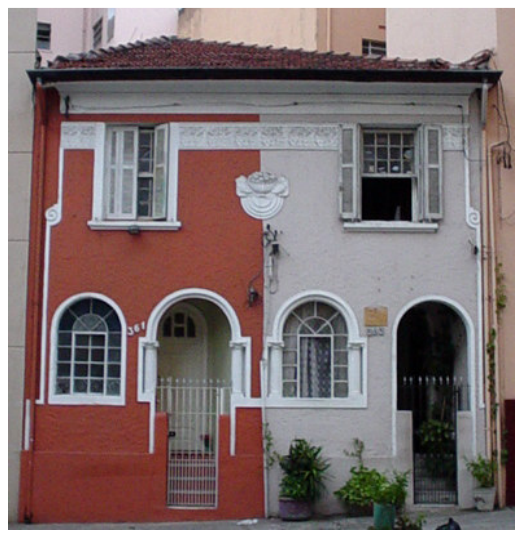

FIGURA 58 : Casas geminadas à rua Martim Francisco.

Para a análise dos projetos de aprovação de construção constantes nos processos sorteados do Arquivo Geral da Prefeitura Municipal de São Paulo foram estabelecidas seis tipologias programáticas residenciais : casa mista $(\mathrm{CM})$, casa operária $(\mathrm{CO})$, casa de classe média baixa $(\mathrm{CMB})$, casa de classe média média $(\mathrm{CMM})$, casa de classe média alta $(\mathrm{CMA})$ e palacete (PA).

\footnotetext{
${ }^{27}$ Esta nova implantação das residências populares (que, em geral, ainda se mantinham paralelas aos limites dos lotes) era naquele momento determinada por exigências sanitárias e de conforto ambiental do Código Sanitário de 1918 (e, posteriormente, do Código de Obras Arthur Saboya /1934), inspiradas nos parâmetros urbanísticos difundidos nos loteamentos da Companhia City, como já foi dito.

28 "O Código de 1918 /.../ de início, induziu ao isolamento das construções, criando jardins fronteiros e laterais que, somados aos tradicionais quintais, proporcionavam pequena taxa de ocupação do lote. A partir daí popularizaram-se, também, os pequenos sobrados geminados formando grupos de até seis unidades. Sobrados de poucos cômodos, todos arejados e insolados." In: LEMOS, Carlos A. C. A República Ensina a Morar (Melhor), p. 86.
} 
Foram classificadas como casas mistas (CM) as de dois pavimentos, com uso comercial no térreo e residencial no andar superior. Para efeito deste trabalho só foram consideradas as casas mistas com uso residencial unifamiliar, e nos casos em que havia mais de uma habitação no segundo pavimento, só foram aceitas aquelas que possuíam entradas independentes, configurando moradias individualizadas. Como exemplo deste último tipo de casa mista podemos citar os projetos 391 a 396, relativos à edificação localizada na rua do Arouche esquina com rua Bento Freitas, composta por seis moradias no pavimento superior (com entradas diferenciadas) e nove armazéns no térreo. ${ }^{29}$
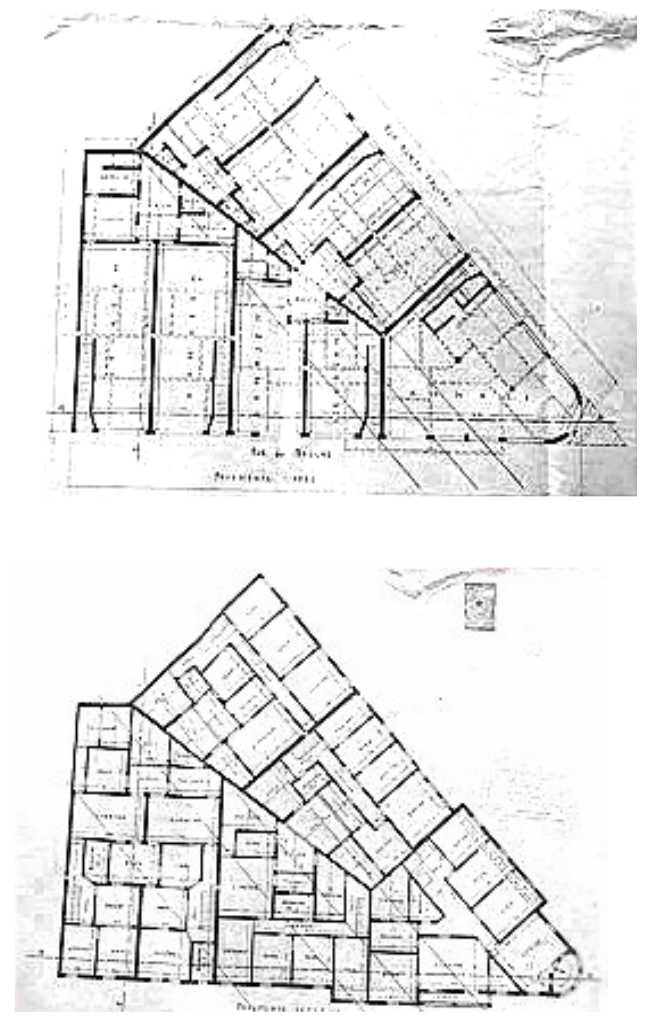

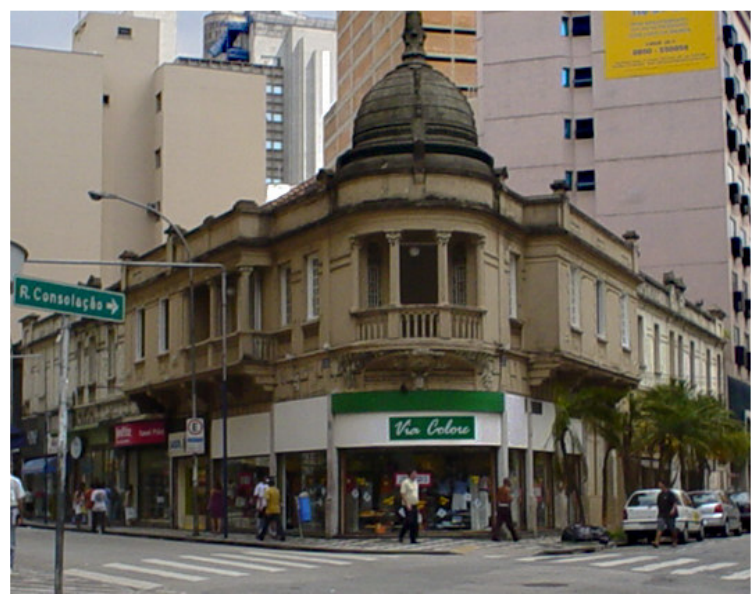

FIGURAS 59, 60 E 61 : Casa mista localizada na esquina das ruas do Arouche e Bento Freitas. (projetos 391 a 396 / processo ํㅜ 269 / 23)

Planta do pavimento térreo.

Planta do pavimento superior.

Fachada atual. (2003)

Como casas operárias (CO) foram consideradas as construções térreas que possuíam até três cômodos - sala, quarto e cozinha - mais o banheiro completo (WC com banho). A área da edificação ficava em torno de 30,00 $\mathrm{m}^{2}$. Existiam sobreposições de funções e os cômodos eram geralmente encarreirados, sem corredor interno. No período estudado, estas construções já possuíam recuos laterais, além dos frontais e de fundos, em

\footnotetext{
${ }^{29}$ Nas plantas constantes no projeto de aprovação da construção pudemos observar que cada uma das seis casas apresentava planta distinta uma da outra. Havia variações no número, dimensão e disposição dos cômodos, configurando seis tipos de agenciamentos diferentes.
} 
função da legislação vigente. Os projetos 212 e 302 são alguns dos exemplos desta tipologia programática selecionados na amostra.

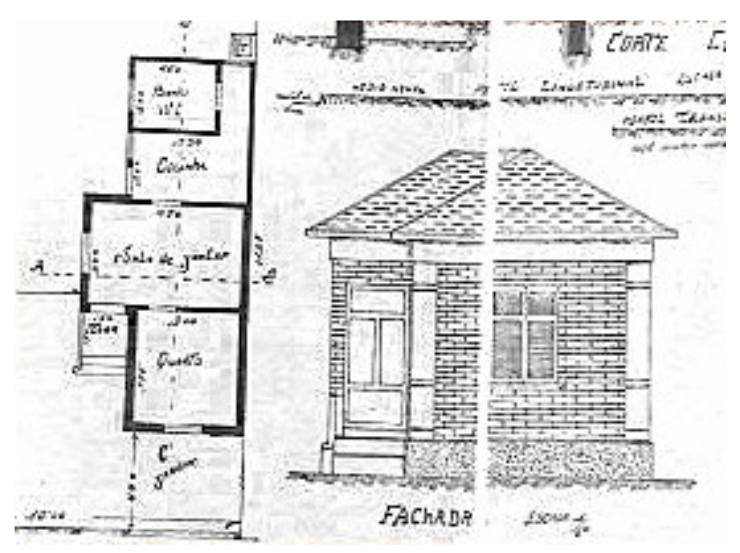

FIGURA 62 : Casa operária na rua Bartira. (projeto 212 / processo ํㅜ 5.379/29)

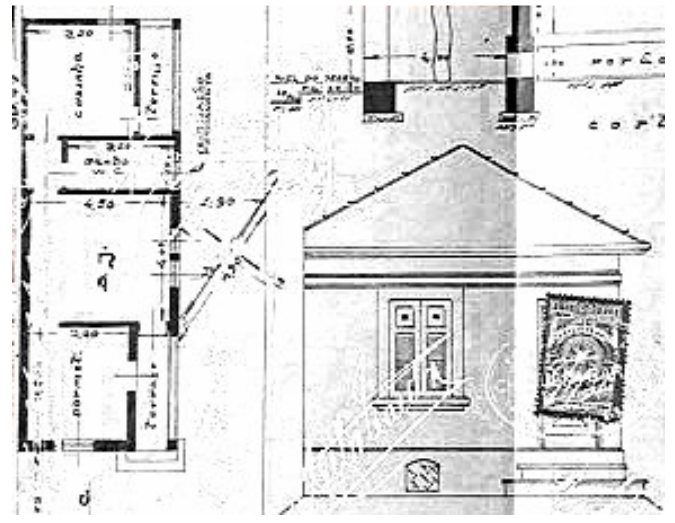

FIGURA 63: Casa operária na rua Cardeal Arcoverde. (projeto 302 / processo $\mathrm{n}^{0}$ 55.979/34)

Classificamos como casas de classe média baixa (CMB) as habitações térreas que apresentavam quatro cômodos em média - sala, dois quartos e cozinha, ou então, duas salas, quarto e cozinha - mais banheiro completo. A organização interna era, via de regra, muito semelhante à das casas operárias, com os cômodos dispostos seqüencialmente a partir da frente até o fundo da casa. O projeto 223 de autoria do arquiteto Rino Levi, referente a uma habitação de classe média baixa na rua Caramuru (Saúde), apresenta uma solução de planta diferenciada do modelo "corredor". O agenciamento dos cômodos é resolvido de maneira compacta, com planta quase quadrada: o acesso para a casa era feito por uma escada lateral, que dava diretamente num corredor central interno de distribuição; à esquerda situavam-se os dois quartos frontais (um deles provavelmente era utilizado como sala no período diurno, evidenciando claramente uma superposição de função - estar e repouso); à direita ficava a cozinha; e, em frente, ao fundo, localizava-se o banheiro. 

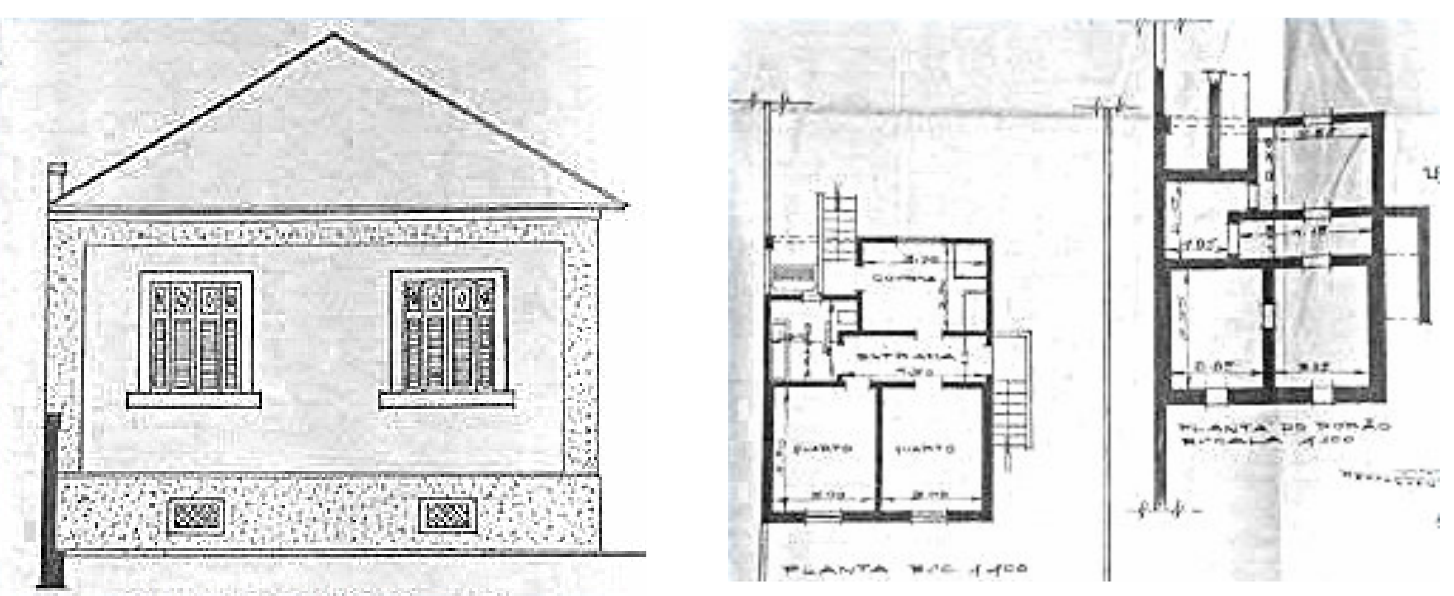

FIGURAS 64 E 65 : Fachada e plantas (térreo e porão) de casa na rua Caramuru projetada por Rino Levi. (projeto 223 / processo no $14.857 / 30$ )

O projeto 104 mostra uma solução de sobrado, pouco usual entre as casas de classe média baixa analisadas na amostra. Os chamados "sobradinhos Ford" eram uma variante desta tipologia programática; configuravam-se pequenos sobrados geminados formando grupos de até seis unidades com número reduzido de cômodos.

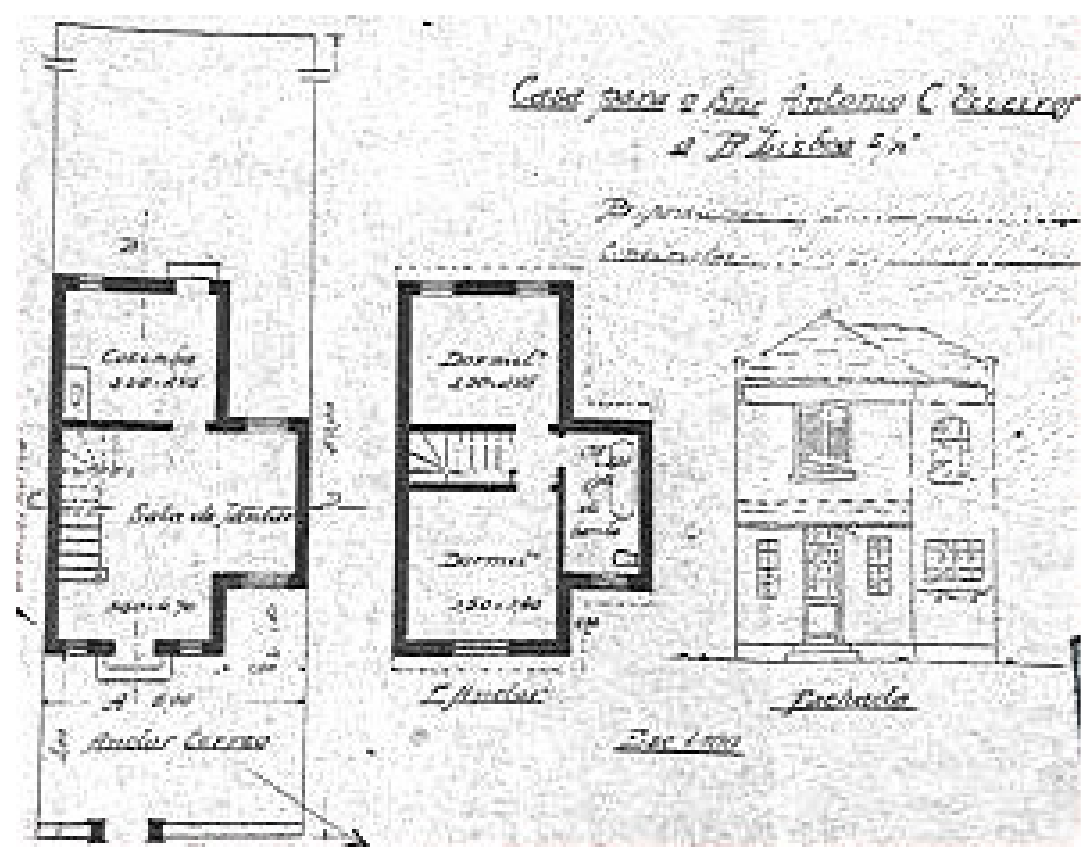

FIGURA 66 : Plantas (térreo e superior) e fachada de casa na rua Lisboa. (proieto 104 / processo no $12.791 / 26$ ) 
As casas de classe média média (CMM) podiam ser sobrados ou térreas. A implantação no lote obedecia geralmente a recuos frontais (com pequeno jardim), de fundos (quintal), e em alguns casos, também laterais (de ambos os lados, ou de um lado só, quando se tratava de construções geminadas). Estas habitações possuíam necessariamente duas salas, uma de visita ou estar e uma sala de jantar (ou varanda); o número de quartos era variável (no mínimo dois); o banheiro era freqüentemente contíguo à cozinha e à área de serviço, para economia da tubulação hidráulica; às vezes, estas moradias tinham acomodação para empregada doméstica, que podia situar-se no corpo da casa, junto à área de serviço, ou então, em pequena edícula no quintal. Como exemplo de sobrado isolado de classe média média pode ser citado o projeto 137 . O projeto 289 , de autoria do escritório Moya \& Malfatti, exemplifica uma solução de sobrados geminados.
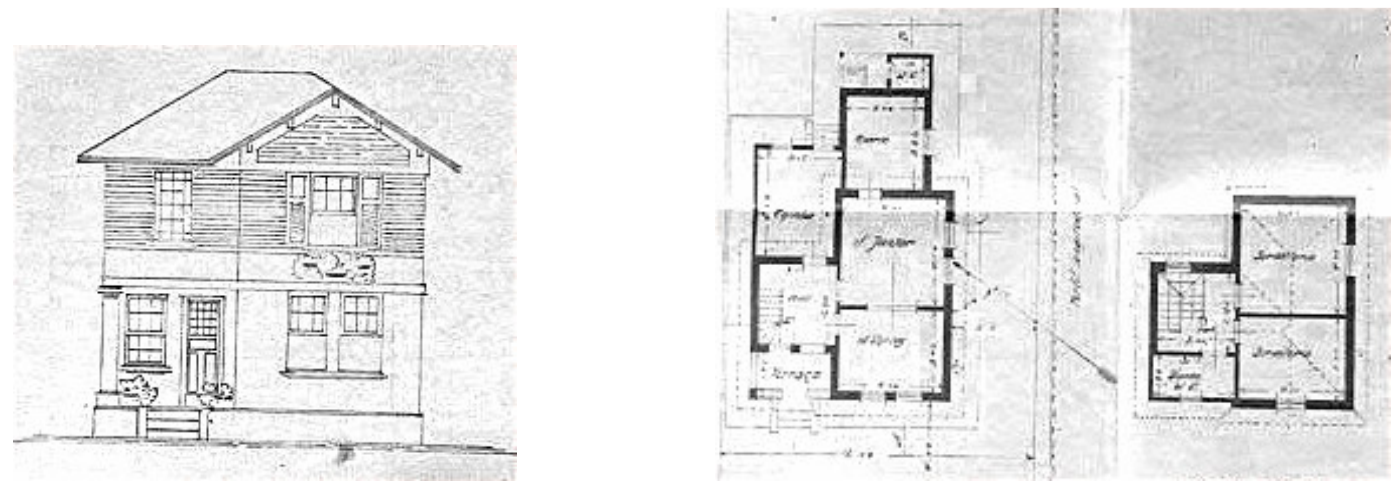

FIGURAS 67 e 68: Fachada e plantas (térreo e superior) de casa na rua Alves Guimarães. (projeto 137 / processo $n^{0} 23.575 / 28$ )
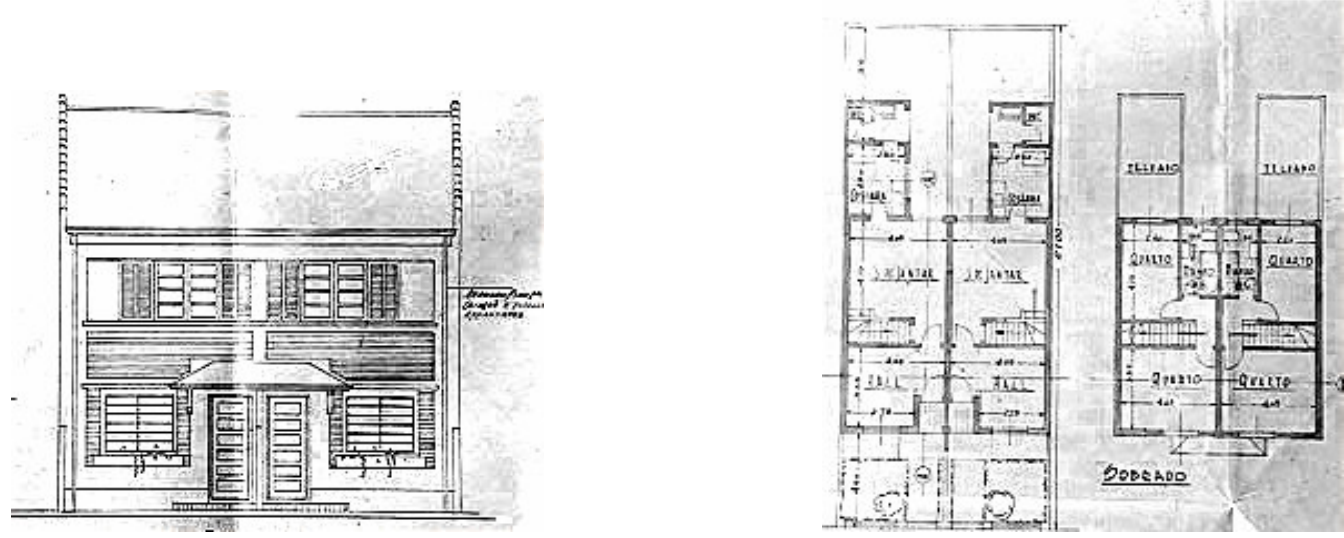

FIGURAS 69 e 70 : Fachada e plantas (térreo e superior) de duas casas geminadas na rua Afonso de Freitas projetadas pelo escritório Moya \& Malfatti. (projeto 289 / processo $n^{\circ}$ 76.281/34) 
O projeto 156 representa uma exceção à regra, ilustrando um exemplo de casa de classe média média, térrea, isolada e com um agenciamento interno curioso, que a aproxima das habitações de classe média baixa. A planta simétrica é dividida em duas alas por um largo e extenso corredor central, que liga diretamente a porta de entrada com a do quintal; do lado direito, situam-se seqüencialmente, da frente para o fundo, um dormitório, a cozinha e outro dormitório; do lado esquerdo, localizam-se encarreirados, a sala de jantar, o banheiro completo e mais um dormitório. Acreditamos que o dormitório frontal, na realidade, tivesse dupla função - estar durante o dia e repouso no período noturno, o que implicaria numa sobreposição funcional semelhante à existente nas casas mais simples.

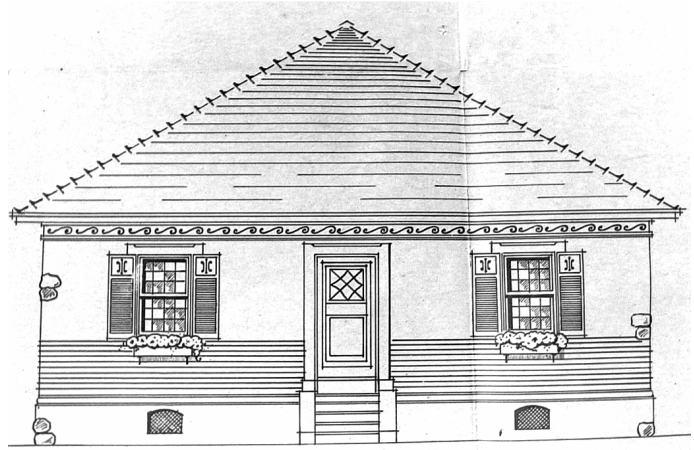

FIGURAS 71 e 72 : Fachada e planta de casa na rua Cunha Gago. (projeto 156 / processo oㅜ 54.901/28)

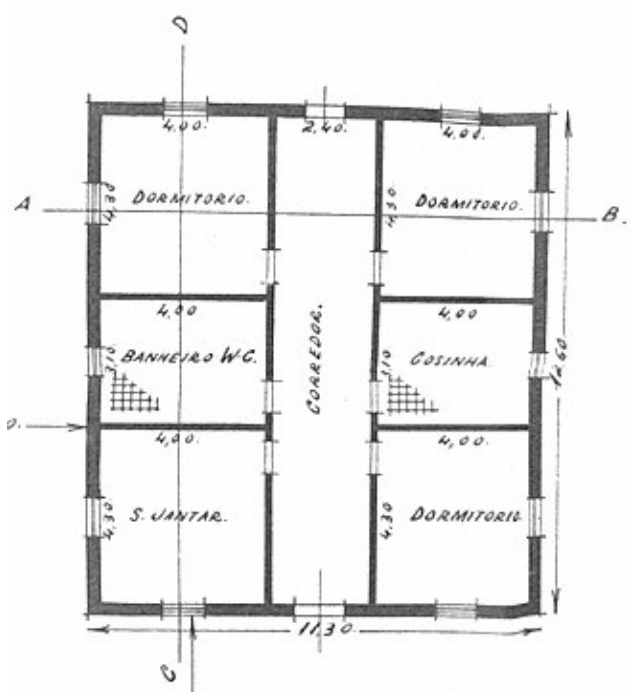

As casas de classe média alta (CMA) analisadas eram comumente sobrados ou térreas com porão habitável, implantadas no meio do lote. O programa destas edificações residenciais era mais complexo que o das anteriores, possuindo em geral três salas: de visitas, um gabinete ou escritório e uma sala de jantar. O número de quartos era variável, nunca inferior a dois. Possuíam banheiro completo situado geralmente no piso superior sobre a cozinha. No térreo ficavam a copa, a cozinha, o WC, as dependências dos empregados e de serviço; às vezes, o quarto de empregada e as instalações do tanque ficavam na edícula localizada no fundo do lote, junto com a garagem. A despensa e/ou quarto de engomar eram opcionais. O projeto 320 , de autoria de Otávio Lotufo, exemplifica esta tipologia programática. 
FIGURAS 73, 74 e 75: Fachada e plantas (térreo e superior) de residência na rua Tupi projetada por

Otávio Lotufo. (projeto 320 / processo ํo 50.029/35)
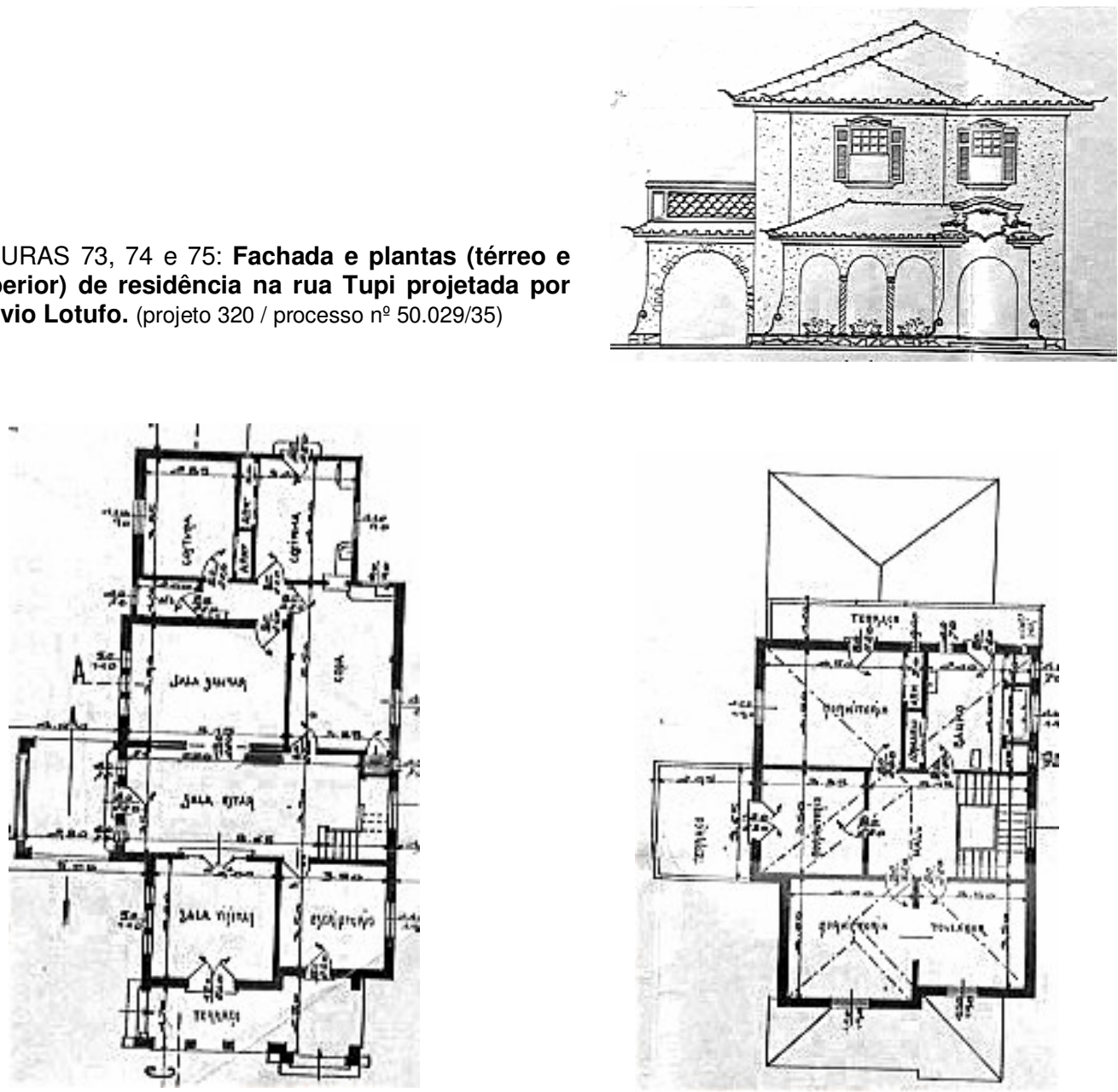

Nos palacetes (PA) o esquema organizacional interno obedecia rigorosamente 0 modelo do "morar à francesa". Existia um afastamento total das divisas do lote e do alinhamento da rua. Havia independência total entre as zonas de estar, de repouso e de serviço das moradias, não havendo superposição de atividades em função da existência de um "hall" de distribuição ou vestíbulo. Raramente eram construções térreas. Os palacetes apresentavam um programa de necessidades complexo e variado, possuíam cômodos específicos para a realização de cada atividade da casa e dos seus moradores: sala da senhora, "fumoir", sala de música, biblioteca, gabinete, quartos e banheiros de hóspedes, sala de bilhar, sala de almoço, quarto da governanta, copa e cozinha, além dos quartos, "boudoir" e banheiros privativos da família. As dependências da criadagem, a lavanderia, a garagem, a oficina etc. ficavam comumente em edículas separadas do corpo da edificação principal. A planta era recortada, com telhado movimentado, para aproveitar todas as 
possibilidades do terreno. Os projetos 11, de autoria de Álvaro da Costa Vidigal, e o 255, de Alfredo Ernesto Becker, exemplificam o programa de palacete.

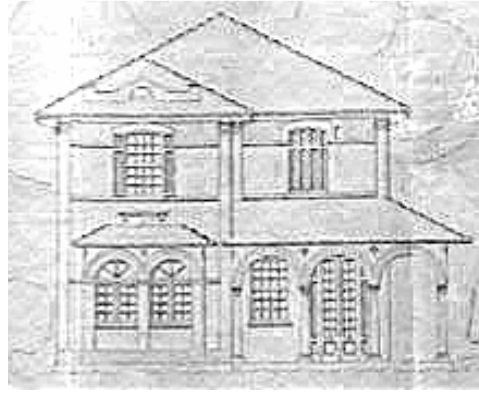

FIGURAS 76 e 77 : Fachada e plantas (térreo e superior) de residência na rua da Consolação projetada por Álvaro da Costa Vidigal. (projeto $11 /$ processo $\mathrm{n}^{\circ}$ 32.139/23)

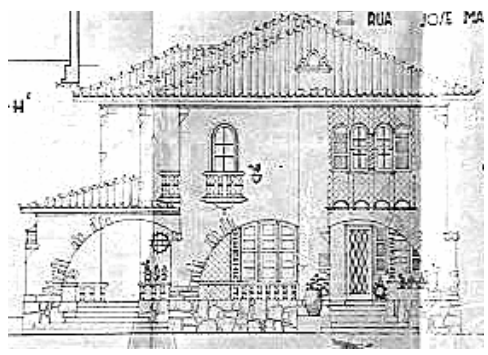

FIGURAS 78, 79 e 80 : Fachada e plantas (térreo e superior) de residência na rua José Maria Lisboa projetada por Alfredo Becker. (projeto 255 / processo $\mathrm{n}^{-}$ 18.049/32)
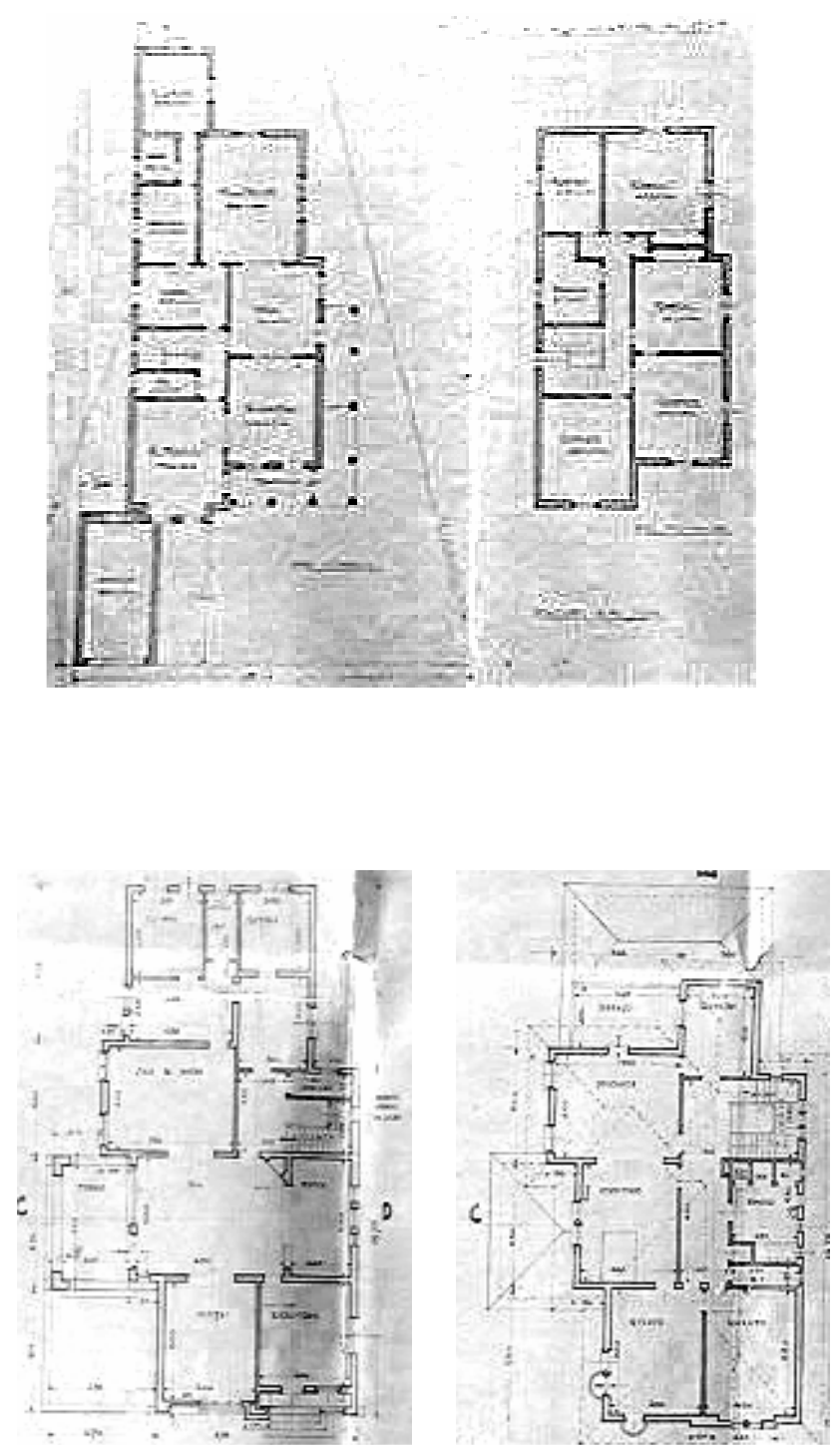

Dentro da amostra de 407 projetos sorteados verificamos a predominância acentuada de residências de classe média (CMB,CMM,CMA) sobre as demais tipologias programáticas, compreendendo cerca de $69,5 \%$ do total. ${ }^{30}$ As casas operárias $(18,2 \%)$, as mistas $(8,1 \%)$ e os palacetes $(4,2 \%)$ foram incidências menos significativas, correspondendo

\footnotetext{
${ }^{30}$ No conjunto de casas de classe média da amostra (283 residências) constatamos que cerca de $55,8 \%$ do total correspondiam a casas de classe média média (CMM), 26,5\% a casas de classe média baixa (CMB) e 17,7\% a casas de classe média alta (CMA)
} 
juntas a 30,5\%. A alta incidência de casas de classe média (CMB,CMM,CMA) encontrada nos bairros levantados das zonas Oeste (Grupo I) e Sudoeste/Sul (Grupo II) nos leva a considerar que ".../ essa classe média é que nos dá o retrato da morada paulistana" ${ }^{31}$ em todo o período estudado.

"A moradia da classe média é que encerra a maior soma de ocorrências quanto à evolução do programa nestes anos de modernidade. Daí o grande interesse de seu estudo; mesmo porque, estatisticamente, é predominante dentro daquilo que chamamos de cidade." (LEMOS, 1979, p. 15)

Na pesquisa arquitetônica empreendida nos projetos residenciais do Arquivo Geral da PMSP observamos também que o "hall" (ou vestíbulo) aparece freqüentemente nos agenciamentos residenciais de classe média média, média alta e palacetes dos anos $20 \mathrm{e}$ 30. Nos casos de sobrados existem sempre dois "halls" servindo como espaços de distribuição: um no térreo e outro no piso superior, interligados por escada interna. O projeto 315 exemplifica a presença do "hall" em sobrados paulistanos deste período.
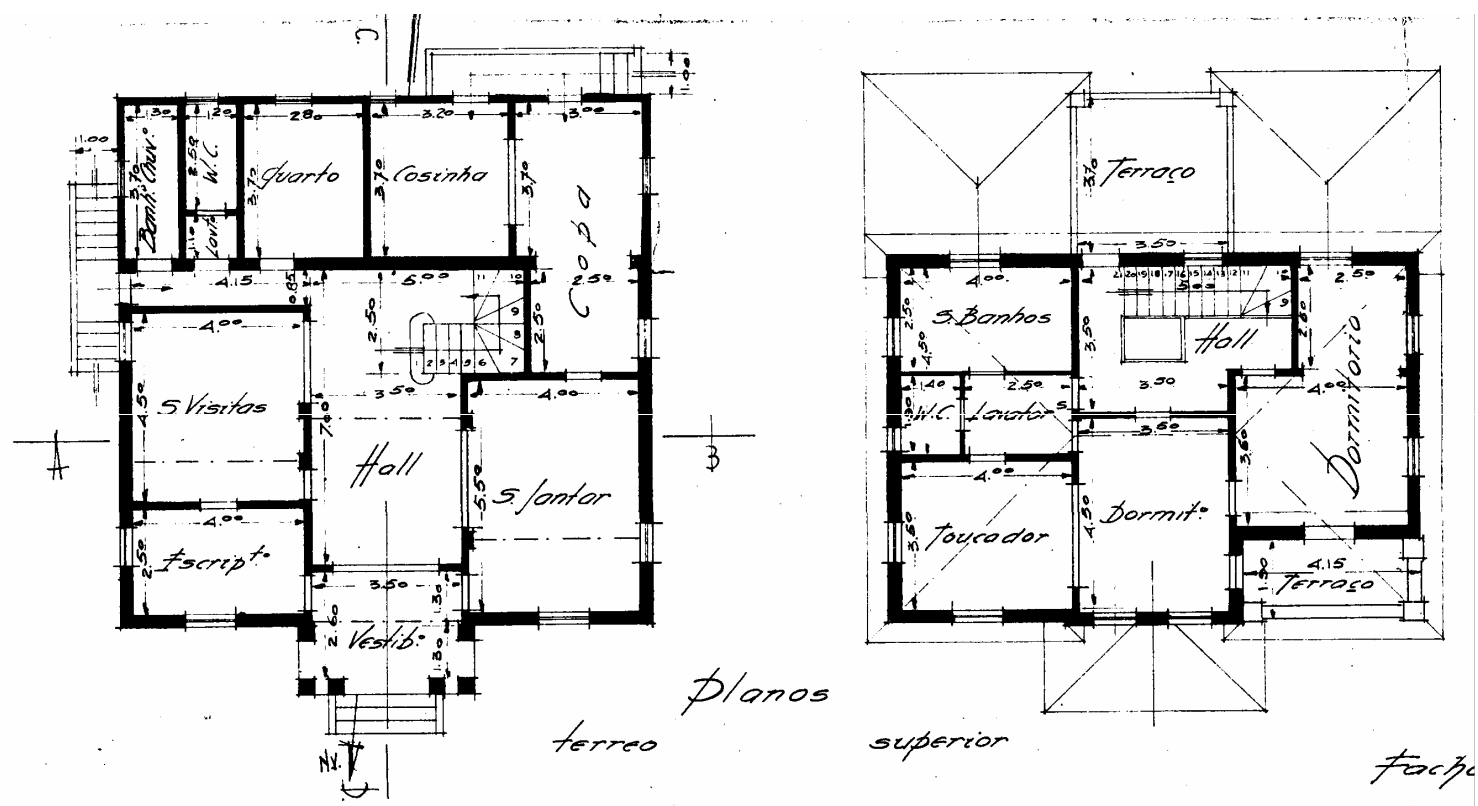

FIGURA 81 : Plantas (térreo e superior) de residência localizada na rua Pinto Ferraz. (projeto 315 / processo ํㅜ 34.553/34)

${ }^{31}$ LEMOS, Carlos A . C. "O Morar no Modernismo Paulistano." In: O Caderno de São Paulo, p. 16. 
Nos exemplares analisados a presença da copa começou a ser notada a partir dos agenciamentos de classe média média, constituindo-se em peça indispensável nos programas residenciais da classe alta. A posição da copa, na distribuição dos cômodos de serviço, estava vinculada diretamente à da cozinha. Assim, por questões de funcionalidade e comodidade a copa e a cozinha ficavam comumente situadas no pavimento térreo. A copa era geralmente um cômodo independente da cozinha, porém, foram observados alguns casos em que ambas configuravam um espaço único, separado apenas por uma passagem larga sem porta. $\mathrm{Na}$ amostra analisada podemos citar como exemplo deste binômio copacozinha o projeto 283.

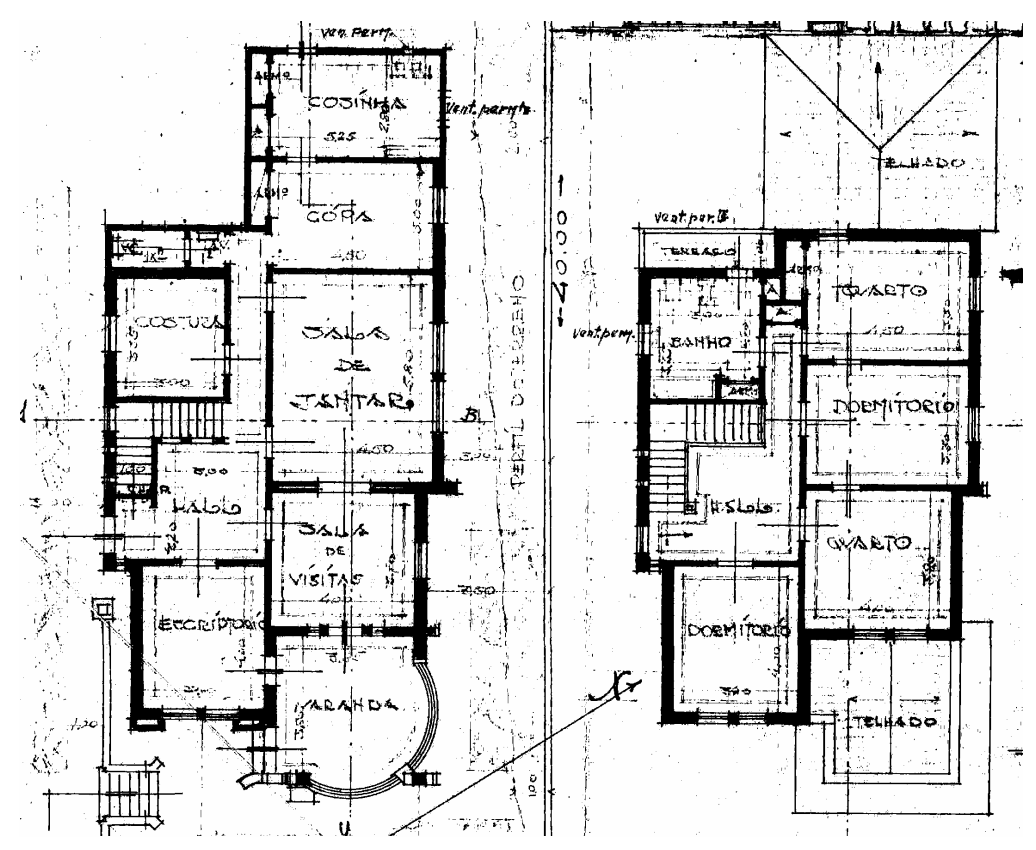

FIGURA 82 : Plantas (térreo e superior) de casa na avenida Brigadeiro Luiz Antonio. (projeto 283 / processo no $63.548 / 34$ )

A já citada residência Armando Álvares Penteado é um caso excepcional à regra, pois apresentava duas copas : uma no porão localizada junto à cozinha e outra no térreo próxima à sala de jantar. No projeto arquitetônico observa-se que não havia comunicação física entre as duas copas; o transporte dos alimentos era feito através de um montacarga. Acreditamos que a primeira copa tivesse o caráter funcional de espaço de apoio para a 
criadagem doméstica do palacete, enquanto a do térreo deve ter sido prevista para o serviço das refeições dos proprietários e eventuais banquetes.
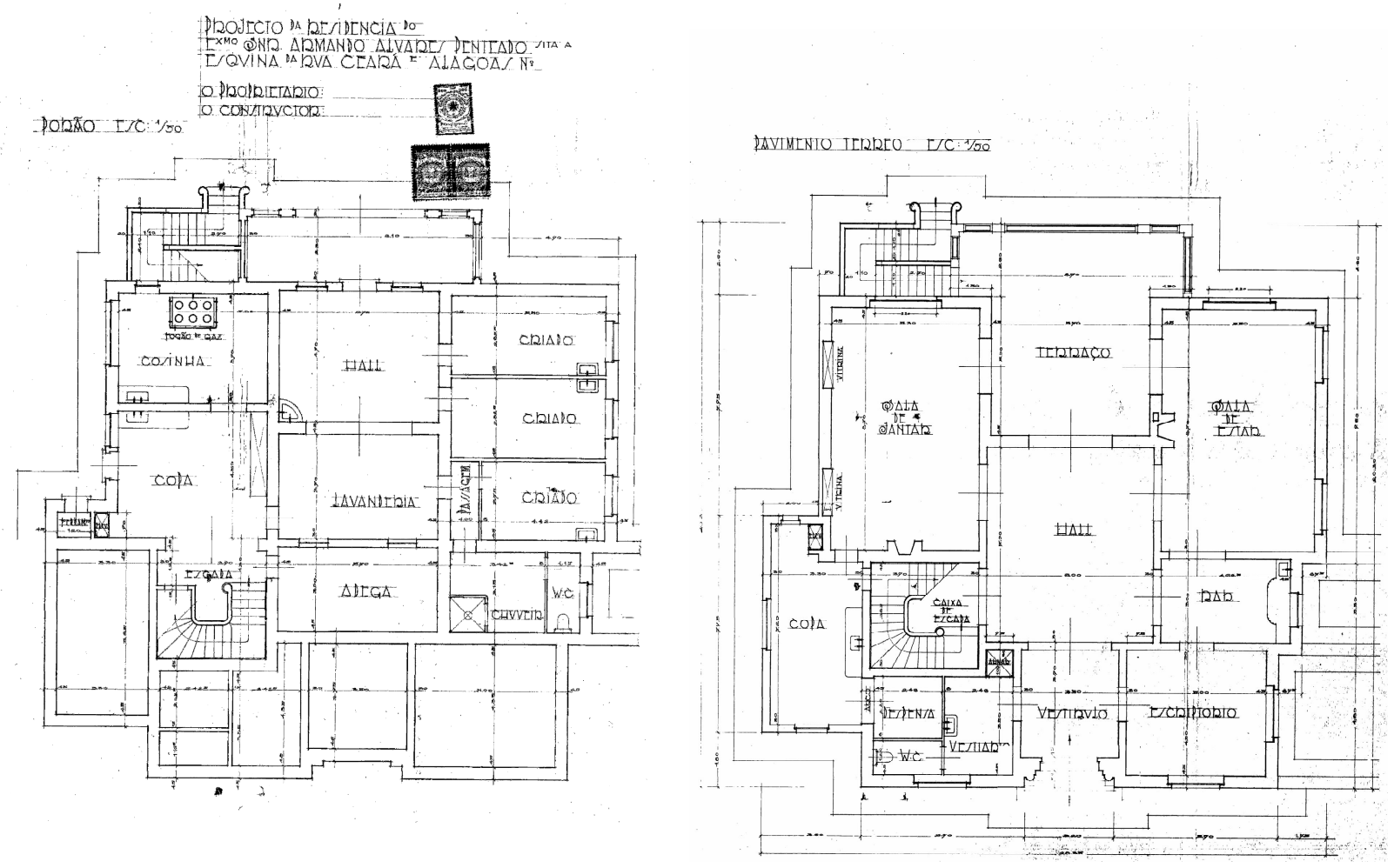

FIGURA 83 : Plantas (porão e térreo) da residência Armando Álvares Penteado na rua Ceará esquina da rua Alagoas. (projeto 231 / processo $\mathrm{n}^{\circ} \mathbf{4 2 . 7 1 6 / 3 1 \text { ) }}$

$\mathrm{Na}$ amostra analisada verificamos que a garagem e a edícula aparecem comumente nos programas de classe média média, sendo, no entanto, edificações obrigatórias nos de classe média alta e palacete. Localizadas invariavelmente no fundo do lote e distantes das zonas sociais da residência, estas construções apresentavam inúmeras soluções, como exemplifica a garagem do projeto 154 e a edícula em sobrado do projeto 70, com garagem e acomodação para empregados no pavimento superior. Observamos também a ocorrência eventual em residências de classe média média de garagem frontal integrada no corpo da casa, como é o caso do projeto 314. 


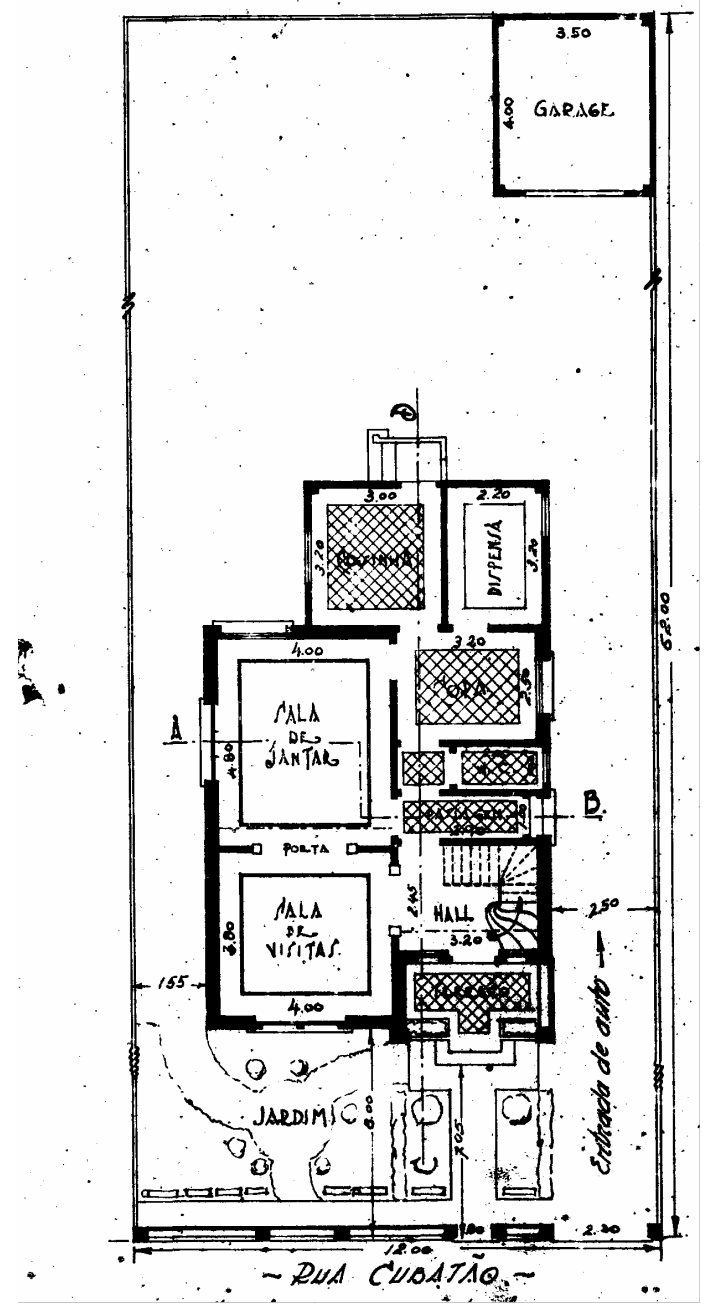

FIGURA 84: Plantas (térreo e garagem) de residência na rua Cubatão. (projeto 154 / processo $\mathrm{n}^{\circ}$ $25.740 / 281$

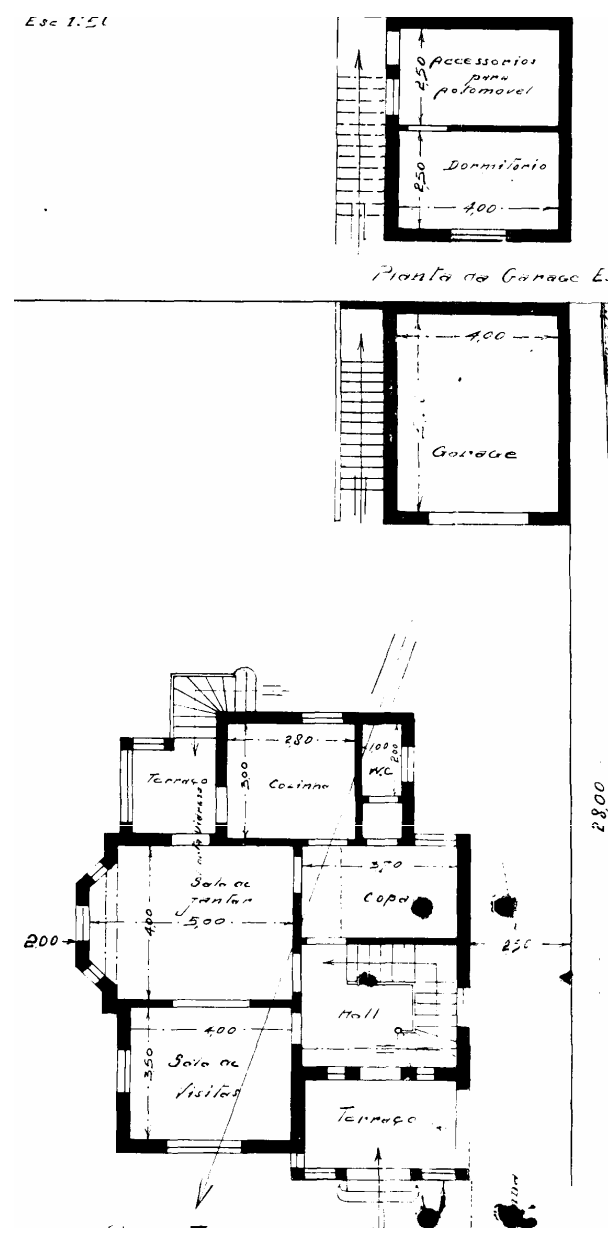

FIGURA 85: Plantas (térreo e garagem / térreo e superior) de casa na rua da Consolação. (projeto 70 / processo $\mathrm{n}^{\circ}$ 23.406/25) 


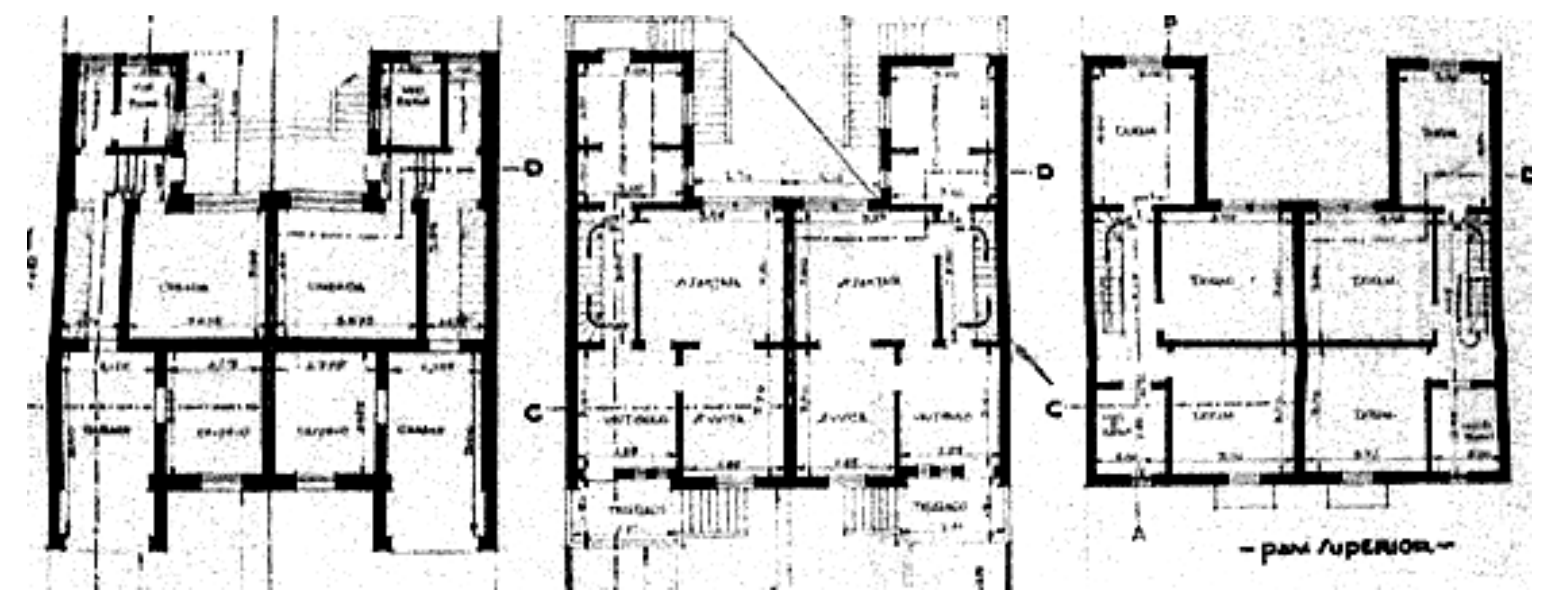

FIGURA 86 : Plantas (térreo e pavimentos superiores) de casa na rua Oscar Freire. (projeto 314 / processo nº $55.646 / 34)$

Sintetizando, pela análise dos exemplares selecionados na amostra percebemos que no período compreendido entre as Grandes Guerras as inovações programáticas atingiram fundamentalmente a classe média média (CMM), que passou a adotar agenciamentos mais diversificados no que se refere à especialização funcional e distribuição dos cômodos e circulações das casas. As moradias operárias e de classe média baixa mantiveram-se, no geral, presas ao esquema tradicional de plantas desenvolvidas através de uma sucessão de peças, sem corredor interno; as residências e palacetes das classes altas poucas alterações sofreram a partir do final do século XIX, com exceção da substituição gradativa das cocheiras e cavalariças pelas edículas com garagens completas compostas por oficinas, depósitos de combustível etc. Assim, o nosso estudo revelou uma grande variabilidade de soluções de agenciamentos surgidas nesta época na cidade de São Paulo para atender, principalmente, os programas residenciais de classe média média; soluções estas, em alguns casos criativas, e, em outros, inadequadas, mas que na sua configuração demonstram claramente o desejo deste estrato social de definir um modo próprio de morar.

\section{III.3. O repertório formal e estilístico}

Ao observarmos atentamente a arquitetura residencial paulistana produzida nos anos 20 e 30 do século passado constatamos que dentre as manifestações arquitetônicas do período, o Neocolonial, nas suas versões luso-brasileira e hispano-americana, e o Art Déco, 
representaram as linguagens estilísticas mais copiadas, recriadas e difundidas, e as que melhor se adaptaram às conveniências e aos anseios de afirmação social e de modernidade da classe média local. ${ }^{32}$ Assim, a partir da identificação e do reconhecimento de obras eruditas de base ${ }^{33}$ que na noção de Pierre Francastel e Damián Bayón podem também ser chamadas de exemplares "cabeça-de-série", ${ }^{34}$ procuramos desenvolver a reflexão acerca do comprometimento formal e das influências estilísticas destes edifícios na formulação de uma linguagem arquitetônica popular resultante de recriações, amplamente disseminada na cidade de São Paulo até o final da década de 30.

A livre apropriação por profissionais habilitados, empreiteiros e mestres-de-obras do repertório formal e estilístico do Neocolonial e do Art Déco, somado a estilemas do Ecletismo Historicista, do Classicizante e a invenções populares, gerou também uma outra categoria de edificações residenciais sem caráter definido, muito freqüente no período entre as Guerras. Nestas residências, geralmente de classe média (CMB, CMM, CMA), o sincretismo arquitetônico conduzia a uma indefinição da linguagem estilística, variando da arquitetura chã até soluções individualistas, nas quais predominava o gosto pessoal do construtor e/ou proprietário, sem preocupação ou pretensão de seguir algum estilo.

O clima de perplexidade e de indefinições do pós-Primeira Guerra juntamente com a vontade explícita de renegar tudo que lembrasse o passado imediato, inclusive a arquitetura eclética praticada até $1918,{ }^{35}$ favoreceram sobremaneira em alguns estratos da sociedade paulistana o desenvolvimento de uma mentalidade mais receptiva a liberdades de expressão, antes nunca pensadas ou experimentadas, e que, em última análise, induziriam no momento posterior ao surgimento de variados processos de criação arquitetônica.

O desejo predominante de modernização em todos os aspectos da vida cotidiana e a crescente influência cultural norte-americana, via cinema e revistas, influíram também de modo significativo nas escolhas arquitetônicas que foram feitas nos anos 20 e 30 em São Paulo. Com exceção do proletariado conservador, que ainda construía suas casas seguindo a estética classicizante dos capomastri, a classe média reagia à padronização do gosto do

\footnotetext{
${ }^{32}$ Esta constatação baseia-se em anos de pesquisa em bibliografia especializada e no estudo sistemático do ambiente urbano paulistano, realizando inúmeros IGEPACs (Inventário Geral do Patrimônio Ambiental, Cultural e Urbano da Cidade de São Paulo), como arquiteta do Departamento do Patrimônio Histórico (DPH).

33 "As obras que, no consenso do público, foram transformadas em modelos constituem normas estéticas, despojam-se de seu caráter singular, para transformarem-se em patrimônios que predeterminam a orientação do gosto das gerações posteriores. $A$ criação desses modelos obedece a uma economia que abrevia, simplifica, homogeneiza o sentido para poder universalizar-se." In: FERRARA, Lucrécia D' Alessio. A Estratégia dos Signos, p.46.

${ }^{34}$ Ver: BAYÓN, Damián. Sociedad y Arquitectura Colonial Sudamericana.

${ }^{35}$ Como já dissemos, no período anterior à Primeira Grande Guerra (1914/18) predominou na sociedade paulistana o gosto pela arquitetura eclética classicizante de inspiração neo-renascentista.
} 
imigrante partindo em busca de manifestações personalistas materialmente acessíveis só à elite.

Imaginamos que os profissionais atuantes no início da década de 20 na capital paulista tenham se indagado muitas vezes sobre qual seria a feição estilística mais adequada para ser empregada nas edificações a partir daquele instante. Assim, supomos que perante os arquitetos e construtores da época tenham sido colocadas questões essenciais sobre qual caminho seguir : ou continuar construindo a partir dos modelos do Ecletismo, já superados e copiados à exaustão; ou procurar novas fórmulas de expressão aproveitando o ambiente libertário e de euforia ocasionado pelo final da guerra. Surge então o desejo de buscar um estilo "novo", sem compromisso com o que se fazia anteriormente ao conflito. Estranhamente esta procura do "novo" foi consubstanciada numa tentativa romântica de resgatar a tradição e a cultura do tempo colonial, configurada na releitura da arquitetura antiga proposta pelo Movimento Neocolonial.

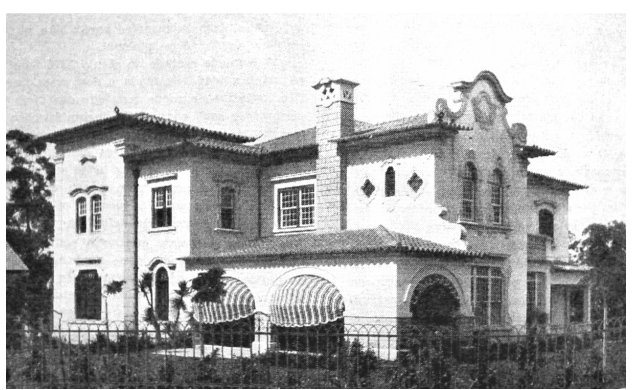

FIGURA 87 : Residência de Rui Nogueira. (Ricardo Severo / São Paulo, década de 1920)

Neste momento, uma parte da elite paulistana adotou o Neocolonial lusobrasileiro difundido por Ricardo Severo como estilo arquitetônico preferencial. Apesar de pouco numerosas, as residências neocoloniais realizadas por Severo, como as da avenida Angélica (1910), a de Numa de Oliveira na avenida Paulista (1916/1918), a de Rui Nogueira e a sua Casa Lusa (1924) na rua Taguá, apresentavam um repertório estilístico inédito, que certamente serviu de inspiração direta para a composição das fachadas de muitas casas populares. ${ }^{36}$

Uma outra importante referência desse período foi o conjunto das obras realizadas pelo arquiteto Victor Dubugras, que acreditamos também tenha servido de modelo para inúmeras manifestações arquitetônicas residenciais de classe média. A arquitetura de caráter individualista de Dubugras, inicialmente neo-românica e Art Nouveau, começou a se transformar visivelmente a partir de meados da década de 10. Não sabemos ao certo se o arquiteto francês assistiu à célebre palestra proferida por Ricardo Severo na Sociedade de

\footnotetext{
${ }^{36}$ O Neocolonial luso-brasileiro ".../ ocupa lugar relevante no panorama arquitetônico porque é o único a possuir exemplos nossos contemporâneos, demonstrando uma longevidade invejável mercê de uma real popularização." LEMOS, Carlos A.C. "Ecletismo em São Paulo" In: FABRIS, Annateresa (org.) Ecletismo na Arquitetura Brasileira, p. 89.
} 
Cultura Artística em 1914. Porém, o fato é que Dubugras deve ter logo tomado conhecimento das idéias tradicionalistas propagadas pelo ilustre engenheiro português, que parecem tê-lo impressionado vivamente, a ponto de impeli-lo a construir as residências de Névio Barbosa (1914) e de Eugênio Gomes do Val (1918) em São Paulo, e diversas casas neocoloniais na cidade de Santos, ${ }^{37}$ entre 1915 e 1917, numa clara demonstração de comprometimento com a nova linguagem.

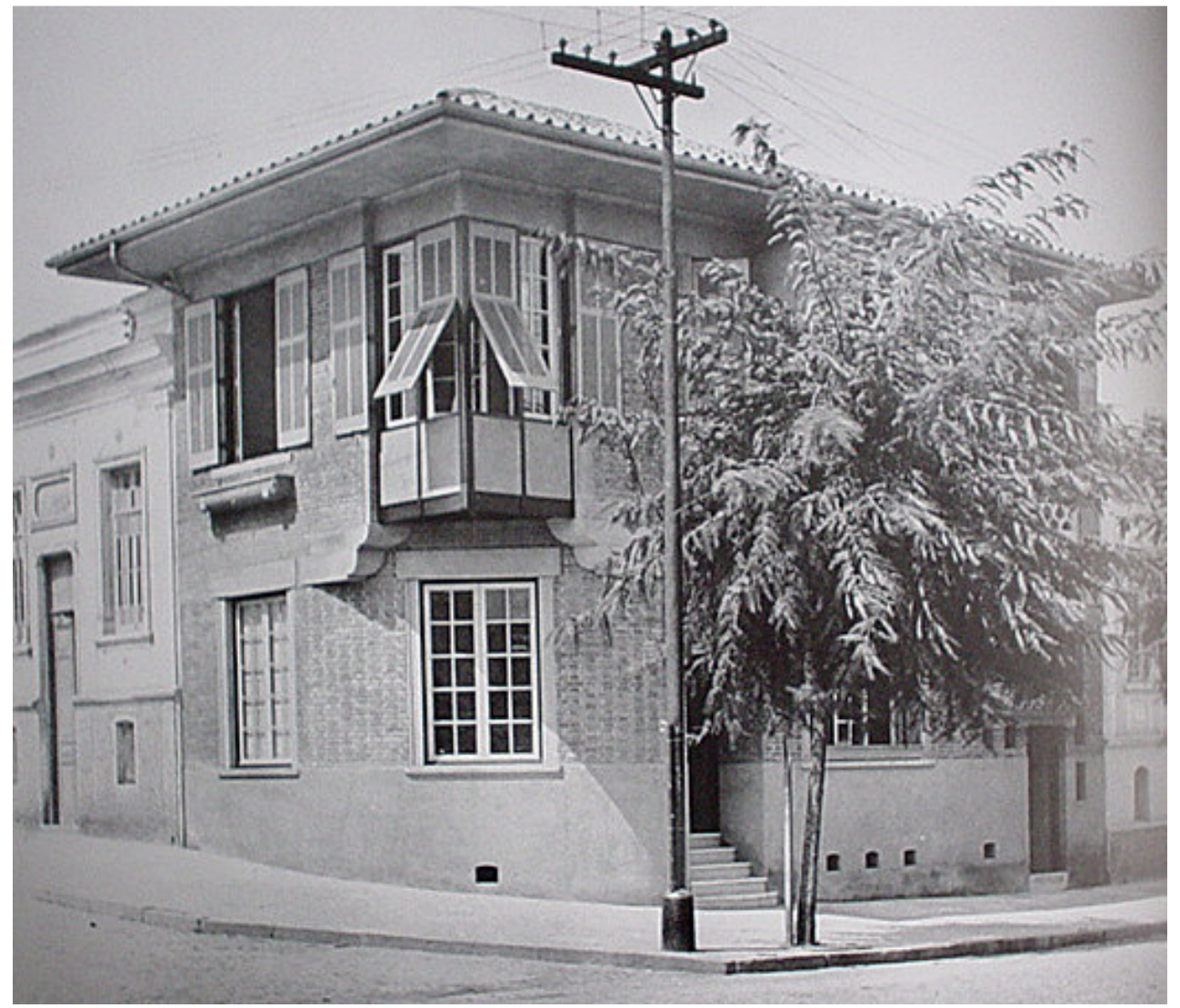

FIGURA 88 : Residência Névio Barbosa localizada na rua Condessa de São Joaquim esquina da rua Bororó. (Victor Dubugras / São Paulo, 1914)

\footnotetext{
${ }^{37}$ Entre 1915 e 1917 Victor Dubugras construiu na cidade de Santos (SP) as residências de Luiz Franco do Amaral (1915), Miguel Presgrave (1915), Saturnino de Brito (1916), Coronel Bento de Carvalho (1916) e de Adalberto Alves (1917), nas quais já estão presentes alguns dos estilemas neocoloniais e outros de criação do próprio arquiteto francês. Ver: REIS FILHO, Nestor Goulart. Racionalismo e Proto-Modernismo na obra de Victor Dubugras, p. 74, 75, 76, 77, 78, 113,114,185.
} 

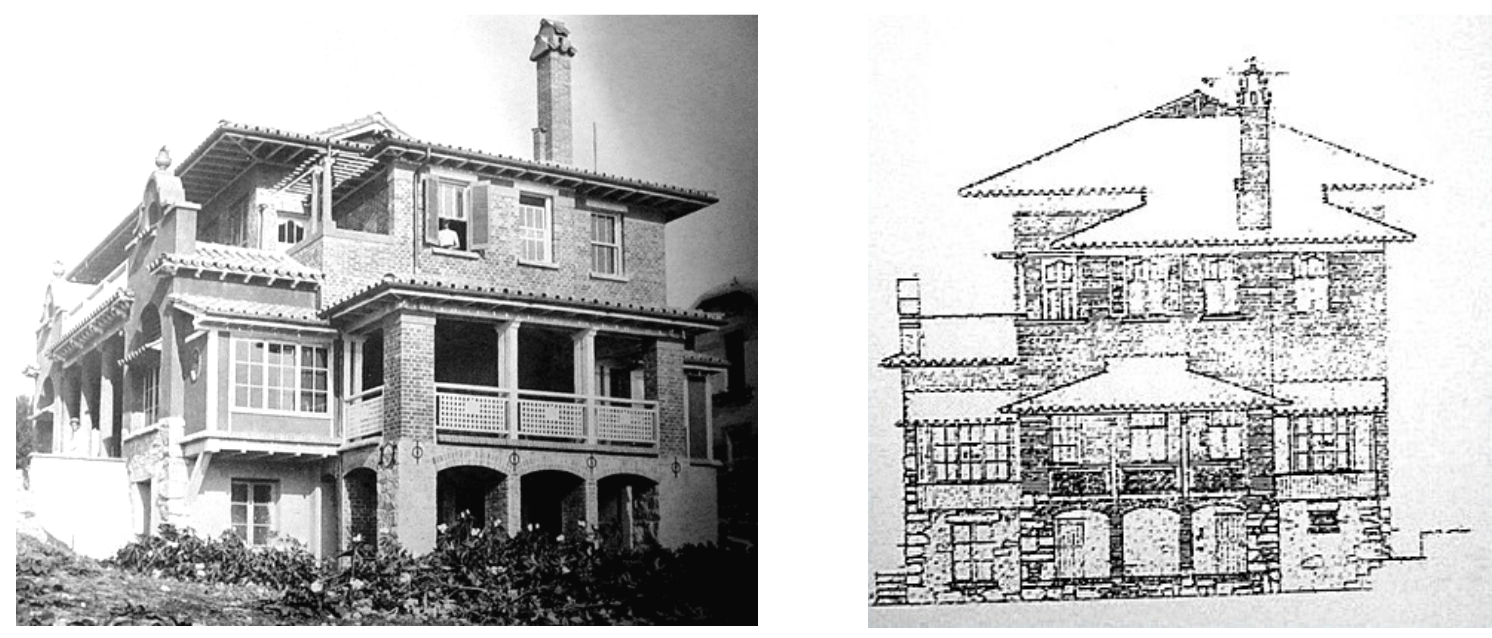

FIGURAS 89 e 90 : Residência Eugênio Gomes do Val na rua Albuquerque Lins - foto e desenho da fachada de fundo. (Victor Dubugras / São Paulo, 1918)

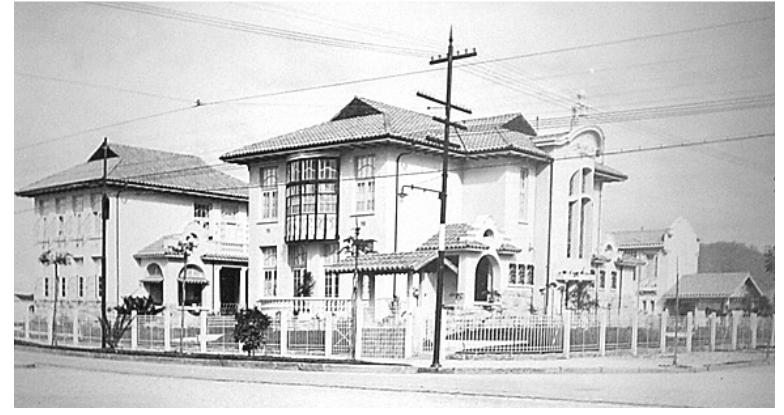

FIGURA 91 : Residências Luiz Franco do Amaral (1은 plano) e Miguel Presgrave (fundo). (Victor Dubugras / Santos, 1915)

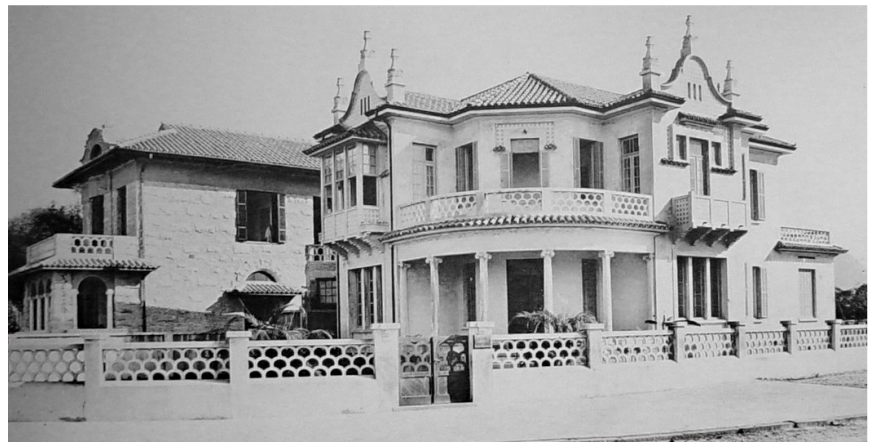

FIGURA 93 : Residências Coronel Bento de Carvalho (1은 plano) e Saturnino de Brito (fundo). (Victor Dubugras / Santos, 1917)

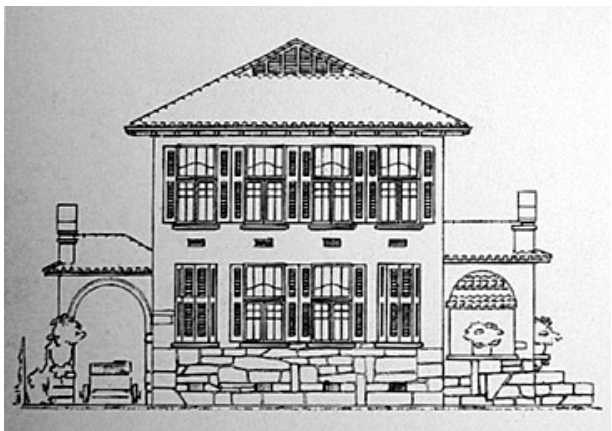

FIGURA 92 : Residência Miguel Presgrave. (Victor Dubugras / Santos, 1915)

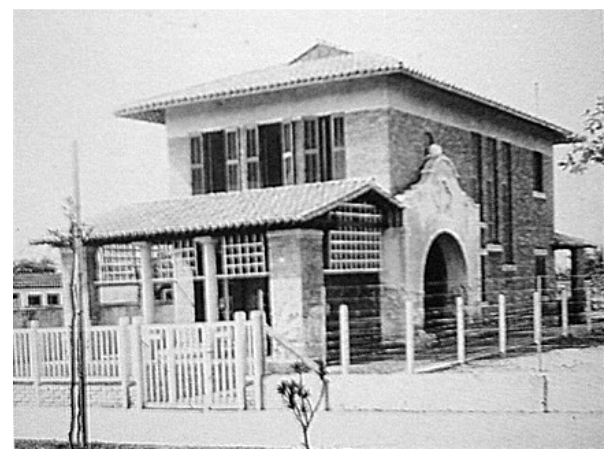

FIGURA 94 : Residência Adalberto Alves. (Victor Dubugras / Santos, 1917) 


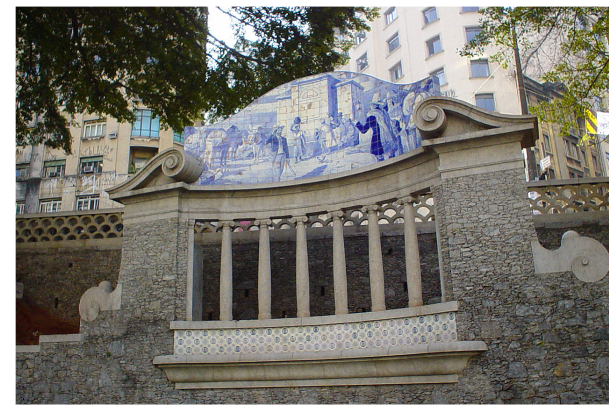

FIGURA 95: Ladeira da Memória / detalhe do painel de azulejo do Monumento do Piques. (Victor Dubugras / São Paulo, 1919/22)

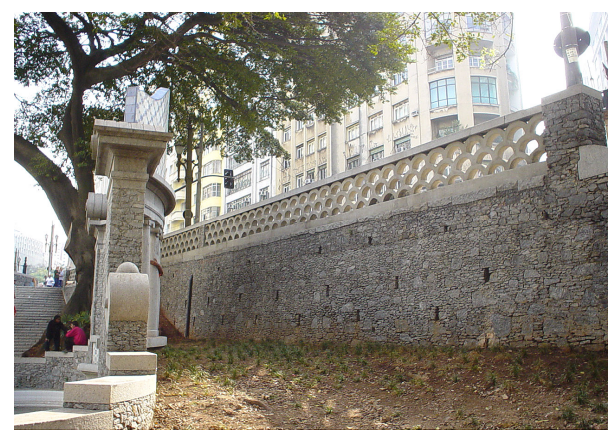

FIGURA 96 : Ladeira da Memória / detalhe do muro de arrimo com guarda-corpo de elementos vazados em forma de meiasluas superpostas. (Victor Dubugras / São Paulo, 1919/22)
O entusiasmo pelas possibilidades de pesquisa arquitetônica que o novo estilo the oferecia, somado às preocupações de realização de uma arquitetura assumidamente coerente com os tempos e os progressos técnicos que se vivia então, fez com que Victor Dubugras desenvolvesse uma linguagem particularizada, em obras significativas como os Pousos do Caminho do Mar (1922) e a reformulação da Ladeira da Memória (1919/1922). Os estilemas criados por Dubugras ao longo da sua carreira, principalmente os empregados nos pousos, no monumento do Piques e nas inúmeras residências projetadas por ele, foram amplamente incorporados, copiados e recriados na arquitetura popular paulistana do período, ${ }^{38}$ daí a importância fundamental do seu reconhecimento para a análise desta arquitetura.

\section{Segundo Yves Bruand a arquitetura de Dubugras}

".../ retomou alguns elementos clássicos da arquitetura luso-brasileira (varandas, balcões, telhados planos de telhas-canal com largos beirais, lintéis das janelas, frontões com pináculos tomados de empréstimo à arquitetura religiosa e não à civil), mas sem pretender utilizá-los de modo arqueologicamente correto : a tudo isso junta outras formas que já vinha utilizando anteriormente com freqüência (arcos plenos de coloração romana, curvas dos degraus da escada ou das muretas das varandas que lembram o art nouveau) ; finalmente e acima de tudo, usava pedra bruta muito escura disposta de modo irregular, o que dava a seus edifícios um aspecto bruto e pesado, em violento contraste com a cor clara do reboco empregado sistematicamente na arquitetura portuguesa." (BRUAND, 1981, p.53)

\footnotetext{
${ }^{38}$ Carlos A. C. Lemos referindo-se ao Monumento do Piques na Ladeira da Memória (SP), projeto de Victor Dubugras, nos diz que ".../ o guarda-corpo que arrematava toda a composição, ao nível da rua Xavier de Toledo, era formado por semicírculos vazados de granito lavrado superpostos desencontradamente formando um desenho semelhante às escamas de peixe, desenho que viria a ser copiado, recopiado e repetido milhares de vezes pela cidade a fora, tornando-se inclusive, uma das "marcas registradas" do neocolonial." In: LEMOS, Carlos A. C . Alvenaria Burguesa, p. 166.
} 


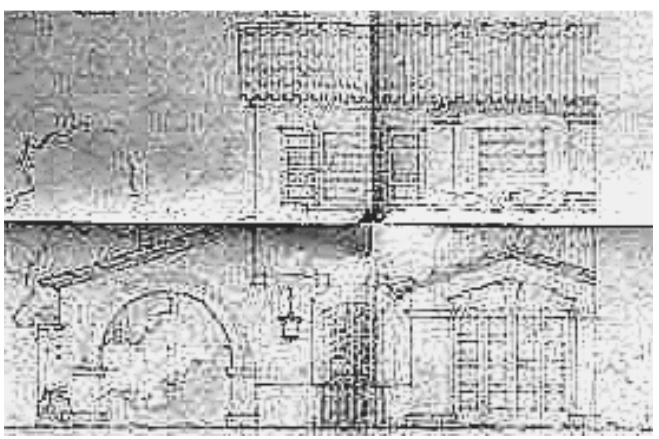

FIGURA 97 : Fachada de residência localizada na rua José Maria Lisboa projetada por Bratke \& Botti. (projeto 360 / processo $n^{\circ} 105.178 / 36$ )

Por influência do Neocolonial hispanoamericano, praticado por arquitetos eruditos, o gosto pelos elementos formais e estilísticos oriundos da arquitetura das missões espanholas do México e da Califórnia foi popularizado nas casas paulistanas dos anos 30. Como exemplares paradigmáticos deste estilo na capital paulista podemos citar as inúmeras residências projetadas no Pacaembu e nos Jardins por arquitetos como Alfredo Ernesto Becker, Alberto Botti, Oswaldo Bratke e Eduardo Kneese de Mello, ${ }^{39}$ entre outros.

No final dos anos 20, a novidade da arquitetura cúbica e austera das residências "modernistas" que o arquiteto Gregori Warchavchik construiu em São Paulo não chegou a comover e nem a influenciar a feição das casas das camadas populares. Estas edificações modernas e sem ornamentação eram, via de regra, rejeitadas veementemente pela população em geral, que não reconhecia nelas nenhum valor artístico, apelidando-as pejorativamente de casas "futuristas".

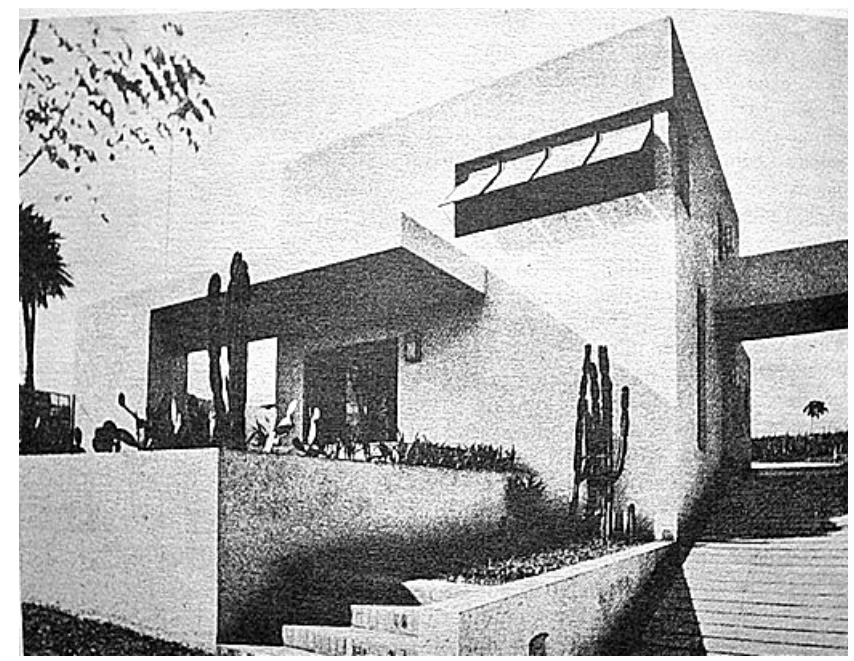

FIGURA 98 : Casa da rua Itápolis. (Gregori Warchavchik / São Paulo, 1927)

\footnotetext{
${ }^{39}$ Ver referências sobre residências em estilo Missões realizadas por Bratke, Botti e Eduardo Kneese de Mello, no início de suas carreiras, no trabalho de Silvia Ferreira Santos Wolff - Jardim América. O primeiro bairro-jardim de São Paulo e sua arquitetura (p. 180 e 181).
} 
Em contrapartida, nos anos 30 com a chegada do Art Déco, surgiu a oportunidade da arquitetura residencial paulistana expressar plenamente um modernismo comportado, sem um afrontamento drástico com a tradição arquitetônica vigente. $O$ intenso desejo de aparentar "modernidade" explica em grande parte a rápida assimilação e ampla difusão desta linguagem estilística nas edificações paulistanas, cujos estilemas foram copiados e reinterpretados em soluções sincréticas por toda a cidade.

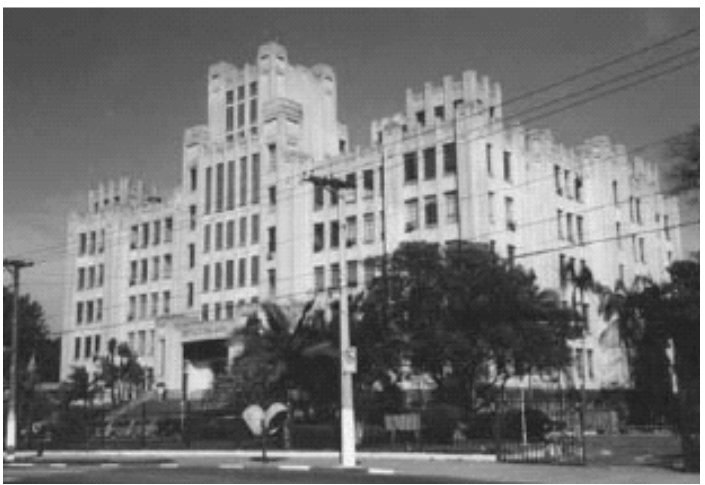

FIGURA 99 : Instituto Biológico. (Mário Whately \& Cia / São Paulo, 1928/45)

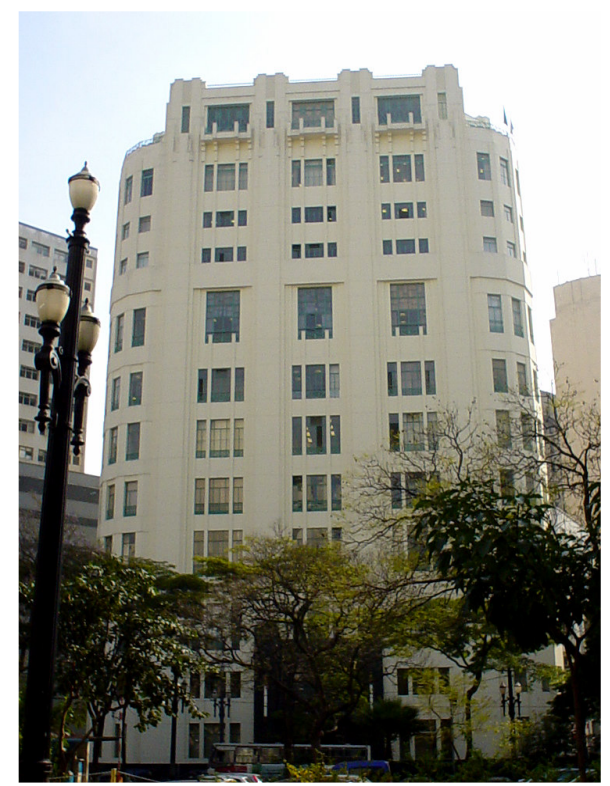

FIGURA 100 : Edifício Saldanha Marinho. (Elisiário Bahiana / São Paulo, 1929/33)
Podemos citar como obras eruditas de base da corrente Art Déco na cidade de São Paulo, os já mencionados edifícios do antigo Banco de São Paulo (1935/38), o Saldanha Marinho (1929/33), o João Brícola (sede do antigo Mappin Stores - 1936/40), além do monumental conjunto arquitetônico do Instituto Biológico (1928/45), cuja novidade formal e estilística deve ter impressionado e impactado profundamente o gosto da sociedade local. Como exemplares "cabeçade-série" residenciais podemos destacar o palacete de Armando Álvares Penteado (1931/32) e as casas de Jayme C. Fonseca Rodrigues (1935) no bairro de Higienópolis.

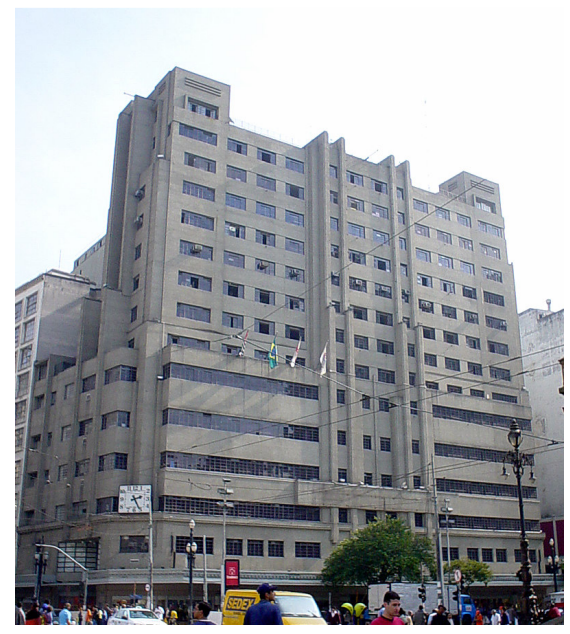

FIGURA 101 : Edifício João Brícola - antigo Mappin Store. (Elisiário Bahiana / São Paulo, 1936/40) 


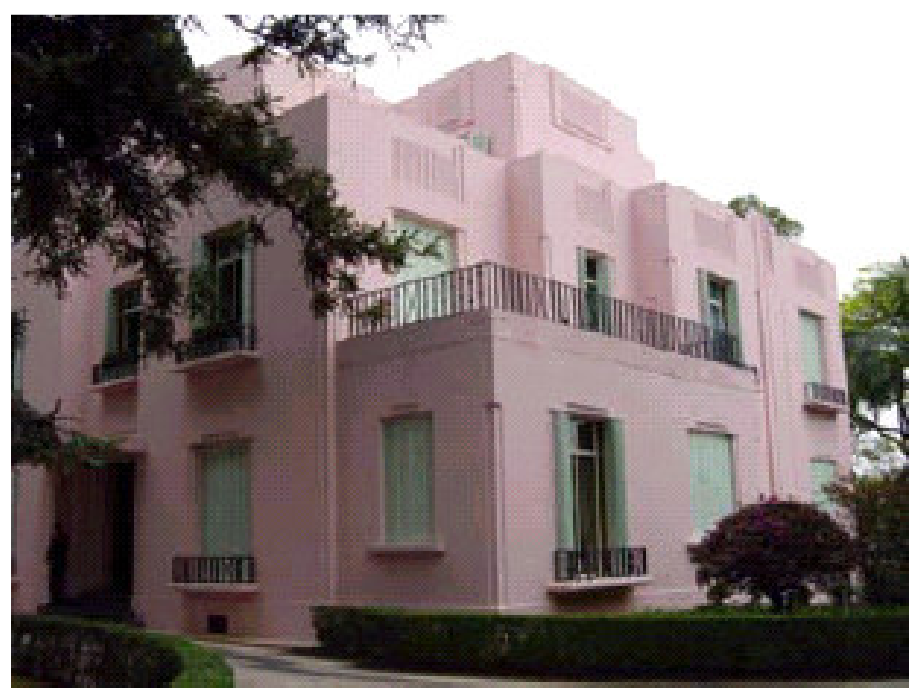

FIGURA 102 : Residência Armando Álvares Penteado na rua Ceará esquina da rua Alagoas. (Dácio Aguiar de Moraes / São Paulo, 1931)

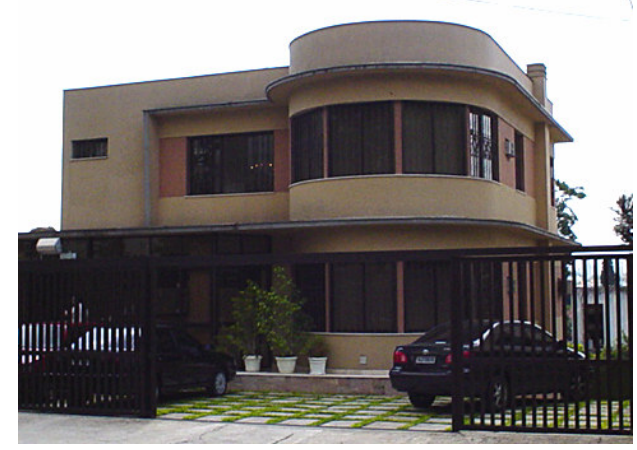

FIGURA 103 : Residência na rua Ceará, 184. (Jayme C. Fonseca Rodrigues / São Paulo, 1935)

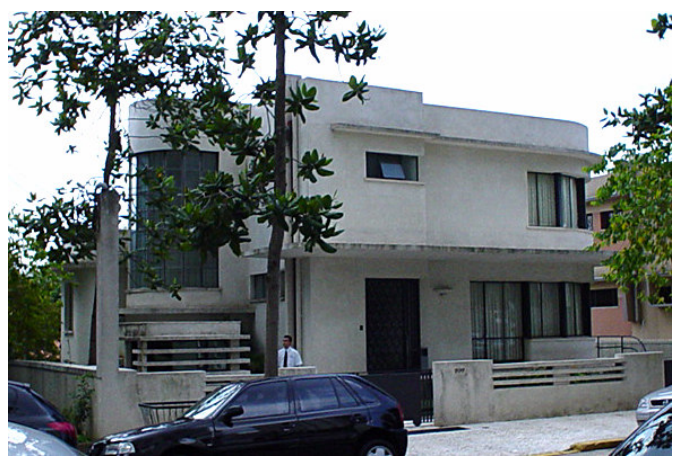

FIGURA 104 : Residência na rua Ceará, 202 (Jayme C. Fonseca Rodrigues / São Paulo, 1935)

$\mathrm{Na}$ classificação estilística da amostra de 407 projetos residenciais, feita a partir da definição inicial dos principais estilemas das linguagens em voga nos anos 20 e $30,{ }^{40}$ foram identificados nove grupos principais: Art Déco (AD); Eclético Classicizante (EC); Eclético Historicista (EH); Estilo Indefinido (El); Moderno (MO); Neocolonial hispano-americano (NH); Neocolonial luso-brasileiro (NL); Neocolonial Simplificado (NS); Normando (NO).

A título de esclarecimento, adotamos neste trabalho o nome Estilo Indefinido (EI) para designar as residências nas quais o construtor não optou por nenhum estilo ou

\footnotetext{
${ }^{40}$ Ver: Principais estilos ou correntes estilísticas presentes na arquitetura residencial paulistana a partir do final do século XIX na seção Apêndices da tese.
} 
linguagem estilística caracterizados por estilemas próprios ou exclusivos. Nestas edificações é claramente perceptível o desejo do construtor em "personalizar" a sua obra ao misturar de maneira aleatória elementos ornamentais, criando novas soluções compositivas ou inventando modinaturas. Percebemos nestas casas uma vontade expressa de renovação ou de "modernidade", subsistindo, no entanto, uma vaga referência ao Ecletismo Classicizante ou Historicista, cujo repertório estilístico aparece diluído na composição das fachadas, dificultando desta forma a sua caracterização e classificação.

Da mesma forma atribuímos o nome genérico de Neocolonial Simplificado (NS) às edificações, predominantemente de classe média, as quais apresentavam similitudes singulares que nos permitiram classificá-las dentro de um mesmo grupo estilístico. Cabe salientar aqui que esta denominação foi usada provisoriamente, uma vez que pretendemos na próxima seção da tese caracterizar e designar com maior precisão esta manifestação arquitetônica residencial paulistana. O termo Neocolonial Simplificado (NS) foi usado pela primeira vez pelo arquiteto e professor Carlos A. C. Lemos para explicar e caracterizar uma parcela da produção arquitetônica paulistana de classe média dos anos 20, que segundo ele, apresentava uma identidade própria. Este autor nos diz que

".../ o aparecimento, digamos espontâneo, de uma corrente estilística autóctone caracterizada pela apropriação e decomposição principalmente dos elementos semânticos do neocolonial e pela simplificação dos critérios eruditos de modinatura: corrente cultuada pela classe média, a que chamamos, na falta de melhor nome, de "neocolonial simplificado". Nasceu ela de intenção plástica ligada ao novo partido arquitetônico definido nos tempos difíceis da paralisação das importações devido à I Grande Guerra, através de improvisações do recente "saber fazer" surgido da tecnologia do imigrante, cujas lições de estética haviam sido esquecidas face à onda nacionalista." (LEMOS, 1985, p. 20)

A análise dos 407 exemplares residenciais selecionados na pesquisa arquitetônica foi dividida em dois conjuntos temporais - projetos de 1923/29 e de 1930/36 - tendo em vista o reconhecimento de especificidades diversas entre a produção arquitetônica dos anos 20 e a dos anos 30. A partir das informações sistematizadas no banco de dados Edificações Residenciais, realizado com base nas informações coletadas nas fichas de cada projeto sorteado, foram produzidos gráficos para melhor compreensão e visualização dos fenômenos arquitetônicos estudados.

O gráfico geral LEVANTAMENTO DOS ESTILOS foi elaborado tomando-se como base toda a amostra da produção arquitetônica residencial paulistana do período (19231936) nos bairros sorteados. Assim, cada uma das nove barras verticais corresponde à porcentagem individual de incidência das linguagens estilísticas encontradas na pesquisa 
arquitetônica e cuja somatória equivale a 100,0\%. Da mesma forma, para uma melhor compreensão da distribuição porcentual dos estilos ou correntes estilísticas por zona da cidade de São Paulo foram realizados os gráficos parciais, LEVANTAMENTO DOS ESTILOS , Grupo I /zona Oeste e Grupo II / zona Sudoeste/Sul.

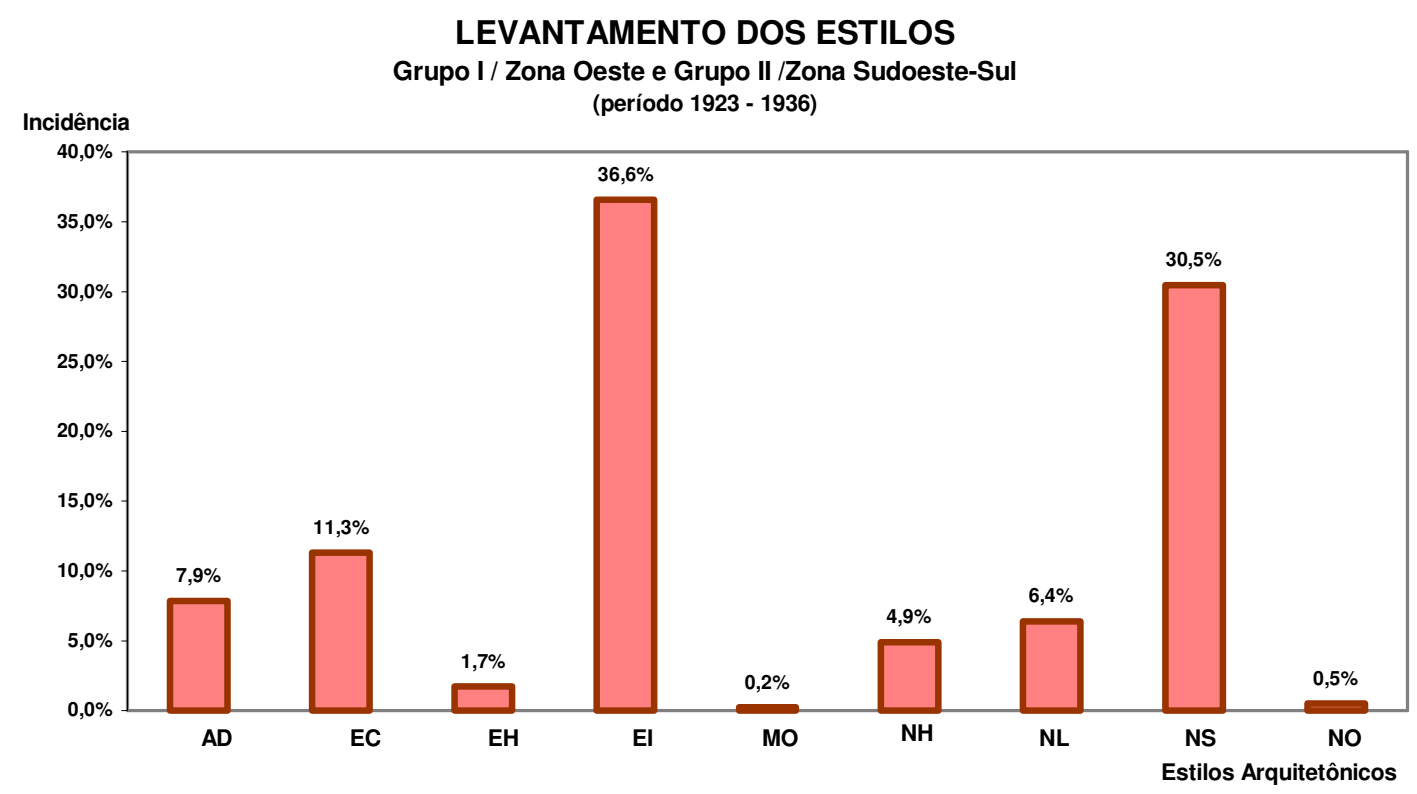

No gráfico geral LEVANTAMENTO DOS ESTILOS observa-se que o Neocolonial Simplificado (NS) e o Estilo Indefinido (EI) compareceram expressivamente no conjunto das manifestações arquitetônicas residenciais paulistanas entre 1923 e 1936, apresentando uma incidência de 30,5\% e 36,6\% respectivamente. Em seguida, vieram o Ecletismo Classicizante, com uma incidência de $11,3 \%$; o Neocolonial, que somou $11,3 \%$, nas suas versões luso-brasileira (6,4\%) e hispano-americana (4,9\%); e o Art Déco com 7,9\%.

É importante ressaltar que os valores porcentuais apresentados nesse gráfico referem-se à totalidade da incidência do estilo ou linguagem estilística durante os anos $20 \mathrm{e}$ 30, não levando em conta que o Neocolonial hispano-americano ( $\mathrm{NH})$, assim como, o Art Déco (AD), só se manifestaram plenamente na capital paulista no decorrer da década de 30 . Desta forma, quando se avalia somente a produção arquitetônica residencial de 1923 a 1929, estes dois grupos estilísticos não aparecem; porém, na análise do período 1930-1936 já notamos a crescente presença do $\mathrm{NH}(11,4 \%)$ e do $\mathrm{AD}(18,3 \%)$ no conjunto dos grupos estilísticos identificados.

Pelo gráfico geral LEVANTAMENTO DOS ESTILOS observa-se, também, que o Ecletismo Historicista (EH), o Normando (NO) e o Moderno (MO) representaram ocorrências 
esporádicas e pouco significativas dentro do universo de exemplares residenciais sorteados nos bairros das zonas Oeste e Sudoeste/Sul, com uma incidência de 1,7\%, 0,5\% e 0,2\% respectivamente.

Quando se faz a mesma análise nos gráficos parciais LEVANTAMENTO DOS ESTILOS, referentes à zona Oeste e à zona Sudoeste/Sul, verifica-se que o NS apresentou pequena variação numérica na sua incidência nos bairros da zona Oeste (33,5\%) em comparação com a observada nos bairros da zona Sudoeste/Sul (27,9\%), em todo o período estudado. Já o El mostrou uma significativa predominância em relação aos outros grupos estilísticos levantados na zona Sudoeste/Sul, com uma ocorrência de 43,8\%; na zona Oeste o El manteve-se com uma incidência de $28,2 \%$. Por estes gráficos percebemos também que o Ecletismo Classicizante (EC) apresenta uma incidência maior nos bairros da zona Oeste $(17,6 \%)$, quando comparada com a detectada na zona Sudoeste/Sul $(5,9 \%)$.
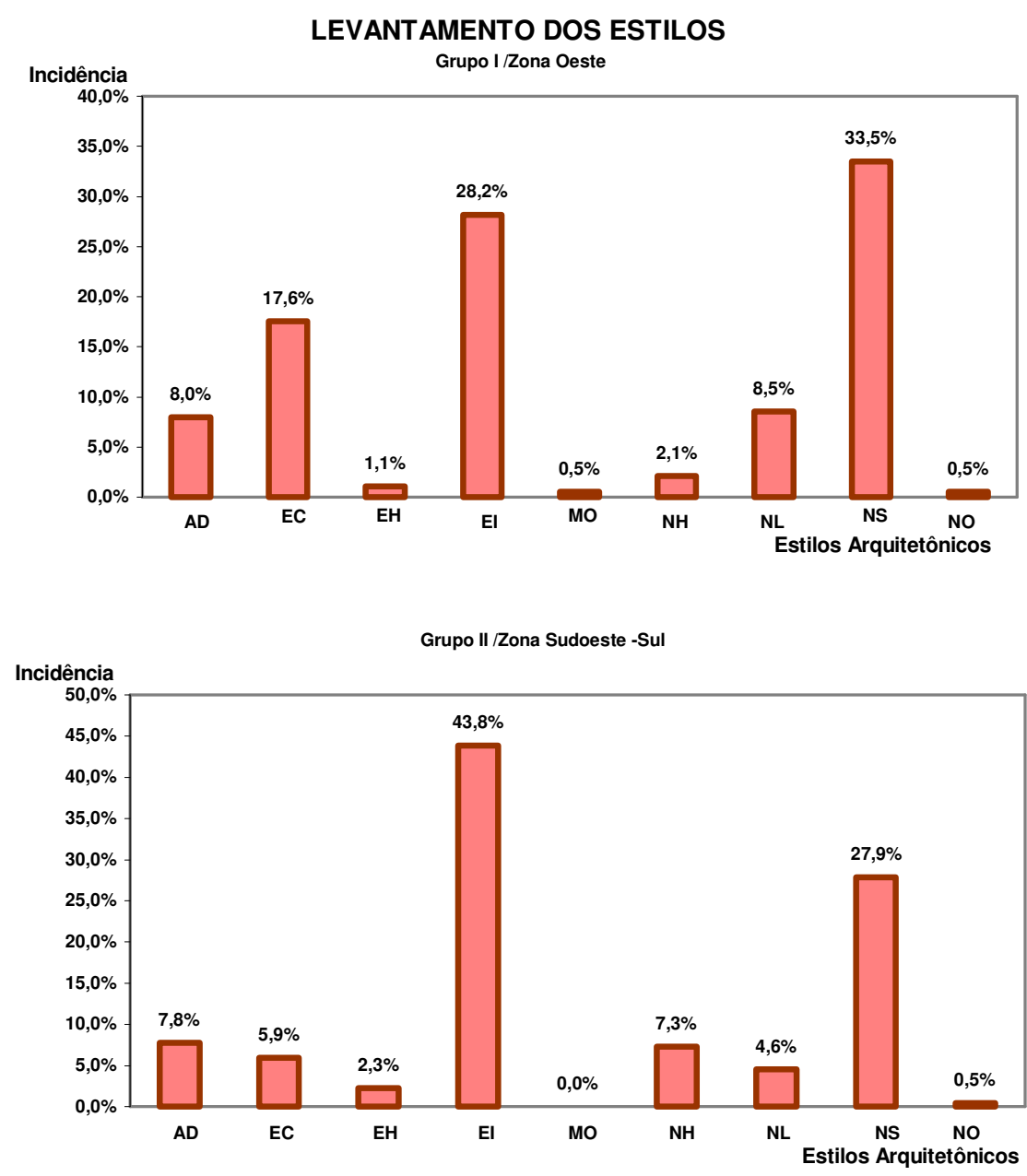
Com o objetivo de analisar mais detalhadamente como se processou o desenvolvimento de cada corrente estilística ao longo do período estudado, elaboramos também gráficos individuais correspondentes à evolução temporal (ano a ano) das principais linguagens estilísticas identificadas na pesquisa arquitetônica. Cada barra vertical dos gráficos EVOLUĈ̃O DOS ESTILOS POR ANO equivale à porcentagem de incidência do estilo ou corrente estilística em relação ao total da produção arquitetônica verificada naquele ano de acordo com a zona estudada.

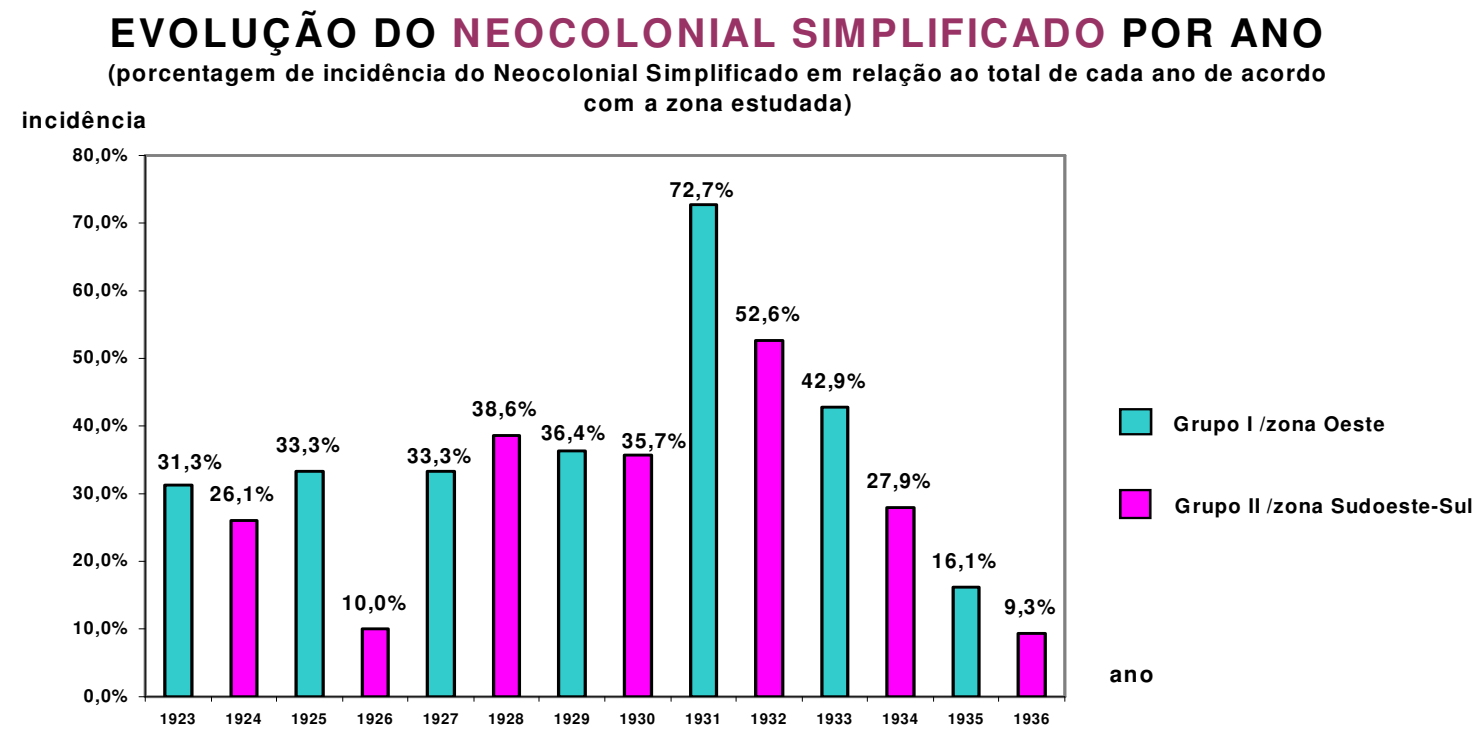

Pode-se constatar pelo gráfico EVOLUÇ̃̃O DO NEOCOLONIAL SIMPLIFICADO POR ANO que durante a década de 20 o Neocolonial Simplificado (NS) manteve-se com uma incidência estável nas duas zonas, em torno de 30,0\%; a partir do ápice em 1931, observa-se que durante os anos 30 houve uma queda acentuada na sua incidência em ambas as zonas até o fim do período estudado, o que demonstra claramente o rápido e progressivo esgotamento desta corrente estilística na cidade de São Paulo. 
O Neocolonial Simplificado apresentou soluções variantes nas suas manifestações arquitetônicas residenciais na capital paulista. Assim, pode-se reconhecer fachadas de alvenaria de tijolos à vista no projeto 64; os projetos 67 e 70 exemplificam residências com paredes revestidas; o uso mesclado de panos de tijolos aparentes com partes revestidas aparece no projeto 89; o projeto 6 mostra um exemplo de telhado com os dois "triângulos" ladeando o oitão frontal, muito freqüentes em São Paulo nas casas de classe média do Neocolonial Simplificado.

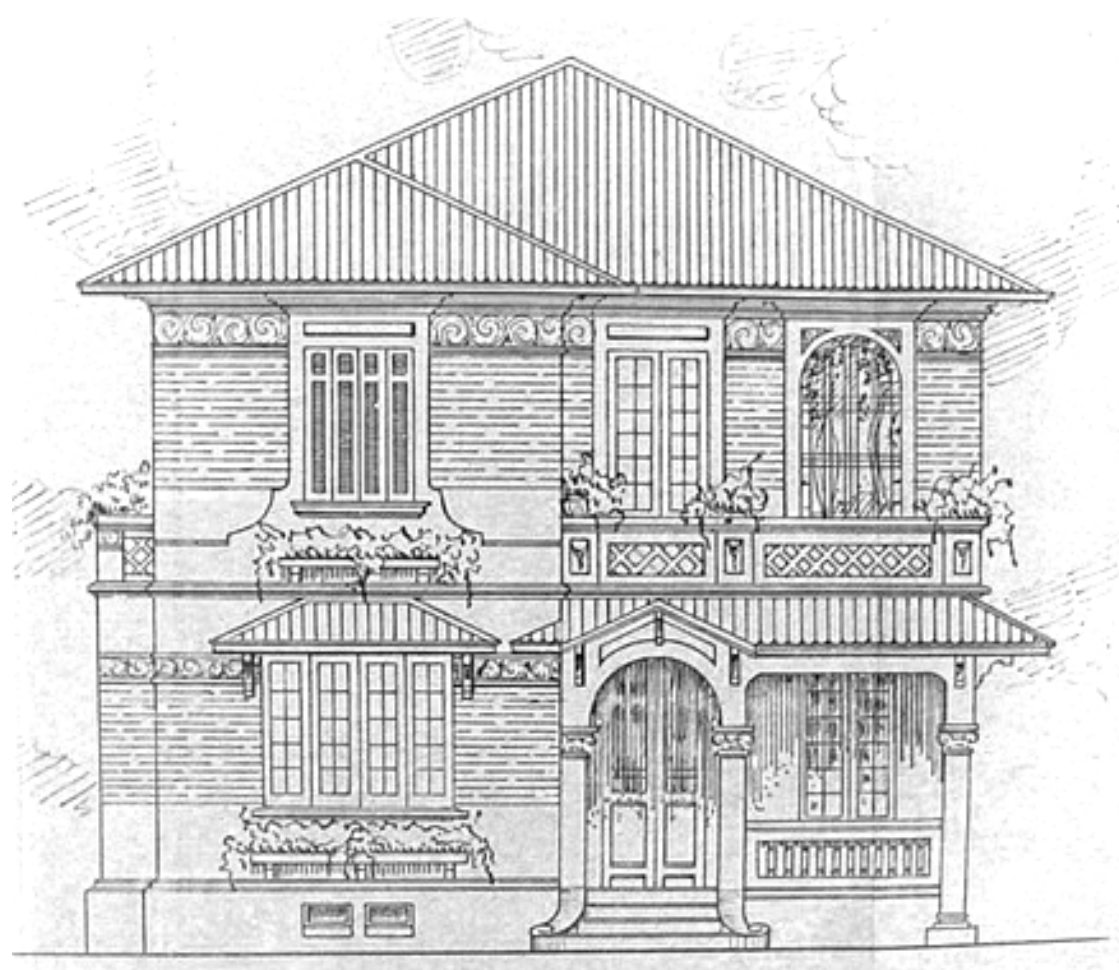

FIGURA 105 : Casa localizada na alameda Itu. (projeto 89 / processo oํ 2.916/26) 


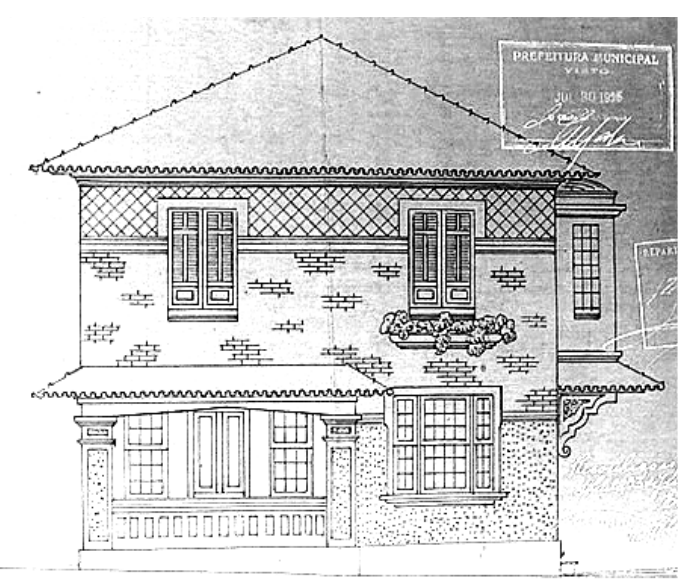

FIGURA 106 : Casa à rua Antonio Carlos. (projeto 64 / processo no 21.877/25)

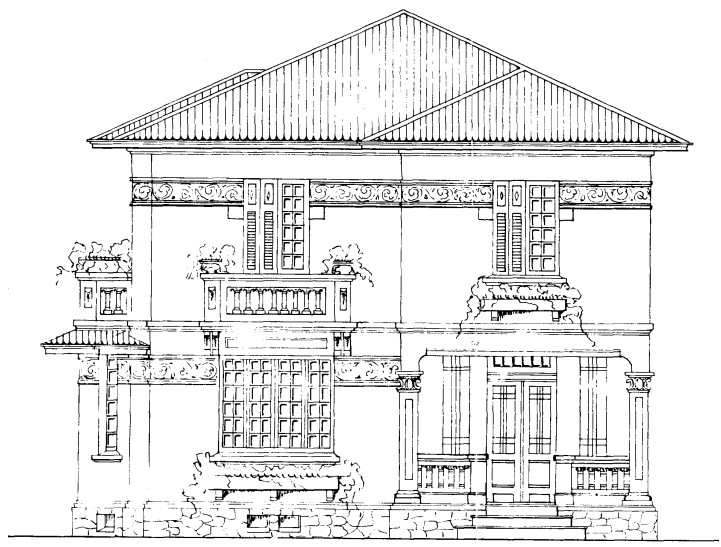

FIGURA 108 : Casa à rua da Consolação. (projeto 70 / processo $\mathrm{n}^{\circ} \mathbf{2 3 . 4 0 6 / 2 5 )}$

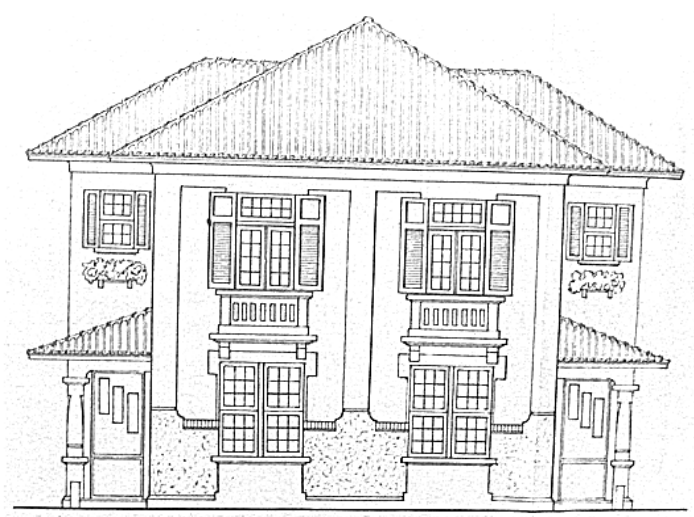

FIGURA 107 : Casa à rua Clélia. (projeto 67 / processo $\mathrm{n}^{\circ} \mathrm{21.179/25)}$

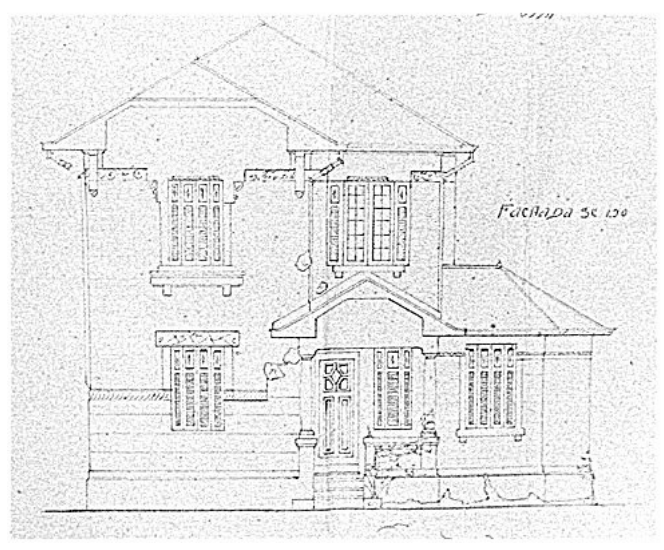

FIGURA 109 : Casa à rua da Consolação esquina da alameda Itu. (projeto 6 / processo no 252/23) 
Outra ocorrência de destaque é o projeto 121, com os cunhais imitando pedras angulares e bossagem, e a faixa horizontal em massa logo abaixo do pequeno beiral do telhado. O projeto 208 é também digno de nota, porque mostra um exemplo raro de casa térrea adotando o Neocolonial Simplificado como linguagem estilística.

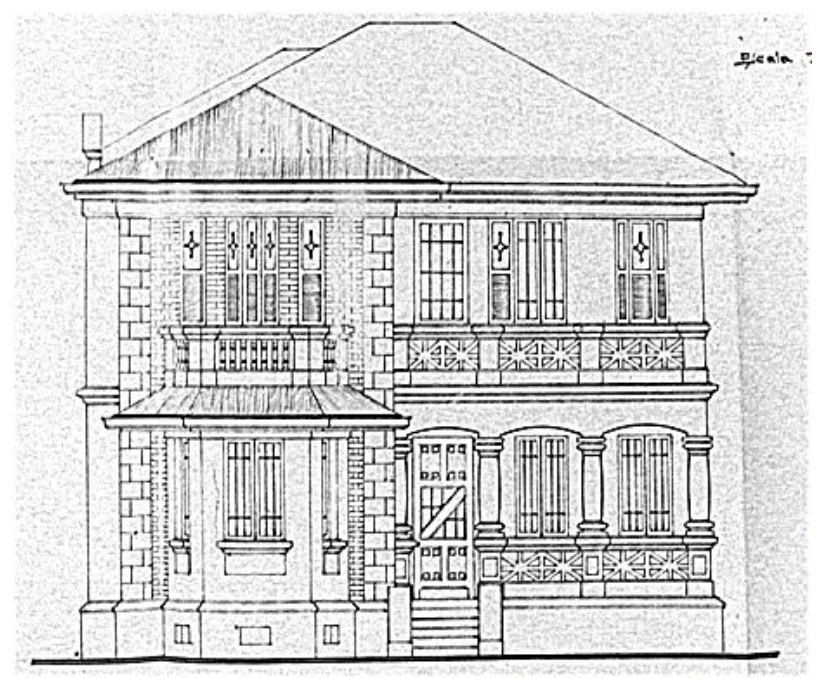

FIGURA 110 : Casa à rua Conselheiro Brotero. (projeto 121 / processo no $48.206 / 27$ )

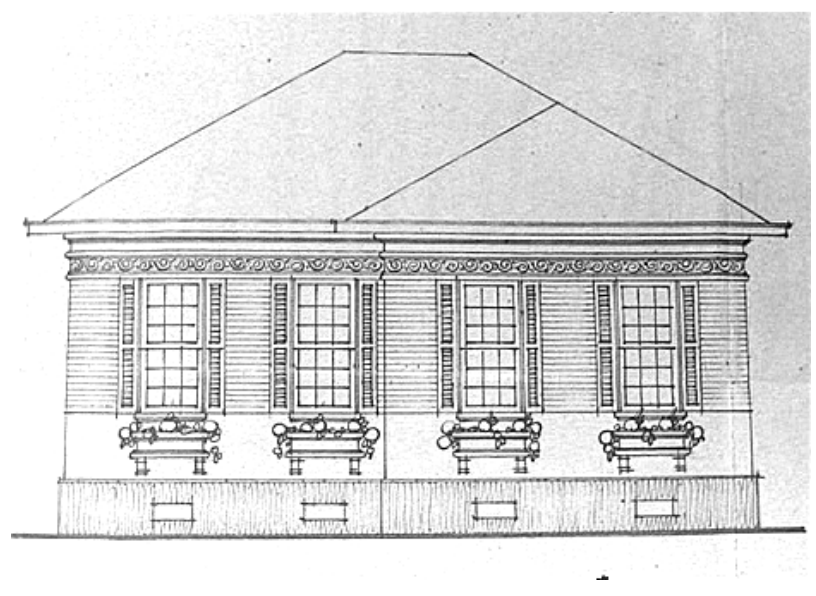

FIGURA 111 : Casa à rua Domingos Rodrigues. (projeto 208 / processo no $48.556 / 29$ ) 
Verificou-se no gráfico EVOLUÇÃO DO ESTILO INDEFINIDO POR ANO que na década de 20 o Estilo Indefinido (EI) esteve presente em níveis expressivos nas manifestações arquitetônicas residenciais, tanto dos bairros da zona Oeste (média no período de 30,0\%), quanto nos da zona Sudoeste/Sul (média no período superior a 53,0\%). Nestes anos, percebeu-se também que a incidência do El na zona Oeste foi mais regular ao longo do tempo quando comparada à da zona Sudoeste/Sul.

EVOLUÇÃO DO ESTILO INDEFINIDO POR ANO

(porcentagem de incidência do Estilo Indefinido em relação ao total de cada ano de acordo com a zona estudada)

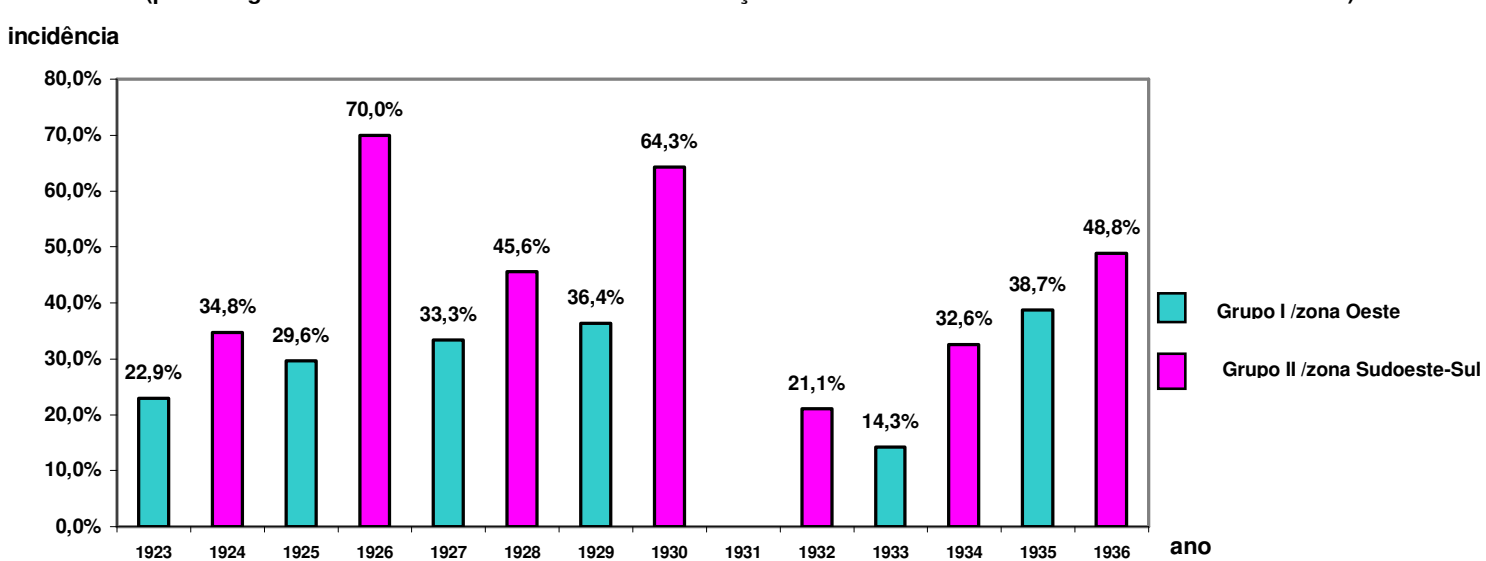

A partir dos anos 30 foi observada nesse gráfico uma queda vertiginosa seguida por uma progressiva recuperação do Estilo Indefinido. Este fato pode ter sido causado pela redução do nível construtivo que atingiu toda a cidade de São Paulo (em particular, as construções populares), conseqüência da crise de 1929 e da Revolução de 1930. Constatou-se nos processos levantados nos primeiros anos da década de 30 (especialmente, no ano de 1931) uma altíssima incidência de pedidos de reforma e de ampliação, superando numericamente, em muito, as solicitações de aprovação de novas construções, o que leva a acreditar na possibilidade dos efeitos da crise econômica-política brasileira estarem, naquele momento, afetando diretamente o poder aquisitivo das camadas menos favorecidas da população paulistana, e conseqüentemente, a produção de novas moradias populares. Depois da Revolução Constitucionalista de 1932, percebeu-se, através da curva ascendente do gráfico, uma retomada do crescimento da incidência do Estilo Indefinido nas edificações residenciais paulistanas em ambas as zonas. 
O reconhecimento do Estilo Indefinido é complexo, uma vez que ele é produto dos mais diversos sincretismos arquitetônicos e abrange uma gama variada de soluções de composição de fachada. Desta forma, foram enquadradas como pertencentes ao Estilo Indefinido todas as casas que não puderam ser classificadas em nenhum dos outros grupos estilísticos. Os exemplos residenciais encontrados na pesquisa arquitetônica incluem desde a arquitetura chã até soluções personalistas inusitadas.

Os projetos 152, 215 e 71 ilustram fachadas em que se percebe a presença de alguns estilemas remanescentes do Ecletismo Historicista e do Classicizante.

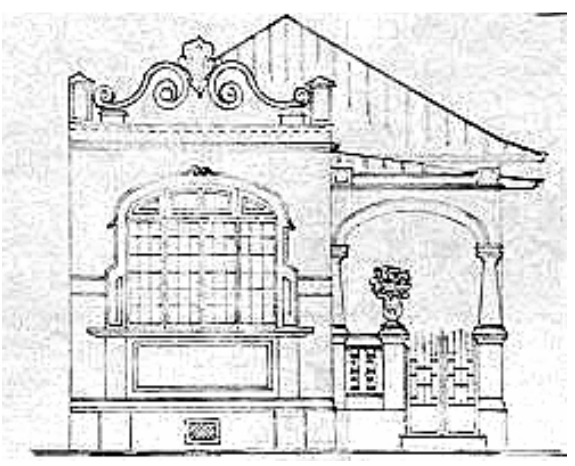

FIGURA 112 : Casa à rua Cônego Eugênio Leite. (projeto 152 / processo no 22.384/28)

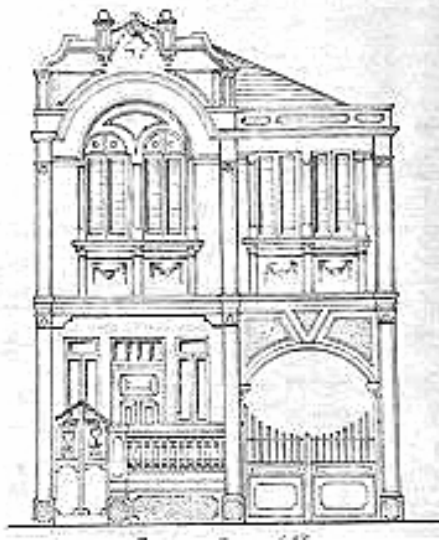

FIGURA 113 : Casa à rua Araújo. (projeto 215 / processo no 2.602/29)

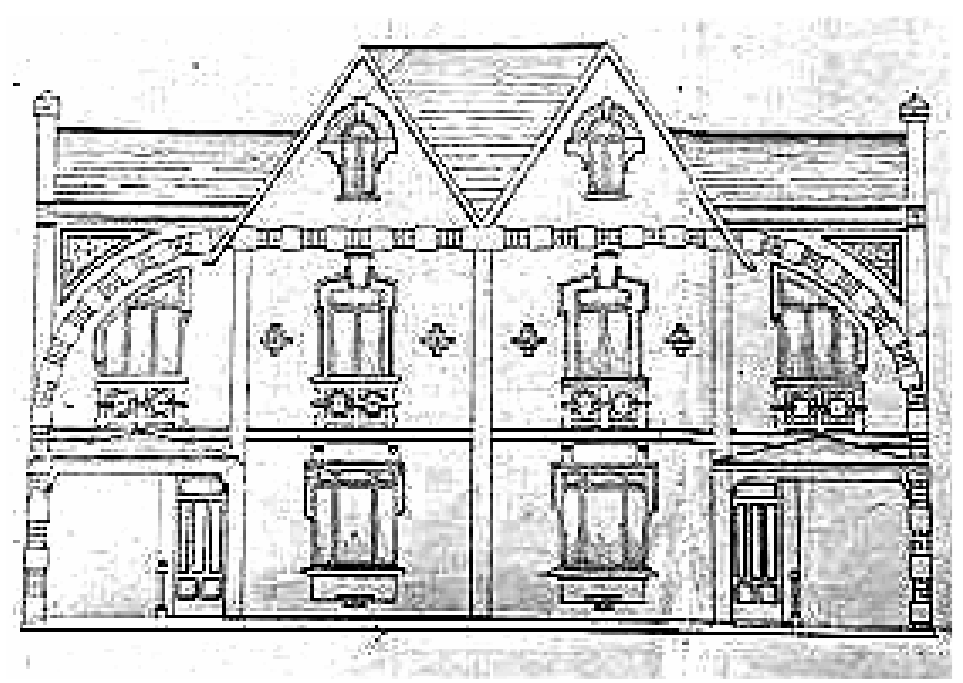

FIGURA 114 : Casas geminadas à rua da Consolação. (projeto 71 /processo no 25.377/25) 
A chamada arquitetura chã é exemplificada pelo projeto 86 , que mostra um conjunto de casas térreas geminadas cujo único elemento de ornamentação é um óculo no oitão.

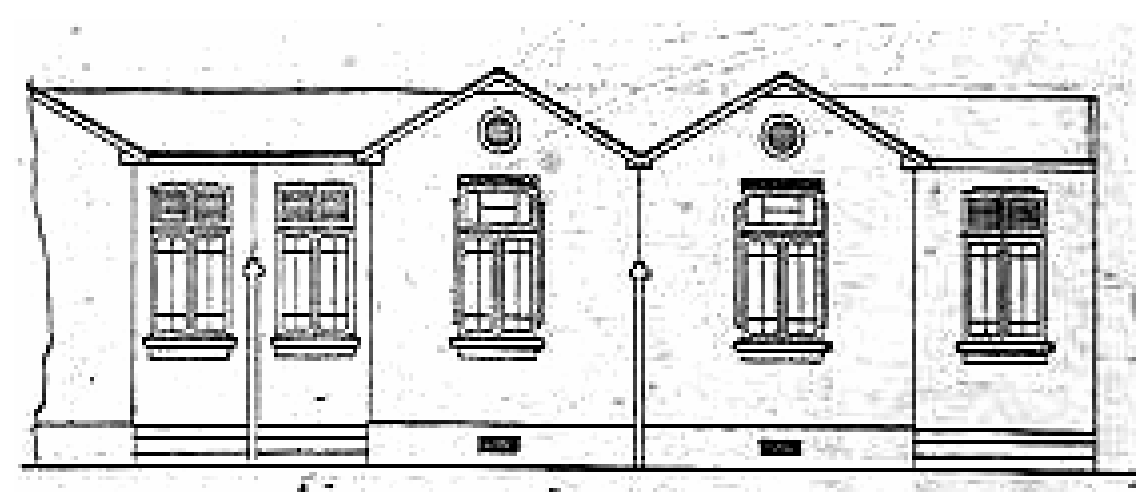

FIGURA 115 : Casas geminadas à rua Afonso Sardinha. (projeto 86 / processo nº 26.000/25)

Os projetos 114 e 168 mostram composições de fachadas sem um caráter definido, onde se encontram misturados estilemas variados, com uma vaga referência ao Neocolonial Simplificado.

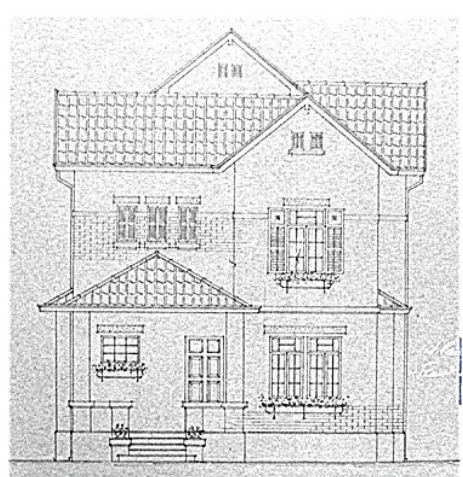

FIGURA 116 : Casa à rua Homem de Mello esquina da rua Caetés. (projeto 114 / processo $\mathrm{n}^{\circ}$ 4.322/27)

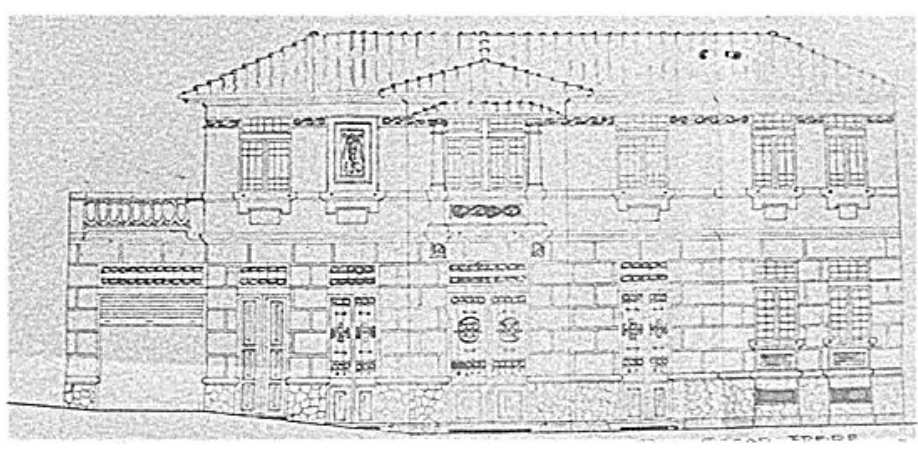

FIGURA 117 : Casa à rua Oscar Freire. (projeto 168 / processo ํำ 22.042/28) 
Os oitões decorados com faixas imitando enxaimel estão presentes nos projetos 151 e 179. O sincretismo entre o Art Déco e o Neocolonial Simplificado pode ser percebido na composição da fachada da residência do projeto 98; e, como exemplo de solução completamente incomum, extravagante e esquisita, pode ser citado o projeto 90 , referente a uma residência que lembra remotamente uma fortaleza medieval.

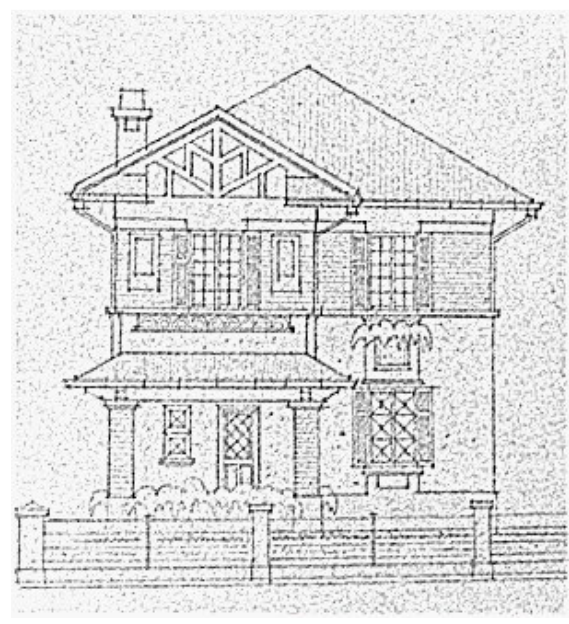

FIGURA 118: Casa à rua Cônego Eugênio Leite. (projeto $151 /$ processo $\mathrm{n}^{0}$ $50.175 / 28)$

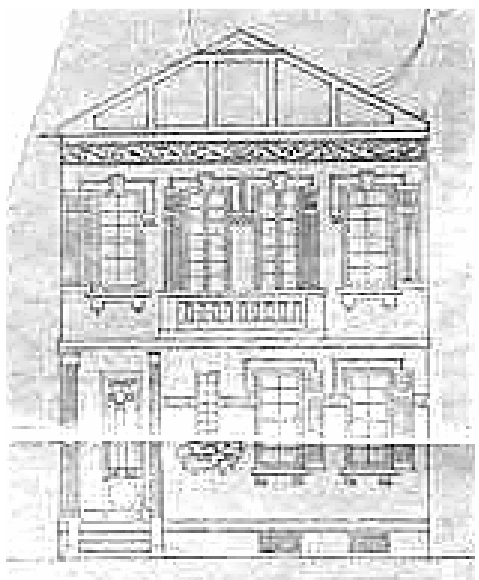

FIGURA 119: Casa à rua Sena Madureira. (projeto 179 / processo $n^{\circ}$ 23.836/28)

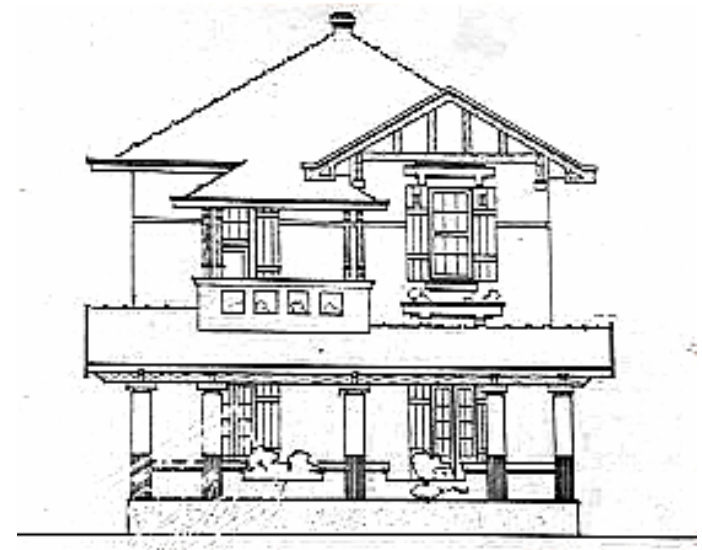

FIGURA 120 : Casa à rua Bela Cintra. (projeto $98 /$ processo $\mathrm{n}^{\circ}$ 10.896/26)

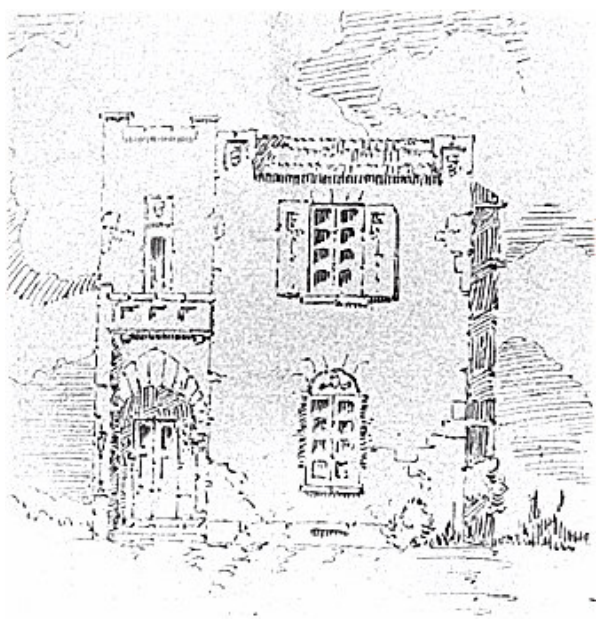

FIGURA 121 : Casa à alameda Casa Branca. (projeto 90 / processo $\mathrm{n}^{\circ} \mathrm{45.780/26)}$ 


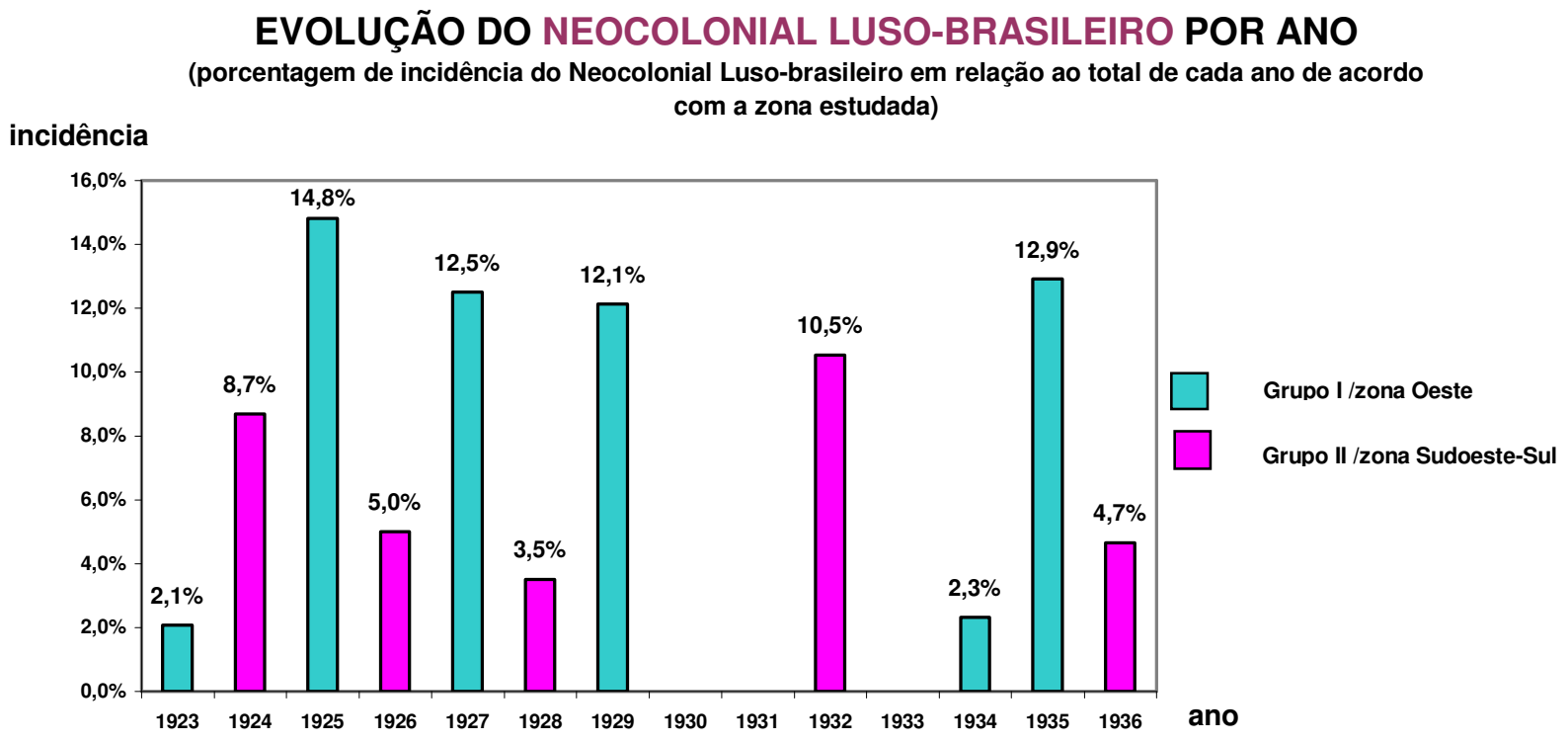

O gráfico EVOLUĈ̃O DO NEOCOLONIAL LUSO-BRASILEIRO POR ANO mostra que o Neocolonial luso-brasileiro (NL) manifestou-se de maneira mais constante durante os anos 20. Quando se analisou a produção arquitetônica deste período percebeu-se que o NL teve uma participação mais expressiva nas residências localizadas nos bairros da zona Oeste (média de 13\%) em comparação com as da zona Sudoeste/Sul (média de 6,0\%). Observou-se também que durante a década de 30, com a concorrência do Neocolonial hispano-americano (ou Missões) e do Art Déco, o Neocolonial luso-brasileiro apresentou uma incidência irregular em ambas as zonas estudadas.

Os projetos 118 e 402 exemplificam residências com fachadas de inspiração Neocolonial luso-brasileiro. A versão hispano-americana do Neocolonial está presente nos projetos 279 e 316. 


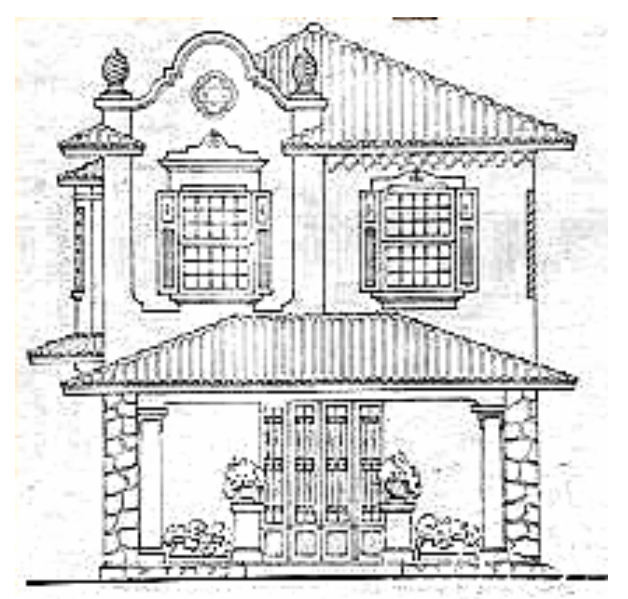

FIGURA 122 : Casa à rua da Consolação. (projeto 118 / processo no 40.583/27)

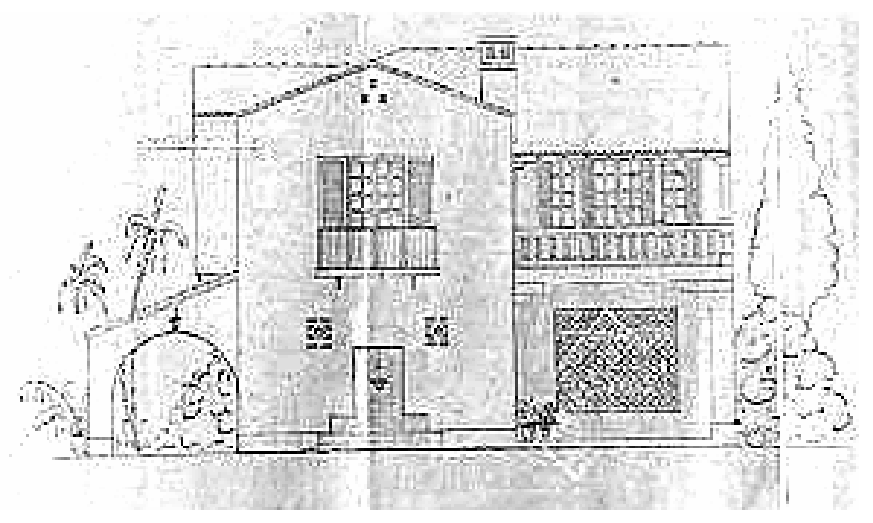

FIGURA 124 : Casa à alameda Itu. (projeto $279 /$ processo $\mathrm{n}^{\circ}$ 23.066/34)

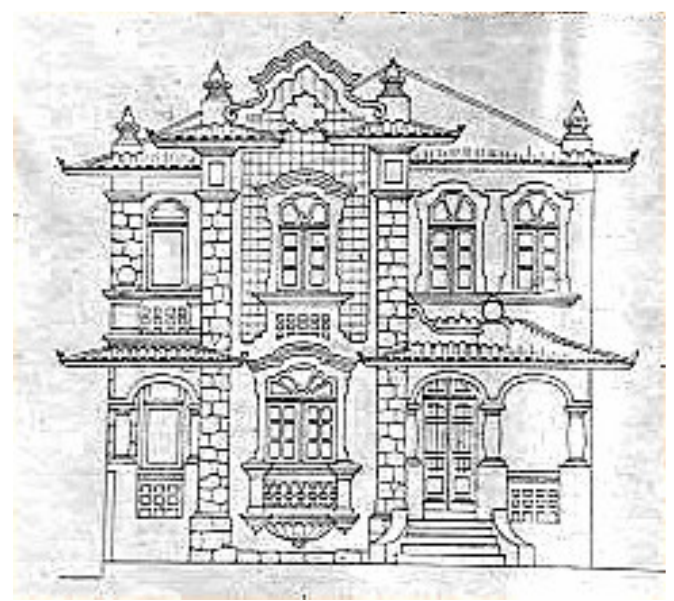

FIGURA 123 : Casa à rua Fernando de Albuquerque esquina da rua Augusta. (projeto 402 / processo $n^{\circ}$ 26.715/27)

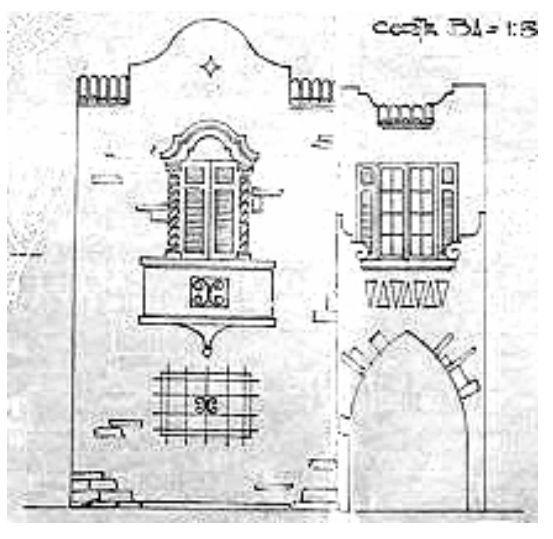

FIGURA 125 : Casa à rua Sena Madureira. (projeto 316 / processo $\mathrm{n}^{0}$ $65.345 / 34)$ 


\section{EVOLUÇÃO DO ART DÉCO POR ANO}

(porcentagem de incidência do Art Déco em relação ao total de cada ano de acordo com a zona estudada)

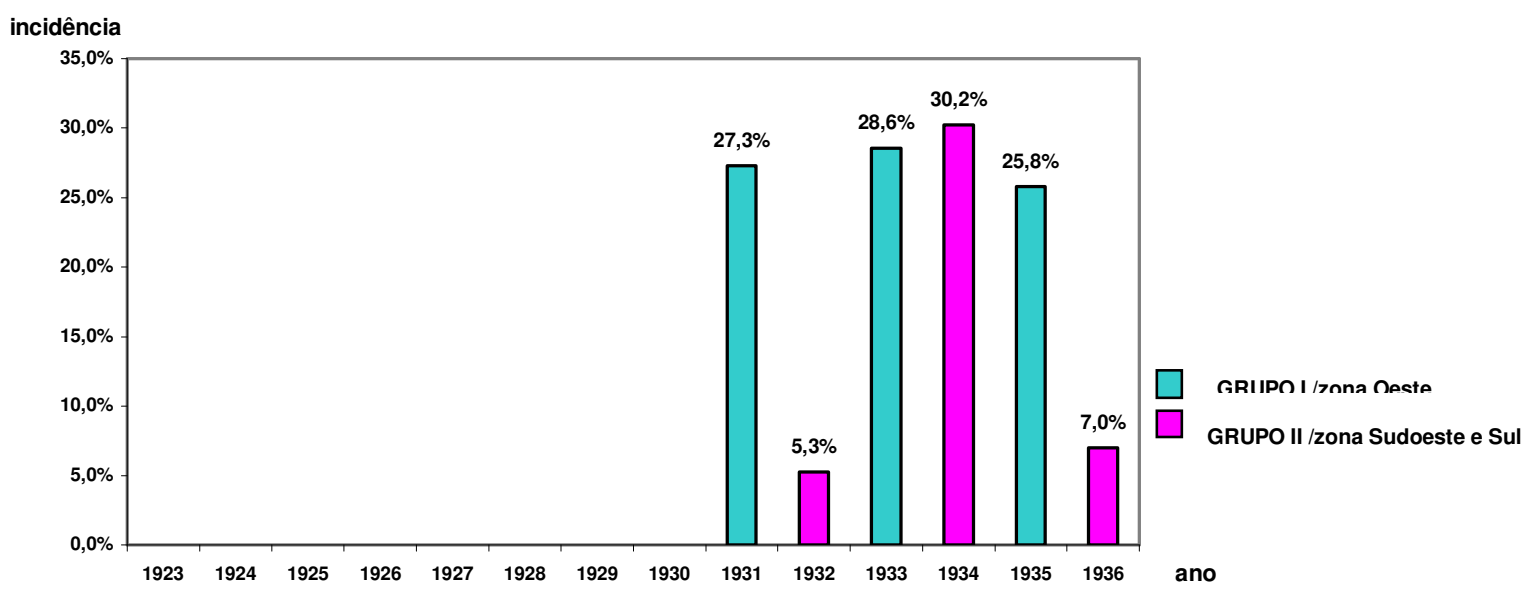

O gráfico EVOLUÇÃO DO ART DÉCO POR ANO demonstra que o Art Déco se difundiu efetivamente em São Paulo a partir dos anos 30 e que as ocorrências desta corrente estilística foram mais regulares nos bairros da zona Oeste, apresentando uma média em torno de $27,0 \%$, quando comparadas com as da zona Sudoeste/Sul.

Como exemplos de residências Art Déco selecionadas na pesquisa arquitetônica podemos destacar os projetos 240, 314 e 231 .

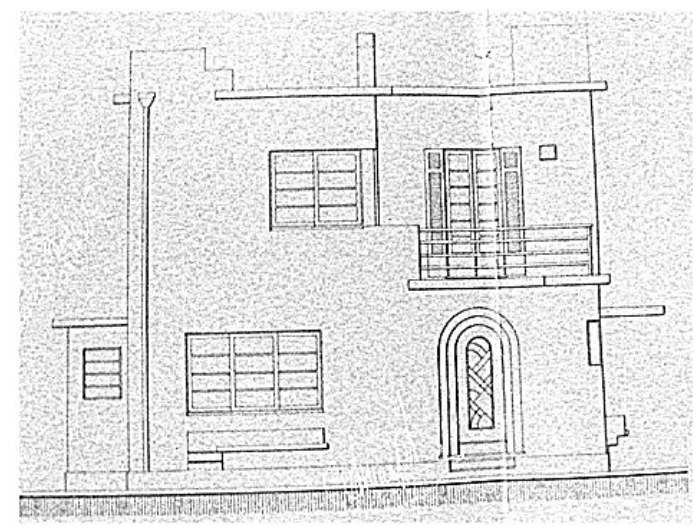

FIGURA 126 : Casa à rua Martinico Prado. (projeto 240 / processo ํㅜ $48.428 / 31$ )

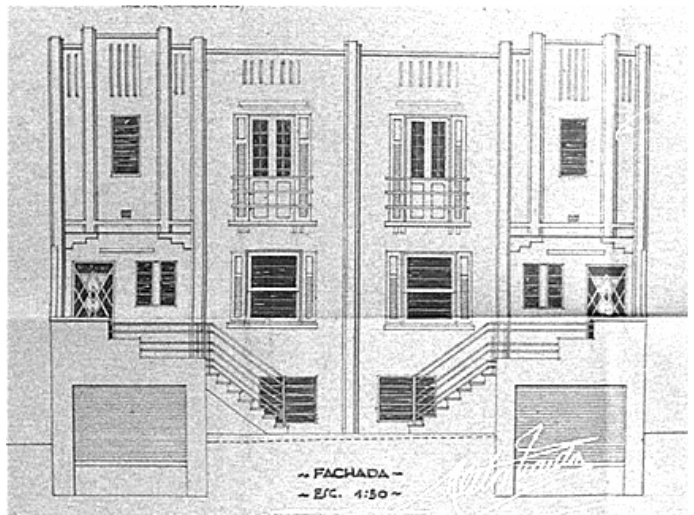

FIGURA 127 : Casas geminadas à rua Oscar Freire. (proieto 314 / processo $\mathrm{n}^{\circ} 55.646 / 34$ ) 

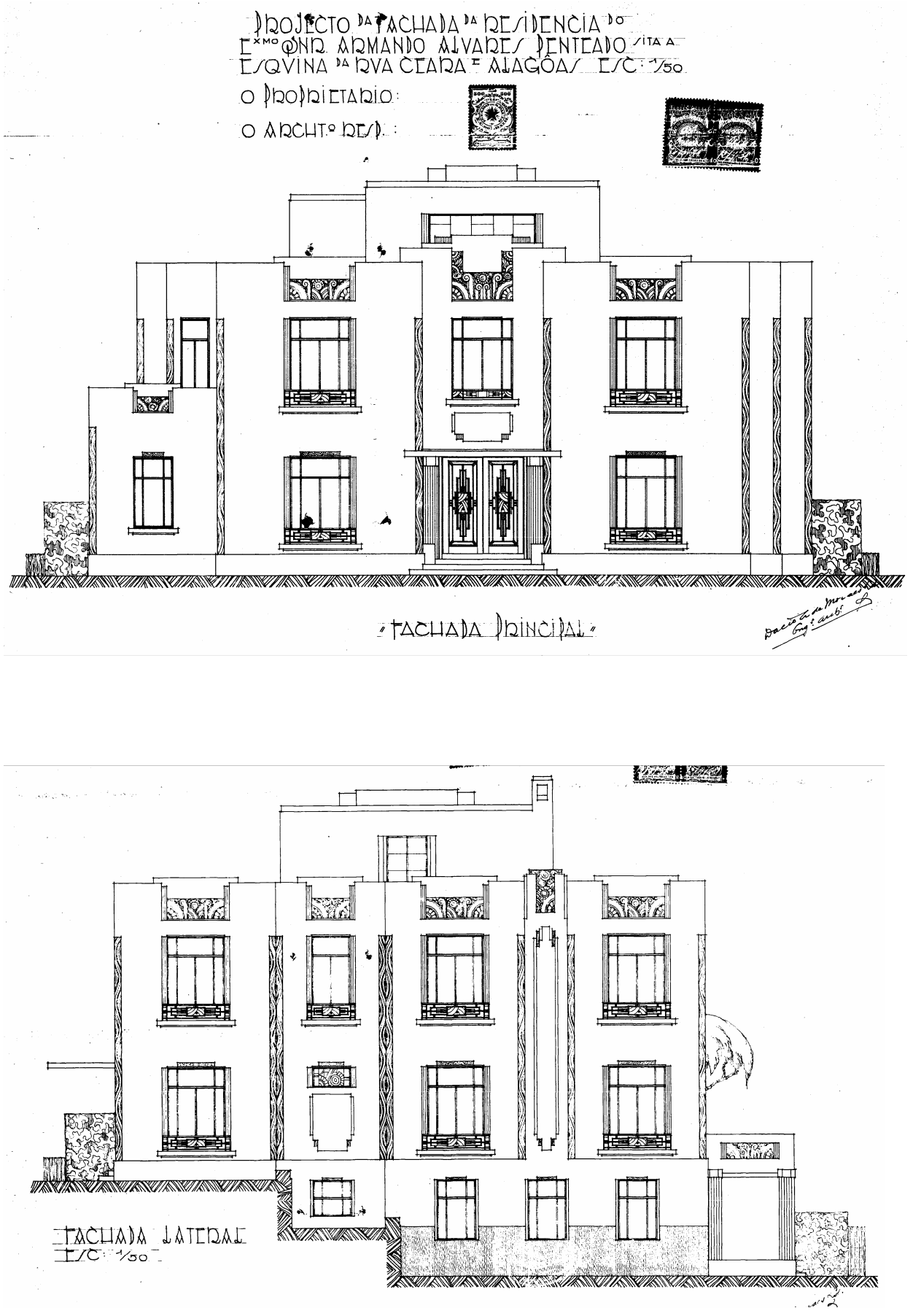

FIGURAS 128 e 129 : Fachadas da residência Armando Álvares Penteado projetada por

Dácio Aguiar de Moraes. (projeto 231 /processo no 42.716/31) 


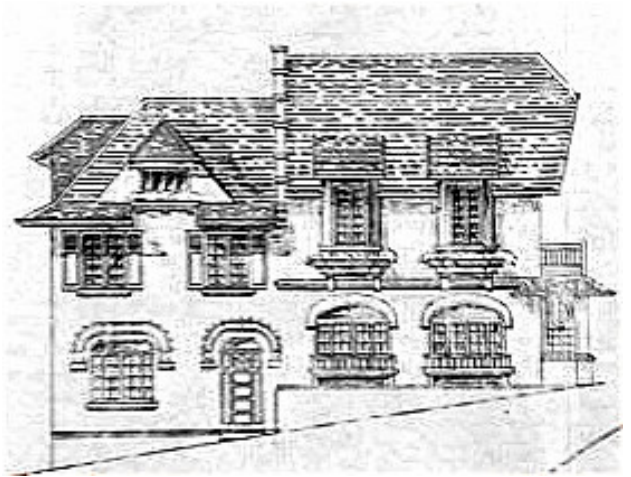

FIGURA 130 : Casas à rua Albuquerque Lins. (projeto 16 / processo $\mathrm{n}^{\circ} \mathrm{37.081/23 \text {) }}$
Como já foi dito, a incidência do Normando (NO) e Moderno (MO) foi excepcional na amostra de projetos sorteados, tendo sido classificadas como normandas somente duas residências, referentes aos projetos 16 e 150 e uma como moderna, correspondente ao projeto 266.
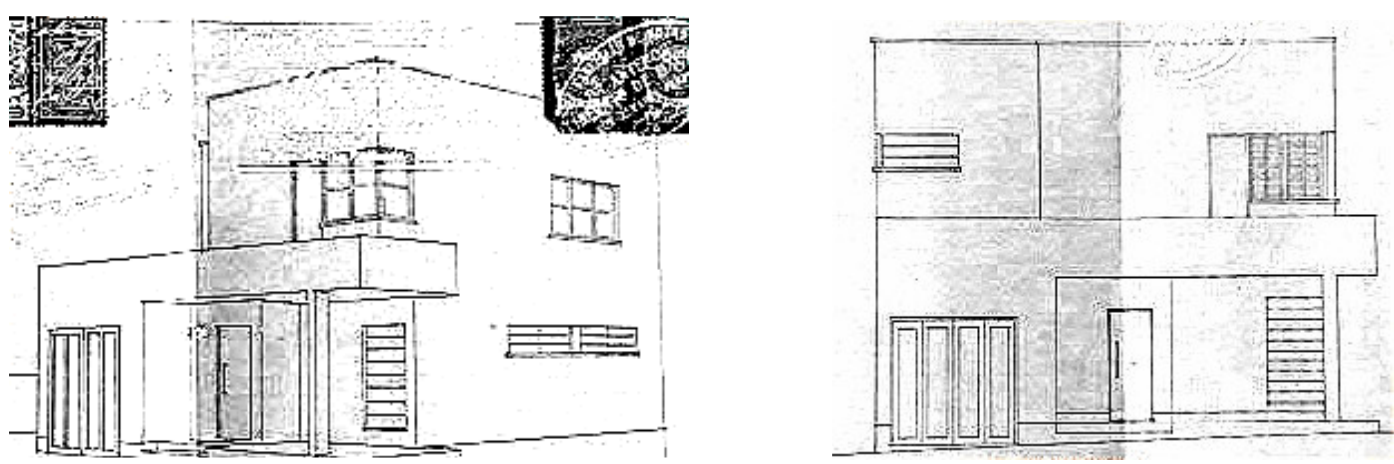

FIGURAS 131 e 132 : Perspectiva e fachada frontal da residência da rua Dr. Franco da Rocha projetada pelo escritório Moya \& Malfatti. (projeto 266 / processo no $17.317 / 33$ )
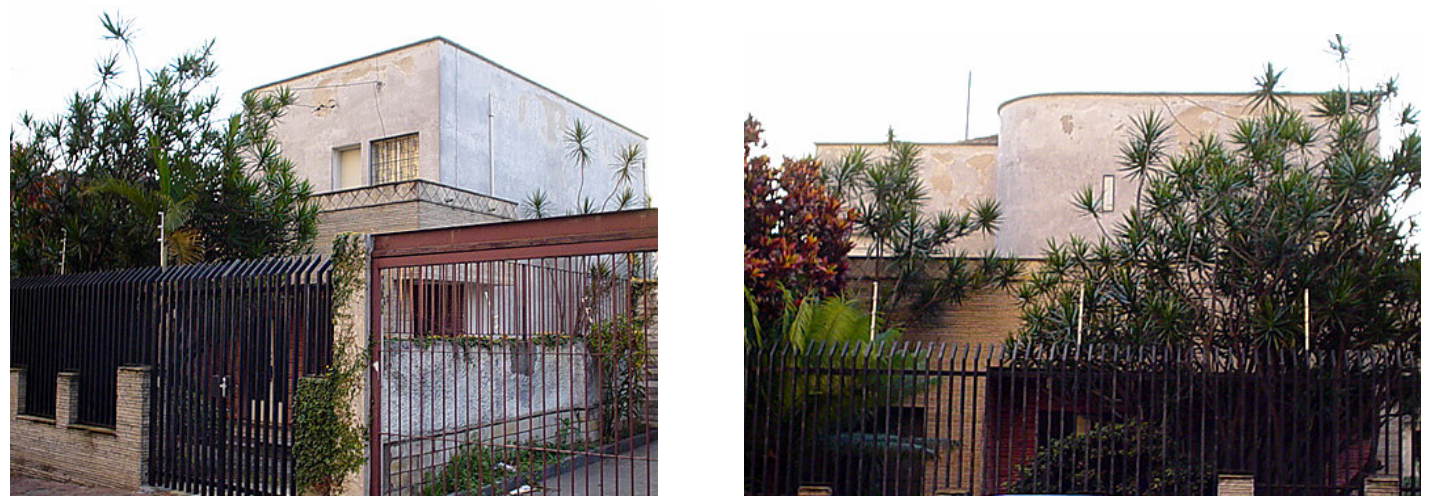

FIGURAS 133 e 134 : Fachada da residência da rua Dr. Franco da Rocha em 2003. 


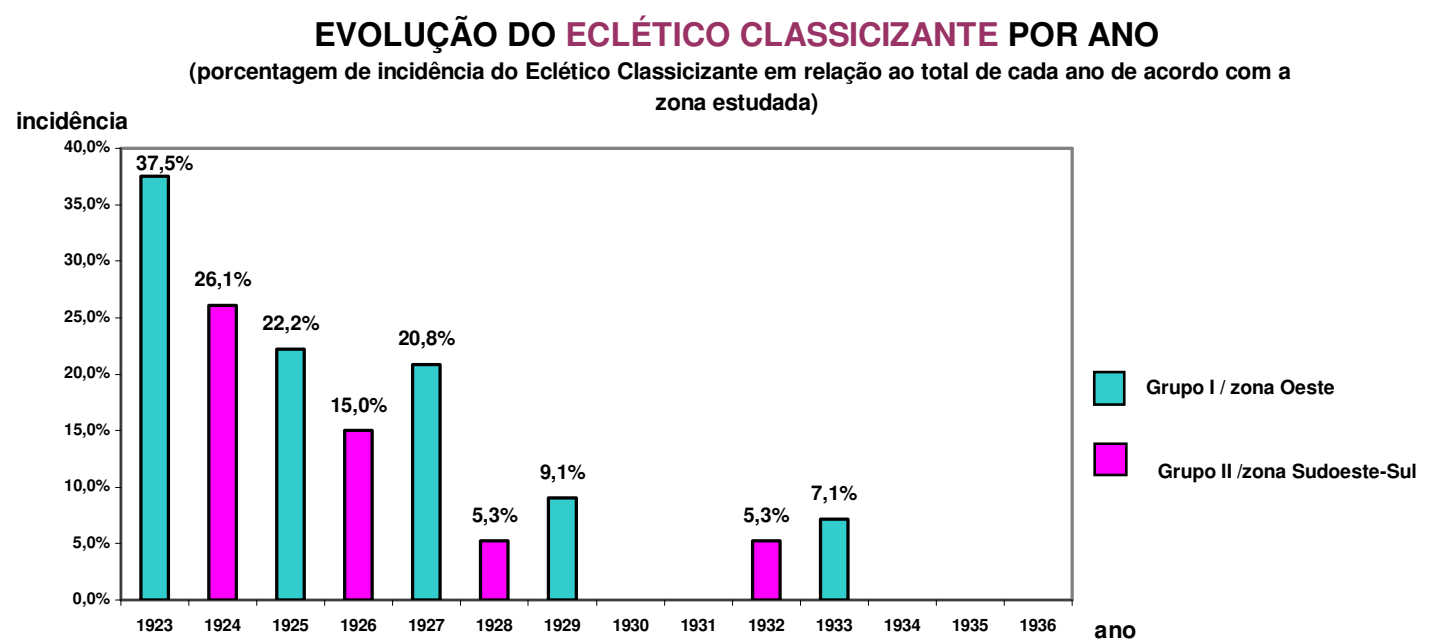

Percebemos no gráfico EVOLUÇ̃̃O DO ECLÉTICO CLASSICIZANTE POR ANO que o Ecletismo Classicizante (EC) manifestou-se durante a década de 20 numa curva descendente, ocorrendo esporadicamente em edificações residenciais paulistanas nos anos 30. A coexistência do EC com outros grupos estilísticos no período 1923-1929 revela uma clara persistência estilística, resultante de uma mentalidade ainda conservadora de parte da sociedade local, em especial da classe baixa.

O projeto 4 mostra um exemplo de fachada eclética classicizante. O Ecletismo Historicista $(E H)$ representa uma incidência ocasional dentro do universo de residências pesquisado na amostra e pode ser reconhecido nos projetos 23 e 59 .

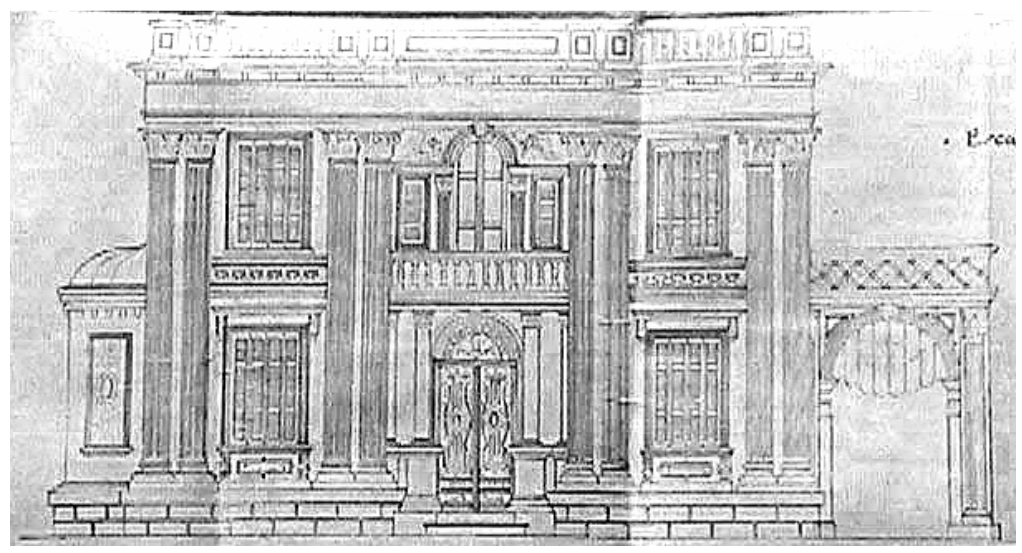

FIGURA 135 : Residência à rua Sabará. (projeto 4 / processo ํำ 9.760/23) 


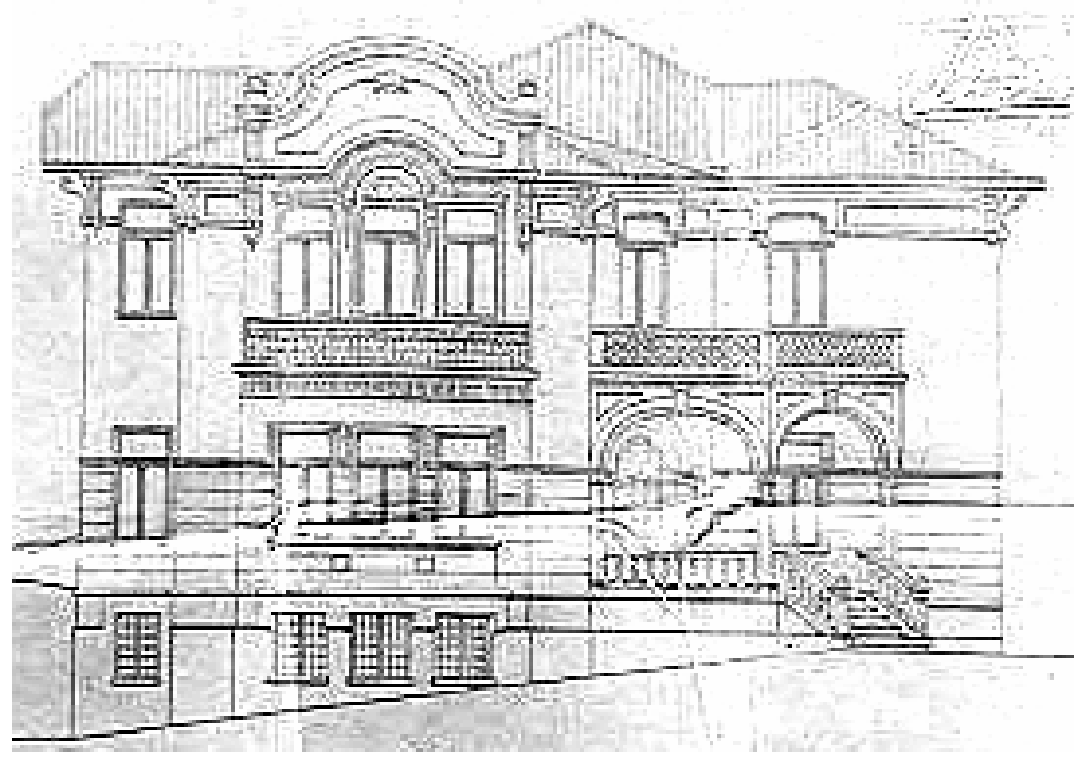

FIGURA 136: Residência à rua Conselheiro Brotero. (projeto 23 / processo $n^{\circ}$ $15.172 / 23)$

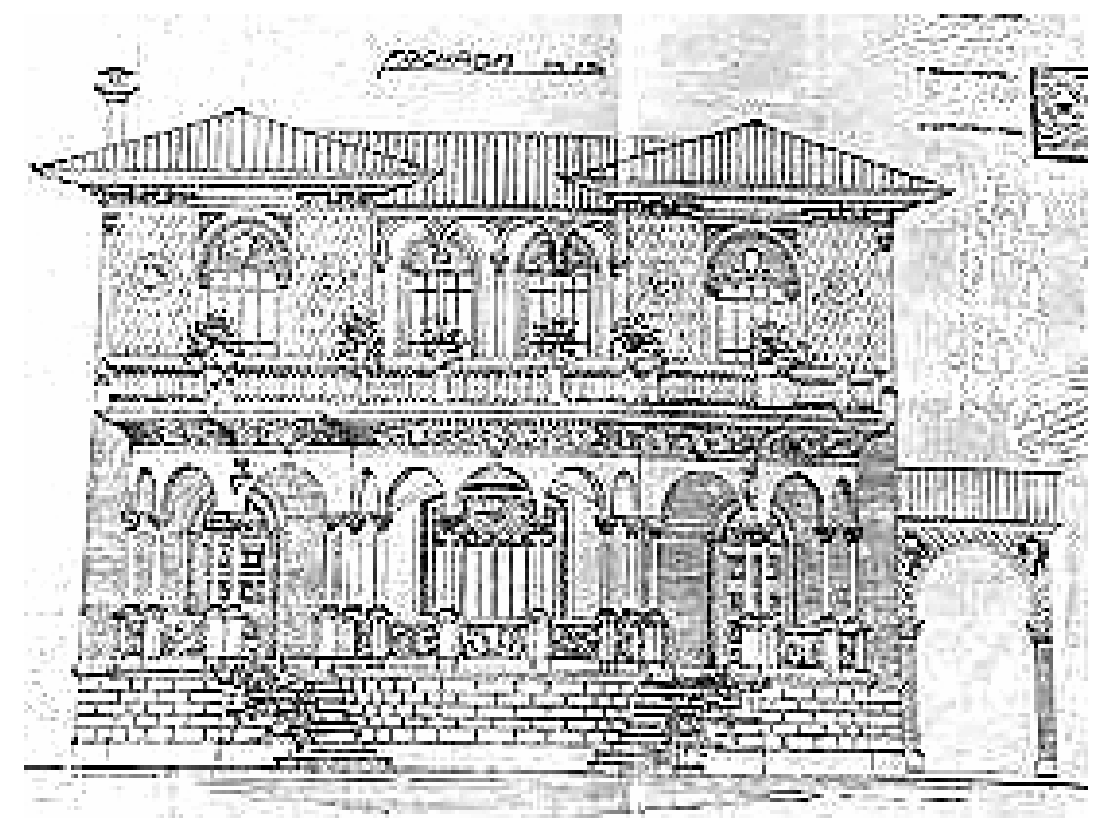

FIGURA 137 : Residência à alameda Santos. (projeto 59 / processo ํํ56.040/24) 
A título de ilustração, elaboramos complementarmente o gráfico INCIDÊNCIA DOS ESTILOS POR ANO, onde é apresentada a síntese da evolução dos nove estilos ou correntes estilísticas identificados na pesquisa arquitetônica. Neste gráfico é possível visualizar simultaneamente as variações temporais e quantitativas de cada linguagem estilística no decorrer do período estudado. Cada coluna do gráfico corresponde ao total de 100,0\% das ocorrências estilísticas verificadas em um ano específico; a incidência porcentual de cada uma das correntes é apresentada através das barras superpostas de cada coluna.

INCIDÊNCIA DOS ESTILOS POR ANO (período 1923 - 1936)

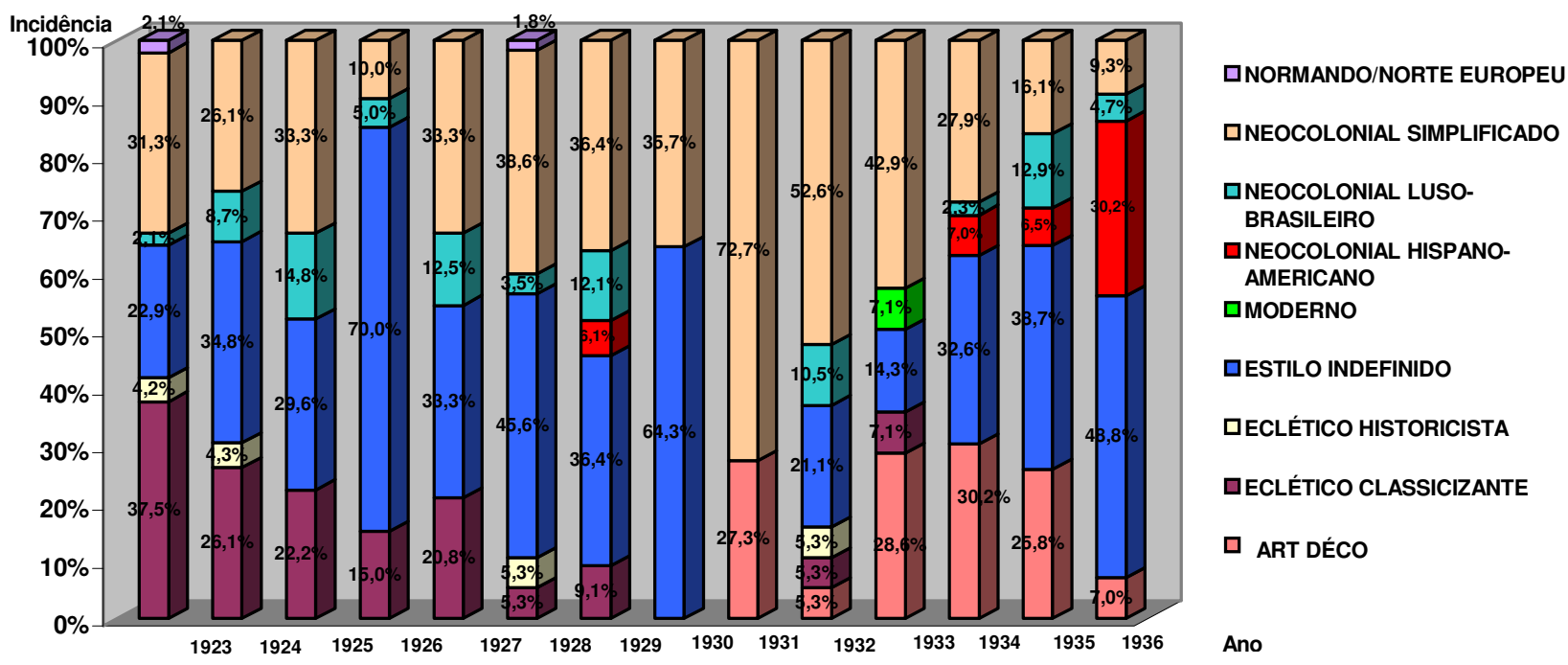

A relação entre os estilos e linguagens estilísticas e os seis programas residenciais reconhecidos na pesquisa arquitetônica - Casa Mista (CM), Casa Operária (CO), Casa Classe Média Baixa (CMB), Casa Classe Média Média (CMM), Casa Classe Média Alta (CMA) e Palacete (PA) - é mostrada no gráfico geral INCIDÊNCIA DOS ESTILOS POR TIPOLOGIA PROGRAMÁTICA, que revela as preferências do gosto por camada social. Cada coluna do gráfico equivale a um programa residencial específico e corresponde ao total de $100,0 \%$ de ocorrências estilísticas verificadas entre 1923 e 1936 nos bairros das zonas Oeste e Sudoeste/Sul; a incidência porcentual de cada um dos grupos estilísticos é apresentada através das barras superpostas de cada coluna. 


\section{INCIDÊNCIA DOS ESTILOS POR TIPOLOGIA PROGRAMÁTICA \\ GRUPOS IE II \\ (período 1923-1936)}

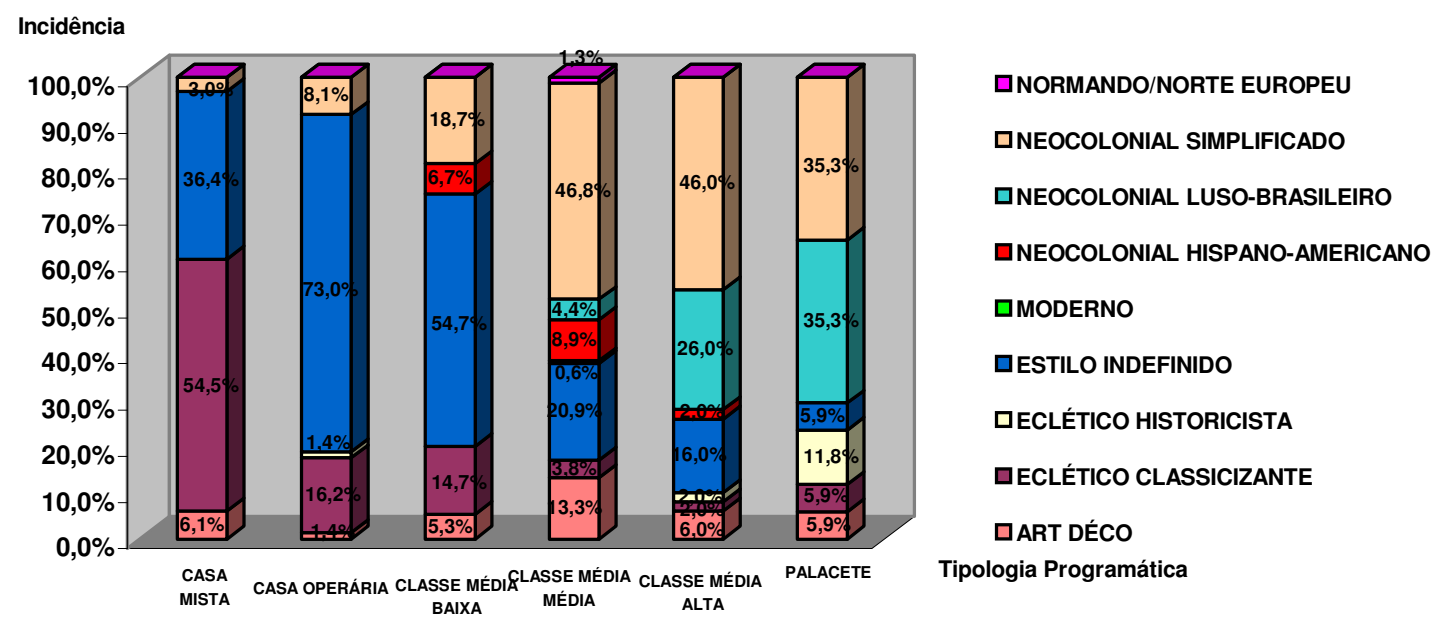

Pela análise desse gráfico geral observa-se que o Neocolonial Simplificado (NS) predominou nas edificações residenciais a partir das casas de classe média média, com incidência de $46,8 \%$ na $C M M$, de $46,0 \%$ na CMA e 35,3\% no PA, enquanto nas habitações mais simples, classificadas como CMB (18,7\%), CO (8,1\%) e CM $(3,0 \%)$, o Neocolonial Simplificado foi pouco expressivo. Estes dados comprovam a nítida preferência das camadas médias da população de São Paulo pelo Neocolonial Simplificado no período entre as Grandes Guerras. Em contrapartida, o Estilo Indefinido (EI) compareceu em valores significativos nas casas operárias $(73,0 \%)$ e nas de classe média baixa $(54,7 \%)$. Nas casas mistas predominou o gosto pelo Ecletismo Classicizante (54,5\%), seguido pelo Estilo Indefinido (36,4\%). O Ecletismo Classicizante (EC) compareceu também, com pequena freqüência, em alguns palacetes $(5,9 \%)$ e residências abastadas de CMA (2,0\%). O Neocolonial luso-brasileiro (NL) ocorreu unicamente nas camadas média e alta, com incidência de 4,4\% na CMM, 26,0\% na CMA e 35,3\% no PA, o que demonstra a sua grande receptividade entre as camadas mais altas da sociedade paulistana. Na amostra estudada o Neocolonial hispano-americano $(\mathrm{NH})$ foi detectado somente em casas de classe média, com maior incidência nas de CMM (8,9\%).

No decorrer dos anos 30, percebe-se o crescimento gradual da preferência pelo Art Déco (AD), que começa a rivalizar com as outras linguagens estilísticas existentes, demonstrando um ímpeto notável de difusão em todas as camadas sociais. Este fato também pode ser comprovado no gráfico geral INCIDÊNCIA DOS ESTILOS POR TIPOLOGIA PROGRAMÁTICA, onde se verifica que o Art Déco esteve presente em todos os programas residenciais, com ênfase nos de CMM (13,3\%). Neste mesmo gráfico 
observa-se que os estilos normando e moderno ocorreram unicamente em casas de classe média média, com as porcentagens de 1,3\% (NO) e 0,6\% (MO).

Os gráficos parciais de INCIDÊNCIA DOS ESTILOS POR TIPOLOGIA PROGRAMÁTICA, elaborados por zona, mostram um quadro muito semelhante ao verificado no gráfico geral. É evidente a predominância do Neocolonial Simplificado e do Estilo Indefinido na produção arquitetônica residencial paulistana dos anos 20 e 30 nas duas zonas estudadas, só que com sutis variações porcentuais, como a maior incidência do Estilo Indefinido nos programas das casas operárias (82,0\%), classe média baixa $(63,6 \%)$ e classe média média $(24,4 \%)$ nos bairros da zona Sudoeste/Sul. Outra diferença observada foi a maior ocorrência do Ecletismo Classicizante nas casas mistas (59,3\%), operárias $(25,0 \%)$, classe média baixa $(22,6 \%)$ e palacetes $(11,1 \%)$ da zona Oeste, denotando a existência de um gosto mais conservador, comum entre as camadas mais baixas e a elite residente nesta zona.

INCIDÊNCIA DOS ESTILOS POR TIPOLOGIA PROGRAMÁTICA
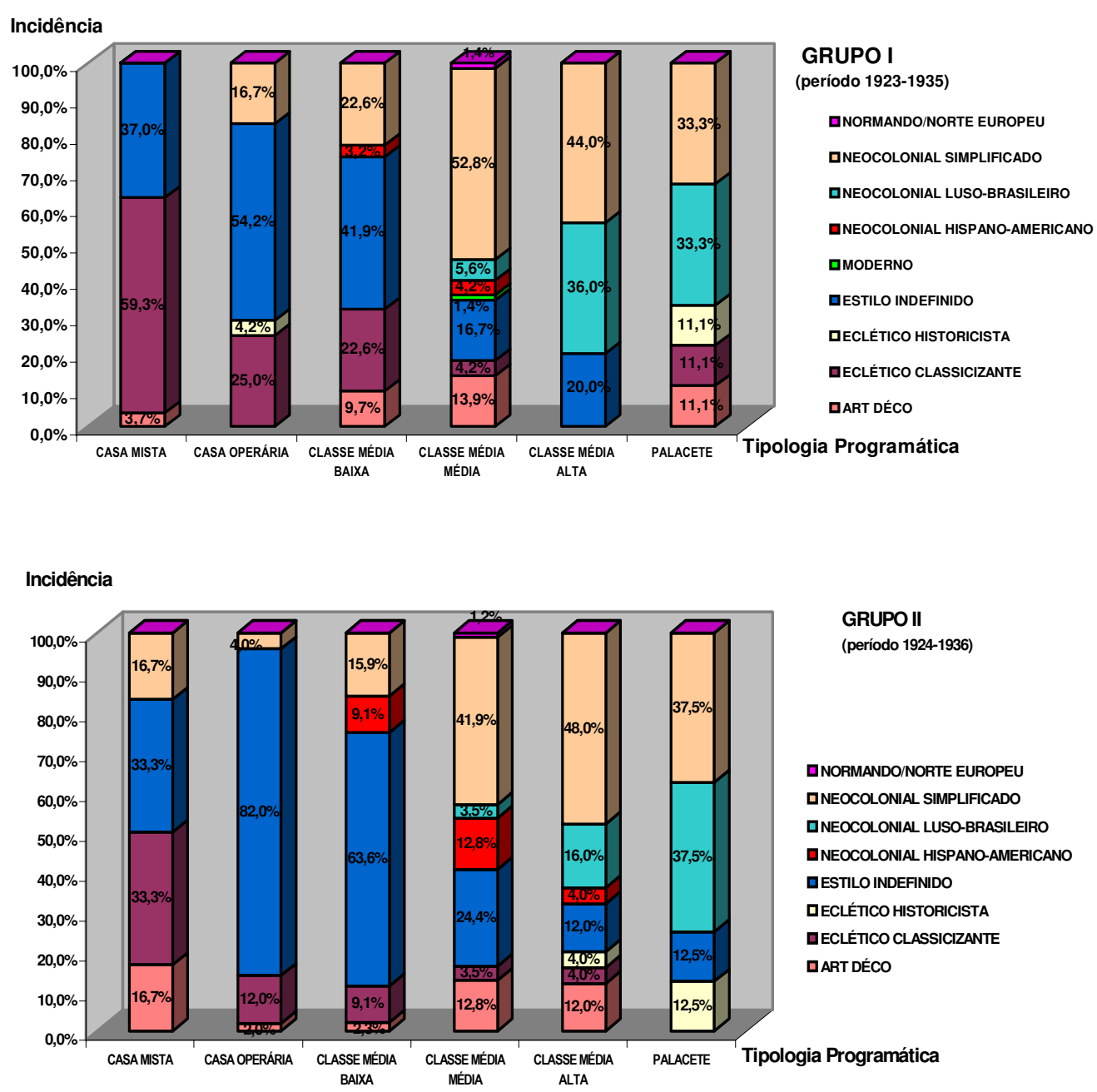
Outra constatação significativa a ser mencionada refere-se à atuação dos profissionais habilitados e às linguagens estilísticas difundidas por eles dentro do conjunto da produção arquitetônica residencial do período. Na nossa pesquisa constatamos que da amostra de 407 projetos apresentados para aprovação na Prefeitura Municipal, entre 1923 e 1936, cerca de 179 eram assinados por engenheiros, arquitetos ou firmas de engenharia civil, o que corresponde a uma porcentagem de $44,0 \%$ do total. ${ }^{41}$ Este número é expressivo e surpreende ao revelar nesta época uma grande participação de técnicos habilitados na construção de residências de todos as tipologias programáticas, nos mais variados estilos, nos bairros das zonas Oeste e Sudoeste/Sul da capital paulista.

Apesar de ser ainda bastante significativa a atividade construtiva de empreiteiros autônomos e mestres-de-obras, principalmente nos projetos residenciais mais modestos, percebe-se que o mercado profissional diversificava-se com a maior penetração de profissionais habilitados projetando e construindo para todas as camadas sociais. Dos 179 projetos assinados, 136 eram referentes a moradias de classe média (76\%), das quais 22 eram de classe média baixa (12,3\%), 75 de classe média média $(41,9 \%)$ e 39 eram de classe média alta $(21,8 \%)$; estes números mostram claramente que no entre-guerras os engenheiros, arquitetos e firmas de engenharia estavam trabalhando primordialmente para a classe média.

Com relação às linguagens estilísticas mais comumente empregadas pelos profissionais atuantes nos anos 20 e 30, constatou-se que dentre os 179 projetos residenciais assinados: 54 eram do Neocolonial Simplificado (30,2\%), 53 do Estilo Indefinido (29,6\%), 22 do Neocolonial luso-brasileiro (12,3\%), 18 do Art Déco (10,1\%), 13 do Ecletismo Classicizante (7,3\%), 12 do Neocolonial hispano-americano (6,7\%) e 4 do Ecletismo Historicista $(2,2 \%)$. Os dois projetos classificados como Normando e o único Moderno, também eram assinados por engenheiros e arquitetos. Por estes números evidencia-se uma preferência dos profissionais habilitados pelo Neocolonial Simplificado e pelo Estilo Indefinido como linguagens estilísticas a serem empregadas nas residências construídas no período, e, em particular, nas de classe média, como já vimos.

É importante ressaltar também, que as linguagens arquitetônicas populares em voga nesta época se manifestaram basicamente ao nível da composição e ornamentação das fachadas, uma vez que maiores alterações da volumetria dependiam das condições legais em vigência e estavam sujeitas às limitações das dimensões dos lotes. Assim, as

\footnotetext{
${ }^{41}$ Para comprovação da habilitação do autor do projeto, além da identificação profissional, efetuada na análise individual de cada projeto, foram realizadas pesquisas complementares em listas de formandos da Escola Politécnica e do curso de Engenharia Mackenzie e em revistas técnicas e acadêmicas dos anos 20 e 30.
} 
residências aparentavam uma nova feição externa, mais condizente com os modismos do momento - o Neocolonial luso-brasileiro nos anos 20 e o hispano-americano (ou Missões) e - Art Déco a partir da década de 30. Movimentação somente a esboçada nos telhados, com a introdução de telhadinhos sobre as entradas frontais ou sobre os pequenos alpendres, numa tentativa explícita de imitar as coberturas caprichosas dos palacetes da classe alta, concebidas em várias águas e em telhados secundários.

O repertório estilístico do Art Déco também contribuiu com alguns elementos para a definição da arquitetura do período pós-1930, principalmente a ornamentação geometrizante, as platibandas retas, a decoração discreta das fachadas e o uso de um revestimento à base de mica, que se tornou marca inconfundível desta corrente. Alguns destes estilemas do déco foram incorporados livremente, gerando sobreposições e recriações de valor variável: desde soluções altamente criativas e surpreendentes até outras beirando o "kitsch".

Sintetizando, nos anos 20, o Neocolonial luso-brasileiro prevaleceu como estilo erudito concomitantemente à corrente estilística de caráter popular, o Neocolonial Simplificado (NS). Nos anos 30, conviveram pacificamente em São Paulo, lado a lado, manifestações residenciais neocoloniais luso-brasileiras, neocoloniais simplificadas, hispano-americanas e déco. Durante as décadas de 1920 e 1930 foram freqüentes também soluções sincréticas misturando elementos do repertório de variadas linguagens estilísticas na composição da fachada de uma mesma residência. Estes sincretismos arquitetônicos, classificados na nossa pesquisa como Estilo Indefinido (El), foram bastante expressivos numericamente, o que demonstra uma certa perplexidade ou desorientação no gosto popular no período entre as Grandes Guerras na cidade de São Paulo.

\section{III.4. As recriações e os sincretismos arquitetônicos : o surgimento de uma linguagem estilística paulistana}

\section{III.4.1. A QUESTÃO DA CÓPIA, DA IMITAÇÃO, DAS RECRIAÇÕES, DOS SINCRETISMOS}

Nesta seção final da tese discutimos as vinculações estéticas que propiciaram a ocorrência de um estreito relacionamento entre a arquitetura erudita e a de cunho popular no período entre as duas Guerras Mundiais na cidade de São Paulo. Amparados por consulta em bibliografia específica, pela nossa extensa pesquisa arquitetônica em fontes primárias (projetos de construção de residências paulistanas sob guarda do Arquivo Geral 
da PMSP) e por uma ampla documentação fotográfica de exemplares remanescentes, procuramos demonstrar a mentalidade reinante na época e os fatores influentes no gosto e nas escolhas estilísticas da população paulistana.

Assim, foi possível perceber a grande ascendência da elite influenciando a preferência da classe média, portadora de um sentimento de ascensão social, que a induzia naturalmente à cópia ou à imitação. ${ }^{42}$ Se por razões financeiras esta classe não podia construir da mesma forma, pelo menos procurava exibir algum elemento de referência da arquitetura erudita nas fachadas de suas moradias, que simbolizasse o "status" almejado e personalizasse a edificação. A feição da casa se transformava num signo do posicionamento do seu proprietário dentro do corpo social, que seria capaz de sugerir para si e para os outros uma noção de individualidade. A cópia ou a imitação, em suma, eram motivadas por um desejo consciente de fazer de modo apenas parecido.

Como não podiam acompanhar a mesma composição de fachada e volumetria dos palacetes, as casas populares se adequavam como podiam às dimensões do lote e ao bolso do proprietário. Sempre foi assim até o começo da década de 20 , quando passamos a observar lentas porém profundas transformações na sociedade local, agora mais receptiva às novidades que vinham da Europa, e principalmente, dos Estados Unidos. Novas idéias, novos confortos, novos gostos. Enfim, era o momento de experimentar as novidades, de início, encaradas com um certo receio, mas depois gradualmente aceitas pelos paulistanos, sempre desconfiados, apesar do seu aparente cosmopolitismo.

O período entre as Grandes Guerras foi o tempo de libertação dos tabus, dos vínculos com o passado recente, dos compromissos com as estéticas passadistas do Ecletismo trazido pelo imigrante, como já foi dito. As notícias que chegavam através dos meios de comunicação, os modismos trazidos pelo cinema de Hollywood, o início da internacionalização. O desejo de estar em sintonia com o mundo, participando ativamente de todas as manifestações artísticas de vanguarda predominava na elite, que em última instância era a formadora de opinião. Desta forma, restava à classe média assistir às modificações rápidas e significativas que estavam ocorrendo ao seu redor e assumir os modelos que se lhe apresentavam.

42 ".../ de um modo geral, a gente pode dizer que a média burguesia, em suas construções, como em outras atividades, sempre produziu com evidente intenção imitativa equacionada em permanente desejo de ascensão social. Só que as limitadas condições naturalmente também sempre situaram as suas construções bastante aquém dos modelos ricos e eruditos. Aquém no tamanho. Aquém no gosto, como dizem os críticos. Aquém no conforto. Imitações reduzidas, mas que desejam manter as aparências. Diríamos uma arquitetura irrisória, que arremeda a outra, mas que nessa emulação vai propiciando aos poucos o nascimento de uma linguagem própria, que representa a média das expectativas estéticas do segmento mediano da sociedade. Define-se uma expressão, um gosto, ou uma falta de gosto, como queiram. Quase sempre uma arquitetura insossa, bem comportada, que resignadamente diz-se inspirada na arquitetura dos ricos. Enfim, essa arquitetura anônima de nossas ruas." In: LEMOS, Carlos A. C . Alvenaria Burguesa, p.12. 
Neste momento de emulação, a arquitetura, e em especial, a residencial de classe média, como uma manifestação de caráter cultural, ${ }^{43}$ refletiu com clareza todas as alterações pelas quais estava passando a sociedade paulistana naquela época. Todas as dúvidas e inseguranças reinantes aparecem refletidas nas novas opções estilísticas derivadas de recriações e sincretismos arquitetônicos surgidos nos anos 20 e 30 . A classe média se sentiu capacitada, também, de escolher e de criar uma arquitetura que revelasse a predominância de seu gosto, que comparecia em número expressivo de exemplares espalhados por inúmeros bairros da cidade. Ao mesmo tempo, este gosto era bastante peculiar, pois viria a ser expressão arquitetônica justa de um estrato da sociedade que, agora, podia se manifestar e recriar uma linguagem estilística própria.

Antes de analisar essa questão do surgimento de nova corrente estilística no período entre as Guerras na cidade de São Paulo, é essencial definir claramente recriação, distinguindo-a de sincretismo arquitetônico.

As recriações seriam basicamente todas as manifestações arquitetônicas em que se percebe uma intenção plástica onde não está explicitado o desejo de se realizar uma simples cópia. O que interessa no caso não é ser exatamente igual, mas ser diferente, inventando uma expressão singular a partir da interpretação de elementos conhecidos originados de um único vocabulário estilístico erudito; enfim, a recriação arquitetônica configuraria uma releitura personalista de um estilo.

Num lato sensu sincretismo seria a "fusão de elementos culturais diferentes, ou até antagônicos, em um só elemento, continuando perceptíveis alguns sinais originários." ${ }^{44}$ Consideraremos portanto neste trabalho como uma arquitetura sincrética aquela resultante de uma colagem de elementos retirados dos repertórios de variadas fontes estilísticas, ainda passíveis de ser identificáveis, ou seja, uma arquitetura derivada da incorporação de estilemas distintos de estilos diversos, não estando afastado o uso de invenções personalistas, sem quaisquer referências estilísticas eruditas.

\footnotetext{
43 " /... para o estudo da psicologia e da sensibilidade do povo, a arquitetura popular tem interesse maior que a erudita, em contraposição, só esta, através de um vocabulário incomparavelmente mais rico, traduz uma elaborada e penetrante compreensão de valores, ignorados ou despercebidos pelos que manipulam a arquitetura popular, que só os atingem, quando os atingem, por via da intuição ou do sentimento. Valores de escala, de proporção, de equilíbrio, de unidade, de modenatura, de comodulação, de estilo, valores exprimindo, no conjunto, a cultura arquitetônica. /.../ A nosso ver ainda que para determinação das constantes da sensibilidade deva ser considerada a arquitetura em todos os seus gêneros e principalmente a Militar, a Religiosa e a Civil -, é indubitavelmente num dos desdobramentos desta última : a Arquitetura Doméstica /.../ que essas constantes melhor se expressam, e o fazem através de uma grande variedade de tipos, dos mais modestos, que se identificam com a popular, aos mais categorizados, que atingem à erudita. Nos tipos mais singelos é usado um vocabulário frusto, num balbuciar de idéias, que, por mais eloqüente que seja, antes se sente, do que se compreende, sem que se possa traduzir num sentido plástico artisticamente definido em termos formais. Ao passo que nos tipos mais qualificados, onde se vislumbra a nota erudita, o fraseado toma sentido mais inteligível, mais claro, porque existe uma gramática como termo de comparação." SANTOS, Paulo F. "Constantes de Sensibilidade na Arquitetura do Brasil." In: Arquitetura Revista FAU / UFRJ v.6,1988, p. 56

${ }^{44}$ Verbete sincretismo. In: Dicionário Aurélio Eletrônico Século XXI versão 3.0.
} 


\section{III.4.2. O "MANEIRISMO PAULISTANO"}

No início dos anos 20, surgiu na cidade de São Paulo uma singular corrente arquitetônica que se difundiu durante todo o período entre-guerras. Esta corrente desenvolveu-se em São Paulo contemporaneamente ao Neocolonial luso-brasileiro e perdurou até a Segunda Guerra Mundial, quando novas condições políticas, econômicas, sociais e culturais emergiram e determinaram o seu esquecimento, propiciando o aparecimento de uma nova estética, agora vinculada ao Modernismo e ao concreto armado.

Pelo nosso estudo, constatamos que inúmeras residências de cunho popular das décadas de 1920 e 1930 utilizavam-se de um mesmo repertório morfológico ou elenco de estilemas, o que revelava o predomínio de um "gosto" comum. A constância de uma "família" arquitetônica, sempre presente num significativo número de edificações semelhantes entre si espalhadas por diversos bairros da cidade de São Paulo, denotava uma forma particular de projetar e construir.

Tal manifestação arquitetônica freqüente à classe média pode ser interpretada como uma recriação, e, em alguns casos, até mesmo, como uma apropriação e simplificação da arquitetura "tradicionalista" de Victor Dubugras. Se considerarmos que a sua notável criatividade definiu uma obra própria e inconfundível, muito apreciada na época, podemos sem receio afirmar que alguns dos estilemas criados por ele serviram de paradigma, e foram incorporados e transformados por aquele setor da coletividade paulistana na formulação de uma determinada linguagem arquitetônica, conforme pudemos comprovar na nossa pesquisa, quando distinguimos o até então chamado Neocolonial Simplificado.

A partir da constatação de que essa produção residencial revelava a singularidade expressiva de um estrato da sociedade paulistana num determinado período, ou mais precisamente, revelava uma maneira de fazer arquitetura da classe média no entre-guerras, julgamos apropriado denominar de "Maneirismo Paulistano" ${ }^{45}$ a corrente arquitetônica que a identificava. Assim, o nome "Paulistano" foi atribuído a esta manifestação arquitetônica residencial porque ela se revelou um fenômeno típico da cidade de São Paulo, conforme pudemos observar, e também porque até o momento só temos conhecimento da ocorrência de casos esporádicos fora da capital paulista.

\footnotetext{
${ }^{45}$ É necessário ressaltar, porém, que o emprego do termo "Maneirismo Paulistano" nesse trabalho não está relacionado com o movimento artístico denominado Maneirismo. ".... Em sentido restrito, o Maneirismo designa as artes plásticas e a literatura da época entre o renascimento tardio e o Barroco, mais ou menos de 1525 a 1620.” In: KOCH, Wilfried. Estilos de Arquitetura II, p. 181.
} 
Cabe salientar, no entanto, que não pretendemos caracterizar o "Maneirismo Paulistano" como um novo estilo, e aqui lembramos as palavras do arquiteto e historiador Ítalo Campofiorito que nos esclarece sobre a distinção entre estilo e o termo italiano “maniera". Campofiorito nos diz que esta diferença ".../ só se firmou no séc. XIX, quando Quatremère de Quincy, /.../ a definiu em seu Dictionnaire Historique (1832)." 46 Segundo ele, Quincy empregava o vocábulo estilo para designar ".../ as qualidades gerais que influem sobre o gosto de cada século, de cada país, de cada escola, de cada gênero" ${ }^{47}$ Assim, um determinado estilo apresentaria um "/../ sentido coletivo, designando repertórios morfológicos, famílias de obras de arte, ou edificações semelhantes", ${ }^{48}$ enquanto que a palavra "maniera" estaria relacionada ao talento pessoal do artista.

Quando tratamos da produção arquitetônica residencial dos anos 20 e 30, percebemos que a partir do estilo Neocolonial luso-brasileiro o arquiteto Victor Dubugras criou à sua "maniera" uma linguagem arquitetônica particularizada, que, por sua vez, serviu de fonte de inspiração para a classe média recriar também à sua "maniera" uma arquitetura singular, mais simplificada e espontânea, o "Maneirismo Paulistano".

Pela nossa análise, com base na pesquisa arquitetônica empreendida nos projetos sorteados do Arquivo Geral da Prefeitura Municipal de São Paulo, constatamos que o "Maneirismo Paulistano" equivaleu integralmente ao que o professor Carlos A. C. Lemos chamou de Neocolonial Simplificado no seu livro Alvenaria Burguesa.

Os estilemas do Neocolonial reinventado por Victor Dubugras ${ }^{49}$ podem ser destacados como repertório morfológico básico presente no "Maneirismo Paulistano". Este arquiteto soube, com maestria e um senso incomum de racionalidade, distinguir a sua obra da dos seus colegas. Com muita imaginação, Victor Dubugras se apropriou de elementos do vocabulário tradicional luso-brasileiro para inventar soluções arquitetônicas originais; tanto no nível formal, criando volumes inéditos, quanto no estilístico, estabelecendo um repertório distintivo para as suas casas.

\footnotetext{
${ }^{46}$ In : PEIXOTO, Gustavo Rocha. Reflexos das Luzes na Terra do Sol, p. 20.

${ }^{47}$ Idem, p. 20 e 21.

${ }^{48}$ Idem, ibidem.

49 "E houve quem inventasse muito, quase tudo. Victor Dubugras foi um deles. /.../ mas a verdade é que o Neocolonial por ele praticado era quase todo inventado ou reinterpretado. Criou uma série de pormenores que passaram a ser copiados pelos outros como se fossem verdades de antigamente." LEMOS, Carlos A. C. "Ecletismo em São Paulo" In: FABRIS, Annateresa (org.) Ecletismo na Arquitetura Brasileira, p. 94.
} 
"Victor Dubugras, com o seu talento fulgurante, aproveitou a deixa, abandonou de vez o $\underline{\text { Art }}$ nouveau e mergulhou na invenção pretextada pelo tradicionalismo. /.../ Dubugras fez escola emprestando aos outros os elementos semânticos de seu discurso, favorecendo a popularização de seu tradicionalismo - que, por sinal, foi praticado sem que se soubesse de alguma ligação com o passado." (LEMOS, 1987, p. 95)

Nas obras neocoloniais de Dubugras eram perceptíveis os elementos inventados pelo arquiteto francês misturados a outros advindos do repertório tradicional luso-brasileiro, utilizado por Ricardo Severo (após a divulgação das pesquisas de Wasth Rodrigues e Felisberto Ranzini), além de alguns estilemas dos palacetes de Ramos de Azevedo, inspirados na arquitetura residencial de César Daly. Este amálgama de influências variadas conformaria indiscutivelmente a arquitetura de Victor Dubugras, e, a partir dela, o "Maneirismo Paulistano".

Nos anos 20 as residências de Victor Dubugras seduziram a classe média paulistana sequiosa de novidades. Assim, muitas das invencionices criadas por ele foram sendo paulatinamente incorporadas em inúmeras casas da época que vulgarizaram os volumes em balanço, os guarda-corpos de meias-luas superpostas, o revestimento de pedras irregulares tipo "canjiquinha", o uso de pedras soltas na alvenaria aparente etc.
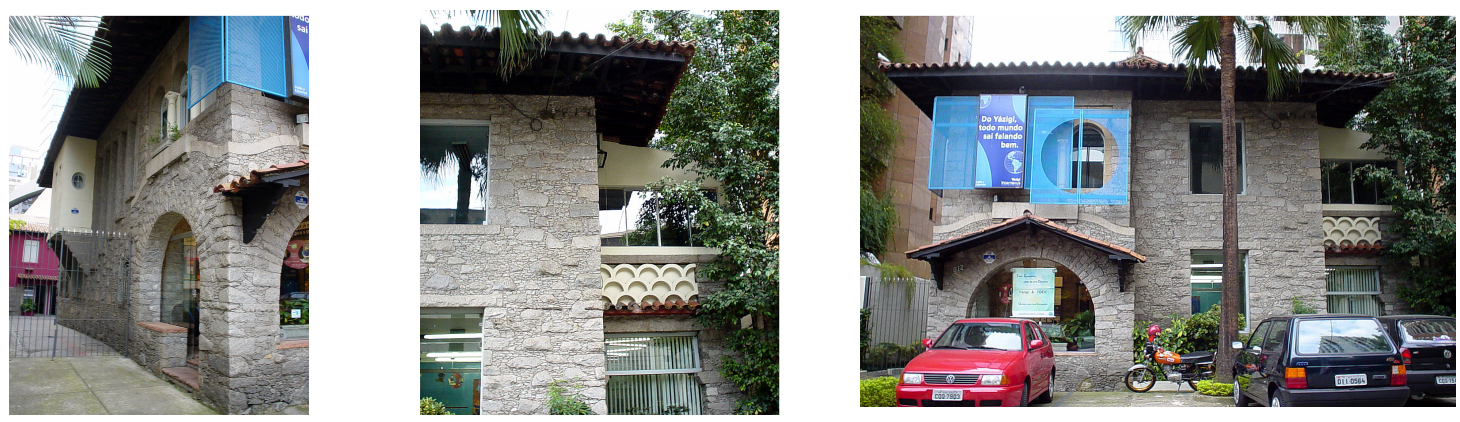

FIGURAS 138, 139 e 140 : A antiga residência David Ribeiro localizada na alameda Joaquim Eugênio de Lima ilustra os principais estilemas empregados por Victor Dubugras nas suas casas. (Victor Dubuaras / São Paulo. 1920) 

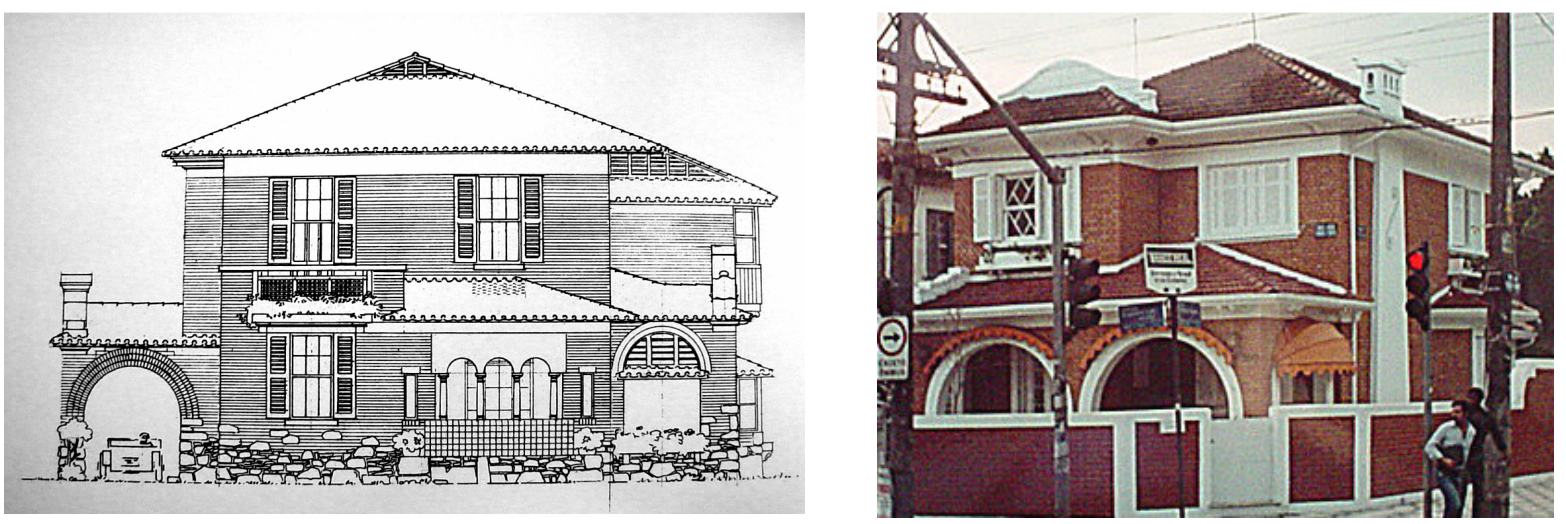

FIGURAS 141 e 142 : Notar a semelhança volumétrica e de composição arquitetônica entre o desenho de fachada elaborado por Victor Dubugras $(s / d)$ e a residência à rua Estados Unidos esquina da avenida Brigadeiro Luiz Antonio. É possível observar o jogo movimentado de volumes, a presença de alpendres, da faixa branca de massa logo abaixo do pequeno beiral circundando todas as fachadas, das janelas com jardineiras no pavimento superior, das paredes de alvenaria de tijolos aparentes etc. No desenho de Dubugras percebe-se também a existência de pedras nos embasamentos e soltas aleatoriamente nos panos de alvenaria aparente, estilema identificado em inúmeras casas do "Maneirismo Paulistano", como se verifica nas figuras 143, 144 e 145.

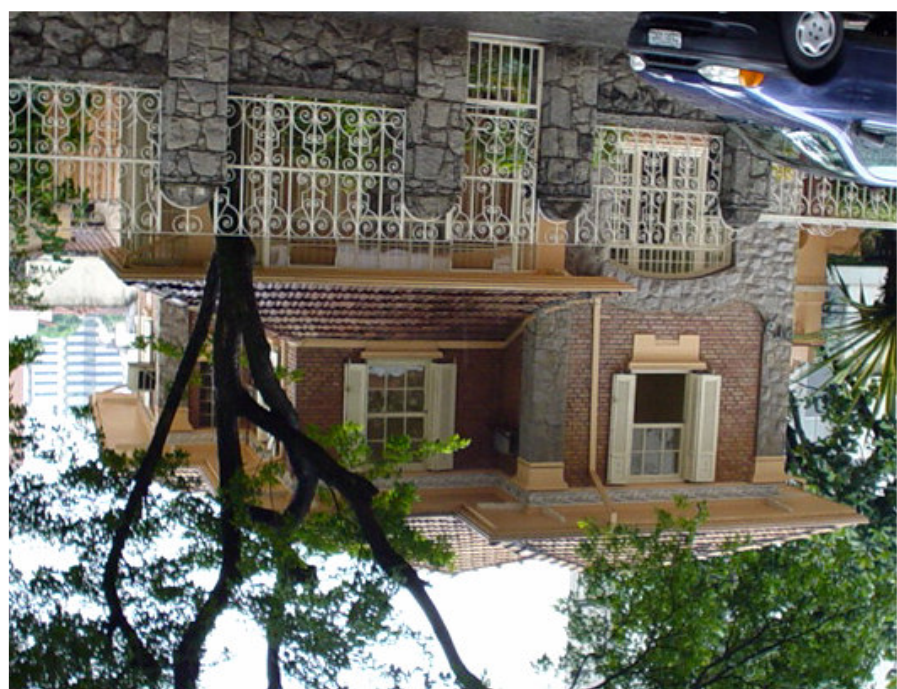

FIGURA 143 : Cunhais e embasamento de pedras na fachada de alvenaria aparente de casa à rua Tupi, artifício de composição arquitetônica muito utilizado nas residências de Victor Dubugras.
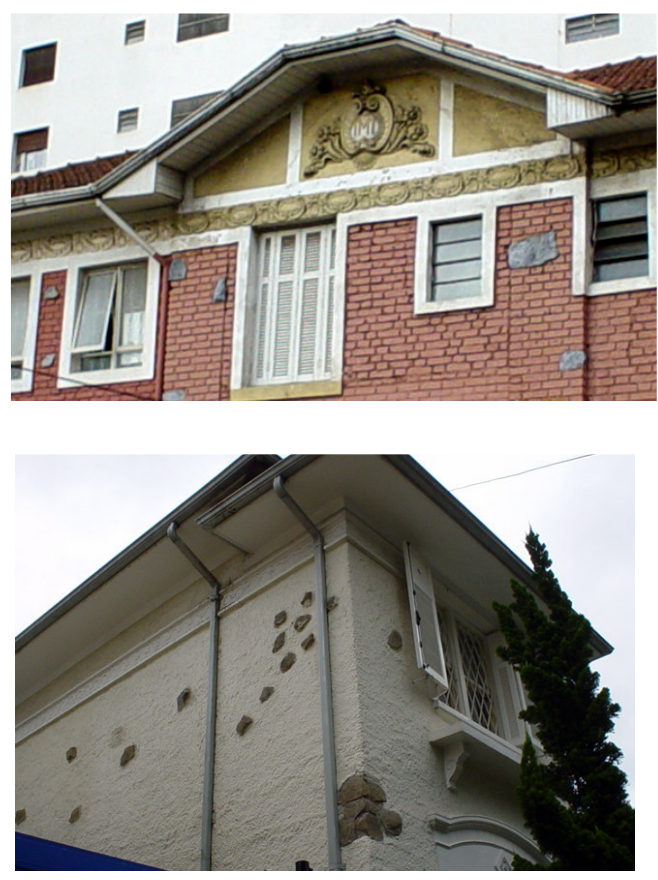

FIGURAS 144 e 145 : Exemplo de pedras soltas na fachada de tijolos aparentes de casa à rua Desembargador do Vale. $\mathrm{Na}$ residência de paredes revestidas da rua Sampaio Viana, notase uma interpretação livre da aplicação de pedras na fachada disseminada por Dubugras nas suas obras. 


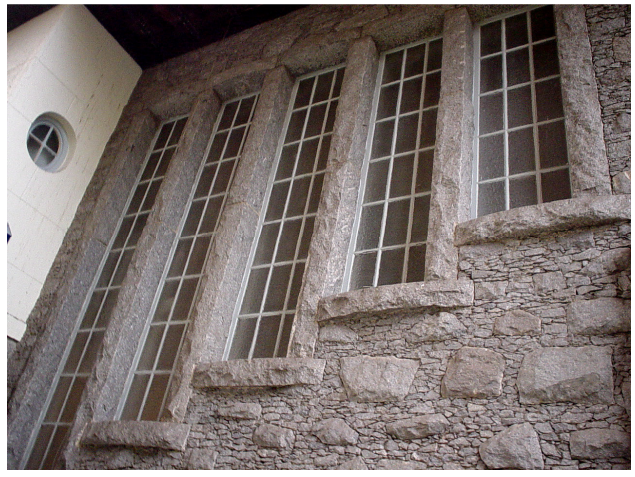

FIGURA 146 : Detalhe de série de janelas seqüenciais da antiga residência David Ribeiro localizada na alameda Joaquim Eugênio de Lima. (Victor Dubugras / São Paulo, 1920)

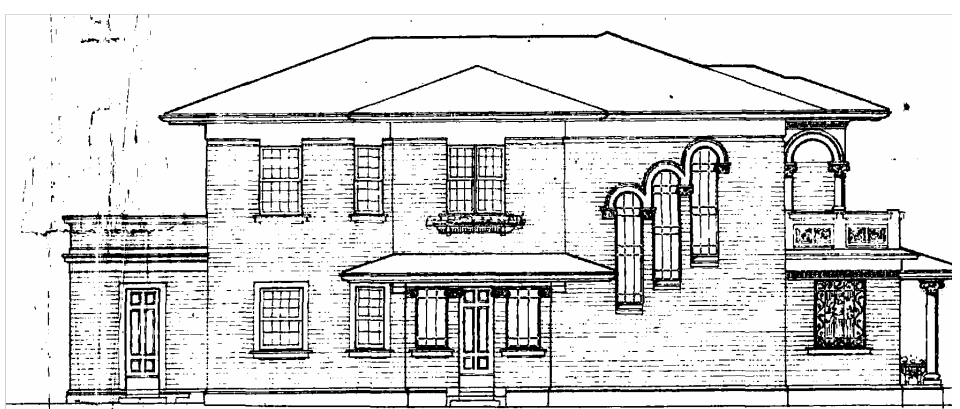

FIGURA 147 : Fachada lateral de residência à rua Bela Cintra apresentando série de três janelas seqüenciais marcando a caixa da escada como nas casas de Dubugras . (projeto 144 / processo no 28.938/28)
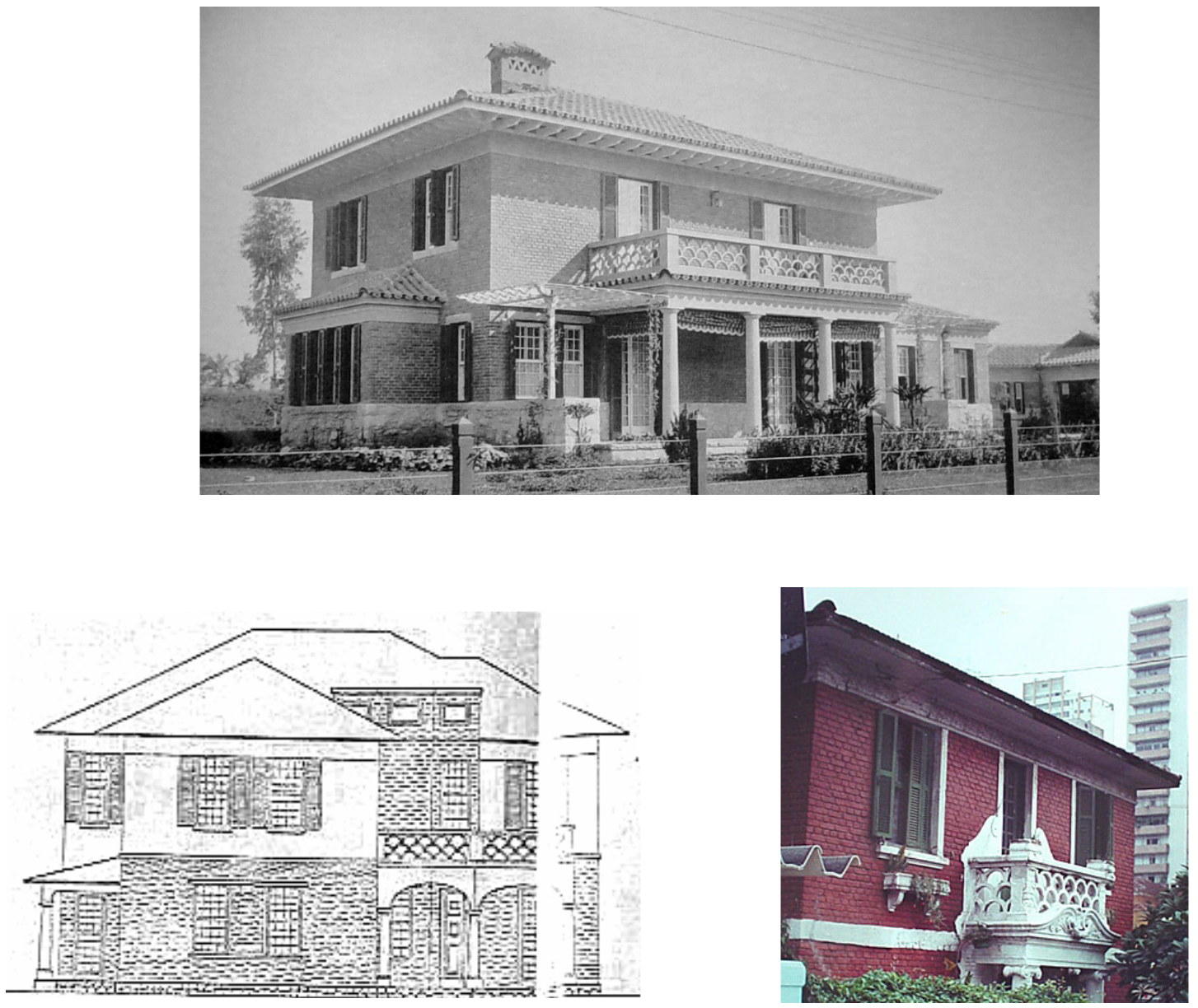

FIGURAS 148, 149 e 150 : Os elementos vazados em forma de meias-luas superpostas dos guardacorpos dos balcões dos terraços superiores comparecem tanto na residência Carlos Whately, projetada por Victor Dubugras (São Paulo, s/d), quanto nas casas da avenida Brasil (projeto 55 / processo $\mathrm{n}^{\circ}$ 54.356/24) e da alameda Barros, representantes do "Maneirismo Paulistano". 
As similitudes entre o "Maneirismo Paulistano" e o Neocolonial de Dubugras podem ser percebidas pela presença constante de pequenos beirais, às vezes decorados com falsos "cachorros", pelos telhados movimentados de várias águas e pela ocorrência eventual de painéis de azulejos nas casas de classe média paulistanas dos anos 20 e 30 . Os resquícios da arquitetura residencial de Ramos de Azevedo também são evidenciados no "Maneirismo Paulistano", particularmente, nas paredes de tijolos à vista e nos requadros de massa branca das envasaduras (e, eventualmente, nos cunhais).

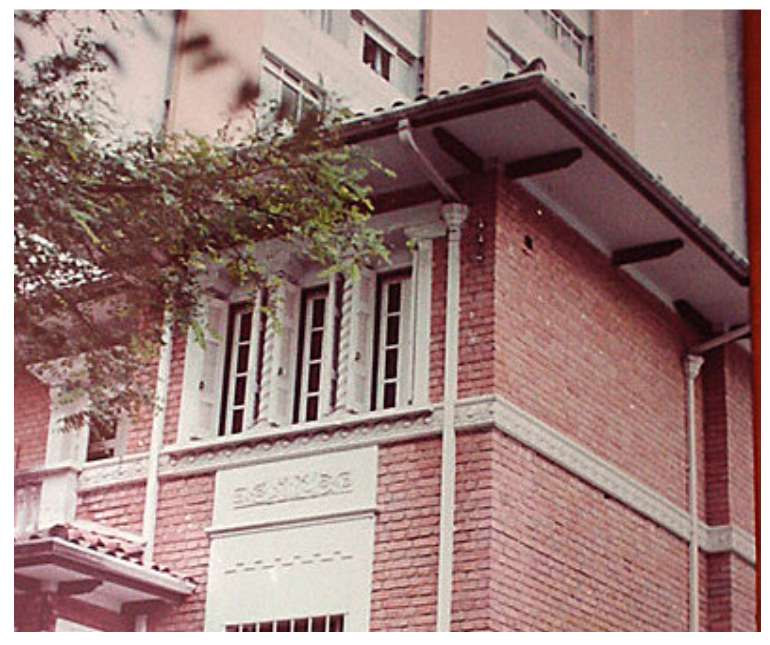

FIGURA 151 : Detalhe de beiral decorado com falsos "cachorros" de casa à rua Traipu.

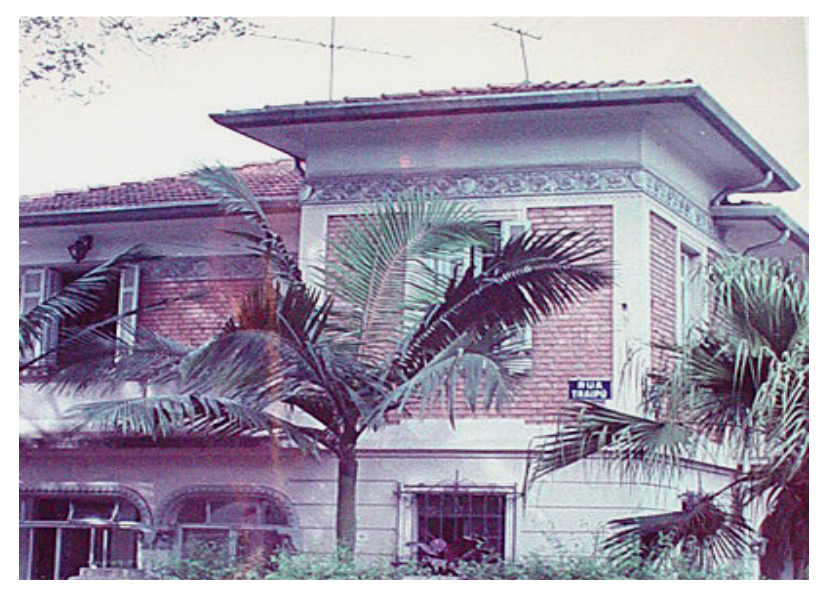

FIGURA 152 : Detalhe de requadros de massa branca nas envasaduras e nos cunhais de casa à rua Traipu. 
Assim, os estilemas caracterizadores do "Maneirismo Paulistano" podem ser sintetizados nos arcabouços cúbicos com panos de tijolos à vista (às vezes, parciais); nos beirais de estuque com falsos "cachorros" imitando beiradas neocoloniais; no emprego de alpendre provido de arcos de pleno cinto; no uso de portas e janelas de vergas retas; às vezes, nos cunhais brancos de massa e na utilização de decoração em relevo pré-moldada de gesso ou cimento nos paramentos e medalhões; no uso de guarda-corpos com elementos vazados em forma de meias-luas ou escamas de peixe; no uso exclusivo de telhas planas, ditas francesas ou de Marselha; no emprego usual de faixas decorativas circundando a construção na altura das vergas das janelas superiores; no uso freqüente de jardineiras guarnecendo os peitoris das janelas; e, na colocação de vitrais decorativos nas caixas de escada.

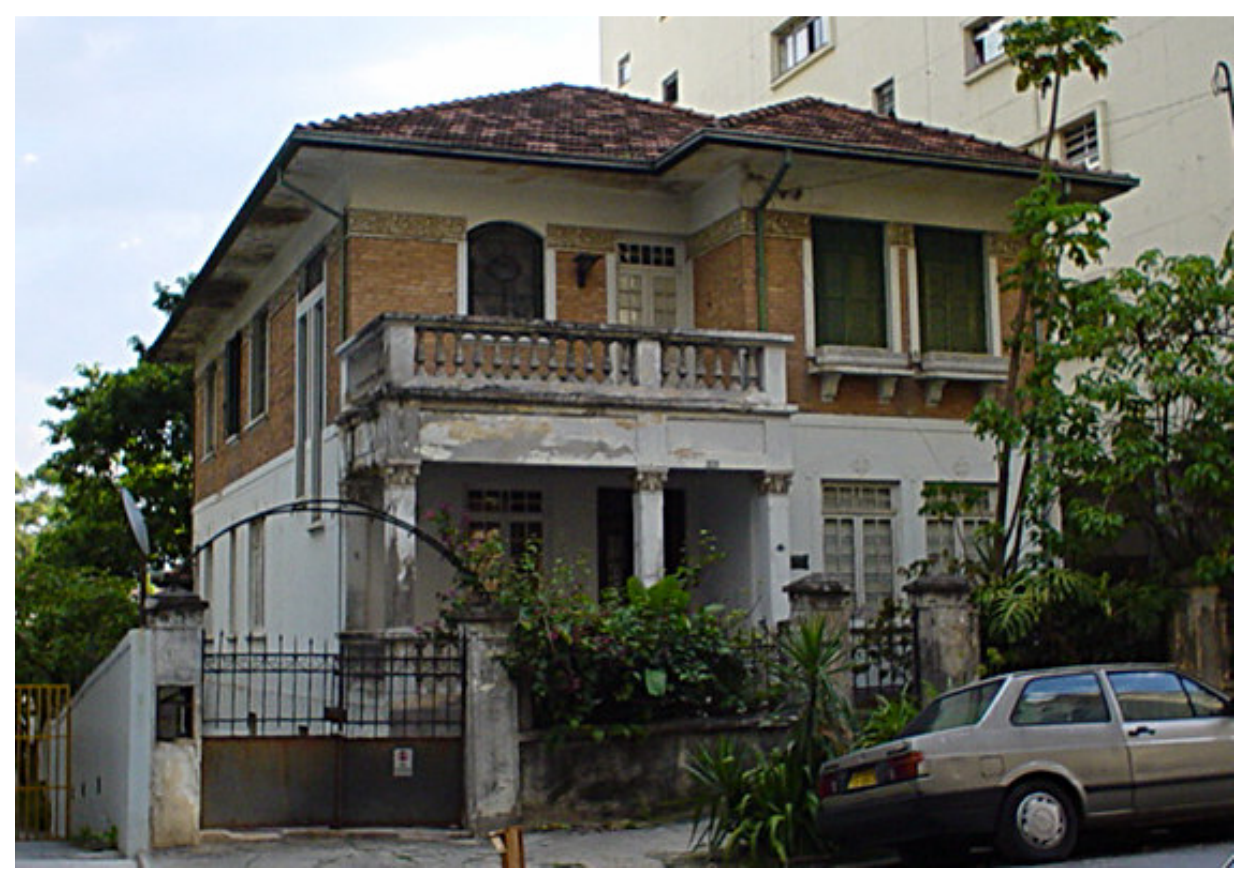

FIGURA 153 : Residência à rua Piauí apresentando os principais estilemas do "Maneirismo Paulistano". 
Do repertório formal e estilístico básico do "Maneirismo Paulistano", acima descrito, pode-se verificar que derivaram algumas soluções variantes mais simplificadas ou estilizadas como:

1. Casas totalmente revestidas com os estilemas anteriores.

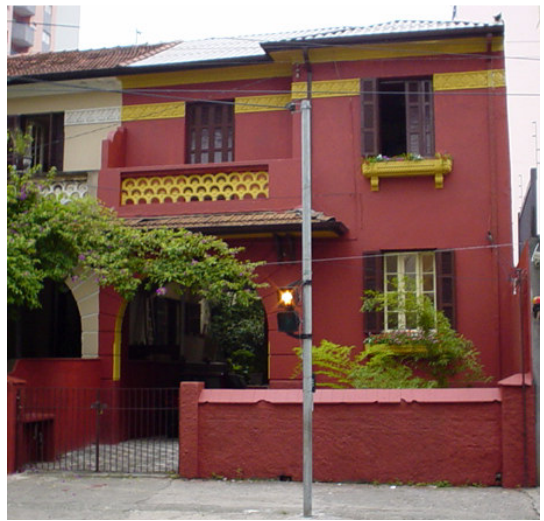

FIGURA 154 : Casas geminadas à rua Frei Caneca.

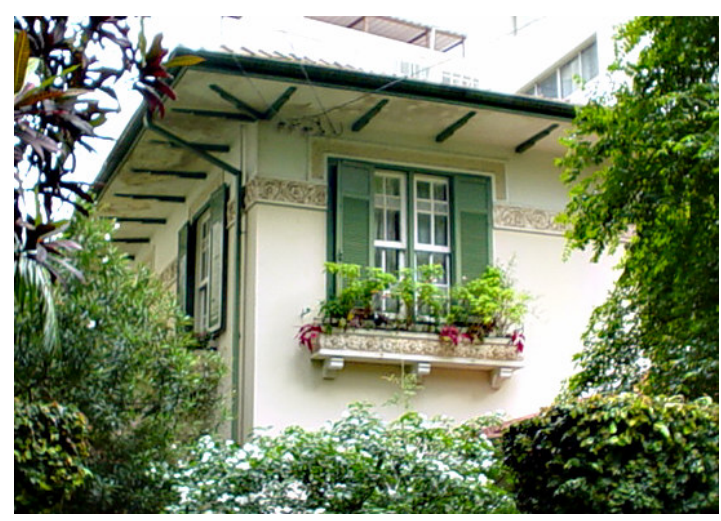

FIGURA 155 : Residência à rua Gabriel dos Santos.

2. Casas revestidas, ou não, apresentando o avanço de um cômodo no pavimento superior, coroado por um telhadinho de duas águas, ostentando dois triângulos de arremate dos beirais das paredes laterais.

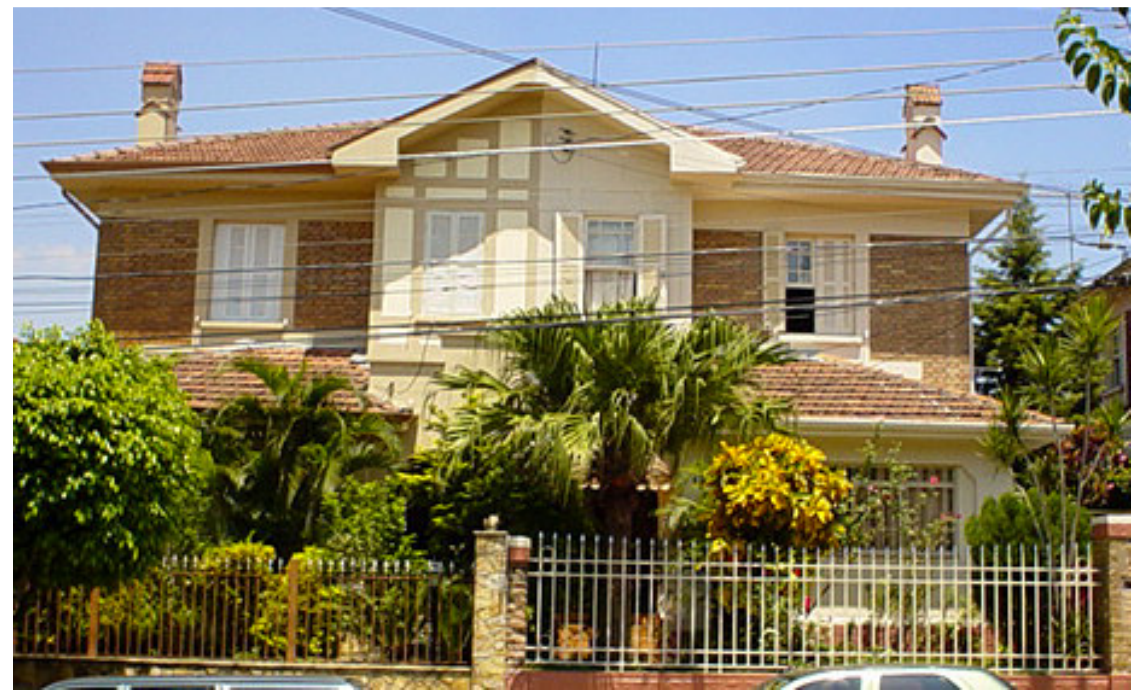

FIGURA 156 : Casas geminadas à rua Jorge Moreira. 
3. casas com oitão decorado com elementos verticais ou horizontais de massa em relevo.

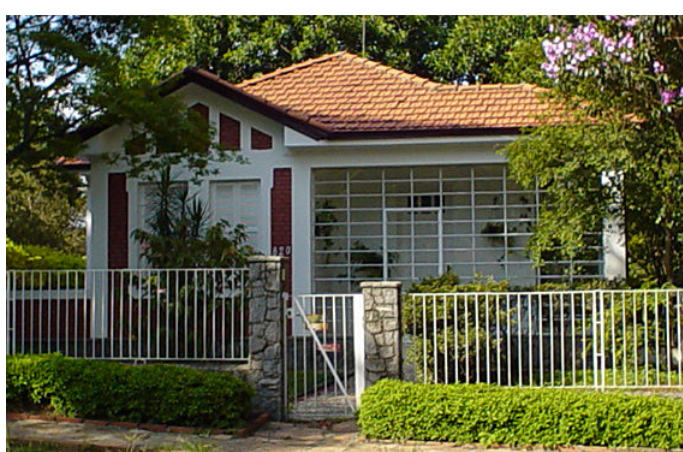

FIGURA 157 : Casa à rua Tomé de Souza.

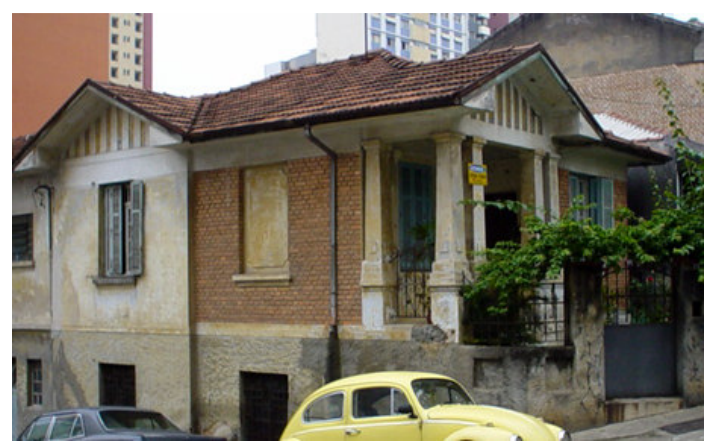

FIGURA 158 : Casa à rua Itararé esquina da rua Herculano de Freitas.

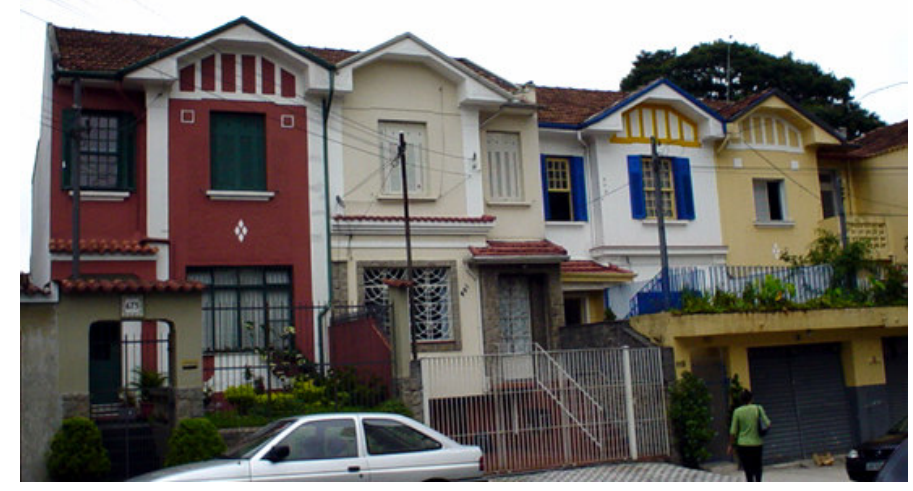

FIGURA 159 : Casas geminadas à rua José Antonio Coelho.

4. casas com ornamentos produzidos industrialmente em massa aplicados em pontos estratégicos da fachada.
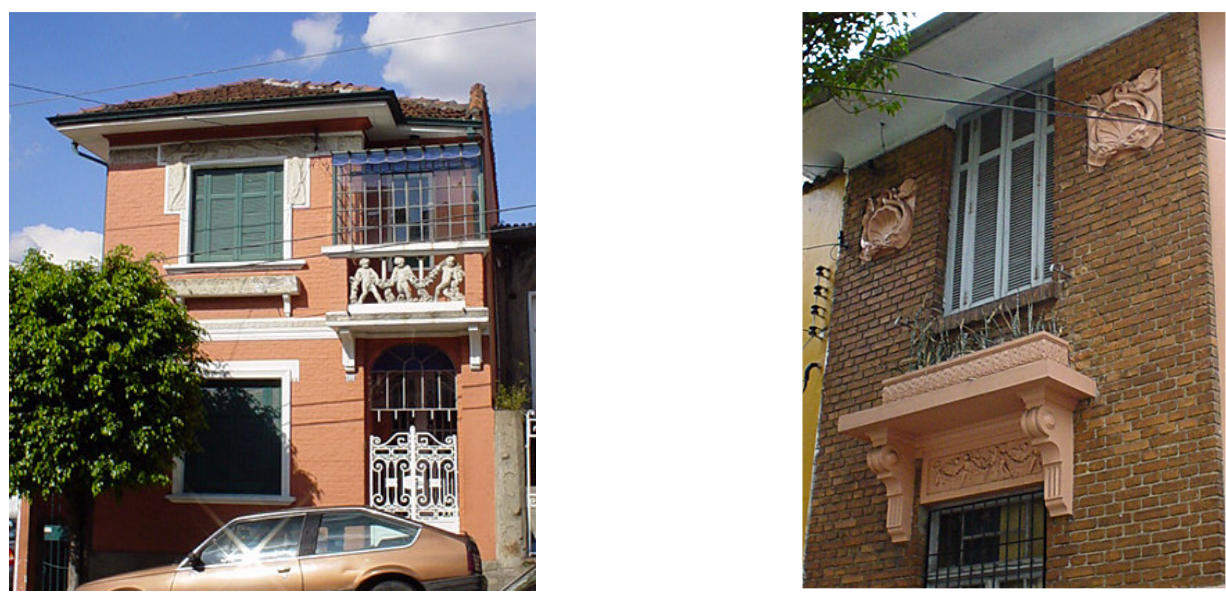

FIGURAS 160 e 161 : Exemplos de decoração parietal e de ornamentos de massa. Notar o guarda-corpo do balcão com figuras de anjos da residência da rua dos Ingleses e o painel em alto relevo embaixo da jardineira da casa da rua Bandeirantes. 
5. casas do "Maneirismo Paulistano" com volumes salientes na fachada.

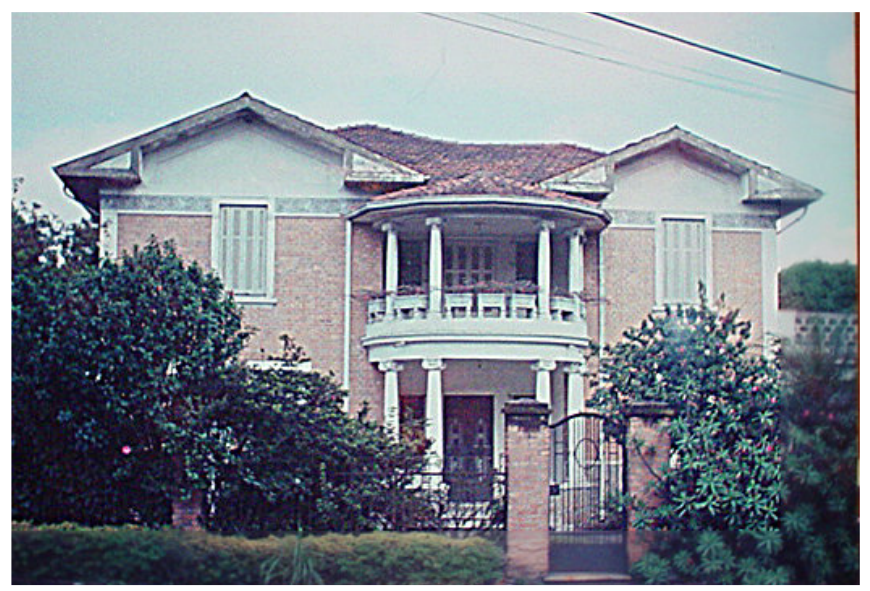

FIGURA 162 : Casa à rua Colômbia.
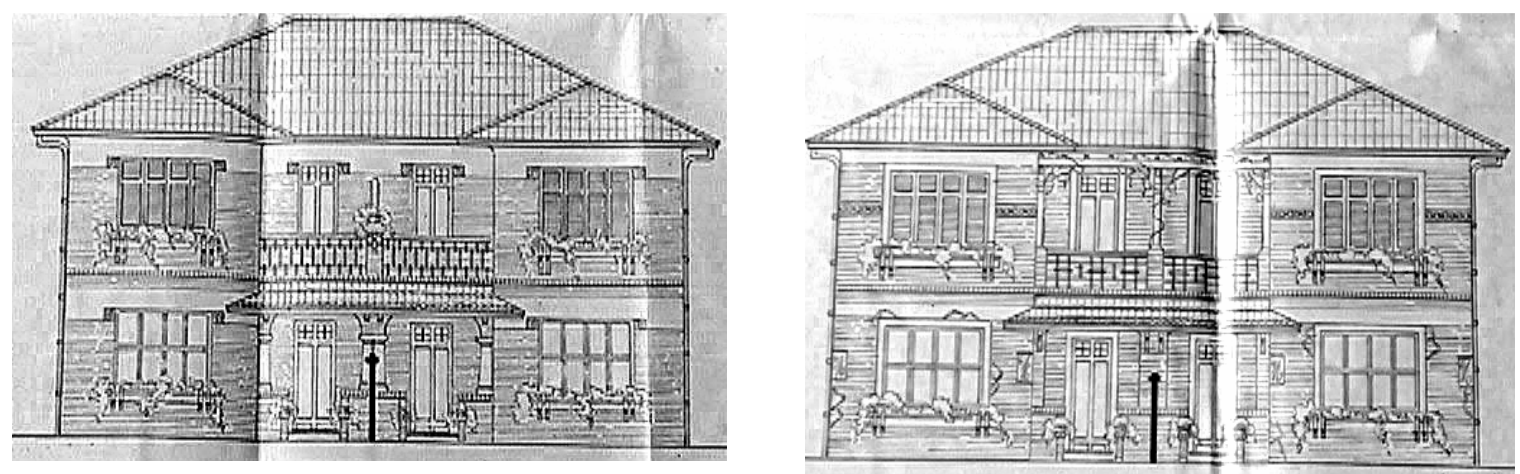

FIGURAS 163 e 164: Dois conjuntos de casas geminadas à rua Dona Antonia de Queiroz. (projeto 3 / processo no 10.665/23)

Em suma, o "Maneirismo Paulistano" foi essencialmente uma recriação arquitetônica coletiva, geradora da expressão própria de uma camada social num determinado momento histórico. Os exemplares remanescentes do "Maneirismo Paulistano" são testemunhos de

“... / uma criação arquitetônica popular autóctone, /.../ porque simplesmente nasceram sem autoria definida - nunca foram obra de autor e, realmente, nada de especial neles nos chama a atenção. /.../ No entanto, neles sempre houve uma intenção plástica, e sua produção estaria, com toda a justiça, inserida dentro daquilo que chamamos de arquitetura. /.../ Tais exemplares são fundamentalmente documentos representativos de esforços populares tendentes a aliar dificuldades materiais a uma certa dignidade ou compostura muito ciente da imprescindibilidade da intenção artística." (LEMOS, 1985, p. 169 e 180) 


\section{III.4.3. UM “ESTILO INDEFINIDO"}

Paralelamente ao "Maneirismo Paulistano" e aos outros estilos arquitetônicos em voga nos anos 20 e 30 na cidade de São Paulo, coexistiu um significativo número de casas de difícil caracterização estilística. Estas construções residenciais, reunidas por questões metodológicas no grupo "Estilo Indefinido" da pesquisa arquitetônica, não apresentavam uma predominância de estilemas que pudessem vinculá-las a um determinado estilo ou corrente estilística, como já vimos.

O termo "Indefinido", atribuído a esse conjunto de residências produzidas no entreguerras, foi adotado por designar tudo o que ".../ não foi claramente definido, demarcado, precisado." ${ }^{50}$ Assim, como se verificou nestas casas uma acentuada indefinição por parte do autor do projeto e/ou proprietário quanto à opção por uma linguagem estilística preferencial para a composição das fachadas das suas moradias, considerou-se oportuna a denominação Estilo Indefinido para caracterizar esta produção arquitetônica.

O "Estilo Indefinido" reuniu um grande número de soluções sincréticas, numa infinidade de variantes residenciais, das mais simples às mais elaboradas, espalhadas por diversos bairros da cidade de São Paulo durante todo o período entre as duas Grandes Guerras, como já foi dito. Nos anos 20, o Ecletismo Classicizante e o Historicista, o Neocolonial luso-brasileiro, além do "Maneirismo Paulistano", forneceram inúmeros estilemas ainda reconhecíveis nas colagens livres das fachadas das casas populares. Ocorreu também nesta época, a incorporação de estilemas provenientes da arquitetura do norte europeu, vulgarizada na capital paulista pelas chamadas casas normandas. ${ }^{51} \mathrm{Na}$ década de 30, com inspiração no estilo Missões, no Art Déco e na Arquitetura Moderna, ocorreram outras manifestações sincréticas, porém de menor significância quantitativa dentro do quadro arquitetônico paulistano.

Nas fachadas das residências da época foi freqüente também a ocorrência de estilemas surgidos da imaginação criadora da população, que eram misturados aleatoriamente com outros oriundos de diversas fontes estilísticas. O resultado era, muitas

\footnotetext{
${ }^{50}$ Verbete Indefinido. In: Dicionário Eletrônico Houaiss da língua portuguesa 1.0.

${ }^{51}$ Pelo nosso estudo acreditamos que as casas normandas não tenham sido unanimidade no gosto paulistano. Estas casas representaram ocorrências eventuais em locais determinados, geralmente conjuntos arquitetônicos, porém, acreditamos que o tom de novidade e exotismo que elas evocavam foi elemento inspirador para muitos construtores da época.
} 
vezes, a gênese de construções insólitas, inesperadas, e até surpreendentes, que acabavam se destacando no contexto urbano em que estavam inseridas.

A "Casa da Árvore", localizada no bairro da Bela Vista, ${ }^{52}$ é um exemplo desse tipo de solução arquitetônica personalista. A edificação térrea, de porte modesto, apresenta pequeno jardim frontal com um muro imitando troncos e galhos de árvores; na fachada, entre as duas janelas, são reproduzidas em argamassa duas árvores estilizadas, cujos galhos sem folhas se entrelaçam até a linha do telhado. Estes elementos decorativos revelam uma evidente reminiscência da arquitetura romântica empregada nas construções dos parques e jardins do final do século XIX, onde era comum a reprodução de troncos e galhos de árvore feitos com argamassa armada.

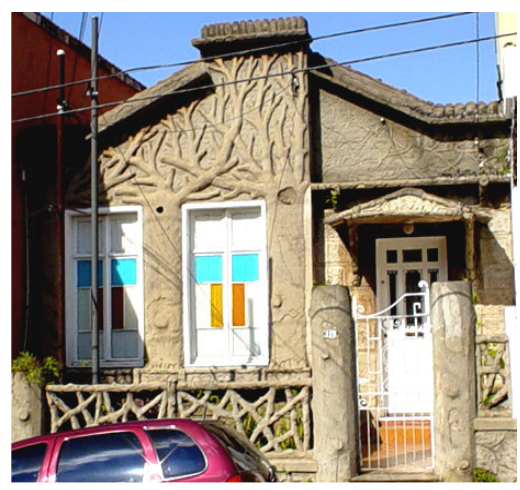

FIGURA 165 : “Casa da Árvore” na rua dos Ingleses.

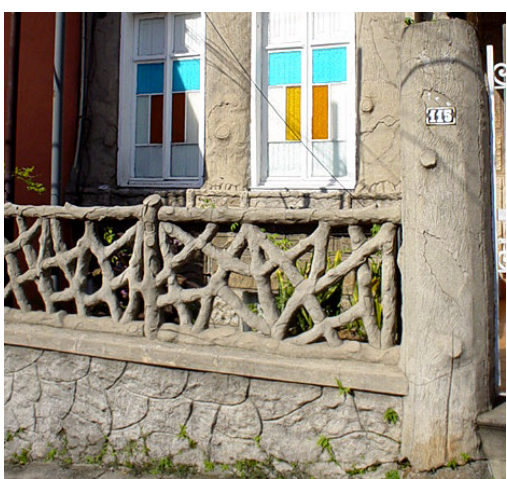

FIGURA 166 : Detalhe do muro frontal da "Casa da Árvore".

FIGURA 167 : Desenhos de um depósito de água, ponte rústica e quiosque para jardim utilizando elementos estruturais em forma de troncos e galhos de árvore, constantes no "Relatorio descriptivo sobre $o$ pedido de previlegio de construcções de beton e ferro (melhoramento do Systema Monier)." (eng. Carlos Poma / Rio de Janeiro, 1891)

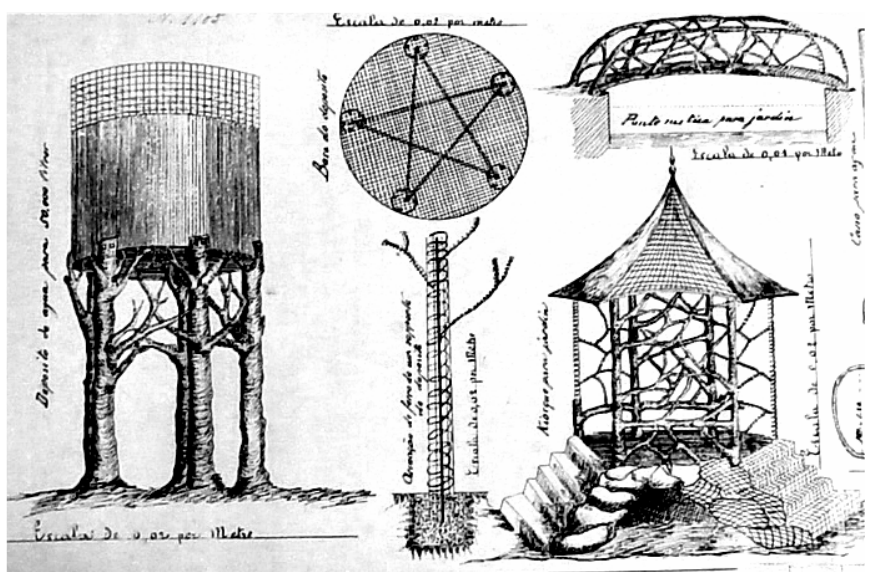

\footnotetext{
${ }^{52}$ A "Casa da Árvore", localizada na rua dos Ingleses, 115, foi tombada a nível municipal pela resolução no 22/CONPRESP/02, que trata do tombamento do bairro da Bela Vista.
} 
As principais variantes sincréticas do "Estilo Indefinido" detectadas na pesquisa arquitetônica e no levantamento fotográfico realizados durante a elaboração da tese podem ser sintetizadas nas:

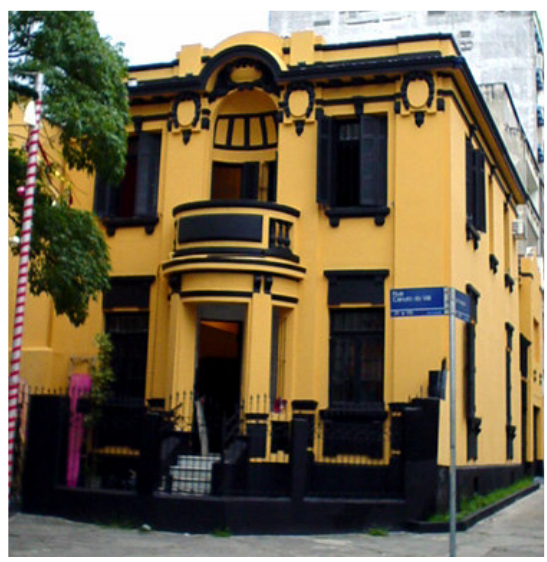

FIGURA 168 : Casa à rua Canuto do Val esquina da rua Fortunato.

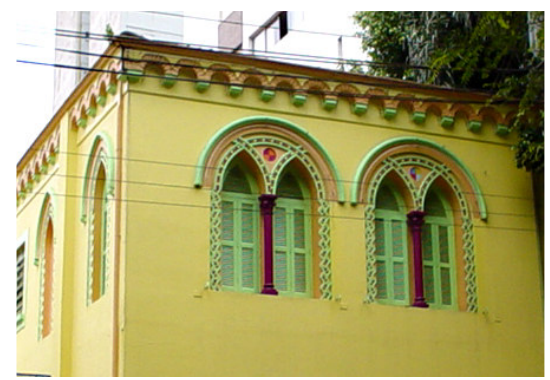

FIGURA 169 : Casa à rua Gabriel dos Santos.

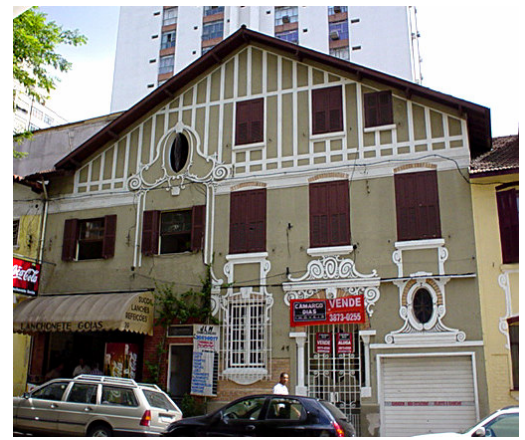

FIGURA 170 : Casa à rua Goiás.
1. Casas apresentando uma mescla de elementos remanescentes do Ecletismo Classicizante, do Historicista e do Normando.

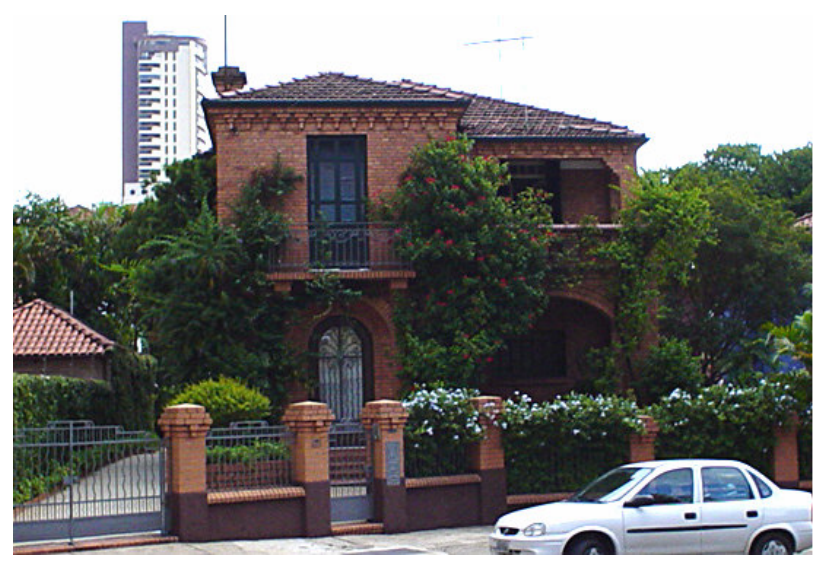

FIGURA 171 : Residência à rua Goiás.

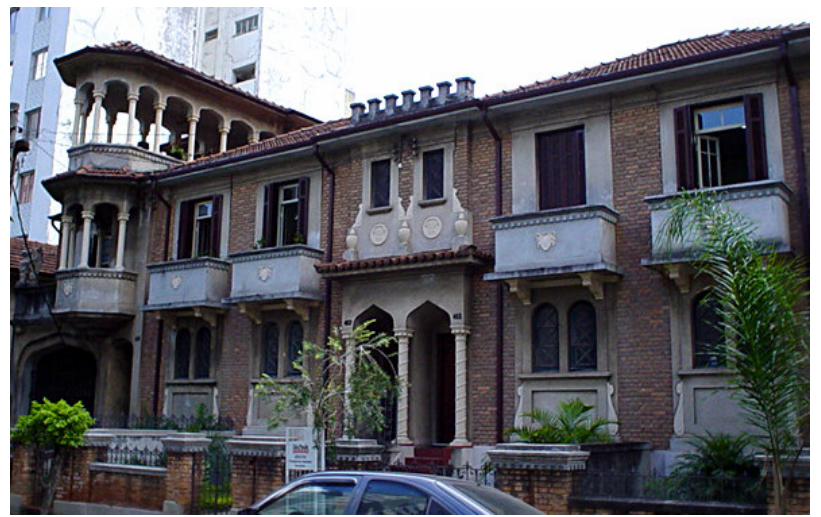

FIGURA 172 : Vila Savoy à rua Vitorino Carmilo. 


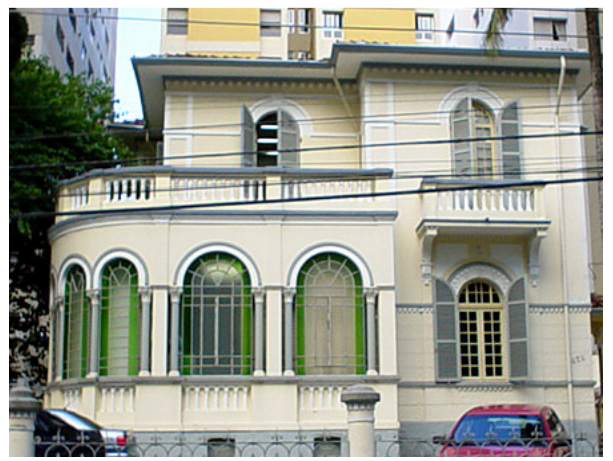

FIGURA 173 : Casa à rua dos Franceses.

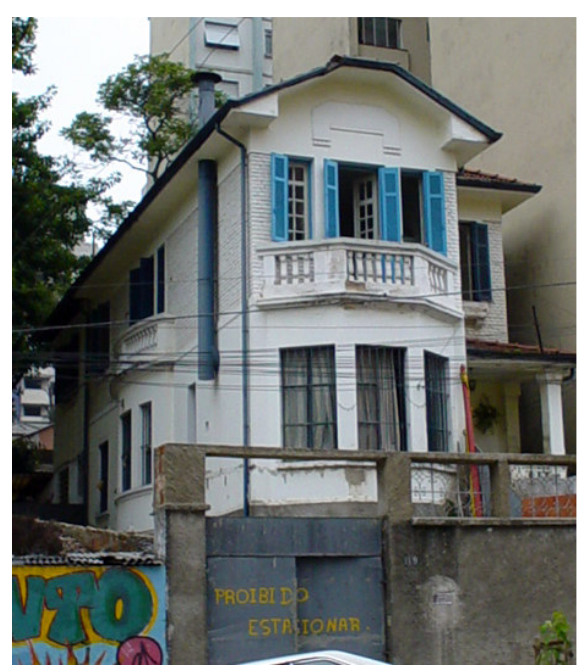

FIGURA 174 : Casa à rua Herculano de Freitas.

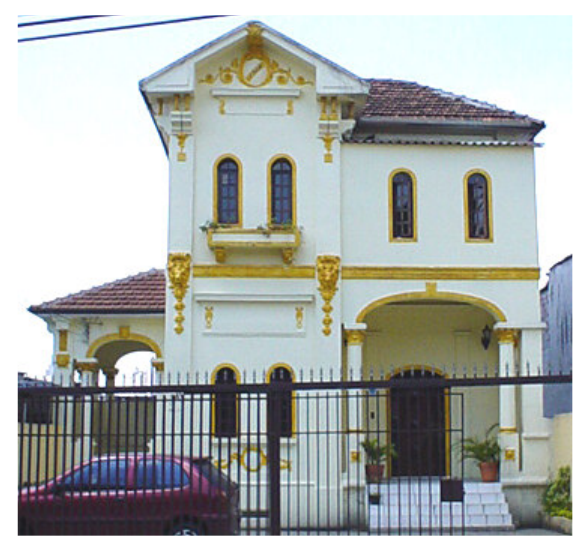

FIGURA 175 : Casa à avenida Independência (inscrição da data 1924 no medalhão).
2. Casas com estilemas do "Maneirismo

Paulistano" e ornamentos do Ecletismo Classicizante ou Historicista.

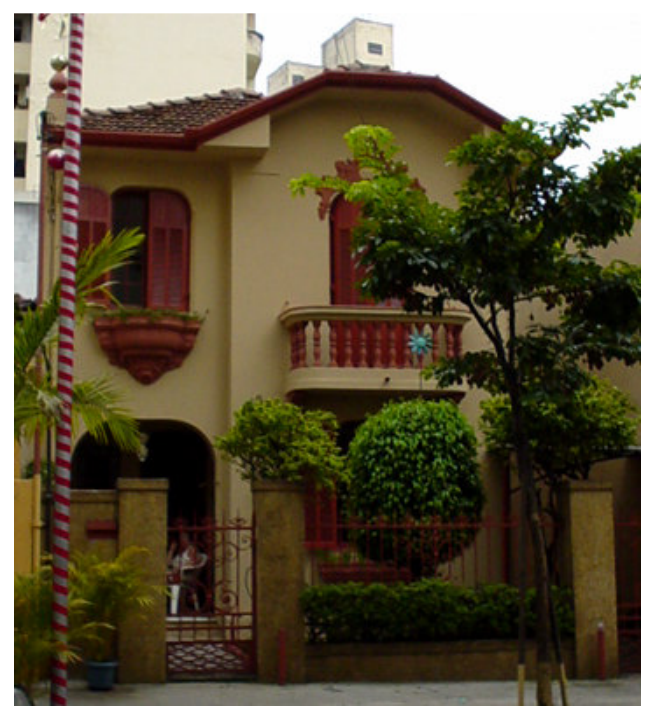

FIGURA 176 : Casa à rua Canuto do Val.

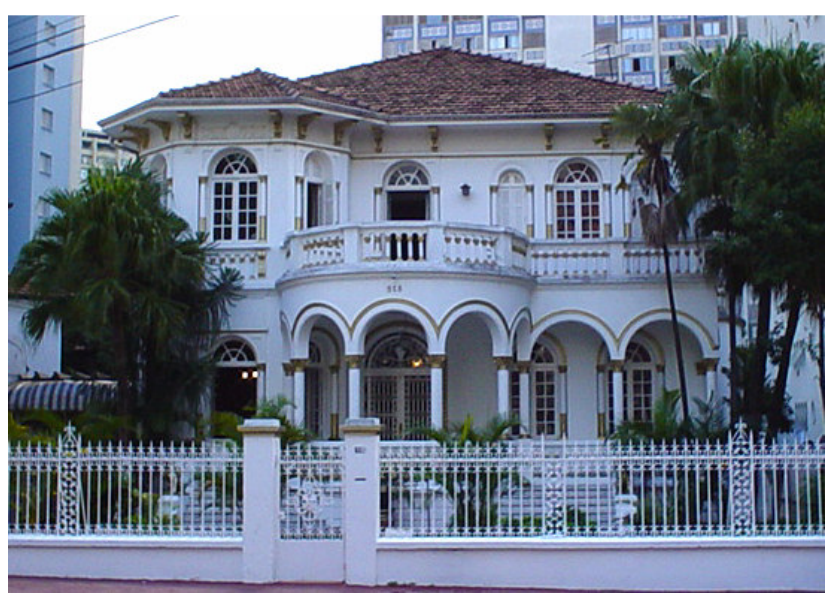

FIGURA 177 : Residência à rua dos Franceses. 


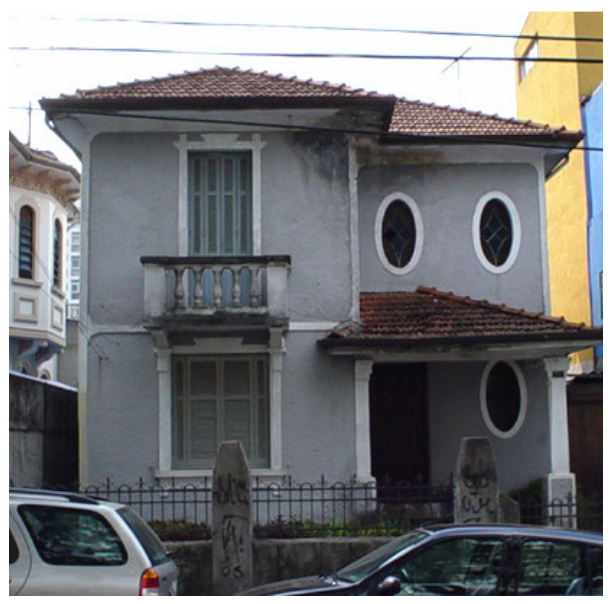

FIGURA 178 : Casa à avenida Pompéia.

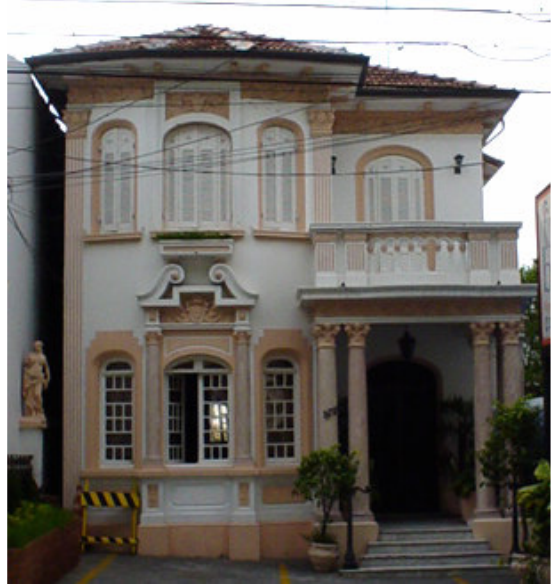

FIGURA 179: Casa à avenida Pompéia.

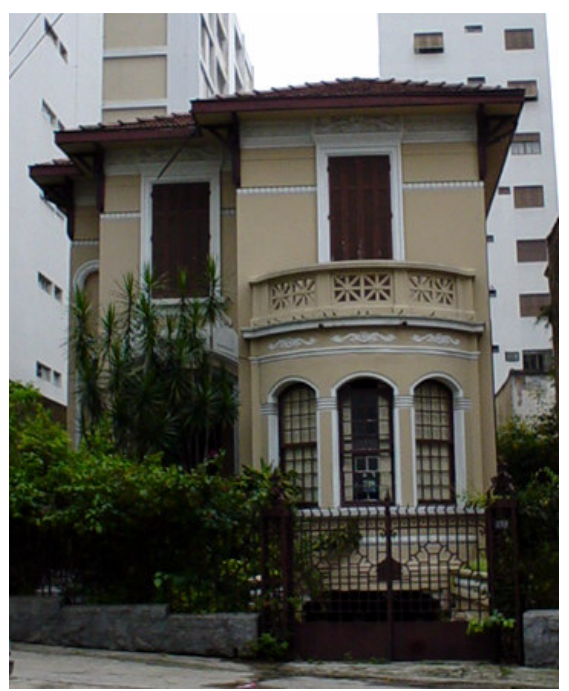

FIGURA 180: Casa à rua Itambé.
3. Casas com volumetria do "Maneirismo Paulistano" e composição de fachada com elementos ornamentais de outras fontes estilísticas.

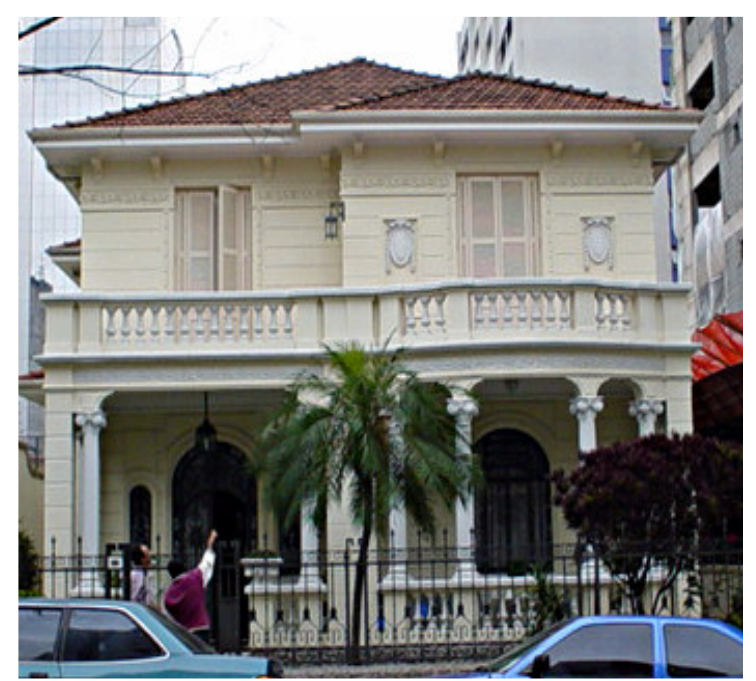

FIGURA 181 : Casa à rua Sampaio Viana.

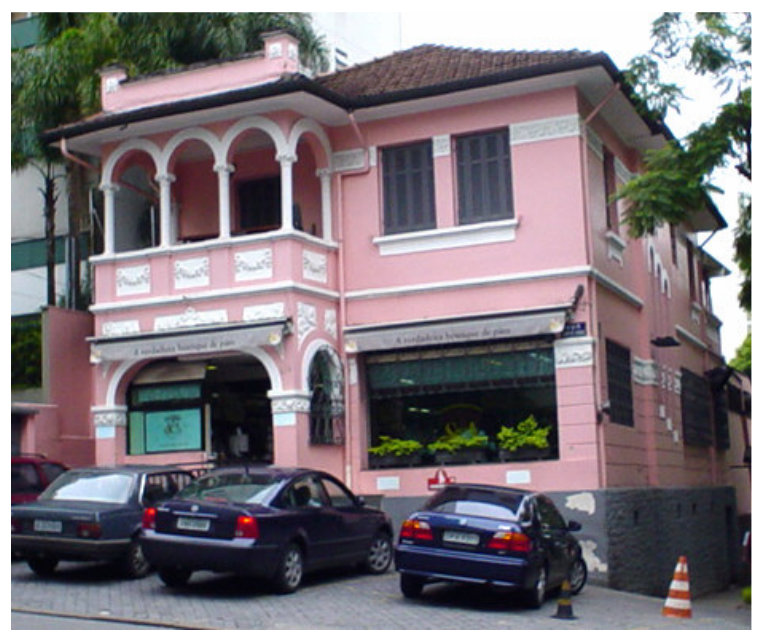

FIGURA 182 : Casa à rua Sampaio Viana. 
4. Casas com volumetria e estilemas do "Maneirismo Paulistano" apresentando alguns elementos ornamentais do Neocolonial luso-brasileiro.

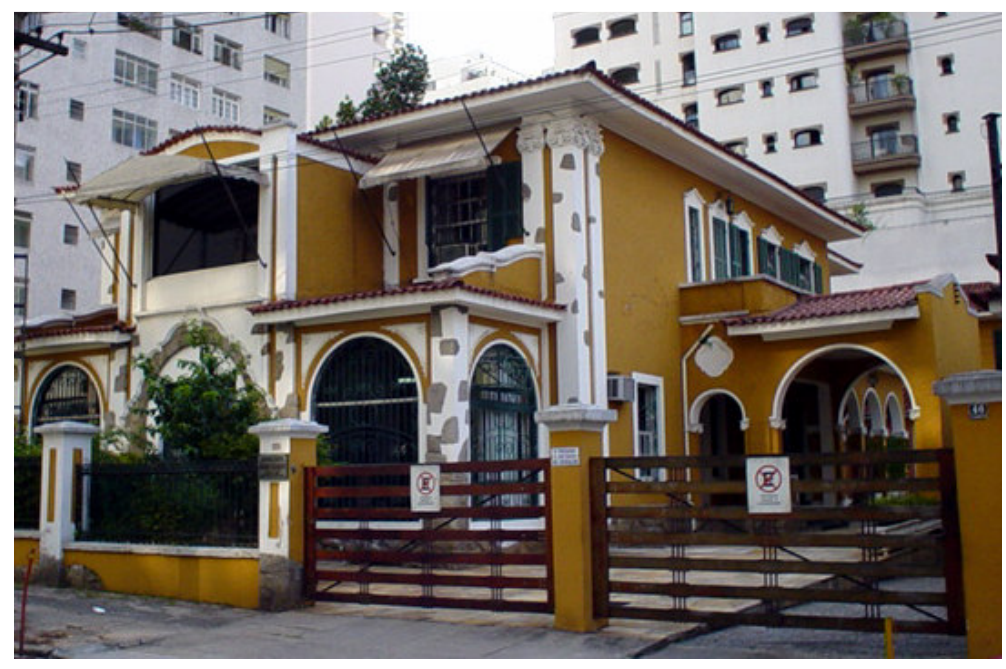

FIGURA 183 : Residência à rua Brasílio Machado.

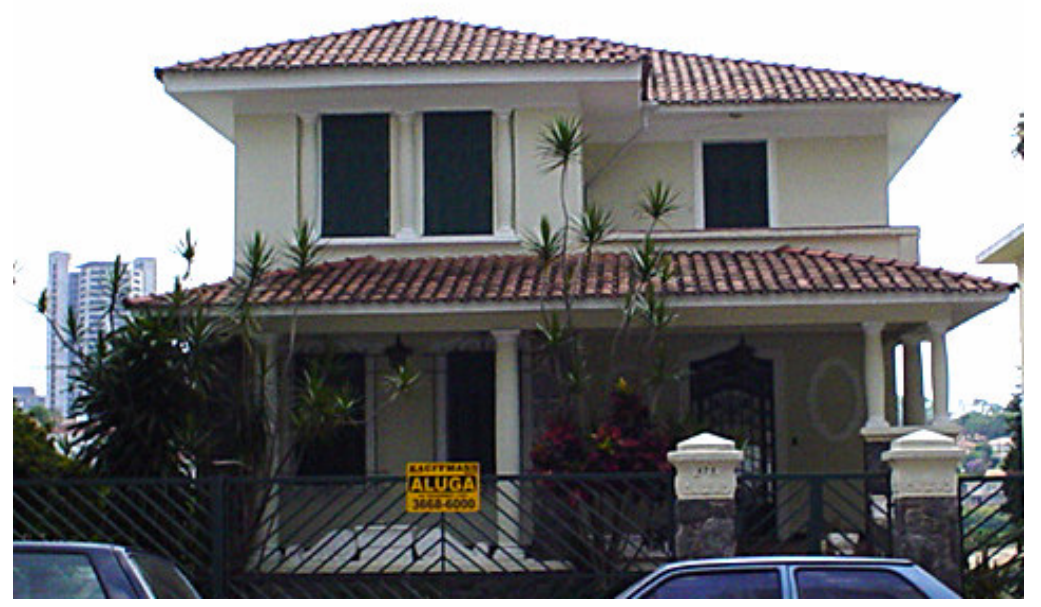

FIGURA 184 : Residência à rua Ceará. 
5. Casas com volumetria do "Maneirismo Paulistano" sem ornamentação.

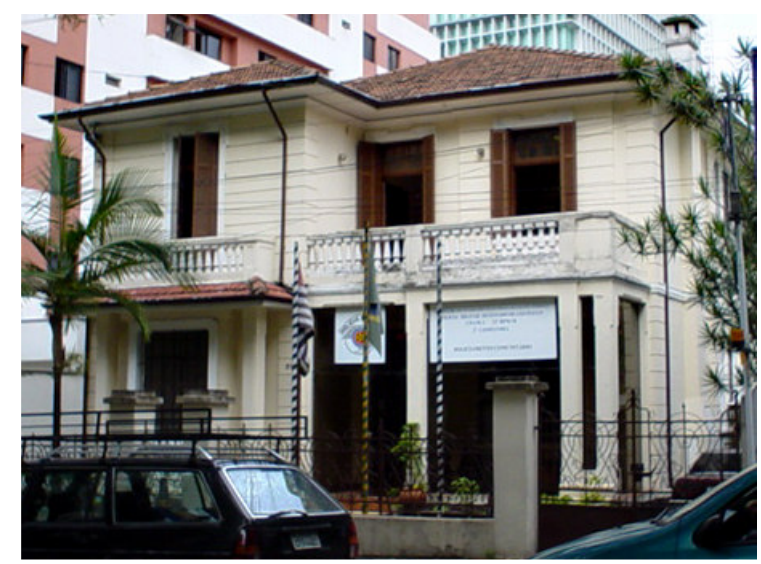

FIGURA 185 : Residência à rua Gabriel dos Santos.

6. Casas misturando estilemas do "Maneirismo Paulistano" com os do Neocolonial hispanoamericano.

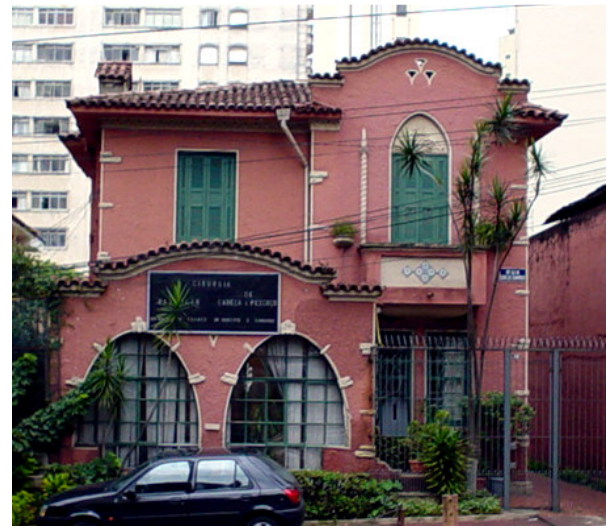

FIGURA 186 : Residência à rua Carlos Sampaio.

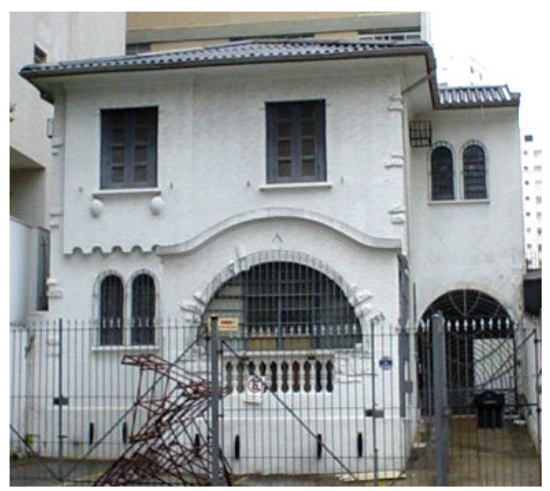

FIGURA 188 : Residência à rua Aureliano Coutinho.

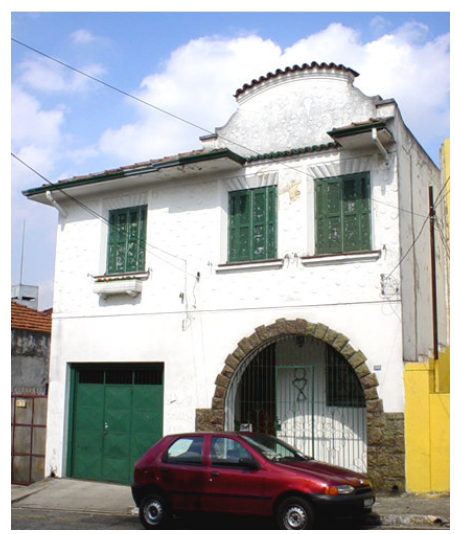

FIGURA 187 : Casa à rua Venâncio Aires.

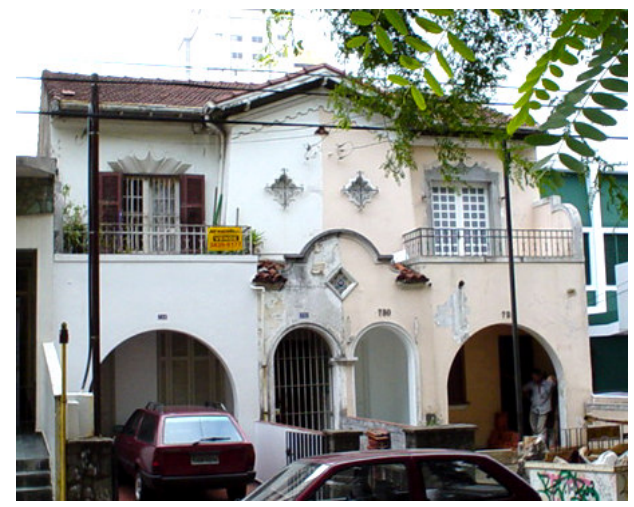

FIGURA 189 : Casas geminadas à avenida Pomnéia. 
7. Casas com estilemas do "Maneirismo Paulistano" e decoração Art Déco.
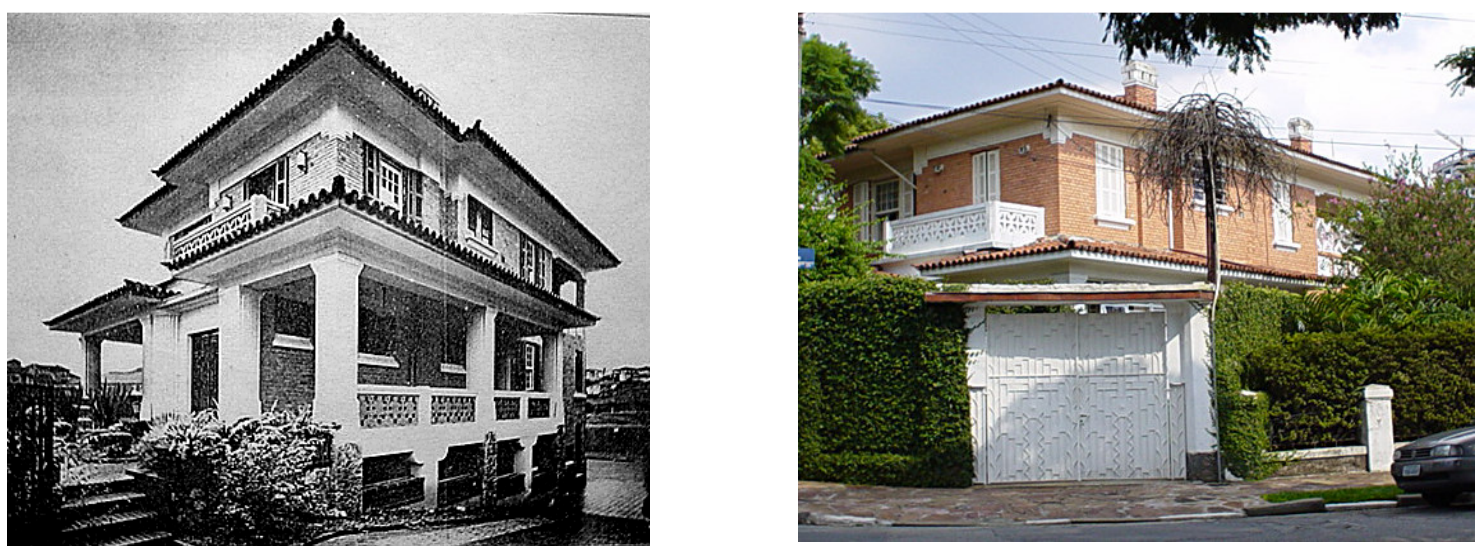

FIGURAS 190 e 191 : Residência à rua Avaré em 1931 e em 2003. (Camargo \& Mesquita Engs. Civis e Architectos / São Paulo. 1931)

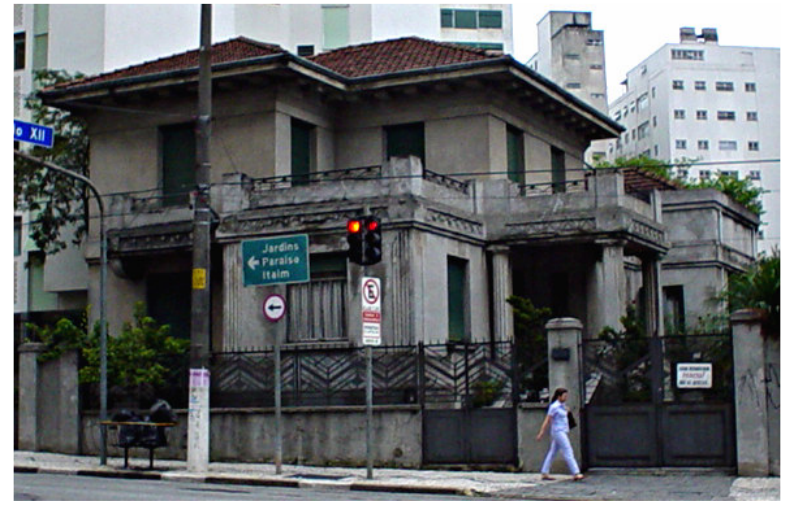

FIGURAS 192 e 193 : Residência à rua Treze de Maio.
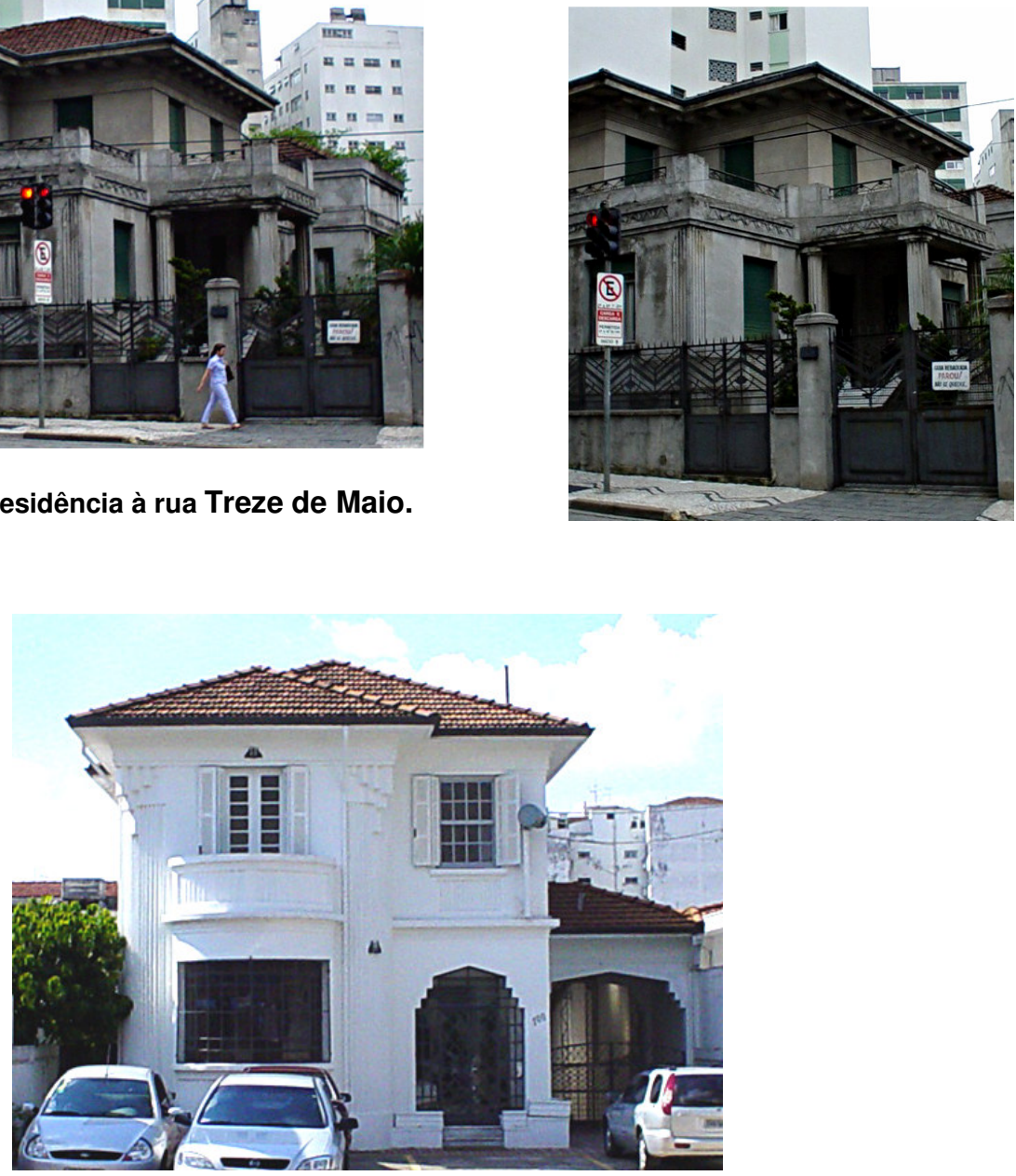

FIGURAS 194 : Casa à rua Tomé de Souza. 
8. Casas com estilemas do Neocolonial luso-brasileiro, hispano-americano e Art Déco. A residência do artista Theodoro José da Silva Braga, ${ }^{53}$ localizada na rua Traipu no bairro do Pacaembu, projeto do arquiteto Eduardo Kneese de Mello (1937), representou um raro exemplo da aplicação de motivos de origem marajoara na ornamentação de fachadas e de interiores de edificações residenciais paulistanas.
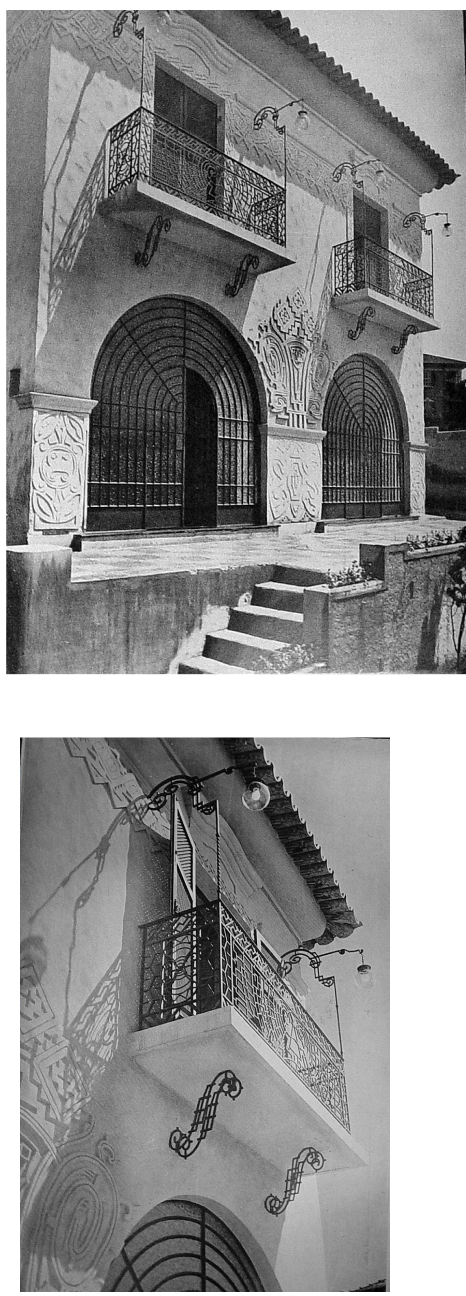

FIGURA 197 : Detalhe do balcão e do guarda-corpo de ferro trabalhado em motivos marajoaras (1937).

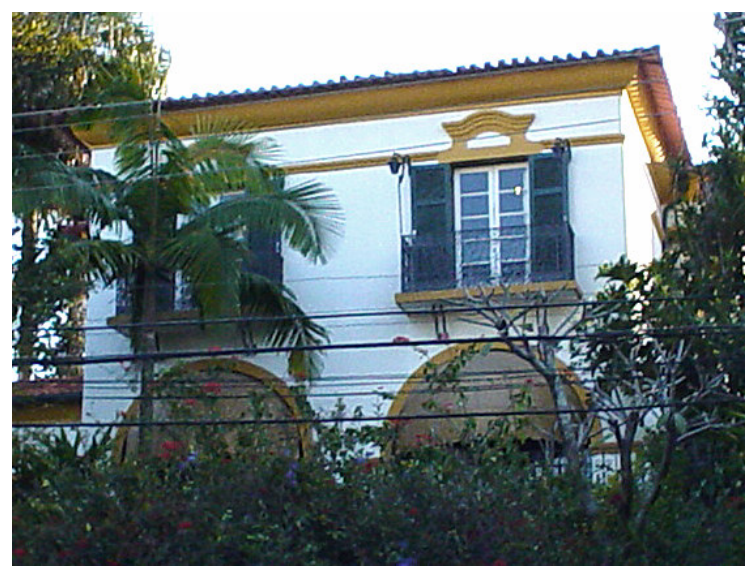

FIGURAS 195 e 196 : Antiga residência de Theodoro Braga na rua Traipu em 1937 e em 2003.

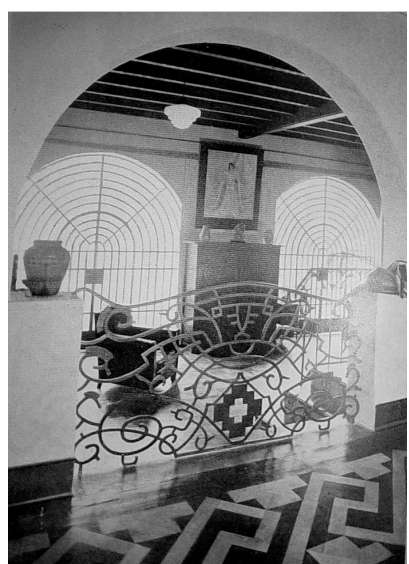

FIGURA 198 : Vista interna da sala de jantar para o estúdio / piso e gradil em motivos marajoaras (1937).

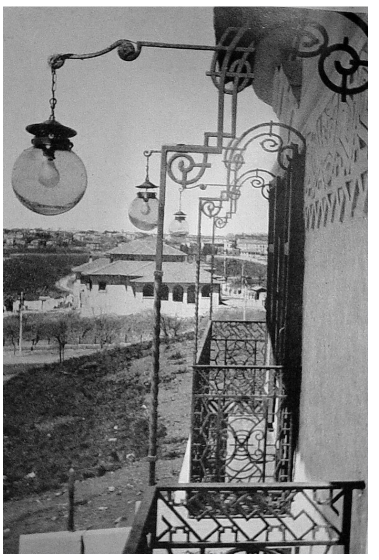

FIGURA 199 : Os dois balcões da fachada e a vista sobre 0 bairro do Pacaembu (1937).

\footnotetext{
${ }^{53} \mathrm{Na}$ década de 30 o paraense Theodoro Braga se configurou em importante divulgador da cultura indígena do norte do país, influenciando diretamente a produção de inúmeros artistas na capital paulistana. "No início da década de 1930, o pintor Theodoro Braga (1872-1953) preconizava uma saída por uma arte brasileira mirando-se na experiência dos países latinoamericanos que adotavam desenhos pré-hispânicos como ornamentação. Braga foi um estudioso dos motivos da cerâmica marajoara." SEGAWA, Hugo. "Modernidade Pragmática. Uma Arquitetura dos anos 1920/40 fora dos manuais." In: Revista Projeto. № 191, 1995, p. 77.
} 
9. Casas de feição Art Déco com elementos decorativos do Ecletismo Historicista.

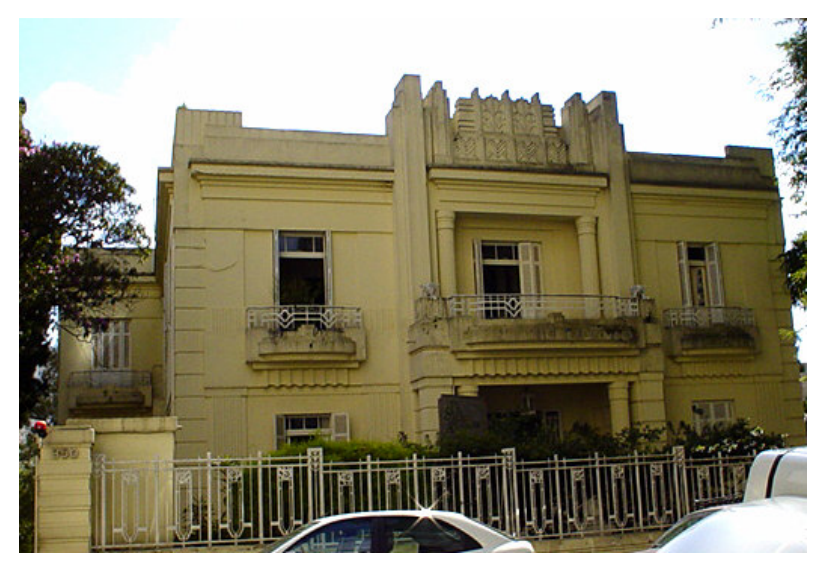

FIGI JRA 200 : Residência à rua dos Franceses.

10. Casas personalistas com referências ao Neocolonial hispano-americano.

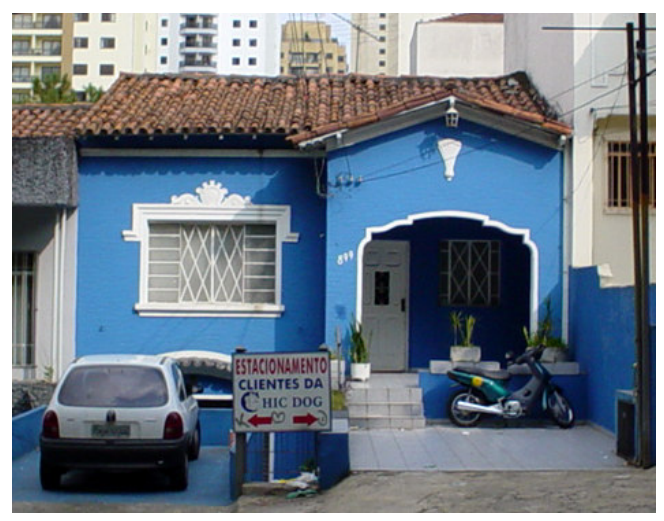

FIGURA 201 : Casa à avenida Pompéia.

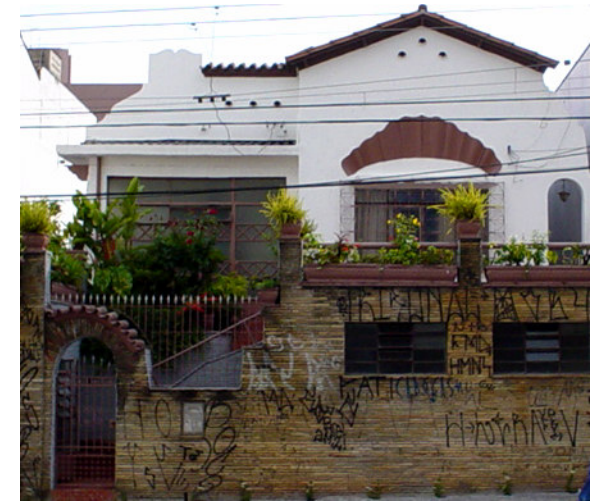

FIGURA 202 : Casa à rua Desembargador do Vale.

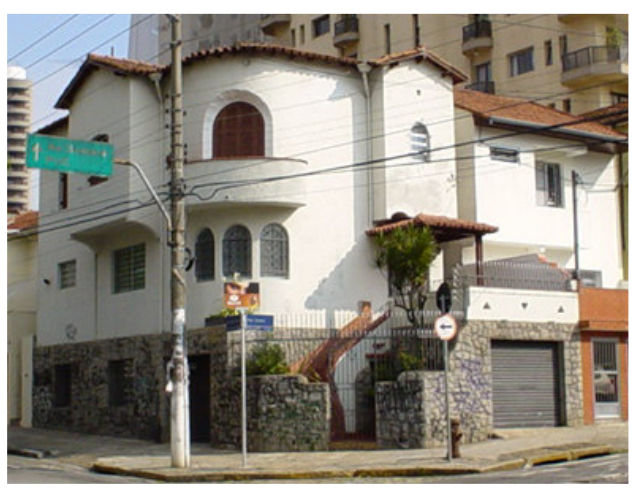

FIGURA 203 : Casa à rua Cotoxó. 
11. Casas personalistas com referências ao Art Déco.

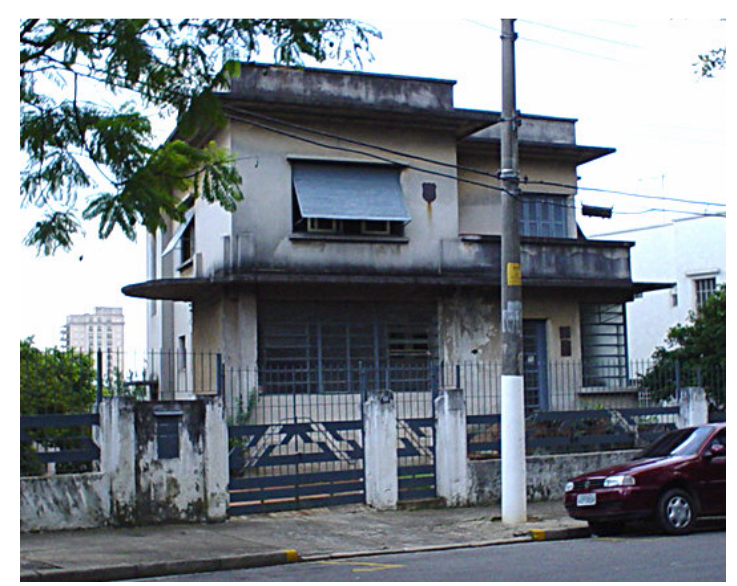

FIGURA 204 : Residência à praça Farias Brito.

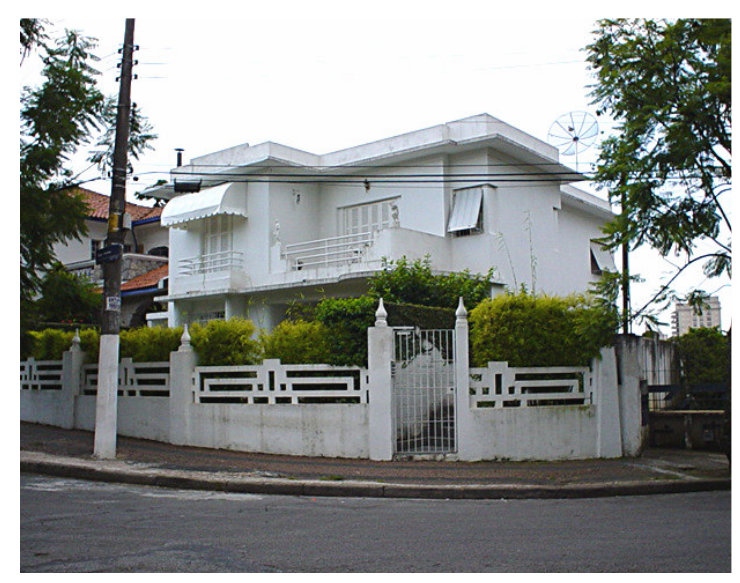

FIGURA 205 : Residência à praça Farias Brito esquina da rua Avaré.

12. Casas sem atavios, chãs.

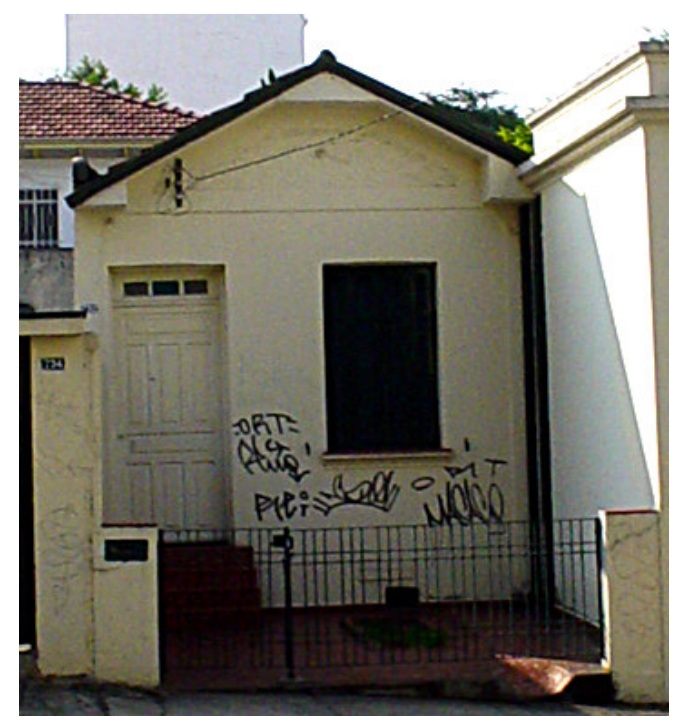

FIGURA 206 : Casa à rua Cotoxó. 
13. Casas resultantes de criações sincréticas livres e personalistas.

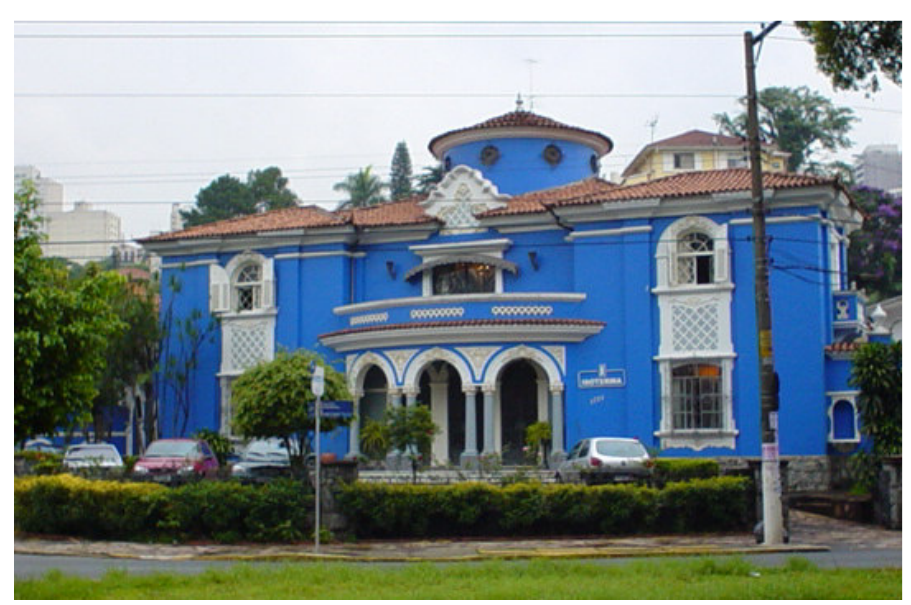

FIGURA 207 : Residência à avenida Pacaembu.

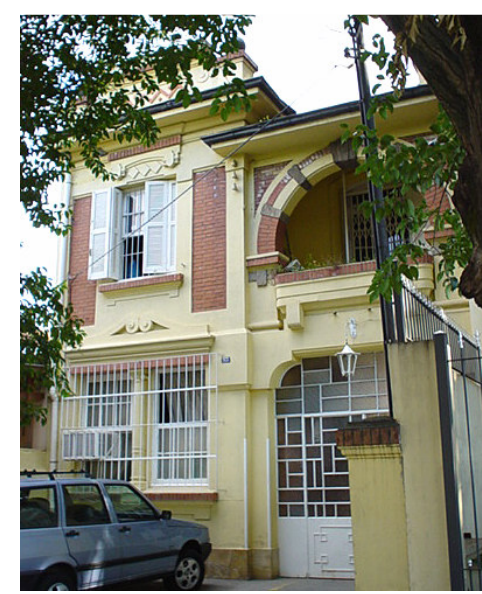

FIGURA 208 : Casa à rua João Annes.

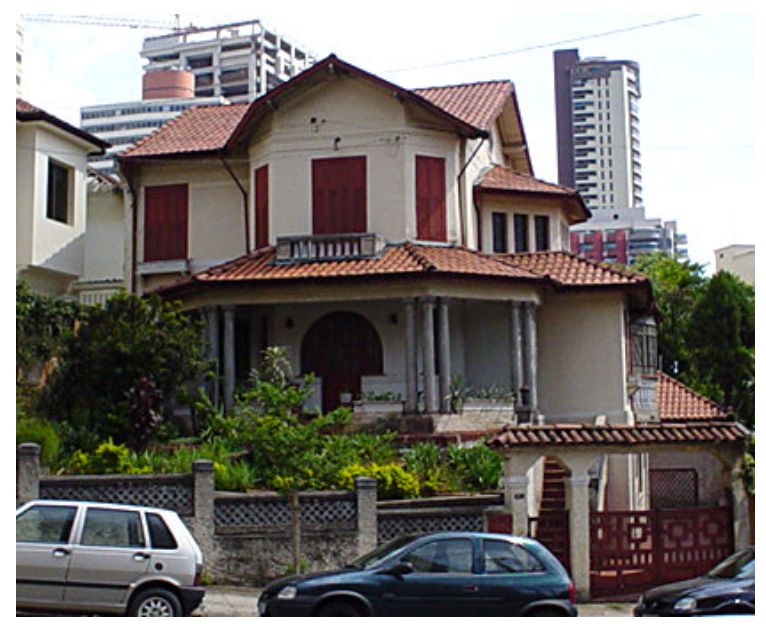

FIGURA 209 : Residência à rua Goiás.

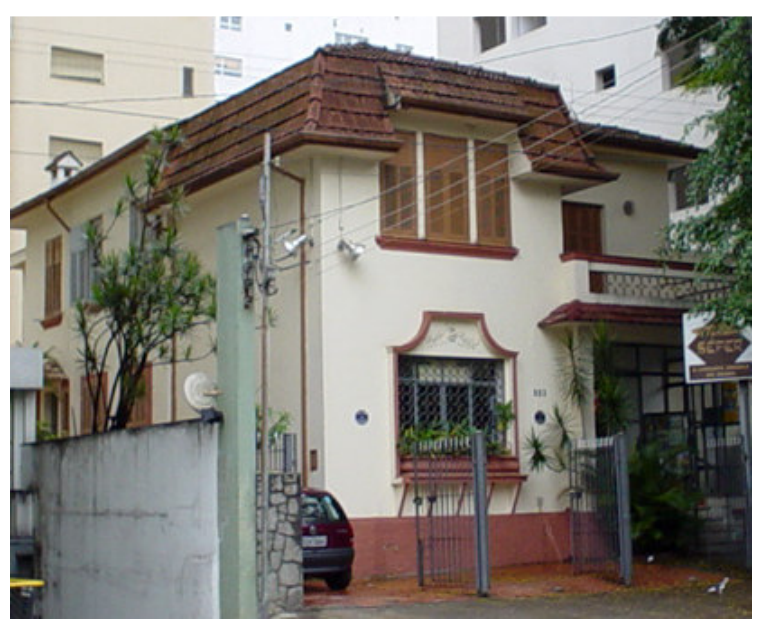

FIGURA 210 : Residência à alameda Barros. 
Concluindo, podemos dizer que na cidade de São Paulo nos anos 20 e 30 as manifestações arquitetônicas residenciais populares predominantes foram resultado de recriações e de sincretismos, que didaticamente neste trabalho denominamos de "Maneirismo Paulistano" e de "Estilo Indefinido". O número dessas edificações residenciais perante o total levantado é significativo, o que nos induz a ponderar a sua importância arquitetônica no ambiente urbano paulistano do período entre as Grandes Guerras, cujo estudo mais atento, em última análise, é que inspirou e justificou este trabalho. 
Considerações Finais 
A análise pormenorizada do conjunto de projetos sorteados na pesquisa e a observação atenta das edificações residenciais produzidas no período entre as Guerras Mundiais, que sobreviveram até nossos dias, nos permitiram constatar a ocorrência de um fenômeno único, caracterizador da arquitetura residencial dos anos 20 e 30 na cidade de São Paulo.

À parte dos exemplares projetados para a elite por profissionais de renome e das habitações operárias e de uso misto, notamos o surgimento quase que espontâneo de manifestações arquitetônicas residenciais provenientes da expressão dos estratos médios da população paulistana, cujo alto índice de incidência verificado nos intrigou, levando-nos a examiná-las com mais cuidado.

Do ponto de vista técnico-construtivo, percebemos que poucas alterações significativas ocorreram até o final da década de 1920, período no qual a alvenaria de tijolos ainda era usualmente empregada na construção das residências populares paulistanas. Somente a partir dos anos 30 é que o uso de estruturas aliando elementos de ferro/aço e de concreto armado começou a se generalizar nas casas de classe média média e média alta. Naquele momento, o concreto armado configurou-se na mais importante inovação técnicoconstrutiva, atuando freqüentemente como coadjuvante em sistemas estruturais mistos. Vimos também que, apesar do seu emprego permitir a solução de vários problemas de ordem estrutural, construtiva e projetual, o uso mais banalizado de elementos de concreto armado nas edificações residenciais da capital paulista pelos profissionais atuantes na época não implicou na busca de uma nova estética arquitetônica ligada a este modo de construir.

No nosso estudo foi possível notar que o programa básico dessas residências se diversificou em uma grande variedade de agenciamentos no entre-guerras. As novidades atingiram fundamentalmente as habitações de classe média média, nas quais vulgarizou-se o "morar à francesa". Nesse tempo difundiu-se o uso do vestíbulo ou hall como espaço de distribuição e de separação funcional entre as áreas de estar, repouso e serviço das residências; as instalações sanitárias com banho foram incorporadas definitivamente no corpo das casas; surgiu a copa junto à cozinha e, no fundo dos lotes, apareceram a garagem e a edícula. Verificamos igualmente nas décadas de 1920 e 1930 o estabelecimento de novos modos de implantação das residências : casas isoladas nos lotes, geminadas duas a duas, ou então, agrupadas formando vilas. 
No entanto, o principal fator de distinção da arquitetura residencial paulistana de classe média deste período vai se concentrar na sua feição estilística. Nesse momento houve uma apropriação seletiva e combinação livre de elementos do repertório dos estilos eruditos, então em voga, que foi geradora de duas vertentes arquitetônicas residenciais de cunho popular, identificadas no trabalho como "Maneirismo Paulistano" e "Estilo Indefinido".

$\mathrm{Na}$ nossa pesquisa constatamos que o "Maneirismo Paulistano" ocorreu concomitantemente ao Neocolonial luso-brasileiro. Percebemos também que essa linguagem estilística foi resultante de recriações inspiradas nas residências neocoloniais projetadas pelo arquiteto Victor Dubugras a partir do final da década de 1910. O "Maneirismo Paulistano" repetiu uma fórmula estilística reconhecível em inúmeras casas construídas na época, utilizando estilemas que se tornaram a marca dessa corrente disseminada amplamente na capital paulista durante os anos 20 e 30 . Acreditamos que este processo de "desconstrução" de uma expressão erudita e conseqüente "reconstrução" de uma linguagem arquitetônica própria pela classe média paulistana, muitas vezes auxiliada por construtores anônimos, ocorreu de maneira natural, sem pretensões claras de gerar um estilo ou de elaborar uma nova estética. Este acontecimento ímpar de manifestação arquitetônica da classe média irá arrefecer-se durante a Segunda Grande Guerra até desaparecer progressivamente no final da década de 1940.

No mesmo período, observamos um número significativo de edificações residenciais sem caráter definido, cuja única afinidade era a exacerbação da individualidade. Verificamos que estas expressões arquitetônicas residenciais surgiram a partir da "contaminação estilística", ou melhor, do "contágio visual" resultante da observação dos palacetes e das casas ricas; da influência do cinema e das revistas de variedades veiculadas na época, além da vontade explícita de "ser" moderno e "estar" na moda, ansiadas pelas camadas médias da população paulistana. Assim, a composição formal e estilística das fachadas destas habitações derivava do sincretismo de estilemas de diversos estilos arquitetônicos e de criações personalistas, gerando uma infinidade de variantes residenciais, das mais simples às mais elaboradas. Estas casas, espalhadas por inúmeros bairros paulistanos, foram englobadas no nosso estudo no "Estilo Indefinido".

O pós-Segunda Guerra caracterizará novos tempos, onde novas condições, novos gostos, novas expectativas e nova estética surgirão, condicionando uma nova arquitetura residencial paulistana. A Arquitetura Moderna aparecerá como opção estilística e como modelo erudito apenas nos anos 50, enquanto o uso do concreto armado será definitivamente vulgarizado nas construções residenciais. 
O inexorável processo de verticalização da cidade, marcado pela crescente construção de edifícios de todos os tipos, possibilitará o surgimento de um novo modo de morar que será adotado paulatinamente pelas classes médias da população paulistana, o edifício de apartamentos. ${ }^{1}$ A partir de programas diferenciados para atender os diferentes estratos da sociedade, serão desenvolvidas soluções arquitetônicas próprias determinando modelos de organização espacial e dimensionamento, referenciados nos moldes das habitações unifamiliares tradicionais e adaptados às novas expectativas de "status" e conforto.

Com o passar do tempo, a classe média paulistana perdeu a expressão arquitetônica própria, que tão bem caracterizou a arquitetura residencial paulistana no período entre a Primeira e a Segunda Guerras Mundiais, para ocupar novamente o papel passivo de simples consumidora dos modelos e padrões arquitetônicos definidos pelas classes altas e sobretudo pelos incorporadores imobiliários.

E, como diz Carlos A. C. Lemos, “... já são outros os tempos, tempos de comunicação fácil, do cinema, da televisão e das revistas de decoração que condicionam o gosto consumista. Hoje se copia tudo. Faz mais de cinqüenta anos que a classe média não inventa e não assume mais nada." ${ }^{2}$

\footnotetext{
1 "Nos anos 30, com a disseminação do uso do concreto, o prédio de apartamentos mostra-se definitivamente como solução de moradia coletiva, até então altamente rejeitada pelo gosto popular e pela classe média que associava os edifícios multifamiliares aos cortiços de pobres. /.../ Morar em apartamento não era uma opção barata. Os edifícios construídos na época eram sempre para aluguel. /.../ A verticalização, aceita inicialmente com relutância, se multiplicaria nas décadas de 30 e 40, constituindo-se numa grande inovação no setor residencial com o surgimento dos prédios de apartamentos." In: SOMEKH, Nadia. A Cidade Vertical e o Urbanismo Modernizador p. 144.

${ }^{2}$ In: LEMOS, Carlos A.C. Alvenaria Burguesa, p. 190.
} 
Referências Bibliográficas 


\section{Obras Publicadas / Livros}

AMARAL, Aracy (coord.) Arquitectura Neocolonial : América Latina, Caribe, Estados Unidos. São Paulo, Fundação Memorial da América Latina, 1994.

Artes Plásticas na Semana de 22. São Paulo, Editora Perspectiva, 1978.

Art Déco na América Latina. $1^{0}$ Seminário Internacional. Rio de Janeiro, Prefeitura da Cidade do Rio de Janeiro - SMU / Centro de Arquitetura e Urbanismo do Rio de Janeiro / Solar Grandjean de Montigny - PUC / RJ, 1997.

. ARTIFEX - Ingeniería Romana en España. Madrid, Museo Arqueológico Nacional, 2002.

. AZEVEDO, Aroldo (org.) A Cidade de São Paulo. Estudos de Geografia Urbana. v. III. São Paulo, Associação dos Geógrafos Brasileiros - Seção Regional de São Paulo / Companhia Editora Nacional, 1958.

- BAYÓN, Damián. Sociedad y Arquitectura Colonial Sudamericana. Una Lectura Polémica. Colección Arquitectura y Critica. Barcelona, Editorial Gustavo Gili, 1974.

. BOSSAGLIA, Rossana. Guide all'Architettura Moderna : L' Art Déco. Roma, Editori Laterza, 1984.

. BRAUDEL, Fernand. Escritos sobre a História. São Paulo, Editora Perspectiva, 1978.

. BRUAND, Yves. Arquitetura Contemporânea no Brasil. São Paulo, Editora Perspectiva, 1981.

- BRUNO, Ernani da Silva. Memória da cidade de São Paulo : depoimentos dos moradores e visitantes 1553 - 1958. São Paulo, Departamento do Patrimônio Histórico (DPH), 1981.

. CAMARGOS, Márcia. Villa Kyrial - Crônicas da Belle Époque Paulistana. São Paulo, Editora SENAC, 2001.

Semana de 22 entre vaias e aplausos. São Paulo, Boitempo Editorial, 2002.

. CARVALHO, Maria Cristina Wolff. Ramos de Azevedo. São Paulo, EDUSP, 2000.

. CAVALCANTI, Lauro. As Preocupações do Belo. Rio de Janeiro, Taurus Editora, 1995.

Quando o Brasil era Moderno. Guia da Arquitetura 1928-1960. Rio de Janeiro, Aeroplano, 2001.

. CZAJKOWSKI, Jorge (org.). Guia da Arquitetura Eclética no Rio de Janeiro. Rio de Janeiro, Prefeitura da Cidade do Rio de Janeiro - SMU / Centro de Arquitetura e Urbanismo do Rio de Janeiro, 2000. 
. Guia da Arquitetura Art Déco no Rio de Janeiro. Rio de Janeiro, Prefeitura da Cidade do Rio de Janeiro - SMU / Centro de Arquitetura e Urbanismo do Rio de Janeiro, 2000.

. DEBENEDETTI, Emma \& SALMONI, Anita. Arquitetura Italiana em São Paulo. São Paulo, Editora Perspectiva, 1981.

. DUNCAN, Alistair. American Art Deco. Londres, Thames and Hudson, 1986.

. Exposition Internationale des Arts Décoratifs et Industriels Modernes - Paris, 1925 : Rapport Général . v. 2. Paris, Librairie Larousse, 1928.

. EWBANK, Thomas. Vida no Brasil ou Diário de uma visita à terra do cacaueiro e da palmeira. Belo Horizonte, Livraria Itatiaia Editora Ltda / EDUSP, 1976.

. FABRIS, Annateresa (org.) Ecletismo na Arquitetura Brasileira. São Paulo, Ed. Nobel / EDUSP, 1987.

. FAUSTO, Bóris. Negócios e Ócios: História da Imigração. São Paulo, Cia. das Letras, 1997.

. FERRARA, Lucrécia D’ Aléssio. A Estratégia dos Signos. São Paulo, Ed. Perspectiva, 1981.

. HOLLINGSWORTH, Mary. Architecture of the 20th Century. New York, Crescent Books, 1988.

. HOMEM, Maria Cecília Naclério. Higienópolis - grandeza e decadência de um bairro paulistano. História dos Bairros de São Paulo, v.17. São Paulo, PMSP/SMC/ $\mathrm{DPH}, 1980$.

. O Palacete Paulistano e outras Formas Urbanas de Morar da Elite Cafeeira 1867 - 1918. São Paulo, Martins Fontes, 1996.

. Homenagem a Ricardo Severo. Centenário de seu nascimento 1869 - 1969. São Paulo, Gráfica Sangirardi, 1969.

. KLEIN, Dan et alii. In the Deco Style. New York, Rizzoli, 1987.

. KOCH, Wilfried. Estilos de Arquitetura I e II. Lisboa, Editorial Presença / Martins Fontes, 1982.

LANGENBUCH, Juergen Richard. Estruturação da Grande São Paulo. Estudo de Geografia Urbana. Rio de Janeiro, Fundação IBGE, 1971.

. LEMOS, Carlos A. C . Cozinhas, etc. São Paulo, Editora Perspectiva, 1976.

Alvenaria Burguesa. São Paulo, Nobel, 1985.

Ramos de Azevedo e seu escritório. São Paulo, Editora Pini, 1993.

A República Ensina a Morar (Melhor). Coleção Estudos Históricos.

São Paulo, Editora Hucitec, 1999. 
. LOBATO, Monteiro. Idéias de Jeca Tatú. São Paulo, Editora Brasiliense, 1967.

. MACEDO, Silvio Soares. Higienópolis e Arredores. Processo de Mutação de Paisagem

Urbana. São Paulo, EDUSP / Editora Pini, 1987.

MAENZ, Paul. Art Déco : 1920-1940. Formas entre dos guerras. Barcelona, Editorial Gustavo Gili, 1974.

. MARGENAT, Juan Pedro. Arquitectura Art Déco en Montevideo (1925-1950) - quando no todas las catedrales eran blancas. Montevidéu, Editorial Dardo Sanzberro, 1994.

MARIANNO (FILHO), José. À Margem do Problema Arquitetônico Nacional. Rio de Janeiro, 1943.

. MOTOYAMA, Shozo (org.) Tecnologia e Industrialização no Brasil - Uma Perspectiva Histórica. São Paulo, Editora UNESP, 1994.

. MOUSNIER, Roland. As Hierarquias Sociais - de 1450 aos nossos dias. Lisboa, Europa-America, 1974.

. Os Engenheiros Politécnicos e sua escola. São Paulo, Livro Poli,1995.

PEIXOTO, Gustavo Rocha. Reflexos das Luzes na Terra do Sol - sobre a Teoria da Arquitetura no Brasil da Independência 1808-1831. São Paulo, Proeditores, 2000.

. PEVSNER, Nikolaus. Os Pioneiros do Desenho Moderno - de Williams Morris a Walter Gropius. São Paulo, Livraria Editora Martins Fontes, 1980.

. QUÉNIOUX, Gaston. Les Arts Décoratifs Modernes. Paris, Librairie Larousse, 1925.

- RANZINI, Felisberto. Estylo Colonial Brasileiro. Composições Architectonicas de Motivos Originaes. São Paulo, Editor Amadeu de Barros Saraiva, 1927.

. REIS FILHO, Nestor Goulart. Quadro da Arquitetura no Brasil. São Paulo, Editora Perspectiva, 1978.

Racionalismo e Proto-Modernismo na obra de Victor Dubugras. São Paulo, Fundação Bienal de São Paulo, 1997.

. RODRIGUES, José Wasth. Documentário Arquitetônico - Relativo à antiga construção civil no Brasil. São Paulo, EDUSP / Livraria Martins Fontes, 1975.

. SANTOS, Maria Cecília Loschiavo dos. Escola Politécnica (1894 - 1984). São Paulo, EDUSP, 1985.

- SANTOS, Paulo F. Quatro Séculos de Arquitetura. Rio de Janeiro, Instituto dos Arquitetos do Brasil, 1981.

. SEGAWA, Hugo . Arquiteturas no Brasil 1900 - 1990. São Paulo, EDUSP, 1998.

. SEVCENKO, Nicolau. Orfeu Extático na Metrópole. São Paulo sociedade e cultura nos frementes anos 20. São Paulo, Companhia das Letras, 1992. 
. SHARP, Dennis. A Visual History of twentieth-century Architecture. Greenwich, Conn., New York Graphic Society, 1972.

. SOMEKH, Nadia. A Cidade Vertical e o Urbanismo Modernizador. São Paulo, EDUSP / Studio Nobel / FAPESP, 1997.

. SOUZA, Maria Adélia Aparecida de. A Identidade da Metrópole. São Paulo, Hucitec / EDUSP, 1994.

. TELLES, Pedro Carlos da Silva. História da Engenharia no Brasil. Rio de Janeiro, Clube de Engenharia, 1993.

. VARGAS, Milton (org.) História da Técnica e da Tecnologia no Brasil. São Paulo, Editora UNESP / CEETEPS, 1994.

. VASCONCELOS, Augusto Carlos de. O Concreto no Brasil : recordes, realizações, história. v. I. São Paulo, Editora Pini, 1992.

O Concreto no Brasil : Professores, Cientistas, Técnicos. v. II. São Paulo, Editora Pini, 1992.

. VERONESI, Giulia. Style 1925. Triomphe et chute des “Arts - Déco". Paris, Editions Anthony Kraft / Bibliothèque des Arts, 1968.

\section{Artigos / Periódicos}

Acrópole. São Paulo, no16, ago. 1939; no 31, nov. 1940; no 37, maio 1941.

ALBUQUERQUE, Alexandre. "Architectura Moderna." In: Revista Polytechnica. São Paulo, no102, nov. /dez. 1931, p.p. 395-398.

. ALMEIDA, Ramiro. "A Expansão Vertical e Latitudinal da cidade de S. Paulo." In : Illustração Brasileira. Rio de Janeiro, nº 109, set. 1929.

. ANDRADE, Mário de. "Arquitetura Colonial." (1928) In: Arte em Revista. São Paulo, Kairós Livraria e Editora Ltda, nº 4, ago.1980, p.p. 12-14.

. "Exposição duma Casa Modernista (Considerações)" (1930) In: Arte em Revista. São Paulo, Kairós Livraria e Editora Ltda, nำ4, ago.1980, p.p.7-8.

ANDRADE, Oswald de. "A Casa Modernista, o pior crítico do mundo e outras considerações." (1930) In: Arte em Revista. São Paulo, Kairós Livraria e Editora Ltda, № 4, ago.1980, p.p.10-11.

. "Aspectos da Cidade Maravilhosa." In: Correio Paulistano. São Paulo, 03/04/1927, p.4. 
. BARATA, Mário. "A Arquitetura Brasileira dos séculos XIX e XX." Separata de "Aspectos da Formação e Evolução do Brasil”, estudos publicados em 1952 no Jornal do Comércio. Rio de Janeiro, 1954.

. BARROS, Liliane S. Lehmann \& MOIZO, Rosana P. Azanha. "Formação Administrativa da cidade de São Paulo 1554 - 1954" In : Revista do Arquivo Municipal. São Paulo, Departamento do Patrimônio Histórico, no 199,1991.

. Boletim de Informações do Instituto de Engenharia. São Paulo, no 15 e 16, set.1927; no 3, março 1928.

. "Casa Marajoara de Theodoro Braga." In: Illustração Brasileira. Rio de Janeiro, no 26, jun. 1937.

. COSTA, Lucio. “Razões de uma Arquitetura.” In: Revista da Diretoria de Engenharia da Prefeitura do Distrito Federal. v.3. Rio de Janeiro, no 1, jan. 1936. . "Muita Construção, Alguma Arquitetura e um Milagre." In: Correio da Manhã. Rio de Janeiro, 15/06/1951.

. CZAJKOWSKI, Jorge. "A Arquitetura Racionalista e a Tradição Brasileira." In : Gávea Revista de História da Arte e Arquitetura. Rio de Janeiro, p.p. 22-35, s/d.

FREITAS, Antonio de Paula . "Construcções de Cimento Armado." In : Revista dos Cursos da Escola Polytechnica do Rio de Janeiro. Rio de Janeiro, 1904, p.p. 151192.

. FREIRE, Victor da Silva. "A Cidade Salubre." In: Revista Polytechnica. São Paulo, Typographia Brazil, no 48, out. / nov. 1914.

- GITAHY, Maria Lucia C. "O Papel do Gabinete de Resistência dos Materiais da Escola Politécnica na Transferência da Tecnologia do Concreto para São Paulo, 1899 1925 : um relato preliminar de pesquisa." In : Revista Pós. número especial 1 (p.p. 232-241). Seminário : O Estudo da História na Formação do Arquiteto. São Paulo, FAUUSP, 1994.

. KESSEL, Carlos. "Estilo, discurso, poder : Arquitetura Neocolonial no Brasil." In : História Social - Revista da Pós-graduação em História IFCH/UNICAMP. Campinas, noㅡ, 1999, p.p. 65-94.

. LEMOS, Carlos A . C. "O Morar no Modernismo Paulistano." In: O Caderno de São Paulo. São Paulo, Rhodia, 1979.

. MONCLUS, Francisco J. "Infraestructuras de transporte y crescimiento urbano en EEUU : literatura recente y nuevas perspectivas." In : Revista Historia Urbana 1. Valencia,1992. 
. NEVES, Christiano Stockler das. "Architectura Colonial." In : Jornal do Commercio. São Paulo, 03/02/1917, p.p. 4-5.

. "Considerações sobre a Architectura Tradicional do Brasil." São Paulo, Secção de Obras de O Estado de São Paulo, 1927. Texto apresentado no III Congresso Pan Americano de Architectos, Buenos Aires, jul. 1927.

. NEVES, José Maria da Silva."Uma Questão de Importância para o Urbanismo Paulistano." In: Illustração Brasileira. Rio de Janeiro, nº 109, set. 1929.

. "Victor Dubugras" In: Boletim do Instituto de Engenharia. São Paulo, no 90, maio 1933, p.p. 319-320.

. PAÍM. "Sobre a Arte dos Interiores." In: Illustração Brasileira. Rio de Janeiro, nº 109, set. 1929.

. PASQUALE, Petrone. "A Cidade de São Paulo no século XX." In: Revista de História. São Paulo, no 21 e 22, jan./jun. 1955, p.p.127-170.

. PINHEIRO, Maria Lucia Bressan. "Ricardo Severo e o estilo Tradicional Brasileiro." In : Revista d' Art. São Paulo, no 03, dez. 1998.

. PRADO, Yan de Almeida. "S. Paulo Antigo e a sua Architectura." In: Illustração Brasileira. Rio de Janeiro, no 109, set. 1929.

. Revista Polytechnica. São Paulo, 1905; nº 22, 1908; no 29, nov./dez. 1909; no 95/96, out. / nov. 1929; no 97/98, março / abr. 1930; no 100, ago./set. 1930; no 101, março/abr. 1931.

. SAIA, Luís. "Arquitetura Paulista" In: XAVIER, Alberto (org.) Arquitetura Moderna Brasileira : Depoimento de uma Geração. São Paulo, Associação Brasileira de Ensino de Arquitetura / Fundação Vilanova Artigas / Editora Pini, 1987, p.p. 95-110.

. SANTOS, Paulo F. "Constantes de Sensibilidade na Arquitetura do Brasil." In: Arquitetura Revista FAU / UFRJ . v.6. Rio de Janeiro, 1988, p.p. 52-71. . "Arquitetura no Brasil ." In: Revista de Arquitetura. Rio de Janeiro, Editora "O Construtor", no 90, maio/jun.1949, p.p. 7-8.

. "400 Anos Memoráveis." Urbanismo e Arquitetura. Caderno Especial do IV Centenário / Jornal do Brasil. Rio de Janeiro, 09/12/1965, p.p. 289-303.

. SEGAWA, Hugo. "Elisiário Bahiana e a Arquitetura Art Déco." In : Revista Projeto. São Paulo, no 67, set. 1984, p.p. 14-22.

. "Modernidade Pragmática. Uma Arquitetura dos anos 1920/40 fora dos manuais." In: Revista Projeto. São Paulo, no 191, nov. 1995, p.p. 73-84.

. SEVERO, Ricardo. "A Arte Tradicional no Brasil." In : Conferências 1914-1915. Sociedade de Cultura Artística. São Paulo, Typographia Levi, 1916, p.p. 37-82. 
. "Architectura Colonial III : Entrevista com o Dr. Ricardo Severo." In : O

Estado de São Paulo. São Paulo, 15/04/1926.

. WARCHAVCHIK, Gregori. "São Paulo e a Architectura Nova." In: Illustração Brasileira.

Rio de Janeiro, no 109, set. 1929.

"Acerca da Arquitetura Moderna" (1925) In: Arte em Revista. São

Paulo, Kairós Livraria e Editora Ltda, no 4, ago.1980, p.p. 5-6.

\section{Trabalhos / Dissertações / Teses}

ALAMBERT, Clara Correia d'. Início do Concreto Armado em São Paulo - o Palacete do Engenheiro Francisco Notaroberto. Trabalho programado, FAU / USP. São Paulo, 2001.

Um Novo Modo de Construção no Limiar do século XX. Concreto

Armado: Experiências Técnicas / Especulações Estéticas. Trabalho programado, FAU / USP. São Paulo, 2002.

. BLAY, Beatriz. Roteiro Art Déco em São Paulo. Trabalho de graduação, FAU Mackenzie. São Paulo, 1979.

. BRITO, Mônica Silveira. A Participação da Iniciativa Privada na Produção de Espaço Urbano : São Paulo, 1890 - 1911. Dissertação de Mestrado apresentada à FFLCH / USP - Departamento de Geografia. São Paulo, 2000.

. CAMPOS, Vitor José Baptista. O Art Déco na Arquitetura Paulistana. Uma outra face do Moderno. Dissertação de Mestrado apresentada à FAU / USP. São Paulo, 1996.

O Art Déco e a construção do imaginário moderno - um estudo de linguagem arquitetônica. Tese de Doutoramento apresentada à FAU / USP. São Paulo, 2003.

- COSTA, José Horácio de Almeida Nascimento. Sobre o Neocolonial. Trabalho de Graduação Interdisciplinar, FAU / USP. São Paulo, 1978.

. FICHER, Sylvia. Ensino e Profissão : O Curso de Engenheiro - Arquiteto da Escola Politécnica de São Paulo. Tese de Doutoramento apresentada à FFLCH / USP Departamento de História. São Paulo,1989.

. GONÇALVES, Ana Maria do Carmo Rossi. A Obra de Ricardo Severo. Trabalho de Graduação Interdisciplinar, FAU / USP. São Paulo, 1977. 
. GROSTEIN, Marta Dora. A Cidade Clandestina : Os Ritos e os Mitos. O papel da “irregularidade” na estruturação do espaço urbano no município de São Paulo. 1900 - 1987. Tese de Doutoramento apresentada à FAU / USP. São Paulo, 1987.

. LEMOS, Carlos A. C. A Arquitetura dos Modernistas de 1922. São Paulo, 2002. (exemplar digitado)

. PASSAGLIA, Luiz Alberto do Prado. O Italianizante : a arquitetura no período de $\mathbf{1 8 8 0}$ a 1914 na cidade de São Paulo. Dissertação de Mestrado apresentada à FAU / USP. São Paulo, 1984.

- RAMALHO, Maria Lucia. Da Beaux Arts ao Bungalow. Dissertação de Mestrado apresentada à FAU / USP. São Paulo, 1989.

- RODRIGUES, Eduardo de Jesus. As fachadas na arquitetura paulistana : o estilo Missões. Dissertação de Mestrado apresentada à FAU/USP. São Paulo, 1985.

. São Paulo (cidade) Estudo da Evolução Urbana da cidade de São Paulo - Análise da Expansão da Cidade de São Paulo a partir de uma Coleção de Plantas Históricas. São Paulo, PMSP/SMC/DPH, s/d. (exemplar mimeografado)

. SAWAYA, Silvana T. Arquitetura Déco na cidade de São Paulo. Trabalho de Graduação Interdisciplinar, FAU / USP. São Paulo, 1982.

- SIMONE, Sérgio de. A Faculdade de Direito do Largo de São Francisco - um paradigma do Neocolonial em São Paulo." Trabalho apresentado para conclusão da disciplina "Tópicos Especiais em História da Arte e da Cultura III". Campinas, UNICAMP, 2002.

. WOLFF, Silvia Ferreira Santos. Jardim América. O primeiro bairro-jardim de São Paulo e sua arquitetura. Tese de Doutoramento apresentada à FAU / USP. São Paulo, 1998.

\section{Obras de Referência}

. Catálogo de desenhos de Arquitetura da Biblioteca da FAUUSP. São Paulo, FAU / USP / Vitae, 1988.

. CORONA, Eduardo \& LEMOS, Carlos A. C. Dicionário da Arquitetura Brasileira. São Paulo, Edart São Paulo / Livraria Editora, 1972.

. Dicionário Aurélio Eletrônico Século XXI versão 3.0. Rio de Janeiro, Ed. Nova Fronteira, 1999.

. Dicionário Eletrônico Houaiss da língua portuguesa 1.0. Ed. Objetiva Ltda, 2001. 
. SPINELLI, Vincenzo \& CASASANTA, Mario. Dizionario Completo. Italiano - Portoghese (Brasiliano). Milano, Editore Ulrico Hoepli, 1988.

. Enciclopédia Abril. São Paulo, Abril Cultural, 1972.

. KOCH, Wilfried. Dicionário dos Estilos Arquitetônicos. São Paulo, Ed. Martins Fontes, 1994.

\section{Mapas / Plantas}

- Planta da Cidade de São Paulo. São Paulo, Comissão Geográfica e Geológica (Alexandre Mariano Cococi e Luiz Fructuoso e Costa), esc.: 1: 20.000, 1905.

. Planta Geral da Cidade de São Paulo. São Paulo, Comissão Geográfica e Geológica (eng. chefe João Pedro Cardoso), esc.: 1: 20.000, 1914.

. Planta da cidade de São Paulo. São Paulo, Directoria de Obras e Viação da Prefeitura Municipal, esc.: 1: 20.000, 1916.

. Planta da Cidade de São Paulo mostrando todos os Arrabaldes e terrenos arruados. São Paulo, Comissão Geográfica e Geológica (eng. Valdomiro Gonçalves), esc.:1: 20.000, 1924.

Planta da Cidade de São Paulo e municípios circunvizinhos. São Paulo, Repartição de Eletricidade Light \& Power, esc.: 1:40.000, 1926-1927.

. Planta da cidade de São Paulo. São Paulo, Repartição de Águas e Esgotos de São Paulo, esc.: 1: 20.000, 1928.

. Mappa Topographico do Municipio de São Paulo. São Paulo, S.A.R.A. Brasil S. A., esc.: 1: $20.000,1930$.

\section{Documentação Pesquisada}

. São Paulo (cidade). Arquivo Histórico Municipal Washington Luís (Departamento do Patrimônio Histórico - DPH / Secretaria Municipal de Cultura de São Paulo). Obras Particulares.

São Paulo (cidade). Arquivo Geral da Prefeitura do Município de São Paulo. Processos consultados referentes a pedidos de aprovação de construção de edificações residenciais na cidade de São Paulo no período entre 1923 e 1936. 


\section{Fontes Eletrônicas Online}

- ARUCA, Lohania. O Art Déco e a Havana do século XX. Disponível em http://www.vitruvius.com.br/arquitextos/arq000/bases/texto049.asp Acessado em 23maio2003.

. TORAYA, Juan de las Cuevas. Contribuição dos materiais de construção cubanos no desenvolvimento e generalização do Art Déco em Cuba. Disponível em http://www.vitruvius.com.br/arquitextos/arq000/bases/texto127.asp Acessado em 23maio2003.

\section{Obras Consultadas}

A Cidade da Light. The City of the Light Company.1899-1930. v. I e II. São Paulo, ELETROPAULO, 1990.

. Annaes do Primeiro Congresso de Habitação. São Paulo, Escolas Profissionaes do Lyceu Coração de Jesus, 1931.

. BRUNO, Ernani da Silva. História e Tradições da Cidade de São Paulo. v. III. São Paulo, Editora Hucitec / PMSP, 1984.

. CARAM, André Luís Balsante. Pujol - Concreto e Arte. São Paulo, Banco do Brasil, 2001.

. Comissão do Patrimônio Cultural. Bens imóveis tombados ou em processo de tombamento da USP. São Paulo, EDUSP/IMESP, 1999.

. DONATO, Hernani. A Revolução de 32. São Paulo, Círculo do Livro, 1982.

. KOPP, Anatole. Quando o moderno não era um estilo e sim uma causa. São Paulo, Nobel, 1990.

. LEMOS, Carlos A. C. Arquitetura Brasileira. São Paulo, Edições Melhoramentos / EDUSP, 1979.

O Álbum de Afonso. A Reforma de São Paulo. São Paulo, Edições Pinacoteca do Estado, 2001.

Memória Paulistana. (catálogo da exposição). São Paulo, MIS, 1975.

. MORSE, Richard M. De Comunidade a Metrópole. Biografia de São Paulo. São Paulo, Comissão do IV Centenário da Cidade de São Paulo, 1954. 
. SALMONI, Anita \& DEBENEDETTI, Emma. Arquitetura Italiana em São Paulo. São Paulo, Ed. Perspectiva, 1981.

. São Paulo (cidade). Paulicéias Perdidas. Registros 14. São Paulo, PMSP/SMC/DPH, 1991.

SEGAWA, Hugo. Prelúdio da Metrópole. Arquitetura e Urbanismo em São Paulo na passagem do século XIX ao XX. São Paulo, Ateliê Editorial, 2000.

. XAVIER, Alberto \& alii. Arquitetura Moderna Paulistana. São Paulo, Pini, 1983.

. ZANINI, Walter (org.). História Geral da Arte no Brasil. v. II. São Paulo, Instituto Walter Moreira Salles / Fundação Djalma Guimarães, 1983.

\section{Arquivos e Bibliotecas Consultados}

Arquivo do Estado de São Paulo

. Arquivo Geral da Prefeitura do Município de São Paulo

. Arquivo Histórico Municipal Washington Luís (São Paulo)

. Arquivo Nacional (Rio de Janeiro)

. Biblioteca da Escola Politécnica / USP

. Biblioteca da Faculdade de Arquitetura e Urbanismo - FAU / USP

. Biblioteca da pós-graduação da Faculdade de Arquitetura e Urbanismo - FAU / USP

. Biblioteca Municipal Mário de Andrade (São Paulo)

. Biblioteca Nacional / Divisão de Publicações Seriadas (Rio de Janeiro)

. Fundação Telefônica / Museu do Telefone (São Paulo) 
Apêndices 


\section{PRINCIPAIS ESTILOS OU CORRENTES ESTILÍSTICAS PRESENTES NA ARQUITETURA RESIDENCIAL PAULISTANA A PARTIR DO FINAL DO SÉCULO XIX.}

Apresentamos a seguir uma sistematização das principais correntes estilísticas surgidas na capital paulista desde o terceiro quartel do século XIX até 1940, realizada por nós com o objetivo determinado de estabelecer parâmetros formais e estilísticos que nos orientassem na análise dos projetos residenciais sorteados na pesquisa empreendida no Arquivo Geral da Prefeitura do Município de São Paulo.

Dessa forma, a partir de bibliografia específica e do exame da amostra de projetos selecionados juntamente com a observação de exemplares remanescentes, documentados em diversos bairros da capital paulista, caracterizamos cada uma das linguagens arquitetônicas presentes nesse período através de uma descrição sintética do partido e dos estilemas mais freqüentes.

CRONOLOGIA DOS PRINCIPAIS ESTILOS OU CORRENTES ESTILÍSTICAS

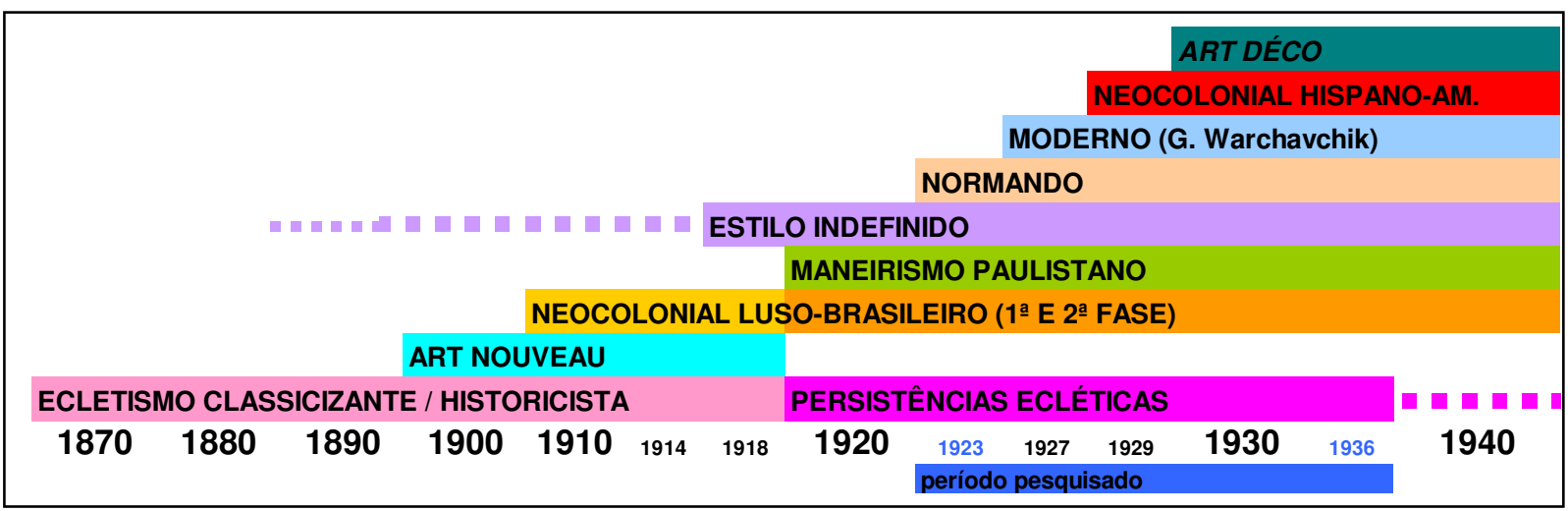




\section{a. Ecletismo Classicizante / Historicista}

Sincretismos estilísticos a partir da mistura de estilemas de variados estilos e regionalismos. Inventividades de Ramos de Azevedo, influências de César Daly etc. Revivescências de inspiração neo-clássicas, neo-renascentistas, neo-góticas, neoromânicas, etc.

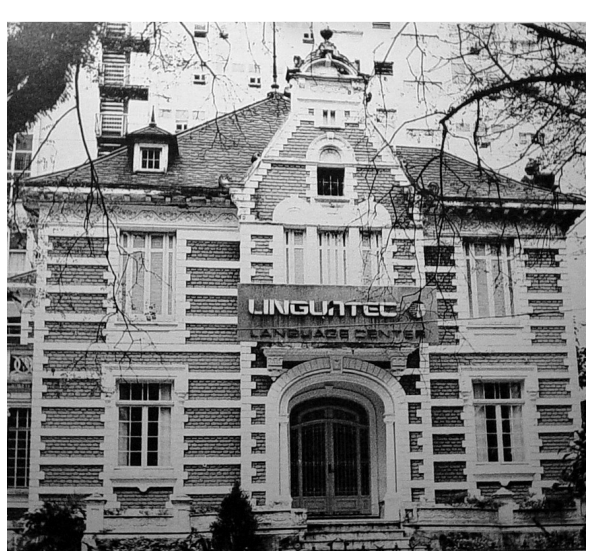

FIGURA 211 : Residência Cardoso de Almeida. (Ramos de Azevedo, São Paulo)

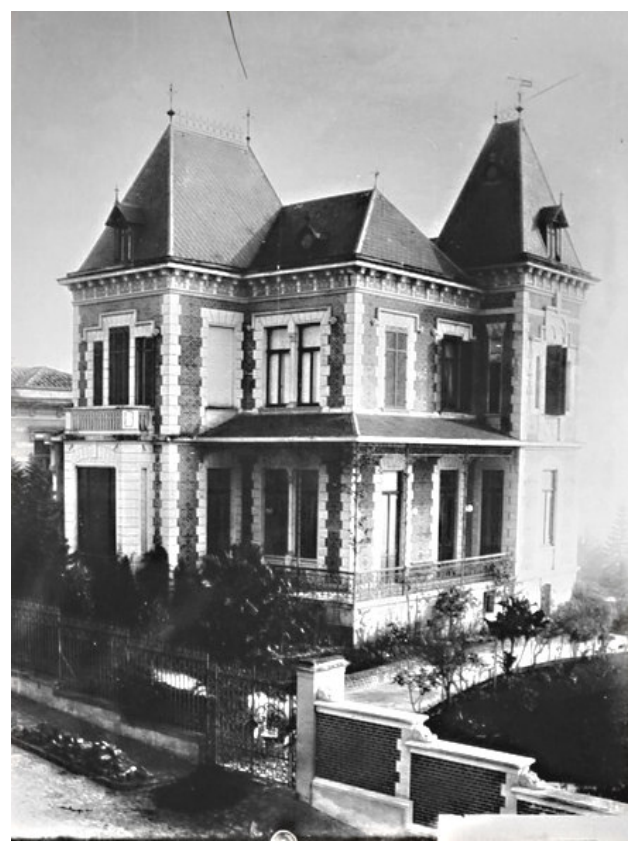

FIGURA 212 : Residência Ramos de Azevedo à rua Pirapitingui. (Ramos de Azevedo / São Paulo, 1891)

\section{Partido arquitetônico}

- planta movimentada com telhado recortado;

- casas térreas ou sobrados, com porão alto ou habitável;

. telhados de quatro águas de telhas francesas tipo "Marselha".

\section{Estilemas mais freqüentes}

- panos de fachada de alvenaria de tijolos à vista;

- cunhais, requadros de envasaduras e faixas de massa branca imitando pedras angulares e bossagem;

.beiral ornamentado com "cachorros"; . platibandas decoradas;

. decoração com ornamentos clássicos nos paramentos, cimalhas, envasaduras etc.;

- revestimento de massa imitando bossagem.

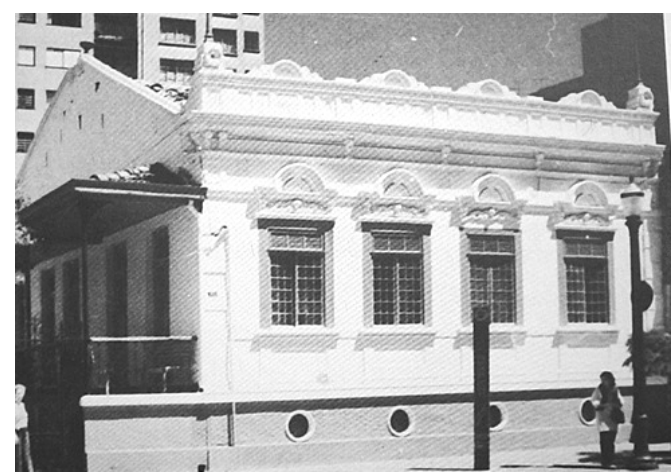

FIGURA 213 : Residência do final do século XIX no Largo do Arouche. 


\section{b. Art Nouveau}

Inclue obras de inspiração francesa, alemã ou austríaca (Sezession).

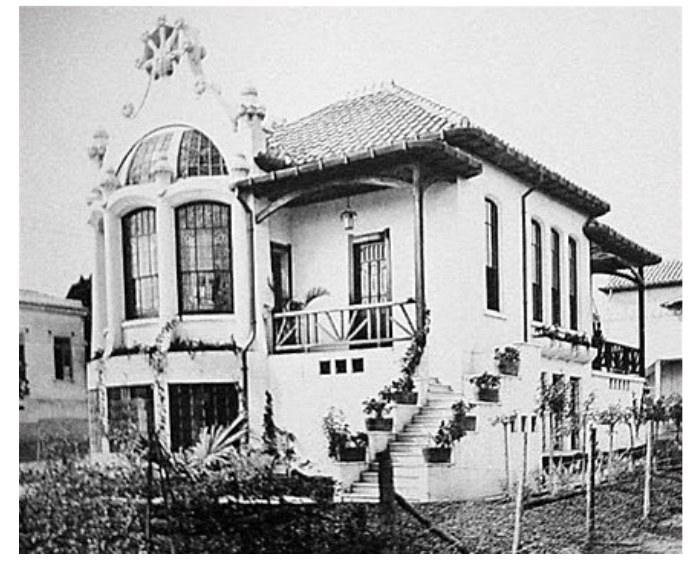

FIGURA 214 : Vila Nenê / Residência Mário

Rodrigues. (Victor Dubugras / São Paulo, 1910)

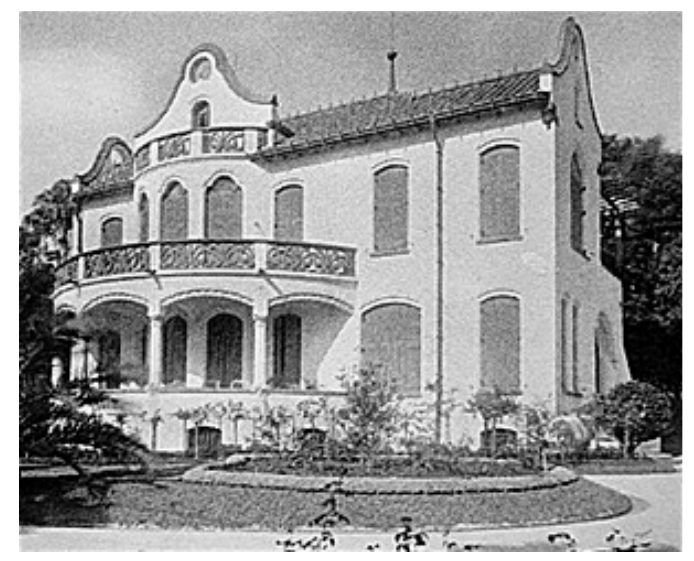

FIGURA 215 : Residência Horácio Sabino. (Victor Dubugras / São Paulo, 1903)

\section{Partido arquitetônico}

. construções assobradadas;

. continuidade espacial nas áreas sociais internas.

\section{Estilemas mais freqüentes}

- decoração floreal nos exteriores e interiores (relevos, estuques, vidros jateados e ferragens).

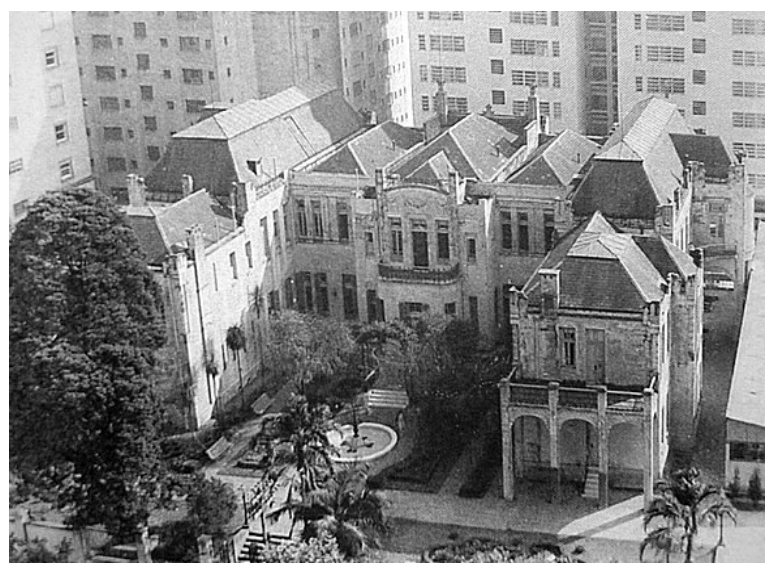

FIGURA 216 : Vila Penteado. (Carlos Ekman / São Paulo, 1903) 


\section{c. Neocolonial luso-brasileiro}

\section{Duas fases principais :}

- 1a fase : Atuação pioneira de Ricardo Severo e Victor Dubugras.

- 2 ${ }^{\text {a }}$ fase : Atuação de arquitetos eruditos de 1920 em diante.

\section{c.1. Atuação pioneira de Ricardo Severo e Victor Dubugras.}

\section{- Contribuição de Ricardo Severo nas primeiras obras a partir de 1910}

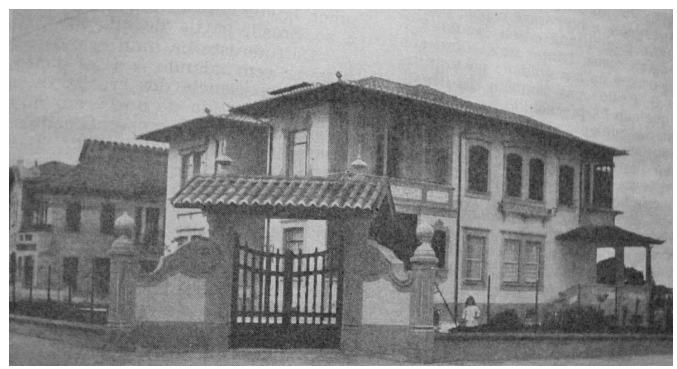

FIGURA 217 : Residência Numa de Oliveira à avenida Paulista. (Ricardo Severo / São Paulo, 1918)

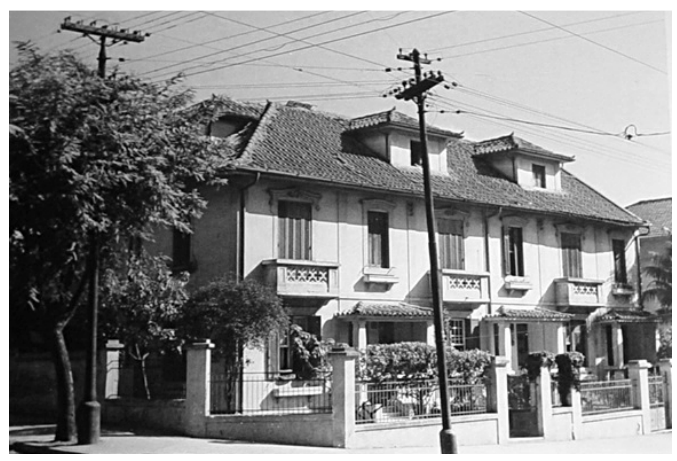

FIGURA 218 : Residência na avenida Angélica c/ rua Pará. (projeto atribuído a Ricardo Severo / São Paulo, década de 1910)

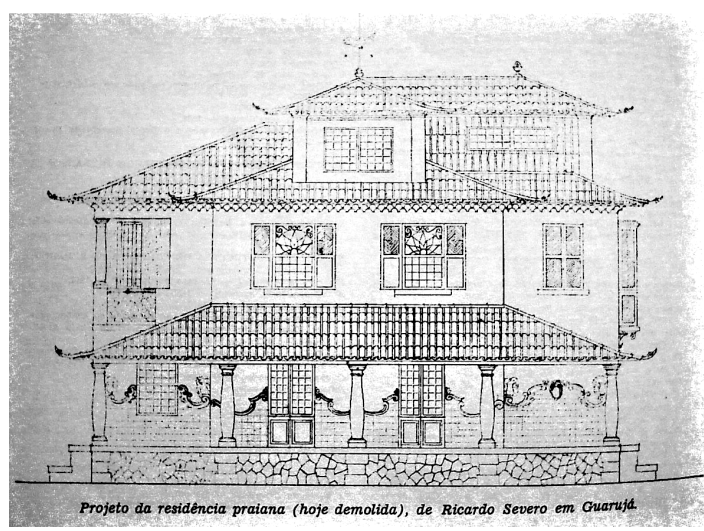

FIGURA 219 : Casa do Guarujá de Ricardo Severo. (fachada frontal)

\section{Partido arquitetônico}

. casas térreas e sobrados;

. fachada composta por volumes térreos e assobradados;

. telhado recortado.

\section{Estilemas mais freqüentes}

. beiral de beira-seveira;

. "cachorros" de madeira;

. mansardas pombalinas;

.uso de telhas tipo capa-e-canal, ditas "paulistinhas", com acabamento arrebitado nos ângulos em forma de lança ou de pomba;

. uso de telhas de faiança pintadas de azul e branco e pinhas de louça;

. chaminés do Algarve;

- alpendres guarnecendo as portas de entrada com colunas de secção circular;

- cunhais em relevo, pintados de cor diferente das paredes, às vezes, imitando pedras aparelhadas ou irregulares;

- envasaduras com vergas recurvadas e discreta decoração barroquizante;

. janelas e balcões treliçados;

- painéis de azulejos decorados situados sobre ou sob as janelas e em paredes internas. 


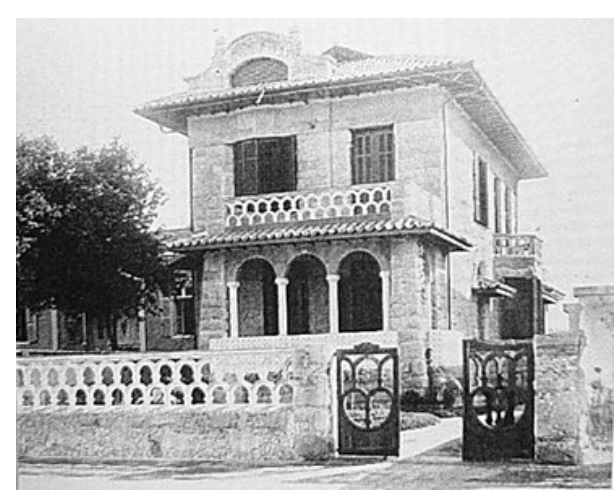

FIGURA 220 : Residência Saturnino de Brito. (Victor Dubugras / Santos, 1916)

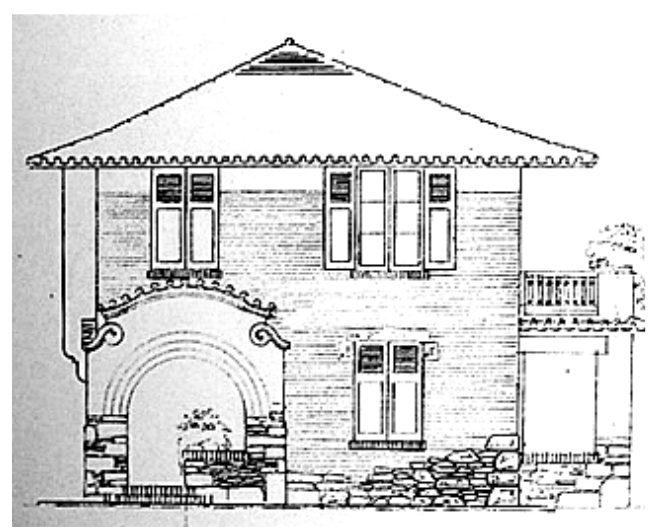

FIGURA 221 : Residência Heitor Ferreira de Carvalho (Victor Dubugras / Santos, 1920)

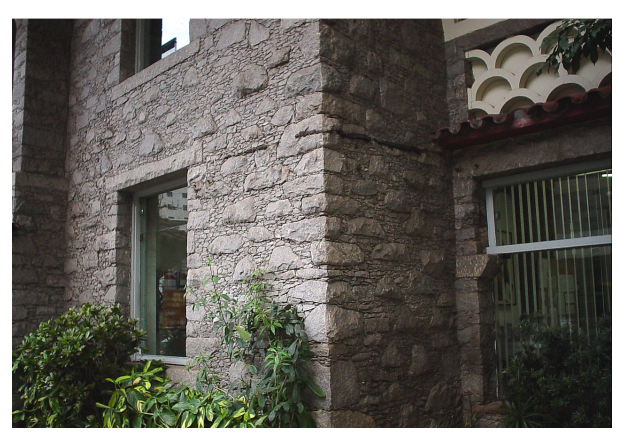

FIGURA 222 : Detalhe de parede revestida com pedras ditas "canjiquinha" da antiga residência David Ribeiro à alameda Joaquim Eugênio de Lima. (Victor Dubugras / São Paulo,1920)

\section{Partido arquitetônico}

- arcabouço prismático ou cúbico, sempre assobradado;

terraços descobertos sobre varandas térreas laterais;

. corpos em balanço compreendendo "bowwindows", patamares de escada, janelas suspensas etc.

. telhados de quatro águas de telhas tipo capa-e-canal, ditas "paulistinhas".

\section{Estilemas mais freqüentes}

. telhados com beirais sem revestimento e "cachorros" de madeira aparentes;

- fachadas de tijolo à vista com pedras irregulares nos embasamentos e/ou pedras soltas aleatoriamente nas fachadas de alvenaria;

- paredes revestidas de pedras irregulares miúdas, ditas "canjiquinhas", às vezes, entremeadas de pedras maiores;

. janelas com venezianas;

- vergas das envasaduras de pedras aparentes;

. faixa horizontal decorativa logo abaixo do pequeno beiral do telhado, circundando todas as fachadas, às vezes, interrompidas pelas janelas;

- janelas seqüenciais de altura variável marcando as caixas de escada;

- jardineiras nas janelas superiores (nos projetos a partir de 1920); 


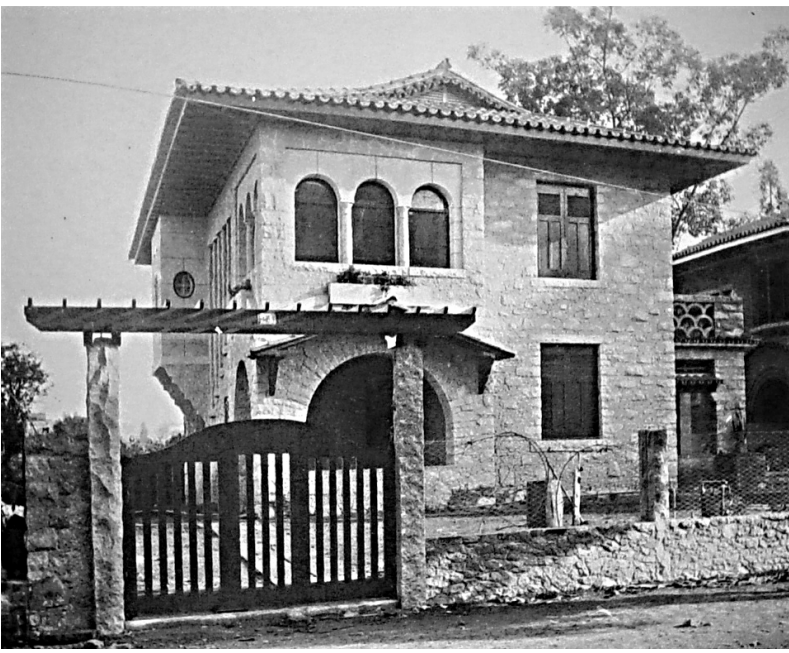

FIGURA 223 : Residência David Ribeiro à rua Joaquim Eugênio de Lima. (Victor Dubugras / São Paulo, 1920)
. elementos vazados em forma de meias-luas superpostas ou escamas de peixe em guardacorpos de terraços e muros.

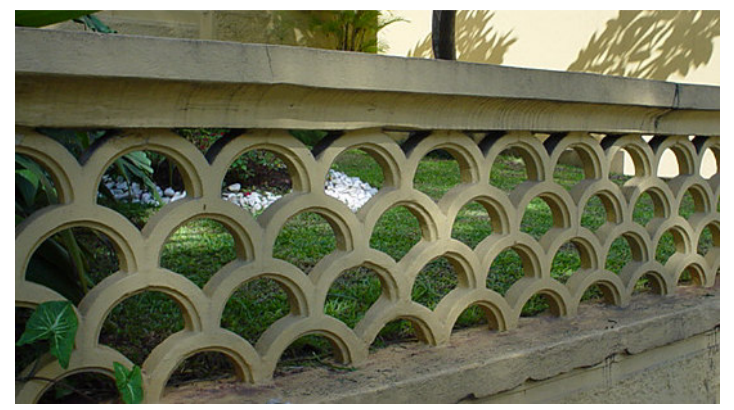

FIGURA 224 : Detalhe dos elementos vazados em forma de meias-luas superpostas do muro de casa à rua dos Franceses.

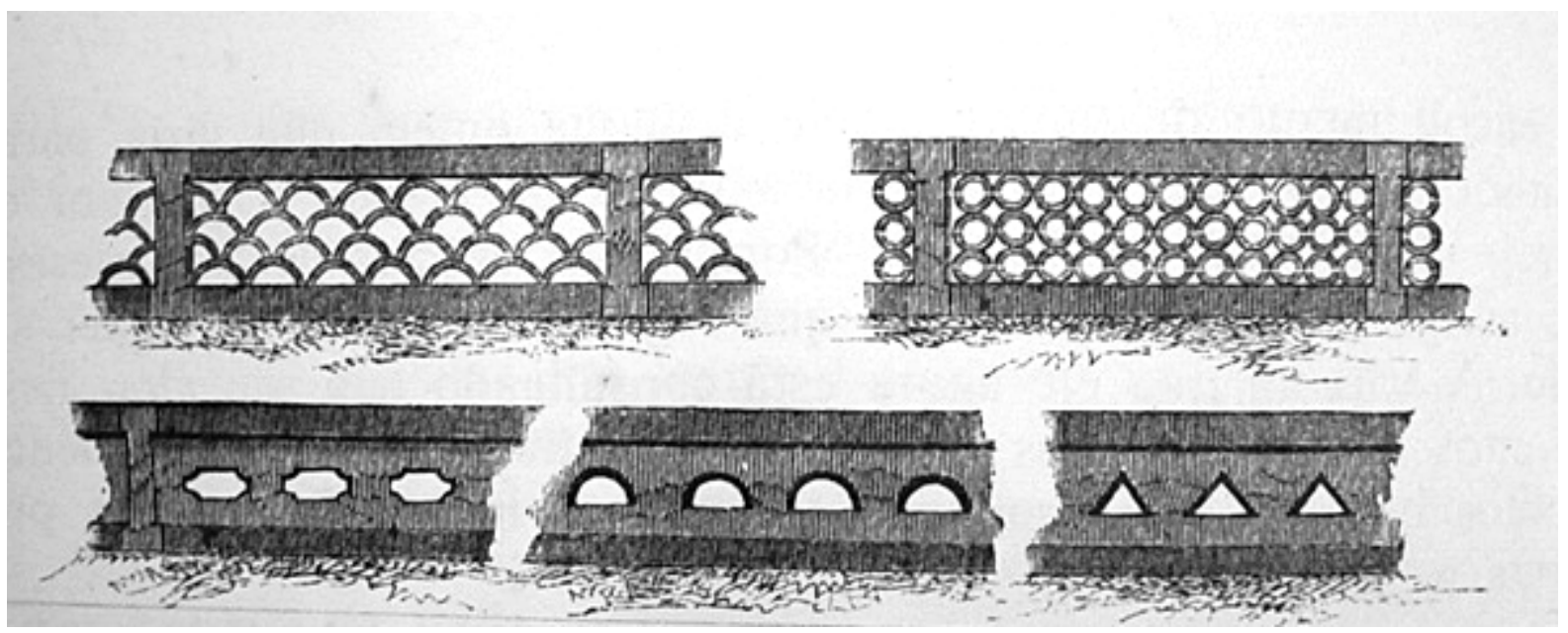

FIGURA 225 : Exemplos de muros com elementos vazados . (Niterói / Rio de Janeiro, c. 1846)

Não temos conhecimento sobre a origem destes elementos de composição ornamental e nem como chegaram ao repertório estilístico brasileiro, porém, temos referências da sua existência em residências de Niterói (RJ) na primeira metade do século XIX (1846) através do texto de Thomas Ewbank sobre a Vida no Brasil.

No seu relato este autor nos conta: "Dirigi-me para Niterói. /.../ Casas baixas e brancas ornam a baía, e são residências antes rurais que urbanas. Como os lugares do interior, são bastante isolados, têm jardins fronteiros, e muros de pedra ou tijolo, rebocados e com numerosas aberturas de fantasia. Alguns muros são retangulares com a justaposição das telhas produzindo uma impressão agradável de rede. Algumas são dispostas de modo a produzir círculos. /.../" In: EWBANK, Thomas. Vida no Brasil ou Diário de uma visita à terra do cacaueiro e da palmeira, p. 219 e 220.

Acompanhando o texto Ewbank apresenta desenhos feitos por ele reproduzindo os muros descritos, muito semelhantes aos elementos vazados em forma de meias-luas superpostas utilizados freqüentemente pelo arquiteto Victor Dubugras nas suas obras. 


\section{c.2. Atuação de arquitetos eruditos de 1920 em diante, a partir da divulgação dos levantamentos de Wasth Rodrigues e Felisberto Ranzini.}

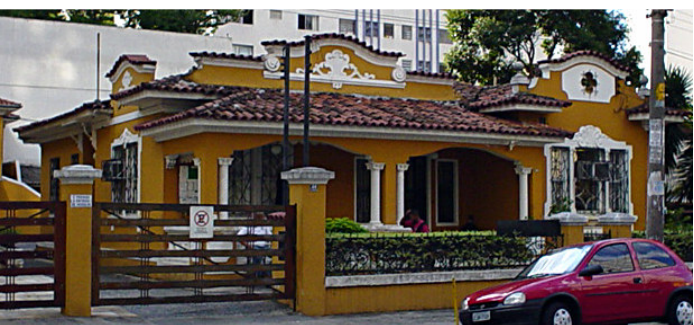

FIGURA 226 : Residência à rua Brasílio Machado.

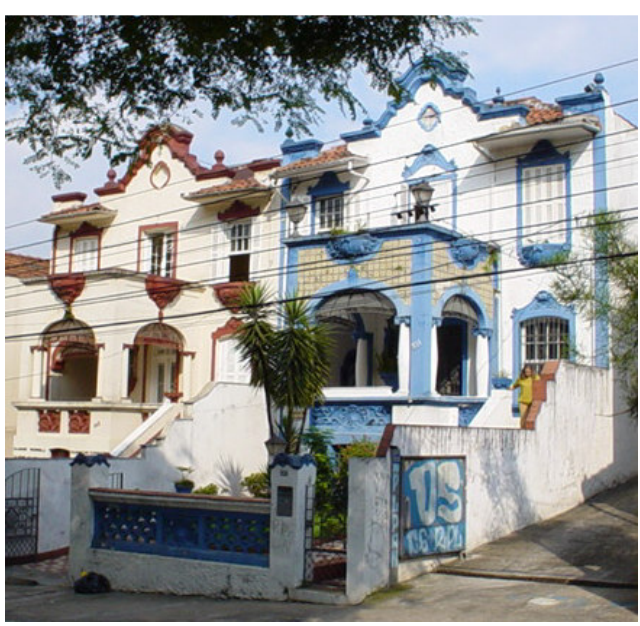

FIGURA 227 : Casas à avenida Pompéia.

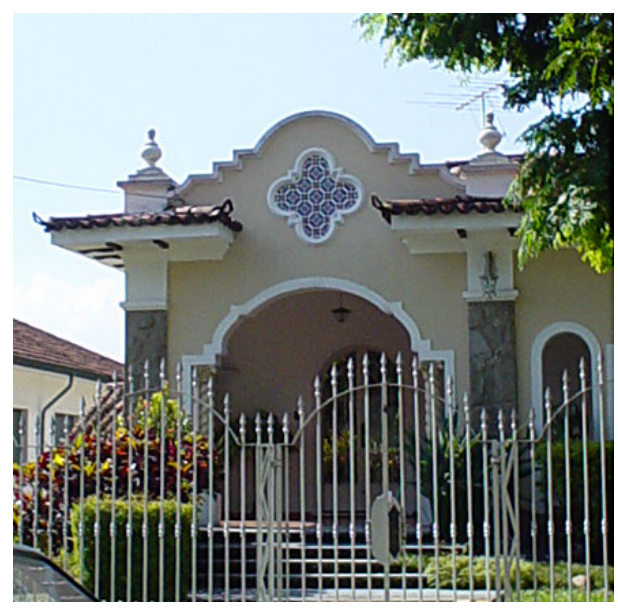

FIGURA 228 : Detalhe de painel quadrilobado de azulejos de casa à rua Tomé de Souza.

\section{Partido arquitetônico}

. casas térreas e sobrados;

- fachada composta por volumes térreos e assobradados;

. alpendres com fileiras de arcos de pleno cinto apoiados em colunas toscanas;

. telhado recortado (sempre com beirais e "cachorros").

\section{Estilemas mais freqüentes}

. frontões barrocos curvilíneos com volutas e contravolutas inspirados nas fachadas da arquitetura religiosa;

. beirais com "cachorros" trabalhados; . janelas com aros lavrados; .óculos ou painéis quadrilobados vazados ou de azulejos;

. vidraças quadriculadas ou losangulares; - portada barroca de pedra ou madeira marcando a entrada principal;

. vitrais com motivos florais ou relembrando a navegação portuguesa (caravelas) nas caixas de escada.

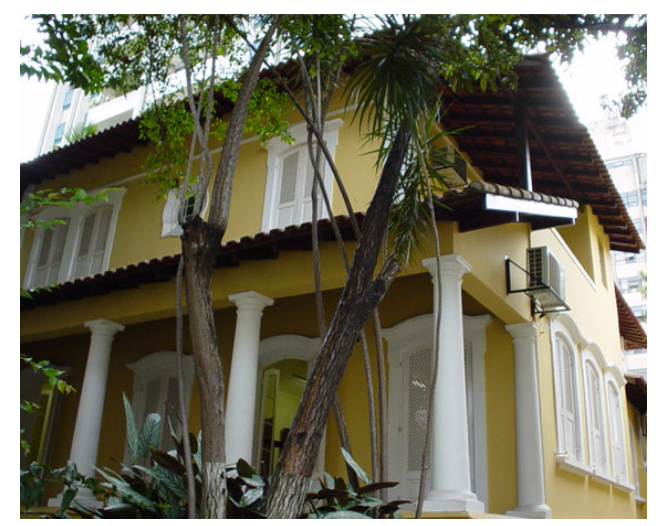

FIGURA 229 : Detalhe das colunas do alpendre de residência à rua Gabriel dos Santos. 


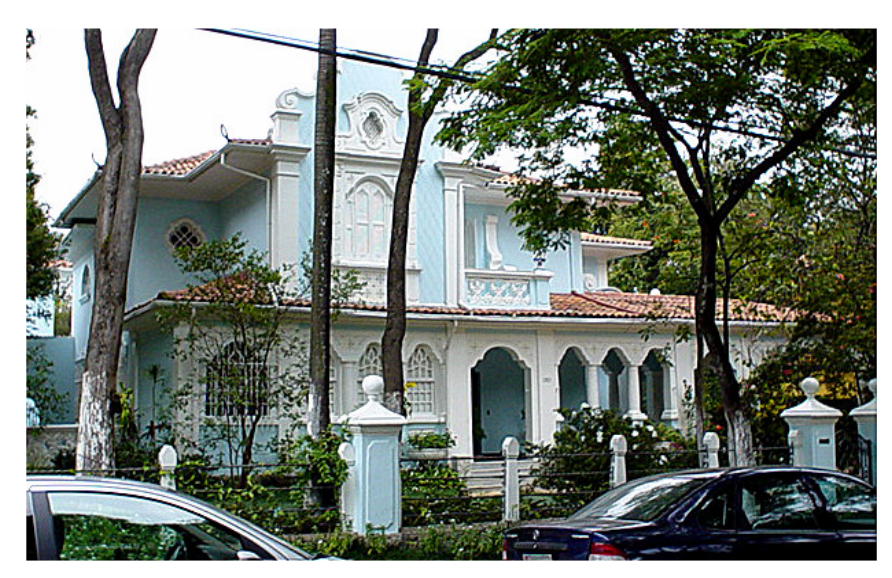

FIGURA 230 : Residência à rua Peru.

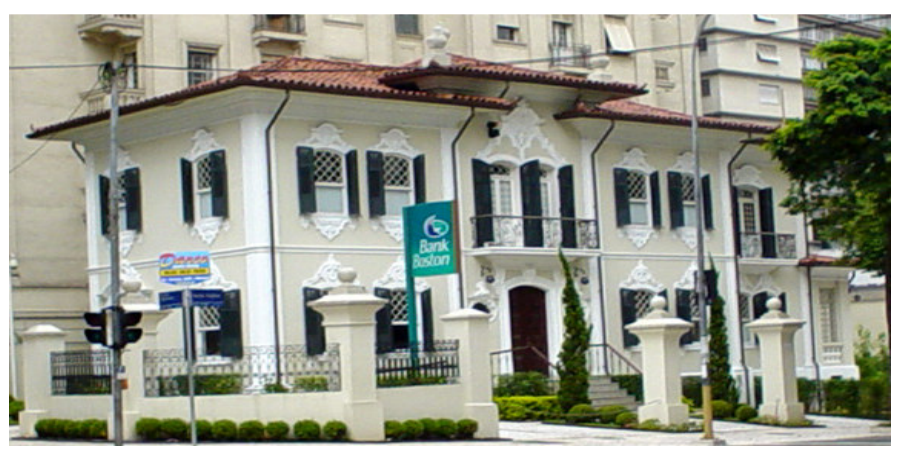

FIGURA 232 : Residência à avenida Higienópolis esquina da avenida Angélica.

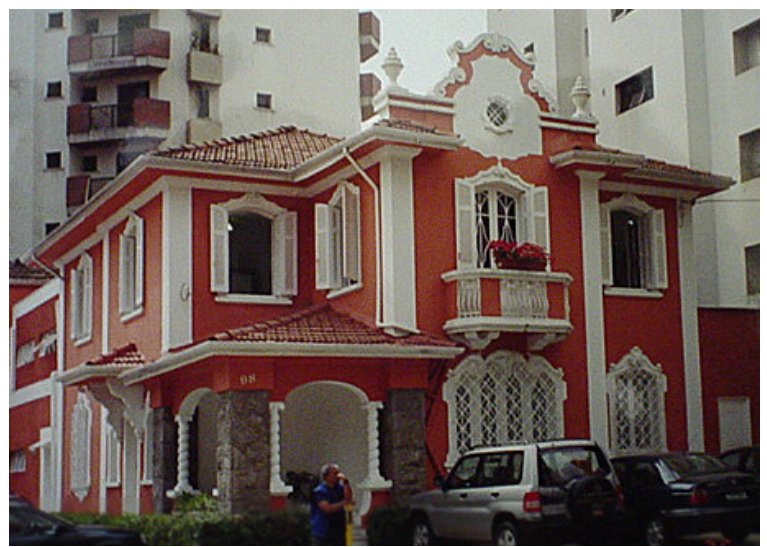

FIGURA 231: Residência à rua Turiassu esquina da rua Capitão Messias.

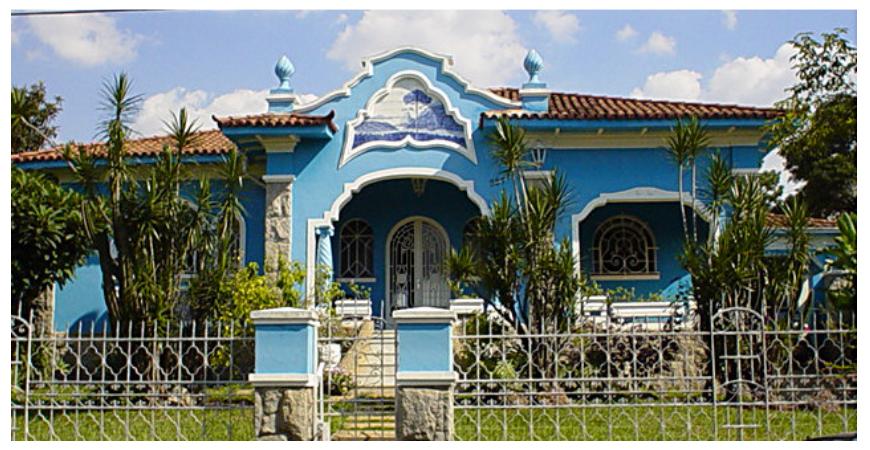

FIGURA 233 : Residência à rua Tomé de Souza. 


\section{d. Maneilrismo Paulistano (ou Neocolonial Simplificado, segundo Carlos A. C. Lemos)}

Recriações a partir de estilemas do Neocolonial luso-brasileiro, via Dubugras, e da contribuição de outras invenções populares.

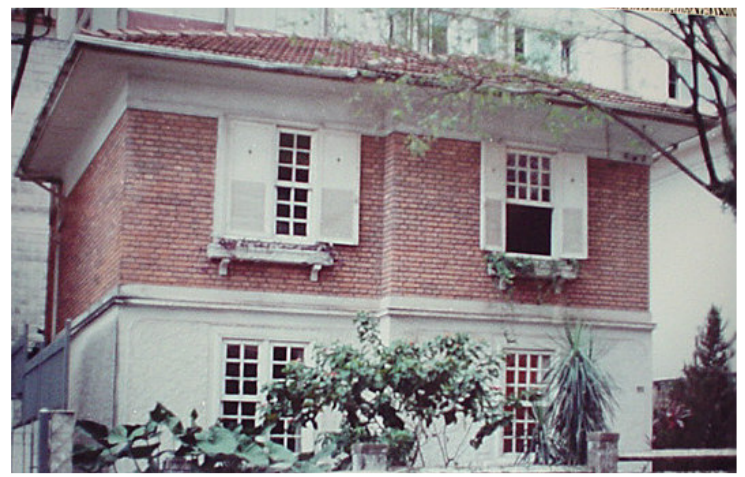

FIGURA 234 : Casa de vila à alameda Franca.

\section{Partido arquitetônico}

. arcabouço prismático ou cúbico de tijolos aparentes;

- telhados de três ou quatro águas de telhas francesas tipo "Marselha";

. alpendre em arco único, às vezes, sustentado por colunas toscanas;

. pórticos com colunas apoiando balcões;

- ocorrência eventual de corpos salientes arredondados como "bow-windows" etc.

\section{Estilemas mais freqüentes}

. pequeno beiral revestido de massa, com ou sem "cachorro" decorativo;

- panos de tijolos à vista ou paredes revestidas, total ou parcialmente, às vezes, com pedras soltas na fachada;

- ocorrência eventual de cunhais e sobrevergas de pedra acompanhando alvenaria de tijolos aparente;

- faixa horizontal contínua com relevos decorativos de massa de cimento e areia ou de gesso ("grega") junto aos beirais ou emoldurando janelas (entre, sob ou sobre as janelas do pavimento superior);

- janelas superiores quadriculadas com venezianas de madeira e jardineiras em balanço abaixo dos peitoris. O uso de venezianas era exclusivo nos dormitórios,

FIGURA 235 : Casa à rua Traipu. 


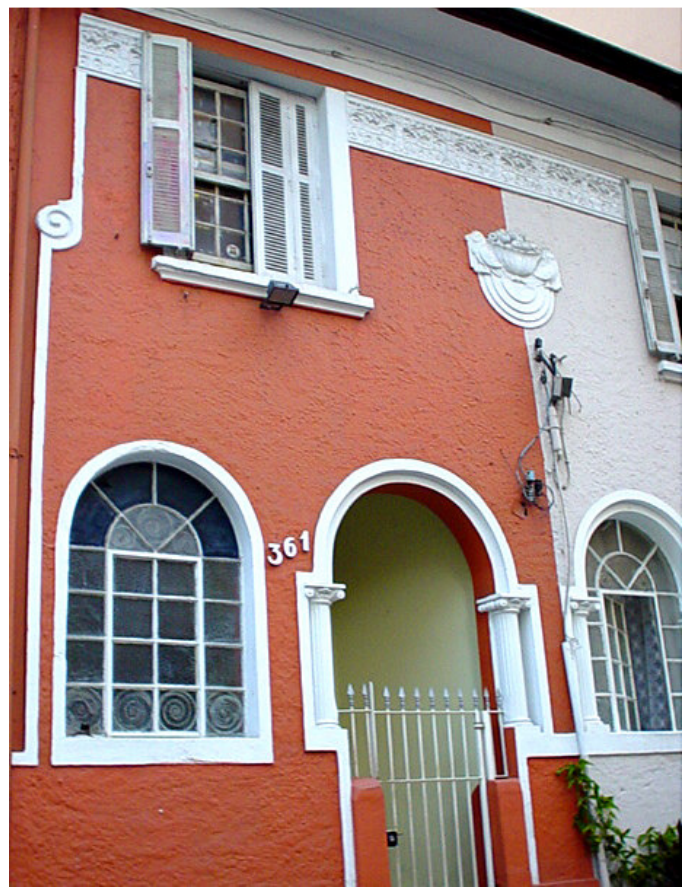

FIGURA 236 : Detalhe de ornamentos de massa aplicados na fachada de casa à rua Martim Francisco.

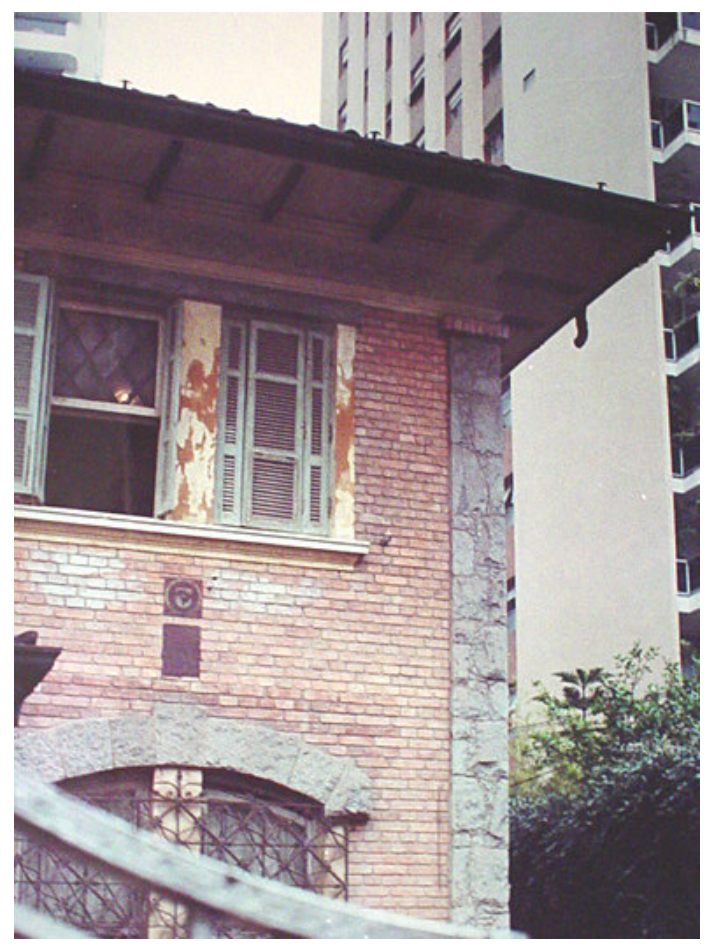

FIGURA 237 : Casa à rua Brasílio Machado. podendo aparecer ocasionalmente nas salas de estar do térreo.

. requadros das janelas e portas em massa branca;

- janelas gêmeas entremeadas por pequenas colunas torsas;

- grupos de janelas paralelas com dimensões variáveis dispostas seqüencialmente;

. guarda-corpos e balcões com elementos vazados em forma de meias-luas superpostas ou escamas de peixe;

.ornamentos figurativos pré-moldados de cimento aplicados em pontos estratégicos da fachada (nos paramentos, ladeando janelas superiores, nos medalhões do oitão etc.). Nos anos 20 e 30 a utilização desses ornamentos na decoração das fachadas das casas foi muito comum, principalmente nas de classe média. Esses elementos decorativos eram produzidos em série, industrialmente, e vendidos em lojas de materiais de construção segundo alguns desenhos básicos, de catálogo, que podiam ser escolhidos de acordo com o gosto do cliente.

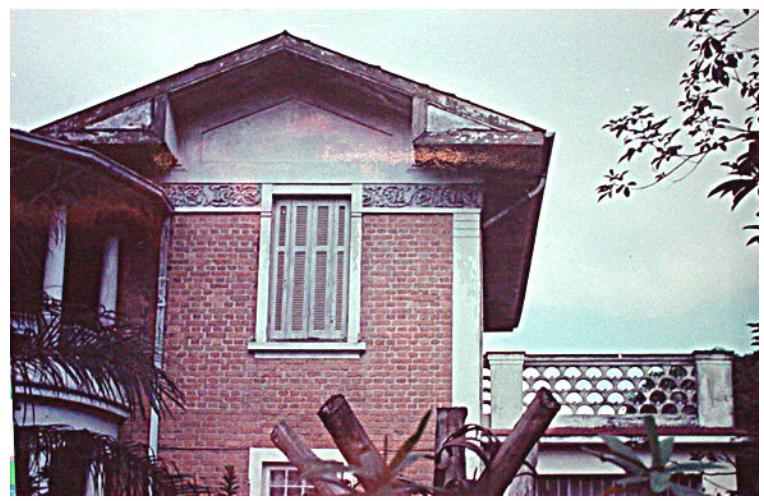

FIGURA 238 : Detalhe do oitão com "triângulos" laterais e guarda-corpo do balcão superior com elementos vazados em forma de meias-luas superpostas de casa à rua Colômbia. 


\section{Partido arquitetônico}

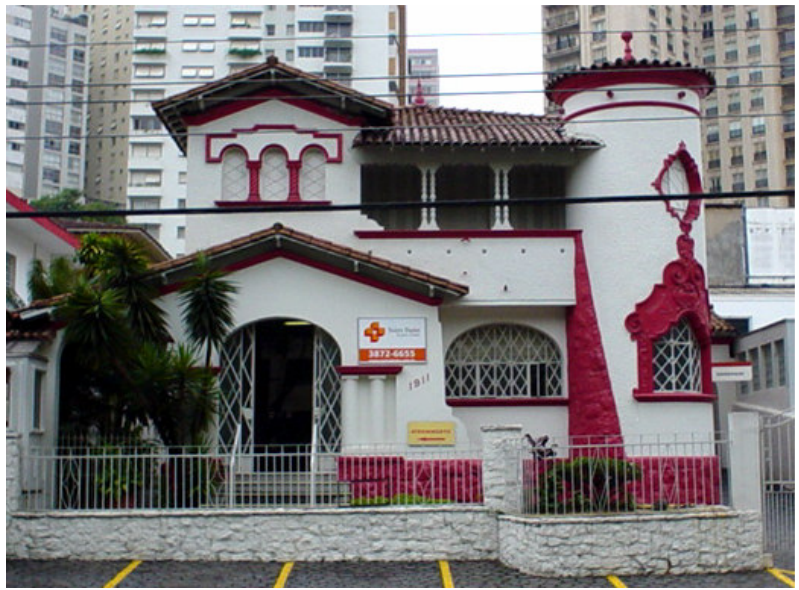

FIGURA 239 : Residência à avenida Pacaembu.

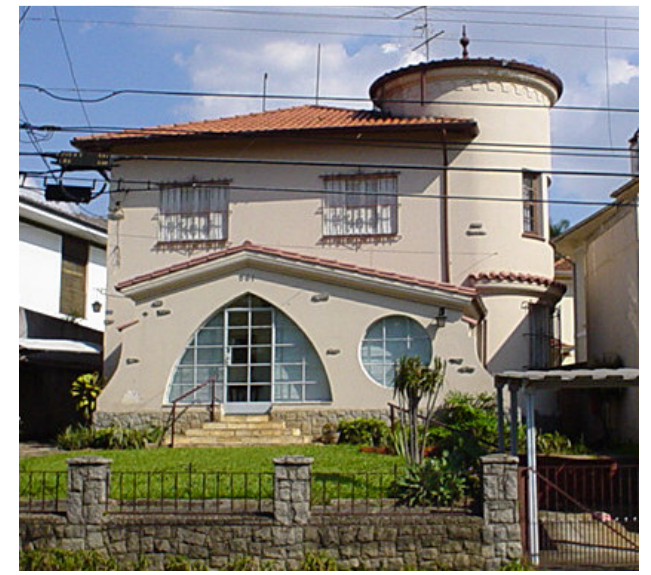

FIGURA 240 : Residência à rua Tomé de Souza.

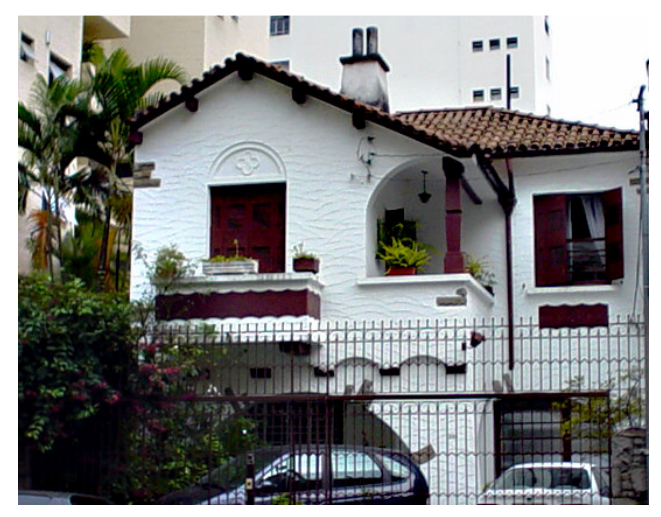

FIGURA 241: Casa à rua Aureliano Coutinho.
- torreão de planta circular, coberto por telhado cônico, marcando a caixa de escada no flanco do arcabouço;

. telhado movimentado de telhas "capa-ecanal";

. fachada principal arrematada, total ou parcialmente, por telhado de duas águas com oitão coberto por telhas "paulistinhas" transversalmente dispostas;

- telhados secundários interceptando segmentos de fachadas.

\section{Estilemas mais freqüentes}

- corpos superiores ressaltados em pequenos balanços;

. chaminés de lareiras;

.elementos decorativos lembrando extremidades de dormentes arrematando inferiormente corpos salientes, janelas e balcões;

- balcões alpendrados no pavimento superior guarnecidos por colunas salomônicas ou torneadas em cilindros (tambores irregulares superpostos); . alpendres com arcos plenos, abatidos ou goticizantes, às vezes, arrematados por tijolos ou pedras dispostos aleatoriamente imitando aduelas;

- fachada marcada por dois grandes arcos correspondentes à entrada da garagem e ao alpendre; 


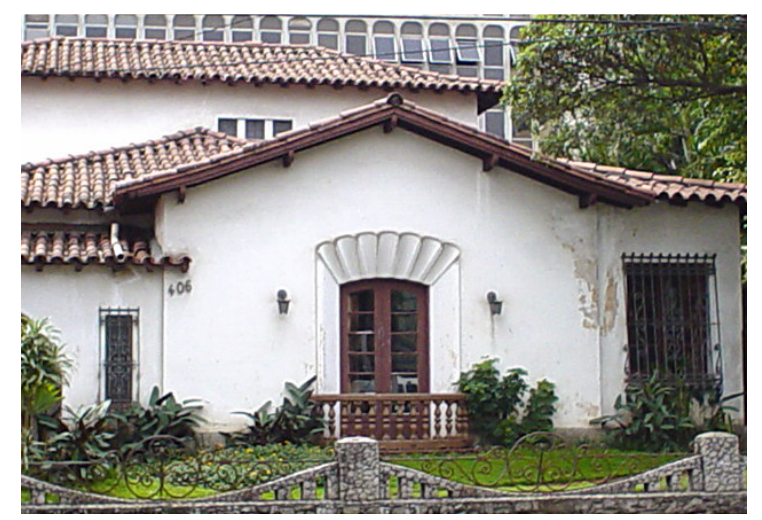

FIGURA 242 : Casa à rua Estados Unidos.

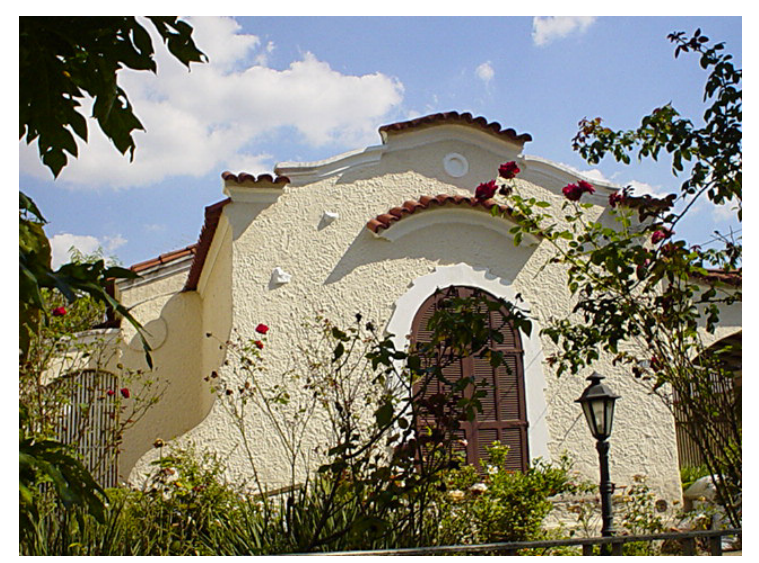

.grupos conjugados de duas ou três janelas em arco, às vezes separadas por pequenas colunas salomônicas;

. janelas com venezianas;

- padieiras de portas e janelas recortadas em forma de plissados ou ondulados;

- gradis de ferro trabalhados em portas e janelas e nos guarda-corpos de balcões, alpendres suspensos etc.;

- mísulas de ferro forjado sustentando balcões;

. luminárias de ferro;

. revestimento rústico das fachadas com reboco grosso em relevo, geralmente de cor branca;

. ornamentação parietal em relevo em torno das envasaduras;

. painéis de azulejos quadrilobados;

. vitrais coloridos com motivos figurativos decorando a torre da caixa de escada.

FIGURA 243 : Detalhe da empena frontal de casa à rua Tomé de Souza.

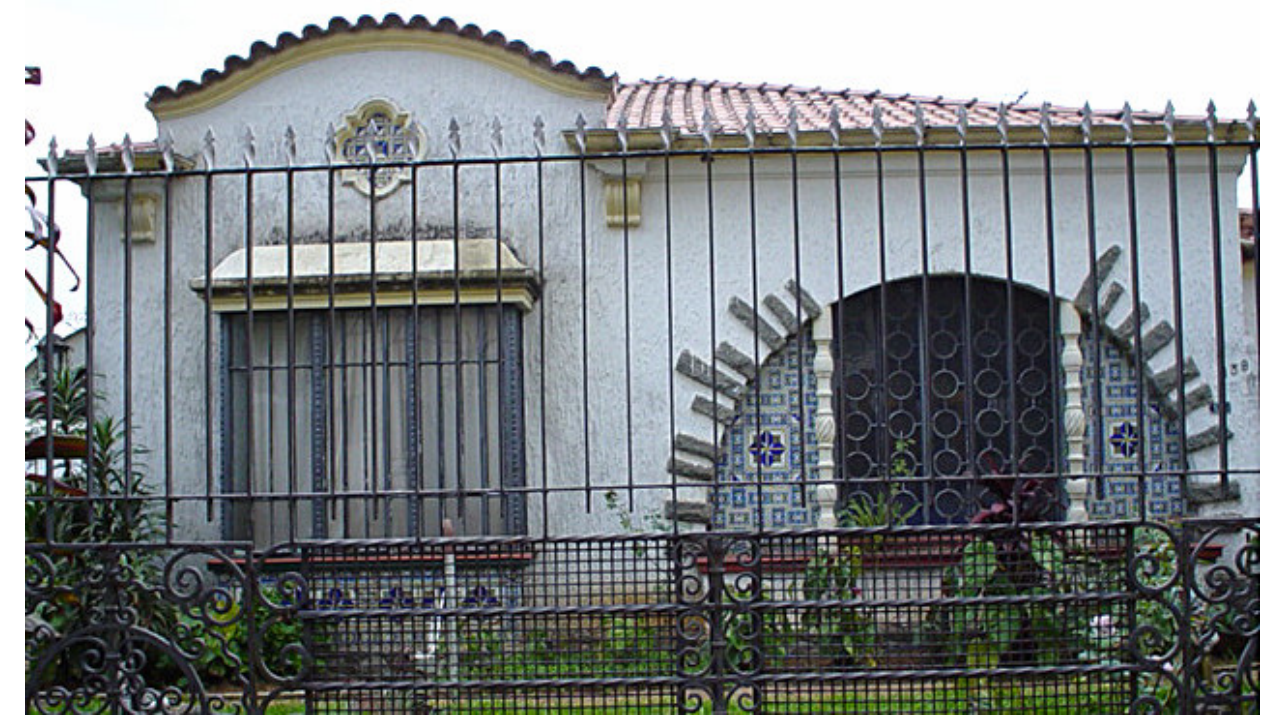

FIGURA 244 : Casa à rua Minas Gerais. 


\section{f. Persistências modernizadas do Ecletismo Classicizante / Historicista}

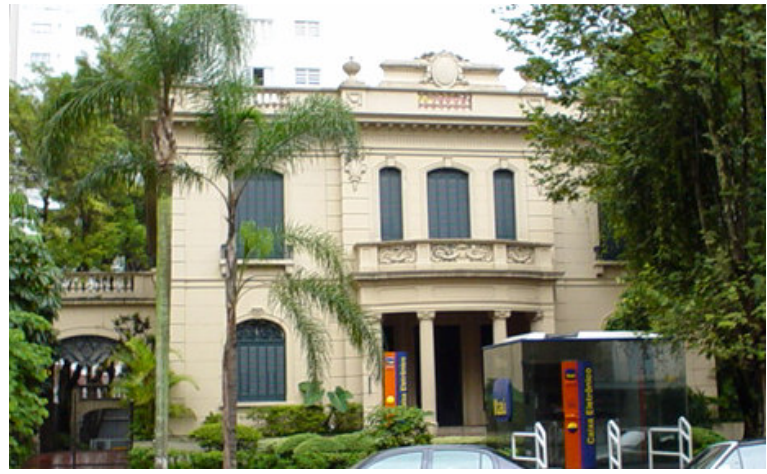

FIGURA 245 : Residência à avenida Higienópolis.

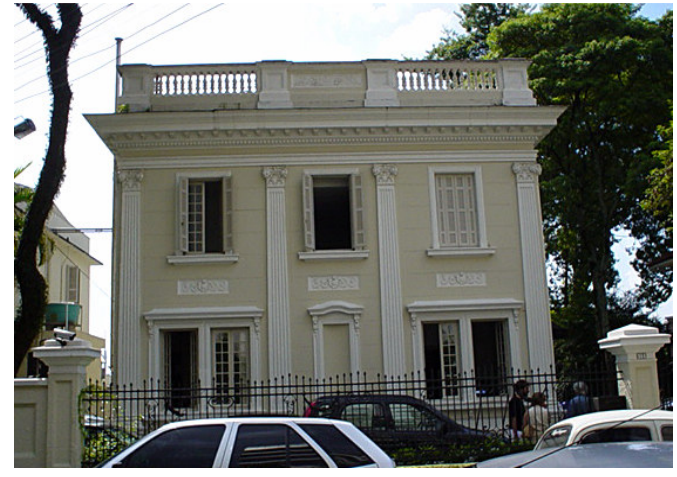

FIGURA 246 : Residência à rua Bahia.

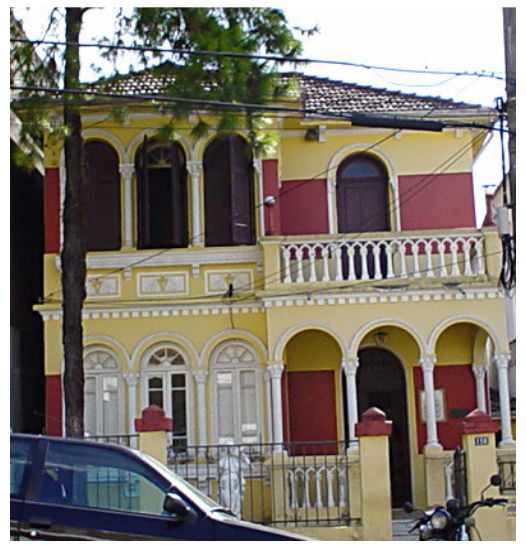

FIGURA 247 : Residência à rua dos Ingleses.

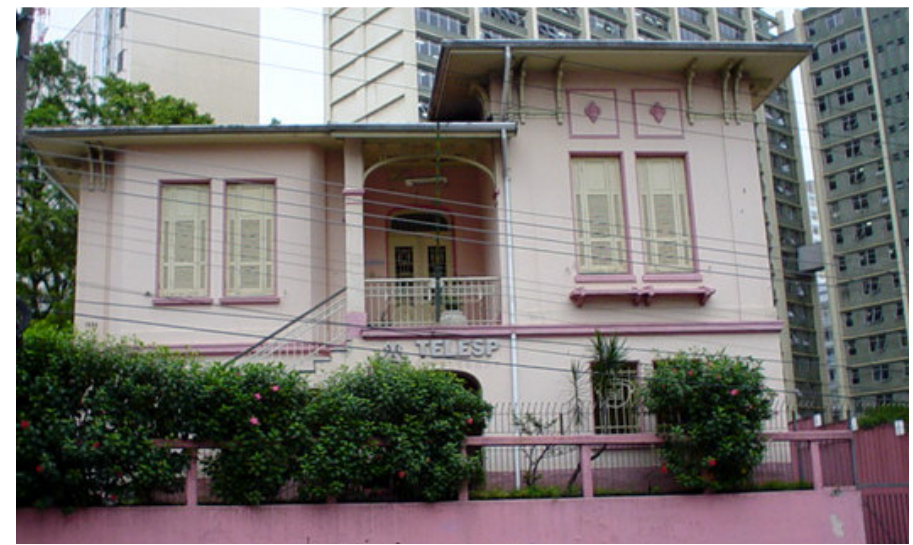

FIGURA 248 : Residência à rua Treze de Maio.

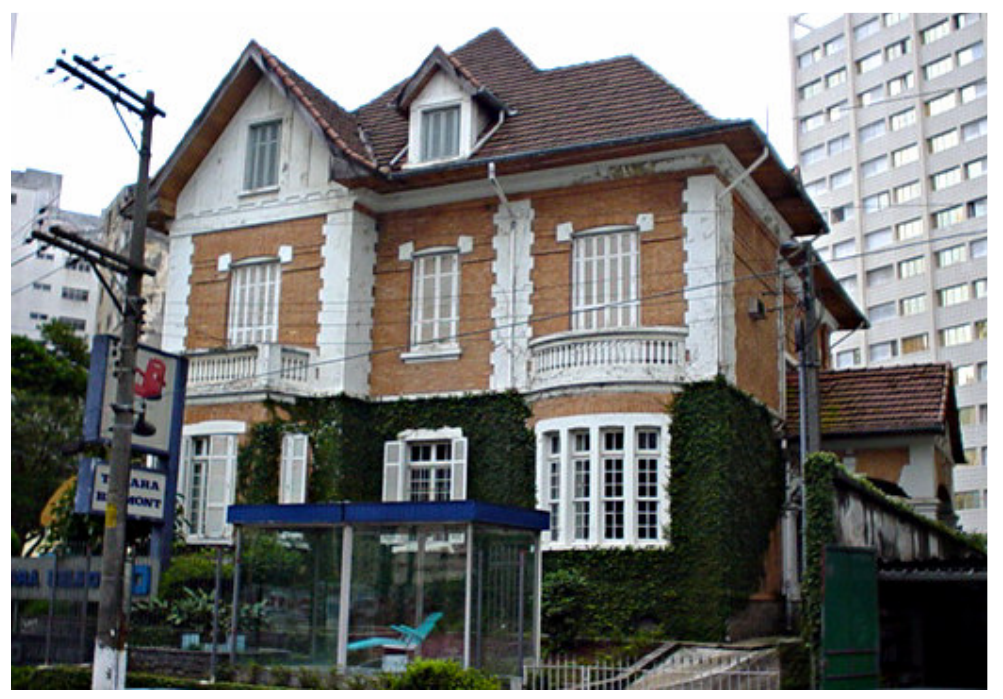

FIGURA 249 : Residência à rua Treze de Maio. 


\section{g. Normando e Estillos norte-europeus}

Apresentam elementos de ornamentação retirados do vocabulário estilístico da arquitetura vernácula e medieval dos países do norte da Europa.

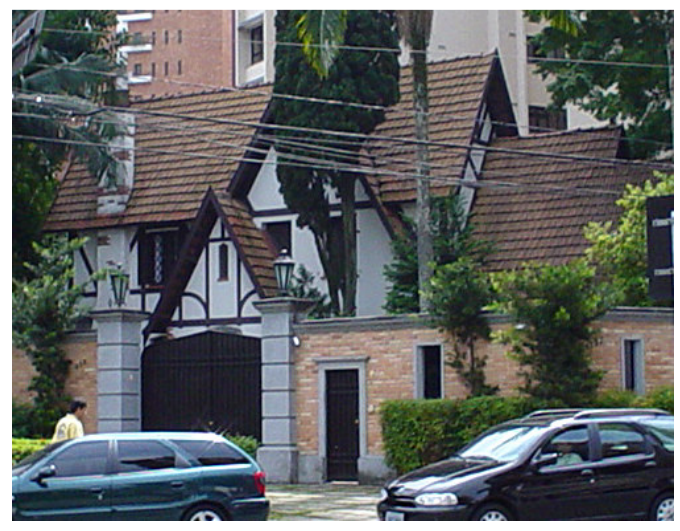

FIGURA 250 : Residência à rua Estados Unidos.

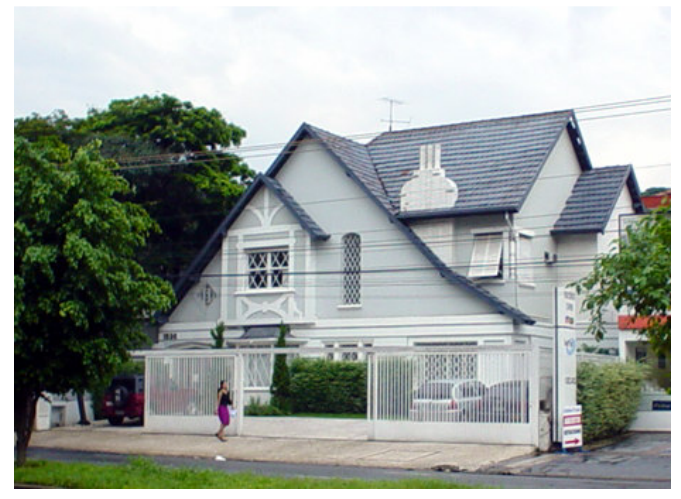

FIGURA 251: Residência à avenida Pacaembu.

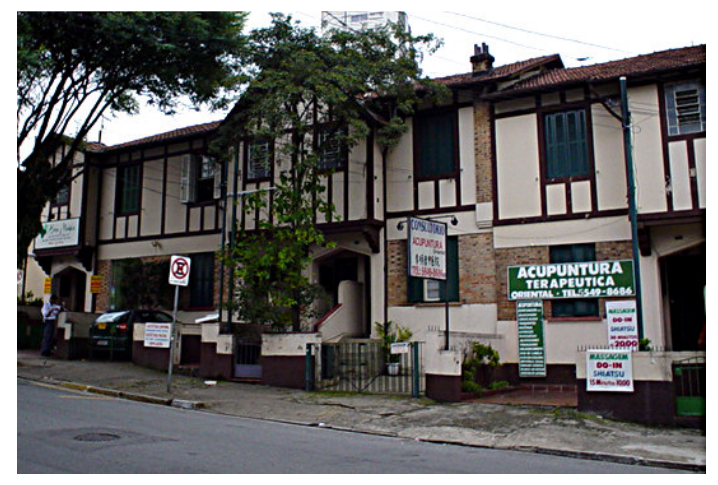

FIGURA 252 : Sobrados geminados à rua Humberto I.

\section{Partido arquitetônico}

. telhados com inclinação acentuada.

\section{Estilema mais freqüente}

. decoração em massa imitando tábuas de madeira (tipo "enxaimel") nos oitões frontais e marcando os panos das fachadas;

- arcos "Tudor" (ogiva gótica abatida, de pequena altura).

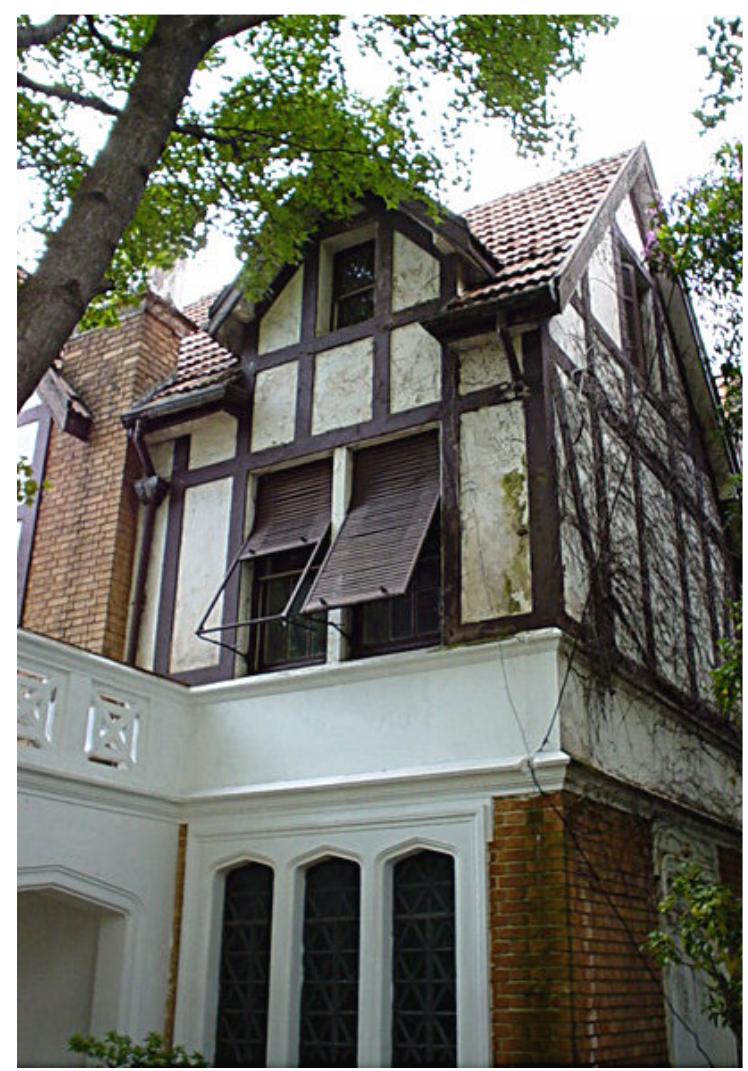

FIGURA 253 : Detalhe de enxaimel de residência à rua Bahia. 


\section{h. Art Déco}

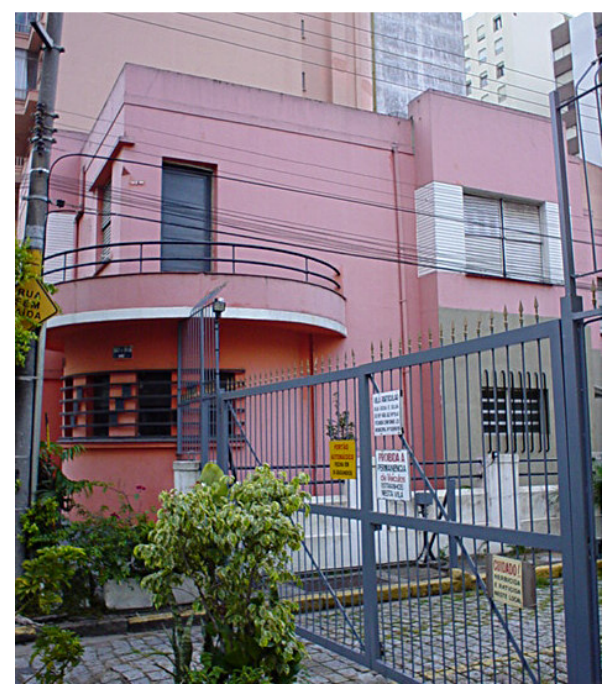

FIGURA 254 : Casa à rua Rosa e Silva.

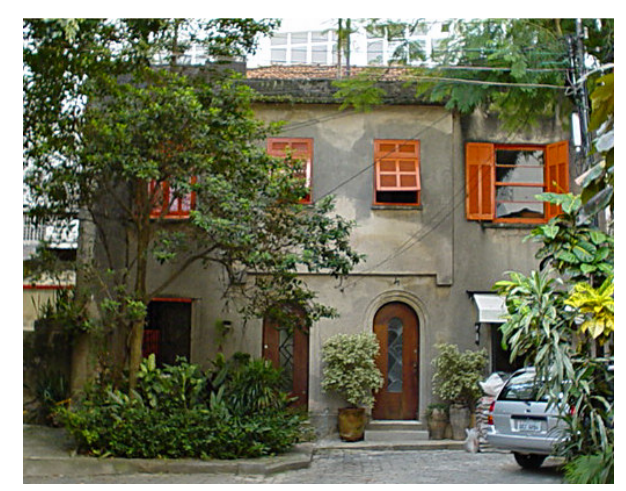

FIGURAS 255, 256 e 257 : Vila Art Déco à rua Piauí. Detalhes de porta e de janela.

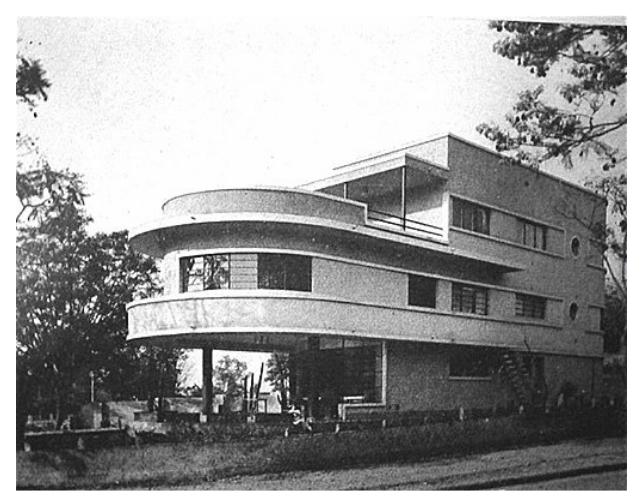

\section{Partido arquitetônico}

- arcabouço cúbico, às vezes, fazendo contraponto com elementos curvos ou escalonados em profundidade e altura.

\section{Estilemas mais freqüentes}

. decoração baseada em linhas geometrizadas e estilizações de motivos de origem grega, asteca, oriental, egípcia etc., zigue-zague, aerodinâmicas etc.;

. terraços com gradis tubulares de terminações curvas;

. óculos nas caixas de escada, banheiros etc.; . vitrais com motivos geométricos;

. revestimento externo à base de mica, às vezes misturado com corantes.
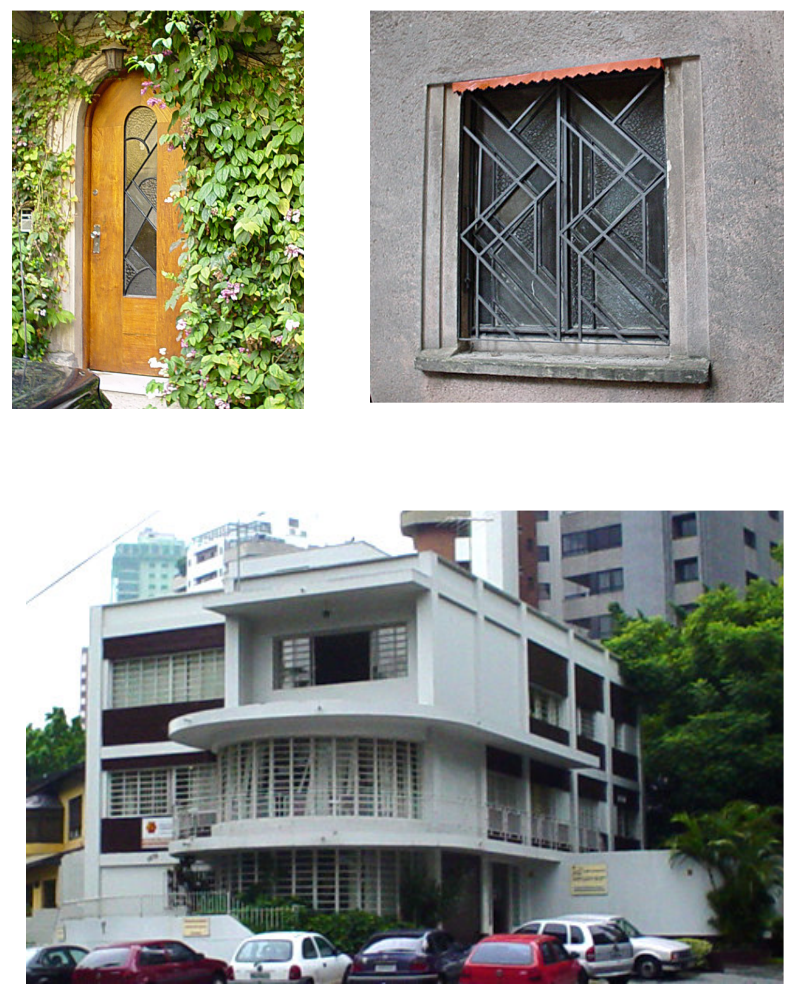

FIGURAS 258 e 259 : Antiga residência Sylvio de Almeida à avenida Pacaembu esquina da rua Tupi em 1940 e em 2003. (Moya \& Malfatti, Prêmio Prefeitura - 2 Salão Paulista de Belas Artes de 1935/ São Paulo) 


\section{i. Moderno}

Arquitetura inicialmente difundida pelo arquiteto Gregori Warchavchik.

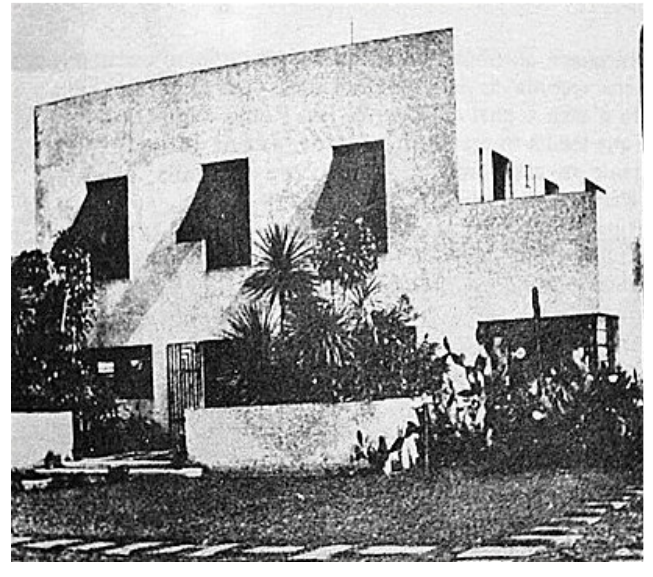

FIGURA 260 : Residência Gregori Warchavchik à rua Santa Cruz. (G. Warchavchik / São Paulo, 1927)

\section{Partido arquitetônico}

. volumetria de formas puras;

. laje plana de concreto.

\section{Estilema mais freqüente}

.arquitetura despojada, sem ornamentação.

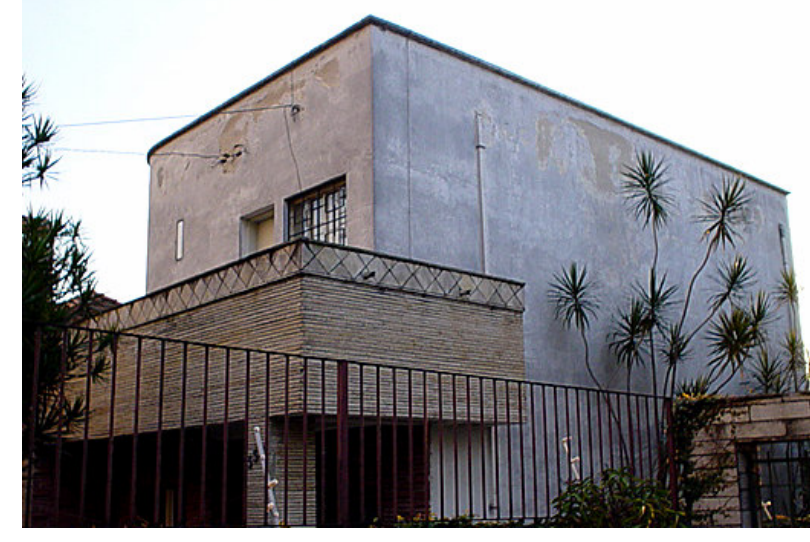

FIGURA 261: Residência à rua Dr. Franco da Rocha. (Moya \& Malfatti - projeto 266 / processo $\mathrm{n}^{0}$ 17.317/33)

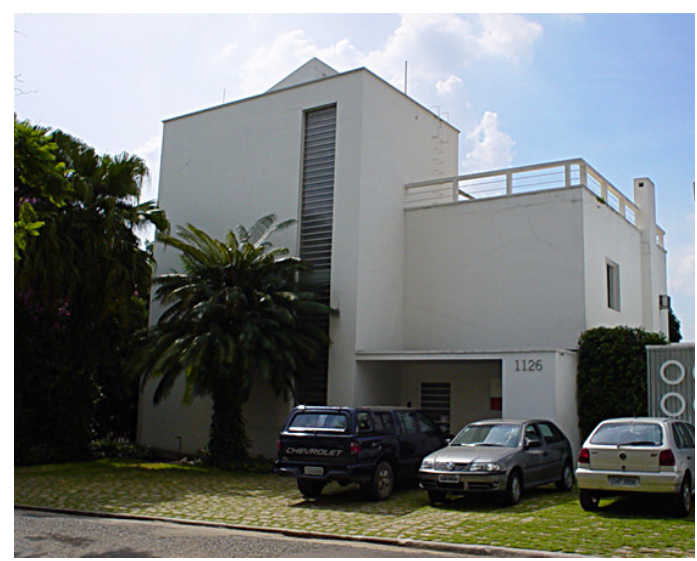

FIGURA 262 : Casa Modernista da rua Bahia. (Gregori Warchavchik / São Paulo, 1930) 


\section{j. Estillo Indefinido}

Engloba um grande número de incidências das mais variadas: desde a arquitetura chã até manifestações personalistas, sem um caráter predominante que as pudesse enquadrar em algum dos grupos estilísticos acima mencionados.

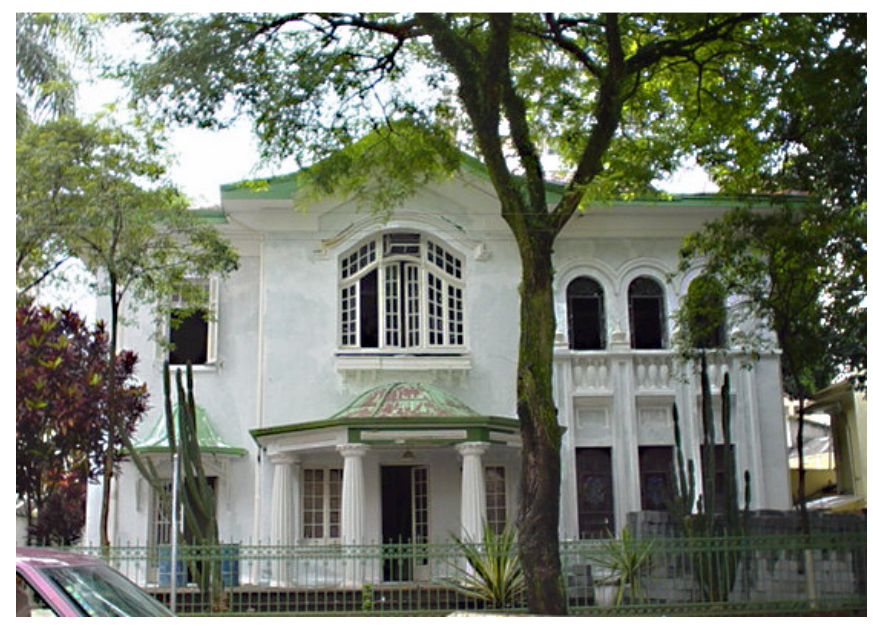

FIGURAS 263 e 264 : Residência à rua Gabriel dos Santos.

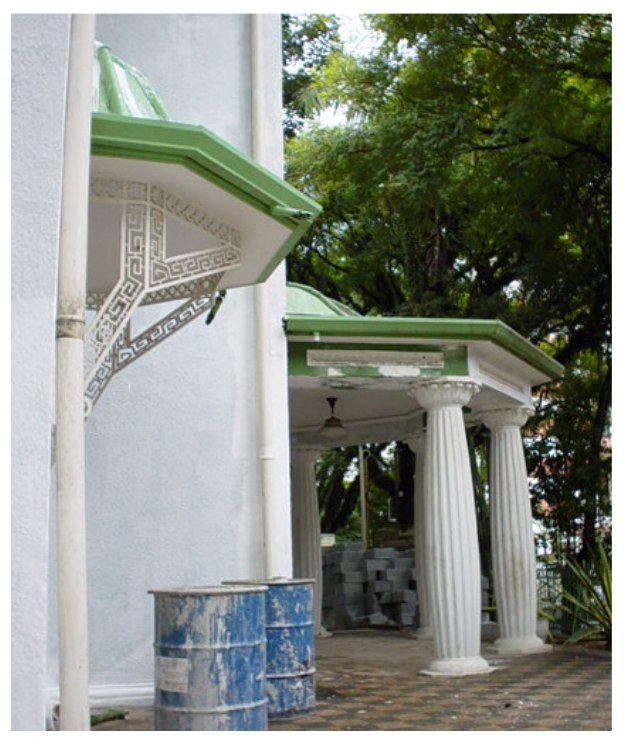

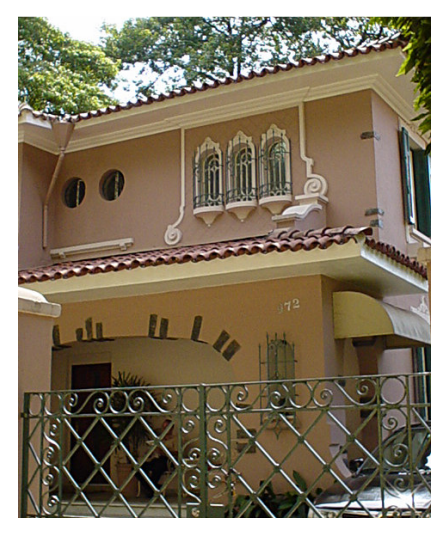

FIGURA 266 : Residência à rua Bahia.

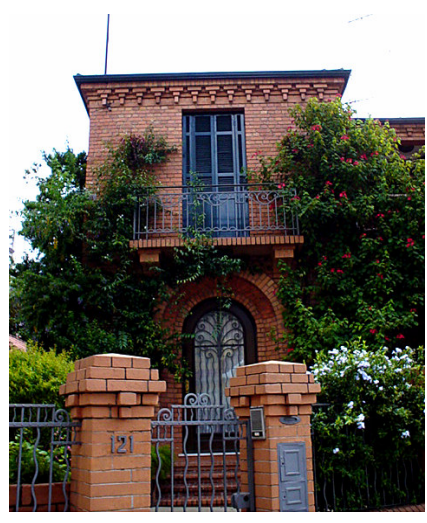

FIGURA 267 : Residência à rua Goiás. 


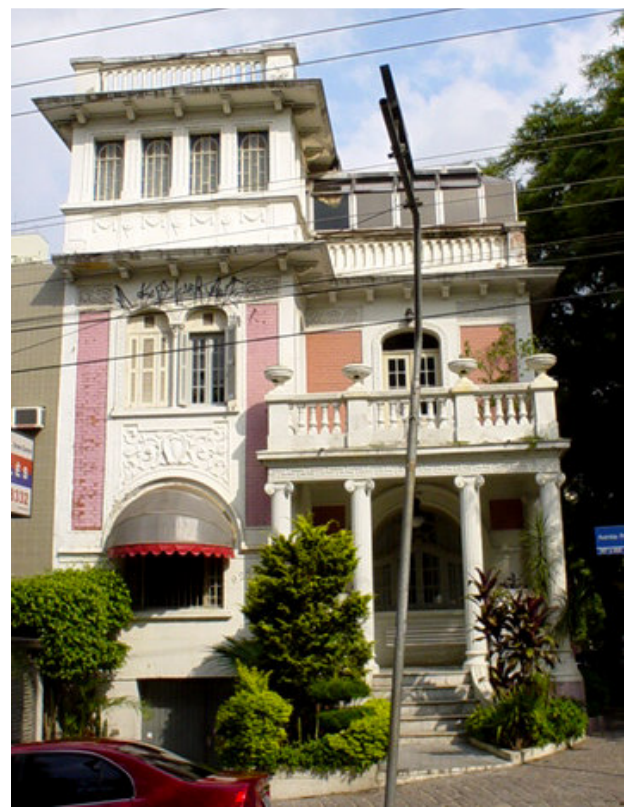

FIGURA 268 : Residência à avenida Pompéia esquina da rua Cel. Melo de Oliveira.

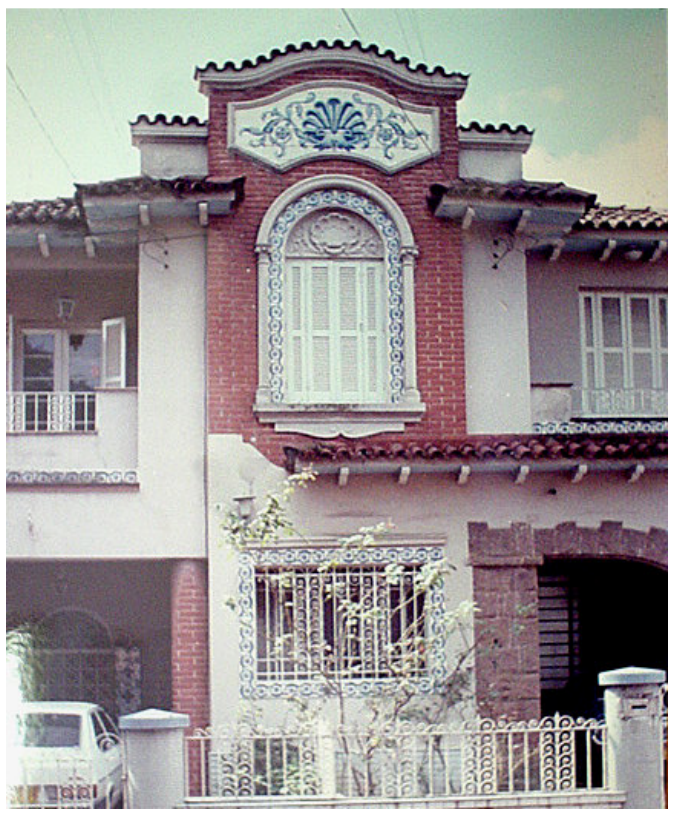

FIGURA 269 : Casa no bairro da Consolação.

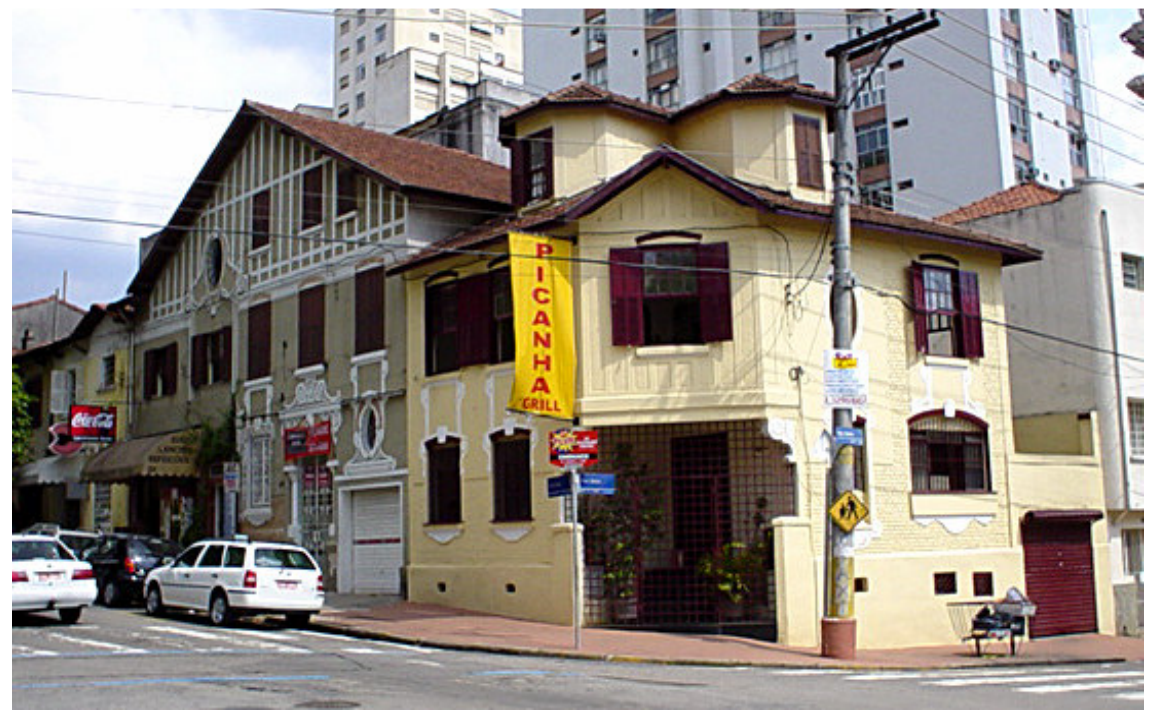

FIGURA 270 : Casas à rua Goiás esquina da rua Bahia. 


\section{Relação dos projetos residenciais sorteados classificados por ano / autor do projeto}

1923

ํo proc. 19367

no proc. 252

no proc. 23353

ABDALLA FARAHAT

no proc. 2194 (I)

no proc. 2194 (I)

ADRIANO MARCHINI (ENG. CIVIL)

ํo proc. 10665

Classe Média Média

no proc. 33567 (IV)
Classe Média Média

Classe Média Média

Classe Média Média

Classe Média Média

Casa Mista

Classe Média Média

Casa Mínima (operária)

Classe Média Média

Classe Média Baixa
Eclético Historicista

Neocolonial Simplificado

Eclético Classicizante

Neocolonial Simplificado Neocolonial Simplificado

Neocolonial Simplificado

Estilo indefinido Estilo indefinido

Eclético Classicizante

Estilo indefinido

\section{Estilo indefinido}

Estilo indefinido no proc. 5284 (I)

no proc. 5284 (II)
Casa Mista

Classe Média Baixa

\section{ALVARO COSTA VIDIGAL (ENG.ARQ.)}

no proc. 32139

Palacete

ÁLVARO NEVES DA ROCHA (ENG.)

no proc. 36538

Classe Média Média

ANTONIO GALLO FERRIGNO (ENG. ARQ.)

ํo proc. 23394

Casa Mínima (operária)

\section{A YROSA \& AYROSA}

ํo proc. 15419

Classe Média Média

\section{CARLOS ECKMAN \& FILHO}

no proc. 16503

Classe Média Alta

CHARLES PONCHON \& CIA. LTDA

no proc. 37081

Classe Média Média

Neocolonial Luso-Brasileiro

Neocolonial Simplificado
Estilo indefinido

Neocolonial Simplificado

Estilo indefinido

Normando 
CIA. INICIADORA PREDIAL

no proc. 3123

no proc. 15172

EDMUNDO KRUG (ARQ.)

no proc. 9031

\section{FERNANDO CORAZZA \& IRMÃOS}

no proc. 8133

Classe Média Média

Classe Média Média

no proc. 37738

Classe Média Média

Palacete

Classe Média Média

Eclético Classicizante

Neocolonial Simplificado

Eclético Historicista

Estilo indefinido

Neocolonial Simplificado ํo proc. 23808

Classe Média Alta

Classe Média Baixa

Casa Mínima (operária)

Classe Média Média

Casa Mínima (operária)

Classe Média Baixa

Casa Mínima (operária)

Classe Média Baixa

Classe Média Baixa

HENRIQUE TAVOLA

no proc. 35912

\section{HUMBERTO BADOLATO}

no proc. $269(\mathrm{~V})$

no proc. $269(\mathrm{VI})$

no proc. 269 (IV)

no proc. 269 (III)

no proc. 269 (II)

ํo proc. 269 (I)

JOSÉ CAMILLO DE SOUZA (ARQ.)

ํㅜ proc. 18659

Classe Média Baixa

Classe Média Baixa

Casa Mista

no proc. 33614

MILTON RANZINI (ENG.)

ํoproc. 26298

Casa Mista

Casa Mínima (operária)
Casa Mista

Casa Mista

Casa Mista

Casa Mista

Casa Mista

Estilo indefinido
Eclético Classicizante Eclético Classicizante Eclético Classicizante Eclético Classicizante Eclético Classicizante Estilo indefinido

Neocolonial Simplificado Estilo indefinido

Neocolonial Simplificado

Eclético Classicizante Eclético Classicizante Eclético Classicizante Eclético Classicizante Eclético Classicizante Eclético Classicizante

Eclético Classicizante

Eclético Classicizante

Eclético Classicizante 


$\begin{array}{cll}\begin{array}{c}\text { NARCISO FREDIANI } \\ \text { no proc. } 29706\end{array} & \text { Palacete } & \text { Neocolonial Simplificado } \\ \begin{array}{c}\text { RENATO R. AGUIAR (ARQ.) } \\ \text { no proc. } 13249\end{array} & \text { Classe Média Média } & \text { Neocolonial Simplificado } \\ \text { SAMPAIO \& MACHADO } & \text { Palacete } & \text { Eclético Classicizante } \\ \text { no proc. } 9760 & & \\ \text { SAMUEL GRAGNANI } & & \text { Neocolonial Simplificado } \\ \text { no proc. } 49422(2) & \text { Classe Média Média } & \end{array}$

1924

ํo proc. 55963

Classe Média Baixa

Estilo indefinido

ADHEMAR QUEIRÓS DE MORAES (ENG.CIVIL)

no proc. 50298

Classe Média Alta

Neocolonial Luso-Brasileiro

ADRIANO MARCHINI (ENG. CIVIL)

no proc. 56040

no proc. 65641

Classe Média Alta

Classe Média Alta

Eclético Historicista

Neocolonial Simplificado

AFFONSO CHIOCCARELLO (ARQ.)

ํo proc. 74345

Classe Média Média

Neocolonial Simplificado

\section{ALEXANDRE DOS SANTOS OLIVEIRA}

ํo proc. 67564

Casa Mínima (operária)

Eclético Classicizante

ÁLVARO CARLOS DE ARRUDA BOTELHO (ENG. ARQ.)

ํo proc. $73947 \quad$ Classe Média Alta

Neocolonial Luso-Brasileiro

ANNIBAL SAINT-ANTRIZ (ENG. ARQ.)

№ proc. 70267

Casa Mínima (operária)

Eclético Classicizante

ANTONIO FERREIRA

ํo proc. 70452

Classe Média Baixa

Estilo indefinido

\section{BENEDICTO BETTAZ}

ํo proc. 67892

Casa Mínima (operária)

Eclético Classicizante

CLAÚDIO M. LEMOS

№ proc. 76384

Casa Mínima (operária)

Estilo indefinido 
DÁCIO AGUIAR DE MORAES (ENG. ARQ.)

№ proc. 68116

Casa Mínima (operária)

DULPHE PINHEIRO MACHADO (ENG.CIVIL)

no proc. 74303

Classe Média Baixa

FRANCISCO ORLANDO

№ proc. 74651

Classe Média Média

HENRIQUE C. ALVARENGA

№ proc. 62205

Casa Mínima (operária)

Casa Mínima (operária)

Classe Média Baixa

Casa Mínima (operária)

№ proc. 47490

N. OLIVEIRA

ํo proc. 58386

NILSSON \& CARLSSON

no proc. 71522

Casa Mínima (operária)

PLÁCIDO DALL'ACQUA / BELMIRO BOTELHO PICERNI (ENGS)

№ proc. 54356

Classe Média Alta

RAPHAEL LANZARA (ENG. ARQ.)

nำ proc. 65181

Classe Média Média

Classe Média Média
Estilo indefinido

Eclético Classicizante

Estilo indefinido

Estilo indefinido

Eclético Classicizante

Eclético Classicizante

Neocolonial Simplificado

Estilo indefinido

Estilo indefinido

Neocolonial Simplificado

Neocolonial Simplificado

Neocolonial Simplificado

\section{5}

ADHEMAR QUEIRÓS DE MORAES (ENG. CIVIL)

no proc. 8226

Palacete

Neocolonial Luso-Brasileiro

ADRIANO MARCHINI (ENG. CIVIL)

no proc. 23406

Classe Média Alta

Neocolonial Simplificado 
ALBERTO DE SÁ MOREIRA (ENG. ARQ.)

no proc. 19999

Classe Média Alta

Classe Média Média

no proc. 21764 (III)

\section{ANTONIO PICAGLI}

no proc. 19020 (I)

no proc. 19020 (II)

Casa Mínima (operária)

Casa Mista

ARNALDO MAIA LELLO (ENG. ARQ.)

no proc. 40711 (II)

no proc. 40711 (I)

Casa Mista

Casa Mista

BERNARDINO JARUSSI

no proc. 39584

Casa Mínima (operária)

Classe Média Alta

no proc. 19967

\section{CAMARGO, BERNARDES \& MESQUITA}

no proc. 10743

Palacete

ENÉAS MARINI (ENG. ARQ.)

no proc. 25377

Classe Média Alta

Classe Média Baixa

no proc. 22988

\section{HEITOR SEABRA}

nº proc. 3263

J. A. FUGULIN (ARQ.)

no proc. 21764 (I)

no proc. 21764 (II)

JACINTHO TEIXEIRA DA SILVA (ARQ.)

no proc. 40440

JORGE BORBA

no proc. 32393

JOSÉ CAMILLO DE SOUZA (ARQ.)

nำ proc. 31598

JOSÉ CEVENINI

no proc. 13572
Casa Mista

Classe Média Média

Classe Média Alta

Classe Média Média

Classe Média Alta

Casa Mínima (operária)

Casa Mista
Neocolonial Luso-Brasileiro

Eclético Classicizante

Estilo indefinido

Estilo indefinido

Eclético Classicizante Eclético Classicizante

Eclético Classicizante

Neocolonial Simplificado

Neocolonial Simplificado

Estilo indefinido

Eclético Classicizante

Neocolonial Simplificado

Estilo indefinido

Estilo indefinido

Neocolonial Simplificado

Neocolonial Simplificado

Eclético Classicizante 


\begin{tabular}{|c|c|c|}
\hline no proc. 21179 & Classe Média Média & Neocolonial Simplificado \\
\hline \multicolumn{3}{|l|}{ O. CAMPOS } \\
\hline no proc. 26000 & Classe Média Baixa & Estilo indefinido \\
\hline \multicolumn{3}{|c|}{ PAULO PRADO VAN ATZINGEN (ENG.) } \\
\hline no proc. 24610 & Classe Média Média & Neocolonial Simplificado \\
\hline \multicolumn{3}{|c|}{ RAUL DOS SANTOS OLIVEIRA (ENG. ARQ.) } \\
\hline no proc. 25039 & Classe Média Baixa & Estilo indefinido \\
\hline \multicolumn{3}{|c|}{ RODOLPHO G.TARTARI } \\
\hline ํo proc. 40521 & Casa Mínima (operária) & Estilo indefinido \\
\hline \multicolumn{3}{|c|}{ SAMPAIO \& MACHADO } \\
\hline no proc. 21877 & Classe Média Média & Neocolonial Simplificado \\
\hline \multicolumn{3}{|c|}{ SYLVIO DE SÁ E SILVA (ENG.) } \\
\hline no proc. 3358 & Classe Média Alta & Neocolonial Luso-Br \\
\hline
\end{tabular}

1926

no proc. 15049

no proc. 15336

no proc. 10581

ADRIANO MARCHINI (ENG. CIVIL)

no ${ }^{\circ}$ proc. 2916

no proc. 45780

ANTONIO FIORE

№ proc. 19746

\section{CIRILLO CLARKE}

no proc. 11759
Casa Mínima (operária)

Classe Média Média

Casa Mínima (operária)

Palacete

Classe Média Alta

Casa Mista

Casa Mínima (operária)

DURVAL COSTA ALVES RIBEIRO (ENG. CIVIL)

no proc. 12791

Classe Média Baixa

Classe Média Baixa

ํo proc. 41880

FERREIRA CINTRA \& CIA

no proc. 18611

Casa Mínima (operária)

\section{EDMUNDO BREHME}

Estilo indefinido

Estilo indefinido

Eclético Classicizante

Neocolonial Simplificado

Estilo indefinido

Eclético Classicizante

Estilo indefinido

Estilo indefinido 
FRANCISCO J. AZEVEDO FILHO

no proc. 8978

J. B. MAURICIO

ํo proc. 16929

Classe Média Baixa

Classe Média Baixa

Casa Mínima (operária)

no proc. 6978

MARIO T. WHATELY (ENG.)

no proc. 15923

Palacete

Classe Média Alta

№ proc. 13430

\section{PASQUAL POMANG}

Casa Mínima (operária)

Classe Média Média

Estilo indefinido

Estilo indefinido

RANULPHO DA MALTA PINHEIRO LIMA (ENG. CIVIL)

ํo proc. 10896

Classe Média Alta

RODRIGO CLAUDIO (ENG. CIVIL)

no proc. 80

Casa Mínima (operária)

Eclético Classicizante

TRAVAGLINI \& CAMILLO DE SOUZA

№ proc. 17438

Classe Média Baixa

Estilo indefinido

\section{7}

no proc. 39070

ABELARDO SOARES CAIUBY (ARQ.)

nำproc. 26715 (II)

no proc. 26715 (I)

no proc. 26715 (IV)

no proc. 26715 (III)

\section{ADRIANO MANZINI}

no proc. 43031

ANDRÉ MARGONI

nºproc. 26751
Classe Média Alta

Classe Média Alta

Classe Média Alta

Classe Média Alta

Casa Mínima (operária)

Classe Média Média
Neocolonial Simplificado

Neocolonial Simplificado Neocolonial Luso-Brasileiro

Neocolonial Simplificado

Neocolonial Luso-Brasileiro

Estilo indefinido

Neocolonial Simplificado 
ANNIBAL MENDES GONÇALVS (ENG. ARQ.)

no proc. 40583

Classe Média Média

ARNALDO MAIA LELLO (ENG. ARQ.)

no proc. 30961

Classe Média Média

Classe Média Alta

Classe Média Alta

no proc. $49264($ II)

no proc. 49264 (I)

FELIX HEGG (ENG.)

no proc. 41090

FRANCISCO CORAZZA (ARQ.)

no proc. 48206

no proc. 16279

Palacete

Casa Mista

FRANCISCO DE SALLES VICENTE DE AZEVEDO (ENG.CIVIL)

nº proc. 4322

Classe Média Alta

Casa Mínima (operária)

Classe Média Alta

Classe Média Baixa

Casa Mínima (operária)

Classe Média Baixa

Classe Média Baixa

Classe Média Baixa

Casa Mista

Classe Média Baixa
Neocolonial Luso-Brasileiro

Neocolonial Simplificado

Estilo indefinido

Estilo indefinido

Eclético Classicizante

Neocolonial Simplificado

Estilo indefinido

Estilo indefinido

Estilo indefinido

Neocolonial Simplificado

Eclético Classicizante

Eclético Classicizante

Eclético Classicizante

Estilo indefinido

Neocolonial Simplificado Eclético Classicizante

Estilo indefinido 
A . DE OLIVEIRA COUTINHO (ENG.)

no proc. 14524

Classe Média Média

Classe Média Alta

Eclético Historicista

ADHEMAR QUEIRÓS DE MORAES (ENG.CIVIL)

ํo proc. 56056

Palacete

\section{ALFREDO SACHELLI}

no proc. 71248

Classe Média Baixa

Classe Média Baixa

\section{ANGELO REINA}

no ${ }^{\circ}$ proc. 23988 /

Casa Mínima (operária)

ANNIBAL MENDES GONÇALVES (ENG. ARQ.)

no proc. 9024 (II)

no proc. 9024 (I)

Classe Média Média

Casa Mista

ANTONIO MARQUES SIMÕES

no proc. 18478

Casa Mista

Classe Média Alta

Classe Média Média

Classe Média Baixa

Classe Média Média

ํo proc. 14145

\section{CAMILLO BERGENSON}

no proc. 13120

no proc. 69221

\section{CARLOS ALBERTO VANZOLINI}

ํo proc. 23836

CARLOS BROWNE (ENG. CIVIL)

ํo proc. 18449
Classe Média Média

Casa Mínima (operária)

Classe Média Média

Classe Média Baixa
Estilo indefinido

Neocolonial Luso-Brasileiro

Estilo indefinido

Estilo indefinido

Eclético Classicizante Eclético Classicizante

Neocolonial Simplificado

Neocolonial Simplificado

Neocolonial Simplificado

Estilo indefinido

Estilo indefinido

Neocolonial Simplificado

Estilo indefinido

Estilo indefinido

Estilo indefinido 
CARLOS BROWNE (ENG.CIVIL)

no proc. 20873

CARLOS GHIRALDELLI

no proc. 36399

Classe Média Baixa

Neocolonial Simplificado

CEVENINI \& OLIVEIRA LTDA.

№ proc. 22042

Casa Mista

Estilo indefinido

EDUARDO BERNARDO OLIVEIRA (ENG.CIVIL)

no proc. 17045

Casa Mínima (operária)

Classe Média Média

no proc. 22058

FRITZ RICHTER (ENG. CIVIL)

ํo proc. 50375

no proc. 64537

ํo proc. 19906 (I)

no proc. 19906 (II)

Classe Média Média

Classe Média Média

Classe Média Média

Classe Média Média

GUERINO CACCHIORU

no proc. 54901

Classe Média Média

GUILHERME SERAPHICO DE ASSIS CARVALHO (ENG. CIVIL)

no proc. 30298

Classe Média Média

GUILHERME THIELEKE (ARQ.)

№ proc. 47907

Classe Média Alta

Classe Média Média

HEGG, CARVALHO \& COMP. LTDA.

no proc. 30856

Classe Média Média

Classe Média Média

Palacete

Estilo indefinido

JOÃO MORRILLO

no proc. 4988

Classe Média Baixa

Neocolonial Simplificado
Neocolonial Simplificado

Eclético Historicista

Normando

Neocolonial Simplificado

Neocolonial Simplificado

Neocolonial Simplificado

Neocolonial Simplificado

Neocolonial Simplificado

Neocolonial Simplificado

JOÃO PAULO CORRÊA DOS SANTOS

no proc. $30310 /$

Classe Média Média

Estilo indefinido 


\begin{tabular}{|c|c|c|}
\hline nº proc. 56695 & Classe Média Baixa & Eclético Classicizante \\
\hline \multicolumn{3}{|c|}{ JOÃO SERATO (ARQ.) } \\
\hline ํo proc. 28938 & Palacete & Neocolonial Simplificado \\
\hline \multicolumn{3}{|c|}{ JOAQUIM MARTINS CORREA } \\
\hline no proc. 29725 & Casa Mínima (operária) & Estilo indefinido \\
\hline \multicolumn{3}{|c|}{ JOSÉ AUGUSTO AVANCINI } \\
\hline no proc. 22384 & Classe Média Média & Estilo indefinido \\
\hline \multicolumn{3}{|c|}{ JOSÉ CAMILLO DE SOUZA (ARQ.) } \\
\hline no proc. 42389 & Casa Mínima (operária) & Estilo indefinido \\
\hline \multicolumn{3}{|c|}{ JOSÉ DE VARGAS CAVALHEIRO (ENG.) } \\
\hline № proc. 28190 & Classe Média Alta & Neocolonial Simplificado \\
\hline \multicolumn{3}{|l|}{ JOSÉ DOS SANTOS } \\
\hline no proc. 8812 & Classe Média Baixa & Estilo indefinido \\
\hline \multicolumn{3}{|l|}{ JOSÉ GUARDINO } \\
\hline no proc. 57995 & Casa Mínima (operária) & Estilo indefinido \\
\hline \multicolumn{3}{|l|}{ JOSÉ PECORA } \\
\hline no proc. 28076 & Classe Média Baixa & Estilo indefinido \\
\hline \multicolumn{3}{|c|}{ L. A. PEREIRA QUEIROZ } \\
\hline ํo proc. 9804 & Casa Mínima (operária) & Estilo indefinido \\
\hline \multicolumn{3}{|c|}{ LUIZ ALVARO DA SILVA (ENG. ARQ.) } \\
\hline ํo proc. 9886 & Classe Média Média & Estilo indefinido \\
\hline \multicolumn{3}{|l|}{ LUIZ ESPINHEIRA } \\
\hline № proc. 25818 & Classe Média Baixa & Estilo indefinido \\
\hline \multicolumn{3}{|c|}{ LUIZ MONTEIRO DA SIL VA (ENG.) } \\
\hline № proc. 26134 & Classe Média Baixa & Neocolonial Simplificado \\
\hline \multicolumn{3}{|l|}{ M. NAVAGLI } \\
\hline № proc. 26122 & Casa Mínima (operária) & Neocolonial Simplificado \\
\hline \multicolumn{3}{|c|}{ MIGUEL DOMINGUEZ } \\
\hline no proc. 42810 & Classe Média Média & Neocolonial Simplificado \\
\hline
\end{tabular}




\section{PAULO D'AMORE}

no proc. 7652

PISTORESI \& STOCK

no proc. 26858

REYNALDO VOSGERAU

ํo proc. 21388

\section{SALVADOR BUCCUTO}

o proc. $11775 /$

\section{SALVADOR GUARDINO}

no proc. 70928

\section{SILVINO REGGI}

no proc. 30038

TRAVAGLINI \& MARIOTTI LTDA

no proc. 25740
Casa Mínima (operária)

Classe Média Média

Classe Média Baixa

Classe Média Baixa

Casa Mínima (operária)

Classe Média Média

Classe Média Alta
Estilo indefinido

Eclético Historicista

Estilo indefinido

Estilo indefinido

Estilo indefinido

Neocolonial Simplificado

Neocolonial Luso-Brasileiro

1929

ํo proc. 41177

no proc. 22744 /

A. DE VILLALVA (ENG.)

no proc. 11980 (I)

ํo proc. 11980 (II)

\section{ÁL VARO VEIGA COIMBRA}

ํo proc. 14155 (I)

no proc. 14155 (II)

AMÉRICO DEL CARLO

no proc. 48556

ÂNGELO AURIEMMA

no proc. 2602

ANTONIO SMITH BAYMA (ENG. ARQ.)

no proc. 46064

\section{AUGUSTO FERNANDO PONTES}

ํำproc. 3087

\section{FERDINANDO DALLA NOR}

ํo proc. 56298 (II)
Palacete

Classe Média Média

Classe Média Baixa

Classe Média Média Classe Média Média

Casa Mínima (operária) Casa Mista

Classe Média Baixa

Classe Média Média

Classe Média Alta

Casa Mista
Neocolonial Simplificado

Estilo indefinido

Neocolonial Luso-Brasileiro Neocolonial Luso-Brasileiro

Eclético Classicizante Eclético Classicizante

Neocolonial Simplificado
Neocolonial Luso-Brasileiro

Neocolonial Simplificado 
FERDINANDO DALLA NOR

no proc. 56298 (I)

\section{FRANCISCO CALIÓ}

no ${ }^{\circ}$ proc. 5478

FRANCISCO CORAZZA (ARQ.)

no proc. 10164

Classe Média Baixa

Classe Média Média

ํo proc. 56061

JACINTHO TEIXEIRA DA SILVA (ARQ.)

no proc. 65425

Classe Média Média

JAYME PLADEVALL

ํo proc. 54382

JOÃO B. QUEIROZ

no proc. 44839

JOÃO SELLAM

no proc. 40830

JOSÉ ALEXANDRE

nำ proc. 5379

JOSÉ FRANCISCO ARANHA

no proc. 6393

Classe Média Média

Classe Média Média

Classe Média Média

Classe Média Média

no proc. 61876

MANOEL COSTA NEVES

no proc. 47374

Casa Mista

MAURO PERRUCCI

no proc. 56002

ํo proc. 67191

NESTOR DALE CAIUBY (ENG.)

no proc. 4102

Classe Média Média

Classe Média Média

Classe Média Alta

Classe Média Alta

Casa Mista

Classe Média Média
Casa Mínima (operária)

Casa Mínima (operária)

Estilo indefinido

Neocolonial Simplificado

Neocolonial Simplificado

Neocolonial Simplificado

Neocolonial Hispano-Americano

Eclético Classicizante
Neocolonial Simplificado

Estilo indefinido

Neocolonial Hispano-Americano 
PAULO P. C. DE SOUZA (ENG.)

no proc. 32995

Casa Mínima (operária)

Estilo indefinido

PAULO PRADO VAN ATZINGEN (ENG.)

ํo proc. 15074

Classe Média Média

Estilo indefinido

RAUL DOS SANTOS OLIVEIRA (ENG. ARQ.)

no proc. 34747 /

Casa Mínima (operária)

Estilo indefinido

SAVÉRIO GARCIA

no proc. 51213

Classe Média Média

Estilo indefinido

SOCIEDADE COMMERCIAL E CONSTRUCTORA LTDA.

ํo proc. 2729

Classe Média Alta

Neocolonial Luso-Brasileiro

\section{0}

nº proc. 19898

A. BRANCO

nº proc. 37329

\section{ALBUQUERQUE \& LONGO}

no proc. 41331

ANGÊLO PODESTÁ

nº proc. 25879

AUGUSTO MERLIN

no proc. 15571

\section{CAETANO REINO}

nº proc. 37194

FRANCISCO NAPOLI

no proc. 44874

\section{GUIDO PUCCINELLI}

no proc. 11962 (I)

ํo proc. 11962 (II)

H. VEIT \& RITZEL

no proc. 23832
Classe Média Alta

Classe Média Média

Classe Média Média

Classe Média Média

Casa Mínima (operária)

Classe Média Baixa

Classe Média Média

Classe Média Média

Classe Média Média

Classe Média Média
Neocolonial Simplificado

Estilo indefinido

Neocolonial Simplificado

Neocolonial Simplificado

Estilo indefinido

Estilo indefinido

Neocolonial Simplificado

Estilo indefinido Estilo indefinido

Neocolonial Simplificado 
JOSÉ CAMILLO DE SOUZA (ARQ.)

ํo proc. 24033

Casa Mínima (operária)

Casa Mínima (operária)

Casa Mínima (operária)

ํo proc. 42268

RINO LEVI (ARQ.)

ํo proc. 14857
Classe Média Baixa
Estilo indefinido

Estilo indefinido

\section{1}

№ proc. 27959

Classe Média Média

Neocolonial Simplificado

DÁCIO AGUIAR DE MORAES (ENG. ARQ.)

no proc. 42716

Palacete

Art Déco

F. S. MALTA JÚNIOR (ENG.)

no proc. 49562

Classe Média Alta

Neocolonial Simplificado

FÉLIX ZOCCOLA

№ proc. 27986

Casa Mínima (operária)

Neocolonial Simplificado

\section{FERNANDO BRESSIANI}

ํo proc. 52665

Casa Mínima (operária)

Neocolonial Simplificado

FRITZ RICHTER (ENG. CIVIL)

ํo proc. 18089

Classe Média Média

Art Déco

JACINTHO TEIXEIRA DA SILVA (ARQ.)

ํo proc. 49832

Classe Média Média

Neocolonial Simplificado

MANOEL FERREIRA DOS SANTOS

ํo proc. 25197

Classe Média Média

Neocolonial Simplificado

MILTON JASMINI

no proc. 47618

no proc. 31031

Classe Média Média

Classe Média Média

Neocolonial Simplificado

Neocolonial Simplificado

MONTEIRO, HEINSFURTER \& RABINOVITCH

ํo proc. 48428

Classe Média Média

Art Déco 
1932

ํo proc. $24876 \quad$ Classe Média Média

ํo proc. 15669

ALFREDO ERNESTO BECKER (ENG. ARQ.)

no proc. 18049

AMÉRICO GIGLIO (ARQ.)

ํo proc. 62

\section{ANTONIO CERRERI}

no proc. 34856 (I)

no proc. 34856 (II)

\section{CARLOS GHIRALDELLI}

no proc. 30856

F. RICHTER \& FLORIANI LTDA.

no proc. 44294

\section{GUIDO PUCCINELLI}

ํo proc. 13397

\section{JOÃO BIETAK}

nop proc. 19048

JOSÉ ANTONIO QUINTA

no proc. 14244

JOSÉ DOS SANTOS

№ proc. 15888

JOSÉ FUGULIN

ํo proc. 33471

JOSÉ TAVARES

no proc. 41037

JÚLIO ALBIERI

no proc. 14659

NICOLA CARRATÚ

no proc. 24215

RAPHAEL VISCONTI (ENG. CIVIL)

no proc. 34970
Palacete

Neocolonial Simplificado

Neocolonial Simplificado

Neocolonial Simplificado

Classe Média Baixa

Eclético Classicizante

Palacete

Palacete

Classe Média Média

Classe Média Alta

Classe Média Alta

Casa Mínima (operária)

Classe Média Média

Neocolonial Simplificado

Casa Mínima (operária)

Classe Média Média

Classe Média Média

Classe Média Média

Classe Média Média

Neocolonial Simplificado

Neocolonial Simplificado 
RAUL SIMÕES (ENG.)

ํo proc. 35665

ํo proc. 5822
Casa Mista

Classe Média Baixa
Estilo indefinido

Estilo indefinido

1933

$\begin{array}{lll}\text { no proc. } 23272 \text { (II) } & \text { Classe Média Média } & \text { Neocolonial Simplificado } \\ \text { no proc. } 49334 & \text { Casa Mínima (operária) } & \text { Neocolonial Simplificado } \\ \text { no proc. } 23272 \text { (I) } & \text { Classe Média Média } & \text { Neocolonial Simplificado }\end{array}$

ANNIBAL MENDES GONÇALVES (ENG. ARQ.)

ํo proc. 46223

Classe Média Média

ARY BIANCO

nำ proc. 29233

Classe Média Média

Neocolonial Simplificado

\section{DOMINGOS PEPE}

no ${ }^{\circ}$ proc. 23502

Classe Média Média

FRITZ RICHTER (ENG. CIVIL)

no proc. 5061 (I)

no proc. 5061 (II)

Classe Média Baixa

Casa Mista

JOSÉ DE VARGAS CAVALHEIRO (ENG.)

ํo proc. 48115

Classe Média Média

Casa Mínima (operária)

no proc. 29318

LUIZ PEDALINI

ํํ proc. 6580

Casa Mista

Classe Média Média

no proc. 17317

SAMUEL GRAGNANI

no proc. 49422

\section{SAVÉRIO GARCIA}

ํo proc. 40062
Classe Média Média

Classe Média Média
Moderno

Neocolonial Simplificado

Art Déco

Art Déco

Art Déco

Estilo indefinido

Eclético Classicizante

Art Déco

Estilo indefinido

\section{4}
ํo proc. 25621
no proc. 64391
no proc. 34380
no proc. 52424

Classe Média Baixa

Classe Média Baixa

Classe Média Média

Casa Mínima (operária)
Neocolonial Simplificado

Estilo indefinido

Estilo indefinido

Estilo indefinido 
A. CRIODI (ARQ.)

no proc. 34646

Classe Média Média

ALBERTO DE SÁ MOREIRA (ENG. ARQ.)

no proc. 38683

Classe Média Média

\section{ALBUQUERQUE \& LONGO}

№ proc. 17791

Classe Média Média

ANTONIO VENDITTI

no proc. 14942

Classe Média Média

ANTUNES, MELLO, MATTOS \& KIEHL

ํo proc. 70676

Classe Média Alta

ARTHUR FRADIQUE

№ proc. 34371

Classe Média Baixa

AUGUSTO DE ARRUDA BOTELHO (ENG. ARQ.)

no proc. 54127

Classe Média Média

COSTABILE AMATO

no proc. 51134 (II)

no proc. 51134 (I)

Classe Média Média

Classe Média Média

CRESTANA, SAVELLI \& BORRELLI LTDA.

no 0 proc. 65345

Classe Média Média

\section{EVARISTO DE VINCENZO}

no proc. 6937

Classe Média Baixa

Classe Média Baixa

Classe Média Média

Casa Mínima (operária)

Classe Média Média

Classe Média Média Classe Média Média

№ proc. 77274 (I)

no proc. 77274 (II)

J. M. MALHEIRO \& CIA.

no proc. 37983

Classe Média Alta

JAYME PLADEVALL
Classe Média Média
Neocolonial Simplificado

Art Déco

Neocolonial Simplificado

Art Déco

Neocolonial Simplificado

Neocolonial Simplificado

Neocolonial Simplificado

Neocolonial Simplificado Neocolonial Simplificado

Neocolonial Hispano-Americano

Estilo indefinido

Art Déco

Estilo indefinido

Estilo indefinido

Neocolonial Hispano-Americano

Art Déco

Art Déco

Neocolonial Luso-Brasileiro

ํo proc. 34553

Art Déco 
JOAQUIM ALCAIIDE VALLS (ENG.)

no proc. 41709

Classe Média Alta

Art Déco

JOSÉ DE BARROS SARAIVA (ENG. CIVIL)

№ proc. 55646

Classe Média Média

Art Déco

LINDENBERG, ALVES \& ASSUMPÇÃO

ํo proc. 63548

Classe Média Alta

№ proc. 70139

Classe Média Alta

\section{LUIZ COSONA}

no proc. 45407

Classe Média Média

\section{LUIZ JOSÉ DE CARVALHO / MELLO MATTOS (ENGS.)}

ํo proc. 23066

Classe Média Alta

LUIZ MONTEIRO DA SILVA (ENG.)

no proc. 43847

Classe Média Média

Casa Mínima (operária)

no proc. 49948

Classe Média Média

nํำproc. 18002

MÁRIO SÍL VIO POLLACO (ENG.)

ํo proc. 59120 (II)

no proc. 59120 (I)

Classe Média Alta

Classe Média Média

Casa Mínima (operária)

№ proc. 55979

MONTEIRO, HEINSFURTER \& RABINOVITCH

№ proc. 41982

Classe Média Média

MOYA \& MALFATTI

ํo proc. 76281

Classe Média Média

PAULO PRADO VAN ATZINGEN (ENG.)

no proc. 38590

no 0 proc. 42678

Casa Mínima (operária)

Casa Mínima (operária)

RAPHAEL VISCONTI (ENG. CIVIL)

№ proc. 65752

№ proc. 76224

Casa Mínima (operária)

Classe Média Média

ROMANO GIORDANO

no proc. 4139

Classe Média Média
Neocolonial Simplificado

Art Déco

Estilo indefinido

Neocolonial Hispano-Americano

Art Déco

Estilo indefinido

Neocolonial Simplificado

Art Déco

Art Déco

Estilo indefinido

Neocolonial Simplificado

Estilo indefinido

Estilo indefinido Estilo indefinido

Estilo indefinido

Neocolonial Simplificado

Estilo indefinido 
TEÓPHILO LASSE (ENG.)

no proc. 30823

Classe Média Média

Art Déco

1935

no proc. 44069 / Classe Média Alta

no proc. $80784 \quad$ Classe Média Média

ANNIBAL MENDES GONÇALVES (ENG.)

no proc. 37963

Classe Média Média

Casa Mínima (operária)

Classe Média Média

no proc. 25803

Casa Mínima (operária)

Classe Média Média

\section{CARLOS GRAZIA}

№ proc. 78475

Classe Média Baixa

CIA. IMOBILIÁRIA PAULISTA DE REEMBOLSO INTEGRAL no proc. 85608

Classe Média Baixa

CONRADO TROSSINI / LEOPOLDO GUEDES (ENGS.)

no proc. 59527

Classe Média Média

F. RICHTER \& FLORIANI LTDA.

no proc. 40473

Classe Média Média

FLÁVIO WETT COSTA

ํo proc. 64367

\section{FORTUNATO}

nº proc. 67360

FRANCISCO BATAZZI (ARQ.)

ํo proc. 81745

FREDERICO GUILHERME DEGEM

ํo proc. 85392
Classe Média Média

Classe Média Baixa

Classe Média Baixa

Classe Média Média
Art Déco

Neocolonial Luso-Brasileiro

Art Déco

Art Déco

Estilo indefinido

Neocolonial Simplificado

Estilo indefinido

Estilo indefinido
Neocolonial Simplificado

Neocolonial Luso-Brasileiro
Neocolonial Hispano-Americano

Art Déco

Estilo indefinido

Art Déco

Estilo indefinido 
GARCEZ, SIRIN LTDA.

ํo proc. 41820

JOSÉ VIADANA

nำ proc. 64719

ํo proc. 72729

\section{JÚLIO ALBIERI}

nำ proc. 14250

JÚNIO PORTELLA (ENG.)

nำproc. 85060

\section{LUIZ BRACEO}

no proc. 31883

\section{MARCELINO MARTINS}

no proc. 34882

MIGUEL MAIA

ํำ proc. 45472

OCTÁVIO FLORENCE WAGNER

ํo proc. 68066

no proc. 80319

RAPHAEL VISCONTI (ENG. CIVIL)

no proc. 75911

RODOLPHO G. TARTARI

no proc. 68049

no proc. 37180

\section{SANTO GIOVANNINI}

no proc. 73839

WILLIAM FORTUNATO (ENG.)

ํo proc. 18619

Classe Média Baixa
Classe Média Alta

Classe Média Alta

Classe Média Média

Classe Média Baixa

Classe Média Baixa

Casa Mista

Classe Média Média

Casa Mista

Classe Média Baixa

Classe Média Baixa

Classe Média Baixa

Classe Média Média Classe Média Média

Classe Média Média

Casa Mista
Estilo indefinido

Neocolonial Luso-Brasileiro

Neocolonial Luso-Brasileiro

Art Déco

Neocolonial Simplificado

Estilo indefinido

Neocolonial Simplificado

Estilo indefinido

Estilo indefinido

Art Déco

Neocolonial Simplificado

Art Déco

Estilo indefinido

Neocolonial Hispano-Americano

Estilo indefinido 
ํo proc. 66002

no proc. 27195

no proc. 26103

no proc. 63912

ํo proc. 56249

no proc. 27207

ํo proc. 63911
Casa Mínima (operária)

Casa Mínima (operária)

Casa Mínima (operária)

Casa Mínima (operária)

Casa Mínima (operária)

Casa Mínima (operária)

Casa Mínima (operária)
Estilo indefinido

Estilo indefinido

Estilo indefinido

Estilo indefinido

Estilo indefinido

Estilo indefinido

Estilo indefinido

\section{ALFREDO ERNESTO BECKER (ENG. ARQ.)}

ํo proc. 100376

Classe Média Alta

ARMÊNIO CRESTANA (ENG. CIVIL)

no proc. 57263

Classe Média Média

AUGUSTO DE ARRUDA BOTELHO (ENG. ARQ.)

no proc. 96916

Classe Média Baixa

\section{BRATKE \& BOTTI}

no proc. 105178 (I)

no proc. 105178 (II)

Classe Média Média

Classe Média Baixa

DANIEL DE BIASE

no proc. 62528

no proc. 34040

Classe Média Média

Classe Média Média

EDUARDO DE SAMPAIO SHELDON (ENG.)

no proc. 81915

Classe Média Média

\section{FRANCISCO TORQUATO AVOLIO}

no proc. 89243 (I)

no proc. 89243 (IV)

№ proc. 89243 (II)

no proc. 89243 (III)

FRANCO JULIANI

no proc. 77389

Classe Média Média

Classe Média Média

Classe Média Média

Classe Média Média

Casa Mínima (operária)

Casa Mista

Classe Média Baixa

Classe Média Baixa

ํo proc. 86400

\section{LUIZ BAHIA}

ํo proc. 35117
Classe Média Baixa
Neocolonial Simplificado

Estilo indefinido

Estilo indefinido

Neocolonial Hispano-Americano

Neocolonial Hispano-Americano

Art Déco

Art Déco

Estilo indefinido

Neocolonial Hispano-Americano Estilo indefinido

Neocolonial Hispano-Americano

Neocolonial Hispano-Americano

Estilo indefinido

Art Déco

Neocolonial Simplificado

Neocolonial Hispano-Americano

Estilo indefinido 
№ proc. 21935

MANOEL COZZOLINI (ARQ.)

ํo proc. 80985

no proc. 50664

ํำ proc. 61784

MARIANO NEVES (ENG.)

ํo proc. 67321

PEDRO TALARICO

no proc. 58267

Classe Média Média

RAUL DOS SANTOS OLIVEIRA (ENG. ARQ.)

ํo proc. 103377

Classe Média Média

RAUL SIMÕES (ENG.)

no proc. 101660

Classe Média Baixa

Casa Mínima (operária)

Classe Média Média

Classe Média Baixa

ํo proc. 58243

№ proc. 98115

RODRIGUES, SÁ \& CIA.

Casa Mínima (operária)
Neocolonial Simplificado

Estilo indefinido

Neocolonial Simplificado

Neocolonial Luso-Brasileiro

Neocolonial Luso-Brasileiro

Neocolonial Hispano-Americano

Estilo indefinido

Estilo indefinido

Estilo indefinido

Estilo indefinido

Neocolonial Hispano-Americano

Neocolonial Hispano-Americano Neocolonial Hispano-Americano Neocolonial Hispano-Americano

Neocolonial Hispano-Americano Estilo indefinido

Estilo indefinido no proc. 94125 (II)

no proc. 94125 (I)

no proc. 94125 (III)

\section{SALVADOR GUARDINO}

no proc. 20620 (II)

no proc. 20620 (I)

Classe Média Baixa

Classe Média Baixa

TEÓPHILO LASSE (ENG.)

no proc. 73366 ํo proc. 79837

VICENTE FERRARI JÚNIOR (ARQ.)

no proc. 52228
Classe Média Média

Classe Média Média

VICENTE DEL NIGRO JÚNIOR (ENG.ARQ.)

Classe Média Média

Classe Média Baixa
Neocolonial Hispano-Americano

Estilo indefinido 